\author{
UNIVERSIDADE DE SÃO PAULO \\ FACULDADE DE FILOSOFIA, LETRAS E CIÊNCIAS \\ HUMANAS \\ DEPARTAMENTO DE HISTÓRIA \\ PROGRAMA DE PÓS-GRADUAÇÃO EM HISTÓRIA SOCIAL \\ Tese em co-tutela com a Università degli Studi di Padova \\ Dipartimento di Scienze Storiche, Geografiche e dell'Antichità
}

\title{
IDENTIDADES POLÍTICAS E POLÍTICAS IDENTITÁRIAS NA GÁLIA MEROVÍNGIA E HISPÂNIA VISIGODA
}

Le identità politiche e politiche identitarie in Gallia Merovingia e Hispania Visigota

Verônica da Costa Silveira

Tese de doutorado apresentada ao Programa de Pós-Graduação em História Social do Departamento de História da Faculdade de Filosofia, Letras e Ciências Humanas da Universidade de São Paulo para a obtenção do título de Doutora em História Social

Orientadores: Prof. Dr. Marcelo Cândido da Silva Prof $^{\mathrm{a}}$. Dr ${ }^{\mathrm{a}}$. Maria Cristina La Rocca 
Para Nair de Almeida Costa

A melhor avó que alguém poderia ter 


\title{
Resumo
}

A pesquisa se dedica ao estudo comparado das construções identitárias como estratégias políticas no cenário de polarização política da Gália Merovíngia e Hispânia Visigoda a partir da análise de diversos gêneros narrativos: Historiae, Leges, Hagiografias. O argumento defendido é que os discursos identitários, especificamente aqueles em torno da Gens Francorum e da Gens Gothorum, eram deliberadamente plurais uma vez que voltados para resolução de conflitos que se desenvolviam no plano político.

Palavras-chave: Gália Merovíngia; Hispânia Visigoda; identidades; política

\begin{abstract}
The research is a comparative study about the construction of identities as political strategies in the context of political polarization of Merovingian Gaul and Visigothic Hispania. Working with the analysis of diverse narrative genres as Historiae, Laws and Hagiographies the inquiry aims to indicate the deliberate plurality of the identity discourses in the Gens Francorum and the Gens Gothorum due to the complexity and diversity of political issues.
\end{abstract}

Keywords: Merovingian Gaul; Visigothic Hispania; identities, politics

\section{Compendio}

La ricerca è dedicata allo studio comparativo delle costruzioni identitarie, come strategie politiche nello scenario di polarizzazione politica della Gallia Merovingia e Hispania Visigota, per mezzo dell'analisi di diversi generi narrativi. Il punto sollevato è che i discorsi sull'identità, in particolare quelli sulla Gens Francorum e sulla Gens Gothorum, erano volutamente diversi in quanto dedicati a risolvere una serie di questioni politiche variabili.

Parole chiave: Gallia Merovingia; Hispania Visigota; identità; politica 


\section{Índice}

Lista de Mapas, tabelas, imagens e gráficos ..........................................................6

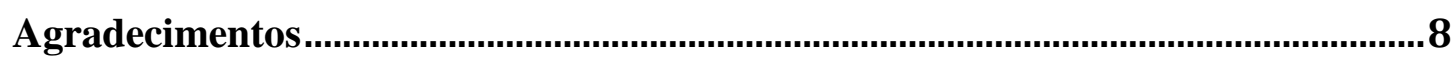

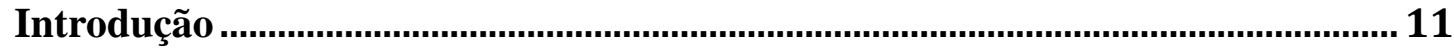

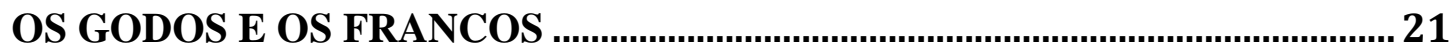

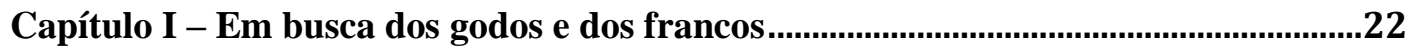

Os godos e os francos: as narrativas das migrações .............................................................23

Posicionamento da pesquisa na historiografia..............................................................53

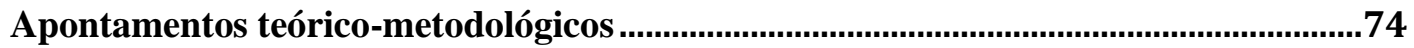

Identidades étnicas - o problema das migrações bárbaras na historiografia ................86

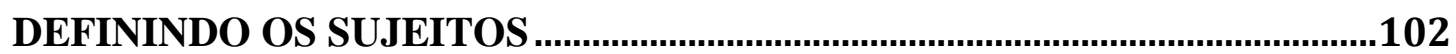

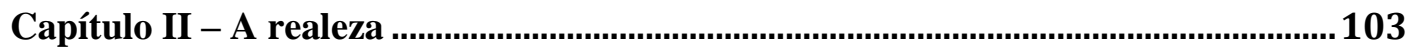

Os reis francos e os reis visigodos da legitimidade teórica à prática............................103

A realeza cristã na historiografia.................................................................................... 105 A teoria política cristã na historiografia sobre a Gália Merovíngia e a Hispânia Visigoda

Os reis

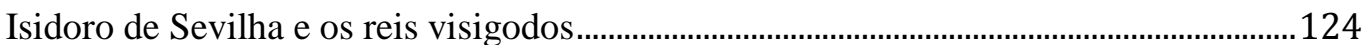

Isidoro de Sevilha, Viterico e a nobreza "goda" de Mérida ................................................126

Gundemaro e as epístolas de Bulgarano .................................................................................132

Sisebuto e Isidoro de Sevilha ..........................................................................................135

A fragilidade dos reis ................................................................................................... 141

Os reis francos - estratégias de uma dinastia...................................................................148

Alianças estratégicas e a autoridade dos reis francos ........................................................149

A divisão de 561 ................................................................................................................155

Clotário II e as oposições regionais - a gens francorum num contexto de disputas......161

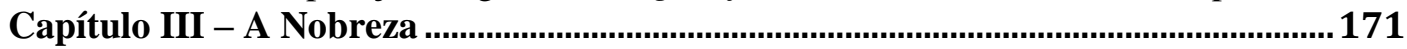

Um grupo difícil de nomear: aristocratas, nobres ou élites? ……………………….........171

A nobreza.......................................................................................................................179

As tantas faces das gentes - a gens gothorum e a gens francorum à luz das disputas políticas da Gália Merovíngia e da Hispânia Visigoda .......................................................210

Capítulo IV - Definindos os sujeitos: as contribuições da arqueologia .......................213

Quadro geral da distribuição demográfica na Hispania .....................................................214

Os Godos na Hispânia .............................................................................................................220

O nascimento dos "francos" - as contribuições da arqueologia .........................................2236

A CONSTRUÇÃO DA MEMÓRIA ................................................................247

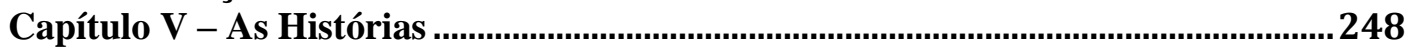

1. Das possibilidades da narrativa histórica na Alta Idade Média ................................248

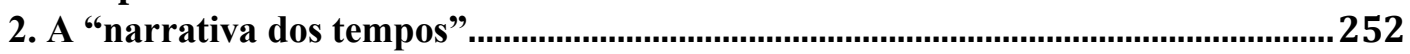

Os godos na história e a construção e uso da memória na Hispania Visigoda - João de

Biclaro, Isidoro de Sevilha e Juliano de Toledo ........................................................... 255

Os francos nas Historiae da Gália Merovíngia - a memória das origens.....................280

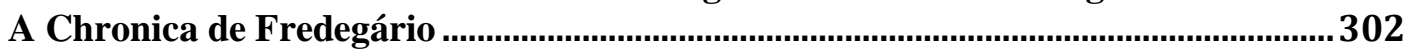

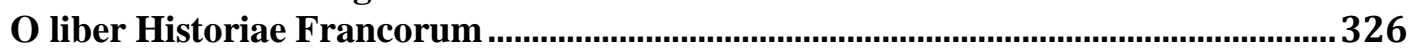

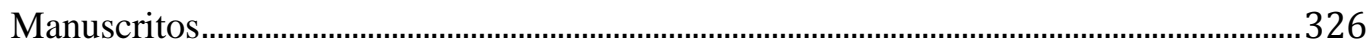

O Liber Historiae Francorum - a força de elites locais e o predomínio das identidades regionais.

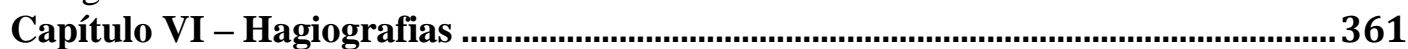


I. A vida dos santos, a vida política dos santos ............................................................361

2. A especificidade das Hagiografias.....................................................................................367

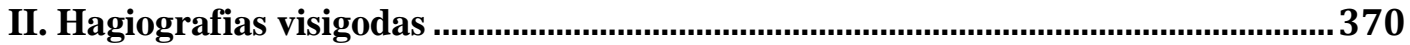

1. Problemas gerais da tradição manuscrita das hagiografias visigodas.............................370

2. Os santos visigodos - contrastes e alianças entre poderes locais e poderes centrais nas

Vitas Sanctorum Patrum Emeretensium ..............................................................................377

3. Isidoro de Sevilha e memória familiar no De Viris Illustribus .......................................383

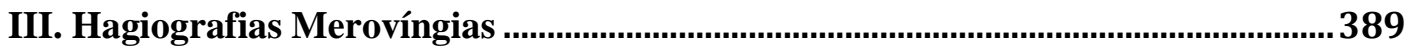

1. Problemas gerais da tradição manuscrita das hagiografias Merovíngias .....................389

2. A Vita Columbani - política e santidade na Gália Merovíngia ......................................400

3. A realeza e a santidade na Gália Merovíngia ..............................................................419

4. Nobres santos, santos nobres - nobreza e santidade na Gália Merovíngia...............426

Histórias e Hagiografias ou o confronto das memórias................................................441

A CONSTRUÇÃO DAS NORMAS..................................................................443

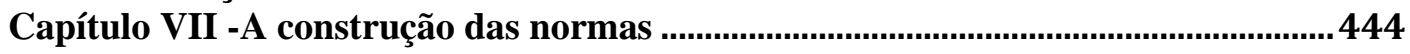

Leis - entre as leis "germânicas" $e$ as leis "romanas" ....................................................444

As leis - o nascimento de uma nova ordem ou a continuidade de um velho sistema447

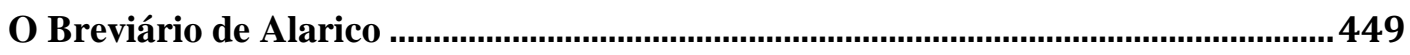

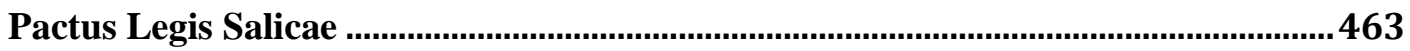

1. Estrutura do Pactus Legis Salicae .....................................................................................463

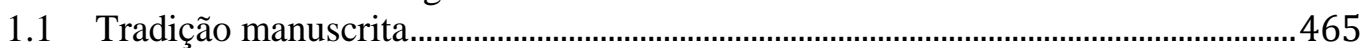

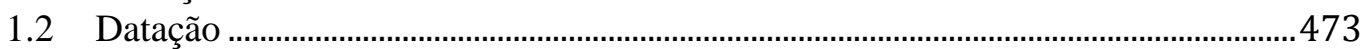

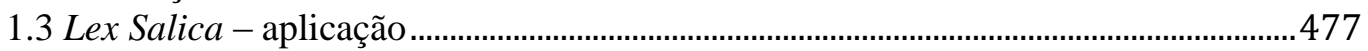

1.3.1. Lex Salica - aplicação entre os romani e franci nos sessenta e cinto títulos ....... 482

Os formulários de Marculf .................................................................................................... 496

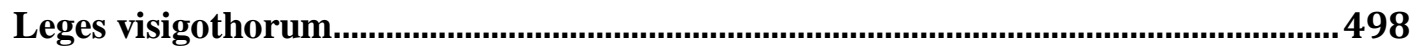

1. Leges visigothorum - estrutura.................................................................................. 498

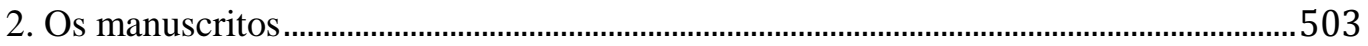

3. Godos e romanos nas Leges Visigothorum ……………………………………...... 512

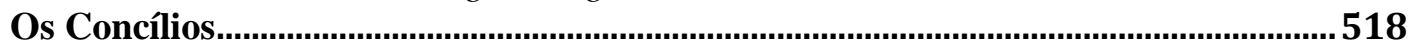

NÓS E OS OUTROS.......................................................................................533

Capítulo VIII - Nós e os outros: correspondências entre os reinos...............................534

1. A escrita epistolar no Alto Medievo - características narrativas e pressupostos de

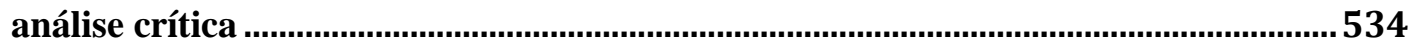

Epistolas Austrasianas e Epistolas Visigodas - "nós e os outros"..................................541

Capítulo IX - Os francos e os godos - alianças e tensões nas Histórias .......................549

Capítulo X - Nós e os outros - as rainhas …….....................................................569

Conclusão - identidades políticas e políticas identitárias como proposta............578

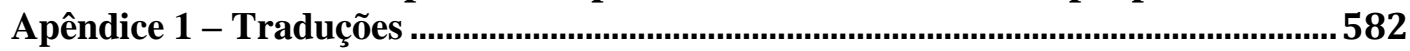

Apêndice 2 - Os reis godos em Jordanes .........................................................................598

Apêndice 3 - Os reis visigodos na Historia Gothorum de Isidoro de Sevilha ..............602

Apêndice 4 - Genealogia dos reis francos.................................................................605

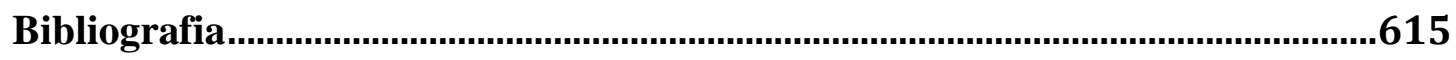




\section{Lista de Mapas, tabelas, imagens e gráficos}

Mapa 1 - Distribuição das populações de origem oriental e africana na Hispânia na Antiguidade Tardia

Mapa 2 - Distribuição da população de origem romana na Antigüidade Tardia

Mapa 3 - Assentamentos visigodos na Hispânia (primeiras gerações)

Mapa 4 - Distribuição das populações de origem romana e visigoda na Península Ibérica

Mapa 5 - Parque Arqueológico de Recópolis

Mapa 6 - Destaque da Belgica II e Germania II no mapa das províncias romanas do Noroeste europeu

Tabela 1 - Os francos nos Decem Libri Historiarum

Tabela 2 - As duas versões de Fredegário para a origem dos francos

Tabela 3 - Os francos no livro I de Fredegário

Tabela 4 - Os francos no livro II de Fredegário

Tabela 5 - Os francos no livro III de Fredegário

Tabela 6 - Os francos no Livro IV de Fredegário

Tabela 7 - Manuscritos do Liber Historiae Francorum

Tabela 8 - Termos identitários no Liber Historiae Francorum

Tabela 9 - Austrásia, Burgúndia e Nêustria no Liber Historiae Francorum

Tabela 10 - Manuscritos do De Viris Illustribus de Isidoro de Sevilha

Tabela 11 - Os Manuscritos com a Vita Columbani

Tabela 12: Manuscritos do Pactus Legis Salicae com trechos do Breviário de Alarico

Tabela 13 Manuscritos da Família A do Pactus Legis Salicae

Tabela 14: manuscritos da Família C do Pactus Legis Salicae

Tabela 15: Os Franci no Pactus Legis Salicae 
Tabela 16: Os godos nos Decem Libri Historiarum

Gráfico 1 - Os francos nos Decem Libri Historiarum

Gráfico 2 - Os francos nos Decem Libri Historiarum (em \%)

Gráfico 3 - A aplicação do termo "Francus” no primeiro livro de Fredegário

Gráfico 4 - Aplicação do termo "Francus" no segundo livro de Fredegário

Gráfico 5 - Aplicação do termo “Francus” no terceiro livro de Fredegário

Gráfico 6 - Aplicação do termo "Francus” no quarto livro de Fredegário

Gráfico 7 - Especificações do termo "Francus” na crônica de Fredegário

Gráfico 8 - Distribuição da aplicação de Francus no sentido de gens francorum na Chronica de Fredegário

Gráfico 9 - Distribuição temporal dos manuscritos do Liber Historiae Francorum

Gráfico 10 - Termos identitários no Liber Historiae Francorum

Gráfico 11 - Termos identitários no Liber Historiae Francorum (em \%)

Gráfico 12 - Distribuição temporal dos mss. com o De Viris Illustribus de Isidoro de Sevilha

Gráfico 13 - Distribuição temporal dos mss. com a Vita Aemiliani de Bráulio de Zaragoza

Gráfico 14 - Distribuição temporal dos manuscritos com a Vita Domnae Balthildis

Gráfico 15 - Distribuição temporal dos manuscritos com o Passio Leudegarii

Gráfico 16 - Distribuição temporal dos manuscritos com o Passio Praejecti

Gráfico 17 - Distribuição temporal dos manuscritos com a Vita Columbani

Gráfico 18 - Distribuição temporal dos manuscritos com a Vita Sanctae Geretrudis

Gráfico 19 - Distribuição temporal geral dos mss. com as Vitae

Gráfico 20 - Percentual da distribuição geral dos mss. com as Vitae

Gráfico 21 Localização dos Manuscritos do Pactus Legis Salicae

Imagem 1 Mapa da circulação dos mss. das Leges Visigothorum estabelecido por Díaz y Díaz 


\section{Agradecimentos}

Eu tive a sorte de ser filha de uma mãe e de um pai amorosos, que sempre me estimularam, que sempre me ajudaram, que sempre estiveram ao meu lado em todos os momentos. Meu primeiro agradecimento é para minha mãe, Nádia da Costa Silveira, e meu pai, Carlos Jupiá da Silveira.

Agradeço ao meu irmão, Vinicius da Costa Silveira, e minha irmã, Karolina de Almeida Silveira, pelos momentos de descontração, pela amizade mais pura e linda que eu poderia ter nessa vida e pelo inestimável apoio.

Agradeço ao meu caríssimo mestre Prof. Dr. Marcelo Cândido da Silva, severo quando necessário, acolhedor quando necessário, um guia e um amigo com uma profunda sabedoria e um espírito provocador que me fascina e inspira. Eu jamais chegaria aqui sem ele. Um homem apaixonado pelo o que faz, com uma inteligência feroz e uma generosidade incomensurável.

Agradeço ainda à Professora Cristina La Rocca que me acolheu tão bem, confiou em mim e me ajudou a ir além do que eu poderia imaginar. Ser orientada por uma historiadora da estatura dela é uma honra. Senhora de uma erudição e senso critico únicos, ela me fez questionar muitas de minhas certezas. Serei eternamente grata.

Evidentemente que qualquer erro presente nesse trabalho é de minha inteira responsabilidade, meus mestres me ofereceram o melhor, se errei é porque não compreendi. Por outro lado, o que há de melhor nesse texto é de responsabilidade do Professor Marcelo Cândido e da Professora Cristina La Rocca, as hipóteses que eu apresentei no início desse projeto de pesquisa foram radicalmente aprimoradas com o apoio, criticas e sugestão deles. Oxalá que um dia eu possa ser uma historiadora digna dos mestres que tive!

Agradeço ainda outros mestres que encontrei ao longo dessa estrada e que sempre serão uma inspiração.

A professora Néri de Barros pelas sugestões que sempre me ajudaram muito e seus trabalhos inspiradores. O professor Renan Frighetto que com suas sugestões e críticas elucidou novos caminhos para a crítica das fontes. A professora Leila Rodrigues que me conheceu quando eu era uma menina impertinente e me ensinou a escrever historiografia. A professora Rossana Pinheiro que me ensinou o valor da 
obstinação. A professora Filomena Coelho que com seus trabalhos me ensinou que ousadia é vital. O professor Stefano Gasparri que me ensinou que dominar historiografia é tão crucial como dominar as fontes. São tantos mestres, tantas fontes de inspiração. Espero não ser injusta a eles.

Agradeço a outros familiares que sempre estiveram comigo. Minhas amadas tias Ana Maria, Sidnéia e Sônia. Meus primos André, Andrea, Adriane, Fabiano, Fabrício, Fernanda, Raphael, Thiago e Roberta! Vocês são irmãos para mim! Um agradecimento especial para minha prima Mariana que sempre confiou em mim.

Um enorme obrigada para meus priminhos da segunda geração: Lucas, Matheus, Vinicius, Gabi, Felipe, Íris, Helena, David, Miguel, Henrique e Laura. O brilho nos olhos de vocês alivia qualquer tormento! Um especial agradecimento para meus afilhados oficiais e adotado! Pedro Augusto, Victor e Rodrigo. Obrigada por tornar essa jornada mais suave.

Às amigas que eu posso chamar de irmãs, que me fazem rir e que estão sempre ao meu lado quando preciso chorar! Luísa, Flávia, Michelle, Tatiane, Fernanda, Fernanda Elias e Fabrícia! Obrigada, garotas! Obrigada Beatriz Soares e Henrique Bonaita pela companhia e por me trazerem comida quando eu me alimentava de coisas congeladas enquanto me debatia com fontes, prazos e burocracias.

Aos meus caríssimos colegas que viraram verdadeiros amigos do Laboratório de Estudos Medievais. Bruna Bengozi, Karen Torres, Renato Boy, Victor Sobreiro, Marcelo Ferrasin, Vinicius Marino e Milton Mazetto. Obrigada pelas enormes contribuições a esse trabalho com suas críticas e aos importantes momentos de descontração.

Aos amigos que fiz na Europa e que me doeu no peito dizer "até mais": Francesco Veronese, Maddalena Betti, Anamaria, Chiara e James Norrie. Vamos nos reencontrar muito ainda!

A outros amigos que conheci na Itália e com os quais tive a chance de aprender que amizade não respeita nacionalidades e as vezes nem compreensão de idiomas: Hasmine Goffin, Michele Nerva, Floriana Terrafino, Elisabeth Spang, Chiara de Zan, Andrea Contin e Giovanna Bressan. Obrigada pela generosidade e pelo acolhimento à brasileira que quando partiu do Brasil tinha medo de ficar isolada.

Um infinito obrigada ao amor que encontrei em terras distantes, minha companheira Arianna Zerbetto. Obrigada por estar comigo, obrigada por confiar em mim e pela paciência. Obrigada Assunta Vigatto e Fábio Zerbetto pela ajuda, pelos 
finais de semana, obrigada por terem sido a família que eu encontrei quando estava longe da família em que nasci.

Obrigada Lívia pelo companheirismo de tantos anos e a amizade que sei que perdurará. Obrigada Janice Pinheiro e José de Arimatéia Pinheiro pelo carinho.

Um agradecimento especial à Fundação de Amparo à Pesquisa do Estado de São Paulo pelo financiamento que me permitiu dedicar o máximo de tempo ao desenvolvimento da pesquisa.

Certamente estou sendo injusta e não mencionei alguém. Não se ofenda. A palavra escrita pode levar à posteridade uma mensagem, mas só aquilo carregamos no coração chegará à nossa eternidade.

Maat. 


\section{Introdução}

The task of historians is to uncover these changes of identity that often (though not always) remain hidden behind contemporary perceptions of immutability. In this respect, early medieval history is a particular promising object of study because for the period between the fourth and the eighth centuries (and in eastern Europe, until the eleventh century), the transformation of social identities was accelerated through Christianization and Islamicization, through migrations and the appearance of new peoples, and through economic and political transformation. (W. Pohl) ${ }^{1}$

These challenges to past errors suggest that students of the Migration Age should take a profound interest in tribes and tribe formations, that this subject is acutely important to understanding the role of the barbarians in late antiquity. Whether or not "ethnicity" returned to the Roman Empire in the fourth century is open to discussion, but there is no doubt - so it is alleged - that ethnicity should have a high priority in today's classroom. We are urged to reorient the focus of attention from wherever it was in the books of, for example, J.B. Bury, Ludwig Schmidt, or Lucien Musset and move instead toward a subject one used to pay little attention to, namely, the 'Germanic tribe'. Is seems to proponents of "ethnogenesis" that a false views of "ethnic identity" should be discarded and replaced by right ones. (W. Goffart)

Esse trabalho enfrenta um debate muito caro à historiografia dos últimos trinta anos. Trata-se fundamentalmente do peso que as identidades, especificamente étnicas, tiveram no processo histórico que redundou na formação dos reinos romano-bárbaros no Ocidente Europeu e Norte da África. Embora aparentemente esse tema seja específico ao período que se estende desde o final do século $\mathrm{V}$ até finais do século VIII e primeira metade do IX acreditamos que a importância que a questão tem para a historiografia dedicada a esse espaço temporal se explique por um problema intrínseco à prática da escrita da história exemplificado pelas citações que abrem essa tese, ou seja: sobre qual tema, sobre qual objeto, devemos nos debruçar para compreendermos o processo histórico?

No que concerne ao tema com o qual dialogamos há duas posições evidentemente opostas. A primeira, que exemplificamos com a citação de W. Pohl,

\footnotetext{
${ }^{1}$ POHL, W. Introduction - strategies of identification: a methodological profile. In: POHL, W. \&HEYDEMANN, G. Strategies of identification. Ethnicity and Religion in Early Medieval Europe. Turnhout: Brepols, 2013. p.5.

${ }^{2}$ GOFFART, W. Barbarian Tides. The Migration Age and the Later Roman Empire. Philadelphia: University of Pennsylvania Press, 2006. p.2.
} 
defende que a compreensão acerca das construções das identidades étnicas é fundamental para a análise do processo histórico. Nesse sentido, a Alta Idade Média seria um campo de estudo privilegiado por trazer elementos cruciais que influenciam nas transformações identitárias: a questão religiosa, marcada no período pela cristianização e islamização; movimentos populacionais, marcados pelas ditas “migrações bárbaras"; e transformações políticas e econômicas advindas de um longo período de crise enfrentado pelo Império Romano. Religião, movimentos populacionais e crises/transformações políticas e econômicas seriam assim fatoreschave para a formação de novas identidades étnicas.

A segunda corrente é aquela que tem W. Goffart como o principal expoente. Nela o papel das identidades étnicas para a compreensão do processo histórico é questionado. Em poucas palavras, a principal crítica de Goffart a linha interpretativa expressa por Pohl se refere ao peso que as identidades étnicas assumem no processo histórico, trata-se, portanto, inicialmente de uma divergência teórico-metodológica referente a qual objeto/tema deve ser privilegiado pela historiografia para outorgar inteligibilidade ao processo histórico. Goffart argumenta que os estudos que privilegiam a questão das identidades étnicas dão uma nova roupagem para uma antiga tese: aquela que compreendeu os "povos germânicos" como os causadores da queda do império romano. ${ }^{3} \mathrm{O}$ autor questiona essa hipótese ao enfatizar que as "migrações bárbaras" foram superestimadas no que concerne ao impacto que tiveram nas transformações na Europa Ocidental, para ele foram problemas enfrentados pelo próprio Império que explicam o rumo que os acontecimentos tomaram, assim, no esquema de Goffart, os "bárbaros" não tiveram qualquer importância no desenrolar dos eventos.

\footnotetext{
${ }^{3}$ GOFFART, W. Barbarian Tides. The Migration Age and the Later Roman Empire...op.cit. p.230233.
} 
As duas vertentes apresentadas a partir dos exemplos de W. Pohl e W. Goffart assim têm como principal ponto de divergência o papel dos ditos bárbaros para o processo histórico correspondente ao o que chamamos de Queda do Império e início da Idade Média. Entretanto, essas duas correntes não existem apenas pelas suas divergências. Há temas importantes que as une.

O primeiro deles é que ambas partem de uma crítica maior aos conceitos operativos da historiografia do século XIX, sendo o principal deles a perspectiva teleológica que analisava a história como um processo linear que irremediavelmente desembocaria na formação dos Estados Nacionais. A partir dessa leitura, o sentido do estudo da Idade Média como um todo e da Alta Idade Média em específico seria desvendar as raízes da formação dos Estados Modernos. A história seria assim uma história das origens. Uma análise detalhada desse problema está presente no nosso capítulo I. O segundo ponto privilegiado pela historiografia foi o papel outorgado aos povos no processo histórico. Esses povos eram analisados como unidades essenciais que traziam em si uma carga cultural relativamente estática que nas relações com o Império sobrepujou ou foi sobrepujada pela cultura romana, a defesa de quem foram os vencedores ou os perdedores dependia da perspectiva que guiava os pesquisadores, romanistas ou germanistas. Esse tema também é contemplado no nosso capítulo I. O que importa dizer aqui, por enquanto, é que tanto Pohl quanto Goffart têm essas leituras historiográficas como fonte de crítica.

A crítica de Pohl advém das releituras sobre as etnias e as etnicidades. Para o autor as identidades étnicas são construções históricas que podem se transformar ao longo do tempo de acordo com as conjunturas. As etnias - em substituição à idéia de "povo" - passam a ser analisadas em sua própria variabilidade, não mais numa busca por suas essências que teriam fundamentado o edifício dos Estados Nacionais. Já 
Goffart refuta mesmo a idéia de etnias. Para ele elas não explicam o processo histórico e, além disso, mesmo com as relativizações, ainda evocam velhas idéias nacionalistas.

É nesse debate que este trabalho se localiza. Entretanto, inspirada pelas pesquisas de Goffart e Pohl proponho uma nova abordagem para o problema. Na leitura aqui presente, concordamos com ambos os autores no que concerne à crítica central à teleologia do XIX, mas problematizamos os outros pontos que eles defendem.

Sobre Pohl, acreditamos que as "etnias" e "etnicidades" se tornaram conceitos tão gerais em seus trabalhos que perdem o valor explicativo. Não obstante, mesmo que ele tenha apontado para a mutabilidade dessas "etnias", ele ainda busca um discurso unificador que cria uma narrativa identitária relativamente coerente. Acreditamos que, embora de grande validade, o trabalho, ao restringir tudo a um conceito "étnico", acaba perdendo de vista as sutilezas pelas quais as narrativas identitárias atuavam entre os séculos VI e VIII. O fato é que a idéia de "etnia" perde de vista construções identitárias que em nada se aparentavam com qualquer identidade étnica. O exemplo mais evidente disso é o crescimento da importância que identidades regionais ganharam no final do século VII e ao longo do século VIII na Gália Merovíngia. Aos poucos, como veremos ao longo desse texto, o termo "francus" perde relevância nas fontes em detrimento a termos relacionados com regiões: Austrasianos, neustrino e burgúndios se tornam os elementos identitários mais importantes das narrativas, sobretudo as históricas. Isso não quer dizer que um certo senso identitário relacionado com os franci desaparece. Ele ganha, todavia, outros contornos com múltiplos significados que muito pouco podem ser entendidos como étnicos. Os franci com os quais a rainha Balthilda teve momentos de aliança e 
contrastes dificilmente podem ser entendidos como um grupo étnicos. Os godos que elegeram Wamba como o rei dos godos muito dificilmente podem ser entendidos como um grupo étnico. A questão é que o confronto com as fontes mostra que a busca por um significado único relacionado com a etnicidade para os termos identitários que surgem nas fontes nos parece um erro metodológico. $\mathrm{O}$ valor das identidades existe na própria diversidade delas, na mutabilidade (e isso defendeu Pohl), mas que transcendia a etnicidade. Os múltiplos sentidos das identidades se revelam tãosomente no contexto político de disputas e alianças que sustentaram os regna Francorum e Gothorum.

Goffart, por sua vez, um pesquisador que inegavelmente trouxe contribuições inestimáveis para o estudo do período aqui contemplado, peca ao negar quase completamente o valor das etnicidades - mas em última instância das identidades - na estruturação política dos reinos dos francos e dos visigodos. Muito embora a crítica dele concernente ao enorme valor dado às etnias seja importante, negar o peso das narrativas identitárias é negar uma importante dimensão da estruturação dos discursos políticos que estavam em constante contraste naqueles reinos.

Propomos portanto a utilização de um outro conceito para dar conta das sutilezas que encontramos nas fontes. Não identidades étnicas, muito menos a negação do valor das identidades, mas sim a idéia de identidades políticas. Identidades que uniam os membros de toda uma elite em torno de um reino dos francos e dos godos centralizado politicamente pelos reis, de um lado, e identidades que uniam elites regionais, ou nobrezas de lugares distintos, em torno de reivindicações que não raro iam de encontro às aspirações centralizadoras dos reis. $\mathrm{O}$ que defendemos é que num contexto de disputa, entre os discursos evocados, os discursos identitários eram umas das principais justificativas para o enfrentamento no 
campo da política: entendida aqui como uma área de disputas nas quais inimigos e aliados se enfrentavam em busca da afirmação da própria autoridade política em regiões específicas ou, em certas ocasiões, mesmo para reivindicar o trono. As reivindicações ao trono foram bem mais comum na Hispânia visigoda, mas a Gália Merovíngia tem também seus casos: lembremos de Grimoaldo que tentou elevar como rei o próprio filho em detrimento ao herdeiro merovíngio do trono.

Esse é o argumento defendido ao longo de todo esse texto. Adotamos o estudo comparativo entre os dois reinos - franco e visigodo - para analisarmos comparativamente como esses discursos políticos identitários funcionaram em duas realidades. A comparação por vezes teve resultados surpreendentes. Nem sempre a afirmação identitária de nobres do reino dos francos ou de nobres do reino dos visigodos se realizava pela oposição entre francos e godos. No caso da rebelião contra Wamba narrada por Juliano de Toledo vemos os nobres dos dois reinos se aliando contra seus reis. O que isso indica é que a própria unidade "reino" precisa ser problematizada: por vezes a unidade inserida no conceito abstrato "reino" era o próprio ponto de tensão que opunha os nobres e seus reis. Nesse contexto outras identidades entravam no jogo político para sustentar novas alianças e questionar a autoridade dos reis. No caso da rebelião contra Wamba vemos a afirmação da identidade de nobres da Gália Narbonense. O que isso indica é que o estudo isolado dos reinos, ou mesmo considerar esses reinos como unidades, é mais uma perspectiva metodológica do que a apreensão da realidade política daqueles séculos, e talvez essa perspectiva ainda seja tão facilmente aceita porque ainda temos como ponto de referência os Estados Nacionais e sua poderosa narrativa identitária como guia para enfrentar fontes de um passado remoto. Não acreditamos que demos conta desse 
problema, mas na medida do possível tentamos apontar para ele ao longo desse trabalho.

No mais, cabe informarmos como está estruturado o texto.

A tese é dividida em quatro partes. Na primeira parte apresentamos o problema dos godos e dos francos nas fontes. Como eles aparecem nas narrativas? Como essas narrativas foram apropriadas quando essas gentes supostamente se assentaram no Ocidente como unidades coesas que traziam uma tradição, uma memória, em outras palavras, uma história? Essa primeira parte inicia com um estudo das fontes anteriores aos assentamentos dos godos e dos francos, esse ponto de referência será importante ao longo de todo o texto e sugerimos que seja confrontado amiúde com os argumentos que apresentamos nas outras partes. Após esse exercício discutimos o mesmo problema na historiografia e localizamos nosso trabalho no quadro geral dos estudos conduzidos sobre o tema das identidades. Em seguida apresentamos nossos pressupostos teórico-metodológicos. Esperamos que assim nossos referenciais fiquem claros para os leitores.

A segunda parte define os personagens principais dessa tese: os reis e os nobres. Como será possível perceber, nesses capítulos procuramos trazer uma introdução geral sobre a historiografia e os principais problemas metodológicos envolvidos nos temas trabalhados. Esse trabalho é formado, podemos dizer, por pequenas discussões historiográficas. Isso faz parte de um esforço de localizar bem os leitores e deixar sempre evidente o nosso posicionamento diante das pesquisas já realizadas e dos principais debates. A segunda parte fecha com uma aproximação à arqueologia num esforço de verificar se as tensões identitárias se manifestavam também nas evidências materiais.

A terceira parte se dedica à construção da memória a partir da análise das 
narrativas históricas e hagiográficas. Entendemos que as identidades assumem diversas facetas em diversos estilos narrativos, escolhemos aqui trabalhar com três principais. A primeira delas é a memória. Como se construiu a memória acerca da origem dos godos e dos francos nas histórias e como essa memória foi reapropriada em narrativas hagiográficas que enfatizavam o poder de nobres regionais? Em poucas palavras, como as memórias em torno das gentes e das nobrezas regionais se construíam e se confrontavam no cenário de disputas políticas?

Em seguida, na quarta parte, tratamos da narrativa concernente à construção das normas. Nossa preocupação é discutir como as gentes que dispunham de memórias conflitantes eram tratadas na normativa desses reinos. Trabalhamos nesse caso com as leges e as atas conciliares por terem tido sempre a pretensão da generalidade, em poucas palavras, por terem sido concebidas para a aplicação a todos sob a égide do reino e dos reis. Em certas ocasiões trazemos o exemplo de normas mais pontuais, como as formulae, mas são as leis mais gerais que são as principais fontes.

A última narrativa que analisamos são as epístolas, nosso objetivo é observar como esses reinos, que internamente eram profundamente polarizados, se apresentavam a reinos estrangeiros e eram reconhecidos por esses reinos. Observamos que no confronto direto com os outros presente nas trocas epistolares a idealização da unidade era recorrente. Além disso, a última parte enfrenta a questão da identidade em confronto com os "outros". Primeiro, numa análise de como as fontes produzidas na Gália retrataram os godos e como as fontes produzidas na Hispânia retrataram os francos; Segundo, a partir de um estudo sobre as rainhas estrangeiras nas cortes reais francas e visigodas, com maior atenção ao caso das rainhas francas uma vez que as fontes da Hispânia pouco mencionaram as rainhas. 
Notar-se-á que temos uma considerável preocupação com a transmissão dos manuscritos das fontes com as quais lidamos. Isso se deve a nossa convicção de que o trabalho com as edições precisa ser profundamente problematizado. Não raro trabalhamos com edições de fontes produzidas entre o século XIX e início do século XX que eram pautadas por uma agenda política e que nos passam a impressão de uma transmissão manuscrita muito clara que permitiria a reconstrução dos textos tal como eles foram escritos. Não conseguimos aqui dar conta de todo o problema envolvido nesse tipo de trabalho, mas nos esforçamos por apresentar aos leitores o fato de que as edições não são as fontes e devem ser criticadas e problematizadas. O mínimo de enfrentamento crítico com essas edições nos permite ao menos a ciência de que não podemos confundir edições com fontes. A consciência disso deve despertar uma profunda desconfiança quando lidamos com uma edição que faz pressupor a existência de uma Lex Visigothorum unitária ou de um Pactus Legis Salicae bem estruturado que circulou e foi aplicado a todos os francos sob a autoridade dos reis francos. Isso vale para todas as fontes aqui contempladas.

Além disso, no trato com as fontes, tivemos grande preocupação em problematizar a questão dos gêneros narrativos, entendidos aqui não como pura "narrativa" em contraste com a realidade, mas como uma realidade em si mesma que lançava mão de diversas estratégias de acordo com as intenções parcialmente detectadas a partir do tipo de gênero escolhido pelos autores para a transmissão das mensagens. O que queremos dizer é que a escolha por registrar algo no formato de uma Historia ou de uma Vita ou mesmo de uma Lex não era aleatória, cada um desses gêneros já indicavam uma intenção pela própria tradição que caracterizava suas especificidades. Nesse caso, não podemos ocultar a forte influência dos estudos de 
Koselleck $^{4}$ na abordagem das fontes e, principalmente, na elaboração de nossa proposta de análise dos documentos baseada na idéia de um "contexto textual" no qual a percepção acerca da narrativa não se alinha a qualquer análise puramente literária, e sim à análise de uma dimensão da realidade concretizada nas narrativas e na elaboração de discursos identitários com uma detectável efetividade política.

No mais, esperamos ter obtido êxito em ao menos deixar claro nossos pressupostos e objetivos, esperamos que esse trabalho seja lido tal como foi concebido: na profunda angústia da dúvida.

\footnotetext{
${ }^{4} \mathrm{O}$ artigo de Koselleck que melhor sumariza os fundamentos de nosso posicionamento é: KOSELLECK, R. Uma história dos conceitos: problemas teóricos e práticos. Estudos Históricos. v.5, n.10, p.134-146, 1992.
} 


\section{PARTE I}

OS GODOS E OS FRANCOS 


\section{Capítulo I - Em busca dos godos e dos francos}

O objetivo deste capítulo é apresentar uma visão geral sobre as informações acerca dos "godos" e dos "francos" em fontes produzidas antes do estabelecimento dessas gentes no Ocidente Europeu, levando em consideração também as contribuições da arqueologia. Com isso, almejamos dois alvos: 1. problematizar as maneiras pelas quais essas gentes foram apresentadas por fontes externas a elas, ou seja, como autores que escreveram sob um ponto de vista "romano" ou sob a autoridade dos imperadores romanos compreenderam essas gentes que aparentemente tornavam-se uma presença política importante nas províncias romanas; 2. Discurtir se as gentes apresentadas nessas fontes tinham uma existência concreta no sentido de se constituírem como um povo coerente que desfrutava de um mesmo senso identitário que fundamentou as bases dos reinos fundados no Ocidente europeu.

A revisão geral das fontes escritas e arqueológicas vem acompanhada de uma discussão acerca das maneiras pelas quais essas informações foram interpretadas pela historiografia e a arqueologia em suas leituras sobre os "bárbaros" e os impactos que eles provocaram no mundo romano.

A importância dessa revisão reside no fato de acreditarmos que, embora essas informações não sejam suficientes para inferirmos a existência dessas gentes como "povos" coesos que migraram com suas tradições políticas e culturais para o Império e provocaram tensões tão marcantes que redundaram na Queda de Roma, elas fundaram uma tradição histórica sobre essas gentes que foram apropriadas futuramente pelos autores que escreveram na Gália Merovíngia e Hispânia Visigoda. O sentido dessas apropriações serão desenvolvidas ao longo da tese. O que importa dizer é que não se trata aqui de tentarmos apenas comprovar ou refutar a existências das gentes, e sim de propor pressupostos para analisarmos o lugar dessas gentes nos 
textos: não a partir de uma análise literária, e sim a partir de uma análise que as entendem como narrativas políticas fundamentadas na construção de um ideal acerca das gentes, ideal esse que chamamos de "identidades políticas". Esse primeiro capítulo é uma introdução a aspectos gerais sobre as gentes e a historiografia sobre elas.

\section{Os godos e os francos: as narrativas das migrações}

Uma pesquisa que se propõe a analisar os usos dos ideais em torno dos godos e dos francos nas fontes produzidas na Gália merovíngia e na Hispania visigoda entre os séculos VI e VIII deve começar pelos próprios francos e godos antes de entrar diretamente no estudo deles nas fontes. Façamos isso partir de um exercício narrativo: vamos contar a história deles pressupondo que existe uma história dos godos e dos francos anterior aos assentamentos nas províncias romanas.

Iniciemos pelos godos. Para tanto a Getica de Jordanes parece ser uma fonte privilegiada já que foi talvez a primeira a localizar uma origem geográfica dos godos. Jordanes começou seu relato tratando de uma ilha, Scandza. Dela uma raça partiu tal como um enxame de abelhas em direção a Europa continental.

Embora ignoradas por Ptolomeu que só falou de sete, naquela ilha muitas nações ${ }^{5}$ existiram. Os Adogit, Screrefannae, Suehans, Theutes, Vagoth, Bergio, Hallin, Liothida, estavam entre elas. Havia ainda os guerreiros Ahelmil, Finnaithae, Fervir e Gauthigoth. Além dos Mixi, Evagre e Otingis, que viviam como animais selvagens, Ostrogodos, Raumarici, Aeragnaricii, Finns, semelhantes a eles eram os Vinovilith. Jordanes falou ainda dos Suetidi, Dani e Heruli, que se destacam pela alta estatura. Havia ainda os Grannii, Augandzi, Eunixi, Taetel, Rugi, Arochi e Ranii, cujo

\footnotetext{
${ }^{5}$ Nesse trecho estamos usando fundamentalmente os termos usado pelo autor. Esse, e outros, serão problematizados ao longo do capítulo.
} 
rei foi Rodulfo por poucos anos. Todas essas gentes superavam os Germanos em tamanho e espírito, e lutavam com a crueldade de bestas selvagens. ${ }^{6}$

Vindos também de Scandza estavam os godos que sob o comando do rei Berig $^{7}$ aportaram seus navios e deram a terra que pisaram o nome de Gothiscandza, logo de lá saíram e partiram para as terras dos Ulmerugi que habitavam as margens do Oceano. Os godos e Ulmerugi batalharam e os últimos foram derrotados e expulsos, depois foram vencidos os Vândalos. Passados cinco anos do reinado de Berig assumiu o controle Filimer, que teve que lidar com o grande incremento no número de godos. Para contornar a situação Filimer decidiu que os exércitos dos godos junto as suas famílias deveriam partir. Chegaram então as terras do escitas, conhecida na língua deles por Oium. Logo os godos encontraram os Spali e mais uma vez guerrearam e saíram vitoriosos e avançaram até o mar de Pontus.

De acordo com Jordanes, todas essas informações são fiadas em antigos cânticos godos. Além dos cânticos ele usou como fonte o cronista Ablablius, cuja obra não chegou aos nossos dias. Mencionou também Flávio Josefo "um fiel relator de anais", mas que para Jordanes, lamentavelmente, não detalhou a origem dos godos em sua obra. Aqui temos um indicativo da importância que as origens, especificamente a dos godos, assumem na obra de Jordanes. O fato de Josefo não a mencionar é tido por Jordanes como uma falha na obra de um cronista que ele considerou no seu texto como competente. Jordanes diz, todavia, que Josefo informou sobre Magog e que os godos eram escitas e assim foram chamados por nome: ${ }^{8}$

Ex hac igitur Scandza insula quasi officina gentium aut certe velut vagina nationum cum rege suo nomine Berig Gothi quondam memorantur egressi: qui ut primum e navibus exientes terras

\footnotetext{
${ }^{6}$ hae itaque gentes, Germanis corpore et animo grandiores, pugnabant beluina saevitia. (Jordanes, Getica, III.)

${ }^{7}$ Um esforço de reconstruir a ordem de sucessão dos reis godos a partir de Jordanes pode ser consultado no Apêndice II.

${ }^{8}$ (Jordanes, Getica, IV).
} 
attigerunt, ilico nomen loci dederunt. nam odieque illic, ut fertur, Gothiscandza vocatur. unde mox promoventes ad sedes Vlmerugorum, qui tunc Oceani ripas insidebant, castra metati sunt eosque commisso proelio propriis sedibus pepulerunt, eorumque vicinos Vandalos iam tunc subiugantes suis aplicavere victoriis. ubi vero magna populi numerositate crescente et iam pene quinto rege regnante post Berig Filimer, filio Gadarigis, consilio sedit, ut exinde cum familiis Gothorum promoveret exercitus. qui aptissimas sedes locaquae dum quereret congrua, pervenit ad Scythiae terras, quae lingua eorum Oium vocabantur: ubi delectatus magna ubertate regionum et exercitus mediaetate transposita pons dicitur, unde amnem traiecerat, inreparabiliter corruisse, nec ulterius iam cuidam licuit ire aut redire. nam is locus, ut fertur, tremulis paludibus voragine circumiecta concluditur, quem utraque confusione natura reddidit inpervium. verumtamen hodieque illic et voces armentorum audiri et indicia hominum depraehendi commeantium attestationem, quamvis a longe audientium, credere licet. haec ergo pars Gothorum, quae apud Filemer dicitur in terras Oium emenso amne transposita, optatum potiti solum, nec mora ilico ad gentem Spalorum adveniunt consertoque proelio victoriam adipiscunt, exindeque iam velut victores ad extremam Scythiae partem, que Ponto mari vicina est, properant, quemadmodum et in priscis eorum carminibus pene storicu ritu in commune recolitur: quod et Ablavius descriptor Gothorum gentis egregius verissima adtestatur historia, in quam sententiam et nonnulli consensere maiorum: Ioseppus quoque annalium relator verissimus dum ubique veritatis conservet regulam et origines causarum a principio revolvat. haec vero quae diximus de gente Gothorum principia cur omiserit, ignoramus: sed tantu Magog eorum stirpe comemorans, Scythas eos et natione et vocabulo asserit appellatos. ${ }^{9}$

Essa relação entre os godos com Magog e os escitas vai aparecer em outras histórias, como as de Isidoro de Sevilha. Mostraremos isso mais a frente. Por enquanto vamos continuar a seguir Jordanes em seu relato sobre os movimentos dos godos no que hoje corresponde ao atual território europeu. Jordanes, sempre alegando ter se baseado em fontes confiáveis, descreve três grandes movimentos migratórios godos. O primeiro os levou as terras dos escitas, nas proximidades do Maeotis, atual mar de Azov, depois foram à Moésia, Trácia e Dácia até que enfim retornaram as regiões escitas e se instalaram nas proximidades do mar de Pontus, atual Mar Negro. ${ }^{10}$

\footnotetext{
${ }^{9}$ Tradução disponível no anexo 1.

${ }^{10}$ [...]quos tantorum virorum formidavit audacia, quorum mansione prima in Scythiae solo iuxta paludem Meotidem, secundo in Mysiam Thraciamque et Daciam, tertio supra mare Ponticum rursus in Scythia legimus habitasse[...]. (Jordanes, Getica, V)
} 
Notamos que os movimentos dos godos se concentraram no que hoje corresponde ao leste europeu, próximo as estepes da onde veio o flagelo dos hunos que seria decisivo para o estabelecimento dos godos dentro dos limites do Império Romano. Esse tema, ou seja, o do "flagelo dos hunos", vai também se manter em outras histórias, e mais uma vez mencionamos o exemplo de Isidoro de Sevilha.

Embora Zózimo tenha registrado que foi a partir do império de Treboniano Galo que os bárbaros, dentre eles os godos, ameaçaram com maior intensidade o Império, Jordanes anotou que durante o governo de Domiciano os godos quebraram os laços de paz com Roma e teve inicio uma batalha donde os Romanos saíram derrotados. A vitória dos godos, conforme o autor da Getica, foi tão notável que os godos começaram a chamar os líderes responsáveis por esse feito de "semi-deuses".

Jordanes tratou ainda da divisão entre os visigodos e ostrogodos. Sobre isso seu texto consiste possivelmente no único de sua era no qual a questão é colocada. Segundo Jordanes, mencionando como fonte Ablatius, a divisão entre ostrogodos e visigodos fundamenta-se no fato de que os godos da região leste do mar Pôntico, cujo rei era Ostrogotha, foram chamados de ostrogodos, tanto por causa da região que ocupavam quanto por causa do nome do referido rei. Os outros godos foram chamados de visigodos, ou seja, godos da parte ocidental. ${ }^{11}$ Depois dessa explicação, Jordanes relatou a ameaça que os hunos representavam para os godos e o consequente pedido de ajuda que os godos fizeram ao imperador romano Valente, que aproveitou a ingenuidade deles e enviou sacerdotes da heresia ariana que os converteu ao arianismo. É nesse ponto que o relato de Jordanes mais se aproxima do de outras Histórias, como a de Isidoro de Sevilha e Paulo Orósio. Vamos retomar isso adiante.

\footnotetext{
${ }^{11}$ XIV. Nunc autem ad id, unde digressum fecimus, redeamus doceamusque, quomodo ordo gentis, unde agimus, cursus sui metam explevit, Ablabius enim storicus refert, quia ibi super limbum Ponti, ubi eos diximus in Scythia commanere, ibi pars eorum, qui orientali plaga tenebat, eisque praeerat Ostrogotha, utrum ab ipsius nomine, an a loco, id est orientales, dicti sunt Ostrogothae, residui vero Vesegothae, id est a parte occidua. (Jordanes, Getica, XIV).
} 
O que é preciso dizer a partir do que até aqui foi colocado é que Jordanes é a fonte textual que localiza a origem dos godos na Escadinávia e os acompanha até seus primeiros contatos com o Império, textos como a História Nova de Zózimo versam sobre os contatos entre os godos e o Império no século III, mas seu ponto de vista é profundamente romano e outorga a esses contatos um caráter catastrófico. Jordanes dá uma dimensão totalmente diferente para isso. A questão é: Por que o relato de Jordanes possui esse tom particular?

O primeiro traço notável é que o De origine actibusque Getarum, comumente conhecido como Gética depois da edição feita pelo monumentista Mommsen, ${ }^{12}$ tem todas as tópicas características dos textos históricos, dentre as quais a preocupação em atestar a verdade das informações mediante a referência a fontes confiáveis ${ }^{13}$ e o próprio fato de narrar a origem dos godos. ${ }^{14} \mathrm{~A}$ história, como atestam muitas das fontes, tinha como prerrogativa a obrigação de narrar a verdade, ${ }^{15}$ de modo que se nos

\footnotetext{
${ }^{12}$ Iordanis. Romana et Getica. Ed: Mommsen, T. MGH.A.A. Tomo V. 1882.

${ }^{13}$ Jordanes, conforme as palavras iniciais da Gética, escreveu a pedido de Castalius que o requisitou para sumarizar os doze livros sobre a história dos godos de Cassiodoro. Ele salientou que não estava com a obra de Cassiodoro enquanto escrevia e que apenas a leu há um certo tempo. Para dar conta desse lapso Jordanes afirmou que se fiaria em histórias latinas e gregas além de detalhes inseridos por ele mesmo. Além desse trecho de abertura, Jordanes acrescentou mais a frente: "aut certe si quis eos aliter dixerit in nostro urbe, quam quod nos diximus, fuisse exortos, nobis aliquid obstrepebit: nos enim potius lectioni credimus quam fabulis anilibus consentimus" (Getica, 38).

${ }^{14} \mathrm{O}$ tema das origens era caro aos historiadores que antecederam Jordanes. (Cf: MOMIGLIANO, A. Some observations on the 'Origo Gentis Romanae'. The Journal of Roman Studies, v.48, n.1/2, p.5673, 1958. Ver ainda: BICKERMAN, E. Origines Gentium. Classical Philology, v.47, n.2, p.65-81, 1952.) Flávio Josefo, citado pelo próprio Jordanes (Getica, IV) ocupara-se com a origem dos judeus, apontando para a importância que o Origo tinha entre fontes usadas pelo próprio Jordanes. Cf: Flávio Josefo, Contra Ápio, especialmente: 1 e 2.

${ }^{15}$ Fizemos essa discussão na dissertação de mestrado: SILVEIRA, Verônica da Costa. História e historiografia na Antigüidade Tardia à luz de Gregório de Tours e Isidoro de Sevilha. 2010. 181 f. Dissertação de Mestrado - Faculdade de Filosofia, Letras e Ciências Humanas/USP. São Paulo, julho de 2010. Para estudos mais profundos: GUENÉE, B. Histoire et culture historique dans l'Occident Médiéval. Paris : Aubier Montaigne, 1980. GABBA, Emilio. True and false history in Classical Antiquity. The Journal of Roman Studies. v.71, p.50-62, 1981. Para um estudo mais contemporâneo e que oferece uma leitura inovadora sobre a escrita da história na Idade Média a partir do estudo das Historiae de Raul Glaber: ALMEIDA, Néri de Barros. Raul Glaber: um historiador na Idade Média (980/985-1047). Revista Signum. vol.11, n.2. p.76-108. 2010. Como muito bem aponta Almeida, os historiadores contemporâneos enxergaram com reservas a verdade do texto dos historiadores do medievo, baseando-se em Guenée ela sublinha: "No que diz respeito à verdade, a distinção feita pela retórica clássica entre a historia que diz a verdade, o argumentum que não diz a verdade, mas o verossímil, e a fabula cujo relato não é verdadeiro, os autores da Idade Média reconheceram fundamentalmente a oposição entre verdade histórica e ficção. No entanto, tendo em vista os problemas
} 
atermos à interpretação mais simplória da definição poderíamos atestar a confiabilidade dos relatos de Jordanes pelo próprio fato dele ter escrito uma história, ou mais precisamente uma origo, que de acordo com Bickerman e Momigliano ${ }^{16}$ assumiu aspectos sinonímicos com o gênero historia. Mas se seguirmos essa linha incorreremos numa grave falácia lógica que toma a fonte como próprio referencial de confiabilidade. O fato de Jordanes ter escrito uma História dos godos não dá ao seu texto veracidade por ter sido uma História, mas pode dizer algo sobre como ele queria que o texto fosse recebido.

Numa passagem da Getica $^{17}$ o autor defende sua versão para a origem dos godos alegando que ele havia se fiado em História. Jordanes argumentou que se alguma pessoa na cidade discordasse do que ele escrevia sobre a origem dos godos, poderia questioná-lo, mas ele preferia acreditar nas coisas que estavam escritas no que em antigas fábulas de mulheres velhas. É possível inferir que a insistência da utilização de fontes escritas nesse trecho em particular denota um desacordo sobre a origem dos godos, é este, a propósito, o trecho mais incisivo da afirmação da confiabilidade dos relatos, onde se delineia um contraste entre a fábula e a lectio (leitura, o que se lê). Ao ter alegado que escreveu uma História usando como fonte de informações outras Histórias, Jordanes queria fortalecer sua versão frente a outras que possivelmente circulavam. Jordanes estava, assim, afirmando o seu texto.

\footnotetext{
de incongruência textual entre o Antigo e o Novo Testamento enfrentados pelos primeiros cristãos, a verdade do texto passou a ser definida a partir ora do sentido literal do escrito, ora a partir da interpretação do "espírito da letra". O relato histórico medieval vai além, sendo a história uma narrativa discursiva específica dos eventos reais considerados dignos de memória ocorridos no passado remoto ou imediato em uma perspectiva cronológica." (p.85) Evidentemente que o sentido que a verdade ocupa nas Historiae de Raul Glaber, e em histórias anteriores, como os Decem Libri Historiarum de Gregório de Tours, não deve ser tomado na acepção atual do termo. Almeida aponta as especificidades no texto de Raul Glaber, esforçar-me-emos por fazê-los nas obras que serão apreciadas no decorrer da pesquisa. Retomaremos o problema no capítulo dedicado às Historiae.

${ }^{16}$ BICKERMAN, E. Origines Gentium...op.cit. MOMIGLIANO, A. Some observations on the 'Origo Gentis Romanae'...op.cit.

${ }^{17}$ Gética, 38.
} 
Nesse momento tocamos numa questão importante para a historiografia produzida sobre Jordanes, a saber, quais eram suas fontes? Essa questão é, como veremos, crucial para a historiografia que se dedicou ao estudo da obra uma vez que o texto do autor foi interpretado como infiel aos fatos e mesmo como uma mera cópia da obra perdida de Cassiodoro que versaria sobre a história dos godos. Por outro lado, o texto de Jordanes foi também tomado como uma fonte fiável para a interpretação de materiais arqueológicos que comprovariam as migrações dos godos a partir da Escandinávia. Em poucas palavras os relatos de Jordanes é interessante para pensarmos dois elementos intimamente relacionados com dois problemas contemplados na pesquisa:

1. Os relatos sobre os godos que a partir do século VI seriam retomados por autores que escreveram desde a Hispânia. Essas apropriações foram de grande importância para a construção de memórias acerca do passado godo centralizado na figura dos reis com a finalidade de reforçar a autoridade deles num cenário de polarização política;

2. As maneiras pelas quais a historiografia e a arqueologia usaram os relatos escritos para comprovar as hipóteses acerca da "migração dos povos" e as críticas que emergiram a essa abordagem.

Comecemos por T. Mommsen. ${ }^{18} \mathrm{O}$ pesquisador listou os autores que ele identificou como as principais fontes de Jordanes: Pompeu Trogo, Virgílio, Lívio, Strabo, Pompônio Mela, Lucano, o já mencionado Josefo, Dio, Tácito, Cláudio Ptolomeu, Dexipus, Fábio, Amiano Marcelino e seu continuador, Rufino, Próspero, Priscus e o misterioso Ablablius - que Mommsen coloca como uma das principais

\footnotetext{
${ }^{18}$ Iordanis. Romana et Getica. Ed: Mommsen, T. MGH.A.A. Tomo V. 1882. p. XXX-XLIV.
} 
fontes de Jordanes, hipótese fortemente questionada por B. Baldwin. ${ }^{19}$ Todavia, nem todos esses autores são citados diretamente por Jordanes e algumas fontes que Mommsen identifica como base em alguns trechos jordanianos estão perdidas, como por exemplo a Historia de Pompeu Trogo, dessa maneira a lista elaborada pelo editor monumentista é passível de crítica já que é extremamente difícil comprovar as fontes de Jordanes a partir de textos perdidos. Mas sem dúvidas dentre as principais supostas fontes de Jordanes o autor que se destaca é Cassiodoro e seus perdidos doze livros.

O próprio Jordanes afirmou que escrevia a sua Gética a pedido de um amigo para sumarizar essa obra perdida de Cassiodoro, não sem antes frisar que a labuta era especialmente difícil por ter tido pouco contato com os livros, de modo que recorreu a outros autores e relatos inseridos por ele próprio. Ora, mesmo frente a essas palavras, a Getica foi interpretada amiúde como uma mera cópia do texto de Cassiodoro. Assim defende Wolfram que retratou Jordanes como o preservador de Cassiodoro para a posteridade $^{20}$ e o utiliza como uma fonte direta para Cassiodoro. ${ }^{21}$ A leitura de Wolfram da Gética não consiste, afinal, numa leitura de Jordanes e sim do texto perdido de Cassiodoro, exercício bastante peculiar para um texto que não chegou aos nossos dias. Kulikowski é ainda menos generoso com Jordanes, além de afirmar que talvez a Getica seja apenas uma sombra pálida da Historia de Cassiodoro, desmerece quase que completamente as informações registradas no escrito. ${ }^{22}$ Para Kulikowski Jordanes foi um autor desimportante valorizado pela historiografia motivada por questões nacionalistas importantes tanto no pré quanto no pós guerra.

\footnotetext{
${ }^{19}$ BALDWIN, B. Sources for the Getica of Jordanes. Revue belge de philologie et d'histoire. T.59, fasc.1, p.141-146, 1981.

${ }^{20}$ WOLFRAM, H. History of the Goths. Berkeley, Los Angeles, London: University of California Press, 1987. p.36.

${ }^{21}$ Como podemos muito bem notar num artigo publicado em 1990: WOLFRAM, H. Le genre de 1’Origo gentis. Revue belge de philologie et d'histoire. T. 68, fasc.4, p.789-801. 1990.

${ }^{22}$ KULIKOWSKI, M. Rome's Gothic Wars. From the third century to Alaric. Cambridge, NY: Cambridge University Press, 2007.p. 43-52.
} 
Essa "falta de originalidade" de Jordanes - já que seus textos seriam meras cópias - foi duramente combatida por pesquisadores como B. Croke e W. Goffart. ${ }^{23}$ Para B. Croke, é possível deduzir que Jordanes foi um godo que serviu, como seu avô, como notarius de um general do Império Oriental chamado Gunthigis ou Baza. ${ }^{24}$ Sobre o latim considerado ruim de Jordanes, o pesquisador assevera que o autor não aprendeu o idioma romano para ler os clássicos, e sim para lidar com documentação militar, que era o seu trabalho. Enquanto Jordanes trabalhava em sua Romana, seu amigo Castalius pediu que ele sumarizasse os doze livros da história dos godos de Cassiodoro. Todavia, Jordanes não teve acesso ao texto de Cassiodoro enquanto escrevia sua Getica. Havia tão-somente lido por breves três dias a obra, de modo que foi obrigado a recorrer à memória quando usou Cassiodoro como fonte, fato que enfraquece a tese de que sua Getica era de fato uma mera cópia de Cassiodoro. ${ }^{25}$ Essa é a hipótese essencial defendida por B. Croke, a saber, Jordanes não foi um mero copista.

Dentre as evidências levantadas por Croke, temos a citação de vários outros autores na Getica, como Orósio, Lívio, Strabo, Tácito, Dio Crisóstomos, Ptolomeu e Flávio Josefo, sobre alguns deles Jordanes demostrava ter conhecimentos que iam além de uma mera atividade copista. Jordanes citou ainda a tradição oral dos godos fonte relativizada, por outro lado, por Goffart - tradição esta que não era de conhecimento de Cassiodoro que tampouco conhecia a língua dos godos. Jordanes também citou fontes gregas, idioma que Cassiodoro também não dominava, conforme Croke. O pesquisador também infere que as passagens pró-godos presentes na Getica podem enunciar o uso de Cassiodoro por Jordanes, todavia, o profundo anti-arianismo

\footnotetext{
${ }^{23}$ CROKE, Brian. Cassiodorus and the Getica of Jordanes. Classical Philology. v. 82, n.2, p. 117-134, abril de 1987. GOFFART, Walter. Jordane's "Getica" and the disputed authenticity of Gothic origins from Scandinavia. Speculum. v. 80, n.2, p.379-398, Abril de 2005.

${ }^{24}$ CROKE, Brian. Cassiodorus and the Getica of Jordanes...op.cit. p. 119.

${ }^{25}$ Ibidem. p.120-121.
} 
demonstrado por Jordanes é outro elemento que nos leva a questionar sua total submissão ao texto de Cassiodoro. ${ }^{26}$

Tanto Croke quanto Goffart compartilham da opinião de que se há alguma propaganda política na Getica, ela consiste ao louvor as conquistas de Justiniano. ${ }^{27}$ Mas as interpretações sobre as intenções de Jordanes com sua Getica são sensivelmente distintas nos estudos de Croke e Goffart. Para o primeiro, Jordanes previu a união dos godos e romanos em uma Itália bizantina reconquistada. Ele compartilhava da visão otimista de Justiniano e é possível que desejasse que o Império Romano fosse energético em seu controle sob a Itália. Para tanto, Jordanes parecia acreditar que o general Belisário era a pessoa ideal. Belisário havia sido forçado a se retirar de suas funções militares e em seu lugar entrou Narses, pela negligencia de Jordanes em falar de Narses, Croke defende que o autor pode ter sido um partidário de Belisário. ${ }^{28}$

Outro autor que tratou esse tema e que merece destaque é W. Goffart. Ele foi além na crítica à subjugação de Jordanes a Cassiodoro e seus argumentos merecem uma análise detida uma vez que tocam em um problema mais profundo que permeia esta pesquisa.

Goffart é um grande crítico da Escola da Viena, grupo de pesquisadores que privilegiam o processo de etnogênese dos bárbaros como um fator importante para a história da Europa Ocidental após a polarização da autoridade política nas mãos de líderes de origem estranha ao Império Romano. Seu artigo específico sobre Jordanes é

\footnotetext{
${ }^{26}$ Ibidem. p.123-125.

${ }^{27}$ Ibidem. p. 127. GOFFART, Walter. Jordane's "Getica" and the disputed authenticity of Gothic origins from Scandinavia...op.cit. p. 395-396.

${ }^{28}$ CROKE, Brian. Cassiodorus and the Getica of Jordanes...op.cit. p. 127-128.
} 
um forte ataque aos pesquisadores identificados com a Escola de Viena, ${ }^{29}$ especialmente R. Wenskus, H. Wolfram e W. Pohl.

Nesse texto, Goffart se dedica ao problema da origem dos godos na ilha de Scandza conforme descrito na Getica de Jordanes. Goffart logo começa sua crítica aos estudos de Wolfram, segundo o qual as origens escandinavas dos godos era mais uma "lenda" cara aos Amali, família a qual pertencia Teodorico, o Ostrogodo, do que uma tradição compartilhada por todos os godos. Wolfram também atribuiu o mérito da Getica a Cassiodoro e analisou o texto de Jordanes como um atrelamento da história dos godos à história romana. Segundo Goffart, a interpretação de Wolfram se deve a um trecho do texto de Jordanes cuja tradução é problemática, ou seja: “Originem Gothicam historiam fecit esse Romanam", que Goffart traduziu como "Ele voltou o descendente [ou passado] dos godos para uma história de estilo romano". 30

Goffart aproxima-se da interpretação de Croke ao assumir uma postura crítica frente àqueles que diminuem o trabalho de Jordanes e então estabelece algumas proposições a partir de uma abordagem que entende Jordanes como um escritor qualificado. Enumera Goffart:

- Jordanes escreveu sob uma perspectiva Oriental e não quis ser considerado simpatizante dos godos;

- Jordanes começou seu trabalho a pedido de um amigo que quis que ele sumarizasse o trabalho de Cassiodoro;

- Quando o amigo de Jordanes fez o pedido, Cassiodoro estava em um autoexílio na Itália e levou consigo seus doze livros sobre a história dos godos, de modo que Jordanes não pôde consulta-los diretamente quando escreveu sua Getica;

\footnotetext{
${ }^{29}$ Sobre a qualificação "Escola de Viena" e "Escola de Toronto": CURTA, F. Some Remarks on ethnicity in medieval archaeology. Early Medieval Europe. v.15, n.2, p. 159-185. 2007.

${ }^{30}$ GOFFART, Walter. Jordane's "Getica" and the disputed authenticity of Gothic origins from Scandinavia...op.cit.p. 381-382.
} 
- Jordanes só teve três dias de acesso ao texto de Cassiodoro e disse que não pôde copiá-lo integralmente, mas manteria o argumento e as informações factuais. Jordanes usou ainda outras fontes para sua labuta. $^{31}$

Apesar de Jordanes alegadamente ter usado Cassiodoro como fonte, pelo fato de texto de Cassiodoro ter se perdido, não há como saber o quanto Jordanes usou de Cassiodoro. Ainda, mesmo que Jordanes tivesse copiado trechos de Cassiodoro, ele não produziu uma imagem exatamente igual ao o que escreveu Cassiodoro. ${ }^{32}$

Sobre as origens escandinavas dos godos, Goffart afirma que Jordanes, ao falar de Scandza, não estava contra a história factual, estava, ao contrário, comprometido com os fatos. Muito embora Jordanes tenha sido o primeiro a ligar os godos à Scandza, antes dele outros autores associaram os godos com o Norte da Europa, como Ambrósio de Milão e o poeta latino Claudiano. ${ }^{33}$ De modo que, se não há como confirmar a origem escandinava sem sombra de dúvidas, Jordanes não parecia estar inventando as informações do nada. No que concerne à leitura de Goffart, que evidentemente é um ataque à interpretação de Wolfram, parece-nos que ao menos nesse ponto Goffart nos ofereceu uma leitura mais consistente. Ora, é muito difícil afirmar que Jordanes copiou um texto justamente por não termos esse texto para comparar.

Goffart volta então aos ataques à Escola de Viena. Diz ele que W. Pohl segue a mesma linha de Wenskus e Wolfram ao questionar as origens escandinavas dos godos. Segundo ele essas origens estavam no âmbito meramente discursivo e não correspondem aos fatos. Isso tem muito a ver com a Escola de Viena que defende a etnogênese como um processo ocorrido entre tribos diversas em contato com o

\footnotetext{
${ }^{31}$ Ibidem.. p. 385-386.

${ }^{32}$ GOFFART, Walter. Jordane's "Getica" and the disputed authenticity of Gothic origins from Scandinavia...op.cit.p. 386.

${ }^{33}$ Ibidem, p.387.
} 
Império Romano. Não é de se surpreender que os partidários dessa perspectiva seriam muito críticos a qualquer referência a uma origem comum, por exemplo, dos godos. Goffart, como forte crítico ao uso do conceito de etnogênese, vai em direção à possibilidade sim de uma origem gótica na Escandinávia. ${ }^{34}$

Goffart apresenta então sua hipótese para a Getica de Jordanes e seus objetivos. Conforme ele, Jordanes estava a serviço do Império Romano e desejava a retomada da Itália pelo Bizâncio. Para Goffart, enquanto Cassiodoro escreveu seus doze livros a pedido de Teodorico e, possivelmente, tendeu a legitimar o governo ostrogodo na Itália, Jordanes escreveu após a derrota dos ostrogodos e enquanto um homem pró-justiniano. Ora, após a derrota dos ostrogodos na Itália, seria interessante preservar uma obra que justamente comemorava o governo ostrogodo na Itália? Goffart assevera que não e foi nesse ponto que entrou Jordanes com seu texto a favor do governo bizantino na Itália. Goffart diz que se Jordanes usou Cassiodoro, foi para conformar a história daquele ao novo contexto da Península Itálica. ${ }^{35}$ Goffart chegou a afirmar que a obra de Jordanes contribuiu para que o texto de Cassiodoro se perdesse. Goffart enumera então, a título de conclusões, que:

1. A Getica foi escrita na Constantinopla sob Justiniano em algum tempo depois de Março de 551;

2. A Getica celebrou as vitórias de Justiniano e Belisário, não era pró-gótica;

3. Talvez Jordanes fosse realmente de origem goda;

4. Jordanes não corroborou com a possível tese de Cassiodoro que via os Amali como legítimos para governar a Itália; ${ }^{36}$

\footnotetext{
${ }^{34}$ GOFFART, Walter. Jordane's "Getica" and the disputed authenticity of Gothic origins from Scandinavia...op.cit. p. 387-388. Outro autor que sugere essa possibilidade a partir da análise dos topônimos é: BRINK, S. People and Land in Early Scandinavia. In: GARIPZANOV, I.H; GEARY, P. \& URBAŃCZYK, P. Franks, Northmen and Slavs: Identities and State Formation in Early Medieval Europe. Turnhout: Brepols, 2008. p.87-112.

${ }^{35}$ BRINK, S. People and Land in Early Scandinavia...op.cit., p.396.

${ }^{36}$ Todos os argumentos são discutidos com mais vagar no livro: GOFFART, W. The narrators of barbarian History. Jordanes, Gregory of Tours, Bede and Paul the Deacon. New Jersey: Princeton University Press, 1988. Na primeira parte dedicada à Jordanes.
} 
Nessa medida, para o historiador nem os doze livros de Cassiodoro nem a Getica de Jordanes se inseriam no gênero das origines de gentes não clássicas, eram obras que referenciavam essas origens como pano de fundo para um intento político. A busca pelas origens dos godos não era, portanto, o fim mesmo dos textos. Até que ponto, então, podemos acreditar nas informações sobre a origem dos godos em Scandza? Até que ponto foi legítimo os usos feitos da Getica para comprovar as migrações dos godos e a origem escandinava deles?

Para Dagron, a Getica traz uma visualização do mundo baseada em três tradições: explicitamente advinda de Orósio e Julius Honorius, que mencionam a Britannia, mas sem qualquer referência à Scandza; os detalhes sobre Scandza eram oriundos de Ptolomeu, que Dagron diz ser uma fábula; a terceira tradição é romana, nela, ao norte havia um golfo onde no centro, tendo ao leste Scythae, ao oeste a Britannia e ao sul a Germania e Sarmatia, estava uma ilha que Pomponio Mela nomeou como "Codanovia". Ao mesclar essas três tradições Jordanes trouxe a Scandza, vinda de uma tradição ptolomeica até então em desuso, para a história e geograficamente a inscreveu na Codanovia. Entre o crepúsculo do século VII e início do VIII Scandza foi registrada na Cosmografia de Ravena, onde Jordanes foi citado oito vezes. $^{37}$

Se Jordanes não inventou que os godos vieram do Norte, como aponta Goffart, a relação entre os godos e Scandza parece ter sido uma idéia ou propagada pelo autor a partir de Cassiodoro ou, caso ele não seja uma fonte fiável, forjada por ele. Ao menos não temos outras fontes para contrapor as duas hipóteses. De todo modo, como já apontamos, a versão de Jordanes não foi contemplada por Isidoro de Sevilha, a quem se atribui a escrita da história "nacional” dos godos, talvez porque o hispalense

\footnotetext{
${ }^{37}$ DAGRON, G. Une lecture de Cassiodore-Jordanès: les Goths de Scandza à Ravenne. Annales.
} Histoire, Sciences Sociales, 26, n.2, p.290-305, 1971. 
desconhecia o texto de Jordanes, ou talvez porque ele optou por não se fiar em um autor que escreveu em prol do Império Oriental, contra o qual o regnum gothorum combateu para conquistar o sudeste da Hispania. ${ }^{38}$ De todo o modo não cabem conjecturas sobre a questão, trabalhar a partir de ausências é uma empreitada no mínimo arriscada.

O outro ponto de vista para pensarmos o problema é a arqueologia. Em poucas palavras, o relato de Jordanes pode ser confrontado com os resquícios arqueológicos para a construção de um quadro sinóptico dos movimentos populacionais supostamente advindos da Escandinávia?

M.Todd defende que resquícios arqueológicos sustentam que movimentos migratórios vindos do sul da Escandinávia em períodos dispersos, não numa migração maciça como indica o relato de Jordanes, redundaram num acréscimo de cultura material na Ucrânia a partir do século II d.C. Mas foi entre os séculos III e V que as mudanças nos resquícios se tornaram mais significativas. Essas transformações foram identificadas por arqueólogos como a cultura "Santana de Mureș", na Romênia, e cultura "Černjakhov", na Ucrânia. ${ }^{39}$ E.A. Thompson mencionou a relação entre a cultura Santana de Mureș e os godos, mais especificamente os visigodos, a partir de escavações arqueológicas conduzidas no início do século XX que encontraram

\footnotetext{
${ }^{38}$ A tese de Goffart de Jordanes como um participante de política bizantina, todavia, não é consensual. Uma hipótese que contraria as interpretações comuns sobre Jordanes foi apresentada por J.J. O’Donell que defendeu que Jordanes estava à parte de questões políticas e foi motivado apenas pelas religiosas (O'DONNELL. The aims of Jordanes. Historia: Zeitschrift für Alte Geschichte, v.31, n.2, p.223240, 1982). Se a hipótese de O`Donnell se sustentasse, o argumento de que a Getica foi preterida por Isidoro de Sevilha por sua versão pró-bizâncio dos fatos cairia, nesse caso poderíamos apontar para outra possibilidade, a de que Isidoro de Sevilha desconhecia a Getica. Sobre as tensões entre Bizâncio e godos que estariam expressas nas Historiae de Isidoro de Sevilha: HILLGARTH, J.N. Historiography in Visigothic Spain. In: Settimane di studio del centro italiano di studi sull'alto Medioevo, XVII. La storiografia altomedievale. Tomo primo. Spoleto: Centro italiano di Studio sull'alto medioevo, 1970. p.261-311. Perspectiva semelhante sustentou Rodriguez Alonso: RODRIGUEZ ALONSO, Cristóbal. Las historias de los godos, vandalos y suevos de Isidoro de Sevilla. Estudios, edición crítica y traducción. Leon: centro de estudios e investigación "San Isidoro". Archivo historico diocesano Caja de ahorros y Monte Piedad de Leon, 1975.

39 ELLIS, L. 'Terra Deserta': Population, Politics, and the [de]Colonization of Dacia. World Archaeology, v.30, n.2, p.220-237, 1998.
} 
espadas identificadas como visigóticas. ${ }^{40}$ Pesquisadores como V. Bierbrauer ${ }^{41}$ corroboram com a identificação das culturas Santana de Mureș e Černjakhov com os godos, embora, como bem destacou Kulikowski, ${ }^{42}$ seja extremamente difícil definir o quê no ambiente multiétnico dos Balcãs era especificamente godo.

Para Kulikowski a relação feita por autores como Thompson e Bierbrauer é equivocada uma vez que a história dos godos começou no século III com os contatos com os romanos, antes não existia um grupo étnico gótico. M. Todd reconhece a dificuldade em identificar o que era efetivamente godo nos Balcãs, segundo ele as populações vindas da Escandinávia mantiveram contatos com populações das estepes asiáticas e no século III é observável a simbiose entre as culturas matérias desses grupos étnicos diversificados. Todd, entretanto, aponta para as dificuldades sem chegar ao extremo de Kulikowski de subordinar totalmente a história dos godos ao Império Romano.

Observamos que a questão é de extrema complexidade. Não há evidências conclusivas para afirmarmos a veracidade dos relatos de Jordanes. Textualmente ele é a única fonte que liga os godos com Scandza. Arqueologicamente é questionável sugerir qualquer continuidade entre culturas matérias escandinavas e balcânicas a ponto de ser possível falar numa origem escandinava dos godos, mesmo que essa continuidade fosse seguramente observável, não teríamos como afirmar que essas populações advindas da Escandinávia se identificavam como "godas".

O que deslumbramos é um cenário de grande dificuldade para mapearmos os godos além das fontes escritas. Todavia, é importante destacar que Jordanes não é a

\footnotetext{
${ }^{40}$ THOMPSON, E.A. Early Germanic Warfare. Past \& Present, n.14, p. 2-29, 1958. Nota 40.

${ }^{41}$ BIERBRAUER, V. 'Archäologie und Geschichte der Goten vom 1.-7. Jahrhundert'. Frühmittelalterlichen Studien, n. 28, p.51-172, 1994. Para uma interessante discussão sobre o tema: HÄRKE, H. Archaeologists and Migration. A problem of attitude? Current Anthropology. v.39, n.1, p. 19-45, 1998. p.23.

${ }^{42}$ KULIKOWSKI, M. Rome's Gothic Wars...op.cit. p. 63-70.
} 
nossa única fonte sobre eles. Outros autores descreveram os godos e em suas narrativas eles desempenham um papel importante.

O fato é que as únicas fontes das quais dispomos sobre os godos, além de Jordanes, foram produzidas por autores do Império Romano. Zózimo, que escreveu entre os séculos V e VI, é cotado como a mais confiável fonte sobre os godos do século III, ou seja, a mais confiável das fontes é de dois séculos depois dos eventos descritos! Mesmo assim, como poderíamos afirmar que os godos de Zózimo do século III eram os mesmos que derrotaram as tropas de Valente na batalha de Adrianópolis e saquearam Roma em 410?

Se Zózimo nos traz notícias do godos no século III, Amiano Marcelino que escreveu no século IV, antes, portanto, de Zózimo, dedicou também significativos trechos de sua Historia a eles. Não por acaso. Durante o governo de Juliano (361-363) os godos já despontavam como uma possível ameaça mais grave contra o Império a ponto dos membros de círculo próximo ao imperador alertarem para a necessidade dele avançar contra os godos, ao que Juliano, engajado em batalhas contra os persas e sassânidas, deu pouca importância e respondeu que contra os godos os Gálatas já eram suficientes. ${ }^{43}$ A partir de agora seguimos o relato de Amiano Marcelino.

Poucos anos depois da morte de Juliano, em 364, após a morte de Joviano, ascendeu ao poder Valentiniano I, que nomeou o irmão Valente para ser o Augusto do império Oriental, enquanto Valentiniano I se responsabilizou pelo Ocidental. ${ }^{44}$ Durante o governo dos irmãos o relato de Amiano Marcelino indica que os assédios

\footnotetext{
${ }^{43}$ 8. Quae cum ita divideret, nihil segnius agi permittens, suadentihus proximis, ut aggrederetur propinquos Gothos, saepe fallaces et perfidos, hostes quaerere se meliores aiebat : illis enim sufficere mercatores Galatas, per quos uhique sine condicionis discrimine venundantur. (Amiano Marcelino, Res Gestae, L. XXII, 7.

${ }^{44}$ Para uma reflexão sobre a partilha: FRIGHETTO, Renan. A Antiguidade Tardia. Roma e as monarquias romano-bárbaras numa época de transformações. Séculos II-VIII. Curitiba: Juruá, 2012. p.120-124.
} 
bárbaros contra o Império se intensificaram, e dentre os inimigos apareciam os godos cujo perigo foi minimizado por Juliano:

5. Hoc tempore velut per universum orbem Romanum, bellicum canentihus bucinis, excitae gentes saevissimae, limites sibi proximos persultahant. Gallias Raetiasque simul Alamanni populabantur; Sarmatae Pannonias et Quadi; Picti Saxonesque et Scotti, et Attacotti Britannos aerumnis vexavere continuis ; Austoriani Mauricaeque aliae gentes, Africam solito acrius incursabant; Thracias et Pannonias diripiebant praedatorii globi Gothorum. ${ }^{45}$

O relato cresce em dramaticidade no que concerne aos godos. Seus assédios contra a Trácia aumentam e eles aparecem como participantes da tentativa de Procópio de usurpar o poder de Valente, desta forma, inseriram-se nas próprias disputas internas que ameaçavam a estabilidade do Império, o fenômeno não parece ser uma novidade, lembremos Treboniano Galo e o apoio que ele obteve dos godos, como registrou Zózimo. Mas as consequências do incremento da ameaça goda no relato de Amiano Marcelino toma proporções mais graves e sinais vaticinavam o que estava prestes a acontecer com o imperador Valente e as terríveis provações que assolariam o Império. ${ }^{46}$

A situação se agravou muitíssimo com o aparecimento dos hunos, descritos como de hábitos tão selvagens e compleição tão grotesca que poder-se-ia questionar se eram homens. ${ }^{47}$ Seus ataques começaram contra o halani e com resultados catastróficos, logo Atanarico e seus Theuringi - identificados como uma banda goda foram também atacados pelos hunos. $\mathrm{O}$ ataque repentino obrigou Atanarico a fugir e alguns de seus subordinados godos desertaram, outros godos tiveram notícias do flagelo huno e decidiram que a melhor escapatória era a Trácia, por suas terras férteis

\footnotetext{
45 Amiano Marcelino, Res Gestae, XXVI, 4. Tradução disponível no anexo I.

${ }^{46}$ Amiano Marcelino, Res Gestae, XXXI, $1,1$.

${ }^{47}$ Amiano Marcelino, Res Gestae, XXXI, 2, 1-25.
} 
e barreiras naturais que impediriam os ataques fulminantes dos hunos. ${ }^{48}$ Sob a liderança de Alavivus os godos se estabeleceram nas margens do Danúbio e mandaram enviados para Valente a fim de pedir que o Imperador os abrigasse, jurando que viveriam pacificamente e disponibizariam auxiliares se as circunstâncias exigissem. Os recém-chegados foram imprudentemente recebidos com otimismo, sem que os riscos fossem ponderados, ${ }^{49}$ a ruína de Roma tinha início. ${ }^{50}$

Como se já não fosse suficiente a ameaça que um grupo tão significativo de bárbaros representavam no interior do Império, dois generais romanos, Lupicínio e Máximo, infligiram humilhações aos recém-chegados assolados pela fome. ${ }^{51} \mathrm{~A}$ revolta se instaurou e os godos se rebelaram contra os romanos. O levante culminou com a famosa batalha de Adrianópolis em 378, quando Valente foi morto pelas tropas liderados por Fridigerno e Atanarico. O corpo de Valente jamais foi recuperado, de modo que foi privado das honrarias funerárias. Amiano Marcelino contou que como o corpo do imperador não foi encontrado as causas de sua morte eram encobertas por mistérios. Poderia ter sucumbido ferido por uma flecha, ou, conforme outra versão apresentada por Amiano Marcelino,Valente não chegou a sucumbir pelo ferimento da flecha e junto com alguns soldados e eunucos conseguiu abrigo numa casa de campo, lá ainda resistiu por um tempo, mas a construção foi posta em chamas e o corpo de Valente e de todos os homens que lá estavam foram reduzidos às cinzas. ${ }^{52}$

O relato de Amiano Marcelino sobre a morte de Valente difere dos que foram escritos posteriormente. Paulo Orósio, Jordanes e Isidoro de Sevilha relacionaram a

\footnotetext{
${ }^{48}$ Amiano Marcelino, Res Gestae, XXXI, 3, 1-8.

${ }^{49}$ Amiano Marcelino, Res Gestae, XXXI, 4, 1-5.

${ }^{50}$ 6. Ita turbido instantium studio orbis Romani pernicies ducehatur. lllud sane neque obscurum est neque incertum, infaustos transvehendi harbaram plebem ministros, numerum eius comprehendere calculo saepe temptantes, conquievisse frustratos, ut eminentissimus memorat vates, "Quem qui scire velit, Lihyci velit aequoris idem Discere, quam multae zephyro truduntur harenae." (Amiano Marcelino, Res Gestae, XXXI, 6.)

${ }^{51}$ Amiano Marcelino, Res Gestae, XXXI, 4, 9-11.

${ }^{52}$ Amiano Marcelino, Res Gestae, XXXI, 13.
} 
morte de Valente à crueldade do imperador que quando requisitado pelos godos para enviar um sacerdote a fim de ensiná-los o cristianismo, mandou um ariano de modo que os godos acabaram convertidos à heresia. Mesmo assim as versões dadas pelos três historiógrafos cristãos diferem entre si no que concerne ao peso do erro de Valente. 
Ipse imperator [Valente], cum [...] ubi lacrimabile bello Thraciam ferro incendiisque sagitta saucius, versusque in commisso vincentibus depopulantur deletoque fugam, aegre in cujusdam Gothis in quodam praedio Romanorum exercitu ipsum vullulae casam depostatus iuxta Adrianopolim saucius Valentem iaculo uulneratum lateret, $a b$ insequentibus ipse refugiens in quondam uillam ugientem hostibus deprehensus, subjecto ignorantibusque, quod succendunt ut merito ipse ab igne, consumptus est: et quo imperator in tam vili casula eis uiuens cremaretur magis testimonium punitionis delitisceret, Gothis, incendio qui tam pulchras ejus et divinae indignationis ignemque, ut adsolet animas ignibus aeternis terribili posteris esset exemplo, saeviente inimico, tradiderat. $^{55}$

etiam communi caruit supposito, cum regali sepultura. ${ }^{53} \quad$ pompa crematus est, haut secus quam dei prorsus iudicio, ut ab ipsis igni conbureretur, quos ipse vera fide petentibus in perfidia declinasset ignemque caritatis ad gehennae ignem detorsisset. $^{54}$

${ }^{53}$ Historiarum Libri Septem, L. VII,33.

${ }^{54}$ Getica, 138.

${ }^{55}$ Historia Gothotum, versão longa, 9. Traduções disponíveis no anexo 1. 
Nos relatos dos três autores a morte de Valente é cotada como uma punição ao imperador. Mas em Jordanes, e especialmente Isidoro de Sevilha, a conversão dos godos ao arianismo por culpa de Valente é destacada e as semelhanças entre os relatos de Jordanes e Isidoro de Sevilha são realmente notáveis. É de se pensar se os dois autores chegaram a conclusões tão parecidas - Valente pereceu pelo fogo, ao condenar ao fogo do inferno/ao fogo eterno os godos - a partir da leitura de Orósio ou por terem lido uma mesma fonte, Cassiodoro, ou por Isidoro de Sevilha ter se inspirado na interpretação do Jordanes. É difícil falar sobre o relato perdido de Cassiodoro, mas se nos atermos à reflexão de Goffart e até mesmo de O’Donnell, dificilmente poderíamos esperar que ele construiria uma narrativa tão anti-ariana escrevendo na Península Itálica a serviço dos ostrogodos arianos. É possível também que estejamos frente a uma coincidência e que Isidoro de Sevilha tenha tido uma interpretação semelhante a Jordanes sem ter lido a Getica. De todo modo, o relato de Isidoro de Sevilha é bem mais generoso com os godos, cujas almas foram adjetivadas como belas.

Mas deixemos a análise mais cuidadosa da questão para o tópico sobre as Historiae. Neste momento urge ressaltar o quanto a ameaça dos godos ao império cresceu em um curto espaço de tempo: desde Juliano e sua atitude de subestimar o perigo até a batalha de Adrianópolis passaram-se menos de duas décadas. Pouco mais de três décadas depois os godos conseguiriam a façanha de saquear a cidade de Roma. Percebemos que a despeito das dificuldades de identificarmos quem eram esses godos, as fontes reconhecem um determinado grupo de indivíduos como tal e atribui a eles eventos decisivos.

Idácio, bispo de Chaves, que escreveu sua Chronica no século V relatou laconicamente: "XVI. Alaricus rex Gothorum Romam ingressus: cum intra et extra 
urbem caedes agerentur, omnibus indultam est, qui ad sanctorum limina confugerunt. ${ }^{, 56}$ Naquele mesmo ano os bárbaros chegaram à Hispania, e o relato de Idácio de Chaves ganha então contornos macabros:

46. Barbari, qui in Hispanias ingressi fuerant, caede depraedantur hostili.

47. Pestilentia suas partes non segnius operatur.

48. Debacchantibus per Hispanias barbaris et saeuiente nihilominus pestilentiae malo, opes et conditam in urbibus substantiam tyrannicus exactor diripit et miles exhaurit. Fames dira grassatur, adeo ut humanae carnes ab humano genere ui famis fuerint deuoratae: matres quoque necatis uel coctis per se natorum suorum sint pastae corporibus. Bestiae, occisorum gladio fame pestilentia cadaueribus adsuaetae, quosque hominum fortiores interimunt eorumque carnibus pastae passim in humani generis efferantur interitum. Et ita, quattuor plagis ferri famis pestilentiae bestiarum unique in toto orbe saeuientibus, praedictae a domino per prophetas suos adnuntiationes implentur. ${ }^{57}$

Os bárbaros em 411 cessaram os saques, Idácio então os nomeia e indica onde se instalaram. Os vândalos ocuparam a Galécia, os suevos a região costeira da extremidade ocidental, os alanos a Lusitânia e Cartagena, enquanto os vândalos ditos Silings se instalaram na Bética, já os hispanos se mantiveram nas cidades que sobreviveram aos bárbaros e se resignaram com a servidão. Os godos aparecem novamente no relato de Idácio em 413, quando chegaram à Narbona. ${ }^{58}$

Em 417 o relato apresenta uma virada sobre o comportamento dos godos. Depois de invadirem Roma em 410, em 417 eles, liderados por Valia, entraram na Hispania e em nome de Roma empreenderam grandes massacres contra os bárbaros. Aqueles que Amiano Marcelino e o próprio Idácio de Chaves descreveram como parte das ameaças ao Império, em 417 lutaram a favor do Império. Derrotaram os vândalos silings na Bética, massacraram os alanos - que de fato parecem desaparecer

\footnotetext{
${ }^{56}$ Idácio de Chaves, Chronica. a.410, 44, XVI O respeito dos godos pelos lugares sagrados foi destacado por Jordanes e Isidoro de Sevilha.

${ }^{57}$ Idácio de Chaves, Chronica. (Tradução no anexo 1)

${ }^{58}$ Idácio de Chaves, Chronica, 49 e 55.
} 
dos registros após a derrota ${ }^{59}$ - depois dos combates os godos foram chamados à Gália por Constâncio e lá receberam "sedes" na Aquitânia, desde Toulouse até as margens do oceano, ${ }^{60}$ permaneceriam na região até 507 quando foram derrotados pelos francos liderados por Clóvis.

Essas são, resumidamente, as informações sobre os godos nas fontes desde a intensificação dos relatos sobre eles em contato com os romanos até os assentamentos na Gália.

Dediquemo-nos então aos francos. As primeiras referências a eles são mais esparsas do que as referências aos francos. No De Caesaribus eles aparecem devastando a Gália, a Hispânia e a província de Tarraconense. ${ }^{61} \mathrm{O}$ já citado Amiano Marcelino, que trouxe notícias importantes sobre os godos, também versou sobre os francos. Lamentavelmente sua grande obra não chegou completa até os nossos dias e o aparecimento dos francos no texto é repentino. O teatro dos acontecimentos é a Gália durante o governo do Imperador Constâncio II. Nessa época um certo Silvanus, de origem franca, usurpou por um mês a dignidade imperial na Gália tendo contato com outros companheiros francos que já estavam bem integrados ao "palácio". Os francos na Res Gestae, diferentemente dos godos, são primeiramente citados no texto de Amiano Marcelino já participando das tensões políticas da Gália de uma forma que vai além dos distúrbios advindos de assaltos como os dos godos na Trácia. ${ }^{62}$

Mas a participação de alguns francos nas conspirações políticas da Gália não significa que todos os francos estavam integrados e não representavam mais ameaças de saques. Em 357 eles iniciaram saques na Germania Segunda e foram reprimidos

\footnotetext{
${ }^{59}$ Sobre o tema: HEATHER, P. Disappearing and reappearing tribes. In: POHL, W. \& REIMITZ, H. Strategies of Distinction. The Construction of ethnic Communities, 300-800.Leiden, Boston, Köln: Brill, 1998. p. 95-111.

${ }^{60}$ Idácio de Chavez, Chronica, 63-69.

${ }^{61}$ Francorum gentes direpta Gallia Hispaniam possiderent vastato ac paene direpto Tarraconensium oppido. De Caesaribus, 33, 3 .

${ }^{62}$ Amiano Marcelino, Res Gestae, L. XV,5.
} 
por Juliano, César da Gália e que futuramente seria o imperador conhecido como "o apóstata". ${ }^{63}$ Juliano combateu com diligência os bárbaros que ameaçavam a Gália, dentre os quais estavam os Alammani, os francos e os Chamari. Tal como outras bandas de godos reconhecidas na Res Gestae, Amiano Marcelino também identifica diferentes grupos francos, dentre os quais os francos sálicos. Em 358, depois de cinco ou seis meses de preparação, Juliano lançou suas tropas contra esses francos:

3. Quibus paratis, petit primos omnium Francos, eos videlicet quos consuetudo Salios appellavit, ausos olim in Romano solo apud Toxiandriam, locum habitacula sibi figere praelicenter. Cui cum Tungros venisset, occurrit legatio praedictorum, opinantium reperiri imperatorem etiara turn in hibernis, pacem sub hac lege praetendens, ut quiescentes cos tamquam in suis, nee lacesseret quisquam nee vexaret. ${ }^{64}$

Juliano fingiu ter acatado o acordo, mas assim que os francos sálicos se desprepararam ele os atacou e os submeteu. Essas vitórias seriam citadas por Juliano em 361 quando ele clamava pelo apoio das tropas para batalhar contra Constâncio, afirmando assim a obrigação do imperador de suprimir os avanços bárbaros. Amiano Marcelino cita o discurso de Juliano ipsis litteris:

3. Arbitrio dei caelestis, vobis inter ipsa iuventae rudimenta permixtus, irruptiones Alamannorum assiduas et Francorum, populandique iugem licentiam fregi, et vigore communi, Romanis agminibus quotiens lihet Rhenum pervium feci, contra rumorum fremitus gentiumque validarum violeutos excursus, stando immohilis, virtutis vestrae nimirum firmamento confisus.[... $]^{65}$

Percebemos que embora as gentes francorum - e o plural é intencional - por vezes eram tema de atrito com o Império, a ponto de seu combate servir como justificativa para uma empresa militar, alguns homens apontados como francos eram

\footnotetext{
${ }^{63}$ FRIGHETO, R. Antiguidade Tardia...op.cit. p.117-119.

${ }^{64}$ Amiano Marcelino, Res Gestae, XVII, 8,3. Tradução no anexo 1.

65 3. Amiano Marcelino, Res Gestae, 1.XXI, 5,3. Tradução no anexo 1.
} 
parte das disputas que envolviam os próprios galo-romanos. Não há, portanto, necessariamente uma associação imediata entre francos e inimigos na Res Gestae.

Mas de onde eles teriam vindo? O De Caesaribus de Aurélio Victor os mencionam dentre os bárbaros que assolaram o já conturbado Império na segunda metade do século III, ${ }^{66}$ após saquearem a Gália e Hispania alguns deles chegaram a tomar barcos e partiram para a África. Ainda no século III, o comandante romano Carausius foi designado para combater os francos e saxões que ameaçavam a costa da Bélgica e Armorica. ${ }^{67}$ Seriam eles os francos identificados como sálicos derrotados por Juliano em 358 na região que atualmente corresponde aos Países Baixos, conforme registrou Amiano Marcelino $?^{68}$ Voltaremos a questão. Por ora cabe dizer que nenhum desses autores do século IV mencionam de onde os francos partiram, eles aparecem em suas Historiae apenas quando mantêm contatos com os romanos. Foi no século VI que emergiram tentativas de identificar a origem dos francos, o mesmo com os godos, afinal, Jordanes escreveu também no século VI.

Sobre a questão Gregório de Tours registrou no seu famosíssimo Decem Libri

\section{Historiarum:}

Hanc nobis notitiam de Francis memorati historici reliquere, regibus non nominatis.Tradunt enim multi, eosdem de Pannonia fuisse degressus, et primum quidem litora Rheni amnes incoluisse, dehinc, transacto Rheno, Thoringiam transmeasse, ibique iuxta pagus vel civitates regis crinitos super se creavisse de prima et, ut

\footnotetext{
${ }^{66}$ 33. Sub idem tempus Licinius Gallienus cum a Gallia Germanos strenue arceret, in Illyricum properans descendit. 2 Ibi Ingebum, quem curantem Pannonios comperta Valeriani clade imperandi cupido incesserat, Mursiae devicit moxque Regalianum, qui receptis militibus, quos Mursina labes reliquos fecerat, bellum duplicaverat. 3 His prospere ac supra vota cedentibus more hominum secundis solutior rem Romanam quasi naufragio dedit cum Salonino filio, cui honorem Caesaris contulerat, adeo uti Thraciam Gothi libere pergressi Macedonas Achaeosque et Asiae finitima occuparent, Mesopotamiam Parthi, Orienti latrones seu mulier dominaretur, Alemannorum vis tunc aeque Italiam, Francorum gentes direpta Gallia Hispaniam possiderent vastato ac paene direpto Tarraconensium oppido, nactisque in tempore navigiis pars in usque Africam permearet; et amissa trans Istrum, quae Traianus quaesiverat. (Aurélio Victor, De Caesaribus, 33)

${ }^{67}$ Per haec tempora etiam Carausius qui vilissime natus strenuae militiae ordine famam egregiam fuerat consecutus, cum apud Bononiam per tractum Belgicae et Armorici pacandum mare accepisset, quod Franci et Saxones infestabant. (Eutrópio, Breviarium, IX, 21)

${ }^{68}$ Verdelinden defendeu veementemente essa hipótese: VERLINDEN, C. Frankish Colonization: a new approach. Transactions of the Royal Historical Society, Fifth Series, v.4, p.1-17, 1954.
} 
ita dicam, nobiliore suorum familia. Quod postea probatum Chlodovechi victuriae tradedirunt, itaque in sequenti digerimus.

Dada a importância do trecho, a tradução segue logo a seguir:

Os historiógrafos cujos trabalhos nós ainda possuímos nos dão essas informações sobre os francos, mas eles nunca registraram os nomes de seus reis. É comumente dito que os francos vieram originalmente da Panonia e primeiro se estabeleceram nos bancos do Reno. Então eles atravessaram o rio, marcharam pela Turíngia, e colocaram em cada pagus e em cada cidade reis de cabelos longos escolhidos entre as mais destacadas e nobres famílias dentre os seus. Como eu mostrarei mais adiante, isso é provado pelas vitórias conquistadas por Clóvis. ${ }^{69}$

Gregório de Tours foi o primeiro a estabelecer um espaço geográfico para a origem dos francos, mas ele apenas registra as notícias que ouviu, não há uma grande digressão sobre o tema até porque Gregório de Tours não tinha em mente a escrita da "história dos francos" propriamente dita, as traduções alteradas do título de seu livro confundem e modificam o significado dos Dez Livros. ${ }^{70}$ Quando muito, a Historia de Gregório é uma narrativa sobre os francos na Gália, muito embora acreditemos que subordinar o significado de sua obra a isso pode outorgar explicações pouco convincentes para a profusão de informações que o bispo de Tours acrescentou no longo texto. Mas o que nos cabe agora perguntar é: há alguma outra evidência além de Gregório de Tours para relacionarmos os francos com a Panônia?

Para M. Todd ${ }^{71}$ não há evidências que sustentem a versão sugerida por Gregório de Tours, Todd o coloca como o inventor da origem dos francos na Panônia.

\footnotetext{
${ }^{69}$ Gregório de Tours, Decem Libri Historiarum, L. II, 9.

${ }^{70}$ Discutimos a questão no texto de nossa dissertação, onde Gregório de Tours e Isidoro de Sevilha foram os autores privilegiados. SILVEIRA, Verônica da Costa. História e historiografia na Antigüidade Tardia à luz de Gregório de Tours e Isidoro de Sevilha. 2010. 181 f. Dissertação de Mestrado - Faculdade de Filosofia, Letras e Ciências Humanas/USP. São Paulo, julho de 2010. Mas evidentemente o artigo de W. Goffart foi fundamental para pensar o problema e implicações desse grave equívoco: GOFFART, W. From Historiae to Historia Francorum and back again: aspects of the textual history of Gregory of Tours. In: Rome's fall and after. Londres e Roceverte: Hambledon, 1989.

${ }^{71}$ TODD, Malcolm. The Early Germans. Maryland, Oxford, Victoria: Blackwell Publishing, 2004. p.9-11
} 
A acusação é injusta, o De Caesaribus de Aurélio Victor relacionou os francos com as gentes que vieram da região dos Balcãs, de modo de Gregório de Tours não deve ter tirado a idéia do nada. Muito embora Aurélio Victor não tenha afirmado que os Balcãs era a "vagina natiorum" dos bárbaros, tal como registrou Jordanos sobre a Scandza, o relato de Gregório de Tours não atentou contra a parcimônia por conta do "método inventivo".

No século VII as dúvidas sobre as origens dos francos que aparecem no texto de Gregório de Tours seriam sanadas nas Historiae da Gália com a Chronica anônima que séculos depois seria atribuída erroneamente pelos humanistas a um certo Fredegário. Na Chronica os francos aparecem a partir da narrativa sobre o início da guerra de Tróia, quando Príamo ${ }^{72}$ raptou a bela Helena e provocou a guerra. Logo depois dessa informação lemos:

Exinde origo Francorum fuit. Priamo primo regi habuerunt; postea per historiarum libros scriptum est, qualiter habuerunt regi Friga. ${ }^{73}$

Os francos então se dividiram em duas bandas e partiram. Uma delas foi para a Macedônia e lá se integraram com os macedônios - que comumente oprimiam outras gentes, mas acolheram os francos. Lá os francos procriaram com os macedônios e forjaram macedônios fortíssimos, força essa confirmada pela fama alcançada pelo rei Felipe e depois por seu filho Alexandre. ${ }^{74}$ A outra banda seria aquela que muito tempo depois entraria na Europa:

\footnotetext{
${ }^{72}$ A Chronica atribuiu à ele o rapto de Helena, quando a tradição grega falava que o responsável foi o jovem príncipe Paris.

73 "Desta maneira foi a origem dos Francos. Tiveram como primeiro rei Príamo, depois, conforme está escrito nos livros de história, tiveram Friga constituído como rei. (Fredegário, L.II, 4)

${ }^{74}$ Postea partiti sunt in duabus partibus. Una pars perrexit in Macedoniam, vocati sunt Macedonis secundum populum, a quem recepti sunt, et regionem Macedoniae, qui oppremebatur a gentes vicinas, invitati ab ipsis fuerunt, ut eis praeberent auxilium. Per quos postea cum subiuncti in plurina procreatione crevissent, ex ipso genere Macedonis fortissimi pagnatores effecti sunt; quod in
} 
Nam et illa alia pars, quae de Frigia progessa est, ab Olexo per fraude decepti, tamen non captivati, nisi exinde eiecti, per multis regionibus pervacantis cum uxores et liberos, electum a se regi Francione nomen, per quem Franci vocantur. In postremum, eo quod fortissimus ipse Francio in bellum fuisse fertur, et multo tempore cum plurimis gentibus pugnam gerens, partem Asiae vastans, in Eurupam dirigens, inter Renum vel Danuvium et mare consedit. $^{75}$

O primeiro rei dos francos, cujo nome Gregório de Tours não conseguiu descobrir depois de procurar em muitas Historiae, é não só nomeado na Chronica como a partir de seu nome os francos passaram a ser chamados.

A origem troiana dos francos descritas na Chronica merovíngia outorgou aos francos o prestígio de terem se originado na famosa Tróia. A diferença entre as dúvidas de Gregório de Tours e as informações inseridas sem questionamentos pelo cronista $^{76}$ são notáveis. E foi a versão do cronista anônimo do século VII que ganhou importância até o século XVI! A partir do XVIII se intensificaram as críticas a essa versão, mesmo que as conclusões desses incipientes estudos críticos pudessem ser perigosas: em 1714 Nicolas Fréret foi mandado para a Bastilha por defender que os francos eram germanos. ${ }^{77}$

Fizemos um esforço por mapear nas fontes - sobretudo a do gênero Historiaas narrativas sobre os godos e francos desde suas origens até seus contatos com o Império Romano. Como é possível notar, essas fontes foram todas escritas por autores que estavam no Império, não há documentos escritos sobre os francos e godos antes

postremum in diebus Phyliphy regis et Alexandri fili sui fama confirmat, illorum fortitudine qualis fuit. (Fredegário, L.II, 4.)

75 Fredegário, L.II, 5. Tradução no anexo 1.

${ }^{76}$ Ou cronistas, uma vez que um amplo debate sobre a autoria da crônica se estabeleceu desde a edição feita por B. Krusch para os MGH e um artigo publicado pelo pesquisador em 1882 onde ele defendeu a tese de que três mãos escreveram a Chronica. S. Hellmann e J.M. Wallace-Hadrill, mesmo que de forma diferente, sustentaram que dois autores escreveram a Chronica, enquanto F. Lot argumentou que apenas um. W. Goffart também é partidário da teoria da única autoria. Cf: Frédégaire. Chronique des temps Mérovingiens (livre IV et Continuations). Edição do texto em latim: WALLACE-HADRILL, J.M. Tradução para o francês, introdução e notas por DEVILLERS, O. \& MEYERS, J. Turnhout: Brepols, 2001. p.10-18. Ainda: GOFFART, W. The Fredegar problem Reconsidered. Speculum, v.38, n.2, p.206-241, 1963. Discutiremos mais sobre esse problema no capítulo sobre as Historiae.

${ }^{77}$ HUPPERT, G. The Trojan Franks and their critics. Studies in the Renaissance, v.12, p.227-241, 1965. 
de seus contatos com os romanos. Das notícias fundamentadas no olhar imperial de Zózimo, Amiano Marcelino, Idácio de Chaves, Eutrópio e Aurélio Victor escritas entre os séculos IV e V até as obras de Jordanes, Isidoro de Sevilha, Gregório de Tours e o cronista erroneamente nomeado Fredegário produzidas entre os séculos VI e VII houve uma significativa mudança nas narrativas sobre esses "povos". Os invasores bárbaros que assolaram o Império na visão dos historiógrafos dos séculos IV e V tornaram-se aqueles cujos cronistas dos séculos VI e VII já viviam sob a autoridade e esforçaram-se por compreender mediante o desvendar de suas origens. Há evidentemente uma exceção a esse olhar romano produzida muito antes do século IV, é a Germania de Tácito. A pergunta que fica é: porque entre os séculos VI e VII houve essas mudanças de perspectivas? Qual é o lugar delas nos textos analisados? O que elas podem nos dizer sobre os regna que pesquisamos?

Essas são algumas das perguntas que enfrentamos nesta pesquisa. De todo modo, o que podemos tirar pelo o que foi dito até aqui, é que os autores dos século VI e VII não partiram do nada quando iniciaram suas narrativas, antes deles havia já uma tradição narrativa que noticiava eventos que envolviam as gentes sobre as quais eles escreveram. A partir dessas narrativas eles construíram novas histórias, outros textos, como leis, fórmulas, hagiografias e atas conciliares que também mencionavam essas gentes foram compilados igualmente a partir de uma tradição narrativa. Desta maneira, a partir de uma base narrativa que conseguimos datar a partir do século IV novas interpretações surgiram. Surgiram porque outras questões que não as ameaças bárbaras para o Império Romano estavam em voga. Surgiram porque os regna dos francos e visigodos deveriam responder a outros problemas inseridos num cenário de relações de forças entre as novas realezas e facções nobiliárquicas cada vez mais fortes. 


\section{Posicionamento da pesquisa na historiografia}

Nossa problemática relacionada com o lugar dos godos e francos nas fontes da Hispânia Visigoda e da Gália Merovíngia advém de uma questão historiográfica clássica concernente ao papel dos povos no processo histórico. Tal perspectiva já no século XVIII norteava as interpretações historiográficas como podemos observar mediante a comparação dos estudos de E. Gibbon e J.G. Herder.

À chegada dos bárbaros no Império Romano foi atribuído um impacto tão significativo que foi consagrado pela historiografia como o fim de uma era, a Antiguidade, e o início de outra, a Idade Média. No século XVIII, a monumental obra de E. Gibbon “O Declínio e Queda do Império Romano” consagrou uma interpretação para as consequências da chegada dos bárbaros que já aparecia na Historiarum ab inclinatione Romanorum imperii decades de Flávio Biondo no século $\mathrm{XV},{ }^{78}$ a saber, os eventos significaram o declínio do Império e o início de uma época diferente, marcada por novas formas de produção, relações pessoais e política, cujos traços foram encerrados no conceito de "feudalidade". ${ }^{79}$ Os séculos trabalhados até agora nesta tese marcariam portanto a transição entre essas duas eras ${ }^{80}$ e a responsabilidade

\footnotetext{
${ }^{78}$ Uma importantíssima reflexão sobre a idéia de "Declínio" é feita no livro de S. Mazzarino: MAZZARINO, Santo. O fim do mundo Antigo. São Paulo: Martins Fontes, 1991.

${ }^{79}$ Sobre o feudalismo o pequeno livro de Ganshof é importantíssimo: GANSHOF. F.L. O que é feudalismo. Lisboa: Europa-América, 1968. Sua tese questiona a de M. Bloch no clássico "A Sociedade Feudal" (BLOCH, M. A Sociedade Feudal. Lisboa: Edições 70, 1970.). Para uma análise sobre a questão é interessante confrontar os dois estudos de M. Cândido e R. Frighetto: FRIGHETTO, R. Transformação e tradição: a influência do pensamento político e ideológico do mundo romano clássico na antiguidade tardia. Diálogos. Maringá: DHI/PPH/UEM, vol., 12, n.,3, p.19-42. 2008. CÂNDIDO, M. Entre "Antiguidade Tardia" e "Alta Idade Média". Diálogos. Maringá: DHI/PPH/UEM, vol.12, n.2/n.3, p. 53-64. 2008. Sobre as críticas à utilização do "feudalismo" como base explicativa para a Europa medieval: BROWN, E. The Tyranny of a Construct: Feudalism and Historians of Medieval Europe. The American Historical Review, v.79, n.4, p.1063-1088, 1974. Sobre os impactos políticos da feudalidade, o instigante debate entre D. Barthélemy e S.D. White é muito ilustrativo: BARTHÉLEMY, D. \& WHITE, S.T. The 'Feudal Revolution'. Past \& Present, n.152, p.196-122, 1996.

${ }^{80}$ Apresentamos uma reflexão sobre a questão à luz da emergência do conceito de Antiguidade Tardia publicada nos Anais do encontro da Anpuh de 2011: SILVEIRA, V. Reflexões sobre o conceito de Antiguidade Tardia. Anais do XXVI Simpósio Nacional de História - Anpuh. São Paulo. Julho de 2011. 
outorgada aos bárbaros nessa transição diz muito sobre os principais debates historiográficos que envolveram os historiadores dedicados aqueles séculos.

No século XIX temos o importante embate entre romanistas e germanistas, mas que teve seu estopim ainda no século XVIII com os livros do já citado Gibbon e de J.G. Herder, onde o primeiro lamentava os destinos de Roma enquanto o segundo denunciava Roma por sua luxúria e tirania que foram finalmente enfrentadas pelos bárbaros: "gigantes do norte diante dos quais os irritados romanos pareciam anões". 81

O debate entre romanistas e germanistas tinha por pano de fundo uma visão dos povos essencialista, ${ }^{82}$ muito bem exemplificada pelas palavras de N.D. Fustel de Coulanges:

Les modernes ont dit „Il y a eu, au Ve siècle, une invasion de Germains en Gaulle; elle a tout bouleversé; c'est elle qui a détruit le régime romain et qui a mis à la place le régime féodal. Ce régime a donc une origine germanique. Il a pour cause première la conquête, et la distinction entre les classes n'est que la suite d'une distinction entre vainqueurs et vaincus" ${ }^{\text {e. }}$. Cette théorie serait bien commode. Par elle les faits s'expliqueraient simplement, logiquement, sytématiquement. L'histoire deviendrait claire et facile. Nous aurions un élément romain et un élément germain, et avec ces grands mots on répondrait à tout, on rendrait compte de toutes les institutions et même de toutes les révolutions du moyen âge. ${ }^{83}$

Existiriam, desta forma, dois elementos muito bem distintos que participavam do teatro dos eventos a partir do século V: de um lado os germanos, do outro os romanos. Esses dois elementos entraram em conflito, suas relações se desenrolavam principalmente de maneira tensa. Fustel de Coulanges questionou essa visão, que ele considerou simplista, que observava as relações entre os dois grupos como necessariamente conflituosas. Entretanto, o valor das "raças" para a história mantevese na leitura do historiador e fica sobressaltada quando confrontamos seus embates

http://www.snh2011.anpuh.org/resources/anais/14/1300808380_ARQUIVO_1_silveira_reflexoes_sobr e_o_conceito_de_antiguidade_tardia_anpuh_2011.pdf (consultado em 7/06/2012)

81 "[...]northern giants, to whom the enervated romans appeared dwarfs[...]". HERDER, J.G. Outlines of a philosophy of the history of man. Vol.II. Londres: Luke Hansard, 1803. p.239.

${ }^{82}$ Tomamos o conceito de M. Gibernau: GUIBERNAU, Montserrat. Nacionalismos. O estado nacional e o nacionalismo no século XX. Rio de Janeiro: Jorge Zahar, 1997.

${ }^{83}$ FUSTEL DE COULANGES, N.D. Histoire des institutions politiques de l'ancienne France. Paris: Libraire Machette, 1890. p.X. v.1. 
com T. Mommsen. O que é pertinente agora é tentar compreender o lugar que as "raças" ocupavam nos estudos dos historiadores do século XIX.

A primeira coisa que é importante ressaltar é como elas eram vistas. No século XIX conceitos como raça e povo experimentavam uma simbiose e eram tidos como naturais, ou seja, metahistóricos - desprovidos de historicidade. ${ }^{84} \mathrm{O}$ darwinismo social ofereceu o aparato científico para a consolidação da noção de que algumas raças eram superiores as outras. Embora o caráter político dessa hierarquização das raças não deva ser negligenciado, insistimos que ele não deve ser o único norte de interpretação da historiografia do período. Leopold von Ranke exemplifica o que queremos dizer:

The intention of a historian depends on his viewpoint, about which two thinks must be said here. First of all, I regard the Latin and the Germanic Peoples as a unit. I reject three analogous concepts: one, the concept of a universal Christendom (which would embrace even the Armenians); two, the concept of the unity of Europe, for since the Turks are Asiatics and since the Russian Empire comprises the whole north of Asia, their situations could not be thoroughly understood without penetrating and drawing in the total Asian situation. Finally, my point of view also excludes the almost exactly analogous concept, that of a Latin Christendom. Slavic, Latvian, and Magyar tribes belonging to the latter have a peculiar and special

\footnotetext{
${ }^{84}$ É interessante analisarmos essa perspectiva à luz do Darwinismo Social que despontava no século XIX. O Darwinismo Social foi um dos desdobramentos do imenso impacto que A Origem das Espécies de Charles Darwin causou na sociedade ocidental de seu tempo, e não é por demais arbitrário dizer que ainda causa (Sobre manifestações contemporâneas do Darwinismo Social, há o interessante artigo: STRAUSS, A. \& WAIZBORT, R. Sob o signo de Darwin? Sobre o mau uso de uma quimera. RBCS, v.23, n.68, p. 125-134, outubro de 2008). Grosso modo os darwinistas sociais tendiam a atribuir moralidade à natureza, que por seu caráter naturalmente bom rumava em direção ao progresso da espécie humana, onde, por exemplo, raças inferiores seriam inexoravelmente subjugadas pelas superiores (Sobre essa interpretação da obra de Darwin: FUTUYAMA, Douglas J. Biologia evolutiva. Ribeirão Preto: Sociedade Brasileira de Genética/CNPq, 1992. p.9-8). Essa idéia de progresso contrariava diretamente o pensamento do naturalista inglês, que escreveu: "Conforme Begehot notou, estamos acostumados a considerar como coisa normal o progresso na sociedade humana, mas a história rejeita isso" (DARWIN, C. A origem do homem. São Paulo: Hemus, 1974. p. 160.). Se o Darwinismo Social consistiu numa má compreensão da obra de Darwin, é importante notar uma série de concepções pré-existentes à Origem das Espécies que fomentaram esses equívocos, como o pensamento tipológico, segundo o qual a essência das coisas possuía um caráter atemporal, ou seja, transcendente à história (MAYR, Ernst. Biologia, Ciência Única. São Paulo: Companhia das Letras, 2005. p.103 e 104). Ora, o pensamento tipológico, conforme E. Mayr foi um dos empecilhos para a aceitação da seleção natural, todavia, por outro lado, acabou também por ser condensado ao Darwinismo Social quando se propagou uma idéia essencialista das nações (GUIBERNAU, Montserrat. Nacionalismos. $\mathbf{O}$ estado nacional e o nacionalismo no século XX. Rio de Janeiro: Jorge Zahar, 1997. p.9) na qual povos naturalmente superiores eram os responsáveis pela fundação de nações igualmente superiores e que estavam fadadas ao progresso.
} 
nature which is not included here. The author remains close to home with the tribally related peoples of either purely Germanic or Germano-Latin origin, whose history is the nucleus of all recent history, and touches on what is foreign only in passing as something peripheral. ${ }^{85}$

É importante manter em foco tal perspectiva sobre o papel das raças no processo histórico a fim de compreendermos o debate historiográfico que caracterizou o século XIX, ou seja, o estudo dessas raças não era, como nos indicou Ranke, um objeto de pesquisa marginal para a história, era o objeto por excelência da história. ${ }^{86}$ Olhando por tal prisma podemos adotar uma postura crítica ao argumento de P. Geary que praticamente reduz a historiografia do XIX a um grande projeto político que objetivava afirmar nacionalismos emergentes. ${ }^{87}$ Se não podemos refutar de todo esse ingrediente sob pena de fazermos uma leitura ingênua da historiografia, ignorar a relação das raças com a concepção acerca do processo histórico pode nos levar a uma interpretação maniqueísta da historiografia do período que negligencia o fato de que o estudo das raças era parte do métier historiográfico.

Não deixa de ser, entretanto, notável o fato de que questões nacionalistas se tornaram particularmente significantes no início da década de 1870 durante a Guerra Franco-Prussiana. ${ }^{88}$ As lutas transcenderam os campos de batalha tradicionais e influenciaram tanto a academia francesa quanto a alemã nas quais seus mais importantes acadêmicos tomaram partido nas tensões entre a França e a Alemanha que emergia enquanto uma nação unificada. O debate entre T. Mommsen e N.D.

\footnotetext{
${ }^{85}$ RANKE, L. von. Preface to the First Edition of Histories of the Latin and Germanic Peoples. (October 1824). In: Idem. The Theory and Practice of History. Leopold von Ranke. Ed. IGGERS, G.G. London \& NY: Routledge, 2011. p.85.

${ }^{86}$ Sobre a visão rankeana da história ver ainda: FUCHS, E. Conceptions of Scientific History in the Nineteenth Century West. In: WANG, Q. \& IGGERS, G.G. Turning points in Historiography. A cross cultural perspective. NY: The University of Rochester Press, 2002. p.148. GADAMER, HansGeorg. Verdade e método. Traços fundamentais de uma hermenêutica filosófica. Petrópolis: Vozes, 1999. p.315-327.

${ }^{87}$ GEARY, P. O mito das nações: a invenção do nacionalismo. São Paulo: Conrad, 2005.

${ }^{88}$ WOOD, I. Barbarian, Historians, and the Construction of National Identities. Journal of Late Antiquity, v.1, n.1, p.61-81, Spring 2008. p.70-72.
} 
Fustel de Coulandes ilustra bem a ascensão das tensões políticas e a afirmação das identidades nacionais nos discursos dos historiadores que lidavam com as gentes que se assentaram nas províncias do Império Romano a partir do século V. Respondendo as cartas enviadas por Mommsen para os jornais italianos "La Perseveranza" e "Il secolo" $^{89}$ - nas quais o historiador alemão instigava os italianos a apoiar os alemães na Guerra Franco-Prussiana - Fustel de Coulanges sublinhou claramente a atmosfera política quando estabeleceu um paralelo entre a Alemanha moderna e os "germanos" que invadiram o Império Romano. ${ }^{90}$

Mas foi durante as Guerras Mundiais que o nacionalismo se transformou num guia majoritário para as pesquisas históricas, mais do que isso, como aponta I. Wood, a historiografia nacionalista foi institucionalizada pelos nazistas com a fundação de institutos como o Deutches Ahnenerbe - Studiengesellschaft für Geistesurgeschichte por Himmel e o Westdeutchen Forschungsgemeinschaft, ambos fundados entre $1931 \mathrm{e}$ 1935. ${ }^{91}$ Entretanto, o clima para a generalização do triunfalismo nacional na historiografia alemã é mais antigo. Ele pode ser detectado desde 1918 com o colapso do Kaiserreich e o impacto catastrófico da I Guerra Mundial para o território alemão. A reação dos historiadores alemães para esses eventos consistiu na supressão de perspectivas historiográficas liberais e a adoção de uma posição nacionalista conservadora. Queremos dizer com isso que os nazistas estimularam um contexto

\footnotetext{
${ }^{89}$ NICOLET, C. 1889, Réflexions sur Fustel de Coulanges. Comptes-rendus des séances de l'Académie des Inscriptions et Belles-Lettres. v.133, n.3, p.721-726, 1989. Note 16, p.726.

${ }^{90}$ A carta pode ser consultada em: FUSTEL DE COULANGES, N. D. Da maneira de escrever a história na França e na Alemanha nos últimos cinqüenta anos. In: HARTOG, F. O século XIX e a história. O caso de Fustel de Coulanges. Rio de Janeiro: Editora UFRJ, 2003. p. 346-356. Ela foi originalmente publicada em: Revue de Deux Monde on September 1, 1872. Ver também: WOOD, I. Barbarian, Historians, and the Construction of National Identities... op.cit. p.70-72.

${ }^{91}$ WOOD, I. Barbarian, Historians, and the Construction of National Identities... op.cit. p.77. Ainda o importante livro sobre a relação entre os nazistas e os acadêmicos alemães: HAAR, I. \& FAHLBUSCH, M. (eds). German Scholars and Ethnic Cleansing, 1919-1945. NY \& Oxford: Berghahn Books, 2005.
} 
historiográfico que já existia. ${ }^{92}$ Não é coincidência que os estudos de G. Kossinna surgiram antes da ascensão do III Reich, seu Ursprung und Verbreitung der Germanen in vor- und frühgeschichtlicher Zeit foi publicado entre 1926 e 1927. Kossinna morreu em 1931, mas alguns de seus pupilos, notadamente Hans Reinerth, desempenharam papéis importantes na política nazista. Isso contribuiu enormemente para a relação que se estabeleceu entre as pesquisas de Kossinna e a política racista e higienista do Nazismo. ${ }^{93}$

Terminada a Segunda Guerra Mundial, os estudos germanistas amargaram uma profunda desconfiança na comunidade internacional. Isso até a publicação do trabalho de R. Wenskus: Stammesbildung und Verfassung. Das Werden der frühmittelalterlichen Gentes no ano de 1961. A importância do texto de Wenskus reside em sua perspectiva histórica sobre as etnias: estas não são uma entidade natural, mas fruto de uma construção histórica. Abria-se a porta novamente para a entrada da etnografia e etnologia entre os estudiosos germanistas e logo posteriormente entre muitos historiadores dedicados a toda Antigüidade Tardia, onde o conceito de etnogênese ganhou destaque.

Etnogênese é um conceito advindo da antropologia ${ }^{94}$ e, como nos conta M. Bartolomé: “[...] foi cunhado para dar conta do processo histórico de configuração de coletividades étnicas como resultado de migrações, invasões, conquistas, fissões ou

\footnotetext{
${ }^{92}$ SCHLEIER, H. German historiography under National Socialism. In: BERGER, S., DONOVAN, M. \& PASSMORE, K. Writing National Histories. Western Europe since 1800. NY \& London: Routledge, 1999. p. 176-177.

${ }^{93}$ DEMOULE, J.-P. Archäologische Kulturen und modern Nationen. In: BIEHL, P.F., GRAMSCH, A. \& MARCINIAK, A. Archäologien Europas. Gerschichte, Methoden und Theorien. Münster, NY, Munich and Berlin: Waxmann, 2002. p.135. Ainda: CURTA, Florin. Some remarks on ethnicity in medieval archaeology. Early Medieval Europe. v.15, n.2, p.159-185, 2004.

${ }^{94}$ GILLETT, Andrew. Ethnogenesis: A contested model of Early Medieval Europe. History Compass v.4, n.2, p.241-269, 2006.
} 
fusões." 95 A adoção dessa perspectiva causou um considerável impacto na historiografia objeto de nosso interesse.

Vistas como entidades culturais intimamente ligadas a características biológicas, as etnias foram entendidas pelos acadêmicos como unidades populacionais coesas, que como tal migraram para o território imperial romano no ocidente e lá implementaram seus valores, costumes, leis e o vigor ou decrepitude a elas imanentes. Os estudos de R. Wenskus questionaram firmemente este paradigma e contribuíram para a reabilitação dos estudos etnológicos concernentes à Antigüidade Tardia, não por acaso, ${ }^{96}$ inicialmente no mundo germânico.

R. Wenskus buscou superar a utilização de termos contemporâneos - como "povos", "nações", "raças" - em favor de expressões presentes nas fontes, dentre as quais gentes, que acabou por se consagrar entre os estudiosos partidários da etnogênese. As gentes que entraram em contato com Império Romano estavam longe de constituir uma unidade coesa, eram grupos heterogêneos que só passaram a compartilhar de uma identidade relacionada com a etnografia de origem grecoromana em contato com o Império Romano. ${ }^{97} \mathrm{Ou}$ seja, o nascimento das gentes conhecidas como "godos", "francos", "suevos" etc foi fruto de um processo histórico devido às migrações desses grupamentos mistos para as províncias romanas. O que Wenskus fez foi apontar para a historicidade das gentes, perspectiva esta que ia de

\footnotetext{
${ }^{95}$ BARTOLOMÉ, Miguel A. As etnogênese: velhos atores e novos papéis no cenário cultural e político. Mana, n.12, v.1, p.39-68, 2006. p.39.

${ }^{96} \mathrm{H}$. Härke salientou a estima que o impacto das imigrações nos processos históricos usufrui dentre os historiadores germânicos, segundo ele, isso deve, entre outros fatores como a própria característica dos estudos acadêmicos na Alemanha, à importância que movimentos populacionais possui na própria história alemã. Conforme Härke, tais tendências revelam muito sobre a historicidade dos estudos históricos, que ele afirma ser bem reconhecida mas pouco ponderada no processo de pesquisa e produção de conhecimento. HÄRKE, Heinrich. Archaeology and migrations... op.cit. p. 19-20.

${ }^{97}$ Sobre a visão heterogeneizante dos romanos concernente aos bárbaros: HEATHER, Peter. The Barbarian in Late Antiquity. Image, reality, and transformation. In: MILES, Richard (Ed.). Constructing Identities in Late Antiquity. London and New York: Routledge, 1999. p. 234-258.
} 
encontro às idéias essencialistas que relacionavam comunidades culturais com características biológicas.

O trabalho de Wenskus foi importante para a compreensão do processo histórico no qual estava envolvido o nascimento das gentes, mas foi graças a Herwig Wolfram que o termo etnogênese, pouco usado por Wenskus, ganhou destaque entre os historiadores ocupados com as (i)migrações da Antigüidade Tardia. ${ }^{98}$

A etnogênese ocupou papel central no estudo de Wolfram dedicado aos godos. Segundo o pesquisador, a etnogênese dos godos foi um processo de integração intimamente relacionado com a entrada de grupamentos guerreiros diversificados no Império Romano. Tal integração se deu em dois níveis: a suplantação da heterogeneidade interna desses grupos e o seu crescente relacionamento com as populações de origem romana, fenômenos estes que ocorreram de maneira concomitante e suplementar. Esse processo foi antes de tudo político e operado pelos altos estratos sociais godos interessados na estabilidade em detrimento da insegurança política oferecida pela organização tribal bélica:

The process of settlement was necessary to transform the Gothic kingship into a Gothic kingdom. Before that, everyone's position rested on the spoils of battle; a form of capital that could only be invested safely if the tribe became sedentary once again. As long as they were part of migrating Gothic groups, Gothic lords and noblemen had to subsist on what they had conquered and they had to replenish it constantly. Further, it was possible to lose everything in a single disastrous encounter. Thus, the Gothic leading strata became interested in the stability provided by an established kingship, located within a specific area. ${ }^{99}$

Para Wolfram a possibilidade da implantação dos reinos latino-bárbaros godos se deu justamente com a anulação dos godos frente aos romanos, ou seja, com a adoção de uma identidade que, embora oriunda da tradição bárbara, era

\footnotetext{
${ }^{98}$ GILLET, Andrew. Ethnogenesis...op.cit. p.242.

${ }^{99}$ WOLFRAM, H. The Goths in Aquitaine. German Studies Review, v.2, n.2, p.153-168. 1979. p.160.
} 
fundamentalmente uma instituição romana. ${ }^{100} \mathrm{Em}$ poucas palavras, sem a etnogênese a história dos reinos godos (ostrogodo e visigodo) seria inviável.

Walter Pohl segue uma linha semelhante ao dar à etnogênese um papel crucial para a série de eventos que marcaram as províncias romanas da Antigüidade Tardia a partir da chegada dos bárbaros. Pohl analisa a etnicidade a partir de uma perspectiva que a entende como uma prática, num evidente esforço por marcar sua não filiação às explicações que a viam como algo orgânico. Segundo ele a capacidade de adaptação dos grupos designados pela alcunha genérica "bárbaros" ao modelo romano foi crucial para o sucesso ou fracasso dos processos de etnogênese que pululavam no período. Ora, a partir da argumentação de Wolfram percebe-se que as identidades adotadas pelos bárbaros eram uma instituição romana. A incapacidade de se adequar a esse modelo - já conforme Pohl - poderia redundar na sublimação de grupos étnicos nascentes, como aponta o exemplo dos ávaros. ${ }^{101}$ Assim como Wolfram, Pohl salienta os aspectos políticos, as tensões internas e as relações de poder que deram a tônica à etnogênese bárbara, ${ }^{102}$ o que nos aponta para uma característica importante do contexto de gêneses étnicas no período: crise.

Os processos de etnogênese na Antigüidade Tardia ocorreram em contextos de crises, e não só daquelas que surgiam no Império Romano, mas também das terras de onde saíram os bárbaros: os diversos grupos chamados de godos que eram pressionados pelos hunos; ${ }^{103}$ a presença romana na Região do Baixo Reno a partir do século I e o caso dos francos; ${ }^{104}$ a presença romana no Alto Reno e no Danúbio e o

\footnotetext{
${ }^{100}$ WOLFRAM, H. History of the Goths...Op.cit. p.9-14.

${ }^{101}$ POHL, W. El concepto de etnia en los estúdios de la Alta Edad Media. In: LITTLE, Lester K. \& ROSENWEIN, Barbara (eds.) La Edad Media a Debate. Madrid: Akal, 2003. p. 48.

${ }^{102}$ POHL, W. The Regia and the Hring - Barbarian places of power. In: DE JONG, M. THEUWS, F. \& VAN RHIJN, C. Topographies of power in the Early Middle Ages. Leiden, Boston, Köln: Brill, 2011. p.439-466.

${ }^{103}$ COLLINS, R. La España Visigoda. 409-711. Barcelona: Crítica, 2005. p.3-32.

${ }^{104}$ MILLER, David H. Ethnogenesis and Revitalization beyond the Roman Frontier: The Case of Frankish Origins. Journal of World History, v.4, n.2, p.277-285, 1993.
} 
confuso caso dos Alamanni e Suebi, ${ }^{105}$ etc. Mesmo assim, esses processos que ocorreram entre os séculos I e III não necessariamente definiram as identidades étnicas que encontramos a partir do século V. ${ }^{106}$ Isso porque o processo de etnogênese é em sua essência dinâmico, melhor, a própria fluidez das identidades e sua - as vezes - constante transformação permitem a etnogênese. ${ }^{107}$

Chegamos assim às principais contribuições que o estudo de Wenskus trouxe à historiografia dedicada à Antigüidade Tardia. O estudioso ao outorgar historicidade aos "povos" e "raças" do período contribuiu enormemente para a retomada da etnografia e etnologia no leque dos objetos e pressupostos teóricos dos historiadores dedicados aqueles séculos. ${ }^{108}$ As etnias neófitas eram, conforme suas colocações e a dos pesquisadores ${ }^{109}$ que se inspiraram nos seus estudos, mais consequiência do que causa dos eventos que mudaram a face das autoridades políticas da Europa Ocidental a partir do século IV, o que gerou uma significativa mudança de enfoque. Como já mencionamos, as transformações operadas pelos bárbaros no Ocidente europeu deixaram de se explicar por si só quando se adicionou à equação as transformações no

\footnotetext{
${ }^{105}$ HUMMER, H.J. The fluidity of barbarian identity: the ethnogenesis of Alemanni and Suebi, AD 200-500. Early Medieval Europe, v.7, n.1, p.1-27, 1998.

${ }^{106}$ GOETZ, H-W. Gens. Terminology and perception of the 'Germanic' peoples from Late Antiquity to the Early Middle Ages. In: CORRADINI, R. DIESENBERGER, M. \& REIMITZ, H. The Construction of Communities in the Early Middle Ages. Texts, resources and artefacts. Leiden e Boston: Brill, 2003. p. 39-61. Ainda: HEATHER, Peter. The Barbarian in Late Antiquity. Image, reality, and transformation. In: MILES, Richard (Ed.). Constructing Identities in Late Antiquity. London and New York: Routledge, 1999. p. 234-258.

${ }^{107}$ DERKS, T. \& ROYMANS, N. (Eds). Introduction. Ethnic Constructs in Antiquity. The role of power and tradition. Amsterdam: Amsterdam University Press, 2009. p.1-2.

${ }^{108}$ Falamos em retomada de objeto pois mediante a etnologia e etnografia a etnogênese virou objeto dos historiadores. Falamos em pressupostos teóricos pois etnogênese é, a priori, um modelo teórico, um conceito relacionado com a íntima relação entre identidade étnica e política. Cf: GONÇALVES, C.P. Política, cultura e etnicidade: indagações sobre encontros intersocietários. Antropologia em primeira mão. n.1, 1995. Disponível em: http://www.antropologia.ufsc.br/70.\%20claudia-etno.pdf

${ }^{109}$ Além dos já citados Wolfram e Pohl, podemos ainda lembrar de: R. Collins, J. Lopez-Quiroga, P. Gueary, P. Hoppenbrouwers, F. Curta. (COLLINS, Roger. La España Visigoda. 409-711. Op.cit.. LÓPEZ QUIROGA, J. La presencia "Germánica" en Hipania en el siglo V d.c. Arqueología y procesos de etnogénesis en la Península Ibérica. CuPAUAM, 30, p.213-223, 2004. GUEARY, Patrick J. O mito das nações: a invenção do nacionalismo. São Paulo: Conrad, 2005. HOPPENBROUWERS, Peter. Such stuff as peoples are made on: ethnogenesis and the construction of nationhood in Medieval Europe. The Medieval History Journal, n.9, v. 2, p.195-242. 2006. CURTA, Florin. Some remarks on ethnicity in medieval archaeology. Early Medieval Europe. v.15, n.2, p.159-185, 2004.). Além de autores também já citados aqui como H.J. Hümmer e D. Miller.
} 
âmbito bárbaro ocasionadas pelo contato com os romanos. Sem essas transformações experimentadas pelos próprios bárbaros a viabilidade dos reinos latino-bárbaros seria improvável. Se tomarmos em conta a importância dada pela historiografia a essas novas entidades políticas para a história ocidental - usada como marco para o fim da Antigüidade e o início da Idade Média - teremos a amplitude dessa mudança de abordagem.

Apesar das enormes contribuições que essas novas perspectivas trouxeram, uma série de problemas ainda se apresentam para os pesquisadores. Em primeiro lugar é preciso ressaltar as dificuldades metodológicas envolvidas nesse tipo de análise e bem sistematizadas por Pohl:

1. Como as etnias não eram fenômenos objetivos, conforme colocou P. Geary, não se encontram provas diretas e objetivas das identidades étnicas. A consciência étnica era fator decisivo, mas geralmente não sabemos a que identidade étnica os indivíduos se sentiam vinculados;

2. Embora os objetos encontrados pelos arqueólogos tragam expressões de uma identidade étnica, não existem objetos que sejam "etnicamente inequívocos".

3. É preciso ter cautela ao lidar com as expressões de identidade étnica nas fontes escritas, já que muitas vezes uma mesma etnia aparece sob diversas designações, e muitas vezes uma designação reúne diversas etnias;

4. As culturas arqueológicas e os grupos étnicos muitas vezes coincidem, mas nem sempre podemos acreditar que é possível identifica-los;

5. É preciso ter sempre em vista que existem diversos tipos de identidades étnicas, não é possível analisar todos esses tipos mediante um mesmo modelo. O pesquisador deve sempre estar atento as especificidades. ${ }^{110}$

Em Segundo lugar destaquemos a pluralidade de explicações para o surgimento das principais etnias que formaram os reinos latino-bárbaros. Essas dificuldades muito têm a ver com os problemas metodológicos levantados por Pohl,

${ }^{110}$ POHL, Walter. El concepto de etnia en los estúdios de la Alta Edad Media...op.cit.. p. 46-47. 
sobretudo no que concerne a dificuldade de identificar as evidências escritas e materiais que podem nos indicar as identidades étnicas. Enquanto estudiosos como Wolfram e Pohl tendem a priorizar os contatos com os romanos como os fatores de peso para a etnogênese, por exemplo, goda, M. Todd afirma que é possível aceitar, a partir de evidencias levantadas principalmente pela arqueologia, que os ancestrais dos grupamentos do século III viveram no final do século I a.C. ${ }^{111}$ As colocações de Todd são polêmicas. Ora, um dos principais argumentos dos partidários da etnogênese baseia-se na flexibilidade da identidade cultural dos bárbaros muito devido a heterogeneidade dos grupos guerreiros que entraram no Império Romano e ao fato de que essas novas identidades eram recentes. Se Todd estiver correto a maior antigüidade das etnias pode ser um elemento importante para se considerar na aplicação do conceito de etnogênese.

Essas diferenças são observadas principalmente se compararmos os trabalhos dos estudiosos que lidam com fontes materiais e os trabalhos dos que usam fontes escritas. Enquanto os autores que estudam fontes escritas tendem a observar os processos de etnogênese cronologicamente muito próximos aos contatos dos bárbaros com os romanos, os pesquisadores mais próximos à arqueologia insistem reiteradamente nas dificuldades de identificar identidades étnicas em resquícios materiais. ${ }^{112}$ Há ainda aqueles que vão mais longe. C. Wickham, um grande crítico do que ele chama de "paradigma romanista" - que privilegia a continuidade do Império em lugar da ruptura ocasionada por crises - enuncia que as diferentes explicações das etnogêneses bárbaras devem mais ao desenvolvimento historiográfico do que ao estudo das fontes. Para Wickham, que defende baseado em fontes arqueológicas que houve sim uma crise e ruptura do Império Romano, se algo bárbaro se transformou

\footnotetext{
${ }^{111}$ TODD, Malcolm. The Early Germans...op.cit..2004. p.9-11.

112 DERKS, T. \& ROYMANS, N. Introduction. Ethnic Constructs in Antiquity.... Op.cit. p.4.
} 
quando entrou em contato com a romanitas não se deveu a vontade dos bárbaros em se apropriar da romanitas mas do que restava dela para ser apropriado, ${ }^{113}$ posicionamento esse bastante crítico a aqueles que subordinam a identidade bárbara ao contato com os romanos.

Há de se destacar que Wickham é bastante desconfiado com as fontes escritas e tende a basear suas interpretações nas fontes arqueológicas. Pesquisadores como Lopez-Quiroga, Derks e Roymans, que costumam mesclar fontes materiais e escritas, são menos céticos frente à importância dos contatos entre romanos e bárbaros para as transformações identitárias dos últimos. Derks e Roymans, por exemplo, insistem mais nas dificuldades da arqueologia em lidar com as etnicidade. Segundo eles uma das dificuldades para a arqueologia se debruçar sobre a etnicidade é a diversidade limitada de fontes a sua disposição. Por exemplo, os arqueólogos que lidam principalmente com fontes materiais raramente conseguem engendrar um estudo de caráter linguístico. ${ }^{114}$ Salientam os autores:

If ethnicity is a form of self-ascription that may vary across time and space, and that may be foregrounded only during particular forms of social interaction, some sort of linguistic evidence seems to be a pre-requisite for accessing the emic viewpoint. The challenge for the archaeologist lies in trying to assess exactly which tokens were ethnically laden under what circumstances precisely. The cases presented by Theuws and Strobel, however, may serve as warnings of the traps and pitfalls we may come across when trying to talk about ethnicity on the (sole) basis of material culture. ${ }^{115}$

Dessas polêmicas e questionamentos levantados por autores como Todd e Wickham e das ressalvas enunciadas por Derks e Roymans podemos inferir algumas questões. Primeiramente percebemos que a despeito do crescente diálogo entre

\footnotetext{
${ }^{113}$ WICKHAM, Chris. Framing the Early Middle Ages. Europe and the Mediterranean. 400-800. Nova York: Oxford University Press, 2005. p. 82-83.

${ }^{114}$ DERKS, T. \& ROYMANS, N. Introduction. Ethnic Constructs in Antiquity. ... Op.cit p. 2-4.

${ }^{115}$ DERKS, T. \& ROYMANS, N. Introduction. Ethnic Constructs in Antiquity. ... Op.cit p. 2-4.
} 
pesquisadores de diversos países e áreas que assistimos nos últimos trinta anos ${ }^{116}$ ainda há uma carência de leituras entre historiadores e arqueólogos e vice e versa. Nota-se isso quando vemos sentenças como as de Derks e Roymans que delegam aos historiadores uma maior importância nos estudos sobre a etnicidade justamente por estes terem contato com fontes escritas, enquanto pesquisadores como Pohl chamam a atenção justamente para as dificuldades de trabalhar com essas fontes escritas por causa da pluralidade de termos utilizados para designar uma mesma etnia ou o uso de um mesmo termo para designar diversas etnias!

Vemos ainda autores como Wickham que negligenciam as fontes escritas por sua intencionalidade inerente e conseqüente deformação das informações, sem levar em conta que essas deformações são também objetos dos historiadores e que as diferentes qualidades de fontes são respostas a níveis distintos das sociedades em que foram elaboradas. Ora, não se pode esperar que uma ata conciliar traga informações que corroborem com um cemitério supostamente bárbaro porque a ata conciliar lida com um plano discursivo inserido intimamente num contextos de disputas. Em poucas palavras, é essencial que o pesquisador tenha bastante claro para si que fontes escritas e materiais não são complementares, mais importante ainda, que fontes escritas não constituem um corpo homogêneo de informações, o que também provavelmente vale para as fontes materiais. E a falta de homogenidade entre as fontes, esperamos, ficará ainda mais evidente quando mostrarmos a multiplicidade de imagens que elas veicularam sobre os franci e os gothi.

E por último, ressaltemos um elemento ainda mais importante para nossos objetivos com esse texto. É notável e enorme dificuldade em se estabelecer afinal quais são os elementos que podem servir como definidores de identidades. Eles são de

\footnotetext{
${ }^{116}$ WICKHAM, Chris. Framing the Early Middle Ages... Op.cit. p.1.
} 
origem material? São aqueles que sobreviveram em sepulturas e que, portanto, supostamente trazem resquícios de vidas cotidianas? Eles são de origem discursiva e, dentro das características sociais e intelectuais da Antigüidade Tardia, trazem anseios de grupos altamente posicionados na hierarquia social? São os dois? Mas nessa situação, como lidar com a falta de confluência entre as informações que trazem?

A despeito de todos os problemas que a abordagem explicitada traz é importante reconhecer um dos seus principais méritos que foi justamente a retomada do problema das identidades étnicas barbaras, e essa retomada não esteve isenta de uma contrapartida advinda do que Curta chamou de "Escola de Toronto" que tem por principal percussor Walter Goffart. Segundo Goffart, a idéia das migrações de povos que experimentavam uma identidade germânica não pode ser comprovada, já que as fontes arqueológicas não correspondem à etnografia greco-romana e pelos resquícios arqueológicos não é possível identificar com segurança a que grupo os indivíduos que deixaram essa cultura material entendiam pertencer. Disse o historiador sobre as migrações que o ocorrido foi o contato de alguns homens e mulheres, encontro esse que se deu entre individualidades, não coletividades. Para Goffart, a unidade dos povos germânicos é um fenômeno, no mais tardar, do século IX. ${ }^{117}$ A crítica de Goffart, contudo, indiretamente corrobora com a tese da etnogênese quando o autor afirma que as fontes arqueológicas não confirmam a existência de uma identidade étnica. Ao fim e ao cabo os historiadores dedicados ao problema das identidades apontam justamente para suas constantes transformações ao sabor das demandas, esperar que nesse contexto se encontrem fontes arqueológicas que apontem irrefutavelmente para a existência de identidades estabelecidas é realmente incoerente.

\footnotetext{
${ }^{117}$ GOFFART, W. Jordane's "Getica" and the disputed authenticity of Gothic origins from Scandinavia. Speculum. v. 80, n.2, p.379-398, Abril de 2005.
} 
E se nos voltarmos para as fontes escritas? Mesmo na análise dessas há vozes opositoras à etnogênese, como M. Coumert e I. Wood. Para a primeira não se pode inferir que ocorreu a etnogênese de todo um "povo" a partir de relatos de grupos minoritários e participantes das estruturas de poder. Isso seria superestimar as narrativas oriundas desses grupos e ignorar a realidade das populações como um todo. ${ }^{118}$ Mas se só contamos com fontes oriundas dos círculos de poder, como podemos avaliar a realidade do restante das populações para afirmarmos que as identidades não eram uma questão importante? A arqueologia tampouco traz luz ao problema... é preciso lidar com o fato de que fora da alta hierarquia daquelas sociedades contamos com raríssimas fontes de informação. A crítica de Wood é semelhante, ele chama a mesma atenção para a necessidade de adotarmos uma postura crítica diante dos textos advindos dos grupos minoritários apontados por Coumert. Segundo o historiador, os autores desses documentos eram homens oriundos de aristocracias senatorias que em seus escritos expressaram a visão justamente dessas aristocracias, preocupadas em preservar os elementos que mantinham sua influência em um cenário de mudanças. ${ }^{119} \mathrm{Sim}$, precisamos adotar uma postura parcimoniosa frente a nossas fontes, mas o problema continua: essas fontes tendenciosas são as únicas que temos, é sobre elas que precisamos trabalhar.

Além de Wickham, Goffart, Coumert e Wood há ainda os interessantes apontamentos de A. Gillet sobre os problemas da etnogênese. Gillett salienta que o conceito de etnogênese, oriundo de estudos antropológicos, experimentou uma ascensão que careceu de debates entre os medievalistas. O mérito da popularização entre os pesquisadores do conceito de etnogênese pode ser atribuído ao trabalho de R.

\footnotetext{
${ }^{118}$ COUMERT, Magali. Origines des Peuples. Les récits du haut Moyen Âge Occidental (550-850). Paris: Institut d'Études Augustiniennes, 2007.

${ }^{119}$ WOOD, Ian. Continuity or calamity?: the constrains of literary models. In: DRINKWATER, J. \& ELTON, H. Fifth-century Gaul: a crisis of identity? Cambridge, New York, Melbourne: Cambridge University Press, 1992.
} 
Wenskus, mas principalmente aos estudos de H. Wolfram, crucial para a disseminação dos estudos de Wenskus e, sobretudo, para a utilização do termo “etnogênese”, pouco usado pelo próprio Wenskus, que lançou mão em seu texto mais do termo Gentilismus, um neologismo criado por ele para fugir das palavras Volkstum, que remetia ao nacionalismo alemão das primeiras décadas do século XX.

Mas para além da falta de debate em torno da importação de um conceito advindo da arqueologia, Gillet salienta, não sem razão, que a idéia da construção de identidades no seio das disputas e crises intensificadas a partir do século IV acabou por redundar na emergência de interpretações que muito rapidamente concluem que toda e qualquer obra escrita a partir do século IV deve ser explicada à luz da etnogênese. ${ }^{120}$ E nessa leitura que privilegia o papel da construção de identidades as Historias, mormente de autores como Jordanes e Isidoro de Sevilha que escreveram sobre as origens dos godos, foram fontes privilegiadas para observar o suposto fenômeno. Lemos então trabalhos que utilizam as fontes com vistas a provar o esquema, não para testá-lo ${ }^{121}$ de modo a interpretaram Isidoro de Sevilha e Jordanes como artífices de identidades étnicas. Não é, entretanto, impertinente dizer que a crítica de Gillet é uma via de mão dupla. Se por um lado efetivamente os partidários da etnogênese por vezes chegam muito rapidamente à conclusão de que certas fontes se inserem num contexto de dinâmicas identitárias, os opositores como Goffart chegam ao extremo oposto e negam veementemente essa possibilidade. Wickham foi perspicaz ao apontar para o quanto esse se tornou mais um debate entre duas correntes historiográficas do que um problema fundamentado no estudo das fontes.

\footnotetext{
${ }^{120}$ GILLET, Andrew. Ethnogenesis...op.cit.

${ }^{121}$ HOPPENBROUWERS, Peter. Such stuff as peoples are made on: ethnogenesis and the construction of nationhood in Medieval Europe...op.cit. POHL, W. Aux origines d'une Europe ethnique: Transformations d'identités entre Antiquité et Moyen Âge. Annales. Histoire, Sciences Sociales. 60e Année, n.1, p.183-208, 2005.
} 
Para concretizarmos o que colocamos, tomemos o exemplo de Isidoro de Sevilha e Jordanes. Mais do que avaliarmos o papel das obras de Jordanes e Isidoro de Sevilha na construção das identidades godas, tentemos refletir sumariamente ${ }^{122}$ sobre o que seus escritos têm a dizer sobre suas próprias identidades.

O primeiro ponto notável quando observarmos suas obras é que o fato do primeiro ter tido origens godas não evidencia uma ligação do autor com os godos, não por acaso ele escreveu em Constantinopla e comemorou as conquistas de Justiniano. ${ }^{123}$ Isidoro de Sevilha, por sua vez um homem de origem romana, estava não só alinhado com as vicissitudes políticas da Hispania goda como celebrou as vitórias dos reis godos contra os bizantinos, a vitória de Suintila que pela primeira vez havia estendido o domínio godo para toda a Hispania, derrotando inclusive tropas do Império do Oriente. Todas essas vitórias são louvadas pelo hispalense. As origens godas de Jordanes e as romanas de Isidoro de Sevilha não tiverem peso na forma como eles narraram os sucessos e dissabores godos e romanos. Embora Jordanes tenha se identificado na própria Getica como de origem goda, são as vitórias de Justiniano e Belisário que encerram triunfalmente o texto, vitórias que perpetuariam os feitos dos dois e os alçariam ao panteão dos grandes vitoriosos de Roma. Isidoro de Sevilha não registrou dados de sua biografia na De origine, mas o conjunto de sua obra não evidencia qualquer peso que ele poderia dar ao fato de ser um hispanoromano.

A aparente desimportância de uma auto-identificação com godos ou romanos presentes nas obras de Jordanes e Isidoro de Sevilha levantam duas possibilidades

\footnotetext{
${ }^{122}$ Uma vez que um estudo mais cuidadoso de suas obras é também contemplado por nosso trabalho.

${ }^{123}$ Uma versão desse trecho que compara Jordanes e Isidoro de Sevilha foi apresentada e publicada no Colóquio "Perspectivas de Estudo em História Medieval no Brasil". Cf: SILVEIRA, V.C. Jordanes, Isidoro de Sevilha e a origem dos godos. In: Perspectivas de Estudo em História Medieval no Brasil. Anais do Workshop realizado nos dias 29 e 30 de setembro de 2011. Belo Horizonte: Faculdade de Filosofia e Ciências Humanas, 2012. p.67-85.
} 
consoantes com o debate que opõe partidários da tese fundada por Wenskus e os opositores ligados a Goffart.

A primeira diz respeito a uma evidência para sustentar a hipótese da construção das identidades e do caráter fluído delas. Ora, embora descendente de godos, Jordanes preteriu essa filiação étnica em favor de uma inserção no ambiente de Constantinopla. Não só serviu como funcionário do Império que enfrentava os godos, como celebrou as vitórias contra eles. Nesse sentido o argumento de Pohl que se preocupa por apontar que as identidades étnicas se transformam diante das conjunturas parece pertinente. ${ }^{124}$ Explicação semelhante poderíamos outorgar ao texto de Isidoro de Sevilha. Sua filiação hispano-romana era um plano secundário diante da sua atuação nos círculos de poder godos. Assim, se as identidades podiam ser estratégias de distinção, por vezes no ambiente das contingências que os atores enfrentavam elas eram sublimadas. As identidades individuais se diluíam num quadro mais amplo. As origens godas de Jordanes perdem importância na produção de uma obra pró-Império enquanto as origens de Isidoro de Sevilha perdem peso frente a sua obra pró-godos. Se havia alguma identidade em questão no texto de Isidoro, poderíamos inferir que era a dos godos: o registro de suas origens e enfrentamentos no âmbito da Hispania e contra os assédios do oriente. As identidades são então inseridas num quadro mais concreto, a identificação com um determinado grupo não se relacionava com as origens dos indivíduos, mas com suas relações práticas.

A segunda possibilidade é radicalmente contrária à primeira e se aproxima dos argumentos de Goffart e dos demais pesquisadores opositores à etnogênese e todas as suas implicações interpretativas. A aparente contradição entre as origens e prováveis identidades de Jordanes e Isidoro de Sevilha e os textos que eles escreveram não

\footnotetext{
${ }^{124}$ POHL, W. El concepto de etnia en los estúdios de la Alta Edad Media...op.cit.
} 
indicariam, nesse sentido, uma fluidez identitária frente às contingências, mas sim uma real desimportância dessas identidades no ambiente onde escreveram. Ser de origem goda, assim, não só não inseria Jordanes numa filiação étnica como não tinha absolutamente importância para sua interpretação sobre a origem dos godos e seus feitos, ser de origem romana tampouco tinha significado relevante para Isidoro de Sevilha durante sua atuação política e episcopal.

Mas talvez a constatação mais difícil que podemos alcançar é que nenhuma das duas possibilidades parece absurda. Mais do que indicar qualquer coisa, elas apontam para as dificuldades de utilizar qualquer pressuposto no enfrentamento das fontes, tanto para confirmá-lo quanto para refutá-lo. A conclusão pode soar temerosa, mas as historiae de Jordanes e Isidoro de Sevilha podem servir de evidências para duas hipóteses contraditórias.

Isso não quer dizer que precisamos deslanchar para o relativismo conformista. As dificuldades na interpretação de nossas fontes são mais um desafio a ser enfrentado do que a justificativa para engessarmos nossos trabalhos. O mérito das novas abordagens reside justamente na percepção de que lidamos com objetos de extrema complexidade e isso nos previne de incorrermos em explicações simplórias.

Mesmo com a complexidade da questão há algo notável que deve ser percebido a partir dos problemas levantados. As duas hipótese elencadas por nós não parecem excludentes. O que queremos dizer com isso é que o problema das identidades pode ser trabalhado de diversas maneiras e nesse trabalho trazemos uma proposta de enfrentamento da questão. Esta proposta visa superar a relação entre identidade e etnicidade, o que queremos dizer é que é possível trabalhar com uma idéia de identidade sem relacioná-la necessariamente com uma etnicidade. O que defendemos é que embora há nas fontes a construção narrativa de uma identidade em torno dos 
termos franci e gothi não significa que devemos concluir que o único sentido desses termos é étnico. Para abrirmos o escopo, ou melhor, para amplificarmos a possibilidade de análise dessas identidades propomos que elas sejam abordadas não como "identidades étnicas" e sim como "identidades políticas" que se construíam nos textos e eram evocadas sobretudo em momentos de tensões que opunham os protagonistas do poder político na Gália e na Hispânia dos séculos VI até o VIII, a saber, os reis e os nobres. Desenvolveremos essa questão no próximo tópico. 


\title{
Apontamentos teórico-metodológicos
}

\author{
Compreender não é compreender melhor, nem de saber mais, no sentido objetivo em \\ virtude de conceitos mais claros, nem no da superioridade básica que o consciente \\ possui com respeito ao inconsciente da produção. Bastaria dizer que, quando se \\ logra compreender, compreende-se de um modo diferente. ${ }^{125}$
}

We are in any case bound to fail. For the facts are infinite in number, and unless we have some ideas about where to begin and why to begin there, we may literally condemn ourselves to going on for ever. ${ }^{126}$

A pesquisa histórica exige uma constante reflexão por parte dos pesquisadores pela própria dificuldade de eleger o objeto por excelência da história. Esse nunca foi consensual. ${ }^{127}$ Enquanto outras disciplinas se caracterizam relativamente bem por seus objetos de pesquisa, a história carece desse direcionamento pois tudo pode ser

${ }^{125}$ GADAMER, H.-G. Verdade e método. Traços fundamentais de uma hermenêutica filosófica. Petrópolis: Vozes, 1999. p.444.

${ }^{126}$ SKINNER, Q. Some problems in the analysis of Political thought and action. Political Theory. v.2, n.3, p.277-303, 1974. p.281.

${ }^{127}$ A eleição do[s] objeto[s] da história se confundiu com a filosofia da história até que a historicidade substituiu o historicismo, muito embora a historicidade não tenha resolvido e, tampouco, mensurado suficientemente o problema. Cf: KOSELLECK, R. On the need for theory in the discipline of History. In. Idem. The Practice of Conceptual History. Timing, History, Spacing Concepts. Stanford: Stanford University Press, 2002. Ora, temos por um lado Hegel que apontou para um desenvolvimento - no sentido real de aperfeiçoamento - cujo determinante é o Espírito donde redunda a história concebida justamente como as mudanças para o aprimoramento. O objeto da história começa com a autoconsciência da Razão que condiciona a liberdade. O objeto da história para Hegel de certa maneira pode ser compreendido como transcendente à própria história uma vez que ele, o Espírito, a determina, não surge dela mas só pode ser apreendido nela, daí uma "Filosofia da História". HEGEL, G.W. Introduction to the Philosophy of History. Indianapolis \& Cambridge: Hackett Publishing Company, 1988. Dilthey, numa interessante resenha sobre o trabalho de Buckle (BUCKLE, H.T. History of Civilization in England. NY: D. Appleton, 1876) criticou o pesquisador inglês por preterir a narrativa das coisas como aconteceram como o objeto da história num esforço por dar à disciplina um caráter semelhante aos das Ciências Naturais. Numa das passagens mais contundentes da resenha, Dilthey sublinhou que: "In order to salvage the scientific rigor of history despite these conditions, [a dificuldade de definir o que exatamente motiva as ações humanas] Buckle commits himself to the most desperate hypothesis that any scholar has ever postulated, and advances the most paradoxical claim ever uttered by a historian. He excludes the actions of individuals, of the mighty ones of this world, from consideration, and he makes social conditions as they manifest themselves in the behavior of masses the only subject of historiography." DILTHEY, W. History and Science (1862), on H.T. Buckle's History of Civilization in England. In: MAKKREEL, R.A. \& RODI, F. (Eds). Hermeneutics and the study of History. Wilhelm Dilthey. Selected Works. Vol. IV. New Jersey: Princeton University Press, 1996. p.265. Dilthey nesse ponto expressa muito bem seu diálogo com a obra da escola histórica alemã, especialmente na figura de Leopold von Ranke, em oposição a filosofia hegeliana. Sobre esse embate: GADAMER, H.-G. Verdade e método. Traços fundamentais de uma hermenêutica filosófica. Petrópolis: Vozes, 1999. p.306-315. A ascensão dos historiadores dos Annales deve ser, em nossa opinião, vista à luz desse debate no qual os historiadores franceses se posicionam numa oposição à escola alemã. Tentamos traçar com isso muito superficialmente os contornos de uma verdadeira disputa intelectual em torno do objeto da história. A crítica Marxista de um lado e a virada pós-moderna de outro dariam o tom das discussões no período pós-guerra. 
histórico. ${ }^{128}$ Talvez a questão da definição do objeto da disciplina histórica seja mais urgente do que a própria discussão metodológica sobre como alcançá-lo e torná-lo inteligível.

Constatamos isso no decorrer da própria pesquisa, de modo que essas notas representam mais a manifestação de nossas dúvidas e os caminhos prévios que adotamos para saná-las do que qualquer pretensão de propor uma resolução do problema no quadro teórico da disciplina. Em poucas palavras, queremos antes expor os problemas, e em certa medida algumas soluções, que desenvolvemos para o desenvolvimento deste trabalho.

Motiva-nos aqui algo que pode ser sumarizado mediante uma paráfrase da célebre pergunta de Michel de Certeau: ${ }^{129}$ o que esta pesquisa faz quando se pretende uma pesquisa histórica?

Voltemos então ao ponto inicial. Quando elegemos o objeto de pesquisa - a investigação das identidades franca e visigoda nas fontes merovíngias e visigodas dos séculos VI e VIII - partimos de certos pressupostos que no momento da delimitação do objeto não estavam claros:

1. Que identidades, a priori vistas como étnicas tinham alguma importância no período;

2. Que analisa-las poderia nos ajudar a compreender aspectos sócio-políticos do período;

3. Que o estudo de identidades tem importância para história.

Cada um desses pontos exigem uma reflexão mais detalhada. A ordem na qual foram elencados não é arbitrária, a partir do primeiro os outros surgiram. Uma

\footnotetext{
${ }^{128}$ KOSELLECK, R. On the need for theory in the discipline of History... op.cit. p.4.

${ }^{129}$ A pergunta de Certeau foi: "O que fabrica o historiador quando 'faz história'?". CERTEAU, M. A escrita da história. Rio de Janeiro: Forense Universitária, 2002. p.65.
} 
reflexão mais profunda indica que eles são basicamente oriundos de um problema complexo relacionado com a prática historiográfica e o uso de conceitos.

Como de praxe a pesquisa começou com um problema: como podemos interpretar os termos tidos como "étnicos" nas fontes produzidas na Gália Merovíngia e na Hispânia Visigoda entre os séculos VI e VIII? O fato é que esse problema se revelou maior do que era inicialmente esperado e isso se deve a questões ao mesmo tempo de ordem historiográfica e conceitual. Digo "ao mesmo tempo" porque a divisão entre temas historiográficos e conceituais por vezes é meramente ilustrativa e isso se revela com vigor no tema com o qual lidamos.

Comecemos pelo impasse conceitual. É mister dizer que toda a reflexão sobre etnicidade não pode prescindir de uma reflexão sobre identidade. O que está incutido na idéia de etnicidade, na sua acepção mais basilar, é que etnicidade é um elemento identitário. Mas de que maneira? Primeiro tentemos compreender o que é etnia, tarefa que não é simples uma vez que o termo é muitas vezes usado pelos pesquisadores sem que uma reflexão sobre o seu significado seja conduzida, mesmo assim, ou justamente por isso, um primeiro exercício de conceitualização deve ser realizado. ${ }^{130}$ Etnia compreende fundamentalmente indivíduos que se sentem parte de uma comunidade, o que implica dizer que outros compartilham do mesmo sentimento de pertencimento. O que faz com que indivíduos se sintam parte de um mesmo grupo, distinto de outros grupos, é o fato de compartilharem coisas: pode ser um mesmo idioma, uma mesma origem ou hábitos comuns, por exemplo, estilo de roupa, corte de cabelo e tipo de

\footnotetext{
${ }^{130} \mathrm{~W}$. Pohl, por exemplo, conduz uma discussão sobre os elementos que podem servir para a contrução de identidades étnicas sem explicitar o que ele entende por etnias: POHL, W. Telling the difference: signs of ethnic identity. In: POHL, W. \& REIMITZ, H. (eds.) Strategies of Distinction. The Construction of Ethnic Communities, 300-800. Leiden, Bostin, Kölh, 1998. p.17-69. A. Gillet chama a atenção para ease problema: GILLET, Andrew. Ethnogenesis: A contested model of Early Medieval Europe. History Compass. n.4, v.2, p.241-269, 2006.
} 
alimentação. ${ }^{131}$ Enfim, etnia, nessa abordagem inicial, implica um autoreconhecimento como parte de uma comunidade constituída por outros membros que também se auto-reconhecem como tal.

Essa primeira definição é contudo simplória à luz dos debates no campo da antropologia acerca da definição de etnicidade/grupos étnicos. Primeiro porque a idéia de que a etnia implica uma consciência de pertencimento a uma comunidade não é uma proposição aceita consensualmente pelos pesquisadores. Aqueles pertencentes à corrente objetivista - que identificava os grupos étnicos como uma entidade cultural e social com fronteiras distintas caracterizadas por relativo isolamento e falta de interação $^{132}$ - não consideravam a consciência étnica como condição imperativa para a existência de um grupo étnico, ou seja, indivíduos poderiam fazer parte de uma etnia mesmo sem se reconhecer como tal. A corrente objetivista, assim como sua antagonista subjetivista, tem passado por críticas, entretanto, a dicotomia entre ambas permanece atual no que concerne à necessidade ou não de uma consciência étnica para a existência de um grupo étnico. ${ }^{133}$

Mesmo assim, entre 1960 e 1970 os subjetivistas se afirmaram como a posição mais importante no debate, e isso se deve muito ao trabalho de F. Barth ${ }^{134}$ que tinha a interação com outros grupos como fator crucial para a definição de um grupo étnico, a

\footnotetext{
${ }^{131}$ FINE, John V.A. Jr. When ethnicity did not matter in the Balkans. A Study of Identity in PreNationalist Croatia, Dalmatia, and Slavonia in the Medieval and Early-Modern Periods. Michigan: University of Michigan Press, 2006. p.2.

${ }^{132}$ A interpretação objetivista fica muito explícita na arqueologia dedicada à Antigüidade Tardia que I. Barbiera identificou como a arqueologia histórico-cultural e esteve fortemente em voga entre os séculos XIX e primeira metade do XX. O relativo isolamento das etnias era um pressuposto que redundava em interpretações que explicavam mudanças em culturas arqueológicas não por transformações internas às comunidades, mas por movimentos migratórios que solapavam a cultura anterior. Ainda, interação entre etnias diversas era algo que não se considerava, as leituras se davam permeadas pela idéia de vencedores - que impunham sua própria cultura - e vencidos. BARBIERA, I. Memorie sepolte. Tombe e identità nell'alto medioevo (secoli V-VIII). Roma: Carocci Editore, 2012. p.58-59.

${ }^{133}$ JONES, S. The archaeology of ethnicity. Construction identities in the past and present. London \& New York: Routledge, 1997. p.56-58.

${ }^{134}$ Para uma ótima introdução ao trabalho de Barth: BARTH, F. I Gruppi Etnici e I Loro Confini. In: MAHER, Vanessa (ed.). Questioni di Etnicità. Torino: Rosenberg \& Sellier, 1994. p.33-72.
} 
saber, quando indivíduos usavam categorias étnicas para se auto-identificar e identificar outros indivíduos num contexto fundamentalmente de interação, tanto entre indivíduos de um mesmo grupo quanto entre indivíduos de grupos distintos, estamos diante de grupos étnicos. ${ }^{135}$

Ainda que represente um ponto de virada importante nas pesquisas sobre etnicidade, o subjetivismo, em geral, e os trabalhos de Barth, em particular, trazem certos problemas. A definição subjetivista que implica um sentimento de autopertencimento redunda numa concepção sobre etnia muito geral que acaba por ser usada como definição para grupos diversos. Como muito bem sublinha S. Jones:

In effect the concept of ethnicity has been used in the analysis of a wide range of groups subject to different kinds of classification, embedded in different forms of social organization, and constituted in diverse social and historical contexts. Moreover, as pointed out earlier, the concept of ethnicity has been influenced by different disciplinary traditions, and used in the analysis of diverse areas such as the political mobilization of ethnic groups, the psychological aspects of ethnicity and the social stratification of ethnic groups. ${ }^{136}$

Ora, o risco dessa definição globalizante é bastante grande para ser ignorado: consiste no perigo de aplicarmos para todos os grupos um fator de coesão étnica e pressupor que todo indivíduo possui uma identidade étnica, dando à etnicidade um papel de enorme importância para a análise das sociedades. Embora em certas circunstâncias a etnicidade seja um fator importante, dificilmente podemos afirmar que ela sempre está presente e é sempre determinante na dinâmica social, desenvolveremos melhor esse argumento posteriormente.

Até aqui o que podemos concluir é que grosso modo temos duas correntes principais que discutem o termo "etnia" e nenhuma delas foi bem sucedida no intento

\footnotetext{
${ }^{135}$ Ibidem, p.59-60.

${ }^{136}$ JONES, S. The archaeology of ethnicity... Op.cit. p. 61.
} 
de transformá-lo num conceito bem delimitado. O globalismo subjetivista tem se mostrado quase tão insuficiente quanto a rigidez objetivista.

Há ainda outra via interpretativa comumente chamada de "primordialista" que emergiu muito graças aos trabalhos de Geertz e Shils. Conforme os primordialistas desde o momento do nascimento a pessoa está conectada com um grupo específico e já integrada a um sistema de valores singulares. Assim o pertencimento a um grupo é algo enraizado na mais tenra idade. Como salienta S. Jones, a vantagem da interpretação primordialista é oferecer instrumentos para compreendermos os sentimentos profundos que mantêm indivíduos conectados a um grupo étnico mesmo quando essa ligação não é vantajosa. ${ }^{137}$ Mesmo assim a mesma autora destaca que também o primordialismo traz problemas, um deles é sua leitura romantizada da etnicidade: vista como algo com raízes profundas e forte efeito psicológico nos indivíduos sem que esses efeitos sejam devidamente mensurados. Poderíamos ainda destacar um apontamento feito por F. Barth que se perde entre os primordialistas, a saber, a etnicidade é algo negociável e fluído, em contato com outros grupos as etnias se transformam, não obstante, um mesmo indivíduo pode transitar por diversas identidades e não necessariamente no momento de interação com outros indivíduos é a etnicidade que se impõem como o fator identitário preponderante. O que podemos tirar disso é que embora o primordialismo possa ajudar a entender certas situações em que a etnicidade é de extrema importância, ele não dá conta dos diversos níveis identitários que um mesmo indivíduo pode assumir, assim como as diversas identidades que podem conviver numa mesma sociedade.

Com isso em vista podemos retomar algo que colocamos no início: as etnias são um elemento identitário, mas não o único. Um indivíduo pode transitar por

\footnotetext{
${ }^{137}$ Ibidem, p.65-71.
} 
diversas identificações étnicas dependendo da situação, além disso, em dadas ocasiões outros fatores como classe, religião, gênero e profissão são mais relevantes na afirmação identitária do que a etnicidade. Ou seja, como bem sublinhou A. Gingrich: “ethnic identity thus in fact contains 'situational', 'perfomative' and 'constructivist' elements". ${ }^{138}$ Dessa maneira a etnia pode ser conclamada ou negada, pode se transformar e, mais importante, pode ser completamente irrelevante. Temos com isso que não só é difícil definir o que é uma etnia como em dadas ocasiões o esforço pode não só ser infrutífero, mas também nublar nossa interpretação sobre uma determinada sociedade. Caberia retomar a primeira definição que propusemos para "etnia", ou seja, o sentimento de pertencimento a uma comunidade. Ora, esse sentimento não precisa se dar necessariamente num nível "étnico" - cujas fronteiras são difíceis de precisar. Um grupo de pessoas pode se manter unido e desfrutar de um forte sentimento de pertencimento graças a uma religião, a uma estrato social ou mesmo a um tipo de comportamento.

Possivelmente já se pode perceber que estamos lidando com um termo/conceito de enorme dificuldade, mas que mesmo assim foi apropriado pela historiografia dedicada à Alta Idade Média para tentar compreender as causas e consequências das ditas "migrações bárbaras". Todavia as dificuldades nesse terreno não se devem apenas a sua falta de definição, mas também à história do próprio termo "etnia": ele vem de estudos antropológicos comumente dedicados a sociedades contemporâneas, não obstante, para antropólogos da cultura, as etnias surgiram no contexto do colonialismo do século XIX. ${ }^{139}$ Os administradores colonialistas

\footnotetext{
${ }^{138}$ GINGRICH, Andre. Envisioning Medieval Communities in Asia: Remarks in Ethnicity, Tribalism and Faith. POHL, W. GANTNER, C. \& PAYNE, R. (eds.) Visions of Community in the post-roman world. The West, Byzantium and the Islamic World, 300-1100. UK: Ashgate, 2012. p.33.

${ }^{139}$ GINGRICH, Andre. Envisioning Medieval Communities in Asia: Remarks in Ethnicity, Tribalism and Faith. POHL, W. GANTNER, C. \& PAYNE, R. (eds.) Visions of Community in the post-roman world. The West, Byzantium and the Islamic World, 300-1100. UK: Ashgate, 2012. p.32-35.
} 
aplicaram o termo "etnia" como uma alternativa à "tribo", por vezes atribuindo a partir de critérios arbitrários uma delimitação étnica estranha a esses grupos. Assim, as etnias, no caso por exemplo da África do século XIX e primeira parte do XX, seriam uma invenção dos colonizadores europeus. ${ }^{140}$ Desta forma o termo "etnia" só seria corretamente aplicado no contexto do colonialismo europeu e tão-somente como uma construção dos colonizadores imposta aos colonizados.

A isso A. Gingrich propõe uma resposta. Conforme ele, as afirmações que colocam a etnicidade como um produto do colonialismo são eurocêntricas uma vez que pressupõem que só os Europeus são capazes de reconhecer diferenças culturais e lingüísticas que distinguem grupamentos humanos uns dos outros. Para o autor isso não é verdade uma vez que fontes da China, Índia e Arábias pré-modernas, ou seja, anteriores ao colonialismo, revelam a existência de uma consciência acerca das diferenças entre grupos humanos. ${ }^{141}$ Todavia a resposta de Gingrich nos leva a outro impasse. Se o reconhecimento étnico não foi uma construção do século XIX no contexto colonialista, poderíamos dizer que a organização humana em grupos étnicos é algo imanente à própria humanidade de modo que o estudo comparativo entre sociedades distantes do tempo, mas com características comuns - como por exemplo, ausência de Estado - nos traria à luz modelos explicativos passíveis de aplicação tanto para os tibetanos do século XIX quanto para os godos assentados nos Bálcãs no século IV? Para autores como Kellas, a resposta é "sim". ${ }^{142}$

\footnotetext{
${ }^{140}$ HEUSCH, Luc De. L'Ethnie: les vicissitudes d'un concept. In: MOFFA, Claudio. L'etnia fra "invenzione" e realtà. Storia e problematiche di un dibattito. Torino: Editrice L'Harmattan Italia, 1999. p.67-68. Também F. Barth notou o quanto os estudos que versam sobre a questão étnica se concentraram principalmente no contexto colonial dos séculos XIX e XX: BARTH, F. I Gruppi Etnici e I Loro Confini. In: MAHER, Vanessa (ed.). Questioni di Etnicità. Torino: Rosenberg \& Sellier, 1994. p.44.

${ }^{141}$ GINGRICH, Andre. Envisioning Medieval Communities in Asia... op.cit.

${ }^{142}$ KELLAS, James G. Nazionalismi ed Etnie. Bologna: Il mulino, 1993. p.17-32.
} 
Kellas sustenta que são pré-condições inscritas na natureza humana que influem na formação de identidades étnicas e nacionalistas, por ser parte da natureza humana, o sentimento de pertencimento a um grupo e a ojeriza a membros de outros grupos é algo imanente à humanidade. A posição é polêmica e difícil de ser aprofundada uma vez que entre as ciências humanas há sérias e justificáveis desconfianças com o uso da biologia para a compreensão sociológica, todavia, se utilizamos o norte etnológico para abordarmos tanto os Nuer do Sudão quanto os Godos do século V deveríamos concordar que há algo na disposição humana que nos leva a uma identificação com um grupo restrito. É crucial levar isso em conta em qualquer pesquisa que parte de referenciais antropológicos.

Mas as dificuldades conceituais não se encerram nos problemas em lidar com um termo que não foi consensualmente definido, nos riscos do anacronismo ${ }^{143}$ e nas implicações de partirmos de um pressuposto que pode nos levar a conjecturar sobre uma suposta natureza humana. Há uma particularidade na própria história dos usos das "etnias" entre os antropólogos que deve, no mínimo, suscitar um alerta para os historiadores.

Entre os autores de língua francesa "etnia" foi aplicado pela primeira vez por Vacher de Lapouge em 1886 para designar "raças", ou seja, a partir de uma perspectiva biologizante e que entendia que existiam raças inferiores e raças superiores. Em 1932, F. Boas reagiu fortemente a essa conotação refutando a hipótese de que havia qualquer relação entre cultura e biologia. Assim, com o surgimento da antropologia cultural "etnia", termo derivado do grego ethnos que significa "povos",

\footnotetext{
${ }^{143}$ Bem discutidos por Reynolds: REYNOLDS, S. Our Forefathers? Tribes, Peoples, and Nations in the Historiography of the Age of Migrations. In: MURRAY, A.C. (ed.) After Rome's Fall. Narrators and Sources of Early Medieval History. Toronto, Buffalo \& London: University of Toronto Press, 1998. p.17-36.
} 
passou a se referir unicamente à cultura. ${ }^{144}$ Entretanto, os antropólogos que lidavam com o termo trabalhavam principalmente com sociedades africanas e numa perspectiva anti-histórica que marcou a antropologia cultural - ou social conforme a terminologia anglo-saxã - numa reação ao historicismo do século XIX que pressupunha que o estudo de sociedades ditas primitivas nos levaria aos primórdios da civilização, ou seja, estudar essas sociedades, que teriam ficado estacionadas em um estágio da evolução humana, era como olhar para o passado das sociedades europeias.

Contra isso se posicionaram estudiosos como Malinowski, Barth (1959), Turner (1957) e Leach (1954) e depois deles o anti-historicismo se enraizou na antropologia. ${ }^{145}$ Esse anti-historicismo entretanto teve desdobramentos mais radicais a ponto de adotar uma postura "anti-história" com estudos que se centravam unicamente na contemporaneidade das sociedades estudadas e na negação inclusive das narrativas sobre o passado que circulavam entre os membros da sociedade. ${ }^{146}$

Podemos exemplificar como isso pode influir nas interpretações dos historiadores - mesmo que de maneira inconsciente - partindo da historiografia que nos interessa. Retomemos o caso da origem dos godos descritas por Jordanes, segundo o qual os godos vieram de Scandza. Jordanes, um homem que se declarou de origem goda mas serviu ao império de Justiniano em Constantinopla, concluiu seu texto por volta de 551. Ao longo do seu relato o autor busca legitimar sua versão da origem dos godos mediante a afirmação de que se fiou em relatos escritos, como já discutimos.

O que nos interessa aqui é que a versão de Jordanes foi desmerecida como uma fonte para a origem dos godos. Para autores como Wolfram o texto estava imerso

\footnotetext{
${ }^{144}$ HEUSCH, Luc De. L'Ethnie: les vicissitudes d'un concept... op.cit. p.67-70.

145 TURTON, D. History, age and the Anthropologists. In: AUSENDA, G (ed.). After Empire. Towards and Ethnology of Europe's Barbarians. San Marino: The Boydell Press, 1995. p.95-112.

${ }^{146}$ Idem. Também: GINGRICH, Andre. Envisioning Medieval Communities in Asia... op.cit.
} 
numa perspectiva histórica norteada pelo valor de Roma e, mais do que ser um relato verídico, objetivava inserir a história dos godos na história mais ampla de Roma. ${ }^{147}$ Para Halsall a Getica não passa de uma concha de retalhos de fontes antigas recheada de relatos sem sentido que não possui qualquer valor histórico para o estudo das origens dos godos. ${ }^{148}$ Estamos diante de uma negação total do valor histórico para um fim específico - a busca da origem dos godos - de uma fonte escrita por uma pessoa que se dizia goda e que confrontou outras fontes para construir uma narrativa verossímil, trata-se de uma negação das narrativas do passado que circulavam, talvez, entre aqueles que se reconheciam como godos na Constantinopla do século VI. Não queremos dizer com isso que podemos confiar cegamente em Jordanes, mas que refutar totalmente sua versão talvez não seja o único caminho viável ${ }^{149}$ e que essa total recusa pode ser fruto de uma abordagem motivada por uma pre-concepção oriunda de pressupostos conceituais insuficientemente discutidos.

É possível, e isso é apenas uma sugestão, que essa seja a consequência imediata de lidar com um aparato conceitual cuja história se desenvolveu a partir de uma negação da história, a fórmula, muito bem sintetizada por D. Turton, se baseava mais no olhar sobre como o presente constrói o passado do que na pergunta sobre como o passado constrói o presente. Mas é mister nos questionarmos porque um esforço conceitualizador com tal história se tornou caro justamente para os historiadores dedicados ao período das migrações bárbaras e dos assentamentos bárbaros no Ocidente europeu.

\footnotetext{
${ }^{147}$ WOLFRAM, H. Storia dei Goti... op.cit.

${ }^{148}$ HALSALL, G. Movers and Shakers. The barbarians and the fall of Rome. In: NOBLE, Thomas F.X.(ed.). From Roman provinces to Medieval Kingdoms. NY \& Abingdon: Routledge, 2005. p.279.

${ }^{149}$ Como defendem KAZANSKI, M. Les goths. (Ier-VIIe après J.-C.) Paris: Editions Errance, 1991. p.9-28. Ainda: GOFFART, Walter. Jordane's "Getica" and the disputed authenticity of Gothic origins from Scandinavia...op.cit. E também o interessante artigo: BRINK, Stefan. People and land in Early Scandinavia. In: GARIPZANOV, I.D., GEARY, P., URBANCZYK, P. Franks, Northmen, and Slavs: Identities and State Formation in Early Medieval Europe. Turnhout: Brepols, 2008. p.88-112.
} 
O problema pode ser desdobrado em duas hipóteses não excludentes. A primeira se refere a um antigo movimento de afastamento entre a história e a filosofia, cuja história data do século XIX, mas que ainda está em curso em nossa disciplina. Nesse sentido, a busca por aparatos conceituais mais passíveis de uma verificação minimamente empírica leva os historiadores a transitar por outras disciplinas. ${ }^{150} \mathrm{~A}$ segunda, que desenvolveremos melhor aqui, concerne às consequências do uso político da história, sobretudo no período entre-guerras. Nota-se que as hipóteses não se excluem uma vez que os usos políticos da história só foram possíveis por conta de pressupostos teóricos da história que entraram em crise no mundo pós-guerras. Analisemos as proposições à luz da historiografia específica ao nosso tema retomando a partir das reflexões aqui apresentadas alguns pontos que levantamos nos tópicos anteriores. As questões são: a partir dos problemas conceituais, como se apresentam os relatos das origens das gentes? E como podemos ler a historiografia que contemplou as fontes à luz desse aparato conceitual?

\footnotetext{
${ }^{150}$ Sobre isso: GADAMER, H.-G. Verdade e Método. Traços fundamentais de uma hermenêutica filosófica. Petrópolis: Vozes, 1999. p. 39-47. Ainda o pequeno mas bem ilustrativo livro de Reis: REIS, José C. A história entre a filosofia e a ciência. São Paulo: Ática, 1996.
} 


\section{Identidades étnicas - o problema das migrações bárbaras na historiografia}

Termos que poderiam ser qualificados como étnicos aparecem nas fontes que trabalhamos, ou seja, fundamentalmente aquelas que podem inicialmente ser qualificadas como normativas e historiográficas. Podemos partir de duas fontes que foram inscritas por seus autores no gênero narrativo História para observarmos isso. Escolhemos narrativas históricas para exemplificar a questão já que entre as diversas características que compõe identidades étnicas está, talvez entre as mais importantes, o sentimento de pertencimento a uma origem comum. ${ }^{151}$ Adotamos aqui fontes anteriores ao recorte da pesquisa com a intenção de discutir a questão das origens comuns, ou seja, elas são descritas nas Histórias antes do início da escrita de textos históricos nos regna gothorum et francorum? Outra pergunta é: qual a função que os termos étnicos exercem no sistema explicativo da trama dos acontecimentos nessas Histórias? Por fim: possíveis identidades étnicas impactaram no desenrolar dos acontecimentos descritos de modo que podem nos ajudar a compreender questões pertinentes ao período histórico no qual nos atemos?

Comecemos então pelo termo "francos". Dentre as mais antigas referências textuais que chegaram aos nossos dias e mencionam a presença de francos na Gália está o texto de Amiano Marcelino, como já mencionamos. O autor esteve na região acompanhando Ursicino que fora designado por Constâncio II para enfrentar Silvano, investido com as insígnias imperiais na região da Colônia. Conforme o relato de Amiano Marcelino sobre os eventos do ano de 355, Silvano era um comandante a serviço das tropas romanas (Silvanus pedestris militiae rector) que enfrentava as desordens da Gália causadas por pilhagens e massacres conduzidos por bárbaros. Silvano acabou envolvido em complicações por conta de um certo Dynamius que

\footnotetext{
${ }^{151}$ HOPPENBROUWERS, P. Such Stuff as Peoples are Made on: Ethnogenesis and the Construction of Nationhood in Medieval Europe. The Medieval History Journal. v.9, n.2, p.196-242, 2006.
} 
iniciou uma circulação de correspondências suspeitas com vistas a aumentar o próprio prestígio. Num dado momento Dynamius atribuiu falsamente uma carta a Silvano e a outro comandante chamado Malarico e a enviou para Cremona. Cremona respondeu pedindo explicações sobre o conteúdo obscuro da carta. Malarico, surpreendido pela inquirição de Cremona e as suspeitas em torno dele e Silvano, recorreu à ajuda dos Francos: "que naquela época eram numerosos e influentes no palácio e falavam de maneira mais audaciosa." ${ }^{\prime 152}$ Não é por acaso que Malarico apelou aos Francos, ele próprio era de origem franca, conforme Amiano Marcelino, assim como Silvano.

Os acontecimentos levaram Silvano a se rebelar e receber a dignidade imperial, dentre esses eventos conta-se a própria ameaça que Silvano recebeu dos Francos. Por fim, Ursicino, enviado pelo Imperador para resolver a questão, conseguiu sair vitorioso e Silvano acabou assassinado.

Há muitos elementos interessantes no relato de Amiano Marcelino. O primeiro é a própria situação de observador privilegiado na qual ele se encontrava por ter estado a serviço de Ursicino. Não podemos, todavia, cair na ingenuidade de acreditar que essa posição torna sua narrativa mais isenta e segura. $\mathrm{Na}$ verdade, as passagens elogiosas referentes ao general romano podem ser atribuídas não apenas ao talento dele, mas também por ter sido um dos seus subordinados que nos legou mais informações sobre sua atuação. De fato, além da obra de Amiano Marcelino, pouco restou de informações sobre Ursicino. Por outro lado Amiano Marcelino não teceu tantos elogios a Constâncio II, que desconfiava do general e o perseguiu. Em dada passagem, precedida pelo relato das ameaças persas e sarracenas nas províncias orientais, Amiano Marcelino disse sobre Constâncio:

\footnotetext{
${ }^{152}$ [...] ]adhibitis Francis, quorum ea tempestate in palatio multitudo florebat, erectius iam loqucbatur [...]. Amiano Marcelino (Am. Marc.) Res Gestae. XV, 5, 11.
} 
Dum haec in oriente aguntur, Arelate hiemem agens Constantius, post theatralis ludos atque circenses ambitioso editos apparatu. ${ }^{153}$

Amiano Marcelino parece ter almejado com isso atribuir incompetência a Constâncio II. A ênfase nesse ponto não se orienta para indicar que esse era o objetivo de Marcelino com sua Res Gestae, mesmo porque a obra não se reduz a um elogio a Ursicino e detração de Constâncio II, evidentemente! Trata-se antes de ter em vista que, a despeito do entusiasmo que uma obra escrita por um autor que testemunhou alguns dos eventos descritos, essa deve ser tratada de maneira crítica tanto quanto qualquer outro texto. Portanto essa reserva deve ser mantida também quando nos debruçamos sobre os francos no texto de Marcelino.

Feitas as devidas ressalvas, voltemos ao relato que sumarizamos anteriormente com foco sobre quais interpretações podem se desdobrar das palavras de Amiano Marcelino sobre os francos.

Uma leitura inicial pode inferir que o termo "francos" se refere a um grupo homogêneo e com especificidades que os diferem de outros grupos. Esse grupo, a despeito de ter sido ímpar, estava integrado na estrutura administrativa romana. Eram cada vez mais numerosos no palatio e tinham peso político a ponto de Malarico recorrer a eles para ajudá-lo a esclarecer a trama na qual Dynamius havia colocado ele e Silvano. Não obstante, os próprios Silvano e Malarico eram de origem franca, conforme Marcelino, e exerciam cargos de comando nas tropas romanas que enfrentavam os assédios bárbaros na Gália. Há mais, poderíamos também inferir que o pedido de ajuda de Malarico aos francos não se devia apenas a crescente influência deles, mas também ao fato de Malarico compartilhar com eles uma origem comum, disso não parece absurdo supor que não só existia uma identidade franca, como ela servia na resolução de querelas políticas: Malarico, por ter sido franco, apelou aos

${ }^{153}$ Am. Marc. Res Gestae. XIV, 5, 1. 
francos para obter auxílio contra as falsidades de Dynamius; os francos, enquanto um grupo coeso, tinham uma força política própria. Nesse sentido seria atestada não só a existência de fato de uma identidade franca, mas igualmente a importância de estudala já que ela teria papel decisivo em circunstâncias relevantes, no caso, os eventos que redundaram na ilegítima elevação de um franco, Silvano, a dignidade imperial romana num quadro de contestação da autoridade legítima do imperador Constâncio II numa época na qual a figura dos imperadores enfrentava esse cenário de instabilidade política e fragilização da autoridade central recorrentemente. A elevação de Silvano e o papel dos francos no teatro dos acontecimentos descritos por Amiano Marcelino seria, desta forma, parte do processo que redundou na "queda de Roma", no "Fim do Mundo Antigo". 154

Há uma outra via de interpretação e ela está atrelada paradoxalmente a Silvano. Marcelino alegou que Silvano foi alertado que sua vida estava em risco e o perigo vinha dos próprios francos. Se por um lado isso mais uma vez atesta o peso político dos francos, por outro enuncia um contraste nas relações que Malarico e Silvano, ambos francos, tinham com outros francos. O fato de uma suposta origem comum não deu aos dois personagens uma ligação simétrica com o grupo do qual se originaram, enquanto o primeiro contou com a ajuda do grupo o segundo se viu ameaçado por ele. As razões dessa assimetria não são esclarecidas no texto de Marcelino, mas nos guiam para uma possibilidade: se havia um "ser franco" ele não era sempre um fator decisivo que garantia a ajuda dos iguais, talvez porque na trama complexa da formação de alianças ou animosidades outros fatores estivessem em jogo

\footnotetext{
${ }^{154}$ S. Mazzarino muito bem sublinhou o peso que o "elemento estrangeiro bárbaro" teve na fundamentação da idéia de "Fim do Mundo Antigo": "«Penetrazione dei sostrati etnici sottomessi (celtico, berbero, egizio, aramaico, ecc.) nella cultura ellenistico-romana»; « squilibrio fra produttività ed esigenze di centralizzazione»: anche queste sono formule. Sebbene esse tentino di riassumere descrittivamente la crisi dell'impero, tuttavia conservano quel tanto di astratto e discutibile che è proprio delle formule. La storia preferisce la narrazione alle teorie, la concreta ricostruzione alla ipotesi metafisica.” MAZZARINO, S. L’Impero romano 2. Roma: Editori Laterza, 2007. p.815
} 
além de pertencimentos a grupos étnicos. Chegamos então a uma possibilidade interpretativa oposta a anteriormente apresentada, ou seja, a questão da existência de uma identidade franca perde potencial enquanto elemento hermenêutico para o período.

Existe ainda outra questão que não pode ser preterida. Amiano Marcelino era um romano e é ele que outorga a um grupo uma possível coesão identitária franca. Ainda, não encontramos no texto que chegou dele aos nossos dias uma indicação sobre o que é ser franco, algo que aparece na obra no caso dos sarracenos, por exemplo. Isso não quer dizer que Amiano Marcelino não tenha empreendido um esforço por descrever os francos - suas características físicas, origens geográficas, costumes alimentares - é que não temos a íntegra de sua obra. No que restou, os francos aparecem como elementos já integrados ao exército romano, participam de tramas conspiratórias e no complexo tecido de alianças da Gália do século IV. De todo modo, Amiano Marcelino é fonte suficiente para podermos defender, a partir do que ele acreditar "ser franco", a existência de francos? Ora, seria bastante presunçoso afirmar que Marcelino foi completamente infiel às informações de seu entorno quando fez a seleção que integrou a trama da história que escreveu. Mas permanece a pergunta: o que ele viu como "francos" era a existência de um grupo que compartilhava de uma identidade franca? Ou ele interpretou os dados nessa direção seguindo uma tradição de escrita da história onde a etnografia greco-romana impactava na escolha de informações e interpretação delas para tecer uma narrativa histórica? ${ }^{155}$ Sim, Amiano Marcelino estava alinhado com uma tradição de escrita da história, a dificuldade é perceber até que ponto isso orientou sua leitura sobre os francos uma vez que não há um outro lado para nos permitir uma comparação além de

155 Sobre o contraste e comparação com o "outro" para a compreensão histórica grega: MOMMIGLIANO, A. As raízes clássicas da historiografia moderna. Bauru: Edusc, 2004. p. 53-83. 
textos escritos por outros romanos. A arqueologia, que poderia fornecer sinais indicativos da existência de um grupo auto reconhecido como franco no século IV, tampouco nos fornece evidências para qualquer afirmativa nesse sentido. ${ }^{156}$ Até esse ponto, no caso dos francos, chegamos à perturbadora constatação de que os dados são inconclusivos.

É preciso retomar ainda do caso dos godos. A História Nova de Zózimo consiste numa importante fonte por apontar para a participação dos godos no conturbado período entre 235 e 284 denominado pela historiografia como "anarquia militar", designação essa que não deixa de fazer justiça aos quase cinquenta anos nos quais não menos do que quatorze homens assumiram o império. ${ }^{157}$ As desordens e disputas internas são apresentadas por Zózimo como a causa da entrada de bárbaros nas províncias romanas. Poderíamos retroceder na narrativa de Zózimo até o período entre 181 e 192 quando Cômodo esteve a frente do Império. Seu assassinato perpetrado por uma concubina foi seguido por querelas intensas que opôs membros do comando do exército ao senado, governadores de províncias distantes ao senado e, irmão a irmão, nas figuras de Geta e Caracala, filhos de Severo que conseguiu, de acordo com Zózimo, governar com sapiência e pôde controlar os dissidentes. É que para Zózimo não parece que foram eventos circunstanciais do século III, no caso os descuidos de Felipe, o árabe, com as fronteiras do império por conta de sua reação às rebeliões da Panônia e Mésia onde Décio se opunha a ele, tampouco apenas as alianças que Treboniano Galo fez com os bárbaros para derrotar Décio, que

\footnotetext{
${ }^{156}$ SCHMAUDER, M. The relationship between Frankish gens and regnum: a proposal based on the archaeological evidence. In: GOETZ, H.-W., JARNUT, J. \& POHL, W. (eds). Regna and Gentes. The Relationship between Late Antique and Early Medieval Peoples and Kingdoms in the Transformation of the Roman World. Leiden \& Boston: Brill, 2003. p.271-306. Ainda: HAKENBECK, S.E. Situational Ethnicity and Nested Identities: New Approaches to an Old Problem. Anglo-Saxon Studies in Archaeology and History, n.4, p.19-27, 2007.

${ }^{157}$ Uma excelente e sumarizada análise sobre o período e o curto governos desses homens pode ser encontrada no trabalho de R. Frighetto. FRIGHETTO, R. Antiguidade Tardia. Roma e as monarquias romano-bárbaras numa época de transformações. Séculos II-VIII. Curitiba: Juruá, 2012. p.69-91.
} 
desembocaram no avanço das pilhagens bárbaras conduzidas também por godos. Foi uma cadeia de desordens, um longo processo de disputas internas, que desestabilizou o Império a ponto de torna-lo vulnerável às ameaças bárbaras. E. Gibbon pareceu ter se convencido do argumento de Zózimo e tal como ele escreveu uma história de Roma como uma história de Declínio e Queda. ${ }^{158}$

A primeira menção aos godos na História Nova, dessa forma, aparece como consequência de problemas intrínsecos à Roma. A incompetência dos imperadores fortaleceu os bárbaros e desembocou, finalmente, na humilhação do saque de Roma conduzido por Alarico I. Não se trata aqui de desmerecer o papel dos godos e demais bárbaros no texto de Zózimo, mas antes indicar que a responsabilidade deles soa secundária dentro do cenário de um caos oriundo de Roma, não de fora dela. Ora, aqui o tema do declínio se explicado mediante a chegada de grupos estranhos aos romanos seria insuficiente.

Se nos centrarmos na questão de grupos étnicos no texto de Zózimo, entramos num labirinto semelhante ao que encontramos na análise dos francos na narrativa de Amiano Marcelino. Quem eram esses godos? Aqueles que assediaram as províncias romanas no século III eram os mesmo que liderados por Alarico saquearam Roma em 410? Quem Zózimo chama de "godos" se identificavam como tal? Difícil saber. E mais uma vez a arqueologia, que poderia trazer informações materiais passíveis de comparação com o texto de Zózimo para confirmarmos a existência de um grupo que se referenciava como godo, não traz elementos conclusivos. A relação entre as culturas "Santana de Mureș" na Romênia e cultura "Černjakhov" na Ucrânia com os godos, como já argumentamos, são extremamente problemáticas.

\footnotetext{
${ }^{158}$ GOFFART, W. Zosimus, the first historian of Rome's Fall. The American Historical Review. v. 76, n.2, p.412-441, 1971. GIBBON, Edward. Declínio e queda do Império Romano. Vol.2. Lisboa: Difusão Cultural, 1995.
} 
É notável como as fontes escritas e as fontes arqueológicas não são harmônicas no que concerne a questão dos francos e dos godos. Enquanto nas fontes escritas eles aparecem como um grupo coeso que desde o século III impactavam nos rumos que o Império tomava, a arqueologia não traz qualquer confirmação da existência desses grupos transcendente aos textos. O impasse continua, o que sabemos sobre godos e francos nos séculos III e IV é tudo o que os romanos escreveram sobre eles.

Isso traz duas questões, uma de ordem teórica e outra de ordem metodológica. A questão de ordem teórica se refere ao pressuposto de que as identidades étnicas impactavam na dinâmica da história como um todo, essas identidades não só podiam ser detectadas - nos resquícios materiais ${ }^{159}$ e escritos - como tiveram papel central nos processos transformadores e nas organizações sócio-políticas, portanto, deviam estar sob a atenção dos historiadores para que eles outorgassem inteligibilidade ao passado, mas mormente explicar o presente. Leopold von Ranke, por exemplo, viu na união de Germanos e Romanos o cerne da fundação dos Estados Modernos do século XIX. ${ }^{160}$ N.D. Fustel de Coulanges insistiu na "raça" como parte e, destarte, objeto do historiador. ${ }^{161} \mathrm{O}$ encontro dessas das duas "raças", romana e germânica, a sublimação de uma pela outra, os resultados disso para a história que se seguiu à deposição de Rômulo Augusto - evento tradicionalmente divisor de águas que separa o mundo antigo do medieval - ditaram o tom dos debates historiográficos do XIX que opôs os

\footnotetext{
${ }^{159}$ Sobre o problema das identidades étnicas na arqueologia: JONES, S. The Archaeology of Ethnicity. Constructing identities in the past and present. Londres \& NY: Routledge, 1997. p.1.55.

160 "Por fim, o próprio direito romano foi adotado pelos povos de origem teutônica. Dessa união nasceram seis grandes nações; em três predominam o elemento românico: no francês, no espanhol e no italiano; em três, o germânico: no alemão, no inglês e no escandinavo." RANKE, Leopold von. Da unidade essencial dos povos romanos e germânicos e de sua comum evolução. In: História. São Paulo: Ática, 1979. p.65.

161 'La race, c'est encore de l'histoire, c'est du passé. La langue, c'est encore de l'histoire, c'est le reste et le signe d'un passé lointain. Ce qui est actuel et vivant, ce sont les volontés, les idées, les intérêts, les affections." FUSTEL DE COULANGES, N.D. L'Alsace est-elle allemande ou française? Réponse a M. Mommsen. Paris: E. Dentu, 1870. p.14
} 
romanistas e germanistas. ${ }^{162}$ De todo modo, a certeza na existência dessas raças bem definidas e que influenciavam na história tornou-se o fator orientador das interpretações históricas! Isso não é desimportante.

Quando supostamente a administração romana foi substituída pelos reinos governados por germanos a historiografia viu o fim de uma era, o Fim do Mundo Antigo, e o início de outra, a Idade Média. Trata-se de um marco divisor da história que trouxe consequências para a nossa disciplina. É que a periodização da história é muito mais do que um ponto de referência didático, diz mais do que uma delimitação temporal, ela traz em si pressupostos, conceitos e interpretações. Periodizar na história é conceitualizar, outorgar a um espaço-tempo características ímpares que o diferencia do anterior e sucessor. ${ }^{163}$

O assentamento dos germanos no Ocidente europeu, pelo fato dos germanos terem sido interpretados como unidades étnicas com organizações próprias e distintas entre si e entre os romanos, assim, significou a formação de uma nova realidade marcada pela polarização da autoridade política, a privatização do poder e, mais popularmente, o feudalismo. Essas tornando-se as peculiaridades que legitimavam chamar aquele tempo de medieval. Essas características vêm à mente do ouvinte quando escuta o termo, de modo que mais do que caracterizar um espaço temporal ele outorga a essa temporalidade certas qualidades e especificidades. Ora, quando lemos obras que tratam da história e cultura histórica no Ocidente medieval ${ }^{164}$ é de se supor que havia uma história e cultura histórica ímpar naquele espaço geográfico durante os

\footnotetext{
${ }^{162}$ Além das referências já citadas sobre o debate, vale ainda consultar: CÂNDIDO, M. A realeza cristã na Alta Idade Média. São Paulo: Alameda, 2008. Um posicionamento um pouco diferente sobre o problema: SILVEIRA, Verônica da Costa. História e historiografia na Antigüidade Tardia à luz de Gregório de Tours e Isidoro de Sevilha. 2010. 181 f. Dissertação de Mestrado - Faculdade de Filosofia, Letras e Ciências Humanas/USP. São Paulo, julho de 2010.

${ }^{163}$ Uma interessante reflexão sobre essa característica da periodização na história pode ser encontrada em: GRININ, L.E. Production Revolutions and periodization of History: a comparative and theoreticmathematical approach. Social Evolution \& History. Moscou: Uchitel, vol., 6, n., 2, p.75-121. 2007.

${ }^{164}$ GUENÉE, Bernard. Histoire et culture historique dans L'Occident Médiéval. Paris: AubierMontaigne, 1980.
} 
séculos que se nomeiam como medievais, o mesmo pode ser dito sobre a economia medieval, a sociedade medieval, as leis medievais, etc. Medieval deixa então de se referir apenas a dez séculos de história - se adotarmos como balizas a deposição de Rômulo Augusto e a Queda de Constantinopla - mas também a dez séculos definidos por certas singularidades: como as formas da escrita da história; as especificidades na economia e no exercício da justiça e assim por diante.

Seria reconfortante dizer que esse problema de ordem teórica está circunscrito à historiografia do século XIX e foi superado com a crítica à idéia do Fim do Mundo Antigo e a ascensão do termo Antiguidade Tardia; ${ }^{165}$ e a crítica à concepção acerca da existência de unidades étnicas muito bem definidas como godos e francos que entraram em contato com os romanos e a utilização do conceito de etnogênese. ${ }^{166}$ Não nos parece ser o caso e dizer isso não significa que encontramos uma solução para o impasse. Primeiro porque não é consenso entre os historiadores que a chegada dos bárbaros não significou uma ruptura com Roma, temos entre as vozes dissonantes pesquisadores como C. Wickham e B. Ward-Perkins, ${ }^{167}$ de todo modo os destinos do Império depois da chegada dos bárbaros continua a ser a pergunta mais comum que se faz ao período. Segundo, os historiadores que questionam a unidade de godos e francos antes de seus contatos com o Império não deixam de ter o peso dessas identidades - agora sob uma nova perspectiva que as entendem como construção histórica - como foco da pesquisa. Mesmo que sob novas perspectivas, O Fim ou

\footnotetext{
${ }^{165}$ BROWN, P. The Making of Late Antiquity. Cambridge: Harvard University Press, 1993. LIM, Richard \& STRAW, Carole. The past before us. The challenge of historiographies of Late Antiquity. Turnhout: Brepols, 2004. Ver especialmente a introdução e o artigo de A. Cameron.

${ }^{166}$ WENSKUS, Reinhard. Stammesbildung und verfassung: Das werden der frühmittelalterlichen gentes. Colônia: Böhlau, 1961.

${ }^{167}$ WARD-PERKINS, B. The fall of Rome and the end of civilization. Oxford e New York: Oxford University Press, 2005. WICKHAM, Chris. Framing the Early Middle Ages. Europe and the Mediterranean. 400-800. Nova York: Oxford University Press, 2005.
} 
perenidade do mundo Antigo diante da chegada dos bárbaros continua a guiar as pesquisas dos historiadores.

Mesmos os pesquisadores que questionam as novas abordagens sobre as etnias mediante o conceito de etnogênese não empreendem uma ruptura com a tradição analítica que tentamos apresentar aqui. A. Gillet, ${ }^{168}$ por exemplo, em sua crítica à ligação entre termos étnicos nos títulos reais e uma população étnica que seria referenciada por esses termos parece não ter compreendido muito bem a mudança que o conceito de etnogênese trouxe, ao contrário de defender a existência dessas unidades, os historiadores partidários dessa hipótese justamente mostram que eram identidades construídas, não "naturais". Não obstante, Gillet, ao criar enormes tabelas onde mostra o aparecimento desses termos junto aos nomes dos reis conforme ele os encontrou nas fontes, isola os termos do todo onde eles foram expressos. Seu texto soa tendencioso, mais do que analisar o que esses termos significavam ele parece ter desejado atacar os historiadores ligados à Escola de Viena. O mesmo podemos dizer de W. Goffart ${ }^{169}$ em diferentes artigos, e nesse sentido a resposta de W. Pohl ${ }^{170}$ foi bastante correta ao dizer que os críticos da hipótese da etnogênese não acompanharam o desenvolvimento dos trabalhos e baseiam seus ataques em interpretações equivocadas sobre a etnogênese, ainda, esses críticos tampouco apresentam alternativas de análise. C. Wickham parece estar correto quando afirma que a querela

${ }^{168}$ GILLET, A. Was Ethnicity politicized in the Earliest Medieval Kingdoms? In: (ed.). On Barbarian Identity. Critical Approaches to Ethnicity in the Early Middle Ages. Turnhout: Brepols, 2002. p.84-121.

${ }^{169}$ Por exemplo: GOFFART, W. Does the distant past impinge on the invasion age germans? GILLET, A.(ed.). On Barbarian Identity. Critical Approaches to Ethnicity in the Early Middle Ages. Turnhout: Brepols, 2002. p.21-37. GOFFART, W. Jordane's "Getica" and the disputed authenticity of Gothic origins from Scandinavia. Speculum. v. 80, n.2, p.379-398, Abril de 2005.

${ }^{170}$ POHL, W. Ethnicity, theory and tradition: a response. In: GILLET, A.(ed.). On Barbarian Identity. Critical Approaches to Ethnicity in the Early Middle Ages. Turnhout: Brepols, 2002. p. 221239. 
transcendeu um debate oriundo da leitura das fontes para se tornar uma disputa no campo estritamente historiográfico. ${ }^{171}$

Nesse ponto podemos tratar do problema de ordem metodológica que referenciamos. Na verdade não se trata de um único problema, mas de três. Vejamos.

1. Termos que poderíamos traduzir arbitrariamente como povo (populos), mais arbitrariamente ainda como tribo (gens) e nação (natio) aparecem nas fontes escritas entre os séculos IV e VII com certeza, o problema, nos parece, é acreditar que eles têm necessariamente um significado que poderia ser traduzido como étnico.

A antropologia do final do século XIX e início do XX na figura de estudiosos como Franz Boas já operava uma distinção entre raça e cultura numa crítica à visão biologizante que entendia existir uma íntima relação entre raça biológica e cultura. Entre 1920 e 1960 os antropólogos começaram a perceber que mesmo com a separação entre raça e cultura, seus esquemas conceituais rígidos ainda não davam conta dos casos estudados onde a realidade se mostrava muito mais complexa e dinâmica. Foi entre 1960 e 1970 que emergiu a "etnicidade" e o termo "grupos étnicos" passou a ser utilizado em lugar de "tribos" numa tentativa de superar a noção de sociedades primitivas que orientavam as teorias antropológicas e também indicar a que as sociedades não representavam unidades culturais. Grupos étnicos coexistem mesmo diante da idéia homogeneizante intrínseca na noção de "Estado-Nação". ${ }^{172}$ Como bem sumarizou S. Jones:

The emergence of the concept of ethnicity as a major taxonomic category in the classification of peoples was partly stimulated by a theoretical shift away from the fixed, reified categories of 'race', 'culture', 'society' and 'tribe' towards a processual analysis of ethnicity as a form of social interaction. Yet other factors have been involved, including the meanings which concepts such as race, tribe and ethnicity have accumulated within the context of a number of different functioning ideological discourses, and the increasing salience of ethnicity in the realm of national and international politics in the last two to three decades. ${ }^{173}$

\footnotetext{
${ }^{171}$ WICKHAM, Chris. Framing the Early Middle Ages...op.cit. p.82-83.

172 JONES, S. The Archaeology of Ethnicity ...op.cit. p.48-54.

${ }^{173}$ Ibidem, p.54-55.
} 
Ora, percebemos que o conceito de "grupos étnicos" é bastante moderno e oriundo de estudos antropológicos de sociedades contemporâneas. Se o adotarmos para os séculos IV e V e VI e VII e VIII (foco da nossa pesquisa), estamos partindo do pressuposto que esse conceito dá conta de uma realidade comum à vida em sociedade humana, independente do contexto histórico, trata-se de dizer que grupos étnicos existiam e existem em todas as formas e períodos das sociedades. Aceitá-lo é partir de um elemento universalizante.

Não queremos com isso refutar a priori a possibilidade de utilizá-lo. A questão se configura de outra maneira. Ora, se partirmos da noção de que em toda sociedade, em qualquer tempo, grupos étnicos coexistem, se transformam e atuam verticalmente na política, economia, religião e assim por diante, qual é o papel do historiador quando estuda história? Desvendar esses grupos étnicos em sociedades estranhas a nossa e em períodos pretéritos? Descobrir como eles impactam na política, economia, religião e em qualquer outro tema que acreditamos ser importante para entender alguma sociedade?

2. A segunda questão é uma retomada de algo que colocamos no início desse tópico, a saber, a existência de um descompasso entre o que as fontes dizem sobre francos e godos e o que podemos tirar dos levantamentos arqueológicos. A pergunta é: o fato de unidades godas e francas existirem, possivelmente, no plano apenas discursivo de um grupo determinado ${ }^{174}$ as tornam irrelevantes uma vez que não podemos confirma-las numa realidade exterior às fontes, no caso, resquícios arqueológicos?

Aqui tocamos na relação que os historiadores tem com as fontes, como se a narrativa nelas inscritas fosse uma interpretação de uma realidade exterior às fontes. Assim, compreender as fontes exige reconstruir o contexto para desvendar a interpretação que a fonte dá a ele. Se o contexto não corroborar as fontes, o discurso escrito é desmerecido como

\footnotetext{
${ }^{174}$ Essa questão é colocada por M. Coumert: COUMERT, M. Origines des peuples. Les récits du
} Haut Moyen Âge Occidental (550-850). Paris: Institut d'Études Augustiniennes, 2007. 
fantasioso. As informações das fontes são subordinadas a um contexto mediante a emulação de uma dicotomia entre narrativa e realidade. ${ }^{175}$

Quais são as implicações disso para o período que estudamos? Ora, é que apreendemos o contexto utilizando justamente os textos, o que poderia vir de fora, as informações arqueológicas, não criam um quadro harmônico com o contexto que os textos oferecem, isso sem levar em conta todos os problemas envolvidos nos vestígios arqueológicos. De todo modo parece que recorrer a um contexto fora dos textos não nos ajuda muito, a única conclusão que poderíamos tirar desse método interpretativo é bastante maniqueísta: ou os textos ou os resquícios materiais são infiéis à realidade. Ao menos para esse impasse adotamos uma proposta metodológica, ou seja, analisamos os textos não como uma narrativa sobre a realidade externa a eles, mas o lemos como uma realidade por si só, mas não isolados: eles compõe uma realidade discursiva junto com outros textos até quando os textos são contraditórios entre si. É nesse ponto que acreditamos que não podemos refutar a hipótese dos grupos étnicos baseando-nos na falta de material além de obras escritas por romanos. A presença de termos como "godos" e "francos" tinha uma razão nesse "contexto textual", esse é o ponto fulcral dessa pesquisa: investigar qual era essa razão, ou essas razões. Entretanto pensamos que aparentemente, e muito por conta do problema conceitual que apresentamos, parece mais pertinente analisar a recorrência desses termos numa perspectiva que os considera num contexto de construção identitário sem necessariamente relacioná-los com etnicidades.

3. O terceiro problema é o mais complexo e já aparece ao longo de todo esse tópico. Mas cabe aqui deixa-lo explícito. Ele consiste na confusão que

\footnotetext{
${ }^{175}$ Nada disso é inédito. Q. Skinner, por exemplo, colocou o problema. Ele também foi contemplado por R. Koselleck e J.G.A. Pocock. A questão está colocada aqui pois a sensação é que ela traz problemas interessantes, especialmente para historiadores que tratam de períodos com carência de fontes e que dependem de textos fundamentalmente para suas análises, é o caso daqueles que se identificam como "medievalistas". Dentre alguns exemplos de textos propedêuticos dos historiadores mencionados nesta nota e que dão uma boa visão da questão colocada: SKINNER, Q. Hermeneutics and the Role of History. New Literary History. Baltimore: The Johns Hopkins University Press, vol.7, n.,1, p.209-232. 1975. POCOCK, J.G.A. Political thought and history. Essays on Theory and Method. Cambridge, NY: Cambridge University Press, 2008. KOSELLECK, R. Crítica e crise: uma contribuição à patogênese do mundo burguês. Rio de Janeiro: EDUERJ, 1999. Dentro os críticos, especialmente à Q. Skinner, vale sugerir as boas colocações de Parekh e Berki: PAREKH, B. \& BERKI, R.N. The history of political ideas: a critique of Q. Skinner's methodology. Journal of the History of Ideas. v.34, n.2, p.163-184, 1973.
} 
existe entre objeto e hipótese. É que quando adotamos o tema dos francos e dos godos nas fontes merovíngias e visigodas dos séculos VI e VII como objeto de pesquisa fizemos algo muito além de apenas escolher um tema para estudar dentre tantas outras possibilidades de objetos. Quando escolhemos esse objeto estava por trás a idéia de que ele foi importante no período e ajuda a compreendê-lo. Vamos esmiuçar esse ponto. Inicialmente é preciso dizer que ele tem íntima relação com o ponto 2. Ora, quando dizemos que analisaremos os francos e os godos no contexto textual merovíngio e visigodo não significa que nossa análise vai se aproximar de uma análise literária onde os termos serão investigados por si. Nossa intenção é tentar analisar esses termos num contexto textual sobre as regna francorum e gothorum. Ou seja, como esses termos são investidos de significados e servem como operativos no contexto textual sobre as regna? Eles aparecem como referenciados a uma unidade política? Ou melhor, eles contribuem para construir essa unidade? É justamente pela pesquisa ser motivada por essas perguntas que optamos por trabalhar com um conjunto amplo de fontes, a opção foi difícil, mas foi a única que deslumbramos. Um único texto não nos parece dar conta de nossa noção de contexto textual - e, enfatizamos, esse contexto textual não é uma substituição da busca por uma realidade, ele é uma realidade, ele diz algo sobre o período. Mas o contexto textual não é um quadro harmônico, ele se compõe por diversos formatos de narrativas, com diversas respostas a diferentes problemas apresentados pelos textos. Escrever uma lei não era análogo a escrever uma história, digamos assim para não deixar nossas palavras num plano de abstração. Mas as leis não ser descoladas das histórias, elas precisam ser analisadas confrontando-as. Para citarmos um exemplo que foge um pouco do exemplo anterior, mas nos parece ilustrar bem onde queremos chegar: as colocações de Isidoro de Sevilha sobre as leis em suas etimologias impactaram nas revisões pelas quais as Leges Visigothorum passaram. E mais, o De Legibus de Isidoro de Sevilha transcendeu as fronteiras do reino visigodo e circulou na tradição manuscrita junto a, por exemplo, as leis sálicas, e é por isso que optamos por não analisar apenas o reino visigodo ou franco, e sim ambos. É evidente que tudo isso não estava em vista quando essa pesquisa teve 
início. Naquele momento nossa intenção era testar a tese da etnogênese e já havia uma resposta prévia, era "não". Nossas expectativas foram frustradas quando partimos para a leitura das fontes e nos deparamos com a constatação que não existe uma resposta fácil, que nossas escolhas orientam nossa leitura e corremos o sério risco de subordinar a segunda às primeiras. O problema é que perceber tudo isso não nos trouxe uma solução. Ainda tateamos, testamos, tentamos.

Esperamos que essas notas elucidem algumas de nossas escolhas e critérios, foi com essa intenção que a escrevemos, e também com o intuito de mostrar algumas de nossas inquietações. 
Parte II

DEFININDO OS SUJEITOS 


\section{Capítulo II - A realeza}

\section{Os reis francos e os reis visigodos da legitimidade teórica à prática}

Por causa do pecado do primeiro homem, Deus impôs ao gênero humano o castigo da servidão, de maneira que com muita benignidade outorga a escravidão a quem sabe não convir a liberdade. E, mesmo que o pecado da origem tenha sido perdoado a todos os fiéis pela graça do batismo, não obstante, o justo Deus dispôs a vida dos homens, constituindo

alguns servos e alguns senhores a fim de que a licença dos súditos para agir mal fosse reprimida com o poder dos soberanos. Porque se todos estivessem sem temor, quem haveria que pudesse afastar o outro do mal? É por isso que também entre os gentis foram escolhidos príncipes e reis, a fim de reprimir os povos do mal pelo medo do castigo e submetê-los às leis para que seguissem uma vida digna. ${ }^{176}$

O pecado do primeiro homem fez todos os seus descendentes vulneráveis ao erro, desde então tornou-se mister a existência de reis e príncipes, para que assim os súditos não errassem, para que a concupiscência fosse controlada e as vias da salvação se tornassem menos acidentadas. O pecado do primeiro homem ao protagonismo o papel dos príncipes e reis no caminho para a salvação. Foi assim que Isidoro de Sevilha explicou e justificou a existência de reis e príncipes. Eles deveriam cumprir uma função, essa era a razão e a justificativa para a autoridade régia. ${ }^{177}$

Com essas considerações Isidoro de Sevilha tornou-se um dos mais importantes artífices da teoria do poder real de seu tempo, seus escritos causaram profundo impacto na vida política da Hispânia goda a ponto de percebermos seus ecos nos concílios toledanos que se seguiram ao seu episcopado e até na revisão legal realizada por Recesvinto. Além da influência na Hispânia, o pensamento isidoriano

\footnotetext{
${ }^{176}$ Propter peccatum primi hominis humano generi poena diuinitus inlata est seruitutis, ita ut quibus aspicit non congruere libertatem, his misericordius inroget seruitutem. Et licet per peccatum humanae originis, tamen aequus Deus ideo discreuit hominibus uitam, alios seruos constituens, alios dominos, ut licentia male agendi seruorum potestate dominantium restringatur. Namsi omnes sine metu fuissent, quis esset qui amalisquempiam cohiberet? Inde et in gentibus principes regesque electi sunt, ut terrore suo populos a malo coercerent, atque ad recte uiuendum legibus subderent. (Isidoro de Sevilha. Sentenças. Livro III, 47,1) Tradução baseada na tradução para o espanhol: San Isidoro de Sevilla. Los três libros de las "Sentencias". Introdução, tradução e notas: Ismael Roca Meliá. Madrid: BAC, 2009.

${ }^{177}$ Sobre a originalidade da definição do sentido do poder real em Isidoro de Sevilha, que o relacionou intimamente com a noção de função e serviço: REYDELLET, M. La royauté dans la littérature latine de Sidonio Apolinaire à Isidore de Séville. Rome: École Française de Rome, 1981. p.554-557 e 568-572.
} 
transcendeu a Península e tornou-se uma das mais importantes referências para todo o período medieval. $^{178}$

Nos escritos do hispalense, especialmente nas suas Sentenças, o poder real foi compreendido a partir de um ponto de vista religioso que outorgava sentido ao poder mediante a providência divina. Essa construção teológica do sentido do poder sintetizada por Isidoro foi tema de importantes estudos historiográficos que tinham como mote a realeza medieval. Nesse capítulo transitaremos pela historiografia acerca do tema e em seguida teceremos nossas próprias considerações sobre a questão a partir da análise das fontes.

O objetivo desse capítulo é tecermos alguns parâmetros acerca da realeza de modo que nos sirva de guia para pensarmos a política na Gália Merovíngia e na Hispânia visigoda a partir da seguinte pergunta: como o ideal de realeza era articulado com as identidades políticas e como era trazido à tona na operação das políticas identitária?

${ }^{178}$ CANNING, J. A History of Medieval Political Thought. 300-1450. Londres e Nova York: Routledge, 1996. p.19-20. 


\section{A realeza cristã na historiografia}

O tema da realeza foi grato aos historiadores. De fato não se pode dizer que o assunto foi marginalizado pela historiografia, ao contrário, foi um dos principais temas contemplados: por ela por ser uma forma de governo que existiu em quase toda a Europa e por sua relação com as "evoluções das instituições europeias" 179 e dos Estados nacionais modernos europeus. Para F. Guizot, por exemplo, o Estado Moderno nasceu no século XV: na Alemanha, com Maximiliano I e a consolidação dos Habsburgos, enquanto que na França o processo se realizou com os reinados de Carlos VII, Luís XI, Carlos VIII e Luís XII. Por outro lado, A. Thierry viu no século XIII o surgimento de uma aliança entre os reis e a burguesia contra a nobreza que conseguiu minar a autoridade regional dos nobres como o ponto crucial para a ascensão dos Estados Modernos. ${ }^{180}$ Assim, o triunfo do centralismo da autoridade pública contra o privatismo das nobrezas locais capitaneada pela ascensão de uma monarquia forte foram os fatores decisivos para o fim do feudalismo e o nascimento dos Estados Modernos. Diante do peso que a figura dos reis possuía para esses historiadores é compreensível a importância do estudo da realeza para a interpretação do processo histórico.

Mas como a Alta Idade Média se encaixa nessa interpretação historiográfica que prioriza exatamente o fim do legado "medieval" - a saber, a privatização da

\footnotetext{
${ }^{179}$ Como constatou M. Bloch: «La royauté ! Son histoire domine toute l'évolution des institutions européennes. Presque tous les peuples de l'Europe Occidentale ont jusqu'à nous jours été gouvernés par des rois ». BLOCH, M. Les Rois Thaumaturges. Étude sur le caractère surnaturel attribué a la puissance royale particulièrement en France et en Angleterre. Paris : Armand Colin, 1961. p.19.

${ }^{180}$ CARBONELL, C.-O. Les origines de l'Etat moderne: les traditions historiographies françaises (1820-1990). In: Visions sur le développement des États européens. Théories et historiographies de L'État moderne. Actes du colloque de Rome (18-31 mars 1990). Rome: École Française de Rome, 1993. p.297-312. p.299-300. Uma excelente análise da historiografia francesa do século XIX pode ainda ser consultada no artigo da historiadora S. Joye: JOYE, S. Les idées de germanisé et de romanité dans l'historiographie française du XIXe siècle. MEFRM, v.119, n.2, p.279-296, 2007.
} 
autoridade pública, a ascensão de poderes regionais e o declínio do poder central como o marco para o surgimento dos Estados Modernos?

Essa pergunta deve ser contemplada a partir de duas abordagens relacionadas com a própria historiografia dedicado ao medievo. Conforme bem salientou C. Wickham, por uma lado o nacionalismo e por outro o modernismo, guiaram a leitura historiográfica sobre o período. Para os nacionalistas o alto medievo era visto sob um ponto de vista teleológico, ou seja, um ensaio para o ápice alcançado pelo nascimento das nações modernas. Já para os modernistas o alto medievo era tão-somente um período de penumbra, algo que estava entre o esplendor da antiguidade e o ressurgimento do Renascimento. ${ }^{181}$

Lemos então F. Guizot reconhecer que após a Queda de Roma já estavam presentes os rudimentos das bases que formariam a civilização europeia ${ }^{182}-\mathrm{o}$ municipalismo romano, o espírito aventureiro germânico e a moralidade cristã; a patronagem militar, a separação entre poder religioso e poder temporal e a diversidade de línguas e costumes ${ }^{183}$ - mas todos esses elementos se encontravam misturados, confusos: era a infância da Europa. ${ }^{184}$ Já L. Halphen afirmou que além dos francos,

\footnotetext{
${ }^{181}$ WICKHAM, C. The inheritance of Rome. Illuminating the Dark Ages 400-1000. Londres: Viking, 2009. p.3-6.

${ }^{182}$ Cabem aqui algumas palavras sobre a idéia do autor sobre o que era a "civilização": em suas palavras "La civilisation est une espèce d'Océan qui fait la richesse d'un people, et au sein duquel tous les elements de la vie du people, toutes les forces de son existence, viennent se réunir". (GUIZOT, F. Histoire de la Civilisation en Europe. Paris: Librairie Académique Didier, 1898. p.10) Esse "oceano" que faz a riqueza dos povos era para Guizot um fato histórico de suma importância pois trazia a essência dos povos. No quadro da civilização européia, retratada pelo autor como superior em relação às outras civilizações, se destacava a França, a nação na qual as maiores inovações da civilização européia, se lá não nasceram, lá foram desenvolvidas. GUIZOT, F. Histoire de la Civilisation en Europe. Paris: Librairie Académique Didier, 1898. p.3-31.

${ }^{183}$ GUIZOT, F. Histoire de la Civilisation en Europe. Op.cit...p. 63.

${ }^{184}$ Nas palavras do autor: Tel est, en effet, le caractère de l'époque barbare: c'est le chaos de tous les éléments, l'enfance de tours les systèmes, un pêle-mêle universel, où la lutte même n'était ni permanente ni systématique. Je pourrais, en examinant sous toutes ses faces l'état social à cette époque, vous montrer qu'il est impossible d'y découvrir nulle part aucun fait, aucun principe un peu général, un peu établi. Je me bornerai à deux points essentiels: l'état des personnes et l'état des institutions. C'en sera assez pour peindre la société tout entière. GUIZOT, F. Histoire de la Civilisation en Europe...op.cit.. p.74.
} 
nenhum dos povos germânicos realizou algo durável para a história. ${ }^{185}$ Foi só nos séculos XII e XIII que as idéias acerca do direito e do governo foram retomadas depois do longo período de penumbra que se seguiu a Queda de Roma. ${ }^{186}$ Na França, foi tão-somente a partir do século XIII, especificamente com o reinado de Luís IX, que o poder real começou a se reestruturar, ${ }^{187}$ não por acaso, tal reflexão se encontra no volume cujo título é “L'Essor de L'Europe”. Por outro lado, a historiografia alemã nacionalista saudava a "herança germânica" como os fundamentos da nação alemã. A fundação do Instituto Monumenta Germaniae Historica sob o slogan "Sanctus amor patriae dat animum" em 1819 sinaliza bem a relação entre a antiguidade germânica representada pela edição das fontes, dos Monumentos Históricos dos Germanos - e o Estado Moderno alemão. ${ }^{188}$ A valorização da tradição germânica se expressava também nas interpretações acerca da realeza alto medieval, como podemos constatar nos trabalhos de F. Kern e na sua leitura que salienta a tensão entre tradição cristã e germânica, sendo a última valorizada pelo autor. ${ }^{189}$ Mais contemporaneamente, K.F. Werner criticou aqueles que diziam não existir qualquer indício das nações modernas no Alto Medievo, ele defendeu por outro lado que não só já existiam os traços das nações como se pode dizer que já estavam formadas as próprias nações. ${ }^{190}$

\footnotetext{
${ }^{185}$ HALPHEN, L. Les Barbares. Des Grandes invasions aux conquêtes turques du XIe siècle. Paris: Librairies Félix Alcan, 1926. p.76.

${ }^{186}$ HALPHEN, L. L'Essor de L'Europe. (XIe - XIIIe siècles). Paris: Libraire Féliz Alcan, 1932. p.12. ${ }^{187}$ Ibidem, p.510-517.

${ }^{188}$ CÂNDIDO, M. \& MAZETTO, M. A realeza nas fontes do período merovíngio (séculos VI-VIII). História Revista. v.11, n.1, p.89-119, jan./jun. 2006. p.90-91.

${ }_{189}$ Algo evidente em seu vaticínio acerca da influência da Igreja nas relações de parentesco germânicas: "But before we come to that, we still have to consider the deadly blows which the Church, at the height of its influence, dealt to the principles of blood-right". KERN, F. Kingship and Law in the Middle Ages. Oxford: Basil Blackwell, 1968. p.30.

${ }^{190}$ WERNER, Karl F. Les nations et le sentiment national dans l'Europe medieval. In: WERNER, K.F. Structures du monde franc (VIe - XIIe siècles). London: Variorum, 1979. p.285-304. Originalmente publicado em: Revue historique, 244, 1970. Por outro lado S. Gasparri empreende uma abordagem crítica ao problema das nações no Alto Medievo partindo do princípio das "nações vegetativas", ou seja, a existência de elementos que poderiam caracterizar uma nação (língua, direito, religião, estado, território), entretanto num nível diverso daquele que se formaria a partir da Revolução Francesa. Aludindo à E. Sestan o autor usou de uma bela metáfora para explicitar seu argumento
} 
A posição historiográfica oscilava assim até meados do século $\mathrm{XX}$ entre o triunfalismo e o pessimismo no que concerne ao papel da realeza alto medieval para a formação da civilização europeia, em geral, e dos Estados Nacionais Europeus, em particular. Posicionamentos esses que se centravam em certos problemas historiográficos que se desdobravam a partir da reflexão maior acerca da natureza das monarquias alto medievais. Compreender as estruturas que sustentavam aquelas monarquias seria o caminho para descobrir até que ponto os reinos daquele período influenciaram ou não a formação dos Estados Modernos Europeus. ${ }^{191}$

Tal direcionamento gerou trabalhos de enorme importância historiográfica com foco na sacralidade do poder real e, mais importante, nos fundamentos da realeza sagrada. Em 1924 o já citado M. Bloch, influenciado pela antropologia de J.G. Frazer, ${ }^{192}$ lançou "Os reis taumaturgos". ${ }^{193}$ Nessa obra clássica o autor se propôs a analisar a idéia acerca de realeza sagrada na Idade Média. Essa idéia diferia da nossa concepção moderna acerca das monarquias: no medievo o personagem real era visto como sagrado, em certos países como taumaturgo. É sobre essa última característica da "mística" da realeza que o autor se debruçou. Para tanto sua proposta era empreender uma aproximação ao tema a partir da etnografia comparada, isso porque a questão não pode ser explicada pelas suas origens, ${ }^{194}$ uma vez que a própria busca das origens dessa concepção é uma empreitada impossível que nos levaria a tempos pré-

principal: as nações vegetativas do medievo eram diversas das modernas como a água quente é diversa da fria, entretanto, exceto pela temperatura, ambas são sempre estados da água, ambas compartilham uma mesma estrutura química. $C f$ : GASPARRI, S. Prima delle nazioni. Popoli, etnie e regni fra Antichità e Medioevo. Roma: La Nuova Italia Scientifica, 1997.

${ }^{191}$ Entretanto não podemos reduzir a historiografia dedicada ao tema à busca das origens dos Estados Modernos, seria um erro crasso colocar por exemplo os trabalhos de M. Bloch nesse sistema, cabe ressaltar entretanto que foi justamente a busca dessas origens que suscitou inicialmente a curiosidade historiográfica acerca dos reis do alto medievo e da natureza do poder real naqueles séculos.

${ }^{192}$ KLANICZAY, G. Holy rulers and Blessed Princesses. Dynastic Cult in Medieval Europe. Cambridge: Cambridge University Press, 2002. p.1-18.

${ }^{193}$ Edição em língua portuguesa: BLOCH, M. Os reis taumaturgos. O caráter sobrenatural do poder régio. França e Inglaterra. São Paulo: Companhia das Letras, 1993.

${ }^{194}$ É interessante notar como Bloch retomaria a questão das "origens" como a maneira de constituir explicações históricas no seu, não menos famoso, "Apologia da História": BLOCH, M. Apologia da história. Ou o ofício do historiador. Rio de Janeiro: Jorge Zahar, 2001. 
históricos. Sim, pré-históricos! Pois para Bloch a "mística" ao redor dos personagens reais residia na psicologia humana, se transformava e se adaptava ao longo do tempo. O historiador assim quis se aproximar de algo mais profundo, dos fundamentos que permitiram o surgimento da realeza sagrada e dos rituais taumatúrgicos especificamente na França e na Inglaterra. ${ }^{195}$

A etnografia comparada proposta por Bloch, entretanto, não se fia numa simples transposição das explicações dadas à "mística" dos chefes polinésios à mística da realeza cristã na Inglaterra e França medievais. O autor constata que a capacidade taumatúrgica dos chefes polinésios mostra acima de tudo que essa idéia tem profundas raízes psicológicas na própria humanidade como um todo. A questão é tentar compreender como isso se desenvolveu na Europa Ocidental, mais especificamente: como o ritual do toque tornou-se possível na Inglaterra e na França. O autor dá uma pista:

Os reis da França e da Inglaterra puderam tornar-se médicos milagrosos porque já eram, havia muito tempo, personagens sagradas: : sanctus enim et christus Domini est" ["o rei e santo; é o ungido do Senhor"], dizia Pierre de Blois, a fim de justificar as virtudes taumatúrgicas de seu monarca, Henrique II. Portanto, convém primeiro indicar de que modo o caráter sagrado da realeza veio a ser reconhecido, antes de explicar a associação de idéias que muito naturalmente depreendeu daí, como uma espécie de conclusão óbvia, o poder curativo dos que eram revestidos com esse caráter sagrado. ${ }^{196}$

Para Bloch os fundamentos dessa realeza sagrada são antigos, eles remetem aos chefes tribais francos, anglos e saxões aos quais os reis franceses e ingleses do século XII estavam filiados, desta maneira, para compreender as monarquias do século XII é preciso antes estudar a realeza germânica. ${ }^{197}$

\footnotetext{
${ }^{195}$ BLOCH, M. Les Rois Thaumaturges...op.cit. p.17-22.

${ }^{196} \mathrm{BLOCH}$, M. Os reis taumaturgos. O caráter sobrenatural do poder régio. França e Inglaterra. São Paulo: Companhia das Letras, 1993. p.70.

${ }^{197}$ Idem.
} 
Conforme o autor, Tácito já observara que entre os germanos os reis eram escolhidos entre os membros de famílias nobres que usufruíam de um prestígio oriundo de uma hereditariedade sagrada. Desta maneira para Bloch os fundamentos da realeza sagrada na Europa Ocidental estão intimamente relacionados com a antiga realeza germânica. O cristianismo, embora tenha influenciado de alguma forma a concepção acerca da realeza, não tocou na sua essência primordial. ${ }^{198}$

Chegamos aqui em uma problemática importante oriunda das reflexões acerca da natureza do poder real no alto medievo que merece ser discutida uma vez que permeou os estudos historiográficos sobre a realeza sagrada medieval: as bases teóricas dessa realeza sagrada se encontravam numa tradição germânica ou cristã? Para Bloch, como podemos bem notar, ela se enraíza na tradição germânica. Uma percepção semelhante, mas que também concatena com mais atenção o papel do cristianismo, encontramos nos estudo de F. Kern, ${ }^{199}$ pesquisador que, a propósito, influenciou também o trabalho de Bloch, mas igualmente a escola da teologia política medieval que tinha como representantes nomes como de W. Ullmann e E. Kantorowicz. ${ }^{200}$

Para Fritz Kern as monarquias romano-bárbaras da Alta Idade Média eram pautadas tanto na tradição germânica quanto na Weltanschauung da Igreja. ${ }^{201}$ Essas duas tradições se combinaram para formar a noção providencialista da realeza que teria marcado o período medieval. Na sua análise Kern vai além e esmiúça tanto a tradição germânica quando a cristã. Entre os germanos os reis eram elevados pela aclamação da comunidade, mas para tanto precisavam contar com uma hereditariedade real, hereditariedade que não estava ligada a indivíduos, mas a

\footnotetext{
${ }^{198}$ Ibidem, p.71-74.

${ }^{199}$ KERN, F. Kingship and Law in the Middle Ages. Oxford: Basil Blackwell, 1968.

${ }^{200}$ KLANICZAY, G. Holy rulers and Blessed Princesses...op.cit.1-18.

${ }^{201}$ KERN, F. Kingship and Law in the Middle Ages...op.cit. p.5-12.
} 
famílias, descendentes de um ancestral mítico que recebeu o direito à realeza por seu heroísmo e sua linhagem que remetia aos deuses. As origens disso estão perdidas no tempo, mas Kern salienta que entre os germanos o "sangue real" não era apenas do indivíduo, mas partilhado por todos os membros de sua família. Fazer parte dessa família é que outorgava aos seus membros o ius ad rem.

Assim, as casas reais limitadas da Europa da modernidade que requeriam a sucessão régia restritas aos filhos dos monarcas ainda não eram uma realidade da Alta Idade Média. ${ }^{202}$ De fato, os homens de sangue real eram muitos entre os germanos, algo também defendido por Bloch $^{203}$ e que se correto for poderia nos ajudar a compreender porque, embora não aceito pelos bispos nas atas conciliares, os golpes contra os reis visigodos quando bem sucedidos eram recorrentes: se muitos eram aqueles que possuíam sangue real, muitos eram candidatos ao trono. É difícil contudo estabelecer que aqueles que disputavam o trono visigodo pertencial a casas reais, como veremos, a condição para que alguém fosse um candidato ao trono entre os visigodos era pertencer ao grupo que as fontes chamam de gothi. Dificilmente, tal como ocorre no caso da realeza franca da dinastia merovíngia, podemos dizer que gothi se referia a grupos que pertencia a famílias reais.

O que observamos nos trabalhos de Kern e Bloch é uma ênfase na tradição

\footnotetext{
${ }^{202}$ Como bem sintetiza o autor: A long time elapsed before a special status by birth for the ruling families grew out of the status of nobility by birth. The tendency in practice for ruler's children appeared much earlier than the assertion of a definite legal preference for such marriages. But a dynastic caste of equals by birth was ultimately created in Europe, though not until modern times; a ruling cast which at least according to the strict rules of family law, can on principle propagate itself only throughout itself, and which loses the attribute of eligibility for the throne itself, and which loses the attribute of eligibility for the throne as a result of the slightest admixture of common blood. Before such a situation arose, however, other factors had to play their part. Had it not been for such factors, the royal houses of Europe, because of their limited numbers, could never have entirely avoided marriages with commoners, or at least could never have avoided considering the "peers" as equals in birth. But in Germany, where political consolidation was achieved not by the monarch but by the princes, several hundred sovereign princes came into existence, all possessing to the same extent the precious virtue of "blue-blood". These German princes in the course of time supplied nearly all the dynasties of Christendom with their prevailed blood, and so constituted what has been called the "princely stud" of Europe. KERN, F. Kingship and Law in the Middle Ages...op.cit. p.20.

${ }^{203} \mathrm{BLOCH}, \mathrm{M}$. Os reis taumaturgos... op.cit.
} 
germânica para a construção da realeza medieval. ${ }^{204}$ Outros autores como Ullmann reconhecem também a tradição germânica na construção da realeza sagrada, ${ }^{205}$ embora considerem o peso do cristianismo mais relevante. ${ }^{206}$ Ullmann tornou-se um célebre pesquisador muito por causa da elaboração de sua tese sobre a concepção da origem do poder. Havia o poder ascendente - advindo da aclamação popular e fundamentalmente representativo, no qual o povo determinava quem era legítimo para legislar - e a concepção descendente segundo a qual a autoridade governativa e a competência legislativa eram provenientes de um poder supremo. Essa última, para Ullmann, pode ser também chamada de "concepção teocrática". ${ }^{207}$

Em suas reflexões sobre as implicações da concepção teocrática do poder real o pesquisador indicou que o poder dos reis no medievo não advinha do povo, mas era

\footnotetext{
${ }^{204}$ Além dos dois autores podemos ainda citar O. Brunner que defende que a fundação dos Estados Ocidentais no e após o período das migrações foi de responsabilidade dos germanos (BRUNNER, Otto. Storia Sociale Dell'Europe nel Medioevo. Bologna: Mulino, 1980. p.45-52), o trabalho de Klaniczay, mais contemporâneo, retoma essa perspectiva sob o ponto de vista do caráter mágico do poder real enfatizando o papel do paganismo na construção da imagem da realeza: KLANICZAY, G. Holy rulers and Blessed Princesses...op.cit. Já Wolfram defendeu que o sistema de governança germânica bipartido do líder guerreiro (reiks ou kuning) e do chefe religioso (thiudans) originou a partir da figura do reiks os reinos bárbaros ocidentais graças à sua incorporação pelo ocidental latino e algumas transformações, visivelmente a adoção de um vocabulário latino para nomear os líderes. WOLFRAM, H. The shaping of Early Medieval kingdom. Viator. v.I, p.1-20, 1970. As raízes da realeza no passado bárbaro de governança bipartida é também defendida por M. Reydellet: REYDELLET, M. La royauté dans la littérature latine de Sidonio Apolinaire à Isidore de Séville. Rome: École Française de Rome, 1981. p.24-27.

${ }^{205}$ Ullmann considera que tanto o cristianismo quanto a tradição germânica contribuíram para a construção da realeza sagrada: Tuttavia, nella maggior parte dell'Europa meridionale e occidentale, la dottrina popolare venne sostituita da quella teocratica. Il motivo va indubbiamente ricercato in parte nell'influenza del tema cristiano stesso, e in parte nella concezione del carattere sacro della regalità germanica, concezione che con il passare del tempo si era andata notevolmente irrigidendo: il passaggio dall'una al l'altra non fu tanto difficile. Il terreno era pronto per questa mentalità teocentrica. Dal periodo merovingio in poi, nella sfera pubblica fu la teoria discendente che predominò per tutto il medioevo. La sua manifestazione più concisa e perfetta è il titolo regale: re per grazia di Dio, il "Rex Dei gratia", che significava l'introduzione nel linguaggio del governo del tema della grazia come favore o beneficio divino. Il re aveva rinunciato alla sua precedente dipendenza dal popolo; egli si era emancipato dai vincoli popolari e aveva posto se stesso in prossimità della divinità. Sebbene di origine indigena, questa adozione franca nel tema teocratico mostrava, per lo meno nella pratica, una straordinaria affinità con quello applicato nell'impero bizantino d'Oriente. ULLMANN, W. Principi di governo e politica nel medioevo.Bologna: Società editrice il Mulino, 1982. p.18. (Primeira edição: ULLMANN, W. Principles of government and politics in the Middle Ages. N.Y.: Barnes and Noble, 1961.)

${ }^{206}$ Outro defensor do cristianismo como a principal base na construção da realeza é F. Graus. $C f$. KLANICZAY, G. Holy rulers and Blessed Princesses...op.cit. p.9

${ }^{207}$ ULLMANN, W. Principi di governo e politica nel medioevo...op.cit. p.13-22.
} 
uma graça de Deus. Ullmann analisa a utilização do termo "Rex Dei gratia" para tratar do tema. Tal concepção já estava expressa na fórmula de Paulo “Gratia Dei sum id quod sum" (I Cor. 15, 10) que tirava dos homens a responsabilidade por suas posições na sociedade. A idéia de "rei graças a Deus" se consolidou entre os carolíngios e contou com a colaboração dos bispos para se afirmar, ${ }^{208}$ entretanto a relação entre reis e epíscopos era uma via de mão dupla. Uma observação mais atenta mostra que o poder dos reis teocráticos tinha algumas limitações.

A principal limitação advinha justamente da construção teórica da realeza baseada no cristianismo, aos poucos o papel dos reis se confundiu com o papel dos eclesiásticos e os reis precisariam prestar contas a estes já que faziam parte também da Igreja. A limitação do poder dos reis é evidenciada pelos símbolos que outorgavam a ele o poder. A unção, que era dada pelos clérigos; o ritual da coroação, que simbolizava seu poder e o juramento que fazia de governar segundo as leis de Deus, de proteger a Igreja e seus ministros e de governar com justiça. Para Ullmann, assim, a limitação do poder dos reis advinha justamente da Igreja. ${ }^{209}$

\section{A teoria política cristã na historiografia sobre a Gália Merovíngia e a Hispânia Visigoda}

Tais reflexões gerais concernentes à natureza do poder real - ou de origem prevalentemente germânica ou de origem prevalentemente cristã - estão presentes, mesmo que sob uma perspectiva crítica, na historiografia específica sobre a Gália merovíngia e a Hispânia visigoda.

No que concerne à realeza goda a conversão do rei Recaredo afirmada nas atas do III Concílio de Toledo de 589 é tida como um divisor de águas. P.D. King por exemplo defende a tese de que a monarquia visigoda era de natureza teocrática na

\footnotetext{
${ }^{208}$ Ibidem, p.147-163.

${ }^{209}$ Ibidem, p.177-192.
} 
qual o rei era apresentado como um agente divino que exercia sua autoridade mediante a elaboração de leis. O exercício legislativo dos reis era por conseguinte muito mais do que a aplicação da vontade da pessoa do monarca, mas a aplicação da vontade divina concretizada pela ação dos reis. Essa elaboração teórica do exercício da autoridade régia visigoda era respaldada pelos bispos nos concílios realizados a partir da conversão de Recaredo, era assim uma teoria do poder real sustentada pela concepção do poder régio cristão, sendo desta maneira intimamente relacionada com a tradição cristã concernente ao poder régio. ${ }^{210}$

Por outro lado, os argumento de García Moreno dedicados à monarquia visigoda exemplificam os avanços trazidos por trabalhos voltados para temas mais específicos, uma vez que em sua pesquisa o foco transcende a análise da influência prioritariamente cristã ou germânica na constituição teórica das realezas do Ocidente pós-imperial. ${ }^{211}$ Feudalização, imperialização, militarização e teocratização são idéias privilegiadas pelo autor para analisar o reino visigodo de Toledo. Feudalização que se observa com o crescimento da autoridade dos nobres locais que cada vez mais contrastava com o poder dos reis. Imperialização que começou com força com Leovigildo que adotou símbolos imperiais bizantinos para reforçar sua autoridade e a legitimidade dos monarcas visigodos frente aos nobres que cada vez mais se fortaleciam. Teocratização que se fortaleceu com a conversão de Recaredo e redundou numa construção teórica teológica do poder dos reis visigodos. Militarização que se observa com a revisão legal iniciada por Chindasvinto e concretizada por seu filho Recesvinto que redundou numa reforma administrativa do

\footnotetext{
${ }^{210}$ KING, P.D. Law \& Society in the Visigothic Kingdom. Cambridge: Cambridge University Press, 1972. p.23-51. Um interessante crítica à essa perspectiva pode ser encontrada no trabalho de T. González no qual a natureza teocrática da monarquia visigoda é uma hipótese descartada pelo autor. GONZALÉZ, Teodoro. Historia de la Iglesia en España. Madrid: BAC, 1979.

${ }^{211}$ Quando dizemos "pós-imperial" não queremos inferir uma idéia de "Queda do Império", aplicamos o termo com o sentido de que o império Ocidental sob o controle dos imperadores não mais existia e eram os reis barbaros que - mesmo que apenas idealmente - exerciam a autoridade política principal.
} 
reino que teve como ponto mais sobressalente a substituição dos funcionários civis na administração por funcionários militares. ${ }^{212} \mathrm{O}$ trabalho de García Moreno, assim, supera a busca por tradições estáticas que serviriam para construir o ideal da realeza, o que o historiador fez foi trazer a análise para um foco político-social que revelou matizes muito mais complexas e ricas.

No que concerne à historiografia dedicada aos francos, sem dúvidas o trabalho de Wallace-Hadrill se destacou por trazer cruciais problemáticas concernentes à realeza. A importância do texto de Wallace-Hadrill se evidencia logo pela problematização que o autor fez sobre o que significava "fracus" uma vez que ele questiona a utilização do termo para designar uma unidade étnica dada, natural, e que teria portado em si uma tradição germânica. Ao problematizar essa proposição o autor colocou um ponto de interrogação na origem germânica do carisma dos reis francos e também da forma de organização do reino. ${ }^{213}$

Tal pressuposto germânico criticado por Wallace-Hadrill por exemplo influênciou as interpretações de um ponto importante acerca da questão dos merovíngios referente à suposta sucessão dinástica dos reis. Em 511 o rei Clóvis morreu em Paris. Após sua morte seus quatro filhos, Teodorico, Clodomiro, Childeberto e Clotário dividiram seu reino entre eles. ${ }^{214}$ Essa primeira divisão do reino inaugurou uma prática singular, a saber, após a morte dos reis o reino deveria ser dividido entre seus herdeiros. O processo Merovíngio de sucessão difere, por exemplo, da prática da sucessão praticada entre os visigodos que teoricamente após a

\footnotetext{
${ }^{212}$ GARCIA MORENO, L.A. Historia de España Visigoda. Madrid: Cátedra, 1989. p.317-337.

${ }^{213}$ WALLACE-HADRILL, J.M. The long-haired kings and other studies of Frankish History. NY: Barnes and Noble, 1962. p.148-154.

${ }^{214}$ Defuncto igitur Chlodovecho regi, quattuor filii eius, id est Theudoricus, Chlodomeris, Childeberthus atque Chlothacharius regnum eius accipiunt et inter se aequa lantia dividunt. Gregory of Tours. Decem Libri Historiarum. Gregório de Tours. Decem Libri Historiarum, III, 1.
} 
morte dos reis convocavam uma assembléia para escolher o novo rei. ${ }^{215}$

A prática merovíngia redundou em duas interpretações centrais para a análise da realeza franca: primeiro, a idéia de que os francos possuíam uma concepção patrimonialista do poder que resultava na divisão do reino tal como uma herança; segundo, que todos os filhos dos reis poderiam suceder seus pais no trono. De fato tais interpretações eram imediatamente relacionadas com uma herança germânica. Ao chamar a atenção para a dificuldade de definir o que era "francus" Wallace-Hadrill ensaiou os passos para superar a interpretação acerca da realeza franca a partir do paradigma germanistas.

M. Cândido, que parte da problematização do conceito de Estado negado ao medievo também por influência de uma concepção centrada nas raízes germânicas da realeza franca, propõe uma análise que se desenvolve a parte de preocupações centradas nas buscas dos elementos germânicos na realeza franca. Ao mostrar o papel crucial da idéia da utilitas publica o autor coloca irremediavelmente um ponto de interrogação na concepção patrimonialista do poder outorgada pela historiografia aos reis francos e, por consequência, na tese de que tal concepção teve uma origem germânica. $^{216}$

Poderíamos sugerir que com a crítica à idéia da existência de uma herança germânica facilmente identificável essas duas interpretações clássicas foram

\footnotetext{
${ }^{215}$ É importante dizer que o problema da sucessão real entre os visigodos era mais complicado do que exposto até aqui. Como bem apontaram pesquisadores como J. Orlandis e García Moreno a convocação da assembléia não parecia ser uma prática recorrente, como bem demonstra os exemplo de Leovigildo que encaminhou a elevação de seus filhos Hermenegildo e Recaredo ao trono, Recaredo que também apontou seu filho como sucessor, Sisebuto que possivelmente também planejava ser sucedido por seu filho e Chindasvinto que chegou a reinar junto com seu filho Recesvinto. Cf: ORLANDIS, J. El poder real y la sucesion al trono en la monarquia visigoda. In: Estudios visigoticos. Consejo superior de investigaciones cientificas delegacion de Roma/ Cuadernos del instituto juridico español. n.16, RomaMadrid, 1962. GARCÍA MORENO, L.A. Prosopography, nomenclature and Royal Succession in the Visigothic Kingdom of Toledo. Journal of Late Antiquity, v.1, n.1, p.142-156, 2008.

${ }^{216}$ CÂNDIDO, M.C. A realeza Cristã na Alta Idade Média. Os fundamentos da autoridade pública no período merovíngio (séculos V-VIII). São Paulo: Alameda, 2008.
} 
colocadas à prova. Num artigo publicado em 2009 M. Widdowson ${ }^{217}$ trouxe também interessantes argumentos contra a tese da concepção patrimonialista do poder ao apontar que a repartição do reino não era um padrão aceito consensualmente. $\mathrm{O}$ autor sublinha que a primeira divisão entre os filhos de Clóvis foi uma alternativa testada para lidar com o problema da sucessão real. Após essa primeira divisão, ao menos duas tendências de sucessão continuaram a coexistir, a primeira era o acordo de que o reino deveria ser dividido entre os herdeiros do rei, a segunda era que apenas um filho poderia herdar o trono, e à luz dessa hipótese que as ações de Chilperico - o "Nero do seu tempo" tal como descrito por Gregório de Tours - deveriam ser analisadas.

Chilperico ao iniciar movimentos para tomar as cidades de seus irmãos estava acima de tudo tomando partido acerca da melhor forma de sucessão ao trono, ele estava questionando o sistema de divisão do reino. Cândido foi além. Sua leitura permite ampliarmos as possibilidades de interpretação acerca da imagem feita por Gregório do reinado de Chilperico. Conforme o historiador, a narrativa gregoriana voltada ao reinado de Chilperico insinua que o rei alimentava pretenções imperiais, pretenções essas que implicavam nos esforços por reduzir a autoridade dos bispos em detrimento à autoridade dos reis. ${ }^{218}$ As pretensões imperiais de Chilperico podem ser levadas em conta mesmo para pensarmos a sua tentativa de questionar a sucessão real na Gália de maneira a eliminar o direito ao trono de seus irmãos.

Já I. Wood questionou a hipótese de que os membros da família dos reis eram candidatos imediatos ao trono ${ }^{219}$ usufruindo assim de uma "Legitimidade Biológica",

\footnotetext{
${ }^{217}$ WIDDOWSON, Marc. Merovingian partitions: a 'genealogical charter'? Early Medieval Europe. v.17, n.1, p.1-22, 2009.

${ }^{218}$ CÂNDIDO, M.C. A realeza Cristã na Alta Idade Média...op.cit.p. 215-230.

${ }^{219}$ Hipótese essa que é chave, por exemplo, para E. James. Mesmo que ele reconhecesse que os reis deveria manter constantes acordos com os nobres ele defendeu que a sucessão restrita aos membros da família merovíngia garantiu maior estabilidade no reino franco do que no reino visigodo, por exemplo, onde todos os nobres supostamente seriam potenciais candidatos ao trono. Conforme argumentou: Elsewhere, in contemporary England or Spain, the inevitable political opposition gathered around a powerful magnate; successful rebellion brought a new and normally short-lived dynasty. In Francia,
} 
para Wood o sangue real merovíngio como suporte de legitimidade dos reis merovíngios estava posto em dúvida muito antes da usurpação de Pipino. O historiador assim traz uma significativa crítica à interpretação historiográfica clássica sobre a sucessão dinástica merovíngia:

Historians have a natural desire to create genealogies, tidying their protagonists neatly into families. In so doing, however, they hide some of the recurrent problems of Merovingian succession. If, instead of trying to identify the parents of all these kings, we recognize that their parentage was uncertain, and if we then add the implications that such uncertainty has for understanding Merovingian politics, we can see that the very fact that there could be uncertainty as to who was and who was not a legitimate prince allowed parties considerable room to man oeuvre at the moment of a king's death. In such maneuvering the party that lost could claim that the successful child was not a true Merovingian, and could thins imply that a usurpation had taken place. Read in this way the succession of Daniel/Chilperic, Chlothar IV and Childeric III meant that Merovingian inheritance had been questionable for the forty years prior to Pippin's usurpation. Whether this made the kings of the period powerless as the support he could muster, and this could be significant even as late as the reign of Chilperic II, alias Daniel. ${ }^{220}$

Temos então que a historiografia recente sobre a Gália Merovíngia, ${ }^{221}$ tal como se pode dizer em certa medida sobre a Hispânia visigoda, tem se esforçado por criticar interpretações clássicas sobre a realeza entre os dois reinos graças aos esforços por superar a dicotomia entre tradições germânicas e tradições romano-cristãs. Não objetivamos aqui identificar o que é cristão, romano-cristão ao germânico na

discontented aristocrats clustered around one of the royal brothers or nephews, or occasionally around a man who claimed Merovingian blood: the dynasty itself was safe. JAMES, E. The origins of France. From Clovis to the Capetians, 500-1000. London \& Basingstoke: The Macmillan Press, 1982. p.134. ${ }^{220}$ WOOD, I. Usurpers and Merovingian Kingship. In: BECHER, M. \& JARNUT, J. Der Dynastiewechsel von 751. Vorgeschichte, Legitimationsstrategien und Erinnerung. Münster: Scriptorium, 2004. p.15-31. p.26.

${ }^{221}$ Nessa linha crítica é digno de nota os estudo de A.C. Murray, tendo como grande trabalho inicial seu livro publicado na década de 1980 que criticava a idéia de parentesco como norte da realeza franca: MURRAY, A.C. Germanic Kinship Structure. Studies in Law and Society in Antiquity and the Early Middle Ages. Toronto: Pontifical Institute of Mediaeval Studies, 1983. Mais enfático ainda no artigo: MURRAY, A.C. Post vocantur Merohingii: Fredegar, Merovech, and 'Sacral Kingship'. In: Idem (ed.). After Rome's Fall. Narrators and Sources of Early Medieval History. Essays presented to Walter Goffart. Toronto, Buffalo, London: University od Toronto Press, 1998. 
construção do ideal das realezas visigodas e francas. Nosso objetivo - à luz das novas discussões historiográficas que superam significativamente a oposição entre romanos e germanos trazendo à luz novas problemáticas referentes as características da construção da teoria política que fundamentava aqueles reinos - é indicar que:

1. Essas ditas "tradições" germânicas, romanas e romano-cristãs estavam em construção nos séculos que nos interessam, não eram portanto tradições dadas, estáticas;

2. Essas construções estavam intimamente relacionadas com os problemas enfrentados pelos reis que lidavam constantemente com levantes regionais liderados por nobres que por vezes também lançavam mão do argumento de que eram os representantes verdadeiros de determinada tradição para fundamentarem suas oposições;

3. Por fim: as tradições - em constante transformação - se construíam e só faziam sentido à luz das disputas pelo poder.

4. Dentre essas tradições construídas e apropriadas o discurso ao redor da idéia de uma unidade identitária relacionada com o rei, a gens e a patria era um dos mecanismos utilizados para sustentar a autoridade dos reis.

Nesse sentido, buscar analisar as estratégias narrativas que emergiam a partir das apropriações da tradição narrativa que apresentamos na parte 1 é um passo importante para a compreensão do sentido que as identidades políticas erguidas em torno da gens francorum e da gens gothorum tinham num cenário de polarização do poder político. Buscaremos assim analisar a elaboração do ideal acerca da realeza não como um objeto em si, e sim buscando o significado dessa elaboração em sua relação com a situação política dos reis diante das aristocracias que despontavam como forças políticas cruciais para legitimar os reis, mas também para questionar a legitimidade 
deles. 


\section{Os reis}

Em Isidoro de Sevilha, como apontamos desde o início, a explicação para o poder régio estava intimamente relacionada com uma perspectiva providencialista cristã, o papel dos reis só fazia sentido à luz da atuação desses em prol da salvação de seus súditos. O poder real delegado por Deus era então pragmático, tinha uma causa o pecado dos homens - uma consequência - a existência dos reis - e um fim - a salvação dos súditos. A elaboração teórica presente na obra isidoriana se repete em textos posteriores. No VIII Concílio de Toledo de 653 o rei Recesvinto reafirmou seu compromisso de guiar os povos sob sua autoridade conforme a verdadeira fé garantindo assim a salvação desses. Entretanto há na intervenção de Recesvinto algo que deve ser acrescentado ao texto isidoriano: a salvação que os reis deveriam garantir dependia da observância da verdadeira fé, que listou Recesvinto como sendo aquela estabelecida pelos concílios de Nicéia (325), Constantinopla (381), Éfeso (413) e Calcedônia (451). ${ }^{222}$

O que observamos tanto em Isidoro de Sevilha quanto na intervenção de Recesvinto é que a origem providencialista do poder real não bastava por si só para sustentar o poder real. Era necessário algo mais: a observância da fé conforme estabelecida pelo cânone católico. Era tão-somente sob essa condição que a relação de casualidade teológica se completaria. Se entretanto, caso o rei agisse em desacordo com a verdadeira fé, perdia-se o sentido do seu poder. Ele se tornaria, portanto,

\footnotetext{
${ }^{222}$ [...] venerari atque diligere, sicut eam apostolica traditio dedit, sicut eam sancta synodus Nicaena constituit, sicut Constantinopolim sanctorum patrum congregatio definivit, sicut Efeseni primi coetus unitas adfirmavit, sicut Calcidonensis concilii definito protulit, hanc cum fidelibus servans, ad hanc salvandos infideles advintans, in hanc subiectos populos regens, hane propriis gentibus tenendam insinuans, hanc populis alienis adnuntians, ut in illa glorificans Deum et in tempore mortalium me summae divinitatis felicitas adsequatur, et in terra viventium haereditas a me gloriae capiatur. VIII Concílio de Toledo.
} 
indigno e um novo rei deveria ser escolhido. O poder real não era portanto imanente à pessoa do rei, mas à prerrogativa da realeza. ${ }^{223}$

Tais considerações trazem à tona alguns problemas que devem ser contemplados. Primeiro, sob essa perspectiva o poder dos reis se confunde com a autoridade dos epíscopos, poderíamos então falar que estamos diante de uma monarquia teocrática cristã? Segundo, quais eram os fatores levados em conta para que um homem fosse considerado digno de exercer tão importante papel? Ora, até agora falamos do que um rei precisaria ter para ser digno de seu cargo, mas o que um homem deveria ter para chegar a se tornar rei? Será que na eleição dos reis prevalecia uma tradição germânica?

Primeiro enfrentemos a primeira pergunta. Se a elaboração de Isidoro de Sevilha, evocada na intervenção de Recesvinto, nos traz elementos para dizer que sim, estamos diante de uma realeza teocrática, precisamos antes nos perguntar se é correto generalizarmos tais laborações. Um caminho a ser seguido seria considerarmos essas duas fontes por elas mesmas, ou seja: quais foram suas finalidades? A definição de Isidoro de Sevilha se encontra nos livros das Sentenças, uma obra escrita por volta de

\footnotetext{
${ }^{223}$ Vem aqui a tentação de recorrermos à tese dos "dois corpos do rei" de E. Kantorowicz (KANTOROWICZ, E. Os dois corpos do rei. Um estudo sobre teologia política medieval. São Paulo: Companhia das letras, 1998), um estudo importantíssimo para a teologia política. Entretanto, a distinção entre o corpo humano e o corpo politico dos reis não era algo observável no período contemplado nesse trabalho. A qualidade de um rei se definia mais pelos seus atos do que pelo fato de ser rei. M. Reydellet por outro lado traz contribuições interessantes. Conforme o autor os textos isidorianos trazem uma concepção da posição do rei não como uma dignidade, mas como um officium. $C f$. REYDELLET, M. La conception du souverain chez Isidore de Séville. Isidoriana. Leon: Centro de Estudios "San Isidoro", 1961. p.457-466. p.458. Ainda nesse sentido P. Díaz traz uma reflexão importante que pode nos servir bem para compreendermos esse aspecto da obra de Isidoro de Sevilha. Conforme Díaz, a fraqueza do rei não implicava na fraqueza da realeza, os nobres que se opunham ao monarca - exceto pela rebelião do $d u x$ Paulo contra Wamba - não pareciam desejar o fim do reino e da instituição monárquica visigoda, mas sim substituir a pessoa do rei, mantendo à pretensão da centralidade de Toledo. Nas palavras do autor: "On the one hand something like the transpersonal nature of the State was achieved, the separation between the actual figure of the king and the idea of royalty, a separation between the rex propria and the publica utilitas." DÍAZ, Pablo C. Visigothic Political Institutions. In: HEATHER, P. The visigoths. From the migration period to the seventh century. An ethnographical perspective. Woodbridge: Boydell Press, 1999. p.342-343.
} 
$613 / 14^{224}$ para servir como um conjunto de ensinamentos morais e religiosos. ${ }^{225}$ Por outro lado, a intervenção de Recesvinto foi feita em um concílio, ou seja, tinha como principais interlocutores bispos convocados à reunião conciliar cerca de dois meses depois que o rei enfrentou a rebelião de Froia no norte da Hispânia, talvez em Tarraconense. ${ }^{226}$ Sob esse ponto de vista um discurso teológico faz sentido, entretanto, tomar o discurso teológico como o único sentido da imagem da realeza para Isidoro de Sevilha e a intervenção de Recesvinto no VIII Concílio de Toledo seria simplista. É que a idealização da realeza tal como feita por Isidoro de Sevilha e expressa por Recesvinto tinha um valor pragmático no contexto textual em que foi elaborada, e escolhemos sustentar nosso argumento traçando um paralelo entre Isidoro de Sevilha e Recesvinto justamente para indicar esse valor pragmático: Recesvinto lançou mão da elaboração isidoriana não só na ocasião do VIII Concílio de Toledo, mas também na revisão das leges do reino que ele empreendeu. Em poucas palavras, tanto as razões que motivaram a elaboração de Isidoro quanto as futuras apropriações dessa elaboração estavam intimamente relacionadas com o cenário de polarização política daquele período. Não se tratava de uma pura cristianização da teoria política trazida pelos germanos, não se tratava de uma retórica desprovida de intenções muito pragmáticas. Apreender as caracteríricas desse cenário, defendemos

\footnotetext{
${ }^{224}$ Conforme a datação mais recente (WOOD, J. The politics of Identity in Visigothic Spain. Leiden \& Boston: Brill, 2012. p.139) Para J. Fontaine, entretanto, o texto é muito mais tardio, consistindo numa das últimas obras do Hispalense (FONTAINE, J. Isidore de Séville. Genèse et originalité de la culture hispanique au temps des Wisigoths. Turnhout: Brepols, 2000.)

${ }^{225} \mathrm{Na}$ definição de J. Fontaine seguida também por Roca Meliá as Sentenças em Isidoro de Sevilha: "Ainsi liée à la notion biblique de "sagesse", telle que l'avait développée le judaïsme hellénistique, la sentent selon Isidore exprime une expérience religieuse autant qu'un précepte général mis en forme persuasive par la brièveté et la force de son expression. Elle transmet une pensée souvent tirée de Grégoire, d'Augustin, parfois de Cassien, mais la développe, la médite, la repense pour la conforme avec justesse au "sentiment" de l'auteur." FONTAINE, J. Isidore de Séville. Genèse et originalité de la culture hispanique au temps des Wisigoths. Turnhout: Brepols, 2000. p. 236. Ainda: ROCA MELIÁ, I. San Isidoro de Sevilla. Los tres libros de las "Sentencias". Madrid: BAC, 2009. p. XI-XII.

${ }_{226}$ THOMPSON, E.A. The Goths in Spain. Oxford: Clarendon Press, 1969. p.199. GARCÍA MORENO, L.A. Historia de España Visigoda. Madrid: Catedra, 1989. p. 165-168.
} 
nessa tese, é crucial para entender o sentido das gentes nos textos com os quais lidamos. O sentido das gentes enquanto identidades políticas.

\section{Isidoro de Sevilha e os reis visigodos}

Antes de analisar como a elaboração isidoriana foi apropriada por Recesvinto, cabe pensarmos primeiro sobre a própria produção de Isidoro de Sevilha. Bispo de Sevilha entre c.599-601 - 636, ao longo de seus mais de trinta anos de episcopado Isidoro talvez tenha visto o fim do reinado ${ }^{227}$ de Recaredo (586-601), ${ }^{228}$ mas certamente era o metropolitano de Sevilha durante o reinado de sete reis: Liuva II (601-603) filho de Recaredo; Viterico (603-610) que assassinou o jovem Liuva II; Gundemaro (610-612), Sisebuto (612-621), Recaredo II (621), Suintila (621-631) e Sisenando (631-636). Isidoro de Sevilha não só foi testemunha ocular desses reinados como escreveu sobre eles na sua Historia Gothorum, Sueborum et Wandalorum e também na sua Chronica, mas, mais importante ainda, ele participou ativamente da vida política do reino.

Isidoro estava próximo aos reis, especialmente a Sisebuto, a quem o bispo dedicou textos como o De natura rerum e talvez sua grande obra, as Etimologias. ${ }^{229}$ Com sua escrita histórica talvez tenha objetivado construir a imagem de um reino unido ao redor do rei que contrastava com o cenário de crescente fortalecimento de elites locais. ${ }^{230} \mathrm{O}$ que queremos dizer com isso é que os textos de Isidoro de Sevilha

\footnotetext{
${ }^{227}$ Uma reconstrução da sucessão régia entre os visigodos conforme descrita por Isidoro de Sevilha pode ser consultado no Apêndice III.

${ }^{228}$ Ildefonso de Toledo afirmou em seu Liber De Viris Illustribus que sim, Isidoro de Sevilha acompanhou os últimos anos de Recaredo no trono: Floruit temporibus Reccaredi, Liuuanis, Vuitterici, Gundemari, Sisebuti, Suinthilanis et Sisenandi regum, annis ferme quadraginta tenens pontificatus honorem insignemque doctrinae sanctae gloriam pariter et decorem. Liber de Viris Illustribus, VIII. Ildefonso de Toledo.

${ }^{229}$ WOOD, J. The politics of Identity in Visigothic Spain. Leiden \& Boston: Brill, 2012. p.59.

${ }^{230}$ J. Wood sumarizou muito bem a questão: "As a result of the continued impetus to disunity in Visigothic Spain, a great deal of effort was expended to try to hold the kingdom together. Therefore, although the legal sources and church council records of the Visigothic kingdom paint a picture of a realm that was - and always had been - united behind a single monarch, this image was largely the result of work done by Isidore and his fellow bishops in the seventh-century. Isidore's historical
} 
estavam voltados para dar conta de questões muito concretas e é à luz da debilidade dos reis visigodos pressionados por aristocratas cada vez mais fortes que devemos ler não só as obras históricas do hispalense, mas também suas Sentenças e a imagem nela feita sobre o poder régio.

Depois da morte de Recaredo I em 601 o reino entrou num novo período governado por reis católicos que tomaram medidas energéticas para afirmar a autoridade central de Toledo num cenário de crescente oposição, Isidoro foi o principal narrador desse período. A rebeldia contra os reis se manifestou logo depois da sucessão de Recaredo. Liuva II, seu filho, foi deposto, teve a mão direita decepada e depois acabou morto por Viterico. ${ }^{231} \mathrm{O}$ próprio Viterico também foi vítima de uma conspiração e morreu assassinado durante um banquete. Gundemaro teve um breve reinado de dois anos, empreendeu expedições contra os vascones ${ }^{232}$ e foi bem sucedido e deteve os bizantinos, morreu de morte natural em Toledo. ${ }^{233}$ Gundemaro foi sucedido por Sisebuto que na região das Astúrias enfrentou uma rebelião vencida por seu dux Riquila, lutou ainda contra os Rocones, que conforme Thompson ${ }^{234}$ provavelmente viviam na Cantábria e enfrentou os bizantinos no sul da Península.

writing played a key role in this project, giving historical substance to the assertion that the Visigoths and Spain were united and bolstering the claims of the contemporary monarchy on the loyalty of the people of Spain by demonstrating their political and religious excellence". WOOD, J. The politics of Identity in Visigothic Spain...op.cit. p.60-61.

${ }^{231}$ Aera DCXXXVIIII, anno impaerii Maurici XVII post Recaredum regem regnat Livva filius eius annis duobos, ignobili quidem matre progenitus, sed virtutum indole insignitus. quem in primo flore adulescentiae Wittericus sumpta tyrannide innocuum regno deiecit praecisaque dextra occidit anno aetatis $X X$, regni secundo. HISTORIA GOTHORUM, 57.

${ }^{232}$ Usamos aqui a nomenclatura sugerida por S. de Brestian. Normalmente "vascones" é trazido pelos historiadores como "bascos" o que causa uma confusão entre os vascones mencionados pelas nossas fontes e os Bascos que habitavam uma região próxima, mas não eram vascones e ainda o País Basco, região autônoma da Espanha Contemporânea. Vascones, nesse caso, se refere à uma população que ocupava a área que se estendia da região desde a costa do Atlântico e o limite ocidental dos Pirineus e se estendia pelos vales dos rios Arga e Ega. Modernamente a região corresponde mais ou menos à província de Navarra. Cf: BRESTIAN, S. de. Vascones and Visigoths: Creation and Transformation of Identity in Northern Spain in Late Antiquity. In: In: MATHISEN, R.W. \& SHANZER, D. (ed.) Romans, Barbarians and the transformation of the Roman World. Cultural Interaction and the Creation of Identity in Late Antiquity. Farnham: Ashgate, 2011. p.283-284 e nota 1.

${ }^{233}$ [...] hic Wascones una expeditione vastavit, alia militem Romanum obsedit, morte propria Toleto decessit. HISTORIA GOTHORUM, 59.

${ }^{234}$ THOMPSON, E.A. The Goths in Spain...op.cit. p.161. 
Morreu de maneira suspeita, por envenenamento, ${ }^{235}$ de acordo com García Moreno, as medidas centralizadoras de Sisebuto podem ter sido a causa de sua morte e a de seu filho, Recaredo II. ${ }^{236}$ O próximo rei foi Suintila, que derrotou os Bizantinos no Sul da península e tornou-se assim o único rei de toda a Hispânia, feito que nenhum outro rei havia obtido. ${ }^{237}$ Em Tarraconense Suintila enfrentou com sucesso mais uma vez os vascones. Foi entretanto deposto por Sisenando em 631.

Temos então que dos sete reis que passaram pelo trono enquanto Isidoro de Sevilha era bispo, três foram assassinados com certeza (Liuva II, Viterico e Recaredo II) um pode ter sido assassinado (Sisebuto) e um foi deposto (Suintila). Apenas dois chegaram ao fim do reinado morrendo de morte natural: Gundemaro e Sisenando. Observemos com mais vagar as fontes para tentarmos apreender os focos dessas tensões de modo a localizar melhor a obra do hispalense e compreender o lugar da gens gothorum no seu texto, tema que será discutido no capítulo dedicado às Historiae.

\section{Isidoro de Sevilha, Viterico e a nobreza "goda" de Mérida}

A Historia Gothorum é muito breve em seus relatos, mesmo assim podemos ter algumas informações sobre as dificuldades enfrentadas pelos reis. Primeiro temos o caso de Liuva II. Filho de Recaredo, o rei responsável pela conversão dos visigodos ao catolicismo, Liuva logo teve seu reinado contestado e foi deposto e assassinado por Viterico. De fato, a contestação à autoridade da família de Liuva II não era novidade. Hermenegildo, seu tio, levantou-se contra seu avô, Leovigildo. Argimundo, dux provincial e membro do cubiculum levantou-se contra seu pai, Recaredo que sufocou

\footnotetext{
${ }^{235}$ hunc alii proprio morbo, alii inmoderato medicamenti haustus asserunt interfectum. HISTORIA GOTHORUM, 61.

${ }^{236}$ GARCÍA MORENO, L.A. Historia de España Visigoda...op.cit. p.152-153.

${ }^{237}$ [...] urbes residuas, quas in Hispaniis Romana manus agebat, proelio conserto obtinuit auctamque triumphi gloriam prae ceteris regibus felicitate mirabili reportavit, totius Spaniae intra oceani fretum monarchiam regni primus idem potitus, quod nulli retro principum est conlatum. HISTORIA GOTHORUM, 62.
} 
a rebelião de Argimundo com sucesso. ${ }^{238}$ A mesma vitória não obteve Liuva II contra Viterico.

Homem de origem lusitana ${ }^{239}$ Viterico estava entre os conspiradores capitaneados por Sunna que contestava o episcopado do bispo Masona de Mérida e muito provavelmente tinham por fim derrotar o próprio rei Recaredo. ${ }^{240}$ Nos eventos ocorridos em Mérida, Viterico acabou por se unir a Masona abandonando assim os rebeldes. Entretanto, tão logo chegou ao trono Liuva II, Viterico mais uma vez se rebelou e conseguiu destronar o rei. Temos aqui um primeiro foco de rebeldia advinda da própria nobreza goda de Mérida.

Sunna, conforme nos relata as Vidas dos Padres de Mérida, não parece ter tido dificuldades para unir os nobres godos da região. ${ }^{241}$ Embora as Vidas dos Padres de Mérida dê um tom religioso ao embate entre Sunna e Masona, e em última instância entre os nobres godos e o rei Recaredo, é preciso levar em conta que as lutas religiosas não se restringiam à fé, eram disputas de caráter também político que opunham grupos na disputa pelo poder. Por trás da oposição do bispo ariano Sunna ao bispo católico Masona estava um fortíssimo embate entre nobres pela primazia sobre a cidade de Mérida e o próprio reino visigodo. Mas atestar as tensões que surgiram em Mérida e que chegaram à Toledo pela figura de Viterico não significa muito. É

\footnotetext{
${ }^{238} \mathrm{O}$ evento é relatado com mais detalhes por João de Biclaro: Nam quidam ex cubiculo ejus etiam provinciae dux, nomine Argimundus, adversus Recaredum regem tyrannidem assumere cupiens, ita ut si posset, eum et regno privaret et vita. Sed nefandi ejus consilii detecta machinatione, comprehensus, et in vinculis ferreis redactus, habita discussione, socii ejus impiam machinationem confessi condigna sunt ultione interfecti. Ipse autem Argimundus qui regnum assumere cupiebat, primum verberibus interrogatus, deinde turpiter decalvatus, post haec dextra amputata, exemplum omnibus in Toletana urbe, Asino sedens pmpizando dedit, et docuit famulos dominii non esse superbos. João de Biclaro, Chr. VIII Ano de Maurício, IV de Recaredo.

${ }^{239}$ GARCÍA MORENO, L.A. Historia de España Visigoda...op.cit. p.144.

${ }^{240}$ VPE, 1. V, c. X

${ }^{241}$ Sunna namque Gotus episcopus, cuius supra memoriam fecimus, irritatus a diabolo quosdam Gotorum nobiles genere opibusque perquam ditissimos, e quibus etiam nonnuli in quibusdam ciuitatibus comites a rege fuerant constitute, consilio diabolico persuasit eosque de catholicorum hagmine ac gremio catholicae eclesie cum innumerabile multitudine populi separauit et contra famulum Dei Masonam episcopum fraudulenta consilia, qualiter eum interficeret, commentabit. VPE, $\mathrm{V}, \mathrm{X}$.
} 
pertinente tentar identificar quem eram esses aristocratas em disputa, e para tanto é pertinente dedicar algumas palavras à Mérida.

Conforme Alonso Campos, a região do Sul da Hispânia era marcada por uma forte presença bizantina indicada pela eleição dos bispos: no século VI foi eleito um certo Paulo, sucedido por seu sobrinho Fidel, ambos identificados como gregos. A elevação de Masona rompeu com a hegemonia de homens de origem grega na sé de Mérida. Godo convertido ao catolicismo Masona representava um outro grupo político que suscitou a revolta daqueles aliados ao grupo de influência grega, o grupo de Masona seria então formado principalmente por godos convertidos ao catolicismo em disputa com o grupo formado principalmente por descendentes de gregos. ${ }^{242} \mathrm{O}$ argumento de Alonso Campos, entretanto, é questionável. Sunna tornou-se bispo por indicação de Leovigildo, difícil crer que o rei que enfrentou os bizantinos apoiaria um homem que representava um grupo marcado justamente pela influência oriental, conforme Alonso Campos. Outro ponto que pode ser posto sob crivo crítico é a sugestão de que as origens orientais da aristocracia ligada a Sunna em detrimento às origens godas da aristocracia ligada a Masona fossem de fato uma das origens das tensões.

Talvez uma busca nos indícios arqueológicos da região de Mérida possam ser mais ilustrativos para pensarmos sobre quem eram esses nobres que se opunham ao poder que se pretendia central de Toledo. Indícios arqueológicos apontam que assentamentos supostamente godos se concentraram na região da Meseta. Por outro lado, na Baetica e Lusitânia indícios da presença goda são muito mais tênues. De acordo com Cordero Ruiz isso se deve à existência de uma aristocracia hispano-

\footnotetext{
${ }^{242}$ ALONSO CAMPOS, J.I. Sunna, Masona y Nepopis. Las luchas religiosas durante la dinastia de Leovigildo. Los visigodos. Historia y civilización. Antigüedad y cristianismo, III, 1986. p.151-157.
} 
romana muito forte e hostil à chegada de elementos estranhos. ${ }^{243}$ Isso entretanto não significa dizer que não existiam nobres identificados como godos em Mérida. Se confiarmos nos registros presentes nas Vidas dos Padres de Mérida podemos dizer que inegavelmente havia uma aristocracia dita goda na região.

Ainda à luz da arqueologia, Cordero Ruiz defende que a partir do século VI intensificou-se a cessão de terras emeritenses à aristocratas "godos" na região de Mérida. Essa nascente nobreza emeritense aumentou ainda mais suas riquezas por mais doações de terras feitas pelos reis e pelo matrimônio com proprietários de origem hispano-romana, com mais terras estava sedimentado o caminho para se alcançar cargos na administração do reino. A cada vez mais forte nobreza "goda" de Mérida gradativamente se regionalizou, afastando-se assim da autoridade central de Toledo. Pelas informações presentes nas Vidas dos Padres de Mérida podemos conjecturar que parte dessa aristocracia se identificou como "goda". Como apontamos na primeira parte da tese, não se trata aqui de dizer que esses indivíduos eram godos num sentido étnico tradicional, mas sim de perceber que essa identidade - que usufruia de uma tradição narrativa - foi usada politicamente. ${ }^{244}$ Podemos interpretar esses dados da seguinte maneira: uma aristocracia que ascendia politicamente assumiu uma determinada identidade usada em seus movimentos políticos. Acreditamos que é assim que esses "godos" de Mérida devem ser compreendidos. O prestígio que o marcador identitário "godo" possuía será explicitado no próximo capítulo e esses movimentos políticos fundamentados em discursos identitários se

\footnotetext{
${ }^{243}$ CORDERO RUIZ, T. El territorio emeritense durante la Antigüedad Tardía. (siglos IV-VIII). Génesis y evolución del mundo rural lusitano. Mérida: Anejos de AEspA, LXVI, 2013. p.314-317. Ainda: GARCÍA MORENO, L.A. Transformaciones de la Bética durante la tardoantigüedade. Mainake, XXIX, p.433-471, 2007. p.437-436. E ainda: WOOD, I. Social relations in the Visigothic Kingdom from the fifth to the seventh century: the example of Mérida. In: HEATHER, P. The visigoths. From the migration period to the seventh century. An ethnographical perspective. Woodbridge: Boydell Press, 1999. p.194.

${ }^{244}$ CORDERO RUIZ, T. El territorio emeritense durante la Antigüedad Tardía...op.cit. p.317-318.
} 
esclarecerão. O que importa agora é tentar decifrar como esses grupos atuavam em relação aos reis para compreendermos a reação política deles. Sigamos.

O fortalecimento de uma nobreza identificada como goda em Mérida não redundou no desaparecimento das tradicionais nobrezas hispano-romanas. Mais uma vez as Vidas dos Padres de Mérida nos trazem apontamentos interessantes sobre a questão ao mencionar o dux Claudio, nobre hispano-romano que em Mérida enfrentou a rebelião de Sunna e seus aliados godos. Esse dado é interessante. Temos um nobre hispano-romano que presta serviço ao rei contra elementos hostil da nobreza goda. Poderíamos então conduzir nossa interpretação pelo seguinte argumento: as origens da oposição aos reis de Mérida advinham de segmentos da nobreza identificados como godos pelas fontes, interpretações arqueológicas sugerem que sim, se pode falar de uma nobreza que se identificava como goda na região. Para fazer frente a esses levantes em Mérida o rei Recaredo contou principalmente com a atuação de Cláudio, dux pertencente à nobreza de origem hispano-romana.

Viterico adveio justamente dos grupos nobiliárquicos godos de Mérida que obtiveram sucesso na rebelião contra Liuva II e ascenderam ao poder real, lá se mantiveram até o assassinato de Viterico. Assim, ao contrário do que sugeriu Alonso Campos, a oposição em Mérida à autoridade central de Toledo não se originava de nobres de origem oriental e sim de nobres identificados como godos, por outro lado, os aliados do rei em Mérida eram capitaneados por Cláudio, um dux de origem hispano-romana. Mesmo que a identificação de objetos arqueológicos como de origem goda seja algo problemático, é preciso lembrar que a principal fonte sobre a região de Mérida do período, as Vidas dos Padres de Mérida, identifica esses grupos rebeldes como godos. Talvez o fato de ser ou não de fato etnicamente godos não seja o mais importante aqui, e sim a construção de um discurso que faz tal identificação. 
Enfim, não se trata de dizer que aqueles elementos opostos aos reis eram godos, e sim que o autor da Vida dos Padres de Mérida assim os descreveu.

O que podemos dizer sem grande dúvida a partir dessas informações é que Viterico era um nobre advindo de Mérida, região que, como indicamos, se destacava por uma grande disputa entre facções nobiliárquicas. Na época de Recaredo um desses grupos, liderado por Claudio e Masona, prevaleceu. Pouco depois da morte de Recaredo, entretanto, um indivíduo que advinha do grupo que se opunha a Claudio e Masona conseguiu derrubar Liuva II, o que pode apontar para um novo fortalecimento do grupo aristocrático que anos antes sofreram uma derrota. Essas informações podem nos ajudar a compreender melhor o relato do hispalense sobre o reinado de Viterico:

Aera DCXLI, anno imperii Maurici XX extincto Liunane Wittericus regnum, quod uiuente illo inuaserat, uindicat annis VII, uir quidem strenuous in armorum arte, sed tamen expers uictoriae. Namque aduersus militem Romanum proelio saepe molitus nihil satis gloriae gessit praeter quod milites quosdam Sagontia per duces obtinuit. Hic in uita plurima inlicita fecit, in morte autem, quia gladio operates fuerat, gladio periit. Mors quipped innocentis inulta in illo non fuit, inter epulas enim prandii coniuratione quorundam est interfectus. Corpus eius uiliter est exportatum atque sepultum. ${ }^{245}$

O relato de Isidoro de Sevilha envolve o reinado de Viterico em ilegitimidade.

Ele reivindicou o reino, ao contrário por exemplo de Sisebuto que foi chamado à dignidade real ([...] Sisebutus post Gundemarum regali fastigio euocatur, regnans annis VIII mensibus $V I .^{246}$ ). O hispalense menciona ainda ações ilícitas realizadas por Viterico além do assassinato de Liuva II, embora essas ações não sejam descritas pelo bispo de Sevilha, poderíamos incluir a participação de Viterico na revolta em Mérida entre esses feitos. O relato sobre o fim de Viterico indica que sua morte e o vitupério contra seu cadáver foram penas pelo assassinato de Liuva II, entretanto, podemos ir

\footnotetext{
${ }^{245}$ Historia Gothorum, 58. Ver tradução 10 no anexo 1.

${ }^{246}$ Historia Gothorum, 60
} 
além e apontar que o levante contra o rei tenha sido uma resposta não só à morte de Liuva mas a toda oposição política que o grupo de Viterico vinha representando desde Mérida à autoridade central de Toledo. Muito mais do que repreender Viterico, Isidoro de Sevilha, mediante tal descrição do reinado de Viterico, estava deslegitimizando a nobreza qualificada pelas Vidas dos Padres de Mérida como "goda" e que se opunha à autoridade dos reis de Toledo.

Interessante perceber que a região de Mérida não deixou de ser um foco de oposição aos reis de Toledo. Duas moedas, uma cunhada em Mérida e outra em Ilíberris por volta de 632, trazem a inscrição IUDILA REX, indicando que muito provavelmente nos primeiros anos do reinado de Sisenando houve uma rebelião na região que redundou na coroação de uma certo Iudila em detrimento a Sisenando. ${ }^{247}$ Não obstante, uma moeda encontrada na região com a inscrição VICTOR durante o reinado de Chindasvinto levou E.A. Thompson a inferir que a perseguição aos nobres liderada pelo rei e descrita pela Crônica de "Fredegário" atingiu principalmente a aristocracia daquela área. ${ }^{248}$

\section{Gundemaro e as epístolas de Bulgarano}

Morto Viterico assumiu Gundemaro que reinou por pouco tempo. Temos poucas informações sobre ele advindas de Isidoro de Sevilha que foi muito breve e mencionou apenas que Gundemaro sitiou alguns soldados romanos - certamente no Sul da Península - e empreendeu expedições contra os vascones.

Podemos saber um pouco mais sobre Gundemaro pelas epístolas do Conde Bulgarano da Septimania. Autor de seis epístolas escritas entre 610 e 612, exatamente

\footnotetext{
${ }^{247}$ GARCÍA MORENO, L.A. Historia de España Visigoda...op.cit. p.156-157. Ainda: THOMPSON, E.A. The Goths in Spain...op.cit. p.175.

${ }^{248}$ Chr. Fredegário 1.IV, c.82. THOMPSON, E.A. The Goths in Spain...op.cit. p.191. Cabe ressaltar que o argumento de Thompson é interessante, mas difícil de ser sustentado uma vez que se baseia apenas numa moeda.
} 
o período do reinado de Gundemaro. As epístolas de Bulgarano são muito interessantes pois revelam a aliança entre Gundemaro e o rei franco da Austrásia Teodoberto II (596-612) contra Teodorico II (596-613) da Burgúndia e sua avó Brunilda.

De acordo com Bulgarano o início da aliança entre Gundemaro e Teodoberto II se deu com a suposta ação de Teodorico II e Brunilda que teriam incitado os ávaros a atacarem o rei da Austrásia. ${ }^{249}$ Os motivos dessa aliança são nebulosos. Segundo E.J. Thomas ${ }^{250}$ essas cartas revelam a hostilidade do rei visigodo contra Brunilda que exercia influência na política visigoda possivelmente pela permanência de uma identidade goda na rainha da Austrásia. Thomas ainda traz um outro elemento importante que pode ter tido um peso maior nos acontecimento da Septimania. Brunilda possuía duas cidades na região - Corneillan e Juvignac. As cidades consistiam no dote da irmã de Brunilda, Gosvinta, que havia sido assassinada. Após a morte de Gosvinta, Brunilda obteve as cidades conforme registrado por Gregório de Tours em sua cópia dos termos do Tratado de Andelot de em 587, ${ }^{251}$ entretanto as terras foram anexadas ao reino de Recaredo que devolveu as cidades à Brunilda, a rainha então possuía territórios na região da Septimania visigoda indicando que era sim influente na política visigoda tal como era na franca. ${ }^{252}$ Exatamente essas duas cidades foram tomadas pelos visigodos durante os eventos registrados nas epístola de Bulgarano como retaliação ao cativeiro impostos a dois visigodos em Irupinae ${ }^{253}$ (região não identificada).

\footnotetext{
${ }^{249}$ Interea notescimus sanctitati vestrae, ad nos opinione vulgata pervenisse, Brunigildem reginam et Theudericum regem amarissima sub dispositione adsueta diffundentes venena in excidium unitae gentis contra gloriosum Theudibertum regem atrocissimum Abarorum excitasse demicare regem. Epistolae Wisigoticae, 11.

${ }^{250}$ THOMAS, E.J. The 'second Jezebel': representations of the sixth-century Queen Brunhild. PhD Thesis. University of Glasgow. School of Humanities. October 2012. 241pp. p.105-106.

${ }^{251}$ Decem Libri Historiarum, IX, 20.

252 THOMAS, Emma Jane. The 'second Jezebel' ...op.cit.

${ }^{253}$ Epistolae Wisigoticae 13
} 
Embora a hipótese de Thomas seja absolutamente interessante por dar atenção à Brunilda nas epístolas de Bulgarano, não se pode dizer que isso explique necessariamente a inclinação de Gundemaro a se aliar aos francos mediante inclusive remuneração a Teodoberto II. ${ }^{254}$ Talvez a atuação de Gundemaro se explique pelos assédios contra a Septimania empreendidos desde a Burgúndia, algo que ocorreu em duas ocasiões durante o reinado do rei franco Gontrão. Ao unir-se com Teodoberto II Gundemaro poderia ao mesmo tempo apoiar o rei da Austrásia e obter dele apoio contra as investidas dos reis da Burgúndia à Septimania e quiçá às investidas da própria nobreza visigoda contra ele, isso poderia ajudar a explicar porque os visigodos ofereceram remuneração aos francos: Gundemaro talvez não contasse com muito apoio e portanto recorreu ao apoio de um rei franco intermediado por seu conde da Septimania. Uma outra possibilidade é a de que Gundemaro tenha acalmado momentaneamente os ânimos da nobreza visigoda de modo que não enfrentou oposições internas, suas principais preocupações seriam o Sul da Península, os vascones e a região da Septimania ameaçada pelos reis francos da Burgúndia, cabe ressaltar que não há qualquer evidência de que Gundemaro tenha sofrido qualquer tentativa de golpe durante seus dois anos de reinado. Mesmo breve, o reinado de Gundemaro é interessante para observar como um rei visigodo pode ter recorrido a apoio estrangeiro, infelizmente as poucas evidências não nos permitem dizer se essa

\footnotetext{
${ }^{254}$ Epistolae Wisigoticae, 12: Et quia latere beatitudinem vestram non arbitror, quod filius vester, domnus Theudibertus rex, cum gentem Gotorum a decidentibus velut olim existit conligata principibus, nunc per pactuum allegatione pacem per legatis idem gentis devobit roborare perpetuam, ex quo aliquod gratie meritum, pecunie numerum, genti pollicitus est inpertire Francorum, unde iam me constat memorato filio vestro, domno Theudiberto, per venerabilem (fratrem) vestrum, domnum et (in Christo mihi pa)trem, Verum episcopum, (destina)sse scripta, per qua inno(tui), quod iam ipsa pecunia a filio vestro, glorioso domno meo, Gundemaro rege, directa hic mihi in Gallias esse dignoscitur, ut prudentes ex suo dirigat conspectu legatos et ea, que ob caritate gens Gotorum universa promisit, tradentibus placita saltim contradamus hominibus. Obinde tuam sactitatem devita humilitate deposco, ut, quantum dominum diligis Iesum, qui pacem preteritis seculis dereliquit futuris, huius confirmatione pro pacis tantum intentere digneris delectabiliter, et, si agnoscitis ea, quem direximus, ad domnum Theudybertum paginam pervenisse, aut si ea, quae per legatis Gotorum sunt sub definitione inita, si manebunt veraciter allegata, vel quantum (pre)dictus filius vester in Abarorum bellica triumphatus est acie, vestris mereamur affatibus informari. 12
} 
ajuda foi buscada por conta de uma debilidade interna de Gundemaro - caso fosse ameaçado por aristocratas visigodos - ou pela força do rei - sem preocupações internas ele poderia se concentrar nas ameaças estrangeiras.

De qualquer maneira o reinado de Gundemaro traz uma possibilidade de fragilidade que é importante para nós. Levando em consideração as demais evidências levantadas a partir dos outros reis da Hispânia nos parece mais provável que as correspondências com Teodoberto II se relacionassem mais com uma tentativa de obter apoio do que com a segunda hipótese. Aparentemente a precariedade da autoridade dos reis godos não foi superada no governo de Gundemaro.

\section{Sisebuto e Isidoro de Sevilha}

Terminado o breve, porém intrigante, reinado de Gundemaro chegou ao trono Sisebuto. Não há praticamente nenhuma informação sobre a vida de Sisebuto antes de que ele se tornasse rei, ${ }^{255}$ entretanto seu reinado é relativamente bem documentado em confronto com os reinados de outros reis visigodos e isso se deve muito aos textos que o próprio Sisebuto escreveu. Do rei nos restaram cinco cartas reunidas inicialmente na edição de epístolas visigodas congregadas sob a alcunha de Epistolae Wisigoticae por Gundlach na edição dos Monumenta Germaniae Historica em $1892,{ }^{256}$ um poema intitulado "De eclipsi lunae" enviado a Isidoro de Sevilha em agradecimento ao De natura rerum escrito pelo bispo de Sevilha e dedicado ao rei e seu texto mais famoso, a Vita Desiderii. Todos esses textos foram produzidos num ambiente de forte influência de Isidoro de Sevilha em que o profícuo hispalense dava conta de uma intensa atividade intelectual aliada com uma íntima proximidade com o rei

\footnotetext{
${ }^{255}$ García Moreno sugere que o rei possa ter sido originário da aristocracia visigoda de Córdoba usando como argumento a política especial do rei voltada aos judeus da região. $C f$ : GARCÍA MORENO, L.A. Building an Ethnic Identity for a New Gothic and Roman Nobility: Córdoba, 615 AD. In: MATHISEN, R.W. \& SHANZER, D. (ed.) Romans, Barbarians and the transformation of the Roman World. Cultural Interaction and the Creation of Identity in Late Antiquity. Farnham: Ashgate, 2011. p.280.

${ }^{256}$ MARTíN-IGLESIAS, J.C. El latín de las Epistulae Wisigothicae. Cuadernos de Filología Clásica. Estudios Latinos. v.34, n.1, p.37-60, 2014. p.38, nota 1.
} 
Sisebuto, ${ }^{257}$ de maneira que podemos dizer com certa segurança que os textos de Sisebuto devem ser analisados à luz da força que o pensamento isidoriano exercia sobre o monarca e talvez justamente por isso a produção de Sisebuto nos ajude a compreender um pouco mais da elaboração isidoriana sobre a realeza visigoda. O confronto entre a produção de Isidoro de Sevilha e a de Sisebuto se centrará na Vita Desiderii escrita pelo rei uma vez que nesta obra se observa a posição do monarca sobre outros reis, nomeadamente Teodorico e Brunilda.

No texto escrito por volta de 613 Sisebuto narrou a vida e morte de Desidério, bispo de Viena entre 596 e 607 outorgando destaque à perseguição sofrida pelo bispo capitaneada por Teodorico e Brunilda. Muito embora não se possa perder de vista a celebração da memória do santo ${ }^{258}$ - a característica crucial de textos hagiográficos a Vida também deve ser vista a partir de seu sentido político. ${ }^{259}$ Não raro considerada uma obra de propaganda conta os francos, ou contra especificamente Teodorico e Brunilda, ${ }^{260}$ acreditamos que o texto traz também elementos sobre a própria situação política do reino visigodo. $^{261}$

\footnotetext{
${ }^{257}$ A influência do pensamento isidoriano no período era de tal modo evidente que levou alguns autores a chamar àquela época de "Renascimento Isidoriano. $C f$. HEN, Y. A Visigothic king in search of an identity - Sisebutus Gothorum gloriosissimus princeps. In: CORRADINI, R., GILLIS, M., McKITTERICK, R. \& RENSWOUDE, I. van. Ego trouble: authors and their identities in the Early Middle Ages. Forschungen zur Geschichte des Mittelalter, n.15. Wien: Verlag der Österreichischen Akademie der Wissenschaften, 2010. p.89-99.

${ }^{258}$ Como muito bem lembrou J.C. Martín: MARTíN, J.C. Verdad Histórica y verdad hagiográfica en la vita desiderii de Sisebuto. Habis, n.29, p.291-301, 1998.

${ }^{259}$ Como chamou a atenção J. Fontaine: FONTAINE, J. King Sisebut's Vita Desiderii and the political function of Visigothic hagiography. In: JAMES, E. (ed.). Visigothic Spain. New approaches. Oxford: Clarendon Press, 1980. p.93-129.

${ }^{260}$ MARTíN, J.C. Verdad Histórica y verdad hagiográfica en la vita desiderii de Sisebuto... op.cit.

${ }^{261}$ Algo já apontado por Adriana Sousa: SOUSA, Adriana C. Literatura hagiográfica e cristianização das atribuições régias no reino visigodo de Toledo (séc. VII): uma análise da atuação dos monarcas na Vita Desiderii, do rei Sisebuto. Anais do XXVI Simpósio Nacional de História - ANPUH. São Paulo, julho $2011 . \quad$ (Disponível em: http://www.snh2011.anpuh.org/resources/anais/14/1313028855_ARQUIVO_ArtigoAnpuh2011_Adria naSousa.pdf )
} 
Tal questão se expressa na primeira condenação de Desidério realizada na ocasião de um concílio ${ }^{262}$ descrito pelo rei como a via da realização da maldade contra o bispo. Interessante notar que durante o reinado de Sisebuto apenas concílios regionais dedicados exclusivamente a questões eclesiásticas foram convocados, ${ }^{263}$ tratam-se do de Egara de 614 que reuniu os bispos de Tarragona e tão somente confirmou o concílio de Huesca no que concerne à castidade dos bispos ${ }^{264}$ e do II Concílio de Sevilha de 619 presidido por Isidoro de Sevilha.

O II Concílio de Sevilha traz alguns pontos interessantes. Logo no primeiro cânone percebe-se que dois viri inlustres da Bética participaram do Concílio, Sisiclo e Suanila, sendo o primeiro responsável pelo governo das coisas públicas e o segundo responsável pelo fisco ([...] cum inlustribus viris Sisisclo rectore rerum publicarum atque Suanilane rectore rerum fiscalium $[\ldots]^{265}$ ), a presença desses dois personagens nomeados logo no primeiro cânone pode ser um indicativo da força de aristocratas locais na região da Bética que participavam ativamente de um concílio eclesiástico, mas também que esses dois nomes eram aliados de Sisebuto, uma hipótese contrária é frágil uma vez que Isidoro de Sevilha dificilmente presidiria um concílio com inimigos do rei ao qual era obviamente aliado. De qualquer maneira o cânone é interessante por outro fator: ele relata a reclamação do bispo Teodulfo de Málaga referente a perda de igrejas da cidade ocasionadas por operações militares, esses

\footnotetext{
${ }^{262}$ Quae instructa in concilio quaesta est, a beatissimo vi stuprum Desiderio esse sibi quondam inlatum; mirantibus cunctis, talibus in rebus fore Dei servum implicitum, criminationes et obiecta commentitia adversus eum fore pensabant. Sed praesidentes sententiam contra insontem iuxta pridem machinationes abtatas ausu temerario malesanam dederunt, quem statim homines punituri ab honore pribatum exilio ad monasterium insula religarunt [...] Vita Desiderii, 4.

${ }^{263}$ Como sublinha E.A. Thompson: THOMPSON, E.A. The Goths in Spain...op.cit. p.163-164.

${ }^{264}$ Convenientes in unum episcopi provinciae Terraconensis in locum Egara, id sancta instituit synodus ut constitutio quae dudum in anno tertio decimo regni divae memoriae Recaredi regis in concilio Oscense, constituta quidem sed minime conscribta fuit, confirmata et in perpetuum valitatura perduret: et omne quicquid ex castimonia presbyterorum et inferius clericorum conscribta sunt eandem formam et de omnibus episcopis sub tali industria sollertiaque omni tempore pepigendo scrutetur, ut auxiliante Domino et adminiculante tali vitae sollicitudinem nulla, quod absit, reprehensionis occasio subrippere aliquando praevaleat. Concilio de Egara

${ }^{265}$ II Concílio de Sevilha, I.
} 
edifícios e seus entornos teriam sido anexadas parcialmente às dioceses de Écija, Elvira e Cabra ${ }^{266}$ todas localizadas na região da Bética. Esse evento reforça a imagem da região da Bética como um foco de muitas tensões regionais, tal como era a Lusitânia como explicitamos no caso da rebelião de Mérida. Tais tensões envolviam os membros da hierarquia eclesiástica que perdiam igrejas e seus territórios por meio de ações militares. As disputas demandavam a intervenção dos bispos mediante um concílio regional e de aristocratas aliados ao rei. O tema de disputas por territórios de autoridade dos bispos se repete no concílio. O cânone II trata das disputas entre os bispos Fulgêncio de Écija e Honório de Córdoba sobre limites territoriais de suas dioceses, já no cânone III fala-se de Espasando que abandonou a igreja de Itálica e transferiu-se para a de Córdoba.

Observamos com isso que os dois concílios realizados por Sisebuto tratavam primeiro da confirmação de um concílio anterior e segundo de questões relativas à complicada região da Bética, isso indica que mesmo que não tenhamos relatos de uma rebelião direta contra o rei partindo da Bética, as disputas na área eram de preocupação de Sisebuto, que buscou impor-se mediante um concílio, concílio esse, entretanto, que além de ter sido presidido por seu grande aliado Isidoro de Sevilha contou com dois aristocratas que provavelmente eram também aliados do rei para controlar não só as deliberações da reunião, mas mesmo o comportamento dos clérigos da Bética, visto que o concílio versa em seus demais cânones exclusivamente sobre a disciplina eclesiástica.

Mesmo que tenha lançado mão de um concílio para lidar com os problemas da Bética Sisebuto não parecia confiar tanto nas reuniões eclesiásticas e isso não é

\footnotetext{
${ }^{266}$ [...] prima actione Teudulfi Malacitanae ecclesiae antestitis ad nos oblata precatio est adserentis antiquam eiusdem urbis parrochiam militaris condam hostilitatis discrimine fuisse descissam et ex parte aliqua ab ecclesiis Astigitanae, Eliberritanae atque Egabrensis urbium esse retentam. II Concílio de Sevilha, I.
} 
indicado apenas pelas características do concílio de Sevilha mas também pela descrição negativa que ele fez do concílio que condenou Desidério. Ora, se por um lado a vita escrita pelo o rei pudesse ser um indicativo de sua piedade cristã, ela também expressa as desconfianças do rei em relação aos membros da alta hierarquia episcopal e poderia nos ajudar a entender porque nenhum concílio de Toledo foi realizado por Sisebuto: mesmo que fosse um fiel cristão ele não tolerava a ingerência episcopal ${ }^{267}$ e apontou com sua vita mediante o exemplo de Teodorico que os bispos poderiam facilmente ser manipulados por maus reis e rainhas para cometer o grave pecado de condenar um verdadeiro servo de Deus.

Mas Sisebuto foi além e apontou para o que caracterizava um mau rei e uma má rainha. Teodorico foi descrito por Sisebuto como um estúpido e Brunilda como uma fiel do mal, ${ }^{268}$ incapazes de melhorar e que se deixavam perder ao invés de governar. Iníquos, estavam apartados da salvação pois eram governados pelo mal. A impiedade e vícios de Teodorico e Brunilda depunham contra o governo deles e o exemplo máximo da indignidade de ambos se realiza pela paixão de Desidério punida pela morte de Teodorico por disenteria e de Brunilda, graficamente descrita por Sisebuto:

De cuius interitu qua vulgata opinione comperimus dicere non pigebit. Est animal tortuosum, immanem anguis obtinens corpus, habens et naturaliter quosdam anfractus: summitas licet dorsi turgentior atque collectior celsiorem artubus reliquis obtinet locum, oneri satis abundeque aptissimum et in vehendis animalibus ceterir rebus praestantior. In huius centri fastigium vestibus detecta antefata sustollitur coramque vultibus hostium ignominiose deducitur ; aliquamdiu foedissimum expectantibus miraculum tribuit. Dehinc caudis sonipedum indomitorum arctatur atque per invia fragosaque loca raptatur: sic equis ferventibus corpus iam senio maceratum frustatim decerpitur, ac divaricata passim sine nomine membra cruentaque laxantur. Taliter terrena materiae

\footnotetext{
${ }^{267}$ GARCÍA MORENO, L.A. Historia de España Visigoda...op.cit.

${ }^{268}$ ([...] regnante simul scilicet Theodorico, totius hominem stultitiae dignum et fautricem pessimarum artium, malis amicissimam Brunigildem. Vita Desiderii, 4.)
} 
anima resoluta perpetuisque poenis nec immerito relegata, tenetur piceis arsura bullientibus undis. ${ }^{269}$

A partir da Vita Desiderii confrontada com as atas do II Concílio de Sevilha e retomando as definições de Isidoro de Sevilha podemos ensaiar uma análise do modelo de monarca estabelecida por Isidoro de Sevilha à luz da apropriação feita por Sisebuto de modo a indicar que tal modelo não era um ideal abstrato mas algo elaborado com vistas a um contexto político e com fins de uso político.

É preciso reiterar a definição de Isidoro de Sevilha: o rei cumpria uma função no plano divino da salvação, a medida que não o cumprisse perdia o direito à dignidade real, no discurso de Isidoro para que essa função fosse cumprida era mister que o rei respeitasse a fé cristã e as leis, o bispo não apenas reforçou a legitimidade régia, hipótese defendida amiúde, ${ }^{270}$ mas antes de tudo abriu brecha para justificar a deposição de reis. Isidoro exemplificou praticamente sua definição na justificativa da deposição de Viterico, Sisebuto - partindo do modelo Isidoriano - indicou a indignidade de Teodorico e Brunilda, que se perdiam ao invés de governar envoltos na impiedade. Podemos ir além e transcender a questão de um ideal de realeza a parte da sociedade, em outras palavras, de uma realeza teocrática. Isidoro de Sevilha estava tão envolvido nas tensões políticas do reino visigodo quanto Sisebuto, e essas tensões se articulavam mormente em torno de grupos aristocráticos que disputavam o poder primeiro regional - como indicam as atas do II Concílio de Sevilha e as Vidas dos Padres de Mérida assim como as ações de Gundemaro na Septimania - quanto central. Quando Isidoro ratificou o reinado de Sisebuto e de outros reis ele estava tomando partido por um grupo de poder e registrou discursivamente seu apoio ao concatenar a narrativa sobre os atos desses reis com as qualidades de um bom

\footnotetext{
${ }^{269}$ Vita Desiderii, 21. Ver tradução 11, anexo 1.

${ }^{270}$ Como no recente livro de J. Wood: WOOD, J. The politics of Identity in Visigothic Spain. Leiden \& Boston: Brill, 2012.
} 
monarca cristão. O que queremos dizer é que as qualidades de um monarca cristão não existiam a priori, não eram a medida para julgar a qualidade dos reis, ao contrário, o teatro político e os grupos de suporte dos reis e de quem narrava sobre esses reis, no caso Isidoro de Sevilha, determinavam o que qualificaria um personagem como mau ou bom monarca, e em certas circunstâncias mudanças nas relações de força influíam nesse aparato discursivo de legitimidade. Sisebuto aparentemente apreendeu tal perspectiva que se impôs no desenrolar da situação política dos reis que o sucederam, dentre eles Suintila.

\title{
A fragilidade dos reis
}

$\mathrm{Na}$ Historia Gothorum a descrição feita por Isidoro do reinado de Suintila engloba as qualidades necessárias para um bom rei:

\begin{abstract}
Praeter has militaris gloriae laudes plurimae in eo regiae maiestatis virtutes: fides, prudentia, industria, in iudiciis examinatio strenua, in regendo regno cura praecipua, circa omnes munificentia, largus erga indigentes et inopes, misericordia satis promptus, ita ut non solum princeps populorum, sed etiam pater pauperum vocari sit dignus. ${ }^{271}$
\end{abstract}

Vitorioso nas empresas militares, fiel, prudente, parcimonioso na emissão de juízos, misericordioso e generoso com os necessitados. Suintila parecia ser o homem certo, no julgamento de Isidoro de Sevilha, para governar o reino dos godos. Apesar disso ele foi deposto por Sisenando, deposição confirmada pelas atas do IV Concílio de Toledo conduzido pelo próprio Isidoro de Sevilha ${ }^{272}$ que lançou mão da mesma argumentação da legitimidade ou ilegitimidade de um rei para justificar a queda de Suintila. No célebre cânone LXXV do mencionado concílio, Suintila perdeu a dignidade real por seus próprios erros e pecados. ${ }^{273} \mathrm{O}$ que queremos dizer com todos

\footnotetext{
${ }^{271}$ HISTORIA GOTHORUM, 64. Ver tradução 12, anexo 1.

${ }^{272} C f$ : GARCIA MORENO, L.A. La oposición a Suintila. Iglesia, Monarquía y Nobleza en el Reino Visigodo. Polis, n.3, p.13-24, 1991.

${ }^{273}$ De Suintilane vero qui scelera propria metuens se ipsum regno privavit et potestatis fascibus exuit [...]. IV Concílio de Toledo, LXXV.
} 
esses exemplos é que a elaboração isidoriana sobre o sentido do poder real não deve ser interpretada como um aparato de legitimidade generalizado para os reis, mas antes como uma elaboração de via dupla que poderia tanto ser usada para fortalecer um rei quanto para justificar sua deposição. Isidoro de Sevilha não estava a serviço da realeza enquanto um ideal abstrato, mas antes tinha um sentido muito prático. Sentido este que mostrou-se muito útil nas décadas seguintes.

O que todas as rebeliões e respostas dadas pelos reis que até aqui explicitamos indicam é que os reis visigodos não usufruíam de qualquer ideal de realeza que garantia por si só a autoridade deles, pelo contrário, a oposição à autoridade dos reis parecia ser a regra, não a exceção. O sucesso ou insucesso de um rei dependia mais de como ele conseguia enfrentar as forças opositoras ao seu governo do que de um aparato discursivo de legitimidade advindo de alguma elaboração teológica, ou, menos ainda para o caso dos visigodos, de uma legitimidade biológica oriunda de uma dinastia - como discutiremos no caso dos francos. Isso não quer dizer que nessas disputas políticas esses reis não buscavam afirmação cooptando forças mediante uma argumentação cristã quando políticas energéticas aplicadas contra forças opositoras falhavam. Isso pode ser observado no caso de Recesvinto.

Recesvinto era filho do rei Chindasvinto. Chindasvinto chegou ao trono por uma rebelião que destronou Tulga. Era um veterano que conhecia muito bem as tensões na aristocracia visigoda e por saber disso, assim que chegou ao reinado, iniciou a perseguição de aristocratas que ele sabia que poderiam iniciar outra revolta contra seu reinado. A crônica Fredegário é a principal fonte que descreve as ações de Chindasvinto contra os nobres. No texto, lemos que Chindasvinto sabia do ímpeto rebelde dos godos - que aqui parece significar nobres - e portanto os atacou diretamente: 
Cumque omnem regnum Spaniae suae dicione firmassit, cognetus morbum Gotorum, quem de regebus degradandum habebant, unde sepius cum ipsis in consilio fuerat, quoscumque ex eis uius viciae prumtum contra regibus, qui a regno expulsi fuerant, cognoverat fuesse noxius, totus sigillatem iubit interfici aliusque exilio condemnare; eorumque uxoris et filias suis fedelebus cum facultatebus tradit. Fertur, de primatis Gotorum hoc vicio repremendo ducentis fuisse interfectis; de mediogrebus quingentis interfecere iussit. Quoadusque hoc morbum Gotorum Chyntasindus cognovissit perdometum, non cessavit quos in suspicionem habebat gladio trucidare. Goti a vero Chyntasindo permoniti, nihil adversus eodem ausi sunt, ut de regebus consuaeverant inire consilium. ${ }^{274}$

Ele ainda convocou o VII Concílio de Toledo no qual impunha severas penas aos refugae $e^{275}$ e ainda instituiu a lei L.V. II, 1, 8 no qual criava mecanismos para que os nobres condenados não transferissem suas propriedades para seus familiares de modo a escapar da perda das propriedades que deveriam ser tomadas pela coroa em caso de rebelião. ${ }^{276}$ Por fim, como descreveu mais uma vez a crônica franca, Chindasvinto nomeou seu filho como co-regente e ambos governaram juntos até a morte do ancião rei. A energética política de Chindasvinto teve consequência no reinado de seu filho e isso se evidencia pela sensível diferença entre as atas do VII Concílio de Toledo, convocado por Chindasvinto, e as atas do VIII Concílio de Toledo convocado por Recesvinto.

Enquanto que no VII Concílio de Toledo convocado sob os auspícios de Chindasvinto logo no primeiro cânone vemos um esforço punitivo contra os clérigos traidores do reino ${ }^{277}$ e no último cânone lemos o ímpeto de controle que o rei objetiva exercer sob o clero ao definir que os bispos das cidades vizinhas à Toledo deveriam residir por um ano na cidade de Toledo, no VIII Concílio de Toledo vemos um rei,

\footnotetext{
${ }^{274}$ Crônica de Fredegário, Livro IV, cap. 82. Ver tradução 13 no anexo 1.

${ }^{275}$ Definidos como aqueles que se dirigiam à terras estrangeiras (...in alienae gentis regionem ...) para desde lá representar oposição ao rei, à gens gothorum e à patria. (...occasione transduxerit, ut exinde superbiendo vel reditum suum vel quolibet aliud videatur expeterem sive estiam quod gente Gothorum vel patriam aut regem specialiter sub hac occasione possit nocere vel fieri disposuerit vel aliquatenus fecerit. VII Concílio de Toledo, I.)

${ }^{276}$ GARCÍA MORENO, L.A. Historia de España Visigoda. Madrid: Catedra, 1989. p.162-163.

${ }^{277}$ VII Concílio de Toledo, I.
} 
Recesvinto, se manifestando na abertura das atas declarando sua sujeição ao clero ao declarar que seu reinado se guiaria conforme as regras da igreja estabelecidas nos concílios. A chave de leitura dessa mudança de postura diante dos concílios observada entre os reinados de Chindasvinto e Recesvinto não deve se focar numa maior ou menor piedade cristã dos reis, mas antes na situação de um rei enfraquecido que se submetia aos bispos num esforço de obter apoio. Isso não era desimportante, lembremos que Isidoro de Sevilha primeiro saudou Suintila e depois elaborou o discurso que ratificou sua deposição.

Observamos assim que é necessário problematizar a proposição de um ideal de realeza para o caso dos visigodos, e essa problemática se estende até o problema da sucessão régia entre os visigodos que, ao contrário dos francos, não restringiam o acesso ao trono a membros de um grupo familiar restrito. A questão é que mesmo que alguns reis tenham se esforçado para estabelecer uma dinastia - como Leovigildo que nomeou seus filhos Hermenegildo e Recaredo como partícipes do reino, ou Recaredo que tentou encaminhar a sucessão a seu filho Liuva II, ou Sisebuto que procurou apontar seu filho Recaredo II como sucessor ou Chindasvinto que nomeou seu filho Recesvinto como co-regente - não há evidências nas fontes visigodas que nos permitam dizer que um grupo familiar específico era privilegiado na obtenção da dignidade real. Pelo contrário, as deliberações das atas conciliares visigodas apontam que os reis deveriam ser eleitos por uma assembleia de bispos e nobres, como explicitado no IV Concílio de Toledo no já citado cânone LXXV:

[...] nullus apud nos praesumtione regnum arripiat; nullus excitet mutuas seditiones civium; nemo meditetur interitus regum, sed defuncto in pace principe primatus totius gentis cum sacerdotibus successorem regni concilio conmuni constituant, ut dum unitatis concordia a nobis retinetur, nullum patriae gentisque discidium per vim atque ambitum oriatur.

Já as atas do V concílio de Toledo celebrado durante o reinado de Chintila que 
sucedeu Sisenando - o mesmo que derrubou Suintila do reino - há uma especificação ainda mais clara para quem poderia ser eleito novo rei, a saber, apenas aqueles que pertenciam à gens Gothorum:

Inexpertis et novis morbis novam decet invenire medelam: Quapropter quoniam inconsiderate quorumdam mentes et se minime capientes, quos nec origo ornat nec virtus decorat, passim putant licenterque ad regiae potestatis pervenire fastigia, huius rei causa mostra omnium cum invocatione divina praeferetur sententia: Ut quisquis talia meditatus fuerit, quem nec electio omnium provehit nec Gothicae gentis nobilitas ad hunc honoris apicem trahit, sit a consortio catholicorum privatus et divino anathemate condemanatus. ${ }^{278}$

Mesmo que a questão da estabilidade da regra eletiva para a sucessão régia dos visigodos tenha sido criticada por autores como J. Orlandis ${ }^{279}$ e com mais vigor por García Moreno ${ }^{280}$ uma vez que comumente eram eleitos reis filhos de reis anteriores, e comumente membros de um mesmo grupo familiar como apontado por García Moreno, ao menos na normativa instituída por esses dois concílios observamos que eram reis em potencial todos os membros da "nobreza da gens gothorum" que poderiam ser escolhidos pelos nobres e bispos numa assembléia. Assim, a condição para ser um candidato na assembleia era pertencer à gens gothorum não a uma família em particular. Mas quem era essa gens gothorum? O tema é absolutamente complexo e será desenvolvido ao longo desse texto, entretanto, nesse tópico em particular podemos assinalar uma possibilidade de significado para gens gothorum partindo do exemplo exposto na Historia Wambae, talvez o melhor registro sobre a eleição de um rei por assembleia.

\footnotetext{
${ }^{278}$ V Concílio de Toledo, III. Ver tradução 14 no anexo 1.

${ }^{279}$ ORLANDIS, J. El poder real y la sucesion al trono en la monarquia visigoda. Roma-Madrid: Consejo superior de investigaciones cientificas, 1962.

${ }^{280}$ GARCÍA MORENO, L.A. Prosopography, nomenclature and Royal Succession in the Visigothic Kingdom os Toledo. Journal of Late Antiquity. v.1, n.1, p.142-156, 2008.
} 
Conforme o texto escrito por Juliano de Toledo por volta de 675, ou seja, aproximadamente dois anos depois da eleição de Wamba como rei em sucessão a Recesvinto, Wamba foi eleito pela comunidade de toda a gens e pátria como o único entre os godos digno de governar:

Adfuit enim diebus nostris clarissimus Wamba princeps, quem digne principari Dominus voluit, quem sacerdotalis unctio declaravit, quem totius gentis et patriae communio elegit, quem populorum amabilitas exquisivit, qui ante regni fastigium multorum revelationibus celeberrime praedicitur regnaturus. Qui clarissimus vir, dum decedentis Recesvindi principis morte exsequiale funus soveret et lamenta, subito unam omnes in concordia versi, uno quodammodo tam animo, quam oris affectu pariter provocati, illum se delectantes habere principem clamant; illum se nec alium in Gothis principari unitis vocibus intonant, et catercatim, ne postulantibus abnuerit, sub pedibus obvolvuntur. Historia Wambae, $2{ }^{281}$

À luz dos concílios IV e V de Toledo parece pertinente interpretarmos a sentença totius gentis et patriae communio como a assembleia de nobres e bispos - o que fica claro pela unção recebida por Wamba - e a gens gothorum como aqueles aptos ao governo. Assim, o significado de gens gothorum não parece ser étnico, mas político. A saber: aqueles entre os nobres que poderiam pleitear o trono. Se retomarmos o cânone III do V concílio de Toledo notamos ainda que alguns homens indignos se diziam membros da nobreza da gens gothorum para tentar disputar o trono, assim podemos sugerir que a identidade inserida no termo era política, era assim uma identidade política. Mas qual era o sentido dessa identidade?

O que veremos nas próximas páginas é que os reis visigodos, mais do que se pautarem num ideal abstrato de realeza, lançavam mão de um discurso que legitimava a autoridade deles baseados numa idéia de harmonia entre o rei, a pátria e a gens no qual eles, os reis, eram os responsáveis pela manutenção do bem da pátria e das gentes que nela habitavam. Essa relação entre rei, pátria e gentes consiste num

${ }^{281}$ Ver tradução 15 , anexo 1. 
discurso identitário, num reforço de uma identidade presente na unidade política formada por três elementos: o rei, a pátria e a gens.

Ora, como observamos no capítulo anterior, a existência de um discurso que dava conta da existência de uma gens Gothorum lideradas por chefes era algo que antecedeu o próprio estabelecimento dos godos na Hispânia, todavia esses discursos foram veiculados no início por autores que escreviam desde um ponto de vista romano e depois por Jordanes. Diante disso, é difícil dizermos até que ponto uma identidade goda foi apreendida por eles ou outorgada por esses autores a uma população que não se identificava como tal. Mais adiante, quando já estabelecido o reino visigodo, seus reis lançaram mão justamente do discurso em torno de uma identidade goda, entretanto, dessa vez esse discurso se articulava com outros elementos-chave para a construção de um ideal no qual a autoridade do rei garantia a unidade entre a patria e as gentes. É esse constructo narrativo que parecia ser o sustentáculo central da autoridade régia num cenário de intensas disputas ao invés de um ideal unicamente cristão, ou uma apropriação de um ideal romano ou menos a evocação de um ideal de monarquia germânico. Isso não quer dizer que esses três ideais não eram reivindicados para pautar algo maior: a identidade da gens e da patria em torno do rei.

Cabe ainda ressaltar algo importante, como veremos no próximo capítulo, o discurso identitário elaborado em torno do rei não era o único, aparentemente ele concorria com outros discursos, os quais não raro reivindicavam os mesmos ideais evocados pelos reis, por personagens que concorriam com a autoridade central do rei em Toledo.

Essa disputa narrativa em algumas de suas facetas discutiremos nos próximos capítulos. 


\section{Os reis francos - estratégias de uma dinastia}

Percorremos até aqui alguns pontos que julgamos importantes sobre a realeza visigoda. Mas o que podemos falar sobre a realeza franca? Para começar a primeira vista ela era distinta da realeza visigoda principalmente porque a sucessão dinástica era o padrão que não aparentava sofrer tantos questionamentos. A questão é que enquanto entre os visigodos a possibilidade de ascensão ao trono era aberta aos membros da gens gothorum entre os francos a priori é possível dizer que apenas os membros da família merovíngia eram aptos a tornarem-se reis, esse é um suposto ponto de diferença importante uma vez que o problema da sucessão real entre os visigodos era significativo. Outro ponto a se destacar é que no reino dos francos não encontramos um pensador com o peso de Isidoro de Sevilha que tenha elaborado algo que podemos chamar de teoria política de maneira sistematizada e com impacto observável nos outros documentos produzidos no reino. Isso entretanto não significa que nas fontes francas não encontramos discursos referentes à realeza, pelo contrário, não só o encontramos como pela maior abundância de fontes francas é possível observar uma mudança no peso dado as qualidades dos reis. É sobre esses discursos que refletiremos a partir de agora seguindo o mesmo critério adotado com os francos, a saber, confrontar esses discursos com o contexto político em que foram elaborados.

O professor Marcelo Cândido já fez um exaustivo trabalho sobre a realeza franca em seu livro “A Realeza Cristã na Alta Idade Média”. Nenhuma linha que possa ser escrita aqui poderá ser mais precisa do que o trabalho feito por ele. Queremos, todavia, enfatizar algo que não foi enfatizado por ele em seu estudo que versou sobre o exercício da autoridade pública, a saber, a fragilidade dos reis francos. Não se trata aqui de questionar a efetividade da autoridade deles e sim de apontarmos que ela era frágil e dependia de estratégias de legitimidade que se pautavam também 
nos discursos identitários. O que queremos enfatizar é:

1. Embora, como indicou Cândido, o exercício da autoridade daqueles reis não sustente a hipótese da privatização do poder uma vez que se articulava sobre um aparato teórico que enfatizava a utilidade pública isso não eliminou a oposição a eles. É a fragilidade deles diante de aristocracias cada vez mais poderosas em suas regiões que queremos enfatizar;

2. Essa discussão é importante para termos um norte de análise da atuação das estratégias identitárias que se desenrolarão nas partes seguintes.

\section{Alianças estratégicas e a autoridade dos reis francos}

Entre 481 e $486^{282}$ numa carta endereçada a Clóvis na qual louvava a conquista da Belgica Secunda o bispo de Reims, Remígio, registrou alguns conselhos ao vitorioso rei para que a ajuda de Deus não o abandonasse e para que ele fosse digno da autoridade real.

Consiliarios tibi adhibere debes, qui famam tuam possent ornare. Et beneficium tuum castum et honestum esse debet, et sacerdotibus tuis debebis deferre et ad eorum consilia semper recurre; quodsi tibi bene cum illis convenerit, provincia tua melius potest constare. Civos tuos erige, adflictos releva, viduas fove, orfanos nutre, si potius est, quam erudies, ut omnes te ament et timeant. Iustitia ex ore vestro procedat, nihil sit sperandum de pauperes vel peregrinis, ne magis dona aut aliquid accipere vellis; praetorium tuum omnibus pateatur, ut nullus exinde tristis abscedat. Paternas quascunque opes possides, captivos exinde liberabis et a iugo servitutis absolvas si quis in conspectu vestro venerit, peregrinum

\footnotetext{
${ }^{282}$ Conforme sumariza I. Wood, alguns pesquisadores adotam 481 como a data da composição da carta por este ter sido o provável ano da morte de Childerico, pai de Clóvis. Já os que defendem a data de 486 a tomam por ter sido a provável data da vitória de Clóvis contra o filho de Aegidio, Siagrio, e a tomada de Soissons. Wood salienta entretanto que é muito difícil adotar uma das datas como definitiva de modo que ele abre o arco temporal e adota o período entre 481 e 486 como a época da redação da epístola. Cf: WOOD, I. The Merovingian Kingdoms. 450-751.London \& NY: Longman, 1994. p.41. Já G. Halsall coloca em dúvida toda essa cronologia ao indicar que ela é baseada numa datação problemática da tumba de Childerico e também num excesso de confiança na cronologia de Gregório de Tours. Guy Halsall aponta que é muito difícil datar a carta de Remígio. Cf: HALSALL, G. Cemeteries and Society in Merovingian Gaul. Selected Studies in History and Archaeology. 19922009. Leiden \& Boston: Brill, 2010. p.169-187. Originalmente publicado em: MATHISEN, R.W. \& SHANZER, D. Society and Culture in Late Roman Gaul. Revisiting the Sources. Andershot, 2001. p.116-33.
} 
se esse non sentiat. Cum iuvenibus ioca, cum senibus tracta, si vis regnare iudicare. ${ }^{283}$

O primeiro conselho de Remígio para Clóvis era que o rei deveria se cercar de bons conselheiros que honrassem a reputação de Clóvis. Ora, logo a partir desse primeiro conselho já notamos uma questão de interesse: Clóvis não tomava decisões sozinho, ele estava cercado de conselheiros. Temos então que desde a época do celebrado Clóvis o rei se cercava de uma rede de apoio - o que, como objetivamos indicar, se torna mais evidente nas fontes do século VII - cuja a importância era percebida por Remígio a ponto de leva-lo a mencioná-la numa carta que trazia ainda outros recomendações a Clóvis. Além de ser honesto e casto, Remígio escreveu que Clóvis também deveria defender os sacerdotes e atentar para os ditames deles. É notável que essa recomendação não vem seguida de qualquer admoestação cristã: Remígio registrou que a boa relação com os sacerdotes garantiria a autoridade de Clóvis na província. Não há aqui menção a proteção de Deus que Clóvis poderia obter ao respeitar os sacerdotes, há aqui uma recomendação para ajudar o rei a afirmar sua autoridade. Mais do que qualquer outra coisa tais conselhos parecem apontar para a importância que o apoio dos sacerdotes poderia ter para a manutenção da autoridade dos reis, mesmo numa situação em que o rei ainda professava o paganismo. No mais, Remígio sugeriu que o rei fosse generoso com os pobres, viúvas e órfãos, que não pedisse nada aos pobres e peregrinos, que em seus tribunais todos pudessem ser ouvidos e que Clóvis usasse as posses herdadas de seu pai para ajudar os cativos.

Das palavras de Remígio dirigidas a Clóvis podemos então tirar algumas observações ao menos sobre a visão do bispo de Reims sobre um bom monarca. Ele deveria ter bons conselheiros, ser generoso com os necessitados, ter boas relações

\footnotetext{
${ }^{283}$ Epistolae Austrasicae, 2. Ver tradução 16 no anexo 1.
} 
com os bispos e manter tribunais onde todos teriam suas causas contempladas. A priori não há grandes novidades na elaboração de Remígio se confrontada com outras imagens acerca da realeza encontradas em outros autores cristãos, tais discursos também são encontrados em documentos da Hispânia Visigoda como indicamos anteriormente. Mas também, como indicamos anteriormente, é interessante pensar sobre quais motivos levaram nossos autores a escrever o que escreveram. Então cabe aqui nos questionarmos: qual era o interesse de Remígio em escrever o que escreveu para Clóvis? E mais, porque um bispo estaria tão preocupado com o governo de um pagão?

Talvez uma importante pista para a carta de Remígio de Reims venha de uma evidência um pouco anterior à carta. Trata-se da tumba de Chilperico, pai de Clóvis, descoberta em Tournai em 1653.

Em um instigante artigo publicado originalmente em 2001 Guy Halsall ${ }^{284}$ recolocou a problemática sobre a tumba de Childerico ao ater sua análise mais à situação de Clóvis, o responsável por enterrar o pai com todos aqueles símbolos, do que ao suposto simbologismo pagão e germânico expresso na tumba. Halsall argumenta que comumente tumbas com ricos artefatos apontam para uma situação política e social de tensão, ao adornar o corpo do pai com tantos símbolos Clóvis poderia estar dando uma resposta a essas tensões. ${ }^{285}$ A partir da mesma carta de Remígio aqui citada, Halsall sugere que talvez Childerico tenha governado a Belgica Secunda e os relatos do exílio dele na Turíngia possam ter significado que ele se retirou quando os embates contra o Magister militum per Gallias Egídio - apontado para o cargo por Majoriano em 457 - se tornaram desfavoráveis a Childerico. Os

\footnotetext{
${ }^{284}$ HALSALL, G. Cemeteries and Society in Merovingian Gaul. Selected Studies in History and Archaeology. 1992-2009. Leiden \& Boston: Brill, 2010. p.169-187. Originalmente publicado em: MATHISEN, R.W. \& SHANZER, D. Society and Culture in Late Roman Gaul. Revisiting the Sources. Andershot, 2001. p.116-33.

${ }^{285}$ Ibidem, p. 175.
} 
embates entre o grupo de Egídio e o grupo de Childerico se estenderam para além da morte do rei franco. Seu filho, Clóvis, se envolveu em disputas com Siágrio, filho de Egídio, e saiu vitorioso tomando a cidade de Soissons. Entretanto talvez Clóvis não fosse visto como legítimo aos olhos da nobreza da região, ao adornar a tumba do pai o filho objetivava fortalecer sua própria autoridade. Posto sob essa perspectiva podemos repensar a própria extensão da autoridade de Clóvis.

Normalmente retratado como um rei prestigioso e vitorioso, talvez Clóvis estivesse mais cercado de opositores do que imaginamos. Numa situação de contestação de sua autoridade ele contou com um certo apoio de Remígio, bispo de Reims, que sugeriu que ele deveria seguir um determinado modelo e cooptar o apoio de outros bispos para que pudesse se manter no reino. A última frase da carta de Remígio é sintomática para essa situação: Cum iuvenibus ioca, cum senibus tracta, si vis regnare iudicare. A legitimidade da autoridade de Clóvis não era um dado já colocado, ele precisava conquistá-la. Assim podemos ler a carta de Remígio de uma maneira um pouco diferente: ela não foi apenas uma celebração da vitória de Clóvis, mas antes um aviso para um rei que conquistava mais e mais regiões e, mesmo que fosse pagão, carecia do suporte dos bispos pois enfrentava oposição. Independente da fé professada por Clóvis, ele deveria abrir concessões e se dobrar a um discurso agradável aos bispos cristãos se quisesse ter sua autoridade reconhecida. Remígio então indicou a Clóvis qual procedimento ele deveria adotar para ter esse apoio. Os indicativos do bom governo dessa maneira não tinha puramente um teor religioso como já apontamos - tampouco apenas celebrativo, era antes a evocação de um discurso com um claro objetivo político, ou seja, advertir um rei que gradativamente se fortalecia de que havia outras forças políticas que ele deveria respeitar. 
Em 511 Clóvis morreu em Paris, algo que inaugurou uma nova situação política. Após sua morte seus quatro filhos, Teodorico, Clodomiro, Childeberto e Clotário dividiram seu reino entre eles. Essa primeira divisão do reino inaugurou uma prática singular na sucessão real na Gália, a saber, após a morte dos reis o reino deveria ser dividido entre seus herdeiros. Evidentemente esse processo de sucessão difere daquele praticado entre os visigodos. $\mathrm{O}$ fato é que a historiografia interpretou o modelo merovíngio de sucessão como o sintoma do processo de privatização do poder na qual o rei via o reino como uma propriedade privada que poderia ser dividida tal como uma herança, processo esse advindo de uma tradição germânica. ${ }^{286}$ A forma da divisão era então tida como algo imanente à própria concepção germânica da realeza. Entretanto, a situação parece ter sido mais complexa e analisá-la pode nos ajudar a compreender alguns aspectos sobre os discursos acerca da realeza encontrados nas fontes do período.

O primeira ponto a ser destacado é que as tensões entre os herdeiros de Clóvis indicam que a divisão do reino entre os filhos do rei não era algo aceito consensualmente. Em 524 morreu Clodomiro, ele deixou três filhos: Teodobaldo, Gontiero e Clodovaldo. Seu irmão Clotário tomou sua viúva como esposa e os filhos de Clodomiro foram deixados sob a proteção da rainha Clotilde. Se a idéia da divisão do reino entre os herdeiros do rei fosse aceita sem problemas poderíamos esperar que os filhos de Clodomiro dividiriam o reino entre eles sem qualquer oposição. Isso não

\footnotetext{
${ }^{286}$ Por exemplo Fustel de Coulanges : Toujours la royauté se transmet comme tout autre héritage et suivant les règles du droit privé. Qu'un roi meure, les choses se passent comme s'il s'agissait d'un particulier. La succession est là, trésors et royaume, comme s'il s'agissait d'un domaine. Elle est dévolue, sans nulles discussions, au fils, quand même le fils serait un enfant en bas âge. (FUSTEL DE COULANGES, N.D. Histoire des Institutions Politiques de l'ancienne France. La Monarchie Franche. Paris: Librairie Hachette, 1905. p.42) Também: C. Bémont and G. Monod: "Les rois considèrent le territoire et les ressources de l'État comme une propriété privée que leurs héritiers se partagent après leur mort. Leur autorité est „une force en présence d'autres forces, non une magistrature au milieu de la sociétée"; subordonnée à la fortune d'un seul, elle se montre ,variable et déréglée, aujourd hui immense, demain nulle, forte ou faible, selon que la guerre tournait contre elle ou en da faveur" (Guizot)" . BÉMONT, Charles. et MONOD, Gabriel. Histoire de I'Europe au Moyen Age (385-1270). Paris: Libraire Félix Alcan, 1924. p.73.)
} 
aconteceu. Os reis Childeberto e Clotário enganaram a rainha Clotilde dizendo que eles elevariam os jovens príncipes ao trono. Clotilde acreditou e enviou os jovens ao encontro de seus tios. Então Clotário e Childeberto enviaram Arcádio para encontrarse com a rainha. Diante de Clotilde, Arcádio mostrou à rainha uma espada e uma tesoura e fez a rainha escolher entre tonsurar seus netos ou permitir que eles fossem mortos. Clotilda respondeu: "Satius mihi enim est, si ad regnum non ereguntur, mortuos eos videre quam tonsus". ${ }^{287}$ Os jovens príncipes foram mortos, apenas Clodovaldo sobreviveu porque foi tonsurado. O reino de Clodomiro foi então dividido entre os restantes herdeiros de Clóvis. Esse não foi o fim das disputas.

Teodorico morreu e seus irmão Childeberto e Clotário tentaram tomar seu reino de seu herdeiro, Teodoberto, que graças ao apoio dos leudes pôde assumir o trono de seu falecido pai. Em 548 Teodoberto morreu e foi sucedido por seu filho Teodobaldo, que morreu em 555. Após sua morte, Clotário tomou seu reino após esposar-se com sua viúva. Em 558 Childeberto morreu e Clotário também tomou seu reino, mas dessa vez ele exilou a esposa de Childeberto. Com essa última conquista Clotário tornou-se o único rei Franco da Gália. Como se nota Clotário obteve essa vitória pelo assassinado dos herdeiros de seus irmãos e pelo matrimônio com as viúvas. A primeira tentativa frustrada de Clotário de tomar o reino de Teodorico ocorreu pelo não reconhecimento dos direitos de Teodoberto, que precisou do apoio dos leudes para assumir. A partir desses complicados eventos podemos apontar alguns pontos interessantes sobre a sucessão real na Gália Merovíngia:

1. Ser filho do rei não era uma garantia para herdar o trono. O "direito de sucessão" poderia se transgredido, como os exemplos dos filhos de Clodomiro e Teodoberto

${ }^{287}$ Gregório de Tours Decem Libri Historiarum (DECEM LIBRI HISTORIARUM), III, 18. 
indicam;

2. O apoio dos aristocratas era crucial para garantir a sucessão real, sem esse apoio Teodoberto talvez não conseguisse suceder seu pai;

3. Entretanto, as usurpações conduzidas por Clotário talvez carecessem de legitimidade já que ele contraiu matrimônio com as rainhas de seus falecidos irmãos, com a única exceção do viúva de Childeberto.

\section{A divisão de 561}

A primazia de Clotário como o único rei franco não acabou com os conflitos em torno da sucessão real. Quando ele morreu em 561 ele deixou quatro filhos e seu reino foi dividido entre eles, conforme registrou Gregório de Tours, autor dos Decem Libri Historiarum, a principal fonte que temos para esse período:

Deditque sors Charibertho regnum Childeberthi sedemque habere Parisius, Gunthramno vero regnum Chlodomeris ac tenere sedem Aurilianensem, Chilperico vero regnum Chlothari, patris eius, cathedramque Sessionas habere, Sygibertho quoque regnum Theuderici sedemque habere Resemsim. ${ }^{288}$

Nesse ponto Gregório de Tours nos ofereceu mais detalhes sobre os eventos que sucederam a segunda grande divisão do reino e o bispo deu especial atenção aos feitos de Chilperico. No mesmo ano da divisão, Sigeberto marchou contra os hunos e Chilperico invadiu a capital de Sigeberto, Rheims e outras cidades que pertenciam ao irmão. A bellum civile começou entre os dois reis. Esse evento tem uma grande importância para a orientação da narrativa de Gregório de Tours a partir do V livro de seus Decem Libri Historiarum, algo que está explicitado no prefácio ao livro $\mathrm{V}^{289}$ :

\footnotetext{
${ }^{288}$ DECEM LIBRI HISTORIARUM, IV, XXII.

${ }^{289}$ Uma interessante análise sobre esse prefácio pode ser encontrada em: HALSALL, G. The Preface to Book V of Gregory of Tourse Histories: Its Form, Context and Significance. English Historical Review. v. CXXII, n.496. p.297-317, 2007.
} 
Taedit me bellorum civilium diversitatis, que Francorum gentem et regnum valde proterunt, memorare; in quo, quod peius est, tempore illud quod Dominus de dolorum praedixit initium iam videmus: Consurgit pater in filium, filius in patrem, frater in fratrem, proximus in propinquum. Debebant enim eos exempla anteriorum regum terrere, qui, ut divisi, statim ab inimicis sunt interempti. Quotiens et ipsa urbs urbium et totius mundi capud ingens bella civilia diruit; quae cessante, rursum quasi ab humo surrexit. Utinam et vos, o regis, in his proelia, in quibus parentes vestri desudaverunt, exercimini, ut gentes, vestra pace conterritae, vestris viribus praemirentur! Recordamini, quid capud victuriarum vestrarum Chlodovechus fecerit, qui adversos reges interficet, noxias gentes elisit, patrias subiugavit, quarum regnum vobis integrum inlesumque reliquit! Et cum hoc facerit, neque aurum neque argentum, sicut nunc est in thesauris vestris, habebat. Quid agetis? Quid quaeritis? Quid non habundatis? In domibus dilitiae supercrescunt, in prumtuariis vinum, triticum oleumque redundat, in thesauris aurum atque argentum coacervatur. Unum vobis deest, quod, pacem non habentes, Dei gratiam indegetis. Cur unus tollit alteri suum? Cur alter concupiscit alienum? Cavete illo, quaeso, apostoli: Si ab invicem mordetis et comeditis, vidite, ne ab invicem consummamini. Scrutamini diligenter veterum scripta, et videbitis, quid civilia bella parturiant. Requirite, quod de Carthaginensibus scribat Orhosius, qui, cum post septingentos annos subversam dicat civitatem et regionem eorum, addidit: Quae res eam tamdiu servavit? Concordia. Quae res eam post tanta distruxit tempora? Discordias. Cavete discordiam, cavete bella civilia, quae vos populumque vestrum expugnant. Quid aliud sperandum erit, nisi cum exercitus vester caeciderit, vos sine solatio relicti atque a gentibus adversis oppressi protinus conruatis? Si tibi, o rex, bellum civili delectat, illut quod apostolus in hominem agi meminit exerce, ut spiritus concupiscat adversus carnem et vitia virtutibus caedant; et tu liber capite tuo, id est Christo, servias, qui quondam radicem malorum servieras conpeditus. ${ }^{290}$

Nesse prefácio Gregório explicita toda a sua preocupação com as guerras entre os reis francos e na descrição de Gregório de Tours Chilperico foi retratado como o grande provocador de todas as tensões ao constantemente ameaçar o reino de seus irmãos e fomentar a guerra civil que era extremamente danosa para os francos e o reino dos francos.

A descrição de Gregório de Tours sobre Chilperico ajudou a criar a lenda negra acerca do rei "O Nero e o Herodes daqueles tempos" ${ }^{291}$, brutal e fraco que

\footnotetext{
${ }^{290}$ DECEM LIBRI HISTORIARUM, Prefácio ao livro V. Ver tradução 17 no anexo 1.

${ }^{291}$ DECEM LIBRI HISTORIARUM, IV, 46.
} 
espoliou as igrejas e os pobres. Essa lenda negra foi sustentada por pesquisadores como J.C.L. Sismondi que escreveu que Chilperico era um rei sedento por sangue que com sua esposa Fredegunda cometeu crimes horrendos, sobretaxou as pessoas e trouxe caos ao reino com guerras que ele empreendeu contra seus irmãos. ${ }^{292}$ Por outro lado J. Michelet tentou entender porque Gregório construiu uma imagem tão negativa de Chilperico. Seus comentários são interessantes. De acordo com Michelet, Gregório retratou Chilperico como um rei mau porque Chilperico tentou recriar um Império na Gália que resultou nas guerras e no aumento das taxas. ${ }^{293}$

É muito difícil dizer com certeza que Chilperico tentou recriar um Império na Gália, mas os apontamentos de Michelet são notáveis porque nos ajudam a pensar no problema da divisão do reino e rediscutir se os Merovíngios viram o reino como um patrimônio privado. Se Chilperico quis recriar o Império, ele tinha uma visão particular sobre o reino diversa da perspectiva patrimonialista. Por outro lado, se ele não objetivou recriar o Império ao menos ele não concordou com a divisão do reino, assim como possivelmente Clotário não concordou. Essa é a hipótese de $\mathrm{M}$. Widdowson. ${ }^{294}$

Conforme o pesquisador as divisões do reino não eram algo já dado. Widdowson sublinhou que a primeira divisão entre os filhos de Clóvis foi uma alternativa encontrada para lidar com o problema da sucessão real. Se retomarmos os problemas levantados no início a partir da epístola de Remígio a Clóvis fica ainda mais claro que ele não estava numa situação confortável e que enfrentava ameaças para o seu governo e a manutenção de sua família no poder. Se de fato a solução da

\footnotetext{
${ }^{292}$ SISMONDI, J.C.L. History of the Fall of the Roman Empire. Filadélfia: Carey, Lea \& Blanchard, 1835. p. 220.

${ }^{293}$ MICHELET, J. Histoire de France au Moyen Age. La Gaule - Les invasions. Charlemagne. Paris: Calmann-Lévy, 1893. p. 194.

${ }^{294}$ WIDDOWSON, Marc. Merovingian partitions: a 'genealogical charter'? Early Medieval Europe. v.17, n.1, p.1-22, 2009.
} 
divisão pode ter ajudado a manter os descendentes de Clóvis no poder, acabou por gerar um outro problema, a saber, a coexistência de ao menos duas perspectivas para a sucessão real. A primeira foi o acordo de que o reino deveria ser dividido entre os filhos do rei, a segunda é que apenas um filho poderia herdar o trono. Como o filho mais velho, Chilperico objetivou ser o único herdeiro e não aceitou a divisão, por outro lado Sigiberto defendeu o sistema adotado depois da morte de Clóvis.

Os argumentos de Widdowson são interessantes principalmente porque nos oferecem uma motivação para os atos de Chilperico e nos ajudam a ter uma perspectiva diferente sobre a imagem negativa feita por Gregório de Tours ao rei da Nêustria. Como muito bem apontou Widdowson, Gregório de Tours devia o seu episcopado a Sigiberto e por essa razão foi um aliado do rei da Austrásia, é então compreensível porque Gregório de Tours defendeu a perspectiva de Sigiberto sobre como deveria ser a sucessão real. Mais importante, Widdowson sustenta que toda a descrição de Gregório de Tours sobre a divisão do reino deve ser interpretada levando em conta a defesa do bispo da divisão entre os filhos do rei.

Essa hipótese se reforça se retomarmos um outro evento descrito por Gregório de Tours. Ao relatar os problemas com os bispos Salônio de Embrun e Sagitário de Gap Gregório de Tours acusou os bispos de uma série de crimes. Para lidar com ambos o rei Gontrão convocou um sínodo em Lyon que decidiu pela culpa dos bispos, que tiveram por pena a perda do bispado. Entretanto eles recorreram ao papa João III (561-574) e foram readmitidos ao episcopado. Mesmo assim, conforme Gregório de Tours, continuaram a cometer crimes de modo que Gontrão os convocou para prestar esclarecimentos. Diante do rei, Sagitário o desafiou ao colocar em dúvida a legitimidade dos filhos de Gontrão de sucederem o pai uma vez que a mãe deles não era da família Merovíngia, o próprio Gregório respondeu à acusação de Sagitário em 
seu relato:

Sed Sagittarius felle commotus, hanc rationem dure suscipiens, ut erat levis ac vanus et in sermonibus inrationabilibus profluus, declamare plurima de rege coepit ac dicere, quod filli eius regnum capere non possint, eo quod mater eorum ex familia Magnacharii quondam adscita regis torum adisset, ignorans, quod, praetermissis nunc generibus feminarum, regis vocitantur liberi, qui de regibus fuerant procreati. ${ }^{295}$

Assim, nessa narrativa, o bispo de Tours mais uma vez defende a tese de que todos os filhos do rei eram dignos de serem chamados "reis", o fez respondendo a outra proposição apresentada por Sagitário, a de que também as mães deveriam advir de uma família digna ao trono. Gregório de Tours se mostrava então partidário de uma linha interpretativa acerca da sucessão real, aquela defendida por Sigiberto: todos os filhos do rei mereciam a alcunha de "reis".

A defesa de Gregório de Tours vem sempre acompanhada pela detração dos partidários de outras possibilidades. Chilperico era o modelo do mau rei, Sagitário um típico mau bispo, modelos estes em contraste com o dos bons reis e bons bispos. Se Chilperico foi o Nero de Gregório de Tours, por razões muito concretas como tentamos indicar, Gontrão foi o seu Teodósio, aquele escolhido por Graciano para colocar ordem no Império e com confiança e misericórdia em Deus conseguiu manter em obediência muitas gentes e que, após depositar toda a sua esperança em Deus, tomou em suas mãos o Império. ${ }^{296}$ Já o Gontrão de Gregório de Tours se diferia dos outros reis por sua fé. Era de tal modo piedoso que Gregório de Tours chega a compará-lo com os bispos, como quando uma epidemia de uma estranha doença assolou a cidade de Marselha e por três dias o rei ordenou que os epíscopos jejuassem e orassem para ajudar os citadinos:

\footnotetext{
${ }^{295}$ DECEM LIBRI HISTORIARUM, V, 20. Ver tradução 18, anexo 1.

${ }^{296}$ DECEM LIBRI HISTORIARUM, 1.II, 42 e 43.
} 
Per triduum enim ipsius elimosinis largius solito praecurrentibus, ita cuncto populo formidabat, ut iam tunc non rex tantum, sed etiam sacerdus Domini putaretur, totam spem suam in Domini miseratione transfundens et in ipso iactans cogitationes, quae ei superveniebant, a quo das effectui tradi tota fidei integritate putabat. $^{297}$

Lemos assim que a preocupação de Gontrão pelo seu povo era tão grande que ele poderia ser comumente tomado mais por um bispo do que por um rei. Nesse ponto encontramos um tema importante que percorre a obra de Gregório de Tours e nos ajuda a compreender a construção da realeza feita pelo bispo. O fato é que para Gregório de Tours, embora os reis tivessem seu papel no curso da história, eles também poderiam ser os protagonistas de atos de enorme crueldade. Isso fica evidente no já citado prefácio ao livro $\mathrm{V}$ quando o bispo se dirigiu diretamente aos reis:

Utinam et vos, o regis, in his proelia, in quibus parentes vestri desudaverunt, exercimini, ut gentes, vestra pace conterritae, vestris viribus praemirentur! Recordamini, quid capud victuriarum vestrarum Chlodovechus fecerit, qui adversos reges interficet, noxias gentes elisit, patrias subiugavit, quarum regnum vobis integrum inlesumque reliquit! Et cum hoc facerit, neque aurum neque argentum, sicut nunc est in thesauris vestris, habebat. Quid agetis? Quid quaeritis? Quid non habundatis? In domibus dilitiae supercrescunt, in prumtuariis vinum, triticum oleumque redundat, in thesauris aurum atque argentum coacervatur. Unum vobis deest, quod, pacem non habentes, Dei gratiam indegetis.

Há aqui uma construção bastante negativa dos reis francos, e Gregório de Tours, embora concentre suas críticas a Chilperico, no prefácio ao livro V não poupou nenhum rei franco. No elogio à piedade de Gontrão destacado na citação anterior, Gontrão foi louvado principalmente por ter atuado menos como um rei e mais como um epíscopo. Isso não quer dizer que Gregório de Tours fez uma imagem negativa da realeza como um todo, mas sim que ele não idealizou essa realeza. Ele a descreveu em sua complexidade, tensões e contradições, e tomou um partido nos projetos de

\footnotetext{
${ }^{297}$ DECEM LIBRI HISTORIARUM, IX, 22.
} 
poder em disputa. O fez nas querelas entre os netos de Clóvis, o fez quando Gontrão teve a legitimidade de seus filhos contestada por Sagitário.

Uma vez que a descrição de Gregório de Tours não se atrelava a um ideal de realeza, podemos até rediscutir seu apoio a Gontrão à luz do que foi discutido até aqui. Gontrão ajudou Childeberto, filho de Sigeberto, quando este se viu ameaçado por Chilperico. É então possível conjecturar que o apoio de Gregório de Tours a Gontrão foi mais uma vez um apoio à forma de sucessão que contemplava todos os herdeiros homens do rei, talvez porque Gregório de Tours acreditou que assim as tensões entre os filhos dos reis que geravam a guerra civil poderiam arrefecer.

Mas as considerações de Gregório de Tours sobre a realeza não podem ser generalizadas para todo o período franco. O bispo de Tours parecia estar ocupado com uma questão pontual concernente à sucessão régia. Já a Crônica dita "de Fredegário", escrita em meados do século VII, apresenta outras matizes sobre a realeza. ${ }^{298}$ Logo na descrição do cronista sobre Gontrão notamos algo que em Gregório de Tours é menos explícito, a saber, uma das qualidades elencadas no reinado do rei da Burgúndia era sua capacidade de lidar com as aristocracias:

Gunthramanus rex Francorum cum iam anno 23. Burgundiae regnum bonitate plenus feliciter regenat, cum sacerdotibus utique sacerdus ad instar se ostendebat et cum leudis erat aptissimus, aelymosinam pauperibus large tribuens, tante prosperetatis regnum tenuit, ut omnes etiam vicinas gentes ad plinitudinem de ipso laudis canerent. $^{299}$

Por que a capacidade de Gontrão de administrar os leudes foi tão destacada por Fredegário? Uma análise mais detida da crônica pode nos oferecer algumas pistas.

\section{Clotário II e as oposições regionais - a gens francorum num contexto de disputas}

\footnotetext{
${ }^{298}$ A discussão detalhada sobre essa fonte, assim como aos Decem Libri Historiarum está disponível no capítulo dedicado às histórias.

${ }^{299}$ Crônica de Fredegário (Fred.), 1. IV, c.1. Ver tradução 19, anexo 1.
} 
Em 613 Clotário II (584-629), filho de Chilperico nascido depois da morte do pai em 584, tornou-se o único rex francorum depois das mortes de Teodoberto II e Teodorico II graças ao suporte dos Grandes da Austrásia e da Burgúndia que não apoiaram Brunilda em sua tentativa de elevar ao trono seu bisneto Sigiberto II. $^{300}$ I. Wood destaca que Clotário II teve uma significativa autoridade sobre todo o reino, entretanto a leitura da Crônica de Fredegário, assim como o Concílio de Paris de 614 e o Edito de Paris do mesmo ano, indicam que o rei operou uma série de negociações para manter-se. Isso não significa que Clotário II foi mais fraco do que os seus antecessores, trata-se mais de um rei que tal como os anteriores precisou costurar alianças para se afirmar.

Ora, o primeiro ato ${ }^{301}$ de Clotário II descrito por Fredegário após a celebração da unificação do reino sob o jovem Clotário foi a nomeação do duque (dux) Herpo em Jura em substituição a Eudila. Herpo era de origem franca, conforme relata a crônica (... Herpone duci genere Franco locum Eudilanae in Pago Vltraiorano instituit). Pouco depois os habitantes de Jura, instigados por Aletio, o bispo de Leudemond (Sion) e o conde Herpino, se rebelaram contra Herpo e o mataram. Clotário II puniu os criminosos.

Apenas nessa passagem podemos pensar em diversas questões. Primeiro, a rebelião dos grandes de Jura que não reconheceram a decisão de Clotário II, o que mostra que a autoridade do rei não era sempre aceita. Segundo, a influência dos rebeldes, que conseguiram instigar os habitantes locais a assassinarem Herpo. Terceiro, a participação de um bispo no levante contra Herpo. E quarto, e mais importante para nosso objetivo aqui, a menção ao fato de que Herpo era de origem franca. Ora, porque o autor da crônica achou importante dizer que Herpo era franco?

\footnotetext{
${ }^{300}$ WOOD, I. The Merovingian Kingdoms. 450-751. London \& NY: Longman, 1994. p.141.

${ }^{301}$ Fred. IV, 43
} 
Ele quis dizer que Herpo era da etnia franca? Ou será que essa informação poderia ajudar a compreender a rebelião que redundou na morte de Herpo? Nenhuma informação pode ser negligenciada no trato com nossas fontes, se o autor da crônica disse que Herpo era franco algum motivo ele teve para fazer isso, qual era o motivo?

Para desenvolvermos nosso argumento precisamos tentar compreender como os francos aparecem na Crônica. Nos primeiros livros, normalmente negligenciados por serem considerados desimportantes por supostamente consistirem numa reprodução de várias fontes - como a versão latina do texto de Eusébio feita por Jerônimo, os Decem Libri Historiarum de Gregório de Tours, a Crônica de Idácio de Chaves e o Liber generationes de Hipólito $(217-35)^{302}$ - os francos recebem um destaque até então inédito nos textos históricos. Se Gregório de Tours não conseguiu definir bem a origem dos francos, na crônica de Fredegário essa origem não só aparece sem qualquer contestação como tem um tom triunfalista. A origem dos francos é relacionado com Tróia e o primeiro rei dos francos é identificado como Príamo, depois Friga. ${ }^{303}$ Em seguida os francos se dividiram em duas partes, uma delas seguiu para a Macedônia onde auxiliaram os Macedônios contra os povos vizinhos, a crônica enfatiza mais ainda o valor dos francos ao insinuar que a força deles foi confirmada pelas vitórias de Alexandre o Grande. A outra parte dos francos continuou sua migração tendo eleito rei Francio, do qual se originou o nome "Francos”, atravessou a Ásia lutando e derrotando muitas gentes até chegar à Europa. Temos o retrato de uma gens forte que se destacava pela força bélica, que não se deixava dominar e derrotou seus inimigos.

A comparação entre a narrativa da crônica e os Decem Libri Historiarum de

\footnotetext{
${ }^{302}$ COLLIS, R. Fredegar. In: GEARY, P. (ed.). Authors of the Middle Ages. Historical and Religious Writers of the Latin West. V. IV, ns. 12-13. Variorum, 1996. p.85. Ainda sobre as fontes de Fredegário: Fredegar problem Reconsidered. Speculum, v.38, n.2, p.206-241, 1963.

${ }^{303}$ Fred. L. II, 4-5 e L. III, 2.
} 
Gregório de Tours nos quais a origem dos francos é indefinida poderia nos levar a inferir que a crônica testemunha a emergência de uma identidade franca que se fundamentava na valorização do passado. Herpo, o duque preterido pelos Burgúndios, seria membro dessa gens valorosa, mas será que isso resume o significa de "francos" na crônica? Será que era realmente isso que seu autor quis dizer quando escreveu que Herpo era um franco? E qual é o sentido dessa informação no desenrolar dos acontecimentos que redundou na morte de Herpo? Precisamos continuar na crônica para tentarmos responder a essas perguntas.

Ora, os três primeiros livros da crônica de Fredegário não podem ser ignorados, mas eles não resumem todo o significado que "francos" possui na crônica. A partir do IV livro temos uma mudança na narrativa que se torna centrada na Gália e também, como tentaremos indicar, uma transformação nos sentidos de "francos" no texto.

Usamos "sentidos", não "sentido" por uma razão. Se há alguma relação entre os primeiros livros de Fredegário no que concerne aos francos enquanto uma unidade e um dos significados desse termo no livro IV ela aparece quando o autor trata das relações do reino dos francos com outras gentes. Um exemplo ocorre quando o autor explica os motivos que levaram os lombardos a pagarem doze mil soles como tributo aos francos:

Langobardorum gens quemadmodum tribute duodece milia soledorum dicione Francorum annis singulis dissoluebant referam, uel quo ordine duas ciuitates Agusta et Siusio cum territuriis ad parte Francorum cassauerant non abscondam. ${ }^{304}$

Emprego de significado semelhante ocorre em outras passagens, como por exemplo, nas batalhas que opuseram os francos e os Bretões em Armórica ( $E$ as difíceis relações entre francos e Bretões na região não era novidade, no II Concílio

\footnotetext{
${ }^{304}$ Chronica de Fredegário, L. IV,45. Ver tradução 20, anexo 1.
} 
de Tours de 567 há uma proibição à elevação ao bispado de um Bretão ou romano sem a explícita autorização do metropolitano de Tours, interessante destacar que esse é o único concílio onde há uma referência explícita a uma gens). ${ }^{305}$ Nesse caso os francos aparecem como uma unidade, mas a semelhança com os relatos dos primeiros livros termina aqui, trata-se de uma unidade política no trato com gentes estrangeira. Uma unidade política que não tem relação com uma unidade étnica, os francos, nesse caso, são o reino dos francos, o regnum francorum, uma unidade idealizada, ou identidade política, que se sobressai nas lidas com os outros, os Bretões, os Lombardos, o Império. Esse reino, entretanto, internamente estava longe de ser uma unidade, regiões, grupos, enfim, outras identidades aparecem em disputa na crônica de Fredegário e é nesse caldeirão identitário que talvez possamos buscar alguma resposta para o caso de Herpo.

Nessa diversidade os francos aparecem, mas aparentemente não enquanto uma unidade étnica. Não estamos fazendo aqui uma constatação nova, I. Wood, por exemplo, indica que a referência ao fato de Herpo ter sido um franco era uma indicação de que ele não fazia parte da aristocracia Burgúndia, o que poderia explicar a oposição dos grandes burgúndios a sua indicação. À luz de outra fonte a hipótese faz sentido. Na Vita Bathilda, texto cuja primeira versão foi escrita por volta de 680 , há uma distinção entre francos, burgúndios e austrasianos, que parece apontar para uma identificação dos francos com habitantes da Nêustria :

Quid plura? Deo iubente, rex Chlodoveus, vir eius, migravit de corpore; relictaque sobole filiorum cum matre, suscepit ilico post eum filius eius Chlotharius quondam Francorum regnum, tunc eteniam precellentibus principibus Chrodoberhto episcopo Parisiaco et domno Audoeno seu et Ebroini maiore domuscum reliquis senioribus vel ceteris quam pluribus, et regno quidem Francorum in pace consistenti. Tunc etenum nuper et Austrasii pacifico ordine, ordinante domna Balthilde, per consilium quidem seniorum receperunt Childericum, filium eius, in regem Austri; Burgundiones

${ }^{305}$ Cronica de Fredegário., L. IV, 11 
vero et Franci facti sunt uniti. Et credimus, Deo gubernante, iuxta somnae Balthildis magnam fidem ipsa tria regna tunc inter se tenebant pacis concordiam. ${ }^{306}$

Será que tal como na vida de Bathilda na Crônica de Fredegário "francos" significa homens oriundos da Nêustria? A oposição aristocrática na Burgúndia à elevação de Herpo seria então uma resposta de uma aristocracia com um forte senso identitário que se recusou a aceitar a autoridade de um homem advindo da Nêustria? Nesse caso, porque Clotário II nomearia um homem para uma região que poderia se rebelar contra o novo representante do rei?

Ora, talvez essas dúvidas sejam fruto de uma interpretação equivocada, porque se "francos" na vida Bathilda pode ser interpretado como "nêustrios" - e isso se dá sobretudo por eliminação ao percebermos que há uma distinção entre "austrasianos", "burgúndios" e "francos", restando aos francos a relação com a Nêustria -, também pode ser entendido como homens que faziam parte do séquito em torno dos reis e rainhas merovíngios. E o mesmo parece valer para o caso da crônica de Fredegário, onde o segundo significado aparentemente é mais forte.

Bathilda foi a construtora do mosteiro de Chelles, ao qual, segundo sua vida, desejava ir por sua vocação. ${ }^{307}$ Contudo, ainda seguindo a versão da vida, os francos por amor à rainha não aceitariam que ela se retirasse para a vida religiosa. Foi necessária uma querela política envolvendo o bispo de Paris Sigobrando, cuja ruína adveio da repulsa que despertava dos francos. Contra a vontade da rainha o bispo foi morto, para protege-la das tensões que surgiram após a morte de Sigobrando os francos permitiram que a rainha se retirasse para Chelles. O trecho da vida é interessante por revelar um outro nível de significado para "francos" :

\footnotetext{
${ }^{306}$ Vita Domnae Balthildis 1, 5. Ver tradução 21 no anexo 1.

${ }^{307}$ Vita Domnae Balthildis 1, 10.
} 
Et exinde orta intentione, dum ipsum contra eius voluntatem interfecerunt, metuentes, ne hoc ipsa domna contra eos graviter ferret ac vindicare ipsam causam vellet, permiserunt eam subito pergere ad ipsum monasterium. Et fortasse dubium non est, quod ipsi principes tunc illus non bono animo permisissent [...]. ${ }^{308}$

Nessa passagem, "francos” estão qualificados como "príncipes", não há qualquer ponto aqui que nos permita dizer que a referencia é exclusiva aos nêustrios, parece que se tratam de homens que estavam envolvidos na política e muito próximos da corte merovíngia. Um significado semelhante aparece na Crônica de Fredegário. Em 625 uma disputa surgiu entre Clotário e seu filho Dagoberto, elevado pelo rei a rei da Austrásia em 622. Clotário tentou retomar o controle sobre tudo o que pertencia à Austrásia e Dagoberto não aceitou. Para arbitrar a disputa entre eles: “Doze Francos foram escolhidos por eles para colocar fim à disputa" (Elictis ab his duobos regibus duodicem Franci ut eorum disceptatione haec finirit intentio [...]). ${ }^{309} \mathrm{~A}$ interpretação possível a essa passagem é que esses doze francos escolhidos pelos reis para arbitrar a disputa eram homens próximos aos reis e de que desfrutavam da confiança deles a ponto de serem escolhidos e lograrem êxito na resolução da disputa envolvendo a Austrásia.

Podemos retornar a Herpo. À luz dessas reflexões uma outra hipótese surge para a oposição dos grandes da burgúndia à escolha dele. Talvez isso não tivesse relação com a recusa de aceitar um homem advindo da Nêustria como autoridade na Burgúndia, e sim uma oposição a um homem próximo ao rei. É possível que o que estivesse em questão era uma oposição à própria autoridade de Clotário II, não por acaso o rei puniu os rebeldes com rigor tirando suas vidas.

Pouco tempo depois, possivelmente para apaziguar os ânimos na Burgúndia, o rei enviou Vanacário, o mestre de seu palácio, para negociar com os bispos da

\footnotetext{
${ }^{308}$ Vita Domnae Balthildis, 10. Ver tradução 22 no anexo 1.

${ }^{309}$ Fred. IV, 53
} 
Burgúndia - lembremos que um bispo teve participação na rebelião que derrubou Herpo - e os Burgundaefaronis, qualificativo que parece se referir aos grande da Burgúndia. As negociações, conforme o relato do cronista, parecem ter sido orientadas de modo a aceitar as reivindicações dos grandes da Burgúndia. Clotário II parece nesse caso ter cedido às pressões, muito provavelmente para diminuir as oposições a sua própria autoridade que emergiam na região.

Ora, o que devemos nos perguntar nesse ponto é se essas tensões surgiam por conta de uma oposição a uma autoridade central - no caso Clotário II - num ambiente de fortalecimento de identidades regionais. É possível, principalmente se considerarmos que ao longo da crônica observamos cada vez mais atores políticos identificados com regiões: a Nêustria, a Austrásia e a Burgúndia. Mas é também possível que essas identidades regionais existissem num plano mais discursivo do que concreto e que não iam além de um pequeno grupo de grandes que disputavam o poder. Essas identidades seriam então identidades políticas proclamadas num ambiente de disputas, identidades políticas que demandavam do rei uma resposta também política mediante ações orientadas levando em conta essas identidades, ou seja, políticas identitárias, no caso em questão, a demanda de grupos específicos da burgúndia.

Nota-se que a Crônica de Fredegário explicita um acentuado momento de fortalecimento das aristocracias regionais que evocavam identidades regionais, ou identidades mais amplas como a do "reino dos francos", para justificar maior autonomia e até mesmo para colocar em dúvida a autoridade dos reis. Disso podemos compreender melhor porque lidar com essas aristocracias se tornou uma qualidade importante para Gontrão no texto de Fredegário.

Indicamos pelo menos dois focos importantes de oposição aos reis francos. O 
primeiro advinha dos próprios membros da dinastia e da falta de um consenso sobre as maneiras pelas quais o reino deveria ser administrado e qual seria a melhor regra para a sucessão. O segundo vem de aristocracias regionais apresentadas a partir do estudo do caso de Herpo.

O sentido disso é defender que por vezes eram as questões políticas que outorgavam sentido à interpretação das fontes, mais do que idéias pré-concebidas: como o pressuposto da concepção patrimonialista do poder. Propomos que são essas questões políticas que nos fornecem o caminho mais promissor para o estudo das identidades expressas naquelas fontes em lugar de idéias estabelecidas a priori: como a tese da etnogênese.

Esperamos que esse percurso nos ajude a colocar alguns temas em evidência que serão de enorme importância ao longo desse texto. $\mathrm{O}$ fato é que para pensarmos nesses reinos não podemos preterir uma reflexão sobre a realeza e a relação entre os reis e a gens que permeará toda essa tese, acreditamos, está intimamente ligada com essas disputas, em poucas palavras, eram as disputas que nos trazem a chave para entender a imagem feita pelas nossas fontes sobre os reis e também sobre as gens.

Finalmente, o que queremos demonstrar é o equívoco de procurarmos o que é cristão, romano ou germânico na idealização da realeza na Hispânia Visigoda e na Gália Merovíngia, o que importa é observarmos como um arsenal discursivo concernente à realeza foi elaborado e evocado para resolver contingências muito urgentes. Por vezes esses discursos se remetiam a uma antiguidade mitológica, como no caso dos francos, por vezes a uma antiguidade bárbara, ou por vezes eram fundamentalmente pautados no cristianismo ou até mesmo no discurso imperializante. Talvez, o único modelo explicativo que podemos encontrar esteja paradoxalmente na diversidade, na polaridade, na falta de uma unidade. 
Há ainda uma questão importante que deve ser ressaltada. Embora a realeza visigoda e a realeza merovíngia se distinguam no desenvolvimento discursivo sobre a imagem dos reis, ambos os reinos lidaram, de formas diversas, com um problema em comum: o desafio enfrentado pelos reis diante de uma aristocracia cada vez mais forte e enraizada regionalmente. Percebemos então que também não podemos preterir essas aristocracias para enfrentarmos nossa problemática. Portanto esse será o tema do próximo capítulo. 


\section{Capítulo III - A Nobreza}

\section{Nobreza}

No capítulo anterior observarmos o quanto as aristocracias foram decisivas para a manutenção ou oposição ao poder dos reis. Diante disso nota-se a importância de contemplarmos esse segmento das sociedades franco-romanas e visigodo-romanas para alcançarmos nosso objetivo nessa segunda parte, ou seja, apresentar os agentes principais que lançaram mão das identidades políticas, e acionaram políticas identitárias, no quadro político da Hispânica Visigoda e da Gália Merovíngia. Assim poderemos compreender como nas relações entre reis e aristocratas as identidades políticas franca e visigoda se articulavam.

\section{Um grupo difícil de nomear: aristocratas, nobres ou élites?}

O problema inicial com o qual lidamos ao falarmos de aristocracias/elites/nobreza na Alta Idade Média é sobretudo conceitual principalmente pela diversidade de termos empregados para definir um grupo de destaque na sociedade, o fato é que no confronto com a historiografia encontramos uma profusão de terminologias: "nobreza", "aristocracias" e "elites" comumente usados sem distinção. Essa terminologia por vezes arbitrária redunda numa enorme dificuldade. Afinal o que define uma aristocracia/elite/nobreza da Alta Idade Média?

Tendo em vista que os estudos sistemáticos sobre o tema começam com a noção de "elites" é por ele que devemos iniciar. ${ }^{310}$ Como mostrou R. Le Jan, no século XIX as elites eram analisadas sob um ponto de vista político orientado por duas correntes principais de pensamento: o conservadorismo liberal exemplificado por Tocqueville e

\footnotetext{
${ }^{310}$ LE JAN, Régine. Historiographie des élites. Introduction. Textes de travail rédigés dans le cadre de la recherche sur «Les Élites dans le haut Moyen Âge VI ${ }^{\mathrm{e}}$-XII ${ }^{\mathrm{e}}$ siècle », (Marne-la-Vallée et Paris 1), 27 et 28 novembre 2003. Disponível em: http://lamop.univ-paris1.fr/spip.php?article438\#.VEELv4uUffI
} 
sua crítica à Revolução Francesa que analisou as elites como "motor da história" e na visão crítica às elites de autores como Gaetano Mosca (1858-1941), Vilfredo Pareto (1848-1923) e Robert Michels (1876-1936). O que há em comum em ambas as perspectivas é a noção estática sobre as elites. Como bem salienta R.L. Testa:

La loro élites tuttavia erano entità rigide, frutto di una visione statica delle gerarchie sociali ancora fortemente condizionata dall'interpretazione marxista della lotta di classe, nonostante il marxismo rigettasse la nozione di élite come categoria interpretativa della storia sociale. ${ }^{311}$

Entre os historiadores dedicados à tardo-antiguidade, ainda conforme Testa, houve uma mudança de abordagem acerca do conceito de elites a partir da década de 1950. A principal característica dessa mudança se deu com o superação da concepção rigorosa das elites. Com a emergência da problemática do Kontinuitättsproblem e as pesquisas prosopográficas conduzidas em Cambridge bastiões historiográficos foram postos à prova graças à análise das elites no seio de sua própria dinâmica em lugar de uma perspectiva que as viam como entidades estáticas, ${ }^{312}$ isso abriu o caminho para que a pluralidade dos grupos comumente generalizados sob a alcunha de "elites" se revelasse, mais do que falar apenas de uma elite, indicou-se a existência de diversas elites: políticas, econômicas, culturais, etc. A discussão sobre a pluralidade das elites também alcançou os historiadores do Baixo Medievo, ${ }^{313}$ todavia entre os historiadores do Alto Medievo a termo foi aplicado principalmente no sentido de "elites políticas" 314 muito possivelmente pela pouca quantidade de fontes produzidas no período. De todo modo, o uso limitado do conceito não impediu o surgimento de

\footnotetext{
311 TESTA, Rita L. Introduzione. In: TESTA, Rita L. Le transformazioni delle élite in età Tardoantica. Atti del convegno internazionale, Perugia, 15-16 marzo 2004. Roma: "L'ERMA" di Bretschneider, 2006. p.10.

${ }^{312}$ Ibidem, p.10-11.

${ }^{313}$ DEPREUX, P. L'historiographie des élites politiques. In: Textes de travail rédigés dans le cadre de la recherche sur «Les Élites dans le haut Moyen Âge $\mathrm{VI}^{\mathrm{e}}-\mathrm{XII}^{\mathrm{e}}$ siècle », (Marne-la-Vallée et Paris 1), 27 et 28 novembre 2003. Disponível em: http://lamop.univ-paris1.fr/spip.php?article438\#.VEELv4uUffI p.2-3.

${ }^{314}$ Ibidem, p.3-4.
} 
debates importantes sobre as elites. A partir da década de 1970, como aponta P. Depreux ${ }^{315}$ esse debate entre os historiadores alemães se centrou principalmente no problema terminológico, o que toca na questão levantada no início desse capítulo: como qualificar esses grupos que se destacavam na sociedade?

P. Depreux defende a utilização do termo "elites" a partir de uma abordagem sociológica, ou seja, menos rigorosa como visavam os pesquisadores envolvidos no debate de 1970, mas como operativo, metodológico. Nessa linha Depreux retoma J. Le Goff ${ }^{316}$ e sua definição de elites: grupos que se afirmam em sua superioridade a partir dos indivíduos que os compõem, em sua qualidade, seu valor e sua natureza minoritária. A pluralidade dessas elites - algo defendido tanto por Depreux e outrora por Le Goff - se sobressai pela uso da forma plural da palavra: sempre élites. ${ }^{317}$ Observa-se assim um uso aberto do termo uma vez que a forma de afirmação do poder das elites poderiam se dar de diversas maneiras, pelo poder econômico, pelo saber, pela capacidade militar, pela posse de terras, pela nobreza etc. ${ }^{318}$ É essa definição mais aberta do termo que se sobressai nos trabalhos conduzidos sobretudo por historiadores franceses ou historiadores com uma forte participação nos eventos organizados pela École Française de Rome ${ }^{319}$ onde o tema foi contemplado. R. Le

\footnotetext{
${ }^{315}$ Ibidem, p.9.

${ }^{316}$ Ibidem, p. 10 .

${ }^{317}$ Nas palavras de Le Goff: "Dans le vocabulaire français actuel, patriciat cher à Pirenne et à Lestocquoy n'est plus en faveur et il n'y a pas à le regretter, le terme renvoyant éventuellement à l'Antiquité mais non au Moyen Age, classes dominantes n'évoquant que l'aspect de la supériorité, élites, en dehors de son écho actuel qui permet d'envisager un certain comparatisme, apparaît comme le concept le plus intéressant par la diversité de ses références, à condition qu'il soit bien employé au pluriel, la diversité demeurant une caractéristique essentielle des réalités sociales auxquelles renvoie le terme. Il réunit les références à la superiorité des groupes et des individus qui les composent; à leur qualité (ce sont des éléments de choix), à leur valeur (qu'elle soit militaire, économique, administrative, culturelle, etc.) à leur nature de minorité." LE GOFF, J. Tentative de conclusions. In: Les élites urbaines au Moyen Âge. XXIVe Congrès de la S.H.M.E.S. (Rome, mai 1996). Paris e Roma: École Française de Rome e Publications de la Sorbonne, 1997. p.448.

${ }^{318}$ Ibidem, p.445.

${ }^{319}$ Como se pode constatar pelos artigos reunidos no volume: BOUGARD, F., FELLER, L. \& LE JAN, R. Les élites au haut Moyen Age. Crises et Renouvellements. Turnhout: Brepols, 2006.
} 
Jan, uma importante representante dessa linha de pesquisa, adota justamente essa definição aberta do termo:

Les élites se composent de tous ceux qui jouissent d'une position sociale élevée, que passe non seulement par la détention d'une fortune, d'un pouvoir ou d'un savoir, mais aussi par la reconnaissance d'autrui. L'appartenance à l'l'élite peut être héritée et se refléter dès la naissance dans le nom, ou acquise par l'union ou l'alliance matrimoniale, la possession foncière ou plus généralement la richesse, l'apprentissage culturel, l'exercice d'une fonction, la faveur du prince: autant de critères, non exclusifs les uns des autres, qui valent surtout par leur combinaison. Être de l'élite, y parvenir sont une chose, s'y maintenir comme individu ou comme groupe doté d'avantages sociaux une autre. ${ }^{320}$

Uma perspectiva sensivelmente diversa aparece no trabalho de K.F. Werner no seu importante estudo sobre o nascimento da nobreza. ${ }^{321} \mathrm{Na}$ pesquisa de Werner a "nobreza" é o foco e muito embora no título do volume os termos "nobreza" e "elites" se confundam, o autor em sua introdução ensaiou uma distinção importante. Segundo ele a nobreza monopolizou o poder direto até os séculos XII e XV, ${ }^{322}$ época na qual a monarquia se revigorou e tentou tomar a relação direta com os súditos, nesse contexto surgem novas elites - e aqui o autor lança mão de uma definição próxima a de Le Goff ao dizer que essas elites eram plurais - que prestavam serviços ao monarca ao contrário de uma nobreza que não raro disputava com o monarca, algo que faz absoluto sentido se retomarmos o capítulo anterior.

O fato é que o ponto central no trabalho de Werner é a defesa da existência de uma nobreza advinda da tardo-antiguidade que se manteve no contextos dos reinos romano-bárbaros, especialmente na França. Para defender sua tese o autor dialoga

\footnotetext{
${ }^{320}$ LE JAN, Régine. Historiographie des élites. Introduction... op.cit.

${ }^{321}$ WERNER, K.F. Naissance de la noblesse. L'essor des élites politiques en Europe. Paris: Arthème Fayard, 1998. Edição usada nesse trabalho: WERNER, K.F. Nascita della nobiltà. Lo sviluppo delle élite politiche in Europa. Torino: Giulio Einaudi editore, 2000.

${ }^{322}$ Nas palavras do autor: "Fino a quel momento, il populus, ovvero il popolo in quanto entità politica, si incarnava nella nobiltà: rappresentando politicamente gli altri uomini, essa poteva eleggere o deporre il re. Per molto tempo, inoltre, nella maggior parte della Francia, i capi dei principati e delle signorie restarono più vicini alle popolazioni di quanto non fosse il re, che aveva assoluto bisogno della nobiltà per esercitare il proprio potere e far eseguire i propri ordini”. Ibidem, p.XVII-XVIII.
} 
diretamente com autores que ou refutam a hipótese da existência de uma nobreza no período anterior aos séculos XII e XV - como F.-L. Ganshof, D. Illmer, W. Haubricks, em certa medida M. Bloch - ou são hesitantes no uso do termo - como E. James e M. Heinzelmann. A argumentação de Werner se concentra principalmente no problema da definição, de acordo com ele, o ceticismo em relação à existência da nobreza no Alto Medievo se deve menos às evidências encontradas nas fontes e mais a uma definição de nobreza restrita que negligencia o sentido de nobilitas romano. Enquanto os céticos salientam o caráter hereditário do nobreza, Werner se centra em outro elemento que para ele é mais importante do que todos na definição do que é um nobre, a saber, a idéia de que eram os nobres que praticamente monopolizavam a res publica:

La specificità della nobilitas non risiede nemmeno nel suo statuto "privilegiato" (quest'ultimo termine risente della fine dell'Ancien Régime), bensì nel suo carattere pubblico, in quanto essa dirigeva la cosa publica. La nobiltà occupava il vertice dello Stato, piuttosto che quello della società, grazie a uno statuto più $\mathrm{o}$ meno privilegiato: ed ecco una delle grandi differenza tra le definizioni comuni e quella che deriva dal postulare una sua origine romana. ${ }^{323}$

Ao encarnar a coisa pública a nobreza se definia e se legitimava pela sua "sacralidade". Talvez seja aqui que o texto de Werner se torne mais frágil uma vez que ele superestima o valor da nobreza eclesiástica. Entretanto, a posição do autor é compreensível. A idéia de continuidade permeia a sua obra e essa continuidade para ele se expressa pela manutenção da autoridade da antiga nobreza romana mediante a ocupação por parte dos descendentes dos antigos nobres romanos de cargos na Ecclesia. Embora o autor saliente algo importante, acaba por perder de vista o fato de que as fontes da Hispânia Visigoda e da Gália Merovíngia não traziam sempre uma

\footnotetext{
${ }^{323}$ Ibidem, p.103-104. Ainda: "La nobilitas romana e franca, francese e tedesca, poteva forse essere altezzosa, arrogante, ma non vanitosa: non affermava di essere la cosa pubblica - lo era e basta. Il suo potere era parte integrante delle società antiche e le sue radici erano sacre." p.115.
} 
hierarquização dos quadros da nobreza exceto em momentos de disputa, isso mais uma vez se pode constatar pelos exemplos trazidos no capítulo anterior, como nos casos da oposição do bispo ariano a Recaredo e o questionamento de Sagitário à legitimidade dos filhos de Gontrão.

Interessante comparar a diferença de perspectiva apresentada por um autor que critica as teses que apontam para a continuidade de Roma após o século V. Falamos de C. Wickham, que adota um termo criticado por Werner, a saber, "Aristocracias". A questão é que Wickham não vê nas aristocracias os depositários da continuidade do Império Romano. A decadência do sistema de taxação do Império Ocidental - o sustentáculo primordial do sistema - para Wickham marcou de fato mudanças significativas o suficiente para não permitir que se fale de uma continuidade após o século V. ${ }^{324}$ Nesse contexto retratado pelo autor as aristocracias têm uma função diametralmente oposta daquela salientada por Werner: elas são o símbolo da descontinuidade. Com o declínio de sistema de taxação romano no Ocidente a separação entre os interesses das aristocracias e os interesses do Estado se dissolveram. No Ocidente a forma de arrecadação e retribuição aos serviços prestados pelos aristocratas passou a se basear num sistema de remuneração por terras o que indica a fragilidade dos reis e gera a regionalização dos aristocratas. ${ }^{325}$ Wickham não se furta ainda de tentar definir o que são as aristocracias. Para Wickham um aristocrata era um membro de uma elite política que devia sua autoridade pelo simples fato de ser um aristocrata. ${ }^{326}$ Entretanto, os critérios para definir um aristocrata eram variáveis, diante dessa dificuldade Wickham definiu seis pontos principais para tal

\footnotetext{
${ }^{324}$ É importante ainda salientar que o autor tem uma postura bastante interessante ao questionar a própria eficiência do sistema romano antes mesmo do início do período marcado classicamente como crítico. Tal posicionamento está bem explicitado no livro: WICKHAM, C. The Inheritance of Rome: Illuminating the Dark Ages, 400-1000. London: Viking, 2009.

${ }^{325}$ WICKHAM, C. Framing the Early Middle Ages. Eurore and Mediterranean, 400-800. Oxford: Oxford University Press, 2005. p.58-59.

${ }^{326}$ Ibidem, p. 153 .
} 
definição, sempre reconhecendo que ela era fluida:

Of these different criteria, six seem to me particularly important as guides to the membership of a broad aristocratic stratum in our period. These are, put briefly: distinction of ancestry; landed wealth; position in an official hierarchy; imperial or royal favor (what the Germans call Königsnähe); recognition by other political leaders; and lifestyle. ${ }^{327}$

Nota-se que muito embora exista uma grande diferença entre Werner e Wickham no que concerne ao papel da nobreza/aristocracia os critérios de distinção dos aristocratas não são dicotômicos. A grande diferença reside no que significou o aumento do poder desses nobres/aristocratas: a preservação da res publica de Werner ou a marca das mudanças que ocorreram principalmente no século V de Wickham.

Aparentemente a mudança de vocabulário para definir esses grupos de poder não é apenas uma casualidade, é o reflexo de uma perspectiva acerca dos anos que contemplamos. O vocabulário da historiografia francesa atual privilegia a pluralidade ao adotar um termo flexível élites, além de denunciar as aproximações de pesquisadores como Le Jan aos estudos antropológicos e sociológicos; Werner foi um defensor da continuidade, mas acima de tudo o defensor de uma tipologia de exercício do poder público encerrado na concepção herdada de Roma da nobilitas; Wickham, por outro lado, tradicionalmente evita tomar partido nas grandes "escolas" do debate historiográfico atual e defende uma idéia de crise que comumente foi posta à prova, entretanto, talvez sua opção terminológica, a saber, a sua defesa do termo "aristocracia", se deva principalmente a sua formação marxista.

A priori o termo elites parece o mais pertinente justamente por sua flexibilidade, entretanto a dificuldade de seu uso reside no fato de que ele advém da sociologia e nesse campo é utilizado de formas distintas daquelas usualmente operadas pela historiografia. Já desde os trabalhos de Wickham e Werner a adoção

${ }^{327}$ WICKHAM, C. Framing the Early Middle Ages... op.cit. p.154. 
dos termos "nobreza" e "aristocracias" trazem significativas implicações uma vez que pressupõem um posicionamento sobre características estruturais do Alto Medievo.

Cabe ainda trazer as contribuições de um trabalho recente que se posiciona bem nesse debate, trata-se do livro de Y. Fox. O pesquisador usa todos os termos até aqui discutidos, a saber, "elites", "aristocracias" e "nobreza" atentando, entretanto, para a diferença entre eles. Para Fox, as aristocracias eram representadas por pessoas e famílias que se distinguiam do resto da população por suas posses, poder político e participação nos cargos da hierarquia oficial que por vezes exerciam um poder político regional mesmo a despeito do reconhecimento dos reis. Já as "elites", termos que o autor reconhece como sendo mais neutro, definem um indivíduo ou grupo que se destacam dos demais membros da sociedade em contextos específicos, por exemplo, quando membros mais ricos da sociedade interagiam com membros com menos posses eles estavam atuando como elites. Por outro lado, a nobreza para Fox segue uma definição mais tradicional, a saber, consistia em indivíduos cuja influência política devia sobretudo à hereditariedade e que se constituíam não raro como opositores aos aristocratas. ${ }^{328}$ Como se pode notar, a definição de Werner para a nobreza é a que mais se afasta das definições mais comuns que as relacionam com a hereditariedade. entretanto, se problematizado, o termo nobilitas traz uma enorme vantagem: ele aparece nas fontes do período sendo portanto talvez o que nos oferece maiores possibilidades de inserção de significados. É claro que adotar esse termo não redunda na presunção de deliminar definitivamente o que significava nobilitas nas fontes do nosso período, antes disso, trata-se de ver como esse termo poderia ser usado de várias formas. Exaurir os diversos significados do termo, todavia, é um trabalho enorme que pode facilmente fugir do nosso escopo. Portanto, nossa análise

\footnotetext{
${ }^{328}$ FOX, Y. Power and Religion in Merovingian Gaul. Columbanian Monasticism and the Frankish Elites. Cambridge: Cambridge University Press, 2014. p.50-52.
} 
aqui se restinge ao objetivo desse trabalho, a saber, a apreensão do significado do termo em confronto com a idéia de gens gothorum e gens francorum.

\section{A nobreza}

Uma das características que são elencadas por todos aqueles que escrevem sobre a nobilitas se refere a sua participação na hierarquia oficial. Parece então pertinente que partamos desse ponto de referência para iniciarmos nossa discussão, e para tanto mais uma vez a obra de Isidoro de Sevilha se destaca por uma descrição sistemática da hierarquia oficial dos reinos feita em suas Etimologias. ${ }^{329} \mathrm{O}$ que se sobressai logo na primeira observação do capítulo 3 do livro IX da obra é que a descrição do reino e dos seus cargos compreende tanto a definição dos termos "reis", "principes" e "imperadores" quanto a descrição dos cargos oficiais da administração e do exército. Os reis e os nobres, assim, não eram duas entidades separadas no todo do reino, ambos - nas funções que deveriam cumprir - formavam a estrutura administrativa do reino.

Isidoro inicia sua descrição com os cargos oficiais romanos a partir da época da República:

1. Conselheiros [consules] - estes tinha por dever aconselhar, como os reis tinham por dever reger, como as leis tinham por dever legislar (consules appellati a consulendo, sicut reges a regendo, sicut leges a legando"). O interessante ainda nessa definição isidoriana reside na origem dos conselheiros: estes foram instituídos pelos romanos em uma resposta ao domínio soberbo dos reis, o que mais uma vez indica que Isidoro de Sevilha não foi um artífice da construção de uma ideal de realeza por si: Nam cum Romani regum superam dominationem non ferrent, anua imperai binosque consules siai fecerunt. Nam fartum regiam non benivolentia consulentis, sed superai dominantis erat. Hinc igitur consules appellati, vel a consulendo civibus, vel a

\footnotetext{
${ }^{329}$ Há uma enorme quantidade de edições e traduções deste que é o texto mais importante do hispalense. Nesse trecho específico trabalhamos com a edição bilíngue (francês-latim) do importante pesquisador M. Reydellet: Isidore de Séville. Étymologies. Livre IX. Texte établi, traduit et commenté par Marc Reydellet. Paris: Société d’Éditions "Les Belles Lettres”, 1984. Entre as edições bilínguies se destaca também a da BAC: Etymologiarum. Ed. Bilíngue (latim-espanhol). J.O. Reta e M.A.M Casqueros. Madrid: BAC, 1975.
} 
regendo cuncta consilio. Ligados aos conselheiros estavam ainda os pró-conselheiros (proconsules) auxiliares dos conselheiros e os exconselheiros (exconsulesz) ou seja, conselheiros que haviam terminado seus "mandatos"

2. Ditadores (Dictatores) - que governaram depois da expulsão dos reis.

3. Césares - título adotado primeiro por Júlio

4. Imperadores - Isidoro explicou que o título se originou da hierarquia militar. Eram chamados imperadores (imperatori) aqueles que detinham o supremo poder militar. Com a ascensão de César Augusto o senado reservou o título à ele a fím de diferenciá-lo dos reis de outras gentes: sed dum diu duces titulis imperatoriis fungerentur, senatus censuit ut Augusti Caesaris hoc tantum nomes esset, evoque is distingueretur a ceteris gentium regibus; quod et sequentes Caesares hactenus usurpaverunt.

Depois de descrever as hierarquias romanas até o surgimento do título “Augusto" Isidoro alargou seu escopo ao iniciar sua argumentação sobre os reis. Após a descrição do termo "Basileo" e "tirano" ele adentra no terreno que nos interessa mais nesse tópico, a saber, as hierarquias que nas fontes tanto da Hispânia quanto da Gália fornecerão os títulos dos nobiles. Os primeiros mencionados por Isidoro de Sevilha são os duces: Dux dictus eo quod sit ductor exercitus. É importante destacar que nessa definição de $d u x$ Isidoro se ocupou em distinguí-los dos reges e principes, o que aponta para um confusão entre os termos pela prerrogativa comum aos três cargos, a saber, o comando:

Sed non statim quicumque principes vel duces sunt, etiam reges dici possunt. In bello autem melius ducem nominari quam regem. Nam hoc nomen exprimit in proelio ducentem.

Dux então se restringe ao comando militar durante batalhas.

Isidoro ainda distingue outros cargos:

- Patrícios, responsáveis pela provisão da coisa pública, tal como os pais provinham aos filhos: Patricii inde vocati sunt, pro eo quod sicut patres filiis, tia providente reipublicae.

- Os prefeitos e pretores que tinha atribuições semelhantes, a saber, a proteção de uma localidade.

Em seguida o hispalense se ocupa de definir os cargos do exército. Os Ciliarci 
responsáveis pelo comando de mil homens; os centuriões que comandavam cem homens; os miles que eram os soldados; Os equestres milites que eram os soldados que lutavam a cavalo; os tirones que eram jovens que entravam no exército e se mostravam aptos a portar armas; os desertores que abandonam o exército e que, segundo Isidoro, normalmente se alinhavam às fileiras inimigas; os obtiones que eram escolhidos para compor o exército e assim sucessivamente.

O que é importante destacar nessa longa descrição isidoriano sobre as hierarquias do reino e do exército é primeiro, como já informamos, a presença no mesmo capítulo da descrição de tais cargos, capítulo este que tem por título De regnis militiaeque uocabulis o que conduz para uma concepção da administração do reino formado pelo todo. Aqui, o rex não está numa posição especial: tal como os duces, os patrícios, os prefeitos e pretores e os comandantes do exército ele forma parte da estrutura administrativa do reino. O segundo ponto notável é que Isidoro de Sevilha exceto quando fala da restrição a escravos de entrarem no exército - não faz qualquer menção à necessidade de pertencer a uma nobilitas hereditária para a ascensão às hierarquias por ele descritas. Se por um lado isso outorga mais evidências para sustentar a hipótese de Werner, por outro nos levanta um questionamento: já que não existia um condicionante claro para o exercício de cargos públicos poderíamos entender que existia uma nobilitas enquanto classe dirigente? $\mathrm{O}$ simples fato de exercer uma função na hierarquia administrativa tornava um indivíduo um nobre? Precisamos ir além na análise de nossas fontes.

Efetivamente alguns dos cargos descritos por Isidoro de Sevilha aparecem tanto nas fontes merovíngias quanto nas fontes visigodas, mas para compreendermos seus sentidos nos textos é preciso considerar algo que vai além da descrição feita pelo hispalense em suas etimologias, é preciso tentar compreender: 
- Quem exercia esses cargos?

- Quais funções cumpriam?

- Que papel desempenhavam?

Desde João de Bíclaro, abade que foi exilado por Leovigildo e testemunhou a conversão de Recado ao cristianismo, detectamos a participação de duces, comes e patrícios na vida política tanto do Império quanto do reino visigodo. No que concerne aos duces o abade de Bíclaro os mencionou em seis passagens de sua crônica:

- Anno V de Justino e III de Leovigildo - O imperador Justino luta contra os Persas com seus duces : 1. Iustinus imperator Armeniam et Hiberiam repulsis Persis Romanas provincias facit et bellum Persarum imperator per duces parat.

- Ano IX de Justino e VII de Leovigildo - O imperador dos Persas inicia saques no território romano e Justiniano, feito $d u x$ do exército romano e general do Oriente por Tibério luta contra ele: Cosdroes Persarum imperator cum nimia multitudine exercitas ad vastandos Romanorum términos promovet. cui Iustinianus dux Romanae militiae e magister militum Orientis a Tiberio destinatus bellum parat [...]

- Ano III de Maurício e XVII de Leovigildo - O imperador Maurício luta contra os Persas por meio de seus duces: 1. Mauricius per duces bellum Persis infert. / Malarico se rebela contra Leovigildo na Galícia, mas foi derrotado pelos duces do rei: 6. Malaricus in Gallaecia tyrannidem assumens quasi regnare vult, qui statim a ducibus Leovegildi regis oppressus comprehenditur et Leovegildo vinctus praesentatur.

- Ano V de Maurício e I de Recaredo - O $d u x$ franco Desidério foi derrotado pelos duces de Recaredo: 6. Desiderius Francorum dux a Gothis satis infestus a ducibus Reccaredi regis superatur et caesa Francorum multitudine campo moritur.

- Ano VII de Maurício e III de Recaredo - Aqui há a narrativa da milagrosa vitória do Duque Cláudio da Lusitânia contra os Francos liderados pelo duque Boso do rei da Burgúndia, Gontrão. Esse mesmo Duque Cláudio será mencionado em outras fontes como nas Vidas dos Padres de Mérida e na Historia Gothorum, em todas essas fontes percebemos o quanto Cláudio foi um importantíssimo aliado de Recaredo na turbulenta região da Lusitânia, especialmente em Mérida: 2. Francorum exercitas a Gonteramno rege transmissus Bosone duce in Galliam Narbonensem obveniunt et iuxta Carcassonensem urgem castra metati sunt. Cui Claudius Lusitaniae dux a Reccaredo rege directus obviam inibi occurrit. [...] nam Claudius dux vix cum CCC viris LX ferme milha Francorum noscitur infugasse et maximam eorum partem gladio trucidasse. 
- Ano VIII de Maurício e IV de Recaredo - Argimundo, que fazia parte do séquito de Recaredo e fora nomeado dux de uma província (João não disse qual) se rebelou contra Recaredo: 3. Reccaredo ergo orthodoxo quieta pace domesticae insidiae praetenduntur. nam quidam ex cubiculo eius, estiam provinciae dux nomine Argimundus adversus Reccaredum regem tyrannidem assumere cupiens, tia ut, si posset, eum et regno privaret et vita.

Em todas as menções aos duces há uma clara relação com a liderança de tropas especialmente no que se refere aos duces do Império Romano. Por outro lado, os duces do reino visigodo mencionados por João de Bíclaro trazem algumas particularidades. Cláudio é citado como $d u x$ não só de um exército, mas de uma região, a Lusitânia. Sua atuação tem um claro escopo regional e ele se constituía, como já mencionado, como um importante aliado de Recaredo numa área que foi o cerne de revoltas contra o rei. Já Argimundo, também nomeado dux de uma província e também próximo ao rei se opôs a Recaredo. Revelam-se assim duas faces dos duces. Ao mesmo tempo que eles podiam ser um importante apoio para os reis eles poderiam também liderar revoltas contra os reis e tentar tomar o trono como dá a entender a crônica com o uso do termo "tirania" ${ }^{330}$ para se referir ao ato de Argimundo.

Os comites também são mencionados pelo biclarence, ${ }^{331}$ mas apenas quando se refere a cargos do Império Romano. O mesmo vale para os patrícios ${ }^{332}$ e prefeitos ${ }^{333}$. No que concerne ao reino visigodo propriamente dito são os duces que aparecem como verdadeiros personagens políticos, ou ao menos assim são nomeados esses personagens.

\footnotetext{
${ }^{330}$ O termo "tirania", como indicou J. Orlandis, era empregado sobretudo com o sentido de oposição ao poder real, à tentativa ilegítima de se elevar ao trono. A mesma conclusão defender García Moreno. $C f$ : : ORLANDIS, J.Estudios visigoticos III: El poder real y La sucesion al trono en la monarquia visigoda. Cuadernos del instituto juridico español n.16. Madrid-Roma: Consejo superior de investigaciones cientificas. Delegacion de Roma, 1962. GARCÍA MORENO, L.A. Alaric II et l'Espagne. In: ROUCHE, M. \& DUMÉZIL, B. Le Bréviaire d'Alaric. Aux origines du Code Civil. Paris: PUPS, 2008. p. 112.

${ }^{331}$ IV anos de Justino II de Leovigildo, 3. VIII ano de Justino VI de Leovigildo, 3. II ano de Tibério e $X$ de Leovigildo, 3. Chronica Biclarense. Ch.B.

${ }_{332}$ II ano de Justino, 1 e 2). X ano de Justino e VIII de Leovigildo, 2. Ch.B

${ }^{333}$ III ano de Justino, 2. Ch.B
} 
$\mathrm{Na}$ Chronica Biclarense não existe uma menção clara à necessidade de pertencer a um segmento reconhecido como nobre para ter algum cargo na hierarquia oficial, entretanto João de Bíclaro indica que ser filho de um patrício poderia ter um peso importante para tornar-se um comandante do exército romano. Isso aparece em dois momento da crônica: quando João fala do general Romano, que era filho do patrício Anagasto ${ }^{334}$, e quando falou de de Justino, filho do patrício Germano e primo do imperador Justino, que foi morto em Alexandria por conspiração de Sofía Augusta. ${ }^{335}$ Certamente esse Justino servia como representante do imperador em Alexandria. Assim, na crônica, dois homens que eram descendentes de patrícios romanos cumpriram cargos na hierarquia oficial. Evidentemente que isso não é nenhuma novidade, entretanto, é um ponto importante a ser levantado à luz da discussão por nós iniciada na primeira parte desse capítulo, a saber, embora ser membro de uma família de destaque não fosse um imperativo para se tornar membro do corpo oficial do Império e também dos reinos bárbaros não deixava de ser algo sim relevante. De fato, ascender a esses cargos sem ter uma origem nobre - ou seja, sem ser originário de uma família com tradição na prestação de serviços na alta hierarquia do Império e depois dos reinos bárbaros - era mais uma exceção do que uma regra.

Isso se observa com clareza no confronto com a Historia Gothorum de Isidoro de Sevilha. Como já discutimos no capítulo anterior, pertencer a um determinado grupo da sociedade, ou seja, ser um "godo" - provavelmente uma designação que determinava status social - era condição necessária para se tornar rei. O que encontramos na Historia Gothorum sobre a origem dos reis é interessante.

A indignidade das origens - ou seja, ser um filho ilegítimo, por exemplo - em

\footnotetext{
${ }^{334}$ Romanus filius Anagasti Patricii magister militae gentis Suanorum regem vivum cepit, quem cum suo thesauro, uxore et fillis Constantinopolim adducit et provinciam eius in Romanorum dominium redigit. X ano de Justino, VIII de Leovigildo, 2. Ch.B.

${ }^{335}$ Iustinus filius Germani patricii consobrinus Iustini imperatoris factione Sophiae Augustae in Alexandria occiditur. Segundo ano de Justino, 2. Ch.B.
} 
Isidoro de Sevilha não se refere mais aos reis. É essa origem vil que Isidoro destaca na sua descrição sobre Geseleco, filho de Alarico II com uma concubina. Os atos desse rei para o hispalense eram tão vulgares como sua própria origem:

Aera DXLIIII, anno XVII imperii Anastasii Gisaleicus superioris regis filius ex concubina creatus Narbona princeps efficitur regnans annis quattuor sicut genere uilissimus, ita infelicitate et ignauia summus. ${ }^{336}$

A mesma menção, mas com um desenrolar oposto, aparece na descrição da deposição de Liuva II, filho de Recaredo deposto por Viterico:

Aera DCXXXVIIII, anno imperii Maurici XVII, post Recaredum regem regnat Liuua filius eius annis duobos, ignobili quidem matre progenitus, sed uirtutum indole insignitus. ${ }^{337}$

A origem ignóbil de Liuva era compensada pela virtude do seu caráter. Muito embora Isidoro não deslegitime Liuva, sua origem materna é vista com reservas. $\mathrm{O}$ que se percebe é que embora não possamos identificar com certeza quem eram os godos nobres que de fato eram legítimos ao trono, podemos ao menos notar que certamente a dignidade real não era acessível a todos, era necessário fazer parte de um grupo específico e pelo relato de Isidoro a descendência materna era também importante para ser parte desse grupo. Isso difere do caso dos francos.

Como também já foi discutido, nos Decem Libri Historiarum de Gregório de Tours vimos como o bispo de Tours desmereceu os argumentos do bispo Sagitário que questionou a legitimidade dos filhos de Gontrão uma vez que eles foram gerados por uma mãe não nobre, o que se nota na realeza Merovíngia, portanto, é que a origem materna não tinha peso determinante para garantir a legitimidade dos príncipes, já a Vida de São Columbano dará uma versão diferente para isso ao retratar Columbano questionando a legitimidade dos filhos de Teodorico II uma vez que eram

\footnotetext{
${ }^{336}$ HISTORIA GOTHORUM, v.1., 37.

${ }^{337}$ HISTORIA GOTHORUM, vl, 57.
} 
fruto de mães ilegítimas, nomeadamente concubinas. De todo modo, mesmo que isso aponte para uma falta de consenso, aparentemente a interpretação de Gregório de Tours prevaleceu.

A possível explicação para essa diferença entre os francos e os visigodos pode residir no problema dinástico. Mesmo que a dinastia merovíngia tenha enfrentado uma certa oposição, como indicou I. Wood, ${ }^{338}$ ela era mais ou menos estabelecida, ou pelo menos, mais estável do que o método de sucessão régio na Hispânia visigoda onde os candidatos ao trono eram em maior número. A restrição à origem materna dos candidatos ao trono poderia ser um subterfúgio ou para diminuir o número deles e assim as disputas ou um mecanismo retórico de deslegitimação dos reis, como faz Isidoro de Sevilha com Geseleco. Entretanto, a primeira hipótese parece ser mais razoável se levarmos em conta que Isidoro trouxe esse mesmo problema quando falou do Liuva II, mesmo que tenha nesse caso relativizado a origem ignóbil de sua mãe.

Tal como nas Etimologias, Isidoro de Sevilha não apresenta na sua Historia Gothorum condições imperativas para que alguém ascendesse a altos cargos. Efetivamente as menções aos nobres na Historia Gothorum são poucas. Há o caso de Teudisclo, rei que assumiu depois do assassinado de Teudis, e acabou assassinado, conforme Isidoro, por ter desonrado as esposas dos potentes $^{339}$, não é dado detalhes sobre quem eram esses potentes, mas sabemos que eles tinham força o suficiente para assassinar um rei durante um baquete. Há ainda uma menção ao dux Claudio da Lusitania que derrotou os francos liderados pelos duces de Gontrão. ${ }^{340}$ A outra

\footnotetext{
${ }^{338}$ Como discute I. Wood: WOOD, I. Usurpers and Merovingian kingship. Der Dynastiewechsel von 751. Vorgeschichte, Legitimationsstrategien ind Erinnerung. p.15-31, 2004. Ainda: WOOD, I. The bloodfeud of the Franks: a historiographical legend. Early Medieval Europe. n.14, p.489-504, 2006.

${ }^{339}$ Qui, dum plurimorum potentum conubia prostitutione publica macularet et ob hoc instrueret animum ad necem multorum, praeuentus coniuratorum manu Hispali inter epulas iugulatur confossusque extinguitur. HISTORIA GOTHORUM, vl, 44.

${ }^{340}$ Egit etiam gloriose bellum aduersus infestas gentes fidei suscepto auxilio. Francis enim sexaginta fere milium armatorum Gallias inruentibus misso Claudio duce aduersis eos glorioso triumphauit euentu. $\mathbf{H B}, \mathrm{vl}, 54$.
} 
referência aparece durante o reinado de de Sisebuto, quando o rei contou com seus duces para derrotar os rocones. ${ }^{341}$ Nos casos de Cláudio e dos duces de Sisebuto mais uma vez há uma clara relação entre a função de $d u x$ e a liderança de tropas em nome dos reis. A menção sobre os potentes que assassinaram Teudisclo é contudo nebulosa, o que se pode dizer é que eles estavam próximos ao rei já que o mataram durante um banquete, tal como, em João de Biclaro, Argimundo estava próximo de Recaredo quando se rebelou contra ele.

A referência feita por João de Biclaro ao fato de que esse Argimundo foi nomeado dux ainda nos traz outro elemento importante: era desse séquito de potentes - homens próximos aos reis - que saíam os duces que representariam os reis nas províncias mais distantes. Não parece, nesse ponto, absurdo supor que era também desse séquito de potentes que surgiam os candidatos ao trono, tendo isso em vista, podemos avançar na análise mediante a comparação com as referências a linhagem materna dos reis feitas por Isidoro de Sevilha e dizer que a linhagem tanto paterna quanto materna era um fator de peso para ser tanto um potente quanto um rei entre os visigodos. Mesmo que isso não fosse uma condição inegociável, como mostra o próprio caso dos reis com origens maternas indignas, era algo que não podemos ignorar. Assim encontramos uma primeira pista para respondermos as perguntas colocadas no início: esses nobres vinham comumente de famílias importantes tanto do lado paterno quanto do lado materno; no caso dos visigodos entre as funções que poderiam cumprir estava a própria ocupação do trono, além de cargos militares como o caso dos duces.

A partir de João de Bíclaro e Isidoro de Sevilha observamos principalmente os nobres cumprindo funções militares e representando os reis em províncias distantes.

\footnotetext{
${ }^{341}$ Ruccones montibus arduis undique consaeptos per duces euicit. HISTORIA GOTHORUM, vl, 61.
} 
Certamente que a descrição dos dois cronistas não encerra as atribuições desses nobres. A leitura das Leges Visigothorum nos revela outras funções exercidas por esses nobres que vão além do exercício militar. No Livro II, t.I, 22 encontramos a seguinte normativa que protegia quem desconfiasse de alguma decisão judicial:

Si quis iudicem aut comitem aut vicarium comitis seu triuphadum suspectos habere se dixerit et ad suum ducem aditum accedendi poscerit aut fortasse eundem ducem suspectum habere dixerit, non sub hac occasione petitor ac presertim pauper quilibet patiatur ultra dilatione. Sed ipsi, qui iudicant eius negotium, unde suspecti dicuntur haberi, cum episcopo civitatis ad liquidum discutiant adque pertractent et de quo iudicaverint pariter conscribant suscribantque iudicium. ${ }^{342}$

Aqui temos três hierarquias aptas a julgar: o juiz, o comes e o vicário do comes o dux é descrito como superior a esses três personagens responsáveis pelo primeiro julgamento. Depois há o bispo que servia como uma espécie de mediador caso o julgamento ainda assim estivesse sob suspeita. O último nível de apelação se dava com o próprio rei. A figura do dux nesse trecho vai além de um simples chefe militar, ele era também responsável por monitorar os julgamentos realizados pelos juízes e comes e tinha até mesmo a autoridade para julgar. Disso se infere que se a função do $d u x$ descrita por Isidoro de Sevilha - profundamente influenciado pela hierarquia oficial romana - era restrita à governança militar, a partir da reforma legislativa visigoda empreendida por Chindasvinto e Recesvinto se revela uma participação dos duces muito mais ampla relacionada com a governança regional. Tal participação é confirmada por outro trecho da lei que estabelece quem poderia assumir o papel de juízes, onde se identificam os comes, vicarius, duces, etc. ${ }^{343}$ A piori, pelas leis, temos

\footnotetext{
${ }^{342}$ Ver tradução 23.

343 Quoniam negotiorum remedia, multimode diversitatis conpendio gaudent, adeo dux, comes, vicarius, pacis adsertor, triuphadus, millenarius, quingentenarius, centenarius, defensor, numerarius, vel qui ex regia iussione aut etiam ex consensu partium iudices in negotiis eliguntur, sive cuiuscumque ordinis omnino persona, cui debite iudicare conceditur, ita omnes, in quantum iudicandi potestatem acceperint, iudicis nomine censeatur ex lege; ut, sicut iudicii acceperint iura, ita et legum sustineant sive commoda, sive damna. Leges visigothorum (LV), 1.II, 1, 25.
} 
o reconhecimento documentado da participação desses homens na organização política do reino. Mas como eles agiam? Como outras fontes falam sobre eles.

O capítulo anterior indicou como eles poderiam ser aliados dos reis, mas também fortes opositores dos reis. Assim, o reconhecimento legislativo das atividades deles deve ser compreendido por um outro viés também: as leis os reconheciam, mas também tentavam controlá-los. E isso não parece ser por acaso.

Em 579 o rei Leovigildo elevou seu filho Hermenegildo como o co-governante da província da Baetica, não muito tempo depois Hermenegildo começou uma rebelião contra seu pai. As razões da revolta não são claras, mas nós podemos propor algumas possibilidades de explicação. A primeira é o problema religioso - o mesmo apontado pelas Vidas dos Padres de Mérida para explicar as revoltas contra Recaredo. De acordo com fontes como a Historia Gothorum de Isidoro de Sevilha, mas também a Getica de Jordanes e os Historiarum Libri Septem de Orósio, ${ }^{344}$ os godos se tornaram heréticos pela perfídia do Imperador Valente que enviou pastores hereges para ensinar sobre a fé cristã aos Godos, assim, pelas fontes, a conversão dos godos ao arianismo ocorreu na segunda metade do século IV.

Conforme García Moreno ${ }^{345}$ o arianismo dos godos se transformou num importante elemento da identidade étnica visigoda e durante o período de Leovigildo era o arianismo que era oficialmente professado pelos godos. Quando Hermenegildo ergueu-se contra seu pai ele era um novo convertido ao catolicismo, uma fé que ele abraçou influenciado pela sua esposa, a princesa franca Ingunda, e o bispo católico Leandro de Sevilha, irmão e antecessor de Isidoro no bispado hispalense. Poderia ter sido a fé católica de Hermenegildo a causa de sua revolta? Para responde a essa questão precisamos analisar alguns pontos:

\footnotetext{
${ }^{344}$ Historia Gothorum, large version, 9. Getica, 138. Historiarum Libri Septem, liber VII, 33.

${ }^{345}$ GARCÍA MORENO, L.A. Etnia Goda e Iglesia Hispana. Hispania Sacra. n.54, p.415-442, 2002.
} 
Primeiro, é importante problematizar a concepção de que o arianismo era algo de fato importante para a afirmação de uma identidade étnica goda. Como muito bem defendeu M. Coumert ${ }^{346}$ nossas fontes sobre os reinos bárbaros referiam-se a um contexto aristocrático, não é possível generalizar todas as referência ao "godos" assumindo o termo como uma referência para toda a gens, como já indicamos também no capítulo anterior. Comumente quando lemos esse termo é preciso ter em conta que os autores estavam falando sobre um grupo aristocrático restrito - exceto em discursos que faziam referência à pátria em contextos específicos de disputas, como indicaremos na conclusão dessa primeira parte. Então, se o arianismo era um importante elemento identitário ele era restrito à identidade aristocrática. Ainda, é notável que as fontes Hispanas que falam sobre a rebelião de Hermenegildo não celebram a rebelião do príncipe, na verdade, as fontes, a saber, a Historia Gothorum de Isidoro de Sevilha e a Chronica de João de Biclaro, são muito críticas à rebelião. Por exemplo, João de Biclaro, que foi inclusive exilado por Leovigildo, escreveu que a rebelião do príncipe foi pior para a Hispania, para os godos e para o romanos, do que as invasões de inimigos. ${ }^{347}$

Isidoro de Sevilha, por sua vez, foi muito lacônico sobre a rebelião limitando-se a dizer que Leovigildo foi bem-sucedido ao enfrentar a rebelião de Hermenegildo. Não se pode ainda esquecer que João de Biclaro tinha origens godas, mesmo assim era católico e tornou-se abade do mosteiro de Biclaro. Já Isidoro tinha origens romanas e era um bispo católico, percebe-se portanto que as origens "étnicas" de ambos os religiosos não foram importantes para determinar seu suporte a Leovigildo,

\footnotetext{
${ }^{346}$ COUMERT, Magali. Origines des Peuples. Les récits du haut Moyen Âge Occidental (550-850). Paris: Institut d'Études Augustiniennes, 2007.

${ }^{347}$ Leovegildus ergo quieta pace regnante adversariorum securitatem domestica rixa conturbat. nam eodem anno filius eius Hermenegildus factione Gosuinthae reginae tyrannidem assumens in Hispali civitate rebellione facta recluditur et alias civitates atque castella secum contra patrem rebellare facit. quae causa provincia Hispaniae tam Gothis quam Romanis maioris exitii quam adversariorum infestatio fuit. III ano de Tibério XI de Leovigildo, 3.
} 
até mesmo a religião dos cronistas não foi determinante uma vez que nenhum deles apoiou a revolta do príncipe na Baetica.

Não obstante durante o reinado dos reis arianos a questão religiosa não parecia central, na verdade a perseguição contra os católicos era rara e ocorreu em momentos críticos, por exemplo, após a rebelião de Hermenegildo, quando Leovigildo exilou alguns católicos, como relatou Isidoro de Sevilha. Todavia, a narração desses exílios surgiu depois da revolta, o que indica que a perseguição pode ter sido mais uma resposta aos apoiadores do filho rebelde. Não se tratava assim de fato de uma perseguição motivada pela religião propriamente dita, mas antes uma resposta política aos apoiadores de Hermenegildo. O que se destaca antes de tudo é que a despeito da dita perseguição aos católicos o balanço final feito por Isidoro e mesmo por João de Biclaro acerca do reinado de Leovigildo foi positivo: ele expandiu as fronteiras do reino, comandou guerras vitoriosas contra os bizantinos que desde a rebelião de Atanagildo eram uma ameaça na Baetica e anexou o reino dos suevos. Em termos gerais o que se pode dizer sobre a política religiosa dos reis arianos é que eles conviviam relativamente bem com os católicos, permitindo até mesmo reuniões conciliares de bispos católicos como exemplifica o II Concílio de Toledo de 527 que ocorreu com a autorização de Amalarico. A partir dessas informações dificilmente poderíamos defender a hipótese de que Hermenegildo era motivado pela fé quando se ergueu contra o pai.

Talvez o contexto da Baetica pode nos trazer pistas mais consistentes. A região era um centro de tensão para os reis visigodos. Um bom exemplo disso é a própria rebelião de Atanagildo ocorrida por volta de 551 que teve início da Baetica, com a assistência de forças bizantinas Atanagildo venceu e se tornou o rei da Hispania. A revolta de Atanagildo indica o complexo contexto do Sul da Hispania, quase três 
décadas depois de sua rebelião vitoriosa Hermenegildo começou uma revolta justamente de lá. Possivelmente não estamos lidando com uma coincidência.

De acordo com García Moreno ${ }^{348}$ a Baetica era uma região com uma considerável presença da nobreza goda, mas a presença dessa nobreza não criou um senso de solidariedade entre os nobres da região e os reis, pelo contrário, a região permaneceu um foco de rebeliões, talvez mesmo com aspirações separatistas. Ainda, desde a rebelião de Atanagildo as forças bizantinas mantinham a Baetica como uma importante fonte de ameaça à autoridade dos reis godos no Sul da Península. Não é absurdo supor que Leovigildo escolheu seu filho para reinar na Baetica objetivando reforçar a autoridade real na área, não apenas para garantir que seu filho o sucederia no trono. A questão é que a opção de Leovigildo por enviar seu filho à Baetica poderia ser antes de tudo um movimento político para lidar com duas ameaças: a presença do exército bizantino na região e a oposição dos nobres da região contra a autoridade do rei. A oposição dos nobres e as intenções separatistas deles poderiam ser sintoma da emergência de uma identidade local nobiliárquica distinta do sentimento de perecimento ao reino. Tal hipótese se fortalece se retomarmos as leges visigothorum, a lei II, 1, VI atribuída a Recesvinto relaciona diretamente os rebeldes à traição à Pátria dos Godos (Gotorum patria) e à gens dos godos:

Ut ergo tam dira temeritas tandem victa depereat, et in huiusmodi transgressoribus manifesta iscelera non relinquantur ulterius inpunita, hac omne per evum valitura lege sancimus, ut quicumque ex tempore reverende memorie Chintilani principes usque ad annum Deo favente regni nostri secundo vel amodo et ultra ad adversam gentem vel extraneam partem perrexit sive perrexit aut etiam ire voluit vel quandoque voluerit, ut sceleratissimo ausu contra gentem Gotorum vel patriam agere aut fortasse conetur aliquetenus agere, et captus sive detectus extitit vel extirerit, sive ad anno regni nostri primo vel deinceps quispiam infra fines patrie Gotorum quamcumque conturbationem aut scandalum in

\footnotetext{
${ }^{348}$ GARCÍA MORENO, L.A. Transformaciones de la Bética durante la Tardoantigüedad. Mainake. $n$. XXIX, p.433-471, 2007. p.436-37.
} 
contrarietatem regni nostri vel gentis facere voluerit, sive ex tempore nostri regiminis tale aliquid agere vel disponere videtur, in necem abiectionem nostram sicem subsequentium regum intendere vel intendisse proditus videtur esse vel fuerit: horum omnium scelerum vel unius ex his quisque reus inventus inrectractabilem sententiam mortis excipiat, nec ulla ei de cetero sit vivendi libertas indulta. $^{349}$

Muito embora isso possa ser um argumento puramente retórico, os movimentos rebeldes do Sul da Península indicam que poderíamos falar da existência de movimentos separatistas liderados por nobres locais, mais ainda, tal como indicam as rebeliões de Atanagildo e de Hermenegildo, que esperava contar com o apoio das forças bizantinas para vencer o pai, esses movimentos não raro recebiam o suporte de forças estrangeiras. Temos então uma nobreza local sem o sentimento de pertencimento à pátria e que por vezes não hesitava em buscar apoios de outros reinos para atingir seus objetivos. O que queremos argumentar com isso é que as identidades dessas elites eram não raro mais fluídas do que os termos "nobreza goda" ou "nobreza hispano-romana" podem levar a crer.

Quase cem anos depois uma outra revolta relacionada com a oposição da nobreza aos reis ocorreu no reino visigodo, mas nesse caso o centro da rebelião foi a Galia Narbonense, uma região descrita pela a principal fonte sobre a insurreição, a Historia Wambae, como "a mãe da traição". ${ }^{350}$

Em 672 após a morte do rei Recesvinto o vir illustris Wamba foi escolhido como o novo rei visigodo. De acordo com a Historia Wambae, escrita pelo bispo de Toledo Juliano, um contemporâneo do rei, ${ }^{351}$ Wamba foi escolhido por toda a gente e

\footnotetext{
${ }^{349}$ Ver tradução 24, anexo 1.

${ }^{350}$ Huius igitur gloriosis temporibus Galliarum terra, altrix perfidiae, infamy denotatur elogio, quae utique inextimabili infidelitatis febre uexata genita a se infidelium depasceret membra. Historia Wambae, 5.

${ }^{351}$ Sobre a posição de Juliano como uma testemunha ocular dos eventos narrados: TEILLET, S. L'Histoire Wambae est-elle une oeuvre de circunstante? Los visigodos. Historia y civilización. Antigüedad y Cristianismo, III, p.415-424, 1986.
} 
a patria e recebeu a unção dos sacerdotes. ${ }^{352} \mathrm{~A}$ unção de Wamba pode ser tomada como um intento dos bispos por legitimar a autoridade do rei, não apenas porque ela confirmou a legitimidade da eleição, mas também porque a narração do evento recebeu uma caracterização muito próxima à narrativa hagiográfica, o novo rei, tal como muitos santos, alegou que ele não era digno de tamanha dignidade. Ainda, as informações acerca da unção e da correção do rei foram elemento que indicavam o quanto Juliano estava muito preocupado em acentuar a legitimidade de Wamba como o novo rei. As preocupações de Juliano, como o desenrolar da narrativa indica, eram relevantes.

Tão-logo Wamba se tornou rei ele enfrentou uma revolta na Galia Narbonense começada por Ilderico, o comes de Nemeausus apoiado pelo bispo Gumildo de Magalona e o abade Ranimiro. Os insurgentes prenderam o bispo Aregio, que se opôs à rebelião, e o enviaram aos francos. ${ }^{353}$ Para lutar contra a insurreição, Wamba enviou um dos seus duces, Paulo. Entretanto Paulo traiu a confiança do rei e começou ele mesmo uma rebelião contra Wamba apoiado pelos duces da Tarraconense, Ranosindo e Hildigiso. $^{354}$

A rebelião de Paulo ganha nuanças ainda mais interessantes quando confrontada com a rebelião de Hermenegildo. Tal como no caso de Hermenegildo, Paulo foi enviado para representar o rei numa região marcada por tensões políticas e tal como o antigo príncipe ele se tornou um rebelde. Todavia, o contexto da revolta de Paulo era substancialmente diverso: durante o século VII os reis visigodos eram já

\footnotetext{
${ }^{352}$ Adfuit enim in diebus nostris clarissimus Wamba princeps, quem digne principari Dominus uolit, quem sacerdotalis unction declarauit, quem totius gentis et patriae communion elegit, quem populorum amabilitas exquisiuit, qui ante regni fastigium multorum reuelationibus celeberrime praedicitur regnaturus. Historia Wambae, 2. Wamba foi o primeiro reis que inquestionavelmente recebeu a unção dos bispos. Essa foi uma inovação no contexto dos reinos bárbaros. Um estudo referencial importante sobre isso pode ser consultado em: BARROSO CABRERA, R. \& MORÍN DE PABLOS, J. Imagen soberana y unción regia en el reino visigodo de Toledo. Codex Aqvilarensis. Cuadernos de investigación del Monasterio de Santa María la Real. n.20, p.6-65, 2004.

${ }^{353}$ Historia Wambae, 6.

${ }^{354}$ Historia Wambae, 7.
} 
católicos, de modo que definitivamente a questão religiosa está eliminada como causa da rebelião. Não obstante a rebelião de Paulo tem um outro elemento ainda mais interessante: a participação dos Francos.

Na Historia Wambae a participação dos francos na rebelião é evidente em dois momentos: quando Ilderico enviou Aregio aos francos e quando Paulo convocou os francos para apoiá-lo. Entretanto, não devemos entender o apoio dos francos à revolta de Paulo como um suporte advindo do reino dos francos à revolta, na verdade os francos que assistiram Paulo eram também rebeldes liderados por Lupo, um homem que estava lutando contra o rei franco Clotário III na Aquitânia. ${ }^{355}$

Nós estamos na verdade lidando com dois movimentos rebeldes que uniram dois grupos nobres de diferentes origens que se opunham à autoridade de dois reis, o franco Clotário e o visigodo Wamba, numa grande região entre a Galia Narbonense, Aquitânia e Tarraconense. O que podemos dizer sobre isso é que talvez a identidade política que unia esses grupos não se relacionava com o pertencimento a um reino específico ou a uma suposta identidade étnica, tal solidariedade transcendia as fronteiras dos reinos e nos abrem uma nova perspectiva: quando nos confrontamos com a oposição da nobreza à autoridade real devemos superar a idéia dos reinos bárbaros como unidades políticas coerentes que podem ser analisadas isoladamente.

Tendo em vista a especificidade das identidades nobres o termo "identidades políticas" parece uma boa opção uma vez que amplifica o aparato conceitual ao não fechar a análise num senso de pertencimento puramente étnico ou nacional. Isso é verdade para o caso da revolta de Hermenegildo, quando os nobres não pareciam estar conectados a um senso de pertenciamento a um grupo étnico e ainda mais claro no exemplo da revolta de Paulo na qual a transcendência identitária é muito evidente.

\footnotetext{
${ }^{355}$ FRIGHETTO, R. Memória, História e identidades: considerações a partir da Historia Wambae de Juliano de Toledo (século VII). Revista de História Comparada. v.5, n.2, p.50-73, 2011. p.61.
} 
Assim, num contexto de disputas políticas, as identidades políticas regionais dos nobres entravam em tensão com o argumento identitário da unidade da patria gothorum liderada pelos reis. Traí-los era trair a pátria, a gens. Nesses movimentos de insurreição advindos de nobrezas regionais observamos ainda que não raro alianças com "inimigos" de outros reinos ocorriam.

O reconhecimento desse fato aparece não só nas leges visigothorum, mas também nas atas conciliares e isso desde antes da conversão dos godos. Como muito bem mostrou Werner, ${ }^{356}$ mas também mostram as fontes, como no caso do apoio dos bispos à primeira rebelião de Ilderico, os bispos devem ser incluídos no que entendemos como a nobreza e isso sem criarmos um contraste entre uma "nobreza laica" e "uma nobreza episcopal". Como parte da nobreza eles estavam profundamente envolvidos nas disputas políticas a ponto de um rei ariano ter se preocupado em evitar que bispos de outros reinos participassem das atividades do clero católico do reino visigodo, como podemos constatar pela leitura das atas do II Concílio de Toledo de 527:

Pari ratione cognovimus quod ad consecrationem basilicum alienae sortis a vobis episcopi invitentur, et licet sint unius fidei copula nobiscum in Christo conexi, tamen nec provinciae privilegium nec rerum Domini noscitur utilitatibus convienire, quia iam ad ipsum huiuscemodi fama perlata est, ideoque salubre ordinatione censuimus, ut si quando talis necessitas incubuerit, litteris nos informare debeatis, et aut per nos aut per eum qui nobis ex fratribus et coepiscopis nostris visus fuerit et consecratio ecclesiarum. Deo auspice, poterit celebrari. ${ }^{357}$

A ingerência de bispos de outros reinos foi assim descrita como ruim não só para a província eclesiástica, mas para o próprio reino como um todo. $\mathrm{O}$ pertencimento ao reino, nesse caso, se sobressai à própria filiação à fé católica. Nesse sentido o papel dos bispos reunidos em concílios era um instrumento de afirmação

\footnotetext{
${ }^{356}$ WERNER, K.F. Nascita della nobiltà...op.cit.

${ }^{357}$ Ver tradução 25 , anexo 1.
} 
régia mesmo antes da conversão ao catolicismo levada a cabo por Recaredo. O que se pretende dizer aqui é que as atas conciliares da Hispânia visigoda consistem numa importante fonte de informação sobre a política do reino, inclusive acerca das alianças feitas entre nobres, independente dos cargos que ocupavam, com gentes de outros reinos que ameaçavam o rei, como indica as atas conciliares do VII Concílio de Toledo:

Ideoque placuit nunc concordi setentia definire: Ut quisquis in ordine clericatus a maximo gradu usque ad minimum constitutus in alienae gentis regionem se quaquumque occasione transduxerit, ut exinde superbiendo vel reditum suum vel quolibet aliud vidcatur expetere, sive etiam quod gentem Gothorum vel patriam aut regem specialiter sub hac occasione possit nocere vel fieri disposuerit vel aliquatenus fecerit sed et qui cum talibus conscius repperitur eisque vel consilium vel opem admnistrasse cognoscitur qualiter aut gentem alienam fugam adpeterent aut in malis quae coeperant perdurarent seu quamquumque laesionem genti Gothorum vel patriae aut principi post fugam inferrent, aut qui in eadem pravitatem perseveraturos dinoscitur suasisse, iste ita indubitanter omni honoris sui gradu privetur, ut locum eius in quo ministraverat alter continuo perpetiam regendum accipiat $[\ldots]^{358}$

Diante de latentes ameaças advindas de nobrezas regionais era essencial aos reis manter alianças com esses nobres, e isso não era verdade apenas para o século VII, é algo que podemos observar ainda no século VI. ${ }^{359}$ Nessas políticas de alianças as identidades cumpriam um papel importante, para fazer frente aos nobres opositores aliados com reinos estrangeiros emergia o discurso da unidade da pátria mantida em torno do rei: uma política identitária em contraste com identidades políticas locais e fluidas que forneciam o aparato de legitimidade para a oposição ao argumento centralista de Toledo.

Um movimento sensivelmente distinto é observável na Gália Merovíngia onde a

\footnotetext{
358 [...] VII Concílio de Toledo, I. Tradução 26, anexo 1.

${ }^{359}$ Como bem observa C. Martin: MARTIN, C. Des fins de règne incertaine: répression et amnistie des groupes aristocratiques dans le royaume de Tolède (Deuxième moitié du VIIe siècle). In: BOUGARD, F., FELLER, L. \& LE JAN, R. Les élites au haut Moyen Age. Crises et Renouvellements. Turnhout: Brepols, 2006. p.207-223.
} 
política dos reis merovíngios assumiu tonalidades diversas em relação a política dos reis visigodos principalmente porque aparentemente os reis francos foram mais flexíveis com as nobrezas locais. Talvez essa flexibilidade se explique pela própria peculiaridade da organização do reino dos francos dividido em três principais reinos. Com tal divisão era mais fácil para os reis controlar as alianças com os nobres locais afastando assim o risco de rebeliões separatistas ou até mesmo golpes contra a sucessão hereditária. Isso ocorreu quando Chilperico ameaçou Childeberto que só conseguiu assumir o trono de seu pai com o apoio de Gontrão e dos nobres, como exemplificamos no capítulo anterior. Ou quando eles impediram o golpe de Grimoaldo que tentou colocar seu filho no trono da Austrásia em detrimento a Dagoberto, filho de Sigiberto. ${ }^{360}$

O que há em comum entre os visigodos e os francos, devemos ressaltar, é a importância da participação dos nobres na administração do reino, entre os francos, entretanto, o peso desses nobres se incrementou ao longo do tempo. Não podemos afirmar que algo semelhante não correu na Hispânica visigoda, entretanto, pela maior disponibilidade de fontes que documentam a história da Gália sob a autoridade dos merovíngios o crescimento da importância dos nobres ao longo do tempo é mais facilmente observável. Isso não quer dizer ainda que eles não fossem importantes desde o tempo de Clóvis, como argumentamos no capítulo anterior, mas é notável o quanto eles ganham mais protagonismo nas disputas políticas do reino como podemos observar a partir do estudo comparativo entre as histórias de Gregório de Tours, Fredegário e o Liber Historiae Francorum.

\footnotetext{
${ }^{360}$ [...] defuncto Sighiberto rege, Grimoaldus filiam eius parvolum omine Daygobertum totundit Didonemque Pectavensem rubis episcopum in Scocia peregrinandum eum direxit, filium suum in regno constituens. Franci itaque hoc valde indignantes, Grimoaldo insidias preparant, eumque exementes, ad condempnandum rege Francorum Chlodoveo deferunt. In Parisius civitate in carcere mancipatus, vinculorum cruciatu constrictus, ut erat morte dignus, quod in domino suo exercuit, ipsius mors valido cruciatu finivit. Liber Historiae Francorum [LHF], 44.
} 
É perceptível o quanto em Fredegário, especialmente a partir do livro IV, os nobres ganham um peso cada vez maior e, mais importante, o peso das nobrezas regionais é assentuado. Esse tema será melhor desenvolvido no capítulo sobre as histórias, mas cabe adiantar que a partir do livro IV há uma significativa redução do emprego do termo gens francorum no sentido de uma unidade e o aumento da recorrência de referências a nobrezas e identidades locais. A referência à Austrásia, Nêustria e Burgúndia, algo que só aparece com raridade a partir do livro III, ganha destaque no livro IV sendo essas entidades mencionadas nos seguintes capítulos:

\begin{tabular}{|l|l|l|}
\hline Austrásia & Burgúndia & Nêustria \\
\hline$\bullet 16$ & $\bullet 1$ & $\bullet 42$ \\
$\bullet 19$ & $\bullet 15$ & $\bullet 47$ \\
$\bullet 35$ & $\bullet 16$ & $\bullet 55$ \\
$\bullet 37$ & $\bullet 27$ & $\bullet 56$ \\
$\bullet 38$ & $\bullet 38$ & $\bullet 60$ \\
$\bullet 40$ & $\bullet 41$ & $\bullet 62$ \\
$\bullet 41$ & $\bullet 42$ & $\bullet 74$ \\
$\bullet 42$ & $\bullet 43$ & $\bullet 76$ \\
$\bullet 43$ & $\bullet 44$ & $\bullet 79$ \\
$\bullet 47$ & $\bullet 47$ & $\bullet 80$ \\
$\bullet 52$ & $\bullet 55$ & $\bullet 90$ \\
$\bullet 53$ & $\bullet 56$ & \\
$\bullet 54$ & $\bullet 58$ & \\
$\bullet 58$ & $\bullet 74$ & \\
$\bullet 59$ & $\bullet 76$ & \\
$\bullet 61$ & $\bullet 78$ & \\
$\bullet 68$ & $\bullet 79$ & \\
$\bullet 74$ & $\bullet 80$ & \\
$\bullet 75$ & $\bullet 89$ & \\
$\bullet 76$ & $\bullet 90$ & \\
$\bullet 83$ & & \\
$\bullet 85$ & & \\
$\bullet 88$ & & \\
\hline
\end{tabular}

É perceptível então o quanto em Fredegário as nobrezas regionais ganham um peso maior no desenrolar das tensões políticas no reino, algo que fica ainda mais 
explícito no Liber Historiae Francorum onde a fragilidade dos reis em relação à nobreza se destaca a ponto de os nobres passarem a representar os grandes responsáveis pelo curso da história no reino. Mas, como já afirmamos, isso não significa que os nobres não fossem já forças políticas importantes muito antes do século VII.

Nos Decem Libri Historiarum de Gregório de Tours, um documento do século VI, já é possível observar a força desses nobres.

Logo de início percebemos que as hierarquias descritas por Isidoro de Sevilha em suas Etimologias aparecem no texto do bispos de Tours. Há os duces, os comes, os vicários e os patrícios, assim como os epíscopos que exerciam também uma enorme participação política. Cabe observar então em Gregório de Tours qual era o papel desses homens. Os duces aparentemente cumpriam uma função semelhante aquela cumprida no reino dos visigodos. Eles eram responsáveis por liderar exércitos, como o duque Beppoleno liderou um contra os Bretões, ${ }^{361}$ mas também eram responsáveis pela administração de cidades, como indica o caso do dux Ragnovaldo que era responsável por Périgueaux até que a perdeu para o dux Desidério que tomou a cidade em nome do rei Chilperico. ${ }^{362}$ De fato, a importância dos duces não é de se ignorar e a prerrogativa de governo que eles possuíam é ainda mais evidente nos documentos da Gália do que da Hispânia.

Quando Chilperico tentou impedir que Childeberto assumisse o trono de seu pai Sigeberto o dux Gondovaldo apoiou Brunilda e garantiu que o jovem príncipe chegasse ao trono. ${ }^{363}$ Algum tempo depois o dux de Champagne, Lupo, começou a ser perseguido por Ursiono e Bertefredo que o queriam derrotar. Brunilda intercedeu a favor de Lupo e foi advertida por Ursiono: o jovem filho da rainha havia chegado ao

\footnotetext{
${ }^{361}$ DECEM LIBRI HISTORIARUM, 1.V, c.XXIX.

${ }^{362}$ DECEM LIBRI HISTORIARUM, I.VI, XII.

${ }^{363}$ DECEM LIBRI HISTORIARUM, V, I
} 
trono não graças a Lupo, mas graças a ele e Bertefredo:

Lupus vero dux Campanensis, cum iam diu a diversis fategaretur et spoliaretur assiduae et praesertim ab Ursione et Berthefredo, ad extremum conventione facta ut occideretur, commoverunt exercitum contra eum. Quod cernens Brunichildis regina, condolens fidelis sui insecutiones iniustas, praecingens se viriliter inrupit medios hostium cuneos, dicens: 'Nolite, o viri, nolite malum hoc facere nolite persequere innocentem; nolite pro uno hominem committere proelium, quo solatium regionis intereat. Haec illa loquente, respondit Ursio: 'Recede a nobis, o mulier. Sufficiat tibi sub viro tenuisse regnum; nunc autem filius tuus regnat, regnumque eius non tua, sed nostra tuitione salvatur. Tu vero recede a nobis, ne te ungulae equorum nostrorum cum terra confodiant. ${ }^{364}$

O que se percebe é que foi antes graças à facção de Bertefredo e Ursiono, que possivelmente era a mesma de Gundovaldo que garantiu a elevação de Childeberto ao trono, que Brunilda e seu filho reinavam. É provável que esse grupo fosse inimigo do grupo de Lupo que Brunilda tentava proteger. Ela foi advertida que dependia do grupo dos adversário de Lupo. E essa facção foi bem sucedida de modo que Lupo escapou e buscou a proteção de Gontrão.

Num outro capítulo muito complexo o papel desses nobres se destaca ainda mais, trata-se do capítulo XI do livro VI. Nele vemos Childeberto mais velho e aliado com Chilperico, o tio que outrora tentou impedir que ele reinasse. Childeberto reclamou a parte da cidade de Marselha que cabia a ele como herança de seu falecido pai e que estava sob o domínio de Gontrão.

O capítulo, entretanto, começa com a querela entre o rector Dínamo e o bispo de Marselha, Teodoro. Segundo Gregório, o bispo estava sendo perseguido por Dínamo e portanto tentou chegar a Childeberto para buscar ajuda, contudo acabou sendo aprisionado por Gontrão. Foi quando Childeberto enviou representantes para Gontrão a fim de obter sua parte de Marselha, pedido este recusado pelo rei da Burgúndia. Childeberto então enviou Gondulfo, que fora parte de seu séquito e era de

\footnotetext{
${ }^{364}$ DECEM LIBRI HISTORIARUM, VI, IV. Ver tradução 27, anexo 1.
} 
família senatorial e havia sido promovido a dux (Haec cernes Chindebertus, Gundulfum ex domestico duce facto, de venere senatorio, Massiliam dirigit) para atuar. Gondulfo todavia não pode passar pelo reino de Gontrão que estava com as passagens fechadas e acabou se hospedando por cinco dias em Tours onde foi recebido por Gregório que o reconheceu como parente de sua mãe (Qui cum non auderet ambulare iam per Guntchramni regnum, Turonus venit. Quem benigna susceptum recognosco matais mear avunculum esse, retentumque mecum quinque diebus, inpositisque necessariis, abire permisi). Depois desses dias em Tours, quando tomamos notícia de que Gondulfo estava ligado por laços familiares a Gregório de Tours e que era um homem que fazia parte do séquito de Childeberto enviado para resolver as querelas de Marselha, encontramos a narrativa da chegada de Gondulfo à cidade, sua luta e vitória contra Dínamo e a restituição de Teodoro ao bispado assim como à tomada de domínio de Marselha em nome de Childeberto, o que deixou Gontrão enraivecido.

Nessa complexa narrativa temos muitos personagens nobres que merecem atenção. Primeiro a intervenção de Gondulfo em nome de Childeberto nos problemas entre o bispo e o rector indica que a briga entre eles tinha um fundo político, a saber, muito provavelmente Dínamo era um aliado de Gontrão contra Teodoro que era aliado de Childeberto, não por acaso assim que Gondulfo vence ele restitui Teodoro ao bispado de Marselha, isso marca a posição de Childeberto na cidade que agora estava sob sua a autoridade. Não obstante, o fato de Gontrão ter aprisionado Teodoro indica que ele tentou neutralizar um apoiador de Childeberto que por sua vez estava aliado com Chilperico, um grande inimigo do rei da Burgúndia.

Os jogos de poder nas cidades envolvendo os nobres assim tinham íntima relação com as disputas políticas entre os reis. Estamos diante de facções 
nobiliárquicas que se aliavam com determinados reis e se opunham a outras facções que eram aliadas ao rei antagonista. Algo que já observamos no caso de Lupo que buscou abrigo na corte de Gontrão e, podemos ir além, as inimizades entre Ursiono e Berthefredo contra Lupo podem ter sido causadas justamente pela proximidade entre Lupo e o rei da Burgúndia. Podemos estar assim diante da afirmação da autonomia dos nobres da Austrásia que apoiaram Childeberto e Brunilda, mas contavam que tanto o rei quanto a rainha estivessem sempre ao lado deles contra, talvez, uma nobreza burgúndia que estava aliada a Gontrão. Nobreza esta ligada a Gontrão contra a qual um nobre advindo da corte austrasiana, Gondulfo, combateu em Marselha.

Todos esses exemplos apontam para a existência de uma nobreza politicamente relevante localizada em regiões específicas e que serviam de apoio para os reis, ou mesmo representavam oposição aos reis como no caso do bispo Teodoro que muito possivelmente estava contra o rei da Burgúndia Gontrão. A participação de Teodoro nessas disputas reforça ainda algo que já salientamos, a saber, a divisão entre uma nobreza eclesiástica e uma nobreza laica não era evidente no calor das tensões políticas, mesmo que alguns autores tenham feito essa divisão baseando-se numa distribuição dos cargos da nobreza laica e eclesiástica a partir da origem galo-romana e franca, ${ }^{365}$ nas narrativas sobre as querelas políticas entre esses nobres a origem franca ou galo-romana não determinava a filiação à uma facção, o fato é que todos, bispos ou duces estavam envolvidos nas disputas políticas, e mesmo um $d u x$ que era certamente de origem galo-romana, já que Gregório o retratou como pertencente a uma família senatorial a qual ele mesmo, Gregório, estava ligado, não só não cumpria uma função na hierarquia eclesiástica como, a despeito de sua origem, fazia parte do

\footnotetext{
${ }^{365}$ Como: GEARY, P. Le monde Mérovingien. Naissance de la France. Paris: Flammarion, 1989. Original: Before France and Germany. The Creation and transformation of the Merovingian World. Oxford: Oxford University Press, 1988. p.196-208. Mas é preciso ressaltar que para Geary essa divisão estava clara tão-somente até o surgimento do monasticismo de Colombano na Gália, a partir do qual a nobreza franca passa a assumir com mais amplitude cargos eclesiásticos.
} 
séquito de Childeberto e liderou um exército contra a facção de Marselha aliada a Gontrão e representada pelo rector Dínamo.

Assim, qualquer qualificativo que resuma a participação na política à filiação a uma origem "étnica" e a um cargo na nobreza - laica ou eclesiástica - é arbitrária. Em todas essas disputas não há qualquer menção relevante nem ao reino dos francos, nem a ser um franco e tampouco a ser um romano. Isso não quer dizer que o argumento em torno da gens francorum ou do reino dos francos jamais aparecesse, como aponta o exemplo dos novos conflitos que ocorreram em Marselha e mais uma vez envolveram o bispo Teodoro.

Nosso narrador é ainda Gregório de Tours nos seus Decem Libri Historiarum, livro VI, capítulo XXIV. Ele contou a história do retorno de Gondovaldo à Gália. Gondovaldo se dizia filho de Clotário I algo que o próprio rei não reconheceu. Após não ser reconhecido por Clotário Gondovaldo foi à Constantinopla onde recebeu instrução. Passado algum tempo o pretenso príncipe retornou à Gália, por razões não esclarecidas, e foi recebido por Teodoro, o bispo de Marselha. Os duces Mumolo e Gontrão-Boso descobriram a presença de Gondovaldo em Marselha e ordenaram a prisão de Teodoro por ter recebido um estrangeiro na Gália e ameaçar assim os francos com a dominação do Império Oriental.

Erat autem tunc Mummolus in civitate Avennica, sicut supra iam diximus Gunthchramnus vero dux adpraehensum Theodorum episcopum in custodia pro hac causa detrusit, repotans, cur hominem extraneum intromisissit in Galliis voluissetque Francorum regnum imperialibus per haec subdere ditionibus. ${ }^{366}$

Gontrão mais uma vez interveio e manteve o bispo no cárcere, algo que indica que as disputas descritas anteriormente não tinham terminado. Se na primeira vez Gontrão não conseguiu neutralizar Teodoro graças à intervenção do $d u x$ de Childeberto, agora ele encontrara uma outra razão para manter o bispo prisoneiro: a

\footnotetext{
${ }^{366}$ DECEM LIBRI HISTORIARUM, VI, XXIV. Ver tradução 28, anexo 1.
} 
ameaça contra os francos representada pela presença de um pretenso príncipe merovíngio vindo de Constantinopla. A questão com a qual lidamos é o recurso ao argumento unitário do reino contra uma ameaça externa, a primeira vista, mas num nível mais profundo o uso desse discurso unitário no seio de disputas que opunham a nobreza de Marselha representada pelo bispo Teodoro e Gontrão e seus aliados. Nesse sentido, Teodoro e Gondovaldo foram retratados como uma ameaça imediata ao reino certamente numa reação às disputas que opuseram Teodoro/Childeberto Dínamo/Gontrão, e nessa resposta o discurso identitário do reino foi evocado contra um grupo nobiliárquico específico, o que se enquadra na nossa proposta de uma análise das políticas identitárias.

Como demonstrado até aqui em Gregório de Tours a atuação de grupos nobiliárquicos regionais cumpria um importante papel no desenrolar de alguns eventos descritos, todavia, as referências a esses grupos no texto do turonense são esparsas. Não porque esses grupos não fossem importantes para a política da Gália no século VI, mas porque narrar a atuação deles não era o objetivo principal de Gregório. Como indica o prefácio do livro $\mathrm{V}$, eram as guerras nas quais estavam envolvidos os reis que constituíam o tema privilegiado pelo bispo de Tours. Nessas guerras, como apontamos até aqui, observamos a atuação de nobres, mas, mais uma vez, eram os reis que eram os protagonistas da narrativa Gregoriana.

Isso se modifica no século VII. É notável, por exemplo, como a atuação de nobres ganha maior relevo na crônica de Fredegário. Podemos trazer como o primeiro exemplo o caso do dux Crodino, cujo óbito é mencionado por Gregório de Tours que também exaltou as qualidades do $d u x$ : ele era bom e generoso com as igrejas, empreendeu obras em vilas e palácios e ajudava os mais pobres. Suas boas ações eram 
tantas que demandariam um longo texto para descrevê-las. ${ }^{367}$ No livro III das crônicas de Fredegário, considerado um trecho que sofreu enorme influência dos Decem Libri Historiarum ${ }^{368}$ o dux Crodino é também mencionado, todavia, temos mais informações sobre ele. Fredegário o localizou como um nobre da Austrásia que havia sido escolhido pelos austrasianos para se tornar o maior domus de Sigiberto. Crodino declinou, sua justificativa é de grande interesse:

'Pacem ego in Auster facere non valeo, maxime omnes primati cum liberis in totum Auster mihi consanguinei sunt; non posso ex eis facere disciplinam nec quemquam interfecere. Ipse vero per me insurgunt, ut agant supersticiose. Eorum acta non permittat Deus, ut me inferni claustra tradant. Elegite alium quem vultis ex vobis ${ }^{369}$

A partir de Fredegário temos ciência de que Crodino não só era um homem ilustre da Austrásia como estava ligado por laços sangüíneos com muitos outros nobres da região e que por causa disso não teria condições de controlá-los e garantir a paz na Austrásia! Nessa narrativa se revela algo que já apontamos, a saber, em Fredegário gradativamente essas nobrezas regionais identificadas como austrasiana, nêustrina ou burgúndia ganham importância a ponto de no livro IV, como indica a tabela por nós mencionada, se tornarem agentes de maior relevo na narrativa. Essas nobrezas, nas quais alguns grupos estavam ligados por laços de consangüinidade, deveriam ser constantemente apaziguadas para garantir, como testemunham as supostas palavras de Crodino, a paz.

A relevância desses grupos nobiliárquicos é ainda mais evidente no Liber

\footnotetext{
${ }^{367}$ Eo anno Chrodinus obiit, vir magnifice bonitatis et pietatis, aelimosinarius valde pauperumque refctor, profluus ditatur eclesiarum, clericorum nutritur. Na, sepe a novo fundans villas, ponens vinias, aedificans domus, culturas eregens, vocatis episcopis, quorum erat parva facultas, dato epulo, ipsas domus cum culturibus et culturis, cum argento, parastromatibus, untensilibus ministris et famolis benigne distribuenat, dicens: 'Sint haec aeclesiare data, ut, dum de his pauperes reficiuntur, mihi veniam obteneant apud Deum'. Multa enim et alia bona de hoc viro audivimus, quae insequi longum est. Transiit autem aetate septuagenaria. DECEM LIBRI HISTORIARUM, VI, 20.

${ }^{368}$ Como discutiremos no capítulo dedicado às histórias.

${ }^{369}$ Chronica de Fredegário III, 58. Tradução 29 anexo 1.
} 
Historiae Francorum. De fato, nesse texto a atuação destes nobres não raro se sobrepõe à autoridade do monarca cujo retrato na narrativa indica uma considerável fragilidade. Foram os nobres da Nêustria que após a morte de Clotário III (rei entre 657 e 673) elevaram Teodorico III (673 e 675-90) ao trono da Nêustria e Childerico II, irmão de Teodorico, ao trono da Austrásia. Tempos depois os nobres seriam os responsáveis pelo o assassinato de Childerico II e sua esposa grávida:

Ex quibus uno Franco nomine Bodilone ad stipitem tensum cedere valde sine lege precepit. Haec videntes Franci, in Ira magna commoti, Ingobertus videlicet et Amalbertus et reliqui maiores natu Francorum, sedicionem contra ipsum Childericum concitantes. Bodilo super eum cum reliquis surrexit, insidiaturus in regem; interficit una cum regina eius pregnante, quod dici dolor est. Liber Historiae Francorum $^{370}$

É a atuação dos nobres que passa a ser o elemento claro e determinante para que os reis merovíngios chegassem ao trono. Eram eles também que definiam se o rei terminaria ou não seu reinado. Bodilo, indicado pelos nobres da Nêustria, pôs fim à vida de Childerico II e a sua descendência quando assassinou a rainha grávida. Mas é interessante perceber uma peculiaridade no Liber Historiae Francorum: ao mesmo tempo que o texto revela toda a força das nobrezas regionais celebra a gens francorum, em especial seus reis de outros tempos, especialmente Clóvis, cujo o nascimento é já assinalado a partir do relato sobre Meroveo quando se adianta que ele seria o pai de Childerico que por sua vez seria pai de Clóvis [Ipse itaque Merovechus genuit filium nomine Childerico, qui fuit pater Chlodovecho rege inclyto atque fortissimo. (LHF, 6)] a valorização da figura de Clóvis é reafirmada quando o autor narra a relação entre Childerico e a mãe de Clóvis (LFH, 7) o autor da crônica diz que Clóvis foi o maior rei dos francos e grande guerreiro, a qualidade de guerreiro está intimamente atrelada com o exercício da autoridade real. $\mathrm{O}$ autor, seguindo muito

\footnotetext{
${ }^{370}$ Liber Historiae Francorum, 45.
} 
proximamente o relato de Gregório de Tours, então narra os feitos de Clóvis. A expansão de seu reino, a sua conversão ao catolicismo e a sua vitória contra os godos arianos.

Percebe-se pela narrativa dos primeiros capítulos do Liber Historiae Francorum, assim, uma celebração da dinastia merovíngia que entra em direto confronto com o desenrolar do texto que mostra a crescente degradação da autoridade dos herdeiros de Clóvis cada vez mais vulneráveis diante dos nobres. A narrativa do declínio da dinastia dos francos aparece também presente na Vita Domnae Balthildis mas sob uma perspectiva diversa: a descendência de Clóvis II e Balthilda foi descrita, junto com o consenso de alguns nobres, como a garantia da pacificação das tensões entre a Austrásia, Nêustria e Burgúndia:

Quid plura? Deo iubente, rex Chlodoveus, vir eius, migravit de corpore; relictaque sobole filiorum cum matre, suscepit ilico post eum filius eius Chlotharius quondam Francorum regnum tunc etenim precellentibus principibus Chrodoberhto episcopo Parisiaco et domno Audoeno seu et Ebroino maiores domus cum reliquis senioribus vel ceteris quam pluribus, et regno quidem Francorum in pace consistenti. Tunc etenim nuper et Austrasii pacifico ordine, ordinante domna Bathilde, per consilium quidem seniorum receperunt Childericum, filium eius, in regem Austri; Burgundiones vero et Franci facti sunt uniti. Et credimus, uniti. Deo gubernante, iuxta domnae Balthildis magnam fidem ipsa tria regna tunc inter se tenebant pacis concordiam. ${ }^{371}$

Ora, o que podemos notar pela comparação entre a Vita Domnae Balthildis e o Liber Historiae Francorum é que o relevo do papel dos nobres é dosado por um contraponto relacionado com a dinastia merovíngia, no primeiro caso, com a celebração de Clóvis, no segundo, com a descendência da rainha Balthilda, ambos os fatos colocam em relevo a unidade e a paz do reino dos francos na figura do rei em contraste com as nobrezas locais. São discursos distintos que se encontram em narrativas únicas que revelam as tensões entre identidades políticas regionais

\footnotetext{
${ }^{371}$ Vita Domnae Balthildis, 5.
} 
representadas pelo nobreza e a imagem do reino dos francos, centralizado pelos reis merovíngios: a identidade da unidade política "reino dos francos" e a polarização das identidades políticas das nobrezas da Austrasia, Nêustria e Burgúndia. Nesses confrontos, as identidades políticas ganham forma nas políticas identitárias tanto pela afirmação das autonomias regionais quanto pela afirmação da unidade da gens francorum inseridas na figura dos monarcas, que mesmo debilitados, ainda representavam a gens e o reino. Os exemplos da Vita Domnae Balthildis e do Liber Historiae Francorum indicam como essas tensões se concretizavam de maneiras diversas nas fontes, na história, com a celebração da descendência de Clóvis, na Vita, onde a memória da rainha era o principal tema, no valor de sua descendência. As peculiaridades dessas narrativas em torno das identidades políticas e das políticas identitárias em diversos estilos narrativos revelam ricas matizes narrativas forjadas no seio das tensões entre as nobrezas e os reis.

O confronto com os exemplos aqui trazidos concernentes a atuação dos grupos nobiliárquicos indica certos elementos que merecem destaque:

É bastante clara a existência de grupos nobiliárquicos regionais que poderiam representar tanto um relevante suporte à autoridade dos reis quanto uma ameaça a autoridade dos reis. Nesse sentido, estabelecer alianças com esses grupos era uma condição indispensável para o sucesso de um reinado. Como bem apontou C. Martin, ${ }^{372}$ um rei forte não se caracterizava por sobrepujar sua autoridade aos poderes nobiliárquicos, pelo contrário, eram pelas estratégias de alianças políticas que a autoridade real se afirmava. No jogo dessas alianças, disputas e dissensões o discurso

\footnotetext{
${ }^{372}$ MARTIN, C. Des fins de règne incertaine: répression et amnistie des groupes aristocratiques dans le royaume de Tolède (Deuxième moitié du VIIe siècle). In: BOUGARD, F., FELLER, L. \& LE JAN, R. Les élites au haut Moyen Age. Crises et Renouvellements. Turnhout: Brepols, 2006. p.207-223. Ainda: CASTELLANOS, S. \& MARTÍN VISO, I. The local articulation of central power in the north of the Iberian Peninsula (500-1000). Early Medieval Europe. v.13, n.1, p.1-42, 2005.
} 
identitário era evocado tanto para afirmar a unidade da patria gothorum ou mesmo da patria francorum em torno de seus reis, ou ainda para afirmar identidades regionais que justificavam as oposições aos reis.

A despeito dessas afirmações é preciso identificar os principais problemas que enfrentamos ao lidar com esses grupos. O primeiro dele é definí-los. A opção pelo termo "nobreza", como bem indicamos, se deve tão-somente à existência do termo nobilitas nas fontes, não entendemos, contudo, nobreza como um conceito fechado, ou seja, não partimos de pressupostos como a idéia de que a nobreza se restringia à hereditariedade. Entrar na nobreza não dependia sempre das origens dos indivíduos, mas ser já parte de uma família nobre era o primeiro passo para atuar como um nobre: ou seja, cumprir um papel importante na estrutura administrativa do reino, mas antes de tudo ser um agente no teatro político.

\section{As tantas faces das gentes - a gens gothorum e a gens francorum à luz das disputas políticas da Gália Merovíngia e da Hispânia Visigoda}

O principal objetivo da primeira e da segunda parte foi inicialmente fazer um apanhado geral sobre a gens gothorum e a gens francorum, primeiro a partir das fontes e, depois, a partir da historiografia. Observamos que a historiografia teve um papel central na atribuição de significado aos termos "godos" e "francos" - primeiro analisados como unidades étnicas, depois analisados como construções. Com esse percurso visamos localizar nosso trabalho tanto nas fontes quanto na historiografia sem criar com isso uma dicotomia entre "fontes" e "historiografia", o que queremos dizer com isso é que a compreensão das fontes passa antes de tudo pela compreensão da historiografia, é por isso que o confronto com as pesquisas será uma constante nesse trabalho. A discussão historiográfica não se encerra no primeiro capítulo, o 
capítulo segundo tal como o capítulo terceiro igualmente começam com a análise historiográfica. O que podemos perceber até aqui é que a despeito dos temas diversos contemplados pela historiografia problemas comuns transpassam toda a produção sobre o nosso tema, o fato é que o nacionalismo e a crítica ao nacionalismo ${ }^{373}$ que motivaram e motivam os historiadores dão a tônica para as interpretações sobre as fontes.

Ao constatar esse fato não temos a pretensão de nos colocar acima da historiografia, antes disso, queremos apenas explicitar os referenciais interpretativos com os quais lidamos. Nesse sentido, o segundo e o terceiro capítulo no que se refere à parte dedicada a historiografia lidam com dois temas que foram caros aos pesquisadores. O primeiro é o tema da realeza, que, como indicamos, era estuda motivada pela busca das origens dos Estados Nacionais europeus num movimento no qual a Alta Idade Média foi ignorada pela fragilidade dos reis ou valorizada como o período no qual as bases das nações modernas foram fundamentadas. Por outro lado as nobrezas, que não raro foram interpretadas como a principal causa da debilidade dos reis pelo exercício de suas autoridades regionais em contraste com o centralismo da realeza, se encaixam num debate ainda mais complexo relacionado com a continuidade de Roma - como revela a interpretação de Werner que via as nobrezas como a encarnação da autoridade pública - e a crise de Roma - como indica Wickham e sua abordagem que outorga ênfase ao sistema econômico que sustentava a autoridade real e/ou imperial e que teria sofrido um forte abalo no ocidente com o declínio da eficiência do fisco. Ao fim e ao cabo há um fio que conduz os debates em torno tanto da realeza quanto da nobreza: o que aconteceu no Ocidente principalmente a partir do século $\mathrm{V}$ e qual foi o resultado disso no processo histórico. Tal fio

\footnotetext{
${ }^{373}$ Algo bem apresentado por Cantor: CANTOR, N.F. Ideological and cultural foundations of European Identity in the Middle Ages. In: MCGUIRE, B.P. The birth of identities Denmark and Europe in the Middle Ages. Copenhagen: C.A. Reitzel Publishers, 1996. p.11-27.
} 
condutor era já presente quando a historiografia via o período sob um ponto de vista teleológico e continuou presente quando se passou a insistir no valor histórico do período por si só, sem necessariamente usá-lo para explicar as nações modernas: nesse sentido, o valor do período para explicar os Estados Nacionais modernos se restringiu a uma análise sobre como a historiografia do século XIX o usou.

Nosso problema central parte dos dois aspectos primordiais analisados pela historiografia na análise dos desdobramentos históricos explicitados: a realeza e a nobreza. Acreditamos que o privilégio dado pela historiografia a esses aspectos não é gratuito. De fato em nossas fontes são essas forças que se sobressaem ora em contraste, ora em alianças. Nossa pergunta entretanto é: como nesses movimentos políticos as narrativas acerca das identidades eram usadas tanto nas políticas identitárias quanto nas identidades políticas encerradas nos discusos incutidos nos diversos significados da gens francorum e da gens gothorum?

O segundo e o terceiro capítulo, mediante alguns exemplos selecionados por indicarem bem os contrastes entre o "ideal" acerca dos agentes e a "prática" de suas ações tal como narradas nas fontes objetivaram antes de tudo apresentar as forças com a qual lidaremos ao longo de todo esse texto. Não se trata, portanto, de esgotar a discussão. Como veremos na análise de diversas fontes, tal como variavam os significados dos termos "godos" e "francos", variavam também as imagens acerca dos reis e dos nobres. A segunda parte é dedicada a discutir justamente a multiplicidade desses significados sempre com vistas ao fato de que as identidades godas e francas mudavam conforme os agentes que as evocavam, conforme as narrativas que as descreviam, conforme as tensões que se desenrolavam. Mas antes de partirmos para o segundo momento da tese é pertinente contemplarmos as contribuições da arqueologia. 


\section{Capítulo IV - Definindos os sujeitos: as contribuições da arqueologia}

O que demonstramos nos capítulos anteriores com argumentos baseados principalmente nas fontes escritas é que o poder dos reis era muito frágil e que para que a autoridade deles fosse afirmada era necessário uma série de alianças com nobrezas de áreas mais periféricas cuja a autoridade regional se fortalecia a ponto de influenciar nos sucessos ou fracassos dos reis e, em casos mais graves, mesmo no assassinato dos reis, algo especialmente comum no contexto da Hispânia visigoda.

Estamos diante assim de dois pólos de poder político: um poder que chamaremos de "central" concentrado em torno da figura dos reis e poderes periféricos representados pelos nobres que chamaremos aqui de "poderes regionais". As tensões aparentes nas fontes escritas nos indicam um quadro relativamente seguro para afirmarmos que o equilíbrio entre esses pólos era crucial para o sucesso da administração dos reis. Entretanto, como insistimos no capítulo I, as fontes escritas compõem um contexto específico: o contexto narrativo. Cabe observamos se essa diversidade de poderes políticos em alianças e disputas que lançavam mão de discursos identitários em busca de auto-afirmação também é observável nos resquícios materiais que chegaram aos nossos dias no que concerne a um processo de afirmação identitária propagada pelas narrativas arqueológicas. ${ }^{374}$

\footnotetext{
${ }^{374}$ Entendemos os resquícios arqueológicos também como narrativas. Uma análise detalhada da questão pode ser encontrada em: HALSALL, G. Cemeteries and Society in Merovingian Gaul. Selected Studies in History and Archaeology. 1992-2009. Leiden, Boston: Brill, 2010. p.215-231. Ainda, como bem definiu F. Theuws: "The graves of the Migration period in Northen Gaul and their contents are comparable to the Lives of the Saints in that they not permit a reconstruction of the actual living historical persons buried in the grave. Instead, they should be analyzed in terms of the rhetorical strategies employed in relation to the political and ideological agendas of the burying group. Thus, the grave is neither a reflection of the social position of the buried person in his or her lifetime, nor a static symbolic representation of a specific, perhaps even ideal, social position. It is the product of a rhetorical strategy." THEUWS, F. Grave goods, ethnicity, and the rhetoric of burial rites in Late Antique Northern Gaul. In: DERK, T. \& ROYMANS, N. Ethnic Constructs in Antiquity. The role of power and tradition. Amsterdam: Amsterdam University Press, 2009. p.295.
} 
Não se trata aqui de pressupor que a análise das narrativas escritas e arqueológicas quando confrontadas nos revelarão um contexto menos lacunar. Não se trata, portanto, de acreditar que cada uma dessas narrativas quando unidas formarão um cenário coerente da Gália Merovíngia e da Hispania Visigoda. De fato, nossas intenções são mais singelas. Queremos investigar se a polaridade política presente nas fontes escritas de alguma maneira também pode ser observada nas narrativas arqueológicas da Gália e da Hispania e se de algum modo há uma afirmação identitária nos dados arqueológicos mais marcante nas áreas que foram focos de rebelião contra os reis.

A primeira parte desse capítulo se esforçará por traçar um quadro geral dos assentamentos ditos "bárbaros" na Gália e na Hispania. A segunda parte se dedicará a um período mais específico, a saber, o arco temporal desde o século VI até o VIII, tentaremos observar se arqueologicamente as identidades burgúndias, austrasianas e neustrinas - que aparecem com mais freqüência em textos do século VII da Gália são também detectáveis na narrativa arqueológica. Por outro lado, tentaremos verificar se essas identidades regionais se afirmavam arqueologicamente em focos de oposição aos reis visigodos, como a Baetica e a Septimania.

\section{Quadro geral da distribuição demográfica na Hispania}

G. Ripoll indicou que a Península Hispânia na Antigüidade Tardia - entendida por ela como o período em que o Império ainda era a autoridade política dominante no Ocidente - apresentava uma grande diversidade populacional. Nas cidades costeiras ou com portos pluviais estavam presente grupos de origem Oriental - 
gregos, sírios, judeus - e africanos (mapa 1) ${ }^{375}$. Já as populações de origem romana eram prevalentes em quase toda a Península (mapa 2).

${ }^{375} \mathrm{O}$ mapas 1, 2, 3 e 4 foram feitos baseados nos dados apresentados por Ripoll: RIPOLL, G. The arrival of the Visigoths in Hispania: Population problems and the process of acculturation. In: POHL, W. \& REIMITZ, H. (eds). Strategies of distinction: the construction of ethnic communities, 300-800. Leiden, Boston, Köln: Brill, 1998. p.153-187. 


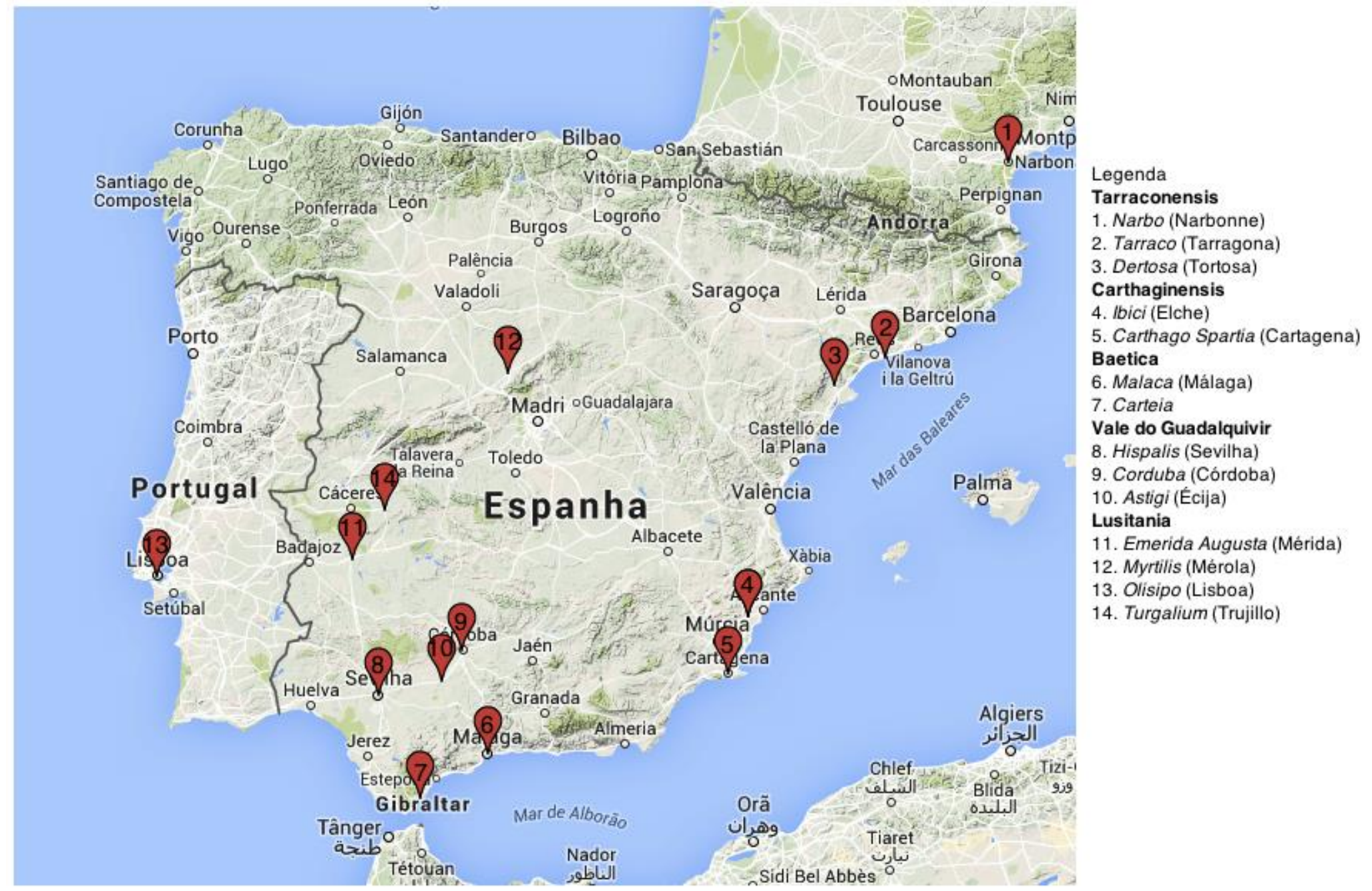

Mapa 1 Distribuição das populações de origem oriental e africana na Hispânia da Antiguidade Tardia 


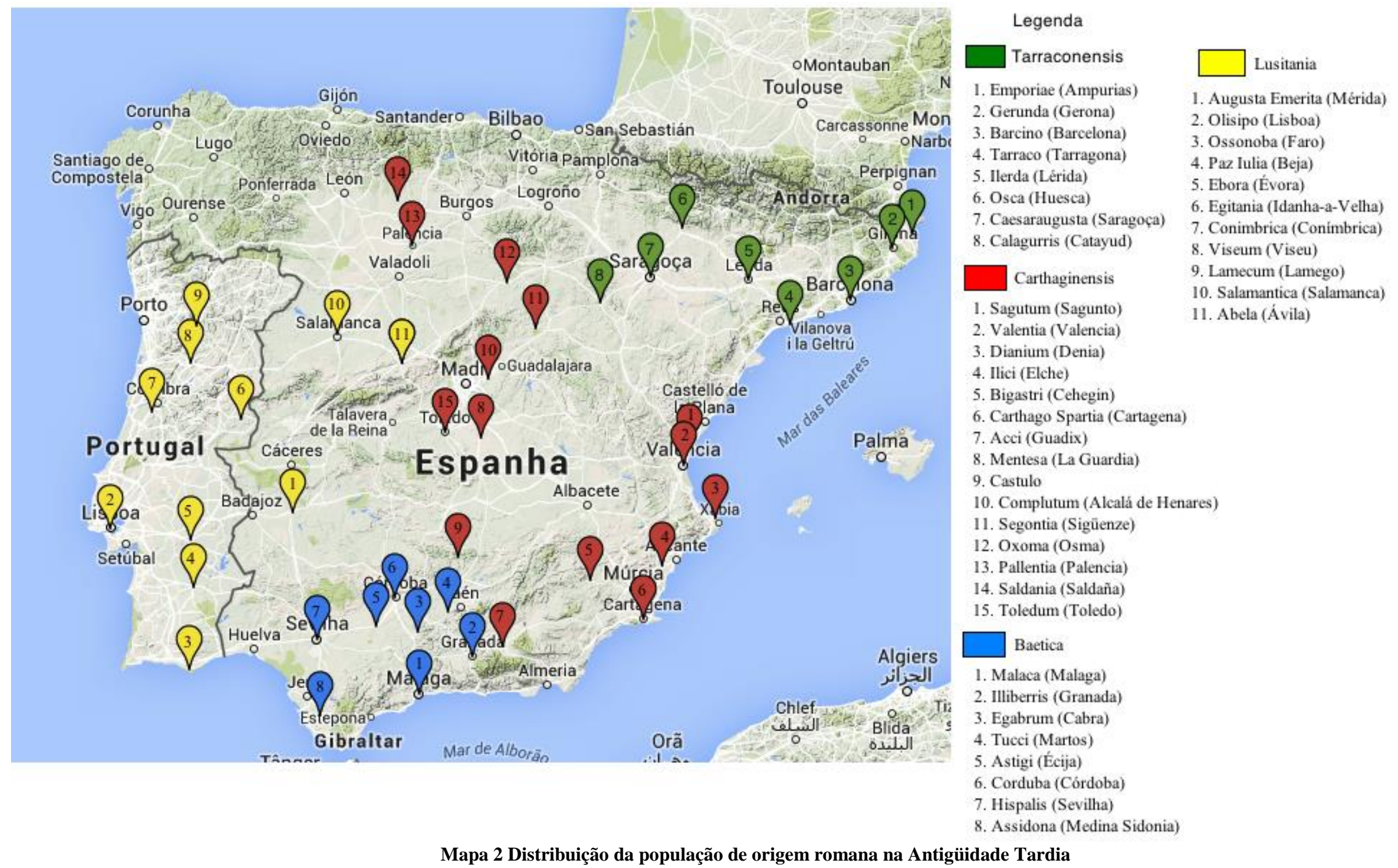


Como é possível notar a distribuição da população romana se estendia por quase toda a Península. A Baetica, como defende Ripoll, era a região com a maior concentração de famílias nobres de origem romana. As famílias de Tarraconensis e Lusitania eram também importantes, mas menos do que as famílias da Baetica. ${ }^{376}$

Foi esse contexto relativamente diversificado mas com prevalência de populações de origem romana que os visigodos que migraram para a Península encontraram. O número exato de visigodos que adentraram a Península é difícil de precisar, mas estimativas variam entre 80.000 e 200.000 mil indivíduos. ${ }^{377}$ Independente da quantidade exata, ambas as cifras refletem que os visigodos eram minoria no quadro geral da população. De fato, o limite geográfico relativamente pequeno no qual essa primeira geração de visigodos ocupou no século $\mathrm{V}$ indica que eles eram pouco numerosos (mapa 3).

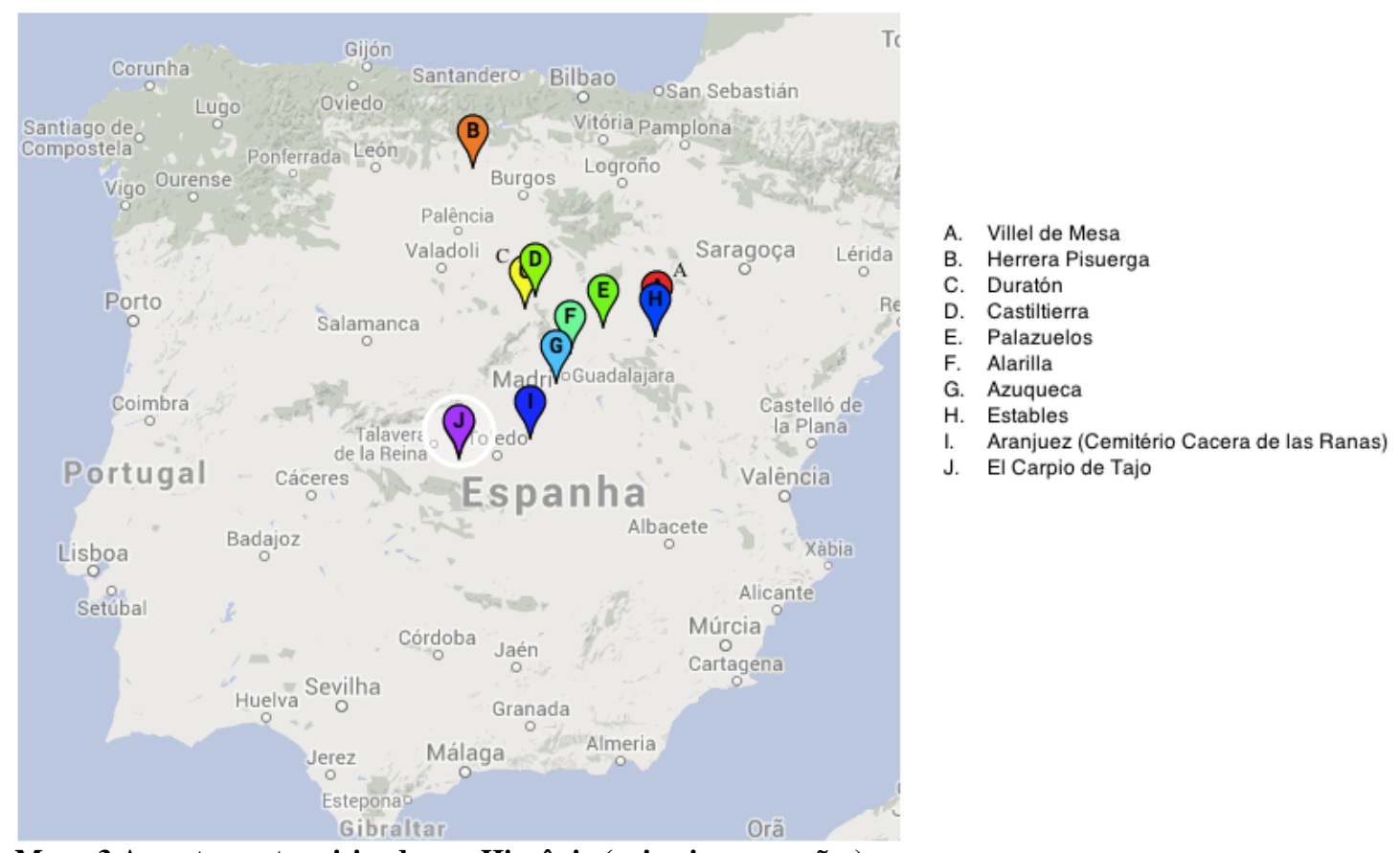

Mapa 3 Assentamentos visigodos na Hispânia (primeiras gerações)

\footnotetext{
${ }^{376}$ RIPOLL, G. The arrival of the Visigoths in Hispania: Population problems and the process of acculturation...op.cit. p.159.

${ }^{377}$ Ibidem, p.160. Ainda: RIPOLL, G. Características generales del doblamiento y la arqueología funeraria visigoda de Hispania. Espacio, Tiempo y Forma, S.I. Prehist. y Arqueol., t.2, p.389-418, 1989. p.392-294.
} 
Um mapa comparado entre os assentamentos de populações de origem romana e os novos assentamentos visigodos do século V dão a dimensão da discrepância populacional (mapa 4).

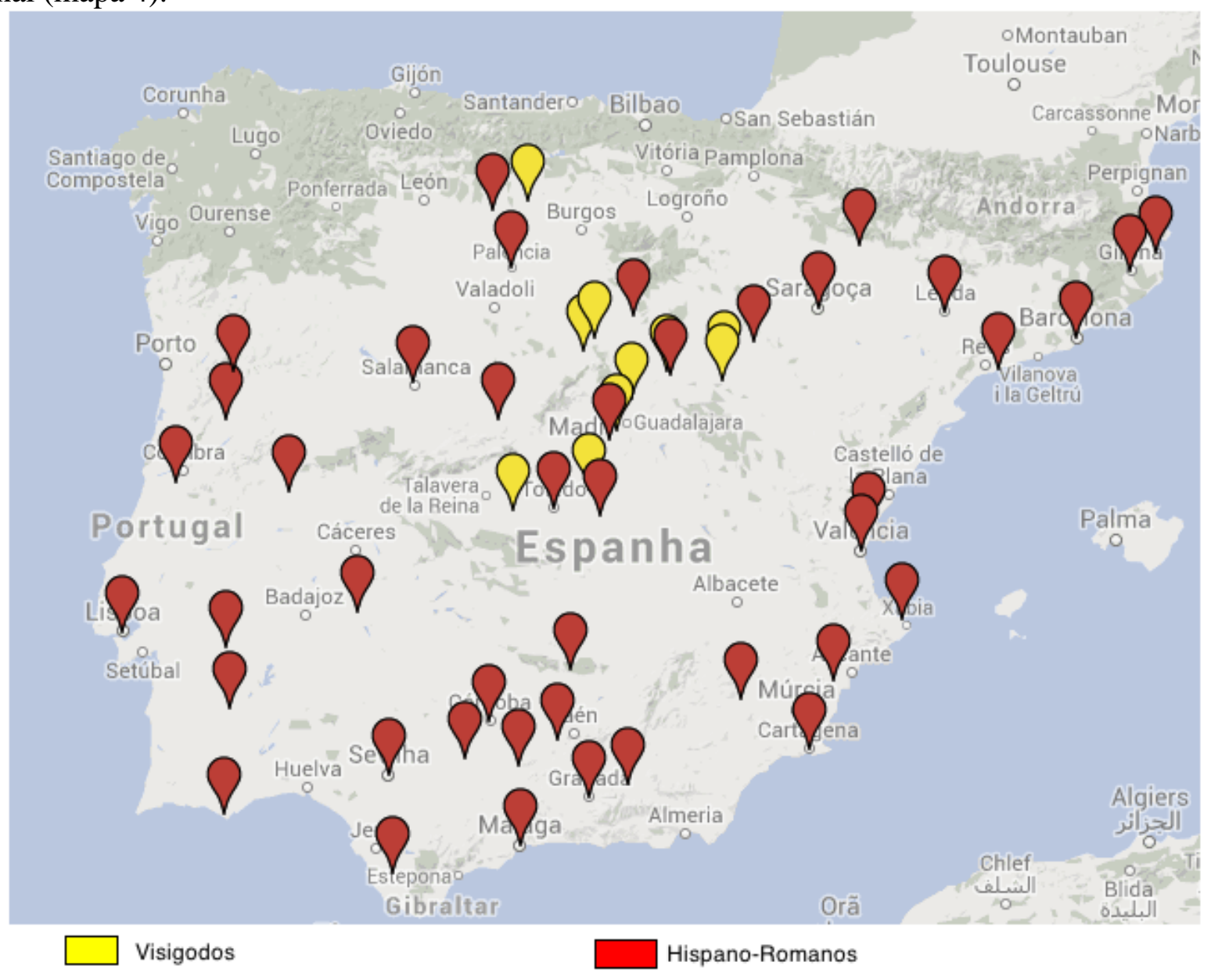

Mapa 4 Distribuição das populações de origem romana e visigoda na Península Ibérica 
Observamos pelo mapa 4 que teoricamente a região de maior contato entre populações de origem romana e populações de origem visigoda na fase inicial das migrações visigóticas seria a área central-norte da Hispânia. O quadro que se revela, em termos bastante simplórios, é de uma Hispânia da Antigüidade Tardia multiétnica com maior diversidade em áreas costeiras e cidades com portos pluviais graças à presença de populações de origem oriental e africana (como pode ser observado pelo mapa 1), em outras regiões, especialmente na Baetica, eram populações de origem romana que prevaleciam (Mapa 2). Com a chegada dos visigodos houve um enriquecimento "étnico" que foi especialmente marcante na área central-norte da Península (Mapa 3).

\section{Os Godos na Hispânia}

A partir desses dados teríamos um quadro relativamente claro da distribuição geográfica de populações de origem goda na Penísula Ibérica. Para Ripoll, inclusive, essa distribuição ajudaria a explicar como a corte dos reis visigodos transitou até se estabelecer definitivamente em Toledo. Segundo ela, Toledo se configurava como uma cidade mais amistosa para a corte dos reis godos graças à existência de uma considerável população de origem goda que habitava na região, ao contrário, de Barcino, que fora capital dos reis Ataulfo, Gesaleico, Amalarico e Teudis; Emerida e Hispalis, capitais respectivamente de Ágila e Atanagildo, que eram áreas com uma forte presença de populações de origem romano-hispânica. ${ }^{378}$ A explicação é bastante sedutora, não fossem os problemas envolvidos na identificação dos visigodos a partir de materiais arqueológicos.

\footnotetext{
${ }^{378}$ RIPOLL, G. Changes in the Topography of Power: From Civitates to Vrbes Regiae in Hispania. In: CORRADINI, R.; DIESENBERGER, M. \& REIMITZ, H. The Construction of Communities in the Early Middle Ages. Texts, resources and Artefacts. Leiden, Boston: Brill, 2003. p.123-148.
} 
O primeiro ponto que deve ser levantado é cronológico. Conforme indicou J. López Quiroga a cronologia da chegada dos visigodos na Península até o século VIII se baseia em artefatos funerários "estrangeiros" encontrados nos cemitérios, tais como fíbulas, anéis e colares. Entretando, precisar a origem "visigoda" desses artefatos é algo absolutamente difícil. O argumento do autor é que a origem visigoda desses artefatos é superestimada, para ele muitos desses objetos são oriundos da região do Danúbio central e chegaram à península antes do marco cronológico do século $\mathrm{V}$, o que nos leva a inferir que as conexões entre a Península Ibérica e a área do Danúbio são muito anteriores ao século $\mathrm{V} \cdot{ }^{379}$ As conseqüências das observações de López Quiroga são de grandes proporções. Significa que muitos dos artefatos encontrados na Hispânia e considerados visigodos podem ser na verdade artefatos oriundos da área central do rio Danúbio e encontrados na Hispânia muito antes da chegada dos godos na Hispânia, de modo que evidenciam mais a circulação de mercadorias entre as duas áreas do que a chegada de uma nova população com uma identidade étnica coerente o suficiente para ser expressada nos objetos funerários. B.K. Young argumenta nessa mesma linha, baseando-se nos estudos de P. Périn e M. Kazanski ${ }^{380}$ que as sepulturas femininas que traziam o signo de distinção étnica considerada visigoda na Gália, a saber, as fíbulas posicionadas nos ombros, ${ }^{381}$ aparentemente se relacionavam mais

\footnotetext{
${ }^{379}$ LÓPEZ QUIROGA, J. Elementos “foráneos" en las necrópolis tardorromanas de Beiral (Ponte de Lima, Portugal) y Vigo (Pontevedra, España): de nuevo la cuestión del siglo V d.C. en la Península Ibérica. CuPAUAM, 27, p.115-124, 2001.

${ }^{380}$ KAZANSKI, M. \& PÉRIN, P. Les barbares 'orientaux' dans l'armée romaine en Gaule. In: VALLET, F. KAZANSKI, M., PÉRIN, P. (ed.). Des Royaumes barbares au Regnum Francorum: L'Occident à l'époque de Childéric et de Clovis. (vers 450-vers 530). Actes des XVIIIes Journées Internationales d'Arquéologie Mérovingienne. Saint-Germain-en-Laye. Musée des Antiquités Nationales, 23-24 avril 1997. Ainda: KAZANSKI, M. MASTYKOVA, A. \& PÉRIN, P. Die Archäologie der Westgoten in Nordgallien. Zum Stand der Forschung. In: Zwischen Spätantike und Mittelalter. (Actes du colloque Gräber, Siedlungen und Identitäten des 4. Bis 7. Jahrhunderts im Western, Freiburg in Br. 2005). RGA-E, 149-192. Boston \& Berlin: Gruyter, 2007.

${ }^{381}$ Essa relação entre as fíbulas e os visigodos é feita por V. Bierbrauer: BIERBRAUER, V. Les Wisigoths dans le royaume franc. In: Actes des XVIIIes Journées Internationales d'Arquéologie Mérovingienne. Saint-Germain-en-Laye. Musée des Antiquités Nationales, 23-24 avril 1997. Num curto, mas interessante artigo, von Rummel defende que embora não seja possível precisar de qual grupo essas fíbulas vinham é possível dizer entretando que elas podem testemunhar perfeitamente a
} 
com um estilo de vestimenta comum às elites danubianas, de modo que dificilmente poderiam ser consideradas visigodas. Outro ponto trazido por Young é que essas fíbulas são encontradas tão-somente no Norte da Gália, surpreendentemente elas não aparecem na Aquitânia, zona que abrigou os primeiros assentamentos visigodos. ${ }^{382}$

Temos então que esses artefatos considerados visigodos e que servem de evidência para determinar a distribuição geográfica dos visigodas na Hispânia são extremamente problemáticos, a arqueologia conecta esses artefatos com a região do Danúbio onde outros grupos viviam. É portanto uma tarefa extremamente difícil identificar qualquer especificidade "visigoda" nesses artefatos. Mas há algo ainda mais complexo envolvido nessa problemática.

Conforme G. Halsall, não há evidências arqueológicas que mostrem a chegada dos visigodos na Aquitânia, região principal dos primeiros assentamentos visigóticos no Ocidente. São tão-somente registros presentes nas fontes escritas que de acordo com Halsall atestam que os visigodos estiveram na Aquitânia. ${ }^{383}$ Desta maneira o mapa de uma migração de visigodos desde a Aquitânia até a Hispânia com traços deixados por resquícios materiais nas sepulturas não é uma transição óbvia, o que dificulta enormemente a identificação de assentamentos visigodos na Hispânia uma vez que faltam evidências arqueológicas. O que temos, como sugere Halsall, mas

presença de estrangeiros: VON RUMMEL, P. Migrazioni archeologiche. Una nota sul problema dell'identificazione archeologica dei barbari. In: EBANISTA, C. \& ROTILI, M. (eds). Archeologia e storia delle migrazioni. Europa, Italia, Mediterraneo fra tarda età romana e alto medioevo. Atti del Convegno internazionale di studi. (Cimitile-Santa Maria Capua Vetere, 17-18 giugno, 2010). Tavolario Edizioni, 2011. p.85-95.

382 YOUNG, B.K. Has anyone seen the Barbarians? Remarks on the missing archeology of the Visigoths in Gaul. In: MATHISEN, R.W. \& SHANZER, D. (ed.). The Battle of Vouillé, 507 CE. Where the France Began. Boston \& Berlin: De Gruyter, 2012. p. 183-201.

${ }^{383}$ HALSALL, G. Ethnicity and early medieval cemeteries. Arqueología y Territorio Medieval. n.18, p.15-27, 2011. Mesmo G. Ripoll reconhece a dificuldade de identificar os visigodos na Aquitânia: RIPOLL, G. Características generales del doblamiento y la arqueología funeraria visigoda de Hispania. Espacio, tiempo y forma. S.I, Prehist. y Arqueol. t.2, p.389-418, 1989. p.394. 
sugerira outrora E. James num importante artigo publicado em 1991, são apenas as narrativas escritas. $^{384}$

Mas a questão é ainda mais complexa. Sarcófagos encontrados na Aquitânia com um estilo particular e único foram relacionados com a chegada dos visigodos na região. Os sarcófagos são de todo singulares, as tampas têm uma forma piramidal e os desenhos esculpidos trazem motivos particulares, E. James descreveu esses sarcófagos da seguinte maneira:

They are in general made from marble quarried at Saint-Béat, on the upper reaches of the Garonne. Their decoration varies considerably. Some resemble the mid-fifth-century sarcophagi of Marselhas, with their rows of apostles under arches. Others show considerable originality, combining apostles and Biblical scenes with vine - or ivy-scroll, or else covering the whole sarcophagus with sober arabesques of vine-ornament. The most ubiquitous feature is the flatness of the relief, quite unlike classical sarcophagi, but resembling the funerary sculpture of the Upper Garonne region of the mid-Imperial period. These south-west Gallic sarcophagi are to be found on both sides of the political frontier of Septimania, and Narbonne and Béziers in Septimania are, with Toulouse, Agen, Bordeaux, the main centres of the production, or at least of the use, of these luxury items. ${ }^{385}$

Esse estilo é único e encontrado apenas naquela região. ${ }^{386}$ Sobre esses sarcófagos ocorre um significativa debate, o primeiro deles referente à data em que foram produzidos, que varia do século V ao VII. J.B. Ward-Perkins, ${ }^{387}$ os data como da segunda metade do século $\mathrm{V}$, cronologia semelhante à adotada por E. James (que admite que os sarcófagos podem ter sido produzidos até o início do século $\mathrm{VI}^{388}$ ) e H.S. Sivan. A questão cronológica é importante, mas como apontado por James, de

\footnotetext{
${ }^{384}$ JAMES, E. 'Les problèmes archéologiques du Sud-Ouest wisigothique et franque', in: PÉRIN, P. (ed).Gallo-Romains, Wisigoths et Francs en Aquitaine, Septimanie et Espagne. Actes des VIIe Journées internationales d'Archéologie mérovingienne, Toulouse 1985. ROUEN, 1991.

385 JAMES, E. Septimania and its Frontiers: An Archaeological Approach. In: JAMES, E. (ed.). Visigothic Spain: New Approachs. Oxford: Clarendon Press, 1980. p.230.

${ }^{386}$ SIVAN, H.S. Funerary monuments and funerary rites in late antique Aquitaine. Oxford Journal of Archaeology. v.5, n.3, p.339-353, 1986. JAMES, E. The historical and archaeological context of the south-west gallic sarcophagi. Antiquité Tardive. v.1, p.23-28. 1993.

${ }^{387}$ WARD-PERKINS, J.B. A carved marble fragment at Riom (Puy-De-Dôme) and the chronology of the Aquitanian sarcophagi. The Antiquaries Journal. v.40, n.1-2, p.25-34, abril de 1960.

${ }^{388} \mathrm{Em}$ artigo anterior publicado em 1980 o autor defendia o século $\mathrm{V}$ como o período de produção da maioria dos sarcófagos, posição que ele modificou em 1991. Cf: JAMES, E. Septimania and its Frontiers: An Archaeological Approach...op.cit.
} 
difícil solução. ${ }^{389}$ O outro ponto de debate é a natureza dessas peças. Para Sivan, a particularidade delas pode ser explicada justamente a partir da presença dos visigodos naquela área até a batalha de Vouillé de 507. Por outro lado, James faz uma análise mais ampla e que soa mais convincente. Esses sarcófagos precisam ser analisados a partir de um contexto mais amplo.

Esse contexto, para o autor, é o de uma aproximação mais íntima entre nobres e as hierarquias eclesiásticas. Os nobres começaram a investir na construção de igrejas em pedra, como a rica Notre-Dame-la-Daurade em Toulouse. Pode ser que esses investimentos nas igrejas tenham se expandido para a produção de sarcófagos mais ricamente decorados. Dessa maneira esses sarcófagos poderiam ter sido produzidos para nobres que floresciam na segunda metade do século $\mathrm{V}$ na região Sudeste da Gália. A relação entre eles e os visigodos, embora sugerida por James a partir dos estudos de M. Kazanski, não é algo que pode ser comprovado. Já para Young, ${ }^{390}$ os sarcófagos atestam a presença dos bárbaros na região, porém bárbaros influenciados pela cultura material da região do Danúbio, desta maneira, esses bárbaros poderiam ser muitos e não é possível dizer que o estilo empregado era definitivamente visigodo. Embora a hipótese de Sivan não deva ser de todo descartada, a de James parece ser a mais interessante. Ora, se de fato os visigodos na Aquitânia foram os responsáveis pelos o surgimento de sarcófagos tão ricamente decorados é de se perguntar o motivo desse tipo de "tradição" não ter chegado até a Hispânia. Aparentemente os sarcófagos parecem definir uma nobreza específica da área do Sudeste da Gália sem uma filiação étnica "visigoda". Em poucas palavras, sem uma prova definitiva, até o momento a afirmação de Halsall e James parecem as

\footnotetext{
${ }^{389}$ JAMES, E. The historical and archaeological context of the south-west gallic sarcophagi...op.cit.

390 YOUNG, B.K. Has anyone seen the Barbarians?...op.cit.
} 
mais convincentes: além das fontes escritas, nada atesta a presença visigoda na Aquitânia.

No que concerne aos visigodos no Ocidente do século V a meados do VI, no mínimo, há um grande descompasso entre o que dizem as fontes escritas e a arqueologia. Isso entretanto não deve nem desmerecer a arqueologia e tampouco as fontes escritas. Deve servir, antes, para pensarmos sobre quais sutilezas se construíam identidades políticas naqueles séculos. O fato é que os visigodos nas fontes escritas, e para esse período se destaca a narrativa de Jordanes, existiam como uma unidade política num contexto de disputas territorias e de autoridade régia sobre seus subordinados. Arqueologicamente falando, contudo, não contamos com dados seguros para afirmar que os visigodos formavam uma gens com uma identidade expressa na cultura material. Ao menos, a partir dos parâmetros atuais, isso não pode ser afirmado.

Tampouco pode ser afirmado com total segurança que o mapa dos assentamentos visigodos apresentado a partir dos dados de Ripoll corresponde às características rigorosas dos assentamentos de grupos humanos qualificados como "visigodos" na Hispânia e o desdobramento desse problema é de enorme impacto para a interpretação das tensões que opunham nobres contra nobres e nobres contra reis, tal como as alianças que uniam esses grupos. Essa questão merece uma análise mais detalhada.

Ampliemos o problema dos assentamentos. Como argumentamos, não há qualquer evidência arqueológica segura que nos indique o mapa das migrações visigodas da Gália para a Hispânia de maneira que é absolutamente difícil identificar 
sepulturas visigodas. Sobre essa questão o trabalho de R. Collins ${ }^{391}$ é muito ilustrativo.

Collins confronta a tese de Zeiss ${ }^{392}$ e Lantier. ${ }^{393}$ Para Zeiss, a partir da escavação de cemitérios supostamente "visigodos", os visigodos se estabeleceram na Meseta, especialmente na região do "Los Campos de los Godos" enquanto o sul continuou com uma população de maioria romana. O cenário da Hispania era então de um norte visigodo e um sul romano em que as duas regiões viviam em constante tensão. Já Lantier, a partir de seus estudos nos cemitérios no Leste dos Pirineos, sugere que os cemitérios da Hispania devem conter na realidade os resquícios de camponeses Hispano-Romanos e não visigodos. Collins, sobre isso, se posiciona da seguinte maneira:

I do not believe in the existence of a large community of Visigothic backwoodsmen lurking on the Meseta and peering down with distaste at the Romanophile proclivities of their betters. Thus I must support Lantier, not least on grounds of common sense. ${ }^{394}$

Collins sugere que os assentamentos de visigodos no Sul da península ocorreu já na metade do século $\mathrm{V}$ de modo que a idéia de que os visigodos se concentravam na Meseta é equivocada. Para defender sua hipótese o autor argumenta que o sul da península era muito mais fértil e rico do que o norte, além de ter sido a área onde a dominação romana se afirmou com mais força na Hispania. $\mathrm{O}$ autor duvida, assim, que os visigodos não tenham se assentado no Sul. Para Collins os nobres desses grupos ditos visigodos que estavam no sul tinham mais preocupações locais do que preocupações com o reino visigodo como um todo. No mais, seus

\footnotetext{
${ }^{391}$ COLLINS, R. Merida and Toledo. 550-585. In: JAMES, E. (ed.). Visigothic Spain: New Approachs. Oxford: Clarendon Press, 1980. p.189-219.

${ }^{392}$ ZEISS, H. Die Grabfünde aus dem spanischen Westgotenreich. Berlin, 1934

${ }^{393}$ LANTIER, R. Comptes-rendus de l'Académie dês Inscription. 1947 e 1948

${ }^{394}$ COLLINS, R. Merida and Toledo. 550-585. op.cit. p.200.
} 
interesses não estavam em oposição com os interesses dos nobres romanos, pelo contrário, se não eram similares eram idênticos, as tensões que se desenvolviam entre esses grupos não seriam assim relacionadas com qualquer filiação étnica. Não havia, em poucas palavras, qualquer tensão baseada em raça na Hispania, os principais fatores de distinção não eram raciais e sim regionais. Desta maneira, a explicação de Ripoll para a escolha de Toledo como capital do reino visigodo não se sustenta. E Collins trouxe sua própria visão sobre a escolha de Leovigildo de manter Toledo como sua sede, algo que já havia começado com Atanagildo. A razão era que Toledo estava mais à parte das disputas entre facções nobiliárquicas regionais que não raro atingiam os reis visigodos, como já indicamos. Não obstante Toledo tinha uma localização geográfica privilegiada estando localizada na área central da Hispânia. O que queremos mostrar com isso é que comumente as leituras sobre os dados arqueológicos e os significados dos termos "étnicos" nas fontes influenciam enormemente nas interpretações historiográficas sobre as razões que levavam à tensões e as maneiras que os reis e nobres atuavam para contornarem as dificuldades que suas autoridades enfrentavam num cenário de profundas disputas que para Ripoll poderiam ser motivadas por questões étnicas e para Collins eram resultado de questões políticas regionais. Provavelmente, até esse ponto, o leitor pode inferir o nosso posicionamento frente à esse problema. Acreditamos que a leitura de Collins explica mais as sutilezas pelas quais os discursos identitários eram evocados do que a de Ripoll. Ao longo desse texto esperamos que nossa posição fique ainda mais clara.

É crucial insistirmos num ponto: embora os visigodos não sejam identificados com segurança nos resquícios arqueológicos dos primeiros assentamentos no Ocidente, eles existiam enquanto um ideal, uma narrativa, um discurso que poderia servir de fundamento identitário com impactos políticos. Isso é 
evidente se confrontarmos o primeiro capítulo desse trabalho, as referências aos "godos" aparecem em fontes "externas" ao reino dos godos. Existia uma tradição narrativa que registrava a existência dos godos e em certos casos mesmo a celebrava, lembremos da Getica de Jordanes. Assim, essa tradição identitária foi apropriada com finalidades políticas ao longo da existência do reino visigodo nas narrativas que foram produzidas naquele contexto. Isso nos parece inquestionável. Cabe investigarmos se o mesmo ocorreu na produção material no âmbito do reino visigodo da Hispânia. Sabemos que na Aquitânia os registros da presença visigoda são polêmicos, mas e ao longo da existência do reino na Hispânia?

No âmbito da arquitetura religiosa P. de Palol em seu exaustivo trabalho de síntese acerca das escavações de edifícios religiosos indicou que embora a arquitetura das igrejas tenha seguido em geral uma tradição edilícia hispano-romana à época do reino visigodo, novos elementos surgiram nos edifícios religiosos até o século VII que, conforme a interpretação de de Palol, se explicam pela influência de Toledo. Os estudos de Palol ficam ainda mais instigantes se notarmos a distribuição geográfica das escavações analisadas. Son Bou, Fornells e Son Peretó, em Minorca; Bovalar, Fraga e Barcelona, territórios que correspondiam à província de Tarraconense e se localizavam em áreas distantes da capital Toledo além de Gerena na Baetica. Todas essas regiões foram ou focos de rebelião contra os reis - lembremos da revolta de Hermenegildo iniciada desde a Baetica com epicentro em Sevilha - ou eram áreas próximas à tumultuada Septimania. ${ }^{395}$ Outro ponto interessante é que todos esses edifícios escavados localizavam-se em zonas rurais. Ora, muitas interpretações podem surgir a partir disso.

\footnotetext{
${ }^{395}$ DE PALOL, P. La arqueologia cristiana en la Hispania romana y visigoda. Descubrimientos recientes y nuevos puntos de vista. In: Actes du XIe congrès international d'archéologie chrétienne. Lyon, Vienne, Grenoble, Genève, Aoeste. 21-28 septembre 1986. École Française de Rome, 1989. p.1975-2022.
} 
Se de fato esses edifícios refletem uma influência de Toledo podemos inferir que a autoridade de Toledo como a sede central da Igreja católica-visigoda se estendeu para áreas periféricas. Embora seja sedutor interpretar esse dado apenas a partir de um ponto de vista religioso devemos recordar que a partir da conversão de Toledo a relação entre os reis e os bispos toledanos se estreitou significativamente. Não obstantes, os concílios toledanos se transformaram em importantes instrumentos políticos uma vez que não só contemplavam questões relacionadas à realeza como eram convocados pelos próprios reis. Assim, a expansão da influência arquitetônica desde Toledo para áreas periféricas no que concerne à construção de edifícios pode ser interpretada a partir de um esforço por parte dos eclesiásticos de Toledo, sob a égide da autoridade dos reis, de afirmar a própria autoridade em áreas distantes e que foram focos de tensões tanto no que concerne aos assédios francos quanto no que concerne à rebeliões contra a autoridade do rei, caso da revolta de Paulo contra Wamba. Esses contextos políticos serão discutidos nos próximos capítulos, de todo modo, embora a leitura aqui apresentada seja mais uma especulação do que qualquer outra coisa já que a conexão entre fontes materiais e fontes escritas não é óbvia, é interessante realizar esse exercício uma vez que ele pode apontar para a utilização de instrumentos materiais na afirmação da autoridade central. Todavia, o caso da arquitetura religiosa não nos traz elementos para afirmarmos a utilização de uma identidade especificamente visigoda na tentativa de fortalecer a autoridade religiosa e política de Toledo nas zonas periféricas do reino visigodo.

Poderíamos nos voltar então para outros tipos de edificações. Como muito bem defendeu C. La Rocca em seus estudos sobre a política de edificações de Teodorico e seus sucessores nas Variae de Cassiodoro, os relatos do autor sobre as construções e reformas de edifícios levadas à cabo pelos reis ostrogodos tem um valor 
no plano político elaborado por Cassiodoro sobre a legitimidade dos reis: a glória das realizações de Teodorico em contraste com as ações duvidosas de Teodato apontam para uma narrativa que entendia as edificações realizadas e restauradas pelos reis como o exercício da autoridade legítima de seus governos. ${ }^{396}$ Cabe pensarmos se uma narrativa semelhante pode ser encontrada nas fontes visigodas.

No que concerne às edificações empreendidas pelos reis visigodos inegavelmente a Recópolis construída por Leovigildo em 578 e nomeada em referência à seu filho Recaredo é a melhor documentada pelas fontes escritas. Ela foi mencionada por João de Bíclaro em sua Chronica $^{397}$ que afirmou que a cidade foi fundada na Celtiberia depois que Leovigildo superou a tirania e as invasões na Hispania. Já Isidoro de Sevilha registrou também a fundação de Recópolis informando, tal como o Biclarense, que a cidade foi fundada na Celtiberia. ${ }^{398}$

Entre 1945 e 1946 foram iniciadas as primeiras escavações na cidade que encontraram uma igreja e um grande edifício. As escavações foram paradas e só no final de 1970 e continuou com muitas interrupções até que em 1996 iniciaram-se as pesquisas mais profundas que revelaram significativos resultados. 399

Dentre os resultados encontrados destaca-se os indícios de que a cidade se tornou um importante centro urbano. A descrição da cidade feita por L. Olmo Enciso revela que a cidade seguia um plano de construção que contava com muros e um

\footnotetext{
${ }^{396}$ LA ROCCA, C. Cassiodoro, Teodato e il restauro degli elefanti di bronzo della Via Sacra. Reti Medievali Rivista. v.11, n.2, p.25-44, junho-dezembro de 2010. Disponível em: www.retimedievali.it

${ }^{397}$ Leovigildus rex, extinctis undique tyrannis et pervasoribus Hispaniae superatis, sortitus requiem propria cum plebe resedit, et civitatem in Celtiberia ex nomine filli condidit, quae Recopolis nuncupatur, quam miro opere et moenibus et suburbanis adornans privilegia populo novae urbis instituit. Chronica, Ano II de Tibério e X de Leovigildo.

${ }^{398}$ Condidit etiam ciuitatem in Celtiberia, quam ex nomine filii sui Recopolim nominauit. Historia Gothorum, versão longa, 51.

${ }^{399}$ OLMO ENCISO, L. The royal foundation of Recópolis and the urban renewal in Iberia during the second half of the sixth century. In: Henning, J. Post-Roman towns, trance and settlement in Europe and Byzantium. Millennium-Studien, 5. v.1-2. Berlim, 2007. p.182.
} 
sistema de abastecimento de água, além de edifícios de proporções significativas e lugares que havia produção de artesanato. ${ }^{400}$

A fundação de Recópolis fez parte de um processo mais amplo de fundações de cidades empreendidas pelos reis visigodos. Além da cidade na Celtiberia, Leovigildo fundou em 581 Victoriaco e restaurou as muralhas de Italica. O rei Suintila também fundou uma cidade, Oligicus. ${ }^{401} \mathrm{Na}$ opinião de Olmo Enciso a fundação dessas cidades revela a importância dos centros urbanos como o ponto nevrálgico da estrutura do sistema fiscal visigodo e uma forma de afirmação da autoridade dos reis. No caso das fundações e reformas empreendidas por Leovigildo, o autor avalia que a orientação da afirmação da autoridade de Leovigildo teria se dado contra os bispos católicos uma vez que a prerrogativa de construção nos centros urbanos estava fundamentalmente sob a responsabilidade dos bispos. No caso de Leovigildo, embora Olmo Enciso tenha razão ao indicar a importância das cidades na coleta dos impostos, a tensão com a religiosa parece ser algo mais difícil de afirmar. Como vemos pelos próprios relatos de João de Biclaro o rei tendeu a não forçar a conversão dos católicos ao arianismo, mais sintomático é observarmos nas Vidas dos Padres de Mérida que o rei antes de depor Masona do bispado de Mérida e elevar Suna primeiro tentou negociar com Masona. Nesse caso seguimos a leitura de Collins mais uma vez. A fundação de cidades em zonas mais distantes de Toledo e a atividade de construção desses reis parecia se relacionar mais com um esforço por afirmar a autoridade dos reis em zonas instáveis e com uma nobreza em ascensão do que qualquer um esforço orientado por piedade religiosa e, muito menos, pela afirmação da validade do domínio dos visigodos na Península Ibérica, algo que, mais uma vez

\footnotetext{
${ }^{400}$ Ibidem, p.182-187.

${ }^{401}$ Ainda sobre esse contexto de fundação de cidades: VELÁZZUEZ, I \& RIPOLL, G. Recopolis: Vrbs Relicta? An Historico-Archaeological debate. In: CHRISTIE, N. \& AUGENTI, A. (eds). Vurbes Extinctae. Archeologies of abandoned Classical Towns. Aldershot-Burlington: Ashgate, 2012. p.146
} 
Collins, argumentou de maneira muito elegante, era algo que não parecia ser a maior preocupação dos nobres - independentes de suas origens "étnicas" - que disputavam a autoridade política nas zonas mais periféricas. ${ }^{402}$

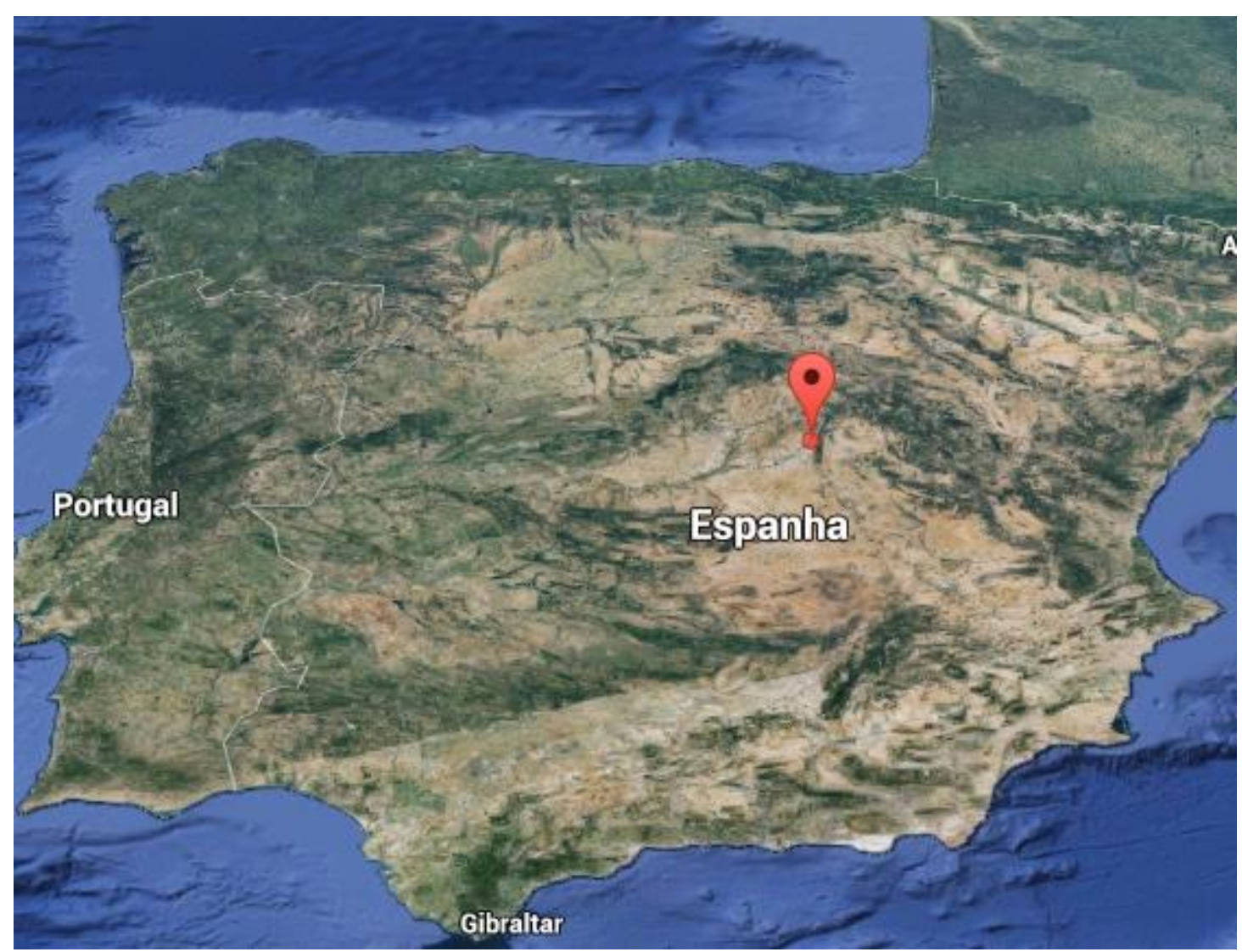

Mapa 5 Parque Arqueológico de Recópolis

Uma interpretação alternativa à fundação de Recópolis foi dada pelas pesquisadoras I. Velázques e G. Ripoll. Segundo elas a cidade tinha por finalidade servir de sede de residência do príncipe Recaredo uma vez que seu irmão mais velho, Hermenegildo, seria o primeiro na linha de sucessão de Leovigildo. A fundação de Recópolis se explicaria assim mais por questões internas ao grupo de Leovigildo - que passava por conflitos por conta da rebelião de Hermenegildo - do que por algum esforço por mitigar as tensões advindas de nobrezas regionais e mesmo por ameaças externas. A explicação faz sentido uma vez que a cidade não era localizada numa

\footnotetext{
${ }^{402}$ OLMO ENCISO, L. The royal foundation of Recópolis and the urban renewal in Iberia during the second half of the sixth century...op.cit. p.189-191.
} 
zona de grandes tensões (Ver Mapa 5) e era relativamente próxima à Toledo - o que fragiliza a hipótese de Olmo Enciso acerca da coleta de impostos - além de não estar localizada na Septimania nem na Baetica, essas sim áreas que abrigavam cidades que foram focos de oposição aos reis visigodos. ${ }^{403}$ Independente da validade de um ou outra hipótese - um vez que ambas são razoáveis - o que cabe ressaltar aqui à luz do interesse de nossa pesquisa é que a fundação de cidades ou reformas empreendidas pelos reis visigodos parecem evocar mais uma prática comum dos imperadores romanos do que uma afirmação de uma identidade visigoda, e nesse ponto tanto Olmo Enciso quanto Velázquez e Ripoll concordam.

Analisamos até aqui três elementos referentes à identidade visigoda nos indícios arqueológicos:

1. O problema da Aquitânia;

2. Já no momento dos assentamentos na Hispânia, a questão da arquitetura religiosa;

3. A fundação de cidades pelos reis visigodos.

Em nenhum desses três pontos a presença de uma narrativa identitária centrada na identidade visigoda é evidente. Cabe então investigarmos outros dados levantados pela arqueologia para refletirmos sobre o problema. Esses dados são fornecidos especialmente pelas sepulturas encontradas na Hispania.

Halsall fez uma importante crítica aos trabalhos de pesquisadores como Bierbrauer, Kazanski e Périn assim como um crítica ao trabalho de P. Heather. ${ }^{404}$ Todos esses pesquisadores, de uma maneira ou de outra, defendem a hipótese de que

\footnotetext{
${ }^{403}$ VELÁZQUEZ, I \& RIPOLL, G. Recopolis: Vrbs Relicta? An Historico-Archaeological debate...op.cit. p.145-176.

${ }^{404}$ Em seu livro publicado em 1996 o autor defende a existência de um grupo de godos que nutriam um senso identitário. Segundo ele, seu estudo não era uma releitura de velhas teses uma vez que ele jogava a luz sobre o papel dos freemen como depositários e transmissores dessa identidade. $C f$ : HEATHER, P. The Goths. Oxford \& Cambridge: Blackwell, 1996.
} 
a existência dos godos enquanto uma unidade formada por indivíduos unidos por um senso identitário não só era uma realidade como de uma maneira ou de outra poderia ser identificada mediante a análise de artefatos descobertos pela arqueologia, artefatos que trariam características singulares relacionadas com uma cultura material visigoda. ${ }^{405}$ A partir dessa mesma perspectiva criticada por Halsall G. Ripoll, nossa referência para elaborarmos os mapas presentes no início desse capítulo, tentou identificar os assentamentos visigodos na Hispânia e usou mesmo diferenças étnicas entre visigodos e hispano-romanos para compreender aspectos políticos importantes do reino, como as mudanças na escolha da sede real do reis.

Os mesmos critérios criticados por Halsall foram usados para identificar uma necrópole do século VI como visigoda encontrada na parte oriental da Tarraconense onde 58 corpos foram identificados como de visigodos por conta de fíbulas e estilo de sepultamento que eram diversos do paradigma considerado romano para os sepultamentos. ${ }^{406}$ Trata-se da aplicação de um pressuposto que é bastante comum quando investigamos a historiografia sobre o período: o que não se encaixa nos modelos "romanos" - tidos como muito estáticos e bem definidos - é imediatamente qualificado como de origem "bárbara".

Não queremos obviamente afirmar que esses artefatos não sejam de origem "bárbara", a questão que parece latente é nos perguntarmos se esses objetos podem

\footnotetext{
${ }^{405}$ As críticas de Halsall foram publicadas em diversos artigos e livros. Cf: HALSALL, G. Barbarian Migrations and the Roman West. 376-568. Cambridge: Cambridge University Press, 2007. Traz uma série de críticas aos estudos de Heather. Já o livro publicado pelo autor em 2010 é muito ilustrativo por reunir uma série de artigos de Halsall publicados entre 1992 e 2009. Nesses dois volumes é possível conhecer detalhadamente os estudos do autor e principalmente seus apontamentos relacionados à possibilidade de que os artefatos considerados "étnicos" comumente eram mais instrumentos de distinção relacionada à gênero e idade do que um marcador étnico. $C f$ : HALSALL, G. Cemeteries and Society in Merovingian Gaul. Selected Studies in History and Archaeology. 1992-2009. Leiden \& Boston: Brill, 2010.

${ }^{406}$ LLINÀS POL, J. et al. Pla de l'Horta (Sarrià de Ter, Girona): una necrópolis con inhumaciones visigodas en la Tarraconense Oriental. Archico Español de Arqueología. n.81, p.289-304, 2008.
} 
ser qualificados como "visigóticos", ${ }^{407}$ uma dúvida que J. López Quiroga levantou de uma maneira muito concreta a partir de um rigoroso estudo arqueológico. ${ }^{408} \mathrm{~A}$ pergunta pode ser colocada de uma maneira ainda mais simples: Podemos definir com precisão como um indivíduo se identificava a partir dos artefatos que encontramos em suas tumbas? Tudo tende à uma resposta negativa. Os sinais de distinção podem ser identificados nas tumbas, mas comumente eles podem apontar para distinções relacionadas com sexo, idade e status social mais do que para distinções étnicas. ${ }^{409}$

Isso tudo não significa dizer que sinais "étnicos" não pudessem ser eventualmente utilizados por membros de uma elite para marcar sua autoridade sobre um determinado território. Como indicado por Sáchez Velasco e García Fernández, a partir do século VII ocorreu um aumento de registros de nomes "germânicos" no século VII na Baetica, ${ }^{410}$ além do aparecimento de armas e esculturas, Halsall apontou para um fenômeno semelhante na região da Septimania. ${ }^{411}$ Como já apontamos, e veremos ao longo desse trabalho, essas duas regiões dos domínios visigodos eram focos de rebelião contra os reis, talvez o aparecimento desses símbolos nessas áreas turbulentas não tenha sido um acaso, mas sim a evocação de um discurso identitário - provavelmente reconhecido pelos grupos sociais em tensão muito graças às referências aos godos nas fontes escritas - para enfrentar questões

\footnotetext{
407 Algo apontado com muito interesse por Sánchez Velasco e García Fernández: SÁCHEZ VELASCO, J. \& GARCÍA FERNÁNDEZ, F.J. Identidades y élites germánicas en la arqueología tardoantigua de la Bética? Estado actual de la investigación y perspectivas de estudio. In: ÁLVAREZ JIMÉNEZ, D., SANZ SERRANO, R. \& HERNÁNDEZ DE LA FUENTE, D.(eds). El espejismo del bárbaro. Ciudadanos y extranjeros al final de la Antigüedad. Anejo 1 de Potestas. Univesitat Jaume I de Castellón, Cartellón, 2012. p.306-328. E ainda por Vigil-Escalera que a partir do estudo comparativo de duas necrópoles, uma considerada "visigoda" e outra "romana" notou que há poucas diferenças entre ambas: VIGIL-ESCALERA, A. Is it really relevant the ethnicity of our historical subjects? Arqueologia y Territorio Medieval. 18, p.45-53, 2011.

${ }^{408}$ LÓPEZ QUIROGA, J. Elementos “foráneos" en las necrópolis tardorromanas de Beiral...op.cit.

${ }^{409}$ Como indicou Halsall: : HALSALL, G. Cemeteries and Society in Merovingian Gaul...op.cit. e também Effros: EFFROS, B. Caring for Body \& Soul. Burial and the afterlife in the Merovingian World. Pennsylvania: Pennsylvania University Press, 2002. p.13-39.

${ }^{410}$ SÁCHEZ VELASCO, J. \& GARCÍA FERNÁNDEZ, F.J. Identidades y élites germánicas en la arqueología tardoantigua de la Bética?..op.cit.

${ }^{411}$ HALSALL, G. Ethnicity and early medieval cemeteries...op.cit.
} 
políticas emergentes. É difícil, todavia, precisar se a evocação desse discurso era uma iniciativa régia ou uma iniciativa de nobres rebeldes aos reis. Como observaremos a narrativa do valor da gens foi apropriada por ambos os segmentos tanto para legitimar quanto para questionar a autoridade dos reis visigodos. De todo modo, tanto para as fontes escritas quanto para as fontes arqueológicas parece cada vez mais evidente que as narrativas identitárias só fazem sentido à luz do contexto de disputas políticas.

\section{O nascimento dos "francos" - as contribuições da arqueologia}

O descompasso entre as fontes narrativas e as evidências materiais oriundas da arqueologia no que concerne às migrações visigodas no Ocidente europeu são objeto de enormes debates ainda hoje. No que concerne aos francos a questão é um pouco mais delicada. Ao contrário dos godos que são registrados nas narrativas desde o texto de Zózimo os francos são mais difíceis de serem encontrados. Como observamos no primeiro capítulo é no texto incompleto de Amiano Marcelino que lemos referências inequívocas aos francos, há ainda outras menções aos "francos" como no panegírico de Mamertinus ao Imperador Maximiniano de 291 d.C. ${ }^{412}$ mas foi com Amiano Marcelino que essa gens entrou na narrativa histórica como participantes dos eventos políticos da Gália.

Talvez o nome genérico "francos" se referia à um conjunto não coeso de gentes que habitavam a região costeira do Norte da Holanda, Baixa Saxônia e Westphalia, essa localização geográfica é adotada por conta de ataques vindos do mar promovidos por essas gentes. Essas gentes possivelmente não se auto-identificavam como "francos" de modo que o termo era outorgado à eles por autores que escreviam

\footnotetext{
${ }^{412}$ SCHMAUDER, M. The relationship between frankish gens and regnum: A proposal based on the archaeological evidence. In: GOETZ, H.-W., JARNUT, J. \& POHL, W. (eds). Regna and Gentes. The Relationship between Late Antique and Early Medieval Peoples and Kingdoms in the Transformation of the Roman World. Leiden \& Boston: Brill, 2003. p.276
} 
a partir de um ponto de vista romano. ${ }^{413} \mathrm{Um}$ hipótese radicalmente contrária foi apresentada por G. Halsall que sugeriu que os "francos" originalmente tenham sido forças advindas do próprio exército romano que se separaram e assumiram uma identidade "franca", a hipótese de Halsall parece ser bastante convincente se levarmos em conta a falta de qualquer resquício material que indica a presença de um grupo “étnico" específico diverso daqueles que já existiam na Gália, não obstante, a hipótese de Halsall baseada na adoção de uma nova identidade nos dá mais elementos para pensarmos sobre as transformações das características das sepulturas observadas a partir do século V. ${ }^{414}$

De fato, como defende Schmauder, os estudos arqueológicos realizados nessa região indicaram a impossibilidade de definir com precisão a existência de qualquer gens específica que poderia ser qualificada como "francos", a situação que se apresenta é então de certa maneira semelhante àquela que observamos no caso dos visigodos na Aquitânia: embora existam alguns registros escritos sobre os franci naquela área - menos do que existem sobre os visigodos na Aquitânia arqueologicamente é difícil identificar a existência dos francos - ou seja, uma gens que se identificava como tal e que tinha uma cultura material funerária que os distinguiam de demais grupos - na Westphalia, Baixa Saxônia e Norte da Holanda. A conclusão de Schmauder é taxativa:

It ought, therefore, to be borne in mind that, on the basis of the archaeological finds from the fourth and the first half of the fifth centuries, no identification as an individual gens (as an ethnically identifiable group) is possible for the Franks, though they are, already at that time, mentioned in historical sources. ${ }^{415}$

\footnotetext{
${ }^{413}$ Ibidem. Ainda: HUMMER, H.J. Franks and Alamanni: a discontinuous ethnogenesis. In: WOOD, I. Franks and Alamanni in the merovingian period. An ethnographic perspective. Woodbridge: Boydell Press, 1998. p.11.

${ }^{414}$ HALSALL, G. Childeric's Grave, Clovis' succession and the origins of the Merovingian kingdom. In: HALSALL, G. Cemeteries and Society in Merovingian Gaul. Selected Studies in History and Archaeology. 1992-2009. Leiden \& Boston: Brill, 2010. p.186.

${ }^{415}$ SCHMAUDER, M. The relationship between frankish gens and regnum...op.cit. p.281.
} 
Entretanto, a partir da segunda metade do século V é detectado na Gália o aparecimento de artefatos no contexto funerário que indicam um novo influxo populacional especialmente na Belgica II e Germania II (Ver mapa 6). De acordo com Schmauder, esses dados indicam a presença de gentes não romanas na região a partir do século $\mathrm{V}$, contudo, não há nenhuma evidência que sustente que alguma dessas gentes eram especificamente franci. ${ }^{416}$ Essa mudança, se levarmos em conta as leituras de Halsall, pode ser também interpretada mais como a adoção de novos artefatos para os ritos funerários que indicaria a adoção de uma identidade diversa por parte de tropas originalmente romanas do que a chegada de novos grupamentos humanos. Lamentavelmente nenhuma das duas hipóteses pode ser descartada com segurança.

Já Theuws apresenta uma outra interpretação em resposta direta à leitura de Halsall. Para o pesquisador, Halsall, na tentativa de eliminar qualquer elemento germânico dessas sepulturas enfatizando que elas seriam resultado de uma nova identidade adotada por grupos do exército romano perdeu de vista a própria mudança dessas sepulturas e eliminou totalmente a possibilidade de que essas sepulturas realmente fossem de elementos "estrangeiros". De fato, Theuws não afirma nem que esses corpos eram de germanos nem de romanos, a sua proposta de análise visa superar justamente essa dicotomia étnica ao analisar esses símbolos como narrativas, como uma retórica que deve ser confrontada com intenções políticas num determinado contexto. Sua interpretação então desemboca no argumento de que os artefatos encontrados nesses sepultamentos - machados, lanças e imagens de caça eram etnicamente neutros. Eles não traziam nenhum identidade étnica específica e estavam presentes nas tumbas para marcar a emergência de um novo grupo social que

\footnotetext{
${ }^{416}$ SCHMAUDER, M. The relationship between frankish gens and regnum ...op.cit $\mathrm{p} .283-284$
} 
reivindicava a posse de terras em um cenário em que as defesas outrora oferecidas pelo exército romano entravam em colapso e que vazios demográficos crescentes deixavam muitas terras desertas que eram reivindicadas por esses grupos sociais que não necessariamente eram nobres. Da onde vinham essas pessoas é uma questão que Theuws deixa deliberadamente em aberto: ao mesmo tempo que não se pode eliminar a possibilidade de que vinham de áreas externas à influência política do Império Romano - e nesse caso poderíamos incluir os germanos - não há qualquer evidência de que esses sepultamentos testemunham as migrações de grupos de fora dos limites do Império. De fato, a proposta de Theuws é que essas características novas das sepulturas do Norte da Gália sejam analisadas a partir de um outro ponto de vista que enfatiza a adoção de certos símbolos nos sepultamentos como uma retórica que sustentava a reivindicação de terras. ${ }^{417}$

\footnotetext{
${ }^{417}$ THEUWS, F. Grave goods, ethnicity, and the rhetoric of burial rites in Late Antique Northern Gaul...op.cit. p.307-315.
} 


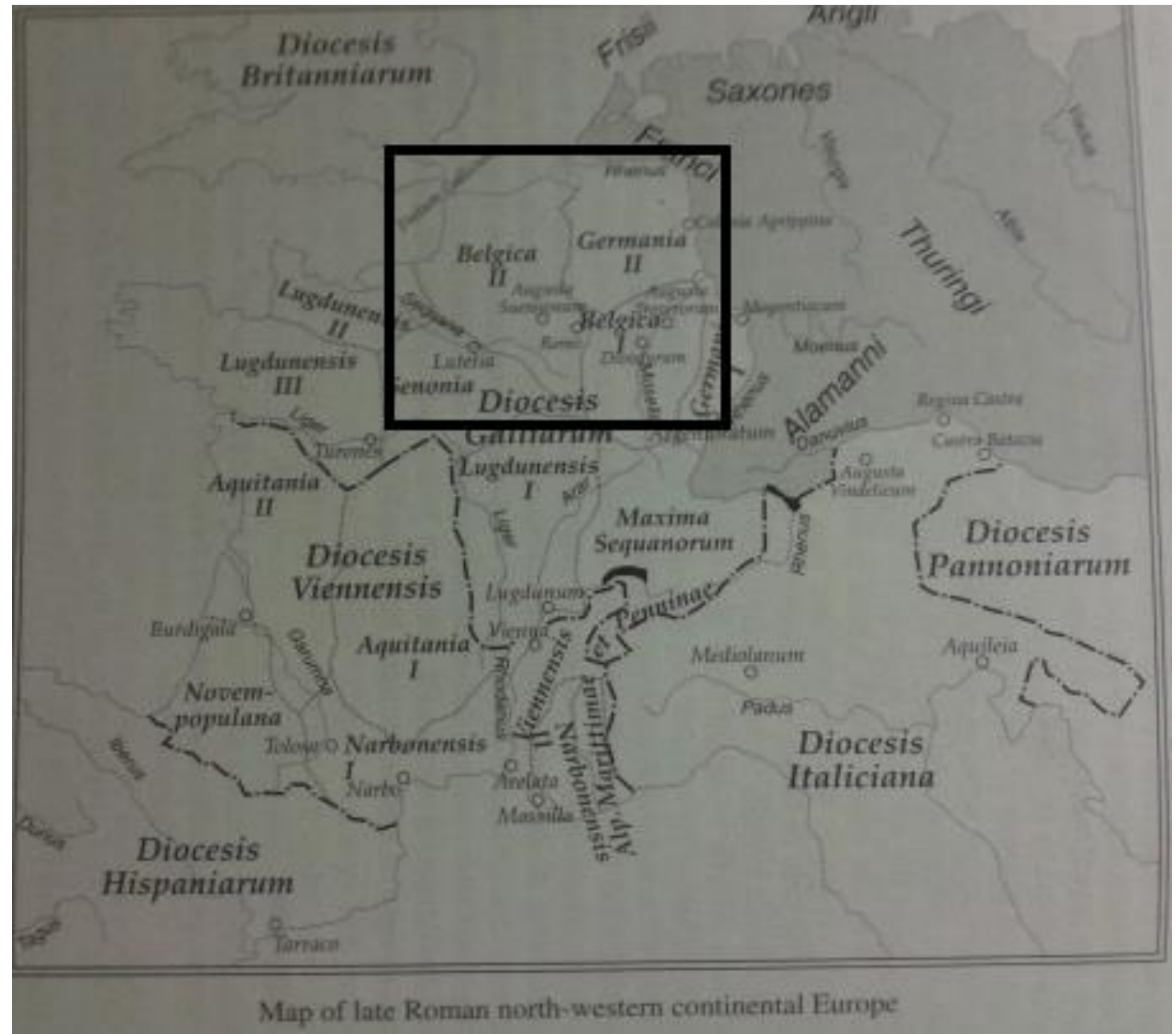

Mapa 6 Destaque da Belgica II e Germania II no mapa das províncias romanas do Noroeste europeu. ${ }^{418}$

Mesmo com a gradativa unificação desses sepultamentos ao longo da segunda metade do século V Schmauder insiste que não é possível identificar o surgimento de uma cultura material que poderia ser indubitavelmente qualificada como "franca" e tampouco relacionada com a idéia de um regnum dos francos. ${ }^{419}$ Outra questão que é preciso ser salientada é que a presença de certos artefatos outrora utilizada como evidência para sustentar a presença de uma população "franca" comumente pode ser interpretada mais como um marcador de status social e de posição social dos indivíduos sepultados de acordo com o gênero do que como marcadores étnicos. Essa interpretação foi desenvolvida, mais uma vez, por G.

\footnotetext{
${ }^{418}$ Mapa extraído de: WOOD, I.(ed.) Franks and Alamanni in the merovingian period. An ethnographic perspective. Woodbridge: Boydell Press, 1998. p.8.

${ }^{419}$ SCHMAUDER, M. The relationship between frankish gens and regnum...op.cit. p.284.
} 
Halsall, um importante crítico das leituras exclusivamente étnicas acerca das sepulturas do Norte da Gália. ${ }^{420} \mathrm{O}$ que percebemos é que, em termos gerais, nas sepulturas da Gália há uma extrema dificuldade para identificar a presença franca para além dos registros escritos e as mudanças das características das sepulturas abrem espaço para diversas possibilidades de interpretação, sendo as duas principais: 1. o fluxo de novos grupos humanos; 2. A adoção de uma nova identidade por parte de um grupo saído das tropas romanas.

De todo modo ao longo do século VI e VII as características dessas sepulturas começaram a se transformar, se ao final do século V e início do VI os arqueólogos encontraram sepulturas com artefatos enterrados junto aos mortos, gradativamente esses artefatos começaram a desaparecer. Esse fenômeno é interessante uma vez que não há proibições específicas nas atas conciliares da Gália Merovíngia ao sepultamento com artefatos de modo que os pesquisadores interpretaram a mudança das características dos sepultamentos como o reflexo de uma transformação espiritual profunda entre os franci provocada pela cristianização e o abandono de ritos pagãos. ${ }^{421}$ Essa leitura, entretanto, foi criticada uma vez que, como bem salienta B. Effros, não é possível determinar o paganismo ou cristianismo de um morto graças ao aparecimento ou não de artefatos em sua tumba. A hipótese defendida por Effros, todavia, não elimina o fator religioso na equação. Segundo ela: "The decreasing use of grave goods by inhabitants of Gaul did not, then, mean that

\footnotetext{
${ }^{420}$ HALSALL, G. Female status and power in early Merovingian central Austrasia: the burial evidence. Early Medieval Europe. v.5, n.1, p.1-24, 1996. Ainda: Cemeteries and Society in Merovingian Gaul. Selected Studies in History and Archaeology. 1992-2009. Leiden \& Boston: Brill, 2010. Especialmente a parte IV. THEUWS, F. Grave goods, ethnicity, and the rhetoric of burial rites in Late Antique Northern Gaul. In: DERK, T. \& ROYMANS, N. Ethnic Constructs in Antiquity. The role of power and tradition. Amsterdam: Amsterdam University Press, 2009. p.283-285

${ }^{421}$ EFFROS, B. Merovingian Mortuary Archaeology and the Making of the Early Middle Ages. Berkeley, Los Angeles \& Londres: University of California Press, 2003. p.85-88.
} 
they were more devout than their acceptors but that they were faced with a changed theological interpretation of the afterlife."422

A hipótese parece razoável especialmente se levarmos em conta que desde o final do século VI e ao longo do século VII, além das mudanças nas estruturas das sepulturas, houve um aumento de doações feitas por nobres às igrejas. De fato, uma análise dos diplomas merovíngios atesta o registro de um conjunto significativo de doações realizadas à igrejas e à mosteiros que os tinham como patronos com a prevalência de doações realizadas pelos mestres dos palácios da Austrásia. Seria possível fazermos essa relação entre as doações feitas pelos nobres da Austrásia e a mudança geral das características das sepulturas na Gália? Para respondermos à esse pergunta é preciso fazer uma análise geral das relações entre os nobres que fizeram as doações registradas nos diplomas e os reis.

G. Halsall no seu importante estudo sobre a região de Metz indicou bem que ao longo do século VII houve mudanças nas relações entre os nobres da Austrásia e os reis. Esses nobres estavam cada vez mais poderosos, possuíam cada vez mais terras não raro doadas pelos reis, como podemos observar pela doação de Grimoaldo de terras que outrora ele havia recebido de Sigiberto ${ }^{423}$ - essa crescente potência política, todavia, dependia de uma série de estratégias para se sustentar. Dentre essas estratégias a principal apontada por Halsall foi a formação e afirmação de uma identidade específica que se estabelecia por um sistema de alianças concretizadas por matrimônios (como a de Begga, filha de Pepino, e Ansigisel, filho de Arnulf de

\footnotetext{
${ }^{422}$ EFFROS, B. Merovingian Mortuary Archaeology and the Making of the Early Middle Ages. ..op.cit. p.88.

${ }^{423}$ Domino sancto et in Christo patri, Rimagilo episcopo, vel omni congregationi monasterio Malmundario seu Stabelau consistentium, Grimoaldus. Recogitans molem peccaminum meorum, qualiter veniam optinere merear, sono vobis donatumque esse volo pro compendiis ipsorum servorum Dei, qui in ipsa monasteria conversare videntur, loco cognominante Germiniaco in pago Remensi, quem domnus gloriosus Sigibertus rex nobis concessit. Diplomata Maiorum Domus e stirpe Arnulforum, 1.
} 
Metz), o envio de jovens para serem criados sob a égide de outros senhores (Arnulfo, enviado para crescer sob a autoridade de Gundulfo, por exemplo) e a adoção do monasticismo de inspiração de S. Columbano. ${ }^{424}$

Halsall interpreta que as mudanças nas características das sepulturas do norte da Gália se relacionam com esse fortalecimento dos poderes regionais. Ele observa que houve uma diminuição de artefatos enterrados com os indivíduos, o status dos mortos passou a ser menos marcado por objetos e mais saliente com a própria valorização dos grupos familiares sepultados em conjuntos e com sinais da força da família. Nas palavras de Halsall:

Seventh-century graves, on the other hand, demonstrated wealth with all of the family's dead, as at Audun-le-Tiche, old women and adolescent males. At Lavoye, we see lavishly furnished children's graves from this period. As noted earlier, this represents a change, and seems to stress the family's local standing further, suggesting that the status brought by family identity was inherited and retained throughout the life-cycle. ${ }^{425}$

O que se pode inferir a partir disso é que tudo parece apontar para o fato de que os investimentos em doações às igrejas e as mudanças nas características das sepulturas vão além do simples fator religioso e se relacionam com o crescimento da autoridade de nobres do norte da Gália que mediante alianças com as igrejas, mediante a construção de uma áurea piedosa e mediante alianças entre outros grupos nobiliárquicos afirmavam uma identidade nobiliárquica relacionada com uma região específica.

O percurso até aqui apontado, como já deve ser possível notar, se restringe à região do Norte da Gália que desde o século V até os séculos VII e VIII registrou

\footnotetext{
${ }^{424}$ HALSALL, G. Settlement and social organization. The Merovingian region of Metz. Cambridge: Cambridge University Press, 1995/2002. p.262-264. Sobre os mosteiros de inspiração colombiana, ver o capítulo sobre hagiografias.

${ }^{425}$ Ibidem, p. 264-265.
} 
mudanças nos materiais arqueológicos que podem ser interpretadas de diversas maneiras, todas essas maneiras, todavia, indicam as dificuldades de identicar uma gens francorum na região, por outro lado, apontam para mudanças no simbolismo dos sepultamentos que podem ser lidas como o sinal do crescimento da importância da autoridade de grupos familiares. Não por acaso foi do Norte da Gália, precisamente da Austrásia, que ascendeu o grupo familiar que colocaria fim à dinastia merovíngia. Nos próximos capítulos veremos como esses grupos regionais ganham cada vez mais importância nas narrativas escritas produzidas na Gália nas quais as regiões: Austrásia, Nêustria e Burgúndia, se tornam entidades políticas cada vez mais significativas em detrimento à unidade ideal do regnum francorum.

Mas o que é notável é que as sepulturas do Norte e do Sul da Gália apresentavam diferenças entre elas com uma prevalência de sepultamentos em sarcófagos de pedra com inscrições ao Sul enquanto ao Norte os sepultamentos eram feitos diretamente no solo e traziam mais artefatos nas tumbas do que ao Sul. A diferença entre esses símbolos funerários foi interpretada em sentidos étnicos: enquanto ao Sul prevaleceria uma população de origem romano, ao norte havia uma presença mais significativa de francos. ${ }^{426} \mathrm{O}$ argumento é circular. Vimos anteriormente que estudos mais recentes apontam para as dificuldades de identificarmos os francos mesmo na especificidade dos sepultamentos que surgiram ao Norte da Gália. Aparentemente a resolução do problema deve partir da superação da dicotomia "francos" e "romanos" na organização social da Gália. De fato, como veremos no capítulo dedicados às leges essa superação deve ser adotada mesmo nos estudos de outras fontes do período. A questão da diferença dos símbolos funerários talvez requeira uma explicação baseada antes na crescente regionalização das

\footnotetext{
${ }^{426}$ EFFROS, B. Caring for Body and Soul. Burial and the Afterlife in the Merovingian World. Pennsylvania: Pennsylvania State University Press, 2002. p.4.
} 
nobrezas que usavam tais símbolos para afirmarem seus poderes locais, ${ }^{427}$ por vezes lançando mão de artefatos que remetiam à uma vida guerreira - como no caso das sepulturas encontradas ao Norte com armas - ou à um passado relacionado com o Império - como as sepulturas do Sul da Gália. De todo modo, o que pesquisadores como Halsall e Verslype observam é que as principais mudanças nos símbolos funerários em toda a Gália parecem apontar para o reforço da memória das famílias e isso transcendia os próprios ritos funerários uma vez que, como observamos, a doação à mosteiros e igrejas também se intensificaram. Talvez essa seja justamente uma das poucas ocasiões que que a arqueologia e as fontes escritas parecem dialogar. O reforço da memória das famílias parecia se extender também para a celebração de indivíduos "santos" e "santas" com o crescimento de hagiografias produzidas ao longo do século VII. Veremos isso também ao longo desse texto.

O que importa dizer por enquanto é que tanto nossas fontes escritas como as contribuições da arqueologia permitem que orientemos nossos estudos para uma abordagem que estude as identidades a partir de um contexto de disputas que opunham ou uniam nobrezas regionais com o poder pretensamente centralizador dos reis. Isso significa que o lugar dos francos e dos godos só faz sentido à luz desse cenário construído por diversas narrativas - não raro conflitantes. Há uma importância das narrativas acerca dos "francos" e dos "godos", mas a importância delas só se revela em todo o seu potencial se considerarmos que essas identidades eram identidades políticas, não naturais, não imanentes aos indivíduos que as portavam e muitas vezes restrita ao plano da narrativa escrita. A arqueologia, embora pouco possa nos dizer sobre os "francos" e os "godos", nos indica que a

\footnotetext{
${ }^{427}$ Embora ainda considere as diferenças étnicas, Verslype tende a enfatizar essa possibilidade para as sepulturas datadas do século VII encontradas na Austrásia e na Nêustria. VERSLYPE, L. "Limites sans frontières". Réflexions sur la perception archéologique de l'espace en Neustrie septentrionale (VeVIIIe siècle). Revue du Nord. v.3, n.351, p.551-572, 2003.
} 
regionalização de famílias que se esforçavam por reforçar um senso identitário pode ser apreendida em certa medida além das fontes escritas, mas a partir de uma outra perspectiva: não se tratava da valorização da gens francorum e da gens gothorum, mas da própria memória familiar que transcendia qualquer sentido exclusivamente étnico. 


\section{Parte III}

A CONSTRUÇÃO DA MEMÓRIA 


\section{Capítulo V - As Histórias}

\section{Das possibilidades da narrativa histórica na Alta Idade Média}

A primeira pergunta que emerge quando lidamos com escrita da história na Idade Média é elementar: existiu história na Idade Média ${ }^{428}$ Se sim, quais são suas características? No que ela difere da história conforme sua acepção contemporânea?

Autores como F. Châtelet ${ }^{429}$ e H. White ${ }^{430}$ foram céticos quanto a possibilidade da existência de história no período medieval. Para o primeiro, a percepção da dimensão política das ações humanas é o motor que nos guia para o ímpeto de fazer história. O homem, enquanto um sujeito auto-consciente de seu papel na história, passa a entender o tempo tendo a ele mesmo como mensura e a história, o curso do tempo, tem igualmente ele como epicentro. No que concerne à Idade Média, O autor reconhece o peso da produção, pelo menos autodenominada "história", dos escritores cristãos do medievo para o desenvolvimento da história-ciência do final do século XVIII e decorrer do XIX, cuja paternidade é atribuída à L. von Ranke e Niebuhr. Duvida, no entanto, que autores cristãos dos séculos que se seguira à "Queda de Roma” tivessem sido capazes de possuir uma concepção histórica séria. Eram eles incapazes de compreender corretamente a experiência histórica por não possuírem a percepção essencial que permite o conhecimento histórico: a consciência do papel dos sujeitos no curso do tempo.

Já White, em seu comentário sobre os anais de Santo Gall, que cobrem os eventos ocorridos entre os séculos VIII e X, atribuiu à falta de conexão entre os

\footnotetext{
${ }^{428}$ Esse primeiro trecho foi originalmente publicado no artigo: SILVEIRA, V.C. Jordanes, Isidoro de Sevilha e a origem dos godos. Anais do Workshop realizado nos dias 29 e 30 de setembro de 2011. Belo Horizonte: Faculdade de Filosofia e Ciências Humanas, 2012. p.67-85.

${ }^{429}$ CHÂTELET, François. La naissance de I'histoire. Tomo I. Paris: Seuil, 1962.

${ }^{430}$ WHITE, Hayden. The value of narrativity in the representation of reality. Critical Inquiry, v.7, n.1, p.5-27, Autumn 1980.
} 
eventos uma espécie de dificuldade por parte dos autores em entender o "sistema social" como relevante. Os acontecimentos eram fortuitos e alheios à vontade humana, que os vivenciavam passivamente diante da impossibilidade de revertê-los. Os humanos simplesmente viviam, sem qualquer possibilidade de atuar em seus destinos. Segundo ele, os lapsos no texto dos anais indicam dois fatos: a inexistência de coerência narrativa no texto e a inexistência de qualquer noção de ordem política e social. O autor corroborou com Hegel ao salientar que um escrito genuinamente historiográfico depende justamente da figuração dos dois elementos faltantes nos anais descritos. White, ainda na trilha das colocações de Hegel, estabelece que a narrativa e a idéia de ordem social pressupõem a existência de um Estado e de uma organização jurídica, estes últimos, por fim, constituem a condição de possibilidade tanto da historicidade quanto da narratividade.

Forçosamente, o que podemos inferir a partir das leituras desses dois autores é que para eles, cada um a seu modo, o conhecimento histórico depende de uma espécie de consciência histórica. Consciência histórica, nas palavras de H.-G. Gadamer é: “o privilégio do homem moderno de ter plena consciência da historicidade de todo presente e da relatividade de toda opinião". ${ }^{431}$

A consciência histórica é, então, não só uma noção dos processos históricos, mas também uma percepção de que toda opinião é relativa, ou seja, são as próprias opiniões revestidas de historicidade. Essa tomada de consciência histórica e percepção da historicidade das coisas é latente no surgimento de confrontos de idéias. As disputas no Kampf der Weltanschauugen (confrontos de visão de mundo) é ao mesmo tempo sintoma e consequência da consciência histórica.

${ }^{431}$ GADAMER, H.-G. O problema da consciência histórica. Rio de Janeiro: FGV, 2003. p.17. 
Uma suposta visão providencialista da história, segundo a qual os seres humanos eram incapazes de intervir nos acontecimentos já que eles eram fruto dos desígnios divinos, impossibilitaria a existência da "consciência histórica" e, destarte, do conhecimento histórico concretizado mediante a historiografia. Essa consciência histórica, imperativo para a historiografia, surgiria apenas do decorrer do século XVIII, com a emergência do Estado moderno - por vezes retratado como causa, por vezes como consequiência, da consciência histórica. ${ }^{432}$

Néri de Barros Almeida sumariza perfeitamente o ceticismo frente à existência da história na Idade Média:

Devido à "barbarização" da sociedade, gêneros narrativos antigos aí quase nada conservariam da tradição anterior além do nome. Seria isso que se daria com as narrativas chamadas de "história". Este seria não apenas um gênero inexistente, mas impossível tendo em vista limites culturais intrínsecos. A história não existiria na Idade Média, época desprovida de meios para uma percepção, recorte e análise objetivos dos acontecimentos. A principal causa dessa desconfiança seria o comprometimento da razão com a fé. Ficava de fora dessa apreciação - particularmente viva no ambiente historiográfico francês - a complexidade da cultura cristã medieval. ${ }^{433}$

O artigo de Almeida é, entretanto, muito mais do que uma reflexão historiográfica sobre a crítica à escrita da história no medievo e uma defesa da história na Idade Média, é sobretudo um apontamento sobre o quanto a reflexão sobre esse tópico, dentre outros como "feudalismo", "heresias", etc emergem num contexto acadêmico mais amplo que repensa a própria Idade Média, ou a "reinventa", conforme as palavras da autora. Reinvenção que se inicia com a crítica da modernidade e a revalorização do Estado que não é mais tido como o depositório da ordem, mas comumente como fonte de coerção. Assim, o suposto caos institucional medieval ganha uma nova abordagem transmutando-se num objeto para o estudo de

\footnotetext{
${ }^{432}$ KOSELLECK, R. historia/Historia. Madrid: Trotta, 2004.

${ }^{433}$ ALMEIDA, Néri de Barros. Raul Glaber: um historiador na Idade Média (980/985-1047). Revista Signum. vol.11, n.2. p.76-108, 2010. p.84-85.
} 
experiências sociais num ambiente de fragilidade estatal, ou mesmo ausência de Estado. $^{434}$

E se nessa reinvenção da Idade Média certos axiomas foram postos na berlinda, a leitura sobre as histórias no medievo também ganhou novos tons. Retomaremos a questão a seguir. Por hora nos limitaremos a um elemento um tanto quanto mais evidente. Ora, a despeito dos questionamentos sobre a existência da história, histórias foram escritas ao longo dos mil anos que convencionamos qualificar como medievais. É pertinente, então, negarmos o qualificativo "história" para obras que receberam o título de "história" por conta de um hipotético lapso de consciência histórica?

Poderíamos retomar as considerações de Ernst Cassirer. Conforme ele, a linguagem atua decisivamente na atividade do conhecimento, permitindo-o. ${ }^{435} \mathrm{O}$ surgimento de palavras para designar experiências indica os meandros do conhecer. A partir disso é possível inferir que a própria figuração do substantivo "História" já aponta para uma preocupação sobre a história. Nesse sentido não cabe utilizar a qualidade narrativa dessas histórias para julgar se elas são efetivamente obras historiográficas, como faz White.

\footnotetext{
${ }^{434}$ Cabe ainda mencionar a reflexão historiográfica conduzida pelo há pouco publicado livro de L.D. Rust (RUST, Leandro D. Colunas de São Pedro. A política Papal na Idade Média Central. São Paulo: Annablume, 2011.p.33-77), obra que propõe uma retomada da história institucional do papado. Como o autor sublinha no seu primeiro capítulo, a história institucional passou pelos extremos da supervalorização e total desvalorização, estando hoje ainda às voltas com o impasse. Interessante perceber como os historiadores no Brasil, como a já mencionada Néri de Barros Almeida, mas ainda Marcelo Cândido da Silva, Maria Filomena Coelho e Renan Frighetto enfrentam a difícil questão sob uma ótica inovadora. Cf: CÂNDIDO, Marcelo. Paz e Violência no Pactus Legis Salicae. In: OLIVEIRA, J.C.M \& Selvatici, M. Textos e representações da Antiguidade: Transmissão e interpretação. Maringá: UEN, 2012. p.91-128. COELHO, Maria Filomena. Justiça e Ordenamento. In: FONSECA, C.; RIBEIRO, M.E. Instituições, cultura e poder na Idade Média Ibérica. Atas da VI Semana de Estudos Medievais - I Encontro Luso-brasileiro de História Medieval. Brasília: PEM-UnB, 2007, p. 177-212. FRIGHETTO, Renan. A Antiguidade Tardia. Roma e as monarquias romanobárbaras numa época de transformações. Séculos II-VIII. Curitiba: Juruá, 2012.
}

${ }^{435}$ CASSIRER, E. Linguagem e mito. São Paulo: Perspectiva, 1972. 
Contudo, utilizar a existência de uma palavra como evidência da gênese de uma determinada forma de conhecer que tão-somente progrediu consiste numa generalização alheia aos diversos sentidos assumidos por dado vocábulo. Uma história da historiografia antes de mirar para o progresso da história deve atentar para os múltiplos significados que o esforço por registrar o passado assumiu. Não se trata de erigir um sólido monumento conceitual para A História, mas sim desvendar as faces das mais diversas histórias.

\section{A "narrativa dos tempos"}

Historia est narratio rei gestae, per quam ea, quae in praeterito facta sunt, dinoscuntur. Dicta autem Graece historê̂n, id est a videre cognoscere. Apud veteres enim nemo conscribebat historiam, nisi is qui interfuisset, et ea quae conscribenda essent vidisset. Melius enim oculis quae fiunt deprehendimus, quam quae autitione colligimus. 2. Quae enim videntur, sine mendacio proferuntur. Haec disciplina ad Grammaticam pertinet, quia quidquid dignum memoria est litteris mandatur. Etymologiarum, I, 41.

Historia é a narração de acontecimentos, pela qual se conhecem os sucessos que tiveram lugar em tempos passados. O nome de história deriva do grego historeîn, que significa ver ou conhecer. E é que entre os antigos não escrevia história quem não tenha sido testemunha e havia visto os feitos que deveriam narrar. Melhor conhecemos os feitos que observamos com nossos próprios olhos que os que conhecemos por ouvido. 2. as coisas que se vê podem ser narradas sem falsidade. Esta disciplina se integra à gramática porque às letras se confia quando é digno de recordação.

A definição de "história" nas Etimologias de Isidoro de Sevilha é ilustrativa da concepção mais fundamental sobre o significado do termo. História jamais é empregada na obra do Hispalense, e tampouco o fora na de Jordanes, para se referir ao tempo passado propriamente dito. História era um gênero narrativo cujo objeto eram os eventos passados, sua raiz etimológica vem do grego que significa ver e conhecer, pois a peculiaridade da narrativa histórica era narrar sem falsidade o que era digno de recordação. Mas a restrição à narrativa de feitos testemunhados impediria a 
escrita da história de um passado longínquo? Não, pois as fontes para esses eventos pretéritos eram as próprias histórias. Como registrou Isidoro de Sevilha na sua História Gothorum, Sueborum et Wandalorum : "Per multa quippe retro saecula ducibus usi sunt, postea regibus, quorum oportet tempora per ordinem cursim exponere et quo nomine actuque regnauerint, de historiis libata retexere.". ${ }^{436}$ Usar histórias como referências para o ordenamento dos eventos - no caso de Isidoro de Sevilha a sucessão dos reis, garantia a confiabilidade das informações. Mas Isidoro não foi o único autor preocupado com uma espécie de pressuposto metodológico que garantiria o status de "História" a uma narrativa. Antes dele, Jordanes registrou o valor das histórias como fonte de verdade.

Jordanes, conforme as palavras iniciais da Gética, escreveu a pedido de Castalius que o requisitou para sumarizar os doze livros sobre a história dos godos de Cassiodoro. Ele salientou que não estava com a obra de Cassiodoro enquanto escrevia e que apenas a leu há um certo tempo. Para dar conta desse lapso Jordanes afirmou que se fiaria em histórias latinas e gregas além de detalhes inseridos por ele mesmo. Além desse trecho de abertura, Jordanes acrescentou mais a frente: "aut certe si quis eos aliter dixerit in nostro urbe, quam quod nos diximus, fuisse exortos, nobis aliquid obstrepebit: nos enim potius lectioni credimus quam fabulis anilibus consentimus". ${ }^{437}$ Ora, podemos apontar então que tanto Isidoro de Sevilha quanto Jordanes não só escreveram histórias como apresentaram elementos que caracterizavam seus escritos como tal. Sumariamente, para ambos os autores, história era uma narrativa confiável de eventos passados. Não se tratava de uma disciplina tal como conhecemos hoje, tampouco era utilizada como sinônimo de passado. Mas há outra coisa em comum entre Isidoro de Sevilha e Jordanes que justifica nossa opção por analisa-los aqui: os

\footnotetext{
${ }^{436}$ História Gothorum, Versão longa, 3.

${ }^{437}$ Getica, 38
} 
dois escreveram a história que tratava dos eventos relacionados à origem dos godos e outorgaram a esses textos um sentido e pressupostos que garantinham a confiabilidade dos relatos.

O mesmo pode ser dito para as Historiae escritas na Gália Merovíngia. Como apontamos em nossa dissertação, ${ }^{438}$ um dos autores de Historiae mais importantes da Gália, Gregório de Tours, nos seus Decem Libri Historiarum tomou parâmetros que caracterizavam seu texto como uma História. Além do próprio título da obra, ${ }^{439}$ o autor explicitou a condição essencial que caracteriza uma narrativa histórica, a saber, a confiabilidade dos eventos narrados:

Sed nos haec narrantis, Salustii sententiam, quam in detractaturibus historiografforum protulit, memoramus. Ait enim: Arduum videtur res gestas scribere: primum quod facta dictis exaequanda sunt; deinde quia plerique quae delecta repraehenderis malevolentia et invidia dicta putant. Sed coepta sequamur. ${ }^{440}$

Escrever história era assim necessariamente narrar algo verídico, mesmo que a veracidade fosse mais uma expectativa do que um critério efetivamente aplicado, perceberemos que esse tipo de critério de veracidade não é recorrente em hagiografias, textos que tinham outra finalidade que não historiográfica e sim propagandísticas. De todo modo, ao classificar o seu próprio texto como uma "história" - à luz do prestígio e da tradição desse tipo de narrativa e o status de veracidade que ela desfrutava - outorgava ao texto uma certa legitimidade. Legitimidade que se explicitava nas referências feitas a outras Historiae como vemos fazer o autor anônimo da Chronica dita de "Fredegário":

Nulla sit dubitatio de ista descripcione, quia de cronica beati Eusebii Caesariensis episcopi adsumpta est usque ad passionem

\footnotetext{
${ }^{438}$ SILVEIRA, Verônica da Costa. História e historiografia na Antigüidade Tardia à luz de Gregório de Tours e Isidoro de Sevilha. 2010. 181 f. Dissertação de Mestrado - Faculdade de Filosofia, Letras e Ciências Humanas/USP. São Paulo, julho de 2010.

${ }^{439}$ Sobre o título dos Decem Libri Historiarum: GOFFART, W. From Historiae to Historia Francorum and back again: aspects of the textual history of Gregory of Tours. In: Londres e Roceverte: Hambledon, 1989. Rome's fall and after.

${ }^{440}$ Decem Libri Historiarum, IV, 13. Ver tradução 30, anexo 1.
} 
domini nostri Iesu Christi; item a passione Domini per paschale Victorii usque in tempore isto invenies veritatem. ${ }^{441}$

A referência a outras histórias serviam como argumento de autoridade, como critério de confiabilidade do próprio texto. Assim, ao qualificar um texto como Historia seus autores estavam passando uma poderosa mensagem: aquele texto, baseado em eventos testemunhados ou descritos em outras histórias traziam narrativas confiáveis. Frente a isso não podemos ser ingênuos diante desse grupo de fontes e tampouco acreditar que seus autores não fizeram uma escolha consciente ao escreverem Historiae. Devemos ler esses textos tento em vista que eles tinham a presunção da verdade e com ela como norte narraram eventos do tempo "Gesta Temporum". 442

\section{Os godos na história e a construção e uso da memória na Hispania Visigoda - João de Biclaro, Isidoro de Sevilha e Juliano de Toledo}

Três autores se destacam na escrita de histórias durante o período visigodo na Península Ibérica. João de Biclaro, autor de uma Chronica que narra os eventos ocorridos entre os anos de 565 e 589; Isidoro de Sevilha, autor de uma crônica e da Historia Gothorum, Sueborum et Wandalorum, escrita em duas versões, uma chamada "breve" que se encerra com o reinado de Sisebuto, e uma longa finalizada no reinado de Suintila; E Juliano de Toledo, autor da Historia Wambae que se concentra na revolta de Paulo contra o rei Wamba. As três obras, unidas, abarcam um período de considerável marco temporal se considerarmos que Isidoro de Sevilha inicia sua narrativa com uma referência à guerra civil de César (49-45 a.C.) e na versão breve

\footnotetext{
${ }^{441}$ Fredegário, Chronica, 1.I, 24.

${ }^{442}$ Como define o autor da Chronica de Fredegário: ...chronicis - verbo huius nomenis Grego, quod Latini interpretatur 'Gesta temporum'... Chronica de Fredegário, prólogo ao livro IV.
} 
encerra a obra com Sisebuto (612-621) e na versão longa com Suintila (621-631), enquanto a Historia Wambae tem uma cronologia mais restrita dedicando-se a 673.

Mesmo que as três obras se enquadrem no gênero narrativo histórico elas têm finalidades diversas. A Chronica de João de Biclaro se centra no reinado de Leovigildo e termina com o reinado de Recaredo. O grande interesse dessa fonte é ter sido escrita por um religioso católico que viveu durante o reinado de Leovigildo de modo que foi uma testemunha tanto da época em que Leovigildo tentou trazer os bispos católicos para o arianismo ${ }^{443}$ quanto da conversão de Recaredo. ${ }^{444}$ Por sua vez, como já é possível perceber pelo enorme número de citações que fazemos à obra, a Historia Gothorum, Sueborum et Wandalorum de Isidoro de Sevilha é uma das mais importantes fontes históricas para o período visigodo, a despeito de sua brevidade e das poucas informações trazidas pelo autor, ela é a mais preciosa fonte de notícias advindas da própria península hispânica sobre os atos dos reis visigodos até Suintila, e é justamente a descrição desses atos que é o objeto de interesse do hispalense com essa obra. Já a Historia Wambae é a última Historia escrita durante o reinado dos visigodos, depois dela nossa principal fonte de informações sobre os reis godos são os Concílio Toledanos, de todo modo, é a narração da infidelidade de Paulo e a vitória do rei Wamba contra o duque rebelde que é o objeto de interesse do autor. O fato é que nessas três obras singularidades no discurso identitátio em torno da gens gothorum nos ajudam a comprender não só os objetivos desses textos, mas também os usos desses discursos no que concerne ao gênero narrativo história.

Em João de Biclaro, por exemplo, o papel da gens gothorum na narrativa é bastante interessante. Como já dissemos, o autor foi um religioso católico que viveu na época do rei ariano Leovigildo, conforme as informações no De Viris Illustribus de

\footnotetext{
${ }^{443} \mathrm{O}$ sínodo reunido por Leovigildo para tentar trazer ao arianismo os bispos católicos foi mesmo registrado pelo biclarense em sua Chronica, IV ano de Tibério, XII de Leovigildo.

${ }_{444}$ Chronica Biclarense, anno V de Maurício e I de Recaredo, 5.
} 
Isidoro de Sevilha, por sua oposição ao arianismo de Leovigildo João de Biclaro foi exilado em Barcelona. ${ }^{445}$ Ao contrário das Vitas Sanctorum Patrum Emeretensium, texto do século VII que analisaremos na área dedicada às hagiografias, o rei Leovigildo não é descrito de maneira negativa pelo biclarense. De fato, os atos do rei que pacificaram o reino depois de um período de rebeliões é celebrado por João de Biclaro:

Huius imperio anno III Leovegildus germanus Livvani regis superstite fratre in regnum citerioris Hispaniae constituitur, Gosuintham relictam Athanaildi in coniugium accipit et provinciam Gothorum, quae iam pro rebellione diversorum fuerat diminuta, mirabiliter ad pristinos revocat terminos. ${ }^{446}$

A imagem discrepante entre a Chronica de João de Biclaro e as Vitas Sanctorum Patrum Emeretensium é de fato muito interessante. João de Biclaro conheceu Masona de Mérida, ${ }^{447}$ tal como o bispo de Mérida foi exilado pelo rei Leovigildo, entretanto enquanto o texto de João não faz críticas ferozes ao rei, as Vidas o fazem. Talvez a distância temporal entre a produção dos dois textos ajude a compreender essa discrepância. Enquanto João de Biclaro escreveu pouco depois da elevação de Recaredo, filho de Leovigildo, ao trono, as Vidas são de um período muito posterior tendo sido escritas no século VII. A passagem do tempo pode ter dado liberdade ao autor das Vidas para criticar Leovigildo enquanto João de Biclaro escreveu quando Recaredo ainda estava no trono. É uma possibilidade explicativa, mas não a única. A outra possibilidade se refere ao valor que João de Biclaro deu ao reino e a gens dos godos e isso nos demanda um discussão mais rigorosa.

A questão religiosa, que conforme Isidoro de Sevilha foi a causa do exílio do biclarense, e recebe grande atenção na descrição dos sucessos de Masona de Mérida,

\footnotetext{
445 ...quo incitante Leovigildo rege Arriana fervebat insania. hunc supra dictus rex cum ad nefandae haeresis credulitatem compelleret et hic omnino resisteret, exilio trusus er Barcinonam relegatus per decem annos multas insidias et persecutiones ab Arrianis perpessus est... De Viris Illustribus.

${ }^{446}$ Chronica Biclarense, Anno III de Justino, 4. Ver tradução 31, anexo 1.

${ }^{447}$ CAMPOS, Julio. Juan de Biclaro obispo de Gerona. Su vida y su obra. Madrid: Consejo superior de investigaciones cientificas, 1960. p. 58.
} 
na Chronica de João de Biclaro não é o tema central. O biclarence citou o arianismo em cinco ocasiões:

1. Ao se referir à um certo bispo ariano chamado Trasarico que levou os tesouros do rei Cunemundo dos Gépidas à Constantinopla depois da derrota do rei diante dos longobardos; ${ }^{448}$

2. Ao mencionar o sínodo ariano convocado por Leovigildo para tentar trazer os bispos católicos ao arianismo; ${ }^{449}$

3. Referência à conversão de Recaredo; ${ }^{450}$

4. Rebelião de Sunna em Mérida contra Recaredo; ${ }^{451}$

5. Menção ao III Concílio de Toledo; ${ }^{452}$

É apenas na quinta vez que João de Biclaro critica com mais força o arianismo apontando a heresia nos pressupostos teológicos da doutrina de Ário. Nas demais vezes em que a seita é mencionada não há uma forte censura do Biclarense, ele, por exemplo, embora não tenha celebrado o sínodo convocado por Leovigildo, registrou o fato como mais um evento e preocupou-se em mencionar que os católicos que se converteram ao arrianismo o fizeram mais por vontade própria do que por imposição:

Leovigildus rex in urbem Toletanam synodum episcoporum sectae Arrianae congregat et antiquam haeresem novello errore emendat, dicens de Romana religione a nostra catholica fide venientes non debere baptizari, sed tantummodo per manus impositionem et communionis praeceptione pollui et gloriam patri per fililum in spiritu sancto dare. per hanc ergo seductionem plurimi nostrorum cupiditate potius quam impulsione in Arrianum dogma declinant. ${ }^{43}$

À luz da primeira descrição de João de Biclaro acerca de Leovigildo, e sua preocupação em dizer que o rei não forçou os católicos à conversão no sínodo que convocou em Toledo, podemos dizer que a imagem de Leovigildo é positiva na Chronica de João de Biclaro, o que ganha mais evidência em sua crítica à rebelião de

\footnotetext{
${ }^{448}$ Chronica Biclarense, VI ano de Justino, IV de Leovigildo.

${ }^{449}$ Chronica Biclarense, IV ano de Tibério, XII de Leovigildo, 2.

${ }^{450}$ Chronica Biclarense, V ano de Maurício, I de Recaredo, 5.

${ }^{451}$ Chronica Biclarense, VI ano de Maurício, II de Recaredo, 1.

${ }^{452}$ Chronica Biclarense, VIII ano de Maurício, IV de Recaredo.

${ }^{453}$ Chronica Biclarense, IV ano de Tibério, XII de Leovigildo, 2. Ver tradução 32, anexo 1.
} 
Hermenegildo, e é a partir de sua crítica que podemos melhor compreender porque João, mesmo perseguido, não condenou Leovigildo em sua Chronica. Nas palavras de João, a rebelião de Hermenegildo causou mais danos aos godos e aos romanos na Hispânia do que as investidas dos inimigos: ...quad causa provincia Hispaniae tam Gothis quam Romanis maioris exitii quam adversariorum infestatio fuit. ${ }^{454}$

Ora, se levarmos em conta que João de Biclaro iniciou seu relato sobre Leovigildo comemorando o fato de que o rei pacificou o reino depois de um período de rebeliões, é de se supor que eram as rebeliões que causavam males à Hispania, e por consequiência aos gothi e romani que preocupavam o biclarense mais do que a questão religiosa por si só. Isso não quer dizer que a religião não fosse importante para o cronista, ele comemorou a conversão de Recaredo que trouxe os godos para o catolicismo:

Reccaredus primo regni sui anno mense $X$ catholicus deo iuvante efficitur et sacerdotes sectae Arrianae sapienti colloquio agressus ratione potius quam imperio converti ad catholicam fidem facit gentemque omnium Gothorum et Suevorum ad unitatem et pacem revocat Christianae ecclesiae. sectae Arrianae gratia divina in dogmate veniunt Christiano. ${ }^{455}$

A conversão de Recaredo conduziu a gens gothorum e os suevos - submetidos ao visigodos durante o reinado de Leovigildo - à verdadeira fé católica sem causar distúrbios no reino e sem causar danos às gentes sob a autoridade dos reis tal como fez Hermenegildo. Era a estabilidade do reino e das gentes sob a autoridade dos reis que interessavam a João de Biclaro, eram os reis os personagens legítimos para conduzir aqueles sob a autoridade deles, não os rebeldes que como Hermenegildo tentaram solapar a autoridade do rei legítimo. O bom caminho do reino e das gentes tinha na figura do rei o seu representante, o seu guia. A Chronica de João de Biclaro assim, quando recorre ao discurso da gens gothorum enfatiza o papel que os reis

\footnotetext{
${ }^{454}$ Chronica Biclarense, III ano de Tibério, XI de Leovigildo, 3.

${ }^{455}$ Chronica Biclarense, V ano de Maurício, II de Recaredo, 5.
} 
legítimos tinham na garantia de que a gens seria bem conduzida. Isso faz sentido se percebermos que o reinado de Recaredo também estava sob pressão opositora. Em Mérida, o bispo arriano Sunna junto com Segga tentou tiranizar o poder:

Quidam ex Arrianis, id est Siuma episcopus et Segga, cum quibusdam tyrannidem assumere cupientes deteguntur; convicti Siuma exilio truditur et Segga manibus amputatis in Gallaeciam exul transmittitur. ${ }^{456}$

Ao centrar na figura dos reis - mesmo Leovigildo que poderia ser indigno por seu arrianismo - a garantia da paz e do valor das gentes, especialmente a gens gothorum, João de Biclaro provavelmente respondia as forças nobiliárquicas que se opunham ao poder dos reis. A rebelião de Hermenegildo, como vimos, causou mais danos aos gothi e romani do que as investidas dos inimigos, qualquer outra rebelião contra os reis legítimos causaria os mesmos danos a gens e ao regnum. O lugar do discurso em torno da gens gothorum na Chronica Biclarense parece ter uma função bem específica: criar um aparato narrativo que se aliava ao poder dos reis contra as forças opositoras. Isso lançando mão do poderoso discurso histórico que, como já dissemos, tinha a presunção de encerrar em si o valor da veracidade das informações transmitidas. Assim, a gens gothorum na narrativa do Biclarense aparentemente fazia parte de um constructo político de apoio ao poder dos reis em detrimento às nobrezas opositoras, discutidas no capítulo III. É importante agora observarmos como esses discursos são articulados na história de Isidoro de Sevilha, um bispo que tinham íntima relação com os reis visigodos.

Discutimos no capítulo II como Isidoro de Sevilha retratou a realeza visigoda, para tanto, além das Sentenças, fizemos muitas referências a sua Historia Gothorum. Entretanto, o estudo da obra do bispo no que concerne a suas contribuições a este trabalho requer uma análise mais aprofundada sobre a própria natureza da obra e suas

\footnotetext{
${ }^{456}$ Chronica Biclarense, VI ano de Maurício e II de Recaredo, 1.
} 
intenções. Não raro retratado como o texto fundador da história da Espanha, objetivamos aqui apresentar uma nova linha de análise sobre o sentido da obra considerando os outros trechos que a integra, a saber, a Historia Wandalorum e a Historia Sueborum.

Como o próprio provável nome original indica, ${ }^{457}$ A História dos Godos, Vândalos e Suevos dedicar-se-ia à narrativa das origens dessas "gentes" e seus reinos. Isidoro de Sevilha ocupou-se em definir o que ele entendia por "gens" tanto em suas famosas Etimologias quanto em seus livros das Diferenças, no qual encontramos uma distinção entre "gens", "gentes" e "genus" bastante proveitosa para termos uma chave interpretativa do uso do termo em suas histórias:

332. (270). Inter gentem et gentes et genus. Gens nationis est, ut Graecia, Asiae; hinc et gentilitas dicitur. Gentes autem familiae, ut Iuliae, Claudiae. Genus uero ad qualitatem refertur, ut pecoris, pomi. ${ }^{458}$

Nas Etimologias o bispo ofereceu uma explicação mais detalhada e rica sobre as gentes, onde explica sobre suas origens e traz notícias sobre algumas gentes.

IX,1. Linguarum diversitas exorta est in aedificatione turris post diluvium. Nam priusquam supervia turris illus diversos signorum sonos humanam divideret societatem, uma omnium nationum língua fuit, quae hebrara vocatur; quam patriarchae et prophetae usi sunt non solum in sermonibus, verum etiam in litteris sacris. Initio autem quot gentes, tot linguae fuerunt, deinde plures gentes quam linguae; quia ex uma língua multae sunt gentes exortae. ${ }^{459}$

Notemos que o Hispalense estabeleceu uma íntima relação entre a origem das diferentes gentes e a multiplicação das línguas após o incidente da Torre de Babel:

\footnotetext{
${ }^{457}$ Bráulio de Zaragoza na lista das obras que fez de Isidoro de Sevilha identificou a Historia Gothorum, Sueborum et Wandalorum da seguinte maneira: "De origine Gothorum et regno Sueuorum et etiam Vandalorum historia librum unum." Braulio de Zaragoza. Renotatio Librorum Domini Isidori.

${ }^{458}$ De Differentiis I. Ver tradução 33, anexo 1.

${ }^{459}$ Etymologiarum, IX, 1. (De linguis gentium). Ver tradução 34, anexo 1.
} 
IX,1. Ideo autem prius de linguis, ac deinde de gentibus posuimus quia ex linguis gentes, non ex gentibus linguae exortae sunt. ${ }^{460}$

Embora a origem de diferentes gentes tenha sido a confusão das línguas conforme descrito no relato bíblico, Isidoro de Sevilha escreveu que com o passar do tempo o número de gentes superou o de línguas, pois de uma mesma língua surgiram diferentes gentes. ${ }^{461}$ Deste modo, compartilhar um idioma não implicava ser parte de uma mesma gens. Continuou o bispo:

IX, 2. Gens est multitudo ab uno principio orta, sive ab alia natione secundum propriam collectionem distincta, ut Graeciae, Asiae. Hinc et gentilitas dicitur. Gens autem appellata propter generationes familiarum, id est a gignendo, sicut natio a nascendo. ${ }^{462}$

Gens não resulta, assim, tão-somente de uma multidão de pessoas de comum origem, mas também da união de gentes distintas em determinada região, como os galos que se mesclaram aos gregos e originaram os "galo-gregos", posteriormente "gálatas". ${ }^{463}$ É certo que Isidoro de Sevilha não compartilhava da consciência histórica ${ }^{464}$ tal como surgida no século XVIII, mas o bispo parecia longe de uma concepção essencialista dos povos tal como, conforme autores como P. Gueary, ${ }^{465}$ interpretavam os historiadores do século XIX. Mas estavam os textos isidorianos, especialmente os historiográficos, de fato inseridos em um discurso identitário ${ }^{466}$

\footnotetext{
${ }^{460}$ Etymologiarum, IX, 1. (De linguis gentium)

${ }^{461}$ Initio autem quot gentes, tot linguae fuerunt, deinde plures gentes quam linguae; quia ex uma lingua multae sunt gentes exortae. Etym. IX,1.

${ }^{462}$ Etym. IX, 2. Ver tradução 35, anexo 1.

${ }^{463}$ Galatae Galli esse noscuntur, qui in auxilium a rege Bithyniae evocati, regnum cum eo parta victoria diviserunt; sicque deinde Graecis admixti primum Gallograeci, nunc ex antiquo Gallorum nomine Galatae nuncupantur. Etym. IX, 2.

${ }^{464}$ Adotamos nesse texto a concepção de consciência histórica tal como definida por H.-G. Gadamer, que infere: "Entendemos por consciência histórica o privilégio do homem moderno de ter plena consciência da historicidade de todo presente e da relatividade de toda opinião." GADAMER, H.-G. Problemas epistemológicos das ciências humanas. In: Idem. O problema da consciência histórica. Rio de Janeiro: FGV, 2003. p.17.

${ }^{465}$ GUEARY, Patrick J. O mito das nações: a invenção do nacionalismo...op.cit.

${ }^{466}$ Como escreveu W. Pohl: "Isidore de Séville, par une vaine spéculation étymologique se fondant sur la proximité des noms Gog, Goth, Gète et Scythe, parvint même à neutraliser le sens apocalyptique du nom des 'Goths', identifiés aux Gog et Magog de la Bible.[...]. Ces mythes des origines (origines
} 
Isidoro de Sevilha em sua Historia Gothorum foi econômico no relato sobre os godos no período anterior ao contato deles com os romanos. Sua história, que conta com duas versões ditas "breve" e "longa", oferece duas narrativas distintas sobre os tempos mais pretéritos da gens Gothorum:

Breve

Gothorum antiquissimum esse regnum certum est, quod ex regno Scytharum est exortum. ${ }^{467}$
Longa

Gothorum antiquissimam esse gentem [certum est]: quorum originem quidam de Magog Iafeth filio suspicantur a similitudine ultimae syllabae; et magis de Ezechiele propheta id coligentes. Retro autem eruditi eos magis Getas quam Gog et Magog appellare consueuerunt. ${ }^{468}$

Já nas Etimologias, o autor atribuiu a Magog tanto a origem dos godos quanto dos escitas. ${ }^{469}$ As duas versões não são contraditórias, versam, todavia, sobre a origem de duas coisas diferentes. A breve fala da origem do reino dos godos, a longa da origem da gens gothorum. "Reino", termo que para Isidoro era algo intimamente ligado aos "reis" "rei” no início das diferentes gentes - originalmente distintas por suas línguas.

Segundo Rodríguez Alonso a versão longa enfatiza questões religiosas por seu caráter apologético. Durante a redação da versão breve, possivelmente entre 619 e 620, o reino godo não havia conquistado a unidade territorial em toda Hispânia, feito que só foi realizado pelo rei Suintila com a vitória contra os rucones, vascones e a expulsão dos bizantinos da Hispânia. ${ }^{471}$ Com a ampliação da autoridade de Suintila

gentium) qui nous sont parvenus contribuèrent de manière fondamentale à la construction des identités." POHL, W. Aux origines d'une Europe ethnique: Transformations d'identités entre Antiquité et Moyen Âge. Annales. Histoire, Sciences Sociales. 60e Année, n.1, p.183-208, 2005.

${ }^{467}$ Historia Gothorum versão breve (VB).

${ }^{468}$ Historia Gothorum versão longa (VL). Ver tradução 36, anexo 1.

${ }^{469}$ Magog, a quo arbitrantur Scythas et Gothos traxisse originem. Etym., IX,2.

${ }^{470}$ Regnum a regibus dictum. Nam sicut reges a regendo vocati, ita regnum a regibus. Etym., IX, 3.

${ }^{471}$ BRONISCH, Alexander P. El concepto de España en la historiografía visigoda y asturiana. Norba. v.9, p.9-42, 2006. p.13. 
em toda Hispânia, Isidoro teria se sentido impelido a reforçar a religião como elemento essencial para a manutenção da unidade. Destarte, ao escrever a segunda versão de sua história, a longa entre 624 e 626, o bispo de Sevilha outorgou à religião papel de destaque desde o início do texto, ao, por exemplo, fazer referência entre a origem do godos e Magog, filho de Jafet e neto de Noé. ${ }^{472}$

M. Reydellet, por sua vez, levanta a hipótese da existência de certa hierarquia das gentes na visão isidoriana. De acordo com o estudioso Isidoro construiu um quadro genealógico das gentes organizado segundo a descendência de Sem, Cham e Jafet. Nesse retrato, cada nação herda seu nome de um dos descendentes desses "pais fundadores". Todavia, com o passar do tempo, o nome das gentes sofre modificações por motivos diversos de modo a ser por vezes difícil traçar seguramente sua linha genealógica. Desde essa perspectiva Isidoro estabeleceu a hierarquia entre os "povos": quanto mais difícil era identificar seus ancestrais mediante o estudo de seu nome, mais degenerada era a gens analisada. Nesse sentido os godos acabaram por assumir um lugar privilegiado já que o Hispalense identificou facilmente sua origem em Magog. ${ }^{473}$

E Isidoro evidentemente deu um peso positivo a essa identificação, como atestam suas Etimologias:

IX, 2. Gothi a Magog filio Iaphet nominati putantur, de similitudine ultimae syllabae, quos veteres magis Getas quam Gothos vocaverunt; gens fortis et potentissima, corporum mole ardua, armorum genere terribilis. ${ }^{474}$

\footnotetext{
${ }^{472}$ RODRIGUEZ ALONSO, Cristóbal. Las historias de los godos, vandalos y suevos de Isidoro de Sevilla. Estudios, edición crítica y traducción. Leon: centro de estudios e investigación "San Isidoro". Archivo historico diocesano Caja de ahorros y Monte Piedad de Leon, 1975. p. 35-39.

${ }^{473}$ REYDELLET, M. La significatión du Livre IX des Etymologies: erudition et actualite. In: GONZÁLEZ BLANCO, A. Antigüedad y Cristianismos. Monografias historicas sobre la Antigüedad Tadia III - Los Visigodos. Historia y Civilizacion. Actas de la Semana Internacional de Estudios Visigóticos (Madrid - Toledo - Alcalá de Henares, 21-25 octubro de 1985) Universidad de Murcia, Fundación Pastor de Estudios Clasicos, Universidad de Alcalá de Henares, 1986. p. 337-350.

${ }^{474}$ Etym., IX, 2.
} 
E mais explicitamente sua Historia Gothorum: Interpretation autem nominis eorum in lingua nostra tecti quod significatur fortitudo: et re vera. Nulla enim gens in orbe fuit, quae Romanum imperium adeo fatigaverit. ${ }^{475}$

A identificação da gens gothorum com uma origem bíblica outorga aos godos um papel de maior relevância no conjunto das Historiae de Isidoro, algo que se destaca se a compararmos com os relatos sobre os vândalos e suevos que não tratam das origens dessas gentes. Não obstante, esse relato presente na versão longa em contraste com a versão breve valoriza ainda mais os godos por dissociar a origem de seu reino do reino dos escitas - também descendentes de Magog - e retroceder o relato até a origem da gens propriamente dita. Se avançarmos na leitura da Historia Gothorum percebemos essa diferença de valor:

Breve Longa

Per multa quippe saecula et regno et regibus usi sunt, sed quia in chronicis adnotati non sunt, ideo ignorantur. ${ }^{476}$

Per multa quippe retro saecula ducibus usi sunt, postea regibus, quorum oportet tempora per ordinem cursim exponere et quo nomine actuque regnauerint, de historiis libata retexere.. ${ }^{477}$

$\mathrm{Na}$ versão longa percebemos que cronologicamente os reis surgiram depois dos chefes (duces). São as ações dos reis que o bispo objetivou registrar com mais vagar, ações essas que, conforme lemos na versão longa, estavam registradas nas histórias. É importante ressaltar que o termo "reino" só aparece na versão longa após Atanarico se tornar o primeiro rei. Na versão breve não há menção ao fato de Atanarico ser o primeiro rei, apenas que ele aceitou assumir o governo da gens

\footnotetext{
${ }^{475}$ HISTORIA GOTHORUM, $V L, 2$.

${ }^{476}$ HISTORIA GOTHORUM, VB.

${ }^{477}$ HISTORIA GOTHORUM, VL, 2.
} 
gothorum ${ }^{478}$ Assim a versão longa da origem dos godos não só os eleva na hierarquia ressaltada por Reydellet, mas também os identifica como uma gens ainda mais antiga em relação ao relato da versão breve. Mais importante, a versão longa revela melhor o intento do bispo com sua história, a saber, mais do que tratar da origem dos godos, ele quis falar de seus reis, respeitando a cronologia de seus reinados, nomes e contando sobre suas ações.

Isidoro de Sevilha não inovou ao relacionar os godos com os escitas e tampouco com Magog. Essa relação já havia sido feita por Santo Ambrósio e São Jerônimo, ${ }^{479}$ assim como aparece na Getica de Jordanes que, ao mencionar os relatos de Flávio Josefo sobre os godos, diz que o historiógrafo apenas citou Magog e ligou os godos aos escitas. ${ }^{480}$ Embora o Hispalense tenha alterado as versões dadas sobre os godos nos textos da patrística a fim de valorizar os godos, como bem apontou Coumert, ${ }^{481}$ ele tampouco inovou ao outorgar adjetivos positivos aos godos, o que indica a existencia de uma tradição narrativa em torno da gens gothorum muito anterior ao texto do bispo de Sevilha. Tal tradição não repercutiu apenas no texto isidoriano.

Nas atas do III Concílio de Toledo, realizado em 589, quando o rei Recaredo professou publicamente a conversão dos godos ao catolicismo depois de ter seguido por muitos anos a heresia ariana, lemos no relato da intervenção de Recaredo frente aos bispos reunidos:

\footnotetext{
${ }^{478}$ Aera CCCVIII, anno Valentis $V$ Gothorum gentis administrationem Athanaricus accepit. HISTORIA GOTHORUM, VB. I Aera CCCVII, anno V imperii Valentis primus Gothorum gentis administrationem suscepit Athanaricus. HISTORIA GOTHORUM, VL, 6.

${ }^{479}$ BRONISCH, Alexander P. El concepto de España en la historiografia visigoda y asturiana...op.cit. p. 16-17. Ainda: COUMERT, Magali. Origines des Peuples. Les récits du haut Moyen Âge Occidental (550-850). Paris: Institut d'Études Augustiniennes, 2007. p.108-110

${ }^{480}$ Ioseppus quoque annalium relator verissimus dum ubique veritatis conservet regulam et origines causarum a principio revolvat. haec vero quae diximus de gente Gothorum principia cur omiserit, ignoramus: sed tantu Magog eorum stirpe comemorans, Scythas eos et natione et vocabulo asserit appellatos. Getica, IV.

${ }^{481}$ COUMERT, Magali. Origines des Peuples... op.cit.
} 
Adest enim omnis gens Gothorum inclyta et fere omnium gentium genuina virilitate opinata quae licet suorum pravitate doctorum a fide hactemus vel unitate ecclesiae fuerit catholicae segregata, toto nunc tamen mecum adsensum concordans eius ecclesiae conmunioni participatur, quae diversam gentium multitudinem materno sinu suscepit et caritatis uberibus nutrit, de qua profeta canente dicitur: 'Domus mea domus orationis vocabitur omnibus gentibus". ${ }^{482}$

Não só os godos são descritos como uma gens ilustre reconhecida por sua virilidade, o que Isidoro de Sevilha destacaria futuramente tanto nas etimologias quanto na Historia Gothorum, como a adesão a heresia ariana foi atribuída à maldade dos doutores. Estes "doutores" eram aqueles que foram enviados pelo Imperador Valente há tempos, quando os godos requisitaram a ele auxílio para receberem ensinamentos na fé cristã, como narrou Isidoro na versão longa de sua Historia Gothorum, ${ }^{483}$ mas outrora havia registrado Jordanes em sua Getica. ${ }^{484}$ A punição de Valente foi a morte pelo fogo, conforme relatou, além de Jordanes e Isidoro, também Orósio na sua História Contra os Pagãos. ${ }^{485}$ Recaredo parecia conhecer essa versão da conversão dos godos ao arianismo, assim como identificava os godos como ilustres e viris antes da celebração que Isidoro faria em seus textos à gens gothorum. O que é importante enfatizar é o fato de Isidoro de Sevilha ter baseado seus textos em versões que já circulavam desde antes do século VII. Embora de fato exista uma especial valorização dos godos nos escritos isidorianos, o Hispalense não parece ter sido seu artífice. À celebração aos godos na Hispânia existia antes do famoso bispo de Sevilha. Pouco depois da conversão dos godos, entre 590 e 602, o já mencionado João de Biclaro destacou a vitória dos godos contra os francos atribuindo-a a providência divina e equacionando-a a vitória milagrosa de Gedão contra os medianitas. Tal como

\footnotetext{
${ }^{482}$ Ver tradução 38, anexo 1.

${ }^{483}$ HISTORIA GOTHORUM, VL, 7.

${ }^{484}$ Getica, XXV.

${ }^{485}$ Livro VII, 33.
} 
Gedeão, o duque Cláudio, a frente do exército godo composto por apenas trezentos homens, deu cabo dos francos que contavam com quase sessenta mil homens:

Francorum exercitus a Gonterano rege transmissus, Bosone duce, in Galliam Narbonensem obveniunt, et juxta Carcassonensem urbem castra metati sunt. Cui Claudius Lisitaniar dux Recaredo rege directus obviam inibi occurrit: cum quo congressione facta, Franci in fugam vertuntur, et direpta castra Francorum, et exercitus a Gohtis caeditus. In hoc ergo certamine gratia divina, et fides catholica quam Recaredus rex in Gothis fideliter adeptus est, esse noscitur operata: quoniam non est difficile Deo nostro, si in paucis una in multis detur victoria. Nam Claudius duz cum CCC viris $L X$ millia ferme Francorum noscitur infugasse, et maximam eorum partem gladio trucidasse. Non immerito Deus laudatur temporibus nostris in hoc praelio esse operatus, qui similiter ante multa temporum spatia per manum ducis Gedeonis MCCC viris multa millia Madianitarum Dei populo infestantium noscitur exstinxisse. ${ }^{486}$

O biclarense narra a derrota dos francos, que eram, cabe destacar, cristãos católicos, frente a um exército godo cujo rei recentemente se convertera. Ao destacar que Gedeão derrotou os medianitas hostis ao povo de Deus, e comparar a vitória dos godos a esse relato, João de Biclaro qualifica os godos como o povo de Deus em detrimento aos francos hostis. Esse tipo de valorização dos godos aparece também no III Concílio de Toledo, quando suas atas versam sobre a vitória contra os Suevos.

Nec enim sola Gothorum conversio ad cumulum nostrae mercedis accessit, quinimmo et suevorum gentis infinita mutituto, quam praesidio coelesti nostro regno subiecimus; alieno licet in haeresim deductam vitio, nostro tamem ad veritatis originem studio revocavimus. ${ }^{487}$

Embora as palavras de Recaredo enunciem que os Suevos aderiram à verdadeira fé graças ao avanço dos godos, os suevos se converteram ao catolicismo antes da derrota que sofreram dos godos que eram governados na época por Leovigildo, um rei ariano que empreendeu, inclusive, perseguições aos católicos do reino. A propósito, o próprio João de Biclaro foi desterrado por Leovigildo. As

\footnotetext{
${ }^{486}$ Ver tradução 39, anexo 1.

${ }^{487}$ Ver tradução 40, anexo 1.
} 
informações que constam nas atas do III Concílio de Toledo e na Crônica de João de Biclaro estão também presentes na Historia Gothorum de Isidoro de Sevilha.

49. Postremum Bellum Sueuis intulit regnumque eorum in iure gentis suae mira celebritate transmisit, Spania magna ex parte po itus, nam antea gens Gothorum angustis finibus arbatur. Sed offuscauit in eo error impietatis gloriam tantae uirtutis. ${ }^{488}$

A vitória contra os suevos se conta entre as virtudes de Leovigildo mesmo tendo ele derrotado uma gens que professava o catolicismo. Isidoro, todavia, ao contrário do III Concílio de Toledo, não atribuiu à submissão dos suevos frente aos godos o fato dos primeiros terem se convertido ao catolicismo. No que concerne à vitória contra os francos conquistada pelo exército godo liderado por Cláudio, Isidoro registrou o mesmo caráter fabuloso da batalha presente na crônica biclarense, sem, contudo, traçar o paralelo com a vitória de Gedeão:

54. Egit etiam gloriose bellum adversus infestas gentes fidei suscepto auxilio. Francis enim sexaginta fere milium armatorum Gallias inruentibus misso Claudio duce adversus eos glorioso triumphauit euentu. Nulla umquam in Spaniis Gothorum uictoria uel maior uel similis extitit.

O que queremos apontar com isso é que Isidoro de Sevilha utilizou amplamente discursos já existentes na Hispânia visigoda na maior parte de suas descrições sobre os godos. Ora, embora o bispo tenha lançado mão de textos ainda mais antigos - como os da patrística - alterando-os para que fossem mais favoráveis a gens Gothorum ele mesmo assim seguiu uma tendência encontrada em documentos hispânicos anteriores a sua época produtiva tanto enquanto bispo quanto enquanto autor. E esses discursos favoráveis aos godos apareciam não só em textos historiográficos, mas também em atas conciliares. Talvez a mais importante contribuição do Hispalense no que concerne a uma imagem coerente sobre a gens

${ }^{488}$ Ver tradução 41, anexo 1. 
Gothorum consista na reunião de relatos esparsos sobre essa gens em um texto, mais do que na construção dessa imagem propriamente dita. Mas isso não é desimportante, principalmente no cenário conturbado da realeza visigoda. E nos parece que era para responder àquelas perturbações que Isidoro escreveu suas histórias. É notável que a maior parte do texto versa sobre os reis propriamente ditos, a origem dos godos ocupa poucos trechos da obra, o que pode nos leva a entender que escrever sobre essa origem não era o principal objetivo do Hispalense. Tal perspectiva se reforça quando observamos a história dos vândalos e suevos, trechos comumente negligenciados pelos pesquisadores.

Dentre todas as gentes que passaram pela Península Hispânica e que foram contempladas pelo De origine Gothorum et regno Sueborum et etiam Wandalorum historia librum unum de Isidoro de Sevilha, somente os godos têm suas origens desvendadas, mas era para os reis que sua obra foi dedicada e eram aos reis que o bispo quis transmitir sua mensagem. Sua mensagem que visava expressar os fundamentos que norteariam a almejada estabilidade do reino, sempre ameaçada pelas disputas entre a aristocracia visigoda em torno da sucessão régia. As notícias trazidas por sua própria obra historiográfica enunciam as constantes ameaças que os reis sofriam.

Isidoro de Sevilha foi talvez o maior sistematizador da moralidade régia da Hispânia no decorrer da Antigüidade Tardia e suas histórias não são um trabalho à parte. O bispo de Sevilha sabia que a desordem política no reino muito devia ao problemático sistema de sucessão. Enquanto a sucessão no reino Merovíngio, por exemplo, era dinástica e só os descendentes de Clóvis eram aptos ao trono, no reino visigodo a sucessão se dava por uma escolha, onde todos os membros da aristocracia eram candidatos em potencial ao trono. Dessa forma, divisões entre as elites godas em 
torno dos reis eleitos eram recorrentes, como já insistimos no capítulo dedicado à realeza.

Já o primeiro rei eleito entre os godos, conforme escreveu Isidoro, enfrentou um dissidente, Fridigerno, que foi proclamado rei por causa de uma divisão entre os visigodos. A mesma cisão ocorreu durante o reinado de Alarico, quando alguns visigodos nomearam Ragadaiso rei. ${ }^{489}$

A ameaça ao governo do rei não ocorria só pela nomeação de outros reis, mas também por assassinatos. Dos vinte e cinco reis mencionados por Isidoro, nove foram assassinados. Dos nove reis assassinado, quatro faziam parte de duas tentativas de estabelecer a sucessão dinástica entre os visigodos.

Teodorico I (418 - 451) foi sucedido por seu filho Turismundo, provavelmente o primogênito. Turismundo acabou morto pelo irmão Teodorico II, este, por sua vez, foi morto pelo também irmão Eurico. Eurico foi sucedido por Alarico, também seu filho que em 507 perdeu o reino de Toulouse para o franco Clóvis, o filho de Alarico, Gisaleico, ainda chegou a assumir o governo até ser deposto por Teodorico, o rei ostrogodo. Gisaleico era filho ilegítimo de Alarico e reinou até 511. Por quase cem anos os visigodos foram governados pelos descendentes de Teodorico I, algo até então inédito. Algo semelhante aconteceria somente cinqüenta e seis anos depois, quando Liuva nomeou seu irmão Leovigildo sucessor e participador do governo. Pouco depois Leovigildo assumiria sozinho o reinado. Em 573, como seu irmão Liuva fizera, Leovigildo associou seus filhos, Hermenegildo e Recaredo, ao reino, o primeiro acabou morto na prisão depois de se levantar contra o pai. O segundo sucedeu Leovigildo e se converteu ao catolicismo.

${ }^{489}$ Ver anexo III. 
Recaredo, segui o exemplo do progenitor e associou seu filho ao trono, Liuva II. Liuva, todavia, acabou assassinado por Viterico em 603.

Aera DCXL, anno XII post Recaredum principem filius eius Liuua regni suscepit sceptra annis duobos, ignobili quidem matre progenitus, sed uirtutum indole insignitus. Quem in primo flore adulescentiae Wittericus sumpta tyrannide innocuum regno deiecit praecisaque eius dextra occidit anno aetatis XX regni uero secundo. ${ }^{490}$

O triste fim de Viterico, tirano e responsável pela morte de um bom rei, serviria de exemplo para aqueles que tivessem em mente ameaçar o reinado de Recimero, herdeiro de um rei igualmente bom. Mas se era aos reis visigodos que Isidoro escrevia, quais os motivos de acrescentar a suas histórias os eventos ocorridos nos reinos suevo e vândalo?

Ora, se olharmos com cuidado esses trechos da obra, em lugar de negligenciálos perceberemos que o regnum Wandalorum e o regnum Sueborum foram destruídos pelos dois fatores que ameaçavam o regnum Gothorum. Os vândalos foram derrotados por Belisário por sua fé ariana e pela perseguição aos bispos. Ao acrescentar notícias sobre os vândalos Isidoro reforçou a importância da conversão dos visigodos e a necessidade dos reis terem respeito pela hierarquia eclesiástica. Os suevos, por outro lado, foram dominados pelos visigodos por causa das disputas que redundaram na deposição de Eborico por Audeca. Conforme Isidoro:

Nam Leuuigildus Gothorum rex Sueuis mox bellum inferens obtento eodem regno Audicanem deicit atque detonsum post regni honorem presbiterii officio mancipauit. Sic enim oportuit, ut quod ipse regi suo fecerat, rursus idem congraua uicissitudine pateretur. ${ }^{49}$

Importante notar que essa preocupação com a estabilidade política do reino também apareceu na Crônica de João de Biclaro quando este salientou que a rebeldia

\footnotetext{
${ }^{490}$ Ver tradução 43, anexo 1.

${ }^{491}$ Ver tradução 44, anexo 1.
} 
do príncipe Hermenegildo, convertido ao catolicismo, ameaçou tantos os godos quanto os hispano-romanos sob a égide do rei Leovigildo, um ariano:

Leovigildo ergo quieta pace regnante adversariorum domestica rixa conturbat. Nam eodem anno filius ejus Hermenegildus factione Gosuinthae reginae tyrannidem assumens, in Hispali civitate rebellione facta recluditur, et alias civitates atque castella secum patrem rebellare facit. Quae causa in provincia Hispaniae tam Gothis, quam Romanis majoris exitii, quam adversariorum infestatio fuit. ${ }^{492}$

As inquietações e dissensões provocadas pelas disputas pelo reinado eram preocupações reais e urgentes já nos anos do Biclarense. Não deixaram de ser durante o período em que Isidoro de Sevilha foi bispo. O IV Concílio de Toledo, que contou com a presença de Isidoro, foi realizado em 633 a pedido do rei Sisenando dois anos após o golpe orquestrado pelo próprio que destituiu do reinado Suintila, justamente o último rei noticiado pela história dos godos. No famoso cânone LXXV do referido concílio lemos uma advertência onde os bispos clamam para que os golpes contra os reis terminem. As disputas não eram mera retórica presente nas histórias, eram recorrentes a ponto de despertar as atenções de João de Biclaro que repreendeu as atitudes do católico Hermenegildo contra o ariano Leovigildo, futuramente preocupou também os bispos reunidos do IV Concílio de Toledo, e Isidoro de Sevilha, especialmente, que escreveu a história de outros reinos como um exemplo do que poderia ocorrer ao godos caso estes não respeitassem a dignidade régia.

É pertinente retomarmos alguns elementos trazidos no início desse texto. Embora o advento dos trabalhos que lidam com a etnogênese tenham trazido importantes e novas problemáticas para o estudo de gentes que, de acordo com certas leituras historiográficas apresentados no nosso primeiro capítulo, fomentaram transformações significativas a ponto de marcar um novo período na história - o

${ }^{492}$ Ver tradução 45, anexo 1. 
início da Idade Média - é preciso lidar com esse "conceito" - tal como com qualquer outro - com prudência. Temos que concordar com A. Gillet ${ }^{493}$ no que tange a generalização acrítica da adoção do termo. De fato, observamos historiadores como P. Hoppenbrouwers ${ }^{494}$ concluindo muito rapidamente que documentos como os Decem Libri Historiarum de Gregório de Tours e a Historia Gothorum Sueborum et Wandalorum de Isidoro de Sevilha serviram a um projeto de etnogênese. Temos que cuidar para não subordinarmos as diferentes fontes com as quais lidamos a um único sistema explicativo. Ora, a etnogênese é um modelo antes de uma explicação final, quando utilizada deve ser sempre com vistas às especificidades do objeto de análise. É por demais suspeito que seja possível aplicar um sistema desse tipo de uma maneira única para explicar realidades tão díspares como foram os casos dos visigodos e dos francos. E mais especificamente, adotar o mesmo para explicar documentos tão diferentes como as histórias de Gregório de Tours e as de Isidoro de Sevilha. E mais, de acordo com o tema de nossa intervenção, com a situação dos godos em tempos tão distintos, do século VI ao século VII!

Não se trata de dizer que o texto de Isidoro de Sevilha não serviu de maneira nenhuma para alimentar um sentimento de identidade entre os visigodos, trata-se de questionar se essa foi a intenção principal do Hispalense. Como tentamos apontar, Isidoro reuniu adjetivos sobre os godos que já circulavam na Península Ibérica antes mesmo de seu episcopado e advinham de uma tradição narrativa ainda mais antiga, como apontamos no primeiro capítulo. Embora ele tenha outorgado um papel de destaque aos godos em suas histórias e em outras de suas obras como as Etimologias e as Diferenças - quando o bispo enuncia sua perspectiva sobre as gentes e as

\footnotetext{
${ }^{493}$ GILLET, Andrew. Ethnogenesis: A contested model of Early Medieval Europe. History Compass. n.4, v.2, p.241-269, 2006.

${ }^{494}$ HOPPENBROUWERS, Peter. Such stuff as peoples are made on: ethnogenesis and the construction of nationhood in Medieval Europe. The Medieval History Journal, n.9, v. 2, p.195-242. 2006.
} 
hierarquiza, conforme bem apontou Reydellet - essa relevância da gens Gothorum aparecia já na Crônica de João de Biclaro e nas atas do III Concílio de Toledo. Não obstante, as origens dos godos não parecem ser o tema protagonista de suas histórias, e sim os reis e as disputas que ameaçavam o reino - que agregava não só godos, mas também hispano-romanos, como era o caso do próprio bispo de Sevilha. O discurso identitário em torno da gens gothorum em Isidoro de Sevilha dessa maneira dialoga com questões mais urgentes em torno das oposições à autoridade dos reis godos, mas os reis que o próprio Isidoro considerava legítimos no contexto de relações de forças da Hispânia Visigoda, como indicamos no capítulo dedicado à realeza. Se a gens gothorum, cujo discurso de valorização fora acionado por Isidoro de Sevilha tinha um valor na história por si só, os reis que eram legítimos para liderá-la deveriam ser defendidos, enquanto os indignos poderiam ser derrubados.

Diante disso defendemos que a idéia de "etnogênese" deve ser descolada dos discursos identitários. Esses discursos não expressavam a tentativa de construir uma etnia e muito menos refletiam uma etnia existente. Eram evocações identitárias com finalidades políticas. A identidade goda nos textos isidorianos era antes uma identidade narrativa política que visava responder a contingências políticas relacionadas com a oposição ao rei de Toledo advinda de nobrezas de zonas periféricas do reino.

Cabe agora nos perguntar como esses discursos são evocados num texto qualificado como uma Historia que narrou exclusivamente uma rebelião. Trata-se da Historia Wambae de Juliano de Toledo. ${ }^{495}$

\footnotetext{
${ }^{495} \mathrm{O}$ tema foi tratado com excelência pelo prof. Renan Frighetto num instigante artigo (FRIGHETTO, R. Memória, História e identidades: Considerações a partir da Historia Wambae de Juliano de Toledo (Século VII). Revista de História Comparada. n.5, v.2, p.50-73, 2011). Visamos aqui trazer mais contribuições na a linha argumentativa de Frighetto.
} 
Como indicamos nos capítulos da primeira parte a Historia Wambae é um documento muito precioso que aponta para as dificuldades enfrentadas pelos reis no que concerne às oposições que se erguiam contra a sua autoridade, nesse sentido, é interessante observarmos como a gens gothorum é usada naquele contexto de intensa disputa como um discurso identitário que respondia a um problema político urgente.

A resposta de Juliano ao evento máximo que será narrado em seu texto aparece logo no início do texto, Wamba foi escolhido por ter sido considerado o único entre os godos digno de reinar: ...illum se nec alium in Gothis principari unitis vocibus intonant et catervatim, ne postulantibus abnueret, suis pedibus obvolvuntur. ${ }^{496}$ Como já apontamos, os "godos" nesse trecho parece significar um grupo específico, a saber, aqueles nobres que eram candidatos legítimos para a sucessão régia, gothi se traduz assim como uma identidade nobiliárquica e política a partir da qual se articulava a política de sucessão régia na Hispania. Nesse cenário, Wamba foi colocado como o único entre esses candidatos digno do trono, assim, desde esse trecho, Juliano de Toledo já aponta a ilegitimidade de qualquer tentativa de questionar o reinado de Wamba. Os "godos" desta forma servem como argumento para dizer que tão-somente um entre os demais godos poderia ser o rei.

Evidentemente que a eleição de Wamba não foi o suficiente para garantir que ele reinasse em paz. Na Gália Narbonense uma rebelião teve início e, enviado para combatê-la, o dux Paulo acabou ele mesmo se tornando um rebelde declarando-se "Rei do Oriente", como indica a carta posta por Juliano no início da Historia Wambae: "In nomine Domini Flavius Paulus unctus rex orientalis Wambani regi austro”. Na sua empreitada contra Wamba, o dux cooptou como aliados os vascones

\footnotetext{
${ }^{496}$ Historia Wambae, 2.
} 
- inimigos de longa data dos visigodos - e os francos. ${ }^{497}$ Ao saber disso o rei Wamba, conforme reproduziu Juliano, se dirigiu as suas tropas da seguinte maneira:

Quae esta enim perituro illi virtus, si Francorum viribus nobiscum decertando confligat? Notissima eorum nobis nec incerta est pugna. Ergo turpe sit vobis eorum testudinem has acies expavescere, quorum nostis infirmiorem semper esse virtutem. Si autem coniuratione Gallorum nititur vindicare tyrannidem, vile putandum est, ut gens sta extremo terrae angulo cedat, et hii, in quibus dilatatum regnum porrigitur, horum motibus perturbentur, quos praesidiali semper vice defendunt. Sive enim Galli sive Franci sint, tantae coniurationis, si placet, vindicandum existiment facinus; nos tamen armis ultricibus gloriae nostrae nomen vindicare debemus. Neque enim cum feminis, sed cum viris nobis certandum est, quamquam notissimum maneat nec Francos Gothis aliquando posse resistere nec Gallos sine nostris aliquid virtutis magnae perficere. ${ }^{498}$

O relato é muito ilustrativo. Confrontado com a aliança entre Paulo e os francos, Juliano criou um contraste entre a bravura dos godos e a debilidade dos francos. Com tal narrativa Juliano sublinha a gens gothorum, uma unidade representada pelo rei Wamba, que se caracterizava pela virilidade e bravura em contraste com a debilidade da gens francorum. O discurso identitário nesse ponto tem dois alvos: o da gens viril liderada por seu rei legítimo em detrimento a gens francorum cooptada pelo ilegítimo Paulo. A própria aliança de Paulo com uma gens covarde já aponta para a indignidade de seu levante enquanto Wamba trazia consigo o apoio dos nobres e corajosos godos. A tradição narrativa celebrativa da memória de uma gens gothorum forte e valoroza é reivindicada no discurso político de Juliano de Toledo para reforçar algo que estava presente em João de Biclaro, foi reorientado no discurso de Isidoro de Sevilha e continuou como um aparato narrativo legítimo no contexto textual da Hispania Visigoda para responder a ameaças políticas advindas de nobres rebeldes. A gens gothorum se afirmava desta maneira como um discurso identitário articulado nas histórias da Hispania visigoda em torno dos reis legítimos.

\footnotetext{
${ }^{497}$ Historia Wambae, 8.

${ }^{498}$ Historia Wambae, 9.
} 
Ela era valorizada, seus feitos comemorados, com uma finalidade muito prática num contexto de tensões em que reis e nobres teciam alianças, mas também se opunham, para levar a cabo a organização política do regnum.

Os holofotes sobre a gens gothorum, todavia, ganhavam tonalidades diversas em outros textos. No caso das hagiografias, como veremos - e isso é verdade também para a Gália Merovíngia - o valor da gens deixa de estar relacionado com uma memória de feitos valorosos que atribuem a ela um sentido por si só. Nas vidas dos santos e santas, o valor dessas gentes é sempre relacionado com intermediação dos santos, estes sim os responsáveis por atribuir valor as gentes. À luz das histórias, entretanto, podemos compreender melhor o lugar dessas gentes - enquanto um discurso identitário político - nas hagiografias. As valorosas gentes, lideradas por reis que em situações de disputas eram retratados como os representantes da bravura de seus subordinados e guias para a realização da glória de seus súditos, ao serem agora subordinadas à atuação dos santos, revelam o quanto as hagiografias tinham um importante papel na afirmação da autoridade dos homens e mulheres de deus, ou seja, num contexto textual que sublinhava a glória da gens, subordinar a gens ao santo era destacar ainda mais a importância que esses homens e mulheres tinham. A construção da memória nas histórias é assim reapropriada para contribuir com a construção da memória de outros agentes de poder que não os reis.

Ao confrontarmos o discurso identitário expresso nas Histórias e nas Hagiografias notamos que as disputas políticas se realizavam também no plano narrativo. A Gens gothorum, valorizada pelas histórias e cuja coesão se concretizava pela figura do rei, nas hagiografia é subordinada à figura dos santos e santas, estes por sua vez comumente estavam intimamente relacionados com nobrezas regionais, quando não eram eles mesmos membros de nobrezas regionais. Ao valorizar a figura 
desses santos e subordinar a gentes à intervenção deles a narrativa se orienta para a valorização de agentes da nobreza local mais do que dos reis de Toledo.

Desta maneira defendemos que é tão-somente pela narrativa das histórias que compreendemos o lugar das gentes nas hagiografias e, além disso, compreendemos a função que esses textos desempenharam na valorização de personagens locais num contexto de disputas entre a autoridade dos reis e a autoridade de nobres regionais. Essa perspectiva realiza o que argumentamos já no primeiro capítulo desse trabalho: o contexto textual. A análise de textos isolados sem o confronto com outros textos produzidos no período limita a análise histórica e nos faz perder de vista as sutilezas discursivas presentes nas fontes. Não se trata aqui de uma análise puramente de discurso, se trata de um esforço por desvendar os mecanismos discursivos que eram reivindicados num cenário amplo de tensões e acordos. Esperamos que no capítulo dedicado às hagiografias isso fique mais claro. Por hora, é pertinente investigarmos se mecanismos semelhantes foram usados na Gália sob o domínio dos reis Merovíngios. 


\section{Os francos nas Historiae da Gália Merovíngia - a memória das origens}

Como notamos no primeiro capítulo e no tópico anterior antes dos assentamentos dos godos na Aquitânia e do surgimento do regnum gothorum existiam referências aos "gothi" em documentos romanos. Se esses eram ou não os mesmos "gothi" que depois fundaram o reino é difícil afirmar, mas ao menos uma tradição narrativa identificava a existência deles, tradição esta que poderia ser apropriada na prática da escrita de história por autores no reino dos godos de modo a enfatizar o papel dos godos no curso de tempo. $\mathrm{O}$ mesmo não pode ser dito sobre os Francos. A primeira menção a eles aparece solta nas Res Gestae de Amiano Marcelino no século IV, sem qualquer descrição detalhada sobre da onde eles vieram e como se tornaram influentes no teatro político da Gália do século IV. De fato, a falta de fontes sobre as origens dos francos foi constatada por Gregório de Tours que buscou o nome do primeiro rei dos francos sem obter sucesso:

Hanc nobis notitiam de Francis memorati historici reliquere, regibus non nominatis.Tradunt enim multi, eosdem de Pannonia fuisse degressus, et primum quidem litora Rheni amnes incoluisse, dehinc, transacto Rheno, Thoringiam transmeasse, ibique iuxta pagus vel civitates regis crinitos super se creavisse de prima et, ut ita dicam, nobiliore suorum familia. Quod postea probatum Chlodovechi victuriae tradedirunt, itaque in sequenti digerimus. $^{499}$

Efetivamente foi o bispo de Tours o primeiro a escrever um relato detido sobre as ações dos reis dos francos muito e embora seja difícil dizer que Gregório tenha tido por objetivo escrever de fato uma "História dos Francos", ${ }^{500}$ título pelo qual sua obra ficou conhecida para a posteridade, ${ }^{501}$ foi ele que primeiro colocou a gens francorum como partícipe de relevo no curso do tempo.

\footnotetext{
${ }^{499}$ Decem Libri Historiarum, II, 9.

${ }^{500}$ Como muito bem argumentou E. James: JAMES, E. Gregory of Tours and the Franks. In: MURRAY, A.C. Narrators and Sources of Early Medieval History. Toronto: University of Toronto Press, 1998. p.51-66.

${ }^{501}$ Um discussão sobre o tema pode ser consultada em nossa dissertação: SILVEIRA, Verônica da Costa. História e Historiografia na Antigüidade Tardia... op.cit.
} 
E. James ${ }^{502}$ num importante artigo que faz uma detida análise da recorrência do termo "francus" nos Decem Libri Historiarum de Gregório de Tours indicou perfeitamente bem o quanto no plano geral da obra as referências aos francus são raras, concentram-se sobretudo no livro II e dificilmente poderiam ser interpretadas como referências a uma unidade "étnicas". A explicação para o autor da maior concentração do termo francus no livro II fundamenta-se no fato de que Gregório para escrever esse trecho de sua obra fiou-se principalmente em fontes escritas por romanos, como Sulpício Alexandre e Renato Profuturo Frigerido. James então salienta que as fontes romanas usavam termos genéricos para se referir aos francus e que não necessariamente representavam a maneira como as gentes assim qualificadas se auto-identificavam. De fato as colocações de James são pertinentes, entretanto, o autor relativiza a importância dos francus no texto de Gregório de Tours a ponto de praticamente dizer que eles eram irrelevantes. ${ }^{503}$

Mesmo que aparentemente escrever uma história da gens francorum não fosse o objetivo de Gregório de Tours e mesmo que suas informações sobre os francus fossem baseadas em textos tendenciosos, James em sua excelente análise entretanto não enfatizou algo que acreditamos ser relevante: a despeito da impossibilidade de traçarmos uma efetiva relação entre os franci das fontes romanas e os franci descritos por Gregório de Tours, o bispo de Tours relacionou os franci dos romanos aos franci que ele conheceu. E fez essa relação destacando o valor dos franci. Uma história unicamente da gens francorum não foi o objetivo de Gregório de Tours, mas uma história das regna francorum, fundados pelos reis

\footnotetext{
502 JAMES, E. Gregory of Tours and the Franks...op.cit.

${ }^{503}$ Mesmo H. Reimitz que privilegia a perspectiva da etnologia em suas pesquisas defende que os francus não eram importantes nos Decem Libri Historiarum. Cf: REIMITZ, H. The providential past: visions od Frankish identity in The Early Medieval History of Gregory of Tours' Historiae (sixth-ninth century). In: POHL, W.; GANTNER, C. \& PAYNE, R. Visions of community in the post-Roman World. The West, Byzantium and the Islamic World, 300-1100. Farham \& Burlington: Ashgate, 2012. p.109-135. Reimitz deu um enfoque em sua obra de modo a destacar a relação entre etnicidade e identidade étnica e religião e, conforme ele, a contribuição de Gregório de Tours nessa questão foi mais com a perspectiva religiosa do que com a etnicidade propriamente dita. Uma análise que prioriza o tom providencialista na obra de Gregório de Tours pode ser encontrada no importante trabalho de M. Heinzelmann: HEINZELMANN, M. Gregory od Tours: History and Society in the Sixth Century. Cambridge: Cambridge University Press, 2001.
} 
advindos dos grupos identificados como francus, estava sim sob a atenção do bispo de Tours enquanto ele escrevia seus Decem Libri Historiarum. O primeiro fundamento para nossa hipótese reside na próprio zelo do bispo em procurar o primeiro rei da gens francorum, mesmo que ele não o tenha encontrado, sua busca indica que os franci ocupavam um lugar importante na narrativa que ele construiu. Em outras histórias, como veremos, a busca de Gregório encontrará uma resposta para dar conta de uma questão muito patente naqueles séculos: a crescente polarização do poder político concentrado nas mãos de nobres que lançavam mão de outros discursos identitários que não aqueles centrado no discurso identitário em torno dos franci.

É importante ainda apontar um problema metodológico no trabalho de James. Apenas contar quantas vezes o termo "francus" aparece na fonte não é o suficiente para afirmar que Gregório de Tours não deu destaque aos francos no texto. É preciso analisar o contexto em que o termo aparece e o valor que possui na narrativa. Façamos então esse exercício. 


\begin{tabular}{|c|c|c|c|c|c|c|c|c|}
\hline Livro II 41 & Livro III 8 & Livro IV 8 & Livro V 2 & Livro VI 5 & Livro VII 5 & Livro VIII 3 & Livro IX 3 & Livro X \\
\hline $\begin{array}{l}\text { 7. Igitur Aetius cum } \\
\text { Gothis Francisque } \\
\text { coniunctus adversus } \\
\text { Attilanem confligit. }\end{array}$ & $\begin{array}{l}\text { 6. Quod Franci } \\
\text { cernentes atque } \\
\text { cognuscentes } \\
\text { Chlodomerem } \\
\text { interfectum, } \\
\text { reparatis viribus, } \\
\text { Godomarum } \\
\text { fugant, } \\
\text { Burgundionis } \\
\text { oppraemunt } \\
\text { patriamque in } \\
\text { suam redigunt } \\
\text { potestatem. }\end{array}$ & $\begin{array}{l}\text { 4. Nam semper } \\
\text { Brittani sub } \\
\text { Francorum } \\
\text { potestatem post } \\
\text { obitum regis } \\
\text { Chlodovechi } \\
\text { fuerunt, et } \\
\text { comites, non } \\
\text { regis appellati } \\
\text { sunt. }\end{array}$ & $\begin{array}{l}\text { Prefácio. } \\
\text { Taedit me } \\
\text { bellorum } \\
\text { civilium } \\
\text { diversitatis, } \\
\text { que } \\
\text { Francorum } \\
\text { gentem et } \\
\text { regnum } \\
\text { valde } \\
\text { proterunt, } \\
\text { memorare } \\
\text { [...] }\end{array}$ & $\begin{array}{c}\text { 2. 'Ego } \\
\text { (Chilperico) } \\
\text { haec ad } \\
\text { exornandam } \\
\text { atque } \\
\text { nobilitandam } \\
\text { Francorum } \\
\text { gentem feci. Sed } \\
\text { et plurima } \\
\text { adhuc, si vita } \\
\text { comis fuerit, } \\
\text { faciam' }\end{array}$ & $\begin{array}{l}\text { 15. Ipse enim } \\
\text { cum Mummolo } \\
\text { praefecto multos } \\
\text { de Francis, qui } \\
\text { tempore } \\
\text { Childeberthi } \\
\text { regis seniores } \\
\text { ingenui fuerant, } \\
\text { publico tributo } \\
\text { subegit. }\end{array}$ & $\begin{array}{c}\text { 31. Magnus } \\
\text { tunc omnes } \\
\text { Rothomagensis } \\
\text { cives et } \\
\text { praesertim } \\
\text { seniores loci } \\
\text { illius Francos } \\
\text { meror obsedit. }\end{array}$ & $\begin{array}{c}\text { 20. et } \\
\text { genetricem } \\
\text { domni } \\
\text { Childeberthi, } \\
\text { domnam } \\
\text { Brunichildem } \\
\text { reginam, vel } \\
\text { filiam eius } \\
\text { Chlodosuindam, } \\
\text { germanam } \\
\text { domni } \\
\text { Childeberthi } \\
\text { regis, quamdiu } \\
\text { intra regionem } \\
\text { Francorum } \\
\text { fuerit [...] }\end{array}$ & $\begin{array}{l}\text { 2. Erant enim ibi } \\
\text { tunc, ut diximus, } \\
\text { legati } \\
\text { Bodigysilus, filius } \\
\text { Mummolini } \\
\text { Sessionici, et } \\
\text { Euantius, filius } \\
\text { Dinami } \\
\text { Arelatensis, et hic } \\
\text { Gripo genere } \\
\text { Francus, qui, } \\
\text { elevantes de epolo } \\
\text { sopore se } \\
\text { dederant pro } \\
\text { quiete. }\end{array}$ \\
\hline $\begin{array}{c}\text { 7. Simili et } \\
\text { Francorum regem } \\
\text { dolo fugavit. }\end{array}$ & $\begin{array}{c}\text { 7. Convocatis } \\
\text { igitur Francis, } \\
\text { dicit ad eos }[. . .] \\
\text { (Teodorico) }\end{array}$ & $\begin{array}{l}\text { 9. Quae fabula } \\
\text { magnum ei } \\
\text { timorem atque } \\
\text { odium } \\
\text { praeparavit. } \\
\text { Sub eo enim et } \\
\text { Buccelenus, } \\
\text { cum totam } \\
\text { Italiam in } \\
\text { Francorum } \\
\text { regno } \\
\text { redigisset, a } \\
\text { Narsitae } \\
\text { interfectus est, } \\
\text { Italiam ad } \\
\text { partem } \\
\text { imperatoris } \\
\text { captam, nec fuit }\end{array}$ & $\begin{array}{l}\text { 18. Haec eo } \\
\text { dicente, } \\
\text { infremuit } \\
\text { multitudo } \\
\text { Francorum } \\
\text { voluitque } \\
\text { ostea } \\
\text { basilicae } \\
\text { rumpere, } \\
\text { quasi ut } \\
\text { extractum } \\
\text { sacerdotem } \\
\text { lapidibus } \\
\text { urgueret; } \\
\text { sed rex } \\
\text { prohibuit } \\
\text { fieri. }\end{array}$ & $\begin{array}{l}\text { 22. Erat autem } \\
\text { tunc Mummolus } \\
\text { in civitate } \\
\text { Avennica, sicut } \\
\text { supra iam } \\
\text { diximus } \\
\text { Gunthchramnus } \\
\text { vero dux } \\
\text { adpraehensum } \\
\text { Theodorum } \\
\text { episcopum in } \\
\text { custodia pro } \\
\text { hac causa } \\
\text { detrusit, } \\
\text { repotans, cur } \\
\text { hominem } \\
\text { extraneum } \\
\text { intromisissit in }\end{array}$ & $\begin{array}{c}\text { 27. Exinde } \\
\text { Tholosam } \\
\text { digressus, emisit } \\
\text { nuntius ad } \\
\text { Magnulfum } \\
\text { episcopum } \\
\text { civitatis, ut ab } \\
\text { eo susciperetur. } \\
\text { Sed, ille, non } \\
\text { inmemor prioris } \\
\text { iniuriae, quam } \\
\text { per Sigulfum } \\
\text { quondam, qui se } \\
\text { in regno elevare } \\
\text { voluit, } \\
\text { pertulerat, dicit } \\
\text { civibus suis: } \\
\text { 'Scimus enim, }\end{array}$ & $\begin{array}{l}\text { 31. 'Noevritis } \\
\text { enim, quia, si } \\
\text { persona, quae } \\
\text { haec } \\
\text { perpetravit, in } \\
\text { medio posita } \\
\text { non fuerit, rex } \\
\text { noster cum } \\
\text { exercitu hic } \\
\text { veniens, omnem } \\
\text { hanc regionem } \\
\text { gladio } \\
\text { incendioque } \\
\text { vastavit, quia } \\
\text { manifestum est, } \\
\text { hanc } \\
\text { interfecisse } \\
\text { gladio } \\
\end{array}$ & $\begin{array}{c}20 . \text { De } \\
\text { civitatibus vero, } \\
\text { hoc est } \\
\text { Burdegala, } \\
\text { Lemovecas, } \\
\text { Cadurcus, } \\
\text { Benarno et } \\
\text { Begorra, quae } \\
\text { Gailesuinda, } \\
\text { germana } \\
\text { domnae } \\
\text { Brunichilde, } \\
\text { tam in dote } \\
\text { quam in } \\
\text { morganegyba, } \\
\text { hoc est } \\
\text { matutinale } \\
\text { donum, in }\end{array}$ & $\begin{array}{l}\text { 3. Ad quem cum } \\
\text { adpropinquassent, } \\
\text { priusquam } \\
\text { flumen, quod } \\
\text { diximus, } \\
\text { transirent, a litore } \\
\text { illo unus } \\
\text { Langobardorum } \\
\text { stans, lorica } \\
\text { protectus et galea, } \\
\text { contum manu } \\
\text { gestans, vocem } \\
\text { dedit contra } \\
\text { Francorum } \\
\text { exercitum, dicens } \\
\text { [...] }\end{array}$ \\
\hline
\end{tabular}




\begin{tabular}{|c|c|c|c|c|c|c|c|}
\hline & & $\begin{array}{l}\text { qui eam ultra } \\
\text { reciperet. }\end{array}$ & $\begin{array}{c}\text { Galliis } \\
\text { voluissetque } \\
\text { Francorum } \\
\text { regnum } \\
\text { imperialibus } \\
\text { per haec } \\
\text { subdere } \\
\text { ditionibus. }\end{array}$ & $\begin{array}{c}\text { regis esse } \\
\text { Gunthchramnum } \\
\text { ac nepotem eius; } \\
\text { hunc autem } \\
\text { nescimus unde } \\
\text { sit. Estote ergo } \\
\text { parati, et si } \\
\text { voluerit } \\
\text { Desiderius dux } \\
\text { hanc } \\
\text { calamitatem } \\
\text { inducere super } \\
\text { nos, simili ut } \\
\text { Sigulfus sorte } \\
\text { depereat; sitque } \\
\text { omnibus } \\
\text { exemplum, ne } \\
\text { quis } \\
\text { extraneorum } \\
\text { Francorum } \\
\text { regnum audeat } \\
\text { violare'. }\end{array}$ & $\begin{array}{l}\text { episcopum, qui } \\
\text { maleficiis } \\
\text { Francum iussit } \\
\text { interemi'. }\end{array}$ & $\begin{array}{c}\text { Francia veniens } \\
\text { certum est } \\
\text { adquisisse, quas } \\
\text { etiam per } \\
\text { iudicium } \\
\text { gloriosissimi } \\
\text { domni } \\
\text { Gunthchramni } \\
\text { regis vel } \\
\text { Francorum, } \\
\text { superstitibus } \\
\text { Chilpericum et } \\
\text { Sigyberthum } \\
\text { regem, domna } \\
\text { Brunichildis } \\
\text { noscitur } \\
\text { adquisisse [...] }\end{array}$ & \\
\hline $\begin{array}{l}\text { 9. Quid de Francis } \\
\text { idemque dicant. }\end{array}$ & $\begin{array}{l}\text { 7. Thoringi vero } \\
\text { venientibus } \\
\text { Francis dolos } \\
\text { praeparant. }\end{array}$ & $\begin{array}{l}\text { 14. Franci } \\
\text { autem nec hoc } \\
\text { adquiescere } \\
\text { voluerunt. }\end{array}$ & $\begin{array}{l}\text { 45. Promittens } \\
\text { vero } \\
\text { Chilpericus rex } \\
\text { nihil de his } \\
\text { contingere, } \\
\text { convocatis } \\
\text { melioribus } \\
\text { Francis } \\
\text { reliquisque } \\
\text { fidelibus, } \\
\text { nuptias } \\
\text { celebravit filiae } \\
\text { suae (Rigunta). }\end{array}$ & $\begin{array}{c}\text { 27. Cui } \\
\text { episcopus } \\
\text { (Magnulfo, } \\
\text { bispo de } \\
\text { Toulouse) ait: } \\
\text { 'Verumne est } \\
\text { ergo, quod } \\
\text { nullus de stirpe } \\
\text { regum } \\
\text { Francorum } \\
\text { remansit, si tu } \\
\text { haec quae dicis } \\
\text { impleberis?' }\end{array}$ & $\begin{array}{l}\text { 37. Post haec } \\
\text { Childebertho } \\
\text { regi filius natus } \\
\text { est, qui a } \\
\text { Magnerico } \\
\text { Treverorum } \\
\text { episcopo de } \\
\text { sacro fonte } \\
\text { susceptus, } \\
\text { Theodoberthus } \\
\text { est vocitatus. } \\
\text { De quo tantum } \\
\text { gaudium } \\
\end{array}$ & $\begin{array}{l}\text { 25. Tantaque ibi } \\
\text { fuit stragis de } \\
\text { Francorum } \\
\text { exercitu, ut olim } \\
\text { simile non } \\
\text { recolatur. }\end{array}$ & $\begin{array}{c}\text { 27. Inter } \\
\text { Tornacensis } \\
\text { quoque Francos } \\
\text { non mediocris } \\
\text { disceptatio est } \\
\text { orta, pro eo quod } \\
\text { unius filius } \\
\text { alterius filium, qui } \\
\text { sororem eius in } \\
\text { matrimonium } \\
\text { acceperat, cum } \\
\text { ira saepius } \\
\text { obiurgabat, cur, }\end{array}$ \\
\hline
\end{tabular}




\begin{tabular}{|c|c|c|c|c|c|c|}
\hline & & & & & $\begin{array}{l}\text { Gunthchramnus } \\
\text { rex habuit, ut } \\
\text { statim legatus } \\
\text { dirigens, multa } \\
\text { ei munera } \\
\text { transmitteret, } \\
\text { dicens: 'Per } \\
\text { hunc enim Deus } \\
\text { eregere } \\
\text { Francorum } \\
\text { regnum propria } \\
\text { maiestates suae } \\
\text { pietate } \\
\text { dignabitur, si } \\
\text { huic pater aut } \\
\text { ipse viverit } \\
\text { patri'. }\end{array}$ & $\begin{array}{l}\text { coniuge relicta, } \\
\text { scortum adiret. }\end{array}$ \\
\hline $\begin{array}{l}\text { 9. De Francorum } \\
\text { vero regibus, quis } \\
\text { fuerit primus, a } \\
\text { multis ignoratur. }\end{array}$ & $\begin{array}{l}\text { 7. In his ergo } \\
\text { foveis, cum } \\
\text { pugnare } \\
\text { coepissent, multi } \\
\text { Francorum } \\
\text { equites } \\
\text { conruerunt, et } \\
\text { fuit eis valde } \\
\text { inpedimentum; } \\
\text { sed post } \\
\text { cognitum hunc } \\
\text { dolum, observare } \\
\text { coeperunt. }\end{array}$ & $\begin{array}{l}\text { 16. Fortiter } \\
\text { tunc rex } \\
\text { Chlotharius } \\
\text { contra Saxones } \\
\text { decertabat. } \\
\text { Saxones enim, } \\
\text { ut adserunt, per } \\
\text { Childeberthum } \\
\text { commoti atque } \\
\text { indignantes } \\
\text { contra Francos } \\
\text { superiore anno, } \\
\text { exeuntesque de } \\
\text { regione sua in } \\
\text { Francia } \\
\text { venerant et } \\
\text { usque Divitiam } \\
\text { civitatem }\end{array}$ & $\begin{array}{c}\text { 45. Quem } \\
\text { cernens regina } \\
\text { commotum, } \\
\text { conversa ad } \\
\text { Francus, ita ait } \\
\text { [...] }\end{array}$ & $\begin{array}{l}\text { 32. Post haec } \\
\text { misit iterum } \\
\text { Gundovaldus } \\
\text { duos legatos ad } \\
\text { regem cum } \\
\text { virgis } \\
\text { consecratis } \\
\text { iuxta ritum } \\
\text { Francorum, ut } \\
\text { scilicet non } \\
\text { contingerentur } \\
\text { ab ullo, sed } \\
\text { exposita } \\
\text { legatione cum } \\
\text { responsu } \\
\text { reverterentur. }\end{array}$ & & $\begin{array}{l}\text { 27. Sed cum } \\
\text { eosdem verbis } \\
\text { lenibus placare } \\
\text { nequiret, } \\
\text { utrumque bipenne } \\
\text { conpescuit. } \\
\text { Invitatis etenim } \\
\text { ad epulum multis, } \\
\text { hos in unum tres } \\
\text { fecit sedere } \\
\text { subsellium; } \\
\text { cumque in eo } \\
\text { prandium } \\
\text { elongatum fuisset } \\
\text { spatio, ut nox } \\
\text { mundum obrueret, } \\
\text { ablata mensa, } \\
\text { sicut mos }\end{array}$ \\
\hline
\end{tabular}




\begin{tabular}{|c|c|c|c|c|c|}
\hline & & $\begin{array}{l}\text { praedas egerunt } \\
\text { nimiumque } \\
\text { grave scelus } \\
\text { perpetrati sunt. }\end{array}$ & & & $\begin{array}{l}\text { Francorum est, } \\
\text { illi in subsellia } \\
\text { sua, sicut locati } \\
\text { fuerant, } \\
\text { resedebant. }\end{array}$ \\
\hline $\begin{array}{c}\text { 9. Eo tempore } \\
\text { Genobaude, } \\
\text { Marcomere et } \\
\text { Sunnone ducibus } \\
\text { Franci in } \\
\text { Germaniam } \\
\text { prorupere, ac } \\
\text { pluribus mortalium } \\
\text { limite inrupto } \\
\text { caesis, fertiles } \\
\text { maxime pagus } \\
\text { depopulati, } \\
\text { Agrippinensi etiam } \\
\text { Coloniae metum } \\
\text { incusserunt. }\end{array}$ & $\begin{array}{l}\text { 7. Ibique tanta } \\
\text { caedes ex } \\
\text { Thoringis facta } \\
\text { est, ut alveos } \\
\text { fluminis a } \\
\text { cadaverum } \\
\text { congeriae } \\
\text { repleretur et } \\
\text { Franci tamquam } \\
\text { per pontem } \\
\text { aliquod super eos } \\
\text { in litus ulteriore } \\
\text { transirent. }\end{array}$ & $\begin{array}{l}\text { 22. Chilpericus } \\
\text { vero post patris } \\
\text { funera } \\
\text { thesaurus, qui } \\
\text { in villa } \\
\text { Brannacum } \\
\text { erant } \\
\text { congregati, } \\
\text { accepit et ad } \\
\text { Francos } \\
\text { utiliores petiit } \\
\text { ipsusque } \\
\text { muneribus } \\
\text { mollitus sibi } \\
\text { subdidit. }\end{array}$ & $\begin{array}{l}\text { 45. Franci vero } \\
\text { multa munera } \\
\text { obtulerunt, alii } \\
\text { aurum, alii } \\
\text { argentum, } \\
\text { nonnulli } \\
\text { equites, } \\
\text { plerique } \\
\text { vestimenta, et } \\
\text { unusquisque ut } \\
\text { potuit } \\
\text { donativum } \\
\text { dedit. }\end{array}$ & $\begin{array}{l}\text { 36. Ascendebant } \\
\text { enim multi per } \\
\text { collem et cum } \\
\text { Gundovaldo } \\
\text { saepius } \\
\text { loquebantur, } \\
\text { inferentes ei } \\
\text { convitia ac } \\
\text { dicentes: 'Tune } \\
\text { es pictur ille, qui } \\
\text { tempore } \\
\text { Chlothacharii } \\
\text { regis per } \\
\text { oraturia parietis } \\
\text { adque camaras } \\
\text { caraxabas? } \\
\text { Tune es ille, } \\
\text { quem } \\
\text { Ballomerem } \\
\text { nomine saepius } \\
\text { Galliarum } \\
\text { incolae } \\
\text { vocitabant? } \\
\text { Tune es ille, qui } \\
\text { plerumque a } \\
\text { regibus } \\
\text { Francorum } \\
\text { propter has } \\
\text { praesumptiones } \\
\text { quas proferis }\end{array}$ & $\begin{array}{c}\text { 31. VII. vero } \\
\text { Volusianus } \\
\text { ordinatur } \\
\text { episcopus, ex } \\
\text { genere senatorio, } \\
\text { vir sanctus et } \\
\text { valde dives, } \\
\text { propinquus et ipse } \\
\text { Perpetui episcopi } \\
\text { decessoris sui. } \\
\text { Huius tempore } \\
\text { iam Chlodovechus } \\
\text { regnabat in } \\
\text { aliquibus urbibus } \\
\text { in Galliis. Et ob } \\
\text { hanc causam hic } \\
\text { pontifex suspectus } \\
\text { habitus a Gothis, } \\
\text { quod se } \\
\text { Francorum } \\
\text { dicionibus } \\
\text { subdere vellit, } \\
\text { apud urbem } \\
\text { Tholosam exilio } \\
\text { condempnatus, in } \\
\text { eo obiit. Huius } \\
\text { tempore vicus } \\
\text { Mantolomaus } \\
\text { aedificatus est et } \\
\text { basilica sancti }\end{array}$ \\
\hline
\end{tabular}




\begin{tabular}{|c|c|c|c|c|}
\hline & & & $\begin{array}{l}\text { tunsoratus et } \\
\text { exilio datus es? }\end{array}$ & $\begin{array}{c}\text { Iohannis ad } \\
\text { Maiorem } \\
\text { monasterium. } \\
\text { Sedit autem annos } \\
\text { VII, menses II. }\end{array}$ \\
\hline $\begin{array}{c}\text { 9. Sed onusti } \\
\text { praeda hostes, } \\
\text { provinciarum } \\
\text { opima depopulati, } \\
\text { Rhenum } \\
\text { transierunt, } \\
\text { pluribus suorum in } \\
\text { Romano relictis } \\
\text { solo, ad repetendam } \\
\text { depopulationem } \\
\text { paratis, cum quibus } \\
\text { congressus } \\
\text { Romanis } \\
\text { adcomodus fuit, } \\
\text { multis Francorum } \\
\text { apud Carbonariam } \\
\text { ferro perimptis. }\end{array}$ & $\begin{array}{l}\text { 11. Post haec } \\
\text { Chlothacharius et } \\
\text { Childeberthus } \\
\text { Burgundia petere } \\
\text { distinant. } \\
\text { Convocatusque } \\
\text { Theudoricus in } \\
\text { solatio eorum, ire } \\
\text { noluit. Franci } \\
\text { vero, qui ad eum } \\
\text { aspiciebant, } \\
\text { dixerunt: 'Si cum } \\
\text { fratribus tuis in } \\
\text { Burgundiam ire } \\
\text { dispexeris, te } \\
\text { relinquimus et } \\
\text { illos sequi satius } \\
\text { praeoptamus' }\end{array}$ & $\begin{array}{l}\text { 40. Denique } \\
\text { Sigyberthus rex } \\
\text { legatus ad } \\
\text { Iustinum } \\
\text { imperatorem } \\
\text { misit, pacem } \\
\text { petens, id est } \\
\text { Warmarium } \\
\text { Francum et } \\
\text { Firminum } \\
\text { Arvernum. }\end{array}$ & & $\begin{array}{c}\text { 31. XVII. } \\
\text { Guntharius ex } \\
\text { abbate monasterii } \\
\text { Sancti Venanti } \\
\text { ordinatur } \\
\text { episcopus, vir } \\
\text { valde prudens, } \\
\text { dum } \\
\text { abbatis fungeretur } \\
\text { officium, et } \\
\text { saepius legationes } \\
\text { inter reges } \\
\text { Francorum } \\
\text { faciens. }\end{array}$ \\
\hline $\begin{array}{c}\text { 9. Cumque } \\
\text { consultaretur } \\
\text { succensu, an in } \\
\text { Franciam transire } \\
\text { deberit, Nannenus } \\
\text { abnuit, quia non } \\
\text { inparatus et in locis } \\
\text { suis indubiae } \\
\text { fortiores futurus } \\
\text { sciebat. }\end{array}$ & $\begin{array}{l}\text { 27. Cumque iam } \\
\text { septimus annus } \\
\text { esset, quod } \\
\text { Wisigardem } \\
\text { disponsatam } \\
\text { haberet et eam } \\
\text { propter } \\
\text { Deuteriam } \\
\text { accipere nollet, } \\
\text { cuniuncti Franci } \\
\text { contra eum valde } \\
\text { scandalizabantur, }\end{array}$ & $\begin{array}{l}\text { 42. Mane autem } \\
\text { facto, statuunt } \\
\text { Saxones } \\
\text { exercitum, } \\
\text { praeparantes se } \\
\text { ad bellum; sed, } \\
\text { intercurrentibus } \\
\text { nuntiis, pacem } \\
\text { fecerunt, } \\
\text { datisque } \\
\text { muneribus } \\
\text { Mummolo, }\end{array}$ & & \\
\hline
\end{tabular}




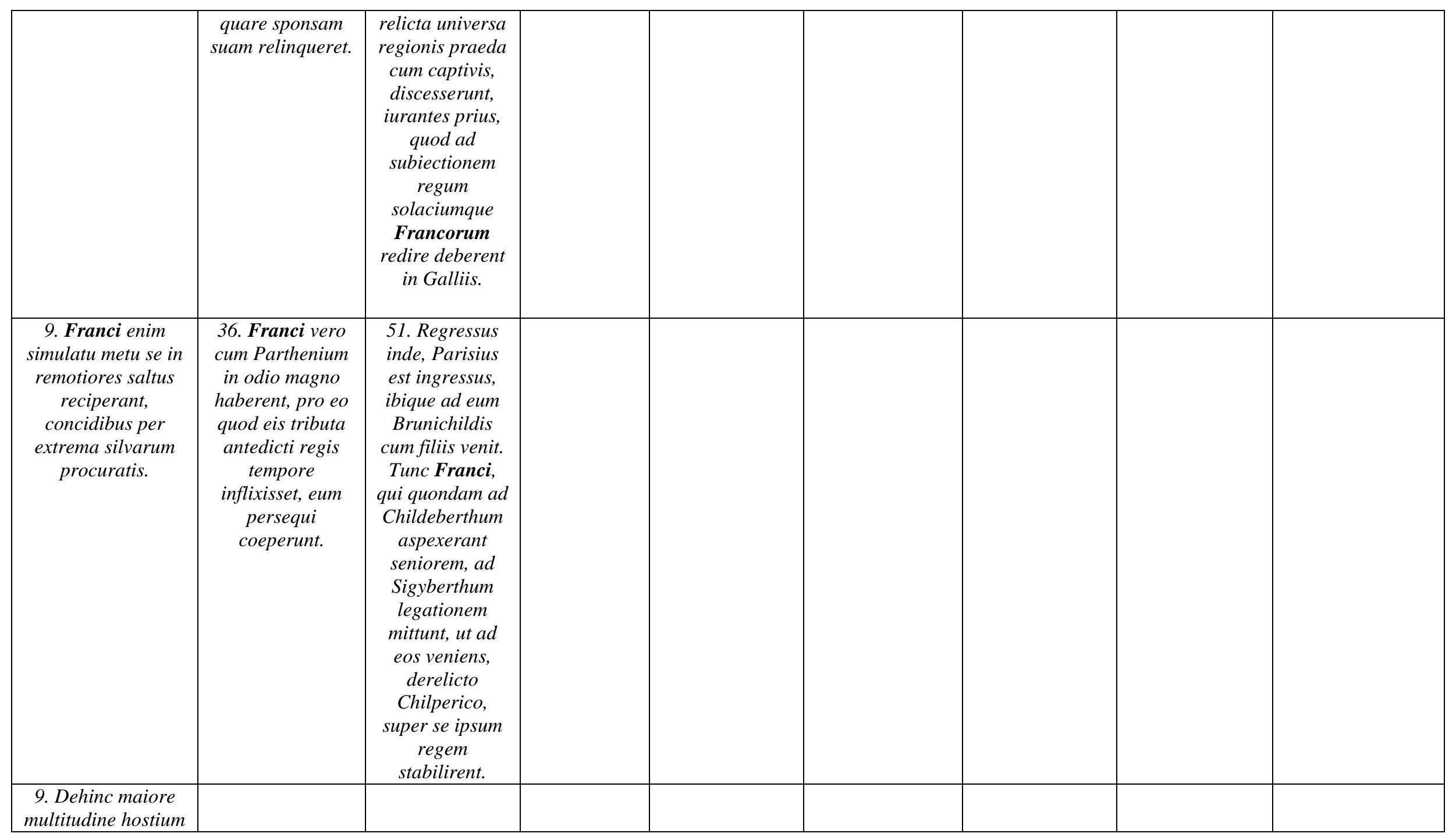




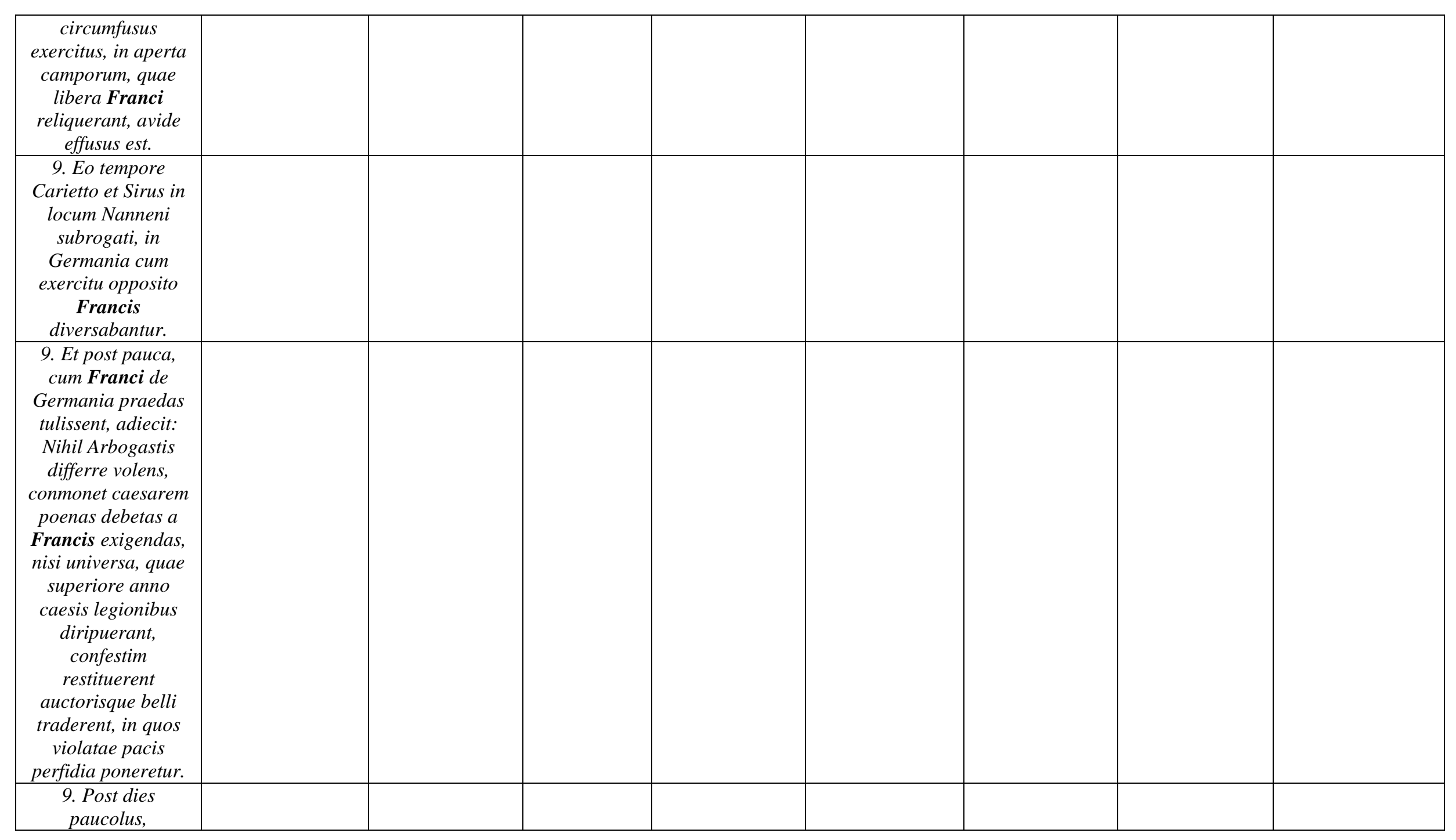




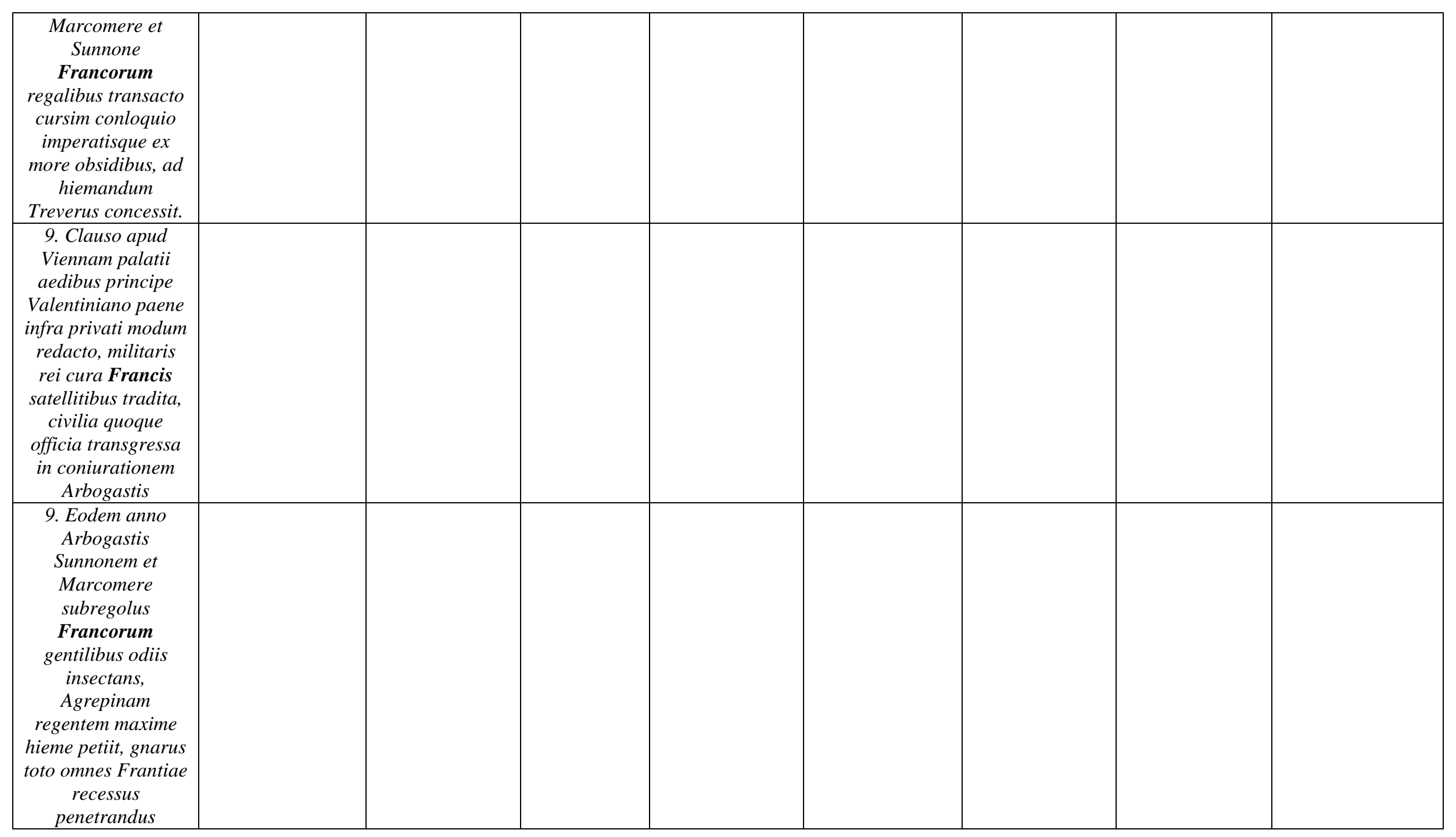




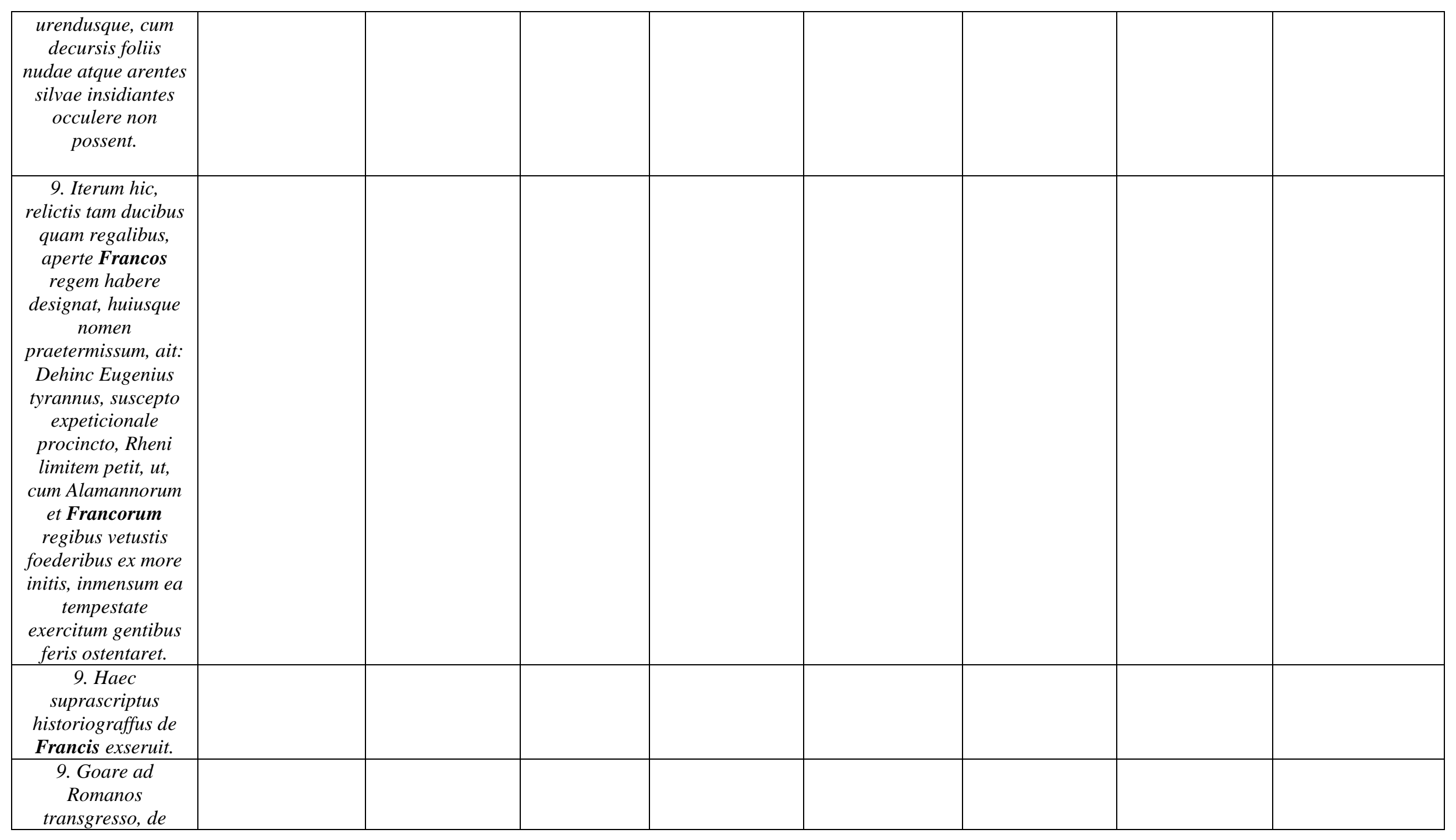




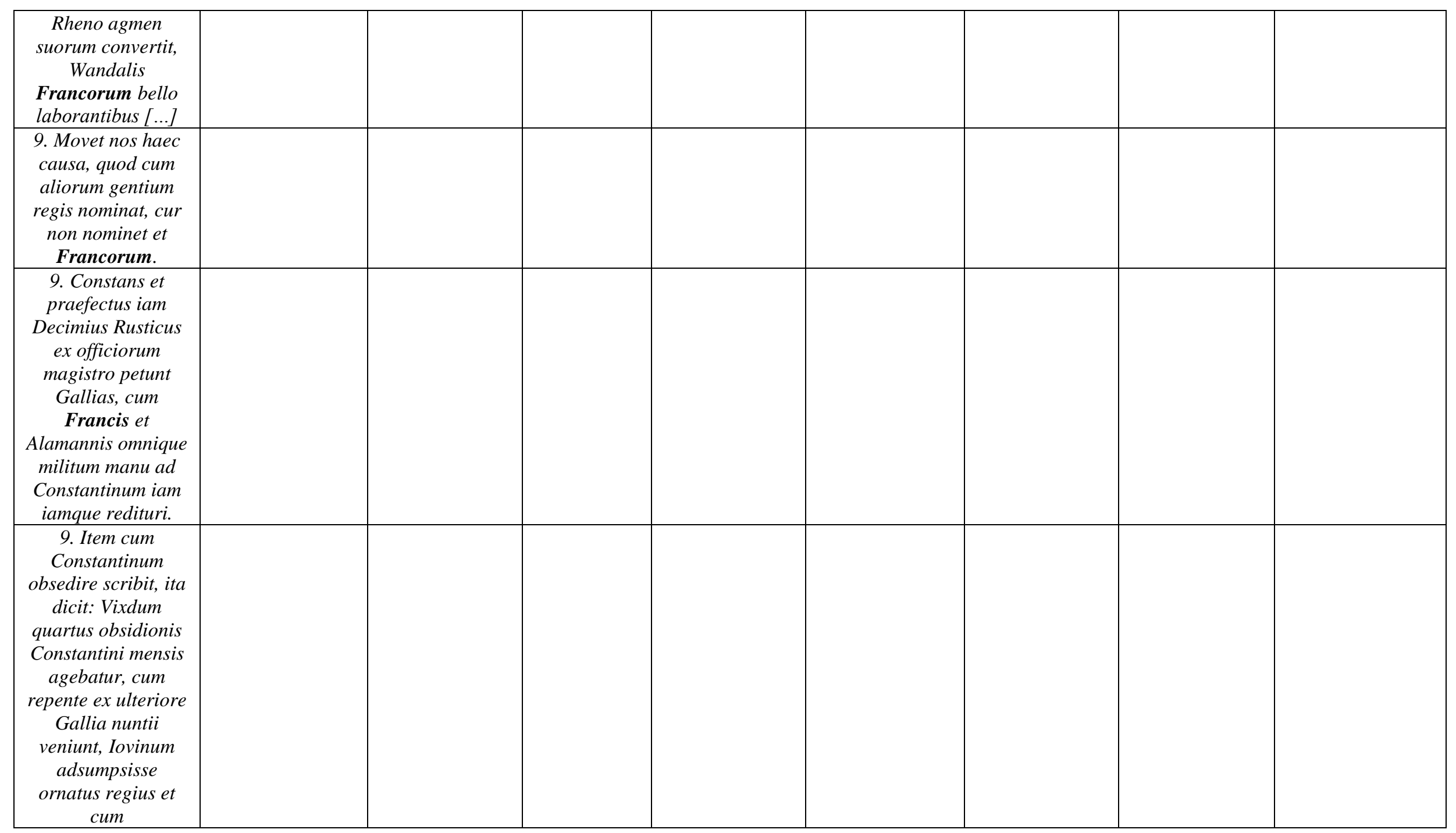




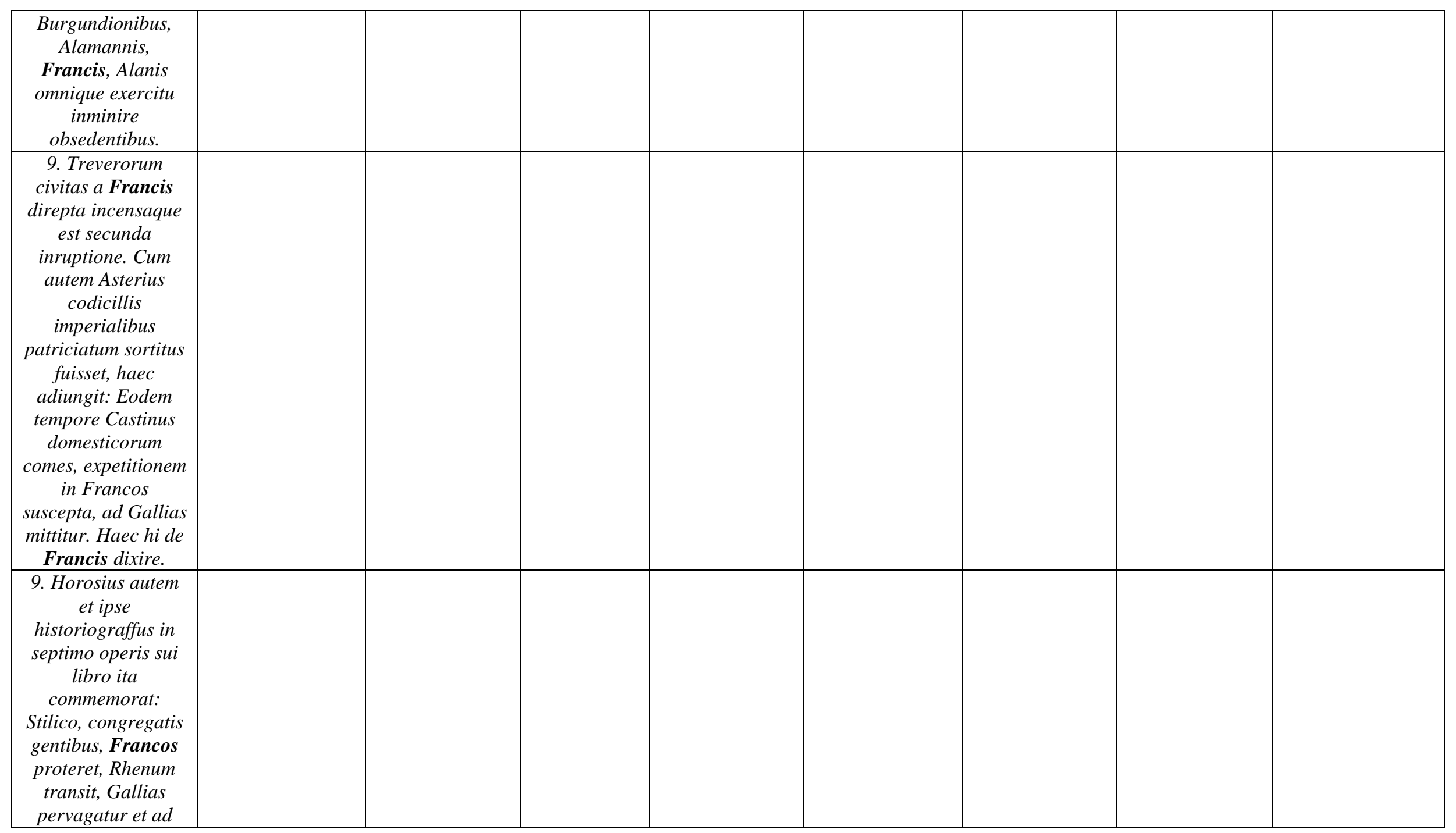




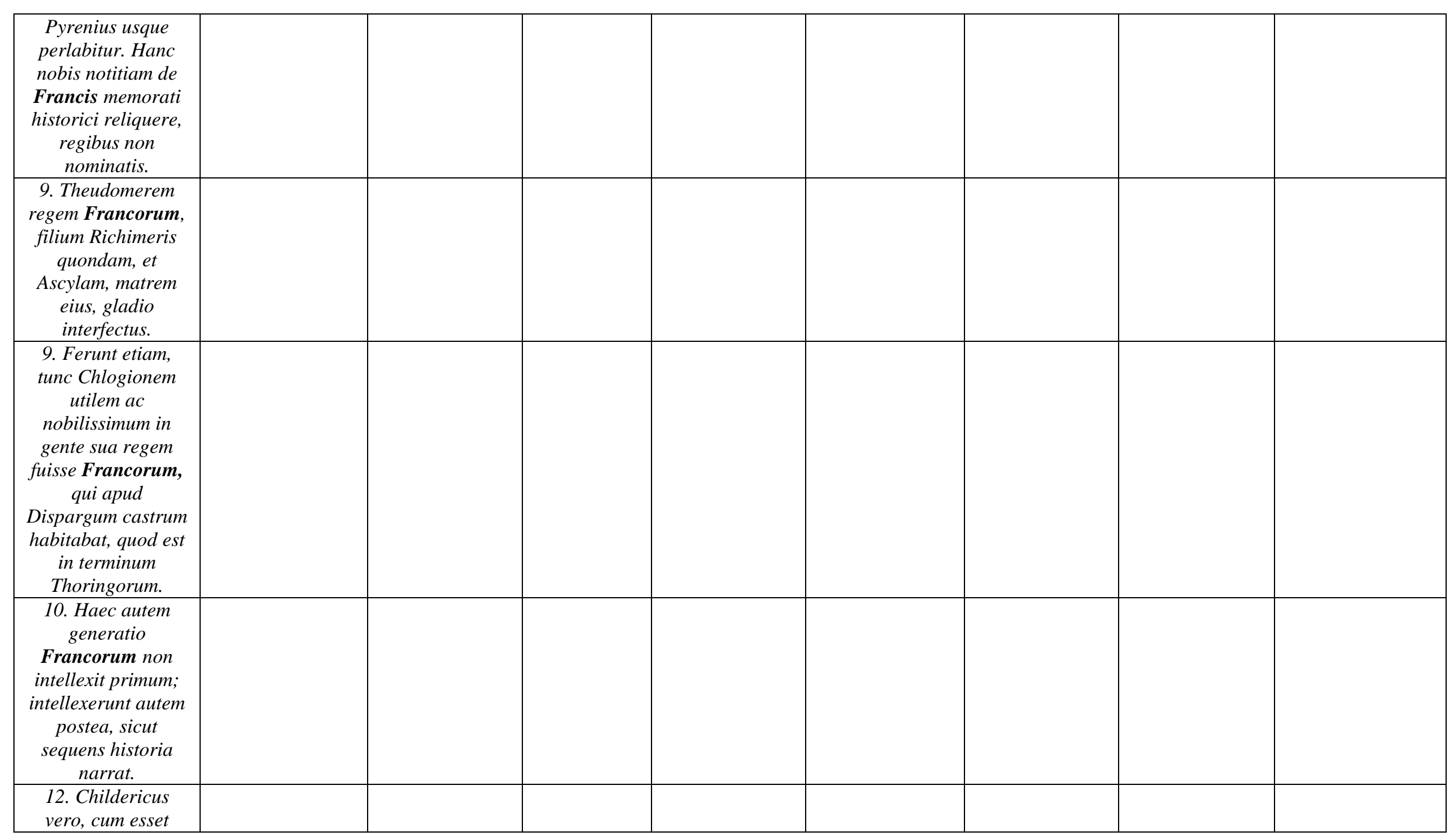




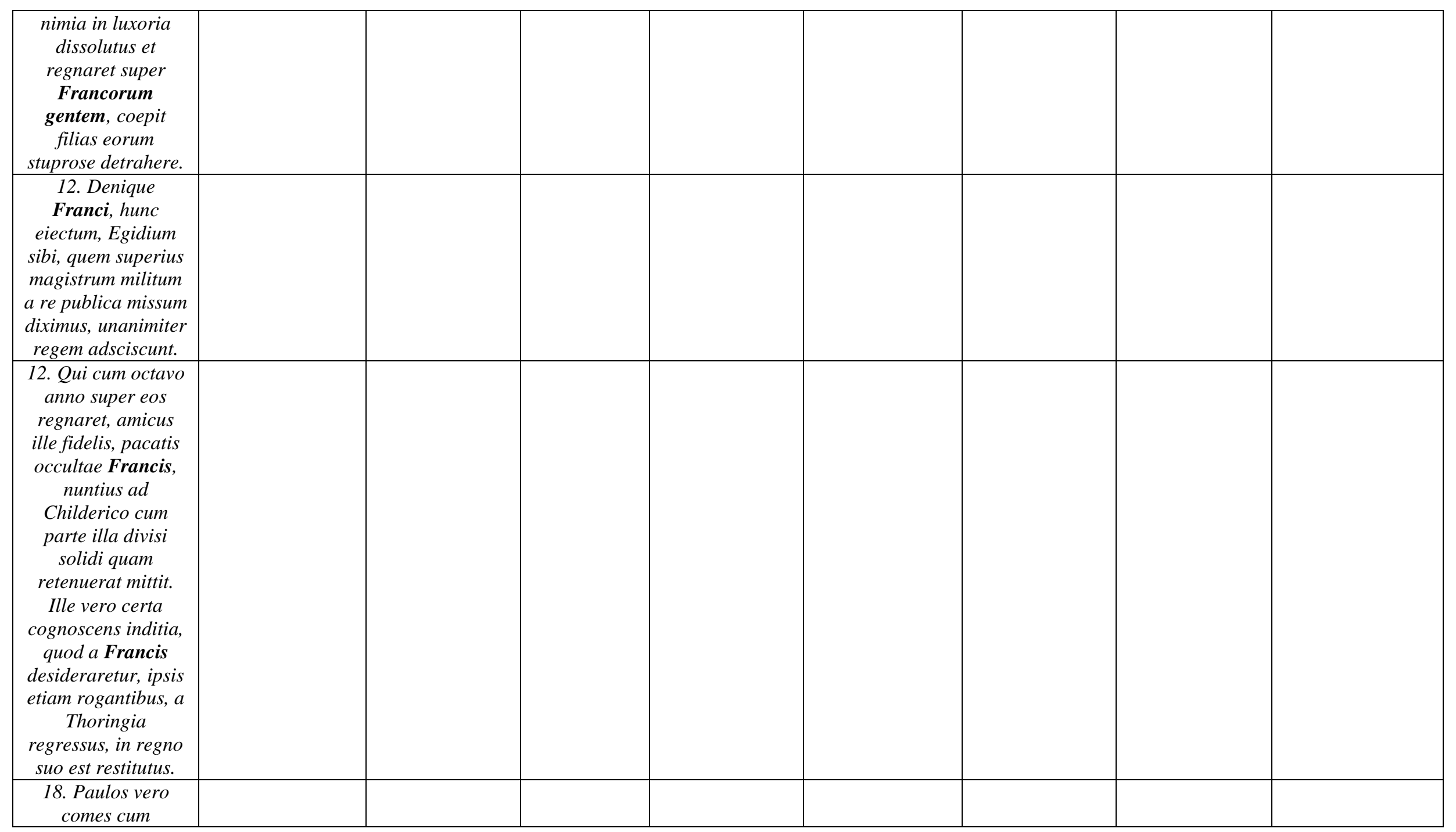




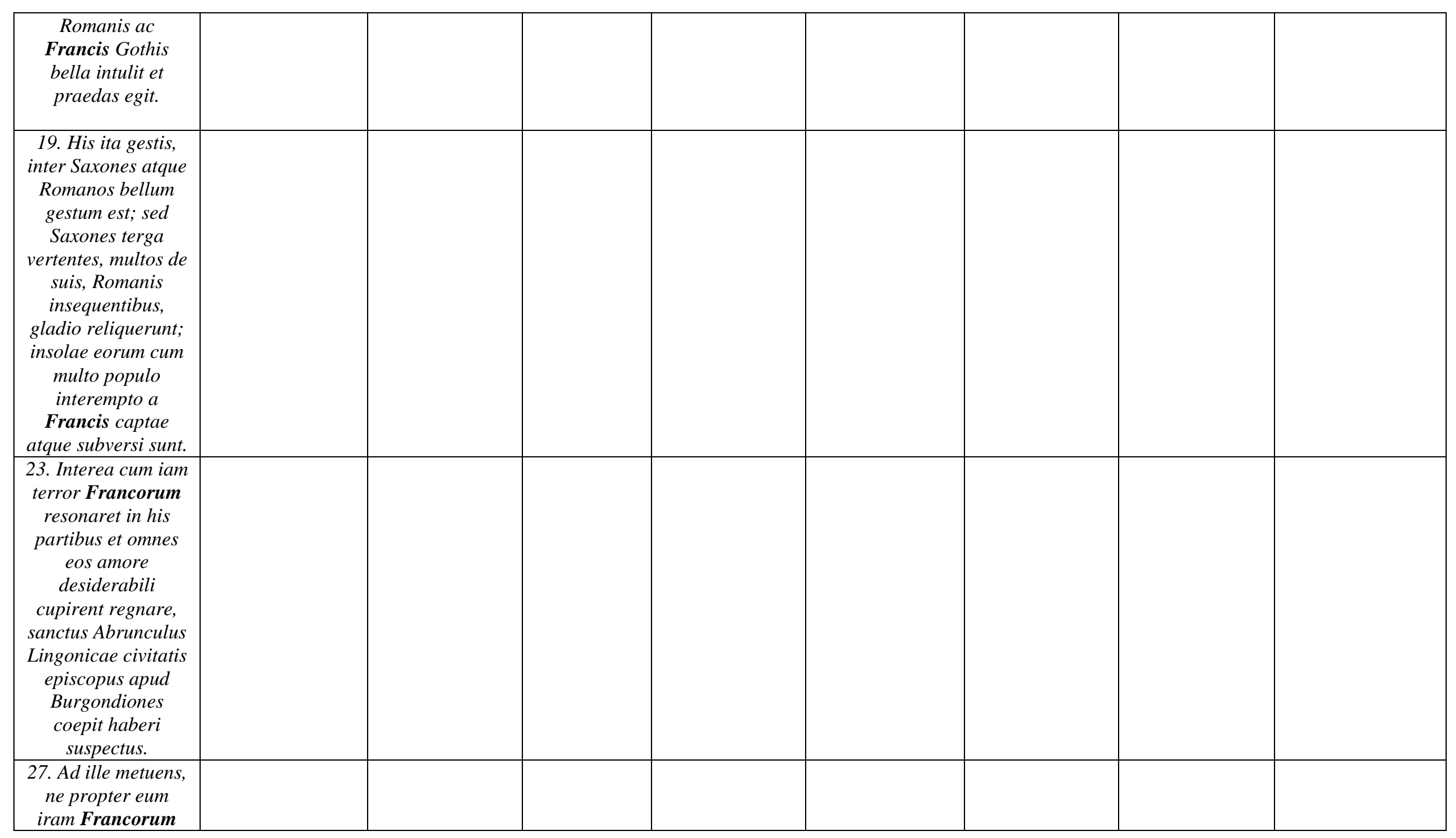




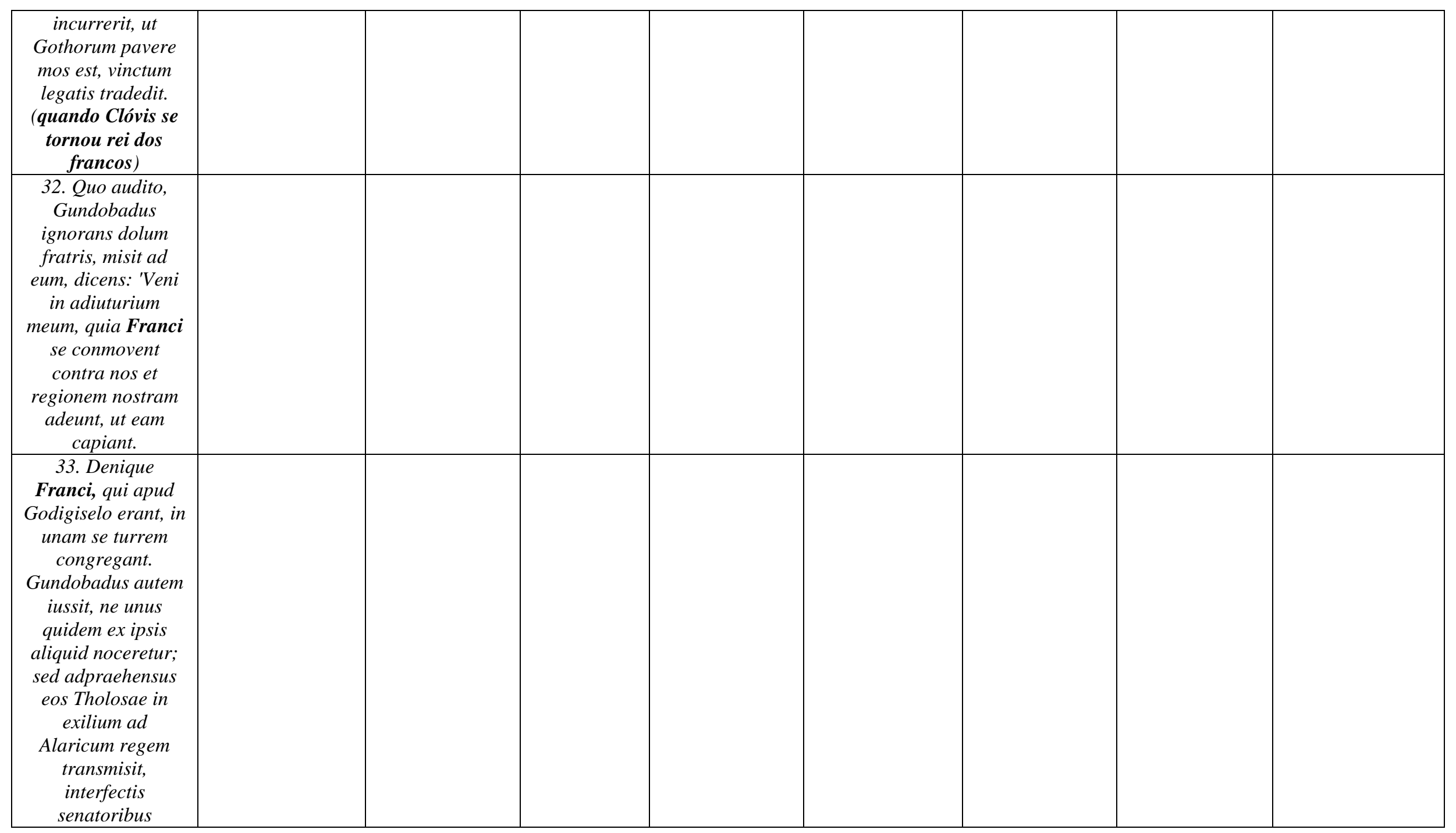




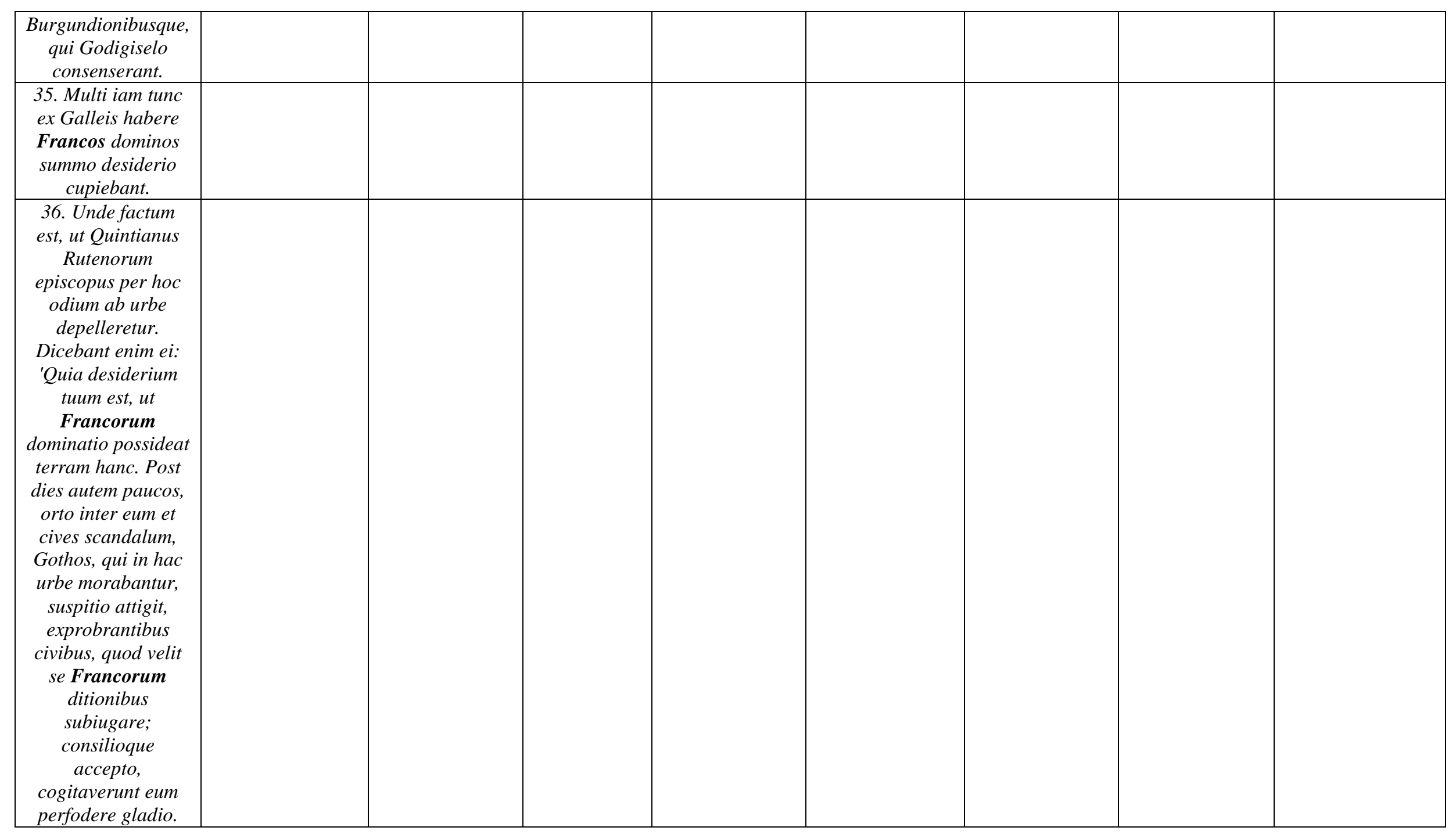




\begin{tabular}{|c|l|l|l|l|l|l|l|}
\hline & & & & & & \\
\hline $\begin{array}{c}\text { 42. Pro qua re } \\
\text { Franci maxima } \\
\text { indignatione } \\
\text { tumibant. }\end{array}$ & & & & & & & \\
\hline
\end{tabular}

Tabela 1: Os francos nos Decem Libri Historiarum

A distribuição do termo ao longo da fonte pode ser ilustrada pelos gráficos a seguir.

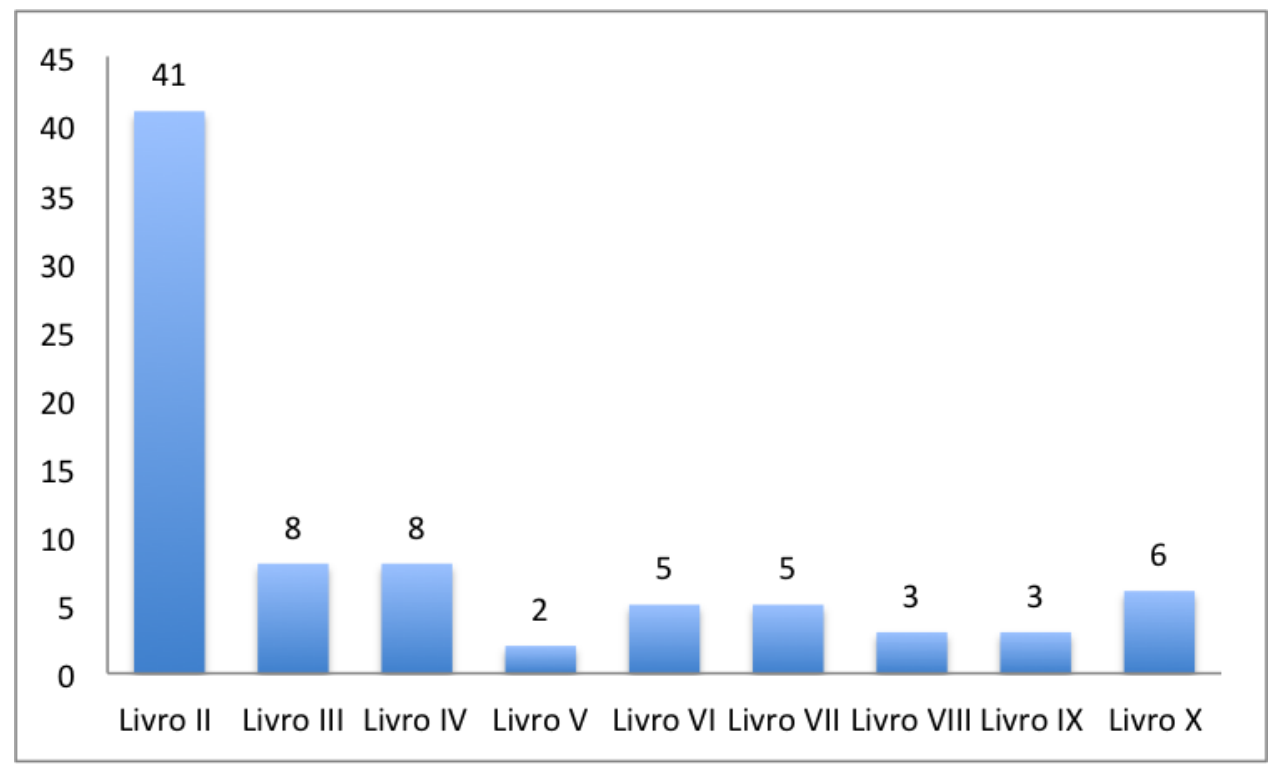

Gráfico 1 Os Francos nos Decem Libri Historiarum 


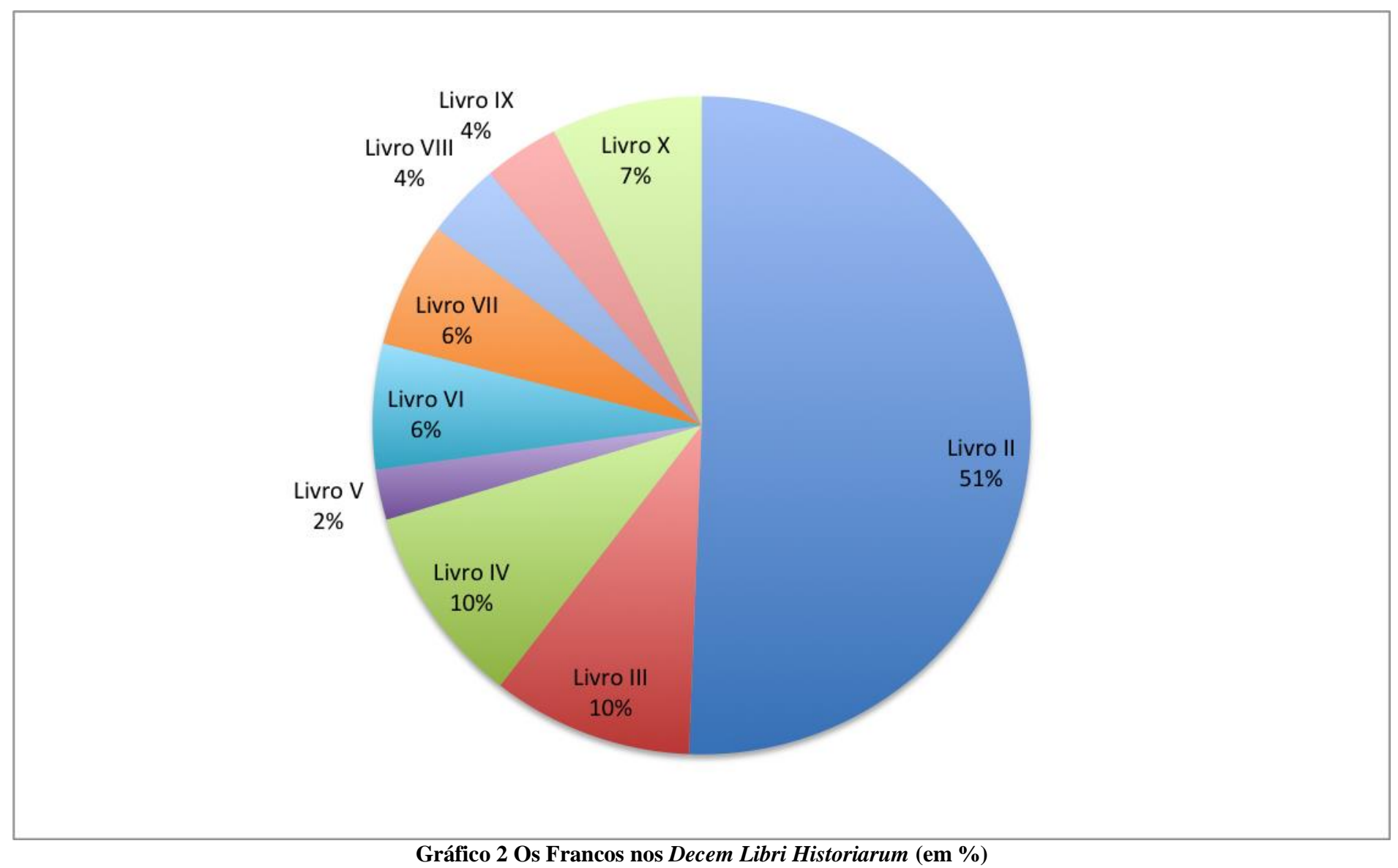

É bastante evidente que o livro II concentra a maior recorrência do termo na fonte. Ele introduz os francos na narrativa iniciada no livro I profundamente inspirada nas histórias bíblicas. 
A característica da distruição do termo nas partes iniciais da obra, como veremos para o caso da Chronica de Fredegário e do Liber Historiae Francorum era bastante comum. O confronto de todas essas Historiae e a comparação do estilo narrativo com essa característica pode nos levar a inferir que esse tipo de formato visa sobretudo introduzir o elemento de destaque na narrativa, a saber, os franci. Dentre as gentes mencionadas pelo bispo de Tours os franci se destacam. Eles estão envolvidos no difícil contexto do Ocidente europeu com a crise do Império que culminou na perda do monopólio da autoridade política de Roma nas províncias Orientais e nesse contexto os franci se destacam na narrativa gregoriana. Naquele momento de dificuldade o bispo de Tours chega a dizer que o avanço dos franci era desejado na Gália, como podemos observar pelo capítulo 35 do livro II. Não obstante, o capítulo 9, justamente o que concentra a maioria das referências aos franci no livro II, se configura como uma cuidadosa análise de fontes históricas em busca da resposta à pergunta: quem foi o primeiro rei dos francos? Gregório, como sabemos, não encontrou a resposta, mas sua pergunta seria cotejada pelos autores da Chronica de Fredegário e do Liber Historiae Francorum que foram profundamentes influenciados pela narrativa de Gregório de Tours.

Como veremos, os autores da Chronica e do Liber Historiae Francorum se reapropriaram da narrativa de Gregório e Tours e deram um valor muito mais significativo a gens francorum em seus textos. Mas foi Gregório, o estilo que ele adotou de introdução dos franci no início da obra e o desenrolar dos eventos nos reinos dos francos que o bispo de Tours desenvolveu que lançou os fundamentos que seriam usados posteriormente num contexto em que identidades regionais entravam com mais força no cenário de disputas políticas da Gália e no qual a reafirmação da identidade franca ser tornava cada vez mais urgente. 
Em poucas palavras, ao inserir os franci na gesta temporum Gregório de Tours, mesmo que não fosse sua intenção, forneceu as bases para as narrativas que viriam a seguir e dariam um novo sentido de destaque para os franci enquanto uma identidade política em confronto com outras identidades políticas que geravam políticas identitárias.

\section{A Chronica de Fredegário}

A principal fonte que podemos qualificar como historiográfica da Gália Merovíngia para o século VII é a Crônica de "Fredegário". O texto de difícil compreensão e estrutura complexa foi alvo de um intenso debate historiográfico iniciado em 1888 com a primeira edição moderna ${ }^{504}$ de autoria de B. Krusch lançada pelos MGH que, a despeito das críticas, se tornou uma importante fonte de referencia: pelo uso do nome "Fredegário" para identifica-la, pelo debate da autoria da obra e pela organização do texto em quatro livros. Seguiremos aqui as linhas do debate.

O primeiro ponto a ser ressaltado é que o autor, ou autores, da crônica era(m) anônimo(s). O nome "Fredegário" apareceu pela primeira vez em 1579 na primeira edição do Recueil des Antiquitez Gauloises et Françoises de Claude Fauchet. ${ }^{505}$ Apenas para fins referenciais seguiremos a sugestão de R. Collins e usaremos “Crônica de Fredegário" para nos referirmos ao texto. De todo modo, o nome do autor da crônica talvez seja um problema menor frente ao debate concernente a quantos autores a crônica teve, debate este iniciado também a partir da edição de B. Krusch de 1888. Para Krusch, pelo menos três homens escreveram a crônica em três períodos

\footnotetext{
${ }^{504}$ KRUSCH, B. Fredegarii et aliorum chronica. MGH, Scriptorum rerum Merovingicarum. t.II, 1888. Será essa a edição principal utilizada neste trabalho, entretanto, trataremos a edição de maneira crítica à luz dos debates historiográficos e sobretudo confrontando-a à reprodução do Paris BnF MS lat. 10910 feita por G. Monod.

${ }^{505}$ COLLINS, R. Fredegar. Aldershot: Variorum, 1996. p.81-83.
} 
diversos: O primeiro autor dedicou-se ao trabalho por volta de 613 e produziu o texto básico que compreendia o Liber Generationis, as crônicas de Jerônimo-Eusébio e Hidácio de Chaves e os contos lendários de Teodorico e Justiniano. A essa compilação foi adicionado um trecho original que compreendia os anos entre 584 e 613. O autor dessa primeira versão foi chamado por Krusch de "A". A partir de 642 um outro autor adicionou um resumo dos seis primeiros livros dos Decem Libri Historiarum de Gregório de Tours e mais uma crônica original que cobria o período entre 614 e 641, esse seria o autor "B". Por volta de 660 um terceiro autor, chamado por Krusch de "C" interpolou aos textos de A e B vários eventos ocorridos fora da Gália e sob um ponto de vista pró-austrásia. Para Krusch, os autores A e B escreveram a partir da Burgúndia, possivelmente em Avenches, enquanto $\mathrm{C}$, por seu tom pró-Austrásia, escreveu evidentemente na Austrásia, possivelmente a partir de Metz. ${ }^{506}$

Por outro lado G. Monod defendeu a autoria única da crônica em um artigo publicado em $1878,{ }^{507} \mathrm{dez}$ anos antes do lançamento da edição de Krusch. O argumento de Monod se baseou sobretudo no manuscrito mais antigo da crônica, o Paris BnF MS lat. $10910^{508}$ que R. Collins data entre c. 679 ou c.714. ${ }^{509}$ A argumentação de Monod leva a crer que a autoria única era já uma dúvida mesmo ele defendendo ser essa a hipótese mais razoável:

[...] mais il importe de faire remarquer qu'elle est évidemment l'ouvre d'un même auteur, comme le prouvent déjà les titres confus et inexacts donnés par le scribe Lucerius aux divers fragments, et les mots chronica sexta appliqués à la chronique qui, dans son

\footnotetext{
506 KRUSCH, B. Fredegarii et aliorum chronica... op.cit.p.4. Ainda: COLLINS, R. Fredegar...op.cit.p.91-97.

${ }^{507}$ MONOD, G. Du lieu d'origine de la chronique dite de Frédégaire. Jahrbuch für schweizerische Geschichte. n.3, 1878. p.141- 163 .

${ }^{508}$ Manuscrito esse que o autor reproduziu: MONOD, G. La compilation dite "Frédégaire". Études Critiques sur les sources de l'histoire mérovingienne. Soixante-troisième fascicule. Paris: F. Vieweg, 1885.

${ }^{509}$ COLLINS, R. Fredegar... op.cit.p. 119.
} 
recueil, occupe la quatrième place. Nous lisons en effet dans le prologue de la chronique ces mots: "...beati Hieronymi, Ydacii et cuiusdam sapientis, sep Hysidori, immo et Gregorii chronicis... percurrens, jusque decedentem regnum Gunthramni, his quinquet chronicis... inserui". Ce passage prouve bien que l'auteur de la chronique originale est aussi le compilateur des cinq autres parties. ${ }^{510}$

Assim, pela forma do verbo inserere na primeira pessoa do singular Monod sustenta que um autor foi responsável pela reunião de todo o material e pelo acréscimo da parte original que corresponderia a uma sexta parte da obra. Sexta parte essa que foi inserida por Krusch no quarto livro de sua edição. Mais, para Monod o autor da crônica era um monge Burgúndio que vivia no Mosteiro de Saint Marcel em Chalon sur Saône ${ }^{511}$ tais especificações do lugar de origem do autor da obra se fundamentavam para Monod pelas seguintes razões: 1. O conhecimento do autor sobre os eventos que ocorriam não só na Burgúndia - teatro majoritário dos acontecimentos descritos na crônica - mas também no resto da Gália e em outros reinos, algo que só poderia ser possível se o autor estivesse perto da corte burgúndia que na primeira metade do século VII tinha Chalon sur Saône como lugar principal; 2. A reprodução na crônica de partes da vida de São Columbano escrita por Jonas Bobbio que vivera por algum tempo no mosteiro de Saint Marcel. ${ }^{512}$

Esses posicionamentos diversos sobre a autoria da obra foram o principal foco de debate entre os historiadores e, interessante notar, eram bem marcados pela tese francesa da autoria única e a tese alemã da autoria múltipla. De fato, foi o discípulo de Krusch, G. Schnürer ${ }^{513}$ que desenvolveu a tese de Krusch modificando entretanto alguns dados cronológicos do mestre. Enquanto isso na França F. Lot, discípulo de G. Monod, fez uma forte crítica à hipótese de Krusch e seu discípulo indicando que não

\footnotetext{
${ }^{510}$ MONOD, G. Du lieu d'origine de la chronique dite de Frédégaire...op.cit. 146.

${ }^{511}$ Ibidem, p.155-159.

512 Idem.

${ }^{513}$ Schnürer, Gustav. Die Verfasser der sogenannten Fredegar-Chronik. Collectanea Friburgensia. Fasciculus IX, 1900.
} 
há possibilidade de fazer a distinção exata entre os autores tal como fizeram os estudiosos alemães, tendo Krusch inclusive levantado a hipótese de um quarto autor ter feito adições posteriores à obra. A crônica seria assim de autoria única. $\mathrm{O}$ autor seria um laico - tese essa que discorda da de Monod que o identificou como um monge de Saint Marcel - e que pela grande quantidade de informações levou Lot a concluir que o autor recorreu a outras fontes para escrevê-la. Isso para Lot diminuía o valor histórico da crônica. ${ }^{514}$

O debate arrefeceu com o início da Primeira Guerra Mundial até que em 1934 surgiu um novo trabalho que mudou o debate, trata-se do estudo de Siegmund Hellmann que fez uma análise linguística do livro IV que trazia fortes elementos para suportar uma versão modificada da hipótese de Krusch. Para Hellmann não havia um terceiro autor austrasiano, entretanto, se pode falar de dois autores da Burgúndia, um que escreveu por volta de 614 e outro por volta de 660. O verdadeiro Fredegário seria o responsável pela compilação final, o segundo autor de 660. Os argumentos linguísticos de Hellmann pareciam tão densos que a sua hipótese permaneceu inalterada e aceita pela historiografia, sendo acatada por M. Wallace-Hadrill em sua edição de 1960 e F.L. Ganshof no seu livro sobre Fredegário publicado em $1970 .{ }^{515}$

Em 1963 W. Goffart retomou o problema e mais uma vez colocou em dúvida a tese da múltipla autoria. Goffart concentrou-se sobretudo nos manuscritos da classe A hoje representado pelo já mencionado manuscrito de Paris. ${ }^{516}$ Segundo ele é o ms. 10910 que traz a versão mais segura da crônica para nos fornecer evidências sobre o

\footnotetext{
${ }^{514}$ LOT, Ferdinand. Encore la chronique du pseudo-Frédegáire. In : Recueil des travaux historiques de Ferdinand Lot. Tome I. Genève, Paris: Droz \& Minard, 1968. p.487-519. Originalmente publicado em : Revue historique, 15, p.305-337, 1914. p.518-519.

${ }_{515}$ COLLINS, R. Fredegar. Aldershot: Variorum, 1996. p.91-97.

${ }^{516}$ Esses manuscritos eram dois, o ms. de Paris 10910 e o ms. de Metz (Metz, Bibliothèque Municipale, MS 134 c.768-91), lamentavelmente o manuscrito de Metz foi destruído em 1944 de modo que o único representante da classe A ainda existente é o importante manuscrito de Paris. $C f$ : COLLINS, R. Fredegar... op.cit.
} 
plano original do texto. O prólogo presente nesse manuscrito indica para Goffart que uma única pessoa produziu o texto. Os argumentos de Goffart são muito semelhantes aos de Monod no artigo publicado em 1878:

Fredegar's prologue is as important evidence for the authorship of the chronicle as for the book's contents. It portrays an author describing how he has gone about his task: "from the beginning of the world to the declining years of Guntram's reign," he recopied and abridged the works of five earlier chroniclers; from 584 onward, he wrote an original continuation of "facts and deeds of later times, finding them wherever they were recorded, and relating of the deeds od kings and the wars of peoples all that I have read or heard or seen that I could vouch for". From all appearances, a single person is speaking here, and the description he gives, though passing in silence over the interpolations of the earlier chronicles, is nevertheless quite sufficient to encompass the entire compilation. The prologue therefore gives a solid basis for the presumption that Fredegar's chronicle is the work of a single anonymous author. In the absence of decisive proof to the contrary, since authorship is and should remain the starting point in all discussions of the chronicle. ${ }^{517}$

Temos então que o prólogo foi o principal indício tanto para Monod quanto para Goffart para defenderem a tese da autoria única. As principais diferença entre as hipóteses de Monod e de Goffart é que Goffart não defende nenhuma hipótese para o local de origem desse autor e propõe que o texto foi escrito por volta de 658 enquanto Monod defendeu duas cronologias: o autor escreveu a primeira parte por volta de 642 e a segunda entre 658 e $664 .^{518}$

Já R. Collins, numa importante contribuição aos estudos sobre Fredegário publicada em inglês em 1994, seguiu um caminho ligeiramente inverso ao discutir o problema da autoria mediante a análise das fontes de Fredegário focando-se não exclusivamente na parte considerada como a "crônica original" - como comumente trabalhou a historiografia - mas também sobre os acréscimos feitos por Fredegário nos trechos tidos como meras cópias de autores como Jerônimo, Eusébio e Gregório de

\footnotetext{
${ }^{517}$ GOFFART, W. The Fredegar Problem Reconsidered. Speculum. v.38, n.2, p. 206-241, 1963. p.216-217.

${ }^{518}$ Ibidem. Ainda: COLLINS, R. Fredegar... op.cit.
} 
Tours. Collins retoma um ponto colocado por Monod em seu artigo de 1878, a saber, a presença de trechos da Vita Columbani de Jonas Bobbio na crônica de Fredegário. Segundo ele essas passagens possuíam um potencial considerável para conjecturarmos acerca do local de produção da crônica e até mesmo acerca do problema da múltipla autoria, o mesmo vale para os trechos da crônica que trazem informações sobre a Itália - especialmente durante o governo de Teodorico - e o Bizâncio, entretanto, a presença dessas fontes levantam mais problemas para determinarmos a origem da crônica do que soluções. O que esses dados indicam é que Fredegário consultou muito material para escrever seu texto de modo que as informações sobre determinados lugares não são indicações seguras sobre o local de produção do texto. Por exemplo, Collins indica que a narrativa de eventos concentradas numa região, como no caso dos acontecimentos ocorridos entre 590-615 no Pagus Ultrajuranus podem se dever mais as fontes usadas por Fredegário do que ao fato do autor ter sido um nativo daquela área, essa hipótese complica muito a possibilidade de identificarmos com segurança o local onde a crônica foi escrita, Collins então amplia o argumento de Goffart sobre essa questão:

The association of Fredegar with a particular region is, from this and other examples, an almost impossible task. For those who espoused the theories of multiple authorship apparent shifts in geographical perspective or political allegiance in the contents of the final section of the chronicle could be rationalized in terms of the differences between the three or two contributors. For adherents of a single authorship these traits in the narrative require explanation in terms of the author's mobility, either physical or political. Making him a cleric, and above all a monk, somewhat inhibits this approach. Overall, Fredegar makes a number of references to places in Burgundy, including Avenches and the Pagus Ultrajuranus, Auxerre, Autun, Chalon-sur-Saône, and Lyon. $\mathrm{He}$ also records events and individuals concerned with Austrasia, with a relative frequent mention of Metz. But he can also lead his readers to Orléans, and the Loire valley, as well as to Paris and Seine. As generations of commentators have come to realize, the range is too great to locate him in a particular geographical 


$$
\text { viewpoint. }^{519}
$$

Collins vai além em sua análise e estuda as possíveis relações políticas do autor da crônica. Pela sua descrição dos nobres Collins sugere que Fredegário pode ter escrito ou na Burgúndia ou na Nêustria, indicando que a produção da crônica na Austrásia é menos provável. Não obstante, pela narrativa de Fredegário que enfatizava virtudes como a piedade Collins sugere que ele era um laico com um forte espírito religioso, o que vai de encontro com a tese de Monod que o colocava como um monge, além disso, Collins propõe como data de produção da crônica o período por volta de $660 .{ }^{520}$

A partir dessa apreciação da historiografia nota-se a enorme dificuldade de estabelecer teorias seguras sobre a produção da crônica no que concerne ao lugar onde foi escrita e a autoria. De fato, tanto a tese francesa da autoria única quanto a tese alemã da autoria múltipla possuem fundamentos. Embora o prólogo - analisado por G. Monod e W. Goffart - traga indícios para falarmos de uma autoria única assim como a análise de R. Collins sobre as fontes do autor e as relações políticas nas quais ele poderia estar envolvido a hipótese alemã também traz elementos importantes para sustentar a hipótese da autoria múltipla. De fato a crônica é redundante em certas passagens e traz versões diversas para eventos importantes como a origem dos francos.

A primeira versão aparece na segunda parte da crônica que no manuscrito de Paris é inaugurada com o título INCIPIVNT CAPETOLARES CRONECE GYRONIMI SCARPSVM seguido de um resumo dos capítulos da crônica de Jerônimo, que consistia numa tradução da crônica de Eusébio de Cesaréia. Os

\footnotetext{
${ }^{519}$ COLLINS, R. Fredegar. Aldershot: Variorum, 1996. p.105.

${ }^{520}$ A conclusão de Collins é: "Overall, while the balance of probability might be thought to favour the view that Fredegar was a layman of high status, writing in the Neustrian-Burgundian kingdom around the year 660, the evidence is not strong enough to command a complete conviction." Ibidem. p.111
} 
capítulos que se seguem são uma versão da crônica traduzida por Jerônimo mas com acréscimos relacionados aos francos. É no trecho sobre Príamo que encontramos a primeira versão para a origem dos francos:

Exinde origo Francorum fuit. Priamo primo regi habuerunt; postea per historiarum libros scriptum est, qualiter habuerunt regi Friga. Postea partiti sunt in duabus partibus. Una pars perrexit in Macedoniam, vocati sunt Macedonis secundum populum, a quem recepti sunt, et regionem Macedoniae, qui oppremebatur a gentes vicinas, invitati ab ipsis fuerunt, ut eis praeberent auxilium. Per quos postea cum subiuncti in plurima procreatione crevissent, ex ipso genere Macedonis fortissimi pugnatores effecti sunt; quod in postreamum in diebus Phylyphy regis et Alexandri fili sui fama confirmat, illorum fortitudine qualis fuit.

Nam et illa pars, quae de Frigia progressa est, ab Olexo per fraude decepti, tamen non captivati, nisi exinde eiecti, per multis regionibus pervacantis cum uxores et liberos, electum a se regi Francione nomen, per quem Franci vocantur. In postremum, eo quod fortissimus ipse Francio in bellum fuisse fertur, et multo tempore cum plurimis gentibus pugnam gerens, partem Asiae vastans, in Eurupam dirigens, inter Renum vel Danuvium et mare consedit. $^{521}$

A segunda versão aparece no livro III conforme a organização feita pela edição

de Krusch e na parte IV conforme a reprodução do manuscrito de Paris feita por

Monod:

De Francorum vero regibus beatus Hieronimus, qui iam olym fuerant, scripsit, quod prius Virgilii poetae narrat storia: Priamum primum habuisse regi; cum Troia fraude Olexe caperetur, exinde fuissent egressi; postea Frigam habuissent regem; befaria divisione partem eorum Macedonia fuisse adgressa; alii cum Friga vocati Frigiis, Asiam pervacantes, litoris Danuvii fluminis et mare Ocianum consedisse; dinuo byfaria devisione Eurupam media ex ipsis pars cum Francionem eorum rege ingressa fuisse. Eurupam pervagantis, cum uxoris et liberis Reni ripam occupant, nec procul a Reno civitatem ad instar Trogiae nominis aedificare conati sunt. Ceptum quidem, sed inperfectum opus remansit. Residua eorum pars, que super litore Danuvii remanserat, elictum a se Torcoth nomem regem, per quem ibique vocati sunt Turchi; et per Francionem hii alii vocati sunt Franci. Multis post temporibus cum ducibus externas dominationis semper negantes. ${ }^{522}$

[...]Franci electum a se regi, sicut prius fuerat, cranium inquirentes diligent ex genera Priami, Frigi et Francionis super se creant,

\footnotetext{
${ }^{521}$ Fredegário, 1.II. c.4-5. (Edição MGH). Na reprodução do manuscrito feita por Monod o trecho está na segunda parte, também no capítulo IV.

${ }^{522}$ Fredegário, 1.III, c.2 (Edição MGH). Parte IV, c.2 reprodução Monod.
} 
Destaquemos a diferença entre as duas versões:

\begin{tabular}{|c|c|}
\hline Primeira & Segunda \\
\hline $\begin{array}{l}\text { - Príamo foi o primeiro rei dos francos; } \\
\text { - Em seguida veio Friga; } \\
\text { Os francos se dividiram em suas } \\
\text { partes: uma se estabeleceu na } \\
\text { Macedônia, ajudou os povos da } \\
\text { região à superar a opressão dos } \\
\text { povos vizinhos, mesclou-se com } \\
\text { os macedônios e eram } \\
\text { responsáveis pela bravura dos } \\
\text { macedônios confirmada pela fama } \\
\text { do rei Filipe e seu filho } \\
\text { Alexandre. A segunda parte } \\
\text { liderada por Friga foi enganada na } \\
\text { Frígia por Ulísses, mas não se } \\
\text { submeteram e escaparam com } \\
\text { suas esposas e filhos, elegeram } \\
\text { como rei Francio do qual se } \\
\text { originou o nome da gens Francos; } \\
\text { Francio era um forte guerreiro e } \\
\text { lutou com muitas gentes, } \\
\text { devastaram parte da Ásia e se } \\
\text { dirigiram à Europa na região entre } \\
\text { o Reno, o Danúbio e o mar. }\end{array}$ & $\begin{array}{l}\text { - A história dos reis dos francos e } \\
\text { buscada em fontes escritas, } \\
\text { nomeadamente na crônica de } \\
\text { Jerônimo que baseava-se na } \\
\text { história narrada pelo poeta } \\
\text { Virgílio. } \\
\text { - Príamo foi o primeiro rei, escapou de } \\
\text { Tróia depois de ser enganado por } \\
\text { Ulisses; } \\
\text { - Tiveram em seguida por rei Friga; } \\
\text { - Se dividiram em suas partes, uma se } \\
\text { dirigiu à Macedônia; } \\
\text { - O outro grupo conhecido como Frígios } \\
\text { liderados por Friga cruzaram a } \\
\text { Ásia e se estabeleceram entre o } \\
\text { Danúbio o mar; } \\
\text { - Ocorreu uma segunda divisão e um } \\
\text { grupo liderado por Francio } \\
\text { dirigiu-se à Europa pela qual } \\
\text { viajaram com suas esposas e } \\
\text { filhos e se estabeleceram às } \\
\text { margens do Reno onde } \\
\text { construíram uma cidade } \\
\text { semelhante à Tróia, começaram o } \\
\text { trabalho mas não o concluíram. O } \\
\text { resto do grupo permaneceu na } \\
\text { área do Danúbio e elegeu como } \\
\text { rei Torcot do qual se originou o } \\
\text { nome dos turcos, enquanto a parte } \\
\text { liderada por Francio recebeu o } \\
\text { nome de Francos. Por muito } \\
\text { tempo liderados por seus duces } \\
\text { resistiram à dominação de outras } \\
\text { gentes. } \\
\text { - Escolheram entre eles um rei de } \\
\text { cabelos longos tal como outrora } \\
\text { elegendo-o cuidadosamente um } \\
\text { membro do gênero de Príamo, } \\
\text { Friga e Francione que se chamava } \\
\text { Teudemaro, filho de Ricamaro. }\end{array}$ \\
\hline
\end{tabular}

Tabela 2 - As duas versões de Fredegário para a origem dos francos

${ }^{523}$ Fredegário, parte 4, VIII. (edição de G. Monod). 
O que podemos destacar de início é que tanto a primeira quanto a segunda versão falam das origens troianas dos francos, a lista dos reis é semelhante exceto pela nomeação de Teudemaro, escolhido depois que os francos voltaram a ser liderados por reis, entretanto o autor enfatizou que Teudemaro foi escolhido cuidadosamente entre os membros do gênero de Príamo, Francio e Friga, os primeiros reis da narrativa da saga dos francos rumo à Europa. No que concerne às principais diferenças, nota-se que a segunda versão logo traz um argumento de autoridade: o autor nomeia suas fontes que seriam um autor cristão, Jerônimo, e um pagão, Virgílio. A primeira versão diz apenas que conforme os livros de histórias Friga foi escolhido rei depois de Príamo.

Não temos aqui a pretensão de darmos uma resposta para os problemas contemplados pela historiografia, talvez seja mister reconhecer que jamais teremos uma resposta definitiva para tais dúvidas, mas não deixa de ser interessante questionarmos porque um autor que escrevia na Gália e estava bem informado sobre o teatro político da região escreveu duas versões diferentes para a origem dos francos.

Apenas o uso de diversas fontes não responde ao problema uma vez que nos levaria a pressupor que Fredegário reuniu informações de fontes diversas sem grandes critérios. O que devemos levar em conta é que as versões diversas são resultado de um fato talvez mais banal do que a tese da autoria múltipla ou a diversidade de fontes inferem: o autor estava contando duas histórias diferentes, a primeira era a origem dos francos, a segunda a origem dos reis francos.

Como observamos na Historia Gothorum de Isidoro de Sevilha esse tipo de dupla história não foi iniciada pelo cronista da Gália, também o bispo de Sevilha contou a história da gens gothorum e a história dos reges gothorum o que indica que esse conduzir narrativo era relativamente difundido e aceito. Não se tratava assim de 
uma falta de coerência, mas de uma estrutura narrativa diferente, uma estrutura que nos dois casos acaba relacionando a origem da gens e seu sucesso com seus reis de modo a criar uma relação entre gens e reges quando analisadas em confronto. Um movimento semelhante aparece na Historia Gothorum.

O que é importante ressaltar nesse ponto é que essas narrativas dão uma resposta dupla a dois problemas: primeiro encontram o primeiro rei dos francos, algo que como já indicamos Gregório de Tours não conseguiu fazer. ${ }^{524}$ Segundo elevam a importância dos francos na gesta temporum ao relacioná-los com um passado glorioso. Nossa análise da Historia Gothorum já apontou para o valor desse tipo de categorização em Isidoro de Sevilha, se considerarmos que Fredegário usou uma técnica narrativa observável na Historia Gothorum, não parece imprudente dizer que ele também estava ciente da hierarquia das gentes que Reydellet apontou como relevante nos textos isidorianos. Estamos aparentemente diante de duas tradições narrativas reapropriadas pelo Chronista: primeiro aquela inaugurada por Gregório de Tours que inseriu os franci no curso do tempo; segundo aquela adotada por Isidoro de Sevilha que narra em dois momentos, mas em estreita relação, ou seja, a origem da gens e de seus reges. Mas qual o sentido dessas apropriações para a construção de uma memória da gens francorum em Fredegário? Para respondermos à pergunta é mister uma análise detida da recorrência do termo franci em seu texto.

\section{Fredegário}

\section{Análise quantitativa e qualitativa da recorrência do termo "francus"}

\section{Legenda}

\footnotetext{
${ }^{524}$ Barlow entretanto defende que Gregório conhecia o mito das origens dos francos como advindos dos troianos. A hipótese é de difícil comprovação, de todo modo, mesmo que conhecesse o mito, o bispo não o acrescentou em seu texto deixando em aberto o problema do primeiro rei dos francos. $C f$ : BARLOW, J. Gregory of Tours and the Myth of the Trojan Origins of the Franks. Frühmittelalterliche Studien. Jahrbuch des Instituts für Frühmittelalterforschung der Universität Münster. n.29. p. 86-95. 1995.
} 
CF - Costume dos francos

DF - Dux Francorum

EF - Embaixadores francos

Exerc.F - Exército Franco

Francia

GF - Gens Francorum

NF - Nobres Francos

OF - Indivíduo de origem franca

Re.F - Reino dos francos

RF - Rei dos francos

Rg.F - Região dos francos

\section{Libro I}

- A primeira menção aos francos se dá com o cômputo dos anos a partir da crônica de Eusébio traduzida por Jerônimo. Os francos são mencionados pelo seu rei, Sigiberto:

A Constantino et Rufo usque ad ann. primum regni Sygiberti regis Francorum, filio Theuderici regis, explentur anni 156. [RF]

- Os francos são inseridos no índice de capítulos da crônica de Jerônimo:

4. De captivitate Troge et inicium Francorum et Romanorum [GF]

5. De Francione rigi Francorum et Francis [RF/GF]

6. De initium docum Francorum

$[\ldots][\mathbf{G F}]$

8. De captivitate Troge et egressionem exinde Priamo et Friga, unde Romani et Franci fuerunt $[\mathbf{G F}]$

$[\ldots]$

58. De Chlodoveo rigi Francorum et Alarico [RF]

\section{Entradas no livro I: 7}

Tabela 3: Os francos no livro I de Fredegário

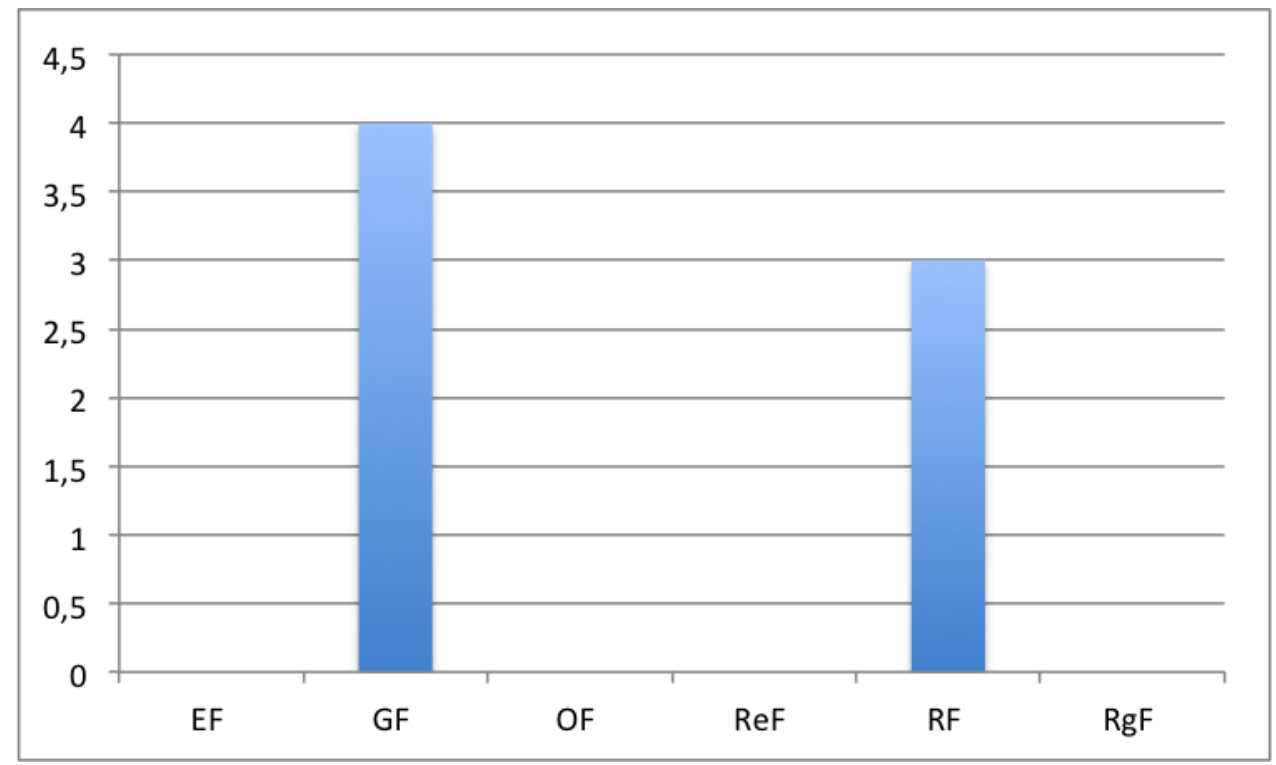

Gráfico 3 Aplicação do termo "francus" no primeiro livro de Fredegário 


\section{Livro II}

- cap.4 - Descrição da origem dos francos "Exinde origo Francorum fuit [...]" [GF]

- cap. 5 - Francio foi eleito rei dos francos e por isso os francos são assim chamados: "[...] electum a se regi Francione nomen, per quem Franci vocantur." [RF/GF]

- cap. 6 - Aliança dos francos com os saxões contra Pompeo: "Sed continuo Franci cum Saxonibus amicicias inientes, adversus Pompegium revellantis, eiusdem rennuerunt potestatem" [GF]

- Nenhuma gens podia superar os francos naqueles dias: Post haec nulla gens usque in presentem diem Francos potuit superare, qui tamen eos suae dicione potuisset subiugare" [GF]

- Os francos atravessam a Ásia. Relação entre os francos e os turcos: "Tercia ex eadem origine gentem Torcorum fuisse fama confirmat, ut, cum Franci Asiam pervacantis pluribus proeliis transissent, ingredientis Eurupam, super litore Danuviae fluminis inter Ocianum et Traciam una ex eis ibidem pars resedit" [GF]

- cap. 40 - Os francos auxiliam os germanos: "Germani Spanias obtenuerunt, etiam et Siriam incursaverunt, Francos in eorum habentes auxilium" [GF]

- "in qua pungna strenuissimae apud eam demicavit Pompegianus dux, genere Francos, cuius familia hodiequae apud Anciociam perseverant"

dux Pompegiano, de origem franca, participa de batalhas no Oriente, sua família continuou na região de Antioquia após sua morte: "[...] in quam pugna strenuissimae apud eam demicavit Pompegianus dux, genere Francos, cuius familia hodiequae apud Anciociam perseverant." [0F]

- cap.42 - Os francos e Constante: "Vario aevento adversum Francos a Constante pugnatur. Multi Oriente urbis terre moto orribile consederunt. Franci a Constante perdomiti; pax cum eis fact. [GF]

- cap. 45 - "Saxones caesi in regione Francorum consedit" [Rg.F]

- cap.53 - "Agecius a Tursemodo decim milia soledus, ut suo ingenio a persecutionem Chunorum liberati Gothi, ad sedis proprias remearint, protinus abigerunt. Agecius vero cum suis, etiam Francos secum habens, post tergum direxit Chunorum, quos usque Toringia a longe prosecutus est [...]" [GF]

- cap.56 - o sangue corria nas Gálias até o advento do reino dos francos que derrotou os godos: "An. 2. regni Antimiae medio Tholose civetatis sanguis erupit de terra et tota diae fluxit, signeficans, Gothorum dominatione sublata, Francorum adveniente regno" [Re.F]

- cap.58 - longo capítulo que trata das relações tempestuosas entre os visigodos e os francos. O termo "francus" é empregado em diversas ocasiões:

- Rex francorum - 1

- Gens francorum - 5 


\begin{tabular}{l}
$\quad$ - Embaixadores francos - \\
$\quad$ - reino dos francos - 1 \\
$\begin{array}{l}\text { cap.62 - Bucceleno, origem franca: "A Buccelenum quidam Franco in Aetalia } \\
\text { superatus est: tantae victuriae nomenis gloriosus a Bucceleno victus, nomen vitamque } \\
\text { admisit. [OF] }\end{array}$ \\
\hline Entradas no livro II - 22
\end{tabular}

Tabela 4: Os francos no livro II de Fredegário

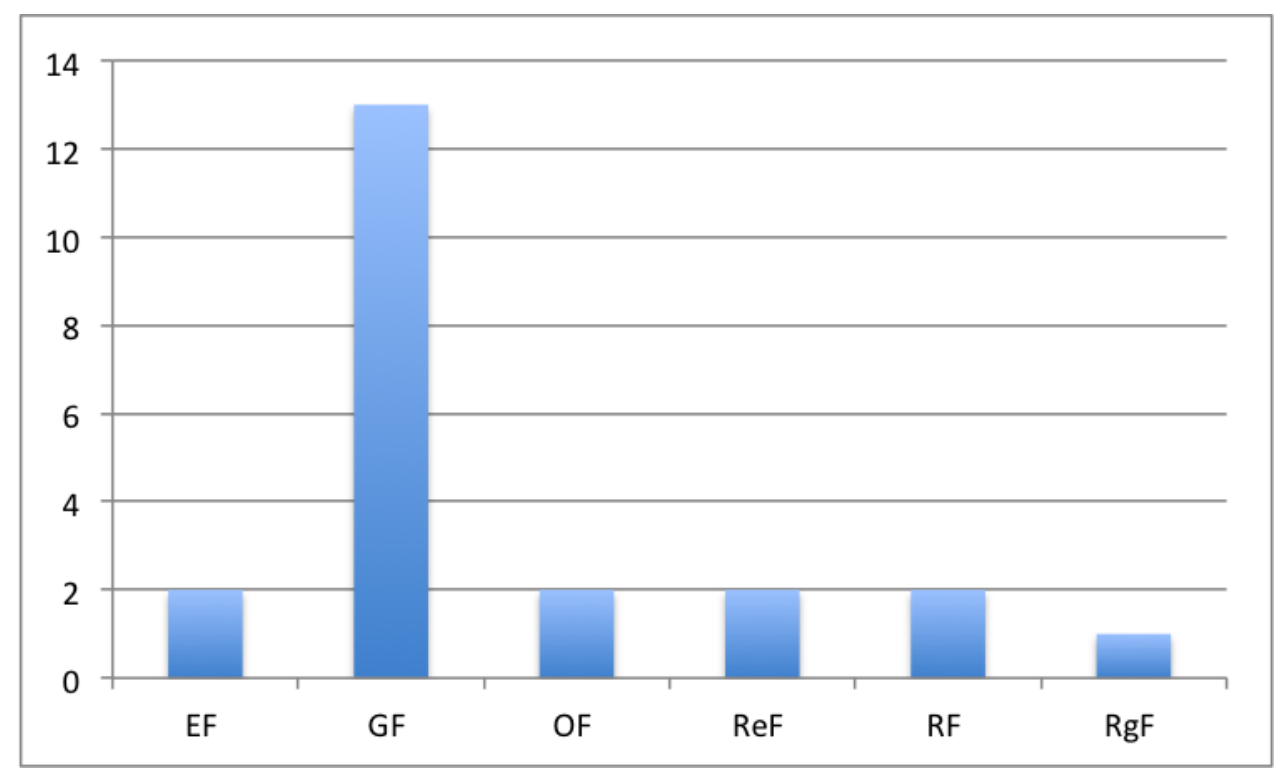

Gráfico 4 Aplicação do termo "francus" no segundo livro de Fredegário

\section{Livro III}

- Prefácio do Livro IV de Gregório de Tours

- 2. De Francorum origine et eorum regibus [RF/GF]

- 3. De docibus Francorum tres et pugnas cum re publeca [DF]

- 4. De Francis et Valentiniano Imperatore [GF]

- 5. De regis dinuo in Francis creates [RF]

- 7. De eversione urbis Treverice, quae a Francis facta est per Lucium [GF]

- 8. De Castino domesticorum comiti pugna cum Francis [GF] - 9. De initium regis dinuo Francorum [RF]

- 11. De Hilderico regi Francorum et Wiomado Franco [RF/OF]

- 31. De Alanis, qualiter in regno Francorum interfecti sunt [Re.F]

- 32. De regis Toringorum, et Toringia dicione Francorum subgicitur [GF]

- 36. Quod rignum Burgundiae dicione Francorum subgicitur [GF]

- cap.2. "De francorum vero regibus..." [RF] [...] "...et per Francionem hii alii vocati sunt Franci" [GF]

- cap.3.

- "Francos transegisse conperimus usque ad Marcomere, Sonnoni et Genebaudum ducibus" [GF] 
- "Francos de Germania eiexerunt" [GF]

"Apud Carbonariam de Francis stragies fietur" [GF]

- "Post Eraclio et Ioviano cum exercito ultra Renum transeuntis, disponentis Francos ad internicionem perdurece, tante stragies ex militibus a Francis factae sunt, ut Aeraclius et Iovianus cum paucis de eodem prilio potuissent evadere, nec ulterius adversus Francos praesumpserunt arma adrepere. Post paucum temporis Arbogastis superbiae aelatus adversus Francos arma commovit; cum eos demigans, victus effugit" [GF - 4 entradas]

- cap. 4.

- "Franci Treverus hiemando resedere praesumunt" [GF]

- "militaris rei cura Francis satillitibus tradita" [GF]

- "exercito fraude Francos deceptus urendusque" [GF]

- cap.5. "Dehinc, extinctis ducibus, in Francis dinuo regis creantur ex eadem stirpe, qua prius fuerant" [RF]

- cap.7. - "Treverorum civitas factione uni ex senatoribus nomen Luci a Francis capta et incinsa est" [GF]

- "Haec indignante Lucio, suae factione derepta est civetas et incensa a Francis" [GF]

- cap.8. - Castinus domesticorum comes expedicionem accepit contra Francos" [GF]

- cap.9. - "Franci electum a se regi..." [GF]

- Cumque in continuo aut a bistea aut a viro fuisset concepta, peperit filium nomen Meroveum, per co regis Francorum post vocantur Merohingii" [RF]

- cap.11. - "filias Francorum stubro tradit" [OF]

- "Wiomadus Francus fidelissimus ceteris Childerico" [OF]

- "eum Franci interficere conarentur" [GF]

- "Si tibi potuero Francos placare" [GF]

- "Franci tunc Eieio unianimiter regem adsciscunt" [GF]

- "Wiomadum amicus Childeric subregulus ab Eieio Francis instituetur" [GF]

- "eiusque consilio omnes Francos singulos aureos tributavit" [GF]

- "Quod cum factum fuisset, adquiescentes Franci dixerunt" [GF]

- "Revellis existunt tibi Franci; nisi preciperis ex eis plurimus iugulari" [GF]

- "Wiomadus secrecius dicens ad Francos..." [GF]

- "Tunc Franci unianimiter dicentes" [GF]

- "Modo est gens Francorum tuae disciplinae perdomita" [GF]

- "Deinde ab omnes Francos resublimatur in regno, multaque prilia cum Eiegio egit; plures strages ab ipso facti sunt in Romanis" [GF]

Esse capítulo é interessante porque parece marcar uma mudança no significado de gens Francorum, dificilmente poderíamos dizer que a intervenção dos francos - que falam unanimemente - se referem à todo o "povo dos francos". Parece que o termo é aplicado aqui para se referir à um grupo específico, talvez uma aristocracia governante. 
- cap. 12

- "cum audisset Childericum a Francis in regno sublimato" [GF]

- "Paulus comex cum Romanis et Francis bellum Gothis expulsi" [GF]

- - "Saxones terga vertentes, multis ex eis extinctis, insulae eorum cum multo populo interrempto Francis capte adque subversi sunt" [GF]

- cap.16. "Haec regem dicenti, respondent Franci" [GF]

- cap.18

- "Chlodoveus rex Francorum me direxit..." [RF]

- "mos erat Francorum" [CF]

- "Venientes cum caeleritate Franci..." [GF]

- "revertentem ab imperio, dixit ad seniores Francis..." [NF]

- - "Franci, levata Chrotechilde super aequun, festini ad Chlodoveo pergunt" [GF]

- cap.19

- "quod amiciciam cum Francis inevemus" [GF]

- - - quam omni tempore tu et tui scandalizeris a Francis" [GF]

- cap. 21

- "qui ei contra Francos auxiliaret" [GF]

- "baptismi gratiam cum sex milia Francis" [GF]

- - "Si ego ibidem cum Francis meis fuissem" [GF]

- cap. 22

- "Veni, ut resistamus Francis unianimiter, ut quod aliae gentes passi sunt non perferamus" [GF]

- Chlodoveus cum Francis adversus hos duos regis castra Divionense campania dirixit ad prilium" [GF]

- cap. 23

- "Chlodoveus rediit in Francia" [Francia]

- "relictis cum Gogyselo quinque milia Francis" [GF]

- - "Francis adgregatis in unam turrem ferro trucidavit"[GF]

- cap. 51

- "Quod Franci accipere dispicientes" [GF]

- "Franci Chlotharium volentis occidere" [GF]

- - "ibique tanta estrages a Saxonibus de Francis facta est, ut mirum fuisset"[GF]

- cap.52 - "Saxones factione Childeberti in Francia venientes, usque Diviciam civitatem predas egerunt." [Francia]

- cap.59. "Tanta mala et effusione sanguinum a Brunechildis consilium in Francia factae sunt, ut prophetia Saeville impleretur, dicens: Veniens Bruna de partibus Spaniae, ante cuius conspectum multae gentes peribunt". [Francia]

cap.90. "Illud tempore Chilpericus Parisius contra pactum, quam cum Francis inierat, ingreditur, ob quam rem porcionem suam exinde iusti admisit" [GF]

Entradas no livro III - 66

Comentário - O livro III traz elementos novos. Primeiro há o aparecimento do termo "Francia" nos capítulos 23, 52 e 59. O termo "reino", sem a especificação de reino dos francos mas referindo-se às possessões dos herdeiros de Clóvis também surge nos capítulos $53,55,70,80,85,86$ e 89 . Surgem também pela primeira vez os termos "Austrásia (cc. 58, 71 e 72) e Nêustria (c.71). Ainda, a partir do capítulo 23, ou seja, 
quando nos aproximamos do fim do reino de Clóvis, há uma redução drástica do termo "francus" sendo usado para se referir à "gens Francorum".

Tabela 5: Os franco no livro III de Fredegário

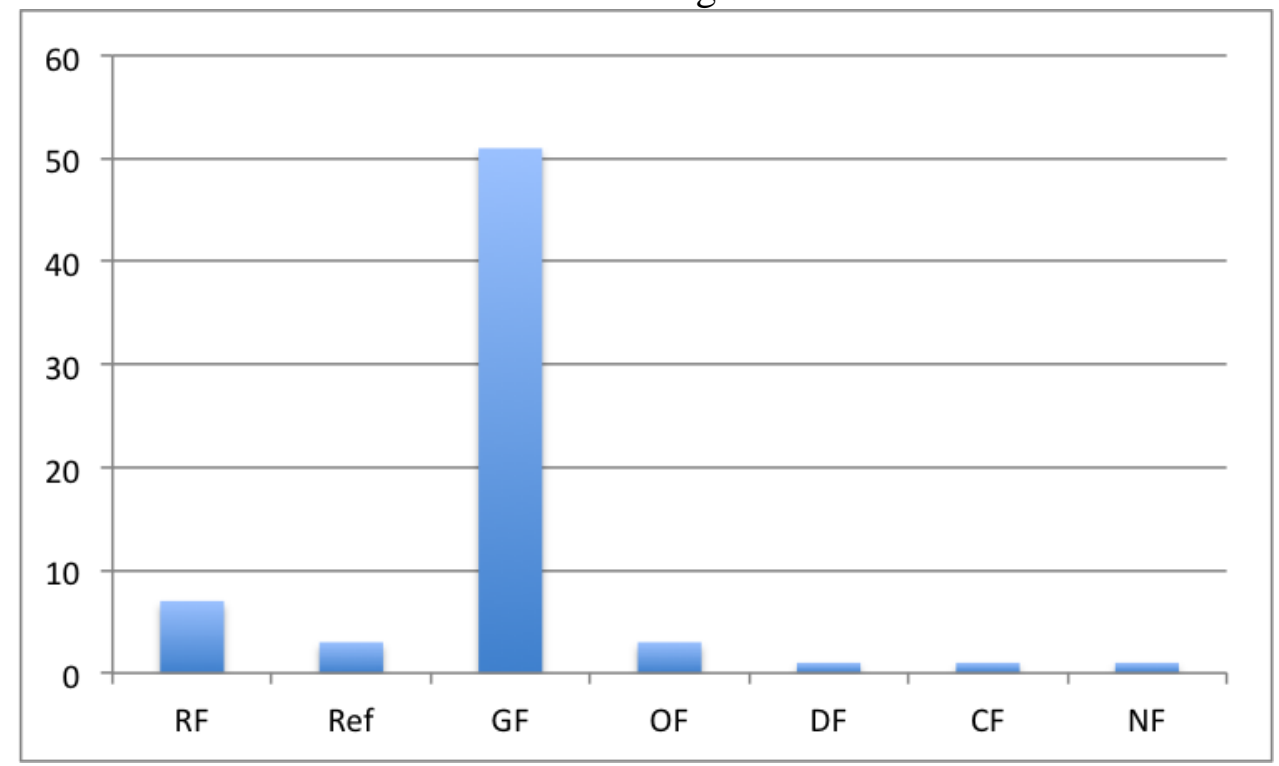

Gráfico 5 Aplicação do termo "francus" no terceiro livro de Fredegário

\section{Livro IV}

- cap.1. "Gunthramnus rex Francorum cum iam anno 23. Burgundiae regnum bonitate plenus feliciter regebat" [RF]

- cap.11. "Eo anno inter Francos et Brittanis super fluvio Vicinonia bellum est ortum" [GF]

- cap.12. "Beppelenus dux Francorum factione Hebracharii idemque ducis a Brittanis interficetur" [NF]

- cap.15. "exercitus Francorum et Brittanorum in invicem proeliantes" EF

- cap.18. "Anno 4. regni Theuderici Quolenus genere Francus patricius ordenatur" [OF]

- cap.24. "Eo tempore Bertoaldus genere Francos maior domus palacii Teuderici erat" [OF]

- cap. 33. "Nam et adversus manum publecam fortiter demicavit; provinciam Cantabriam Gothorum regno subaegit, quam aliquando Franci possederant. Dux Francio nomen, qui Cantabriam in tempore Francorum egerat, tributa Francorum regibus multo tempore impleverat" [GF/GF/RF]

- cap.34. "Ago rex Langobardorum accepit uxorem Griomoaldi et Gundoaldi germanam nomen Teudelendae ex genere Francorum, quem Childebertur habuerat disponsata" [OF]

- cap.37. "Anno 15. regni Theuderici cum Alesaciones, ubi fuerat enutritus, preceptum patris sui Childeberti tenebat, a Theudeberto rito barbaro 
pervadetur. Unde placetus inter his duos regis, ut Francorum iudicio finiretur, Saloissa castro instituunt." [GF]

- cap.38. "Fertur, a Francorum ceterasque gentes ab antiquito sic forte nec aliquando fuisse prilium conceptum" [GF]

- cap.40. "Chlotharius respondebat et per suos legatus Brunechilde mandabat, iudicio Francorum electorum quicquid, precedente Domino, a Francis inter eosdem iudicabatur, pollicetur esset implere" [GF/GF]

- cap.42. "Clotharius, cum Burnechildis suum presentatur conspectum, et odium contra ipsam nimium haberit, repotans ei, eo quod dece reges Francorum per ipsam interfecti fuissent - id est Sigybertus et Meroeus et genitor suos Chilpericus, Theudebertus et filius suos Chlotharius, item Meroueus, filius Chlothariae, Theudericus et eiusdem filiar tres, qui ad presens estincti fuerant -..." [RF]

- Firmatus est omnem regnum Francorum, sicut a priorem Chlotharium fuerat dominatum, cunctis thinsauris dicione Chlothariae iunioris subiecitur, quod feliciter post sedecem annis tenuit, pacem habens cum universas gentes vicinas" [Re.F]

- cap.43. - "Cum anno 30. regni sui in Burgundia et Auster regnum arepuisset, Herpone duci genere Franco locum Eudilanae in pago Ultraiorano instituit." [OF]

- cap.45. "Lamgobardorum gens quemadmodum tributa duodece milia soledorum dicione Francorum annis singulis dissolvebant, referam; vel quo ordine duas civitates Agusta et Siusio cum territuriis ad parte Francorum cassaverant, non abscondam" [GF/GF]

- "Ipsoque tempore, sicut super scriptum legitur, per loca in regno Francorum proruperunt" [RF]

- "Itequem et alius legatarius duodicem ad Gunthramnum et Childebertum destinant, ut patrocinium Francorum et defensionem habentes, duodece milia soledus annis singulis his duobus regibus in tributa implerint, vallem cuinomento Ametegis. [GF]

- Post haec integra decocione patrocinium elegunt Francorum. [GF]

- Et Autharius rex tributa, quod Langobardi ad parte Francorum sponderant, annis singulis reddedit. [GF]

- "ut illa duodece milia soledorum, quas annis singulis Francorum aerariis dissolvebant. [GF]

- cap.48 - "homo nomen Samo natione Francos de pago Senonago" [OF]

- cap.51 - "qua de re Gundebergam reginam, parentem Francorum, huuliasset" $[\mathbf{O F}]$

- cap.53 - "Elictis ab his duobos regibus duodicem Francis, ut eorum disceptatione haec finirit intentio" [GF]

- cap.58 - "ut nullus de Francorum regibus precedentibus suae laudis fuisset precellentio" [RF] 
- cap. 65 - "legationem ad Dagobertum regem Francorum dirigens" [RF]

- cap. 68 - Eo anno Sclavi coinomento Winidi in regno Samone neguciantes Francorum cum pluere multetudine interfecissent et rebus expoliassint, haec fuit inicium scandali inter Dagobertum et Samonem regem Sclavinorum" [OF]

- "Multis post haec vecebus Winidi in Toringia et relequos vastandum pagus in Francorum regnum inruunt" [Re.F]

- "que ex genere Sclavionorum erant et ad regnum Francorum iam olem aspecserant" [Re.F]

- "Estaque nicturia, qua Winidi contra Francos meruerunt, non tantum Sclavinorum fortitudo optenuit, quantum dementacio Austrasiorum, dum se cernebant cum Dagoberto odium incurrisse et adsiduae expoliarintur" [GF]

- cap.71. "Audebo legatarius dirictus a Chlodoveo regi causam legationes usque ad Chrotharium regem Langobardorum, Papia coinomento Ticino civitatem Aetaliae pervenisset, cernes regina, quam sepius in legationem veniens viderat, et ab ipsa benigne semper susceptus fuerat, fuisse retrusam, quasi iniunctum habens, exinde inter citera Chrothario regi sugessit, quod illam parentem Francorum, quam reginam habuerat, per quem etiam regnum adsumserat, non dibuissit umiliare; multum exinde regis Francorum et Franci essint ingrati. Quam Chrotharius de presenti, reverenciam Francorum habens, iubit egredi foris; et post quinque circeter annis per totam civitatem et foris Gundoberga regili ordine per loca sanctorum ad oracionem adgreditur. [OF/RF/GF/GF]

- cap.72. "Burgaris superatis, nove milia verorum cum uxoris et liberis de Pannonias expulsi, ad Dagoberto expetint, petentes, ut eos in terra Francorum manendum receperit" [Rg.F]

- Dagobertus iobit eos iaemandum Badowarius recipere, dummodo pertractabat cum Francis, quid exinde fierit. [GF]

- "Cumque dispersi per domus Baioariorum ad hyemandum fuissent, consilium

Francorum Dagobertus Baioariis iobet, ut Bulgarus illus cum uxoris et liberis unusquisque in domum suam una nocte Baiuariae interficerint. [GF]

- cap.73. "Cumque in Espania devolgatum fuissit, exercitum Francorum ausiliandum Sisenando adgredere, omnis Gotorum exercitus se dicione Sisenando subaegit" [Exerc. F.]

- cap. 74 - "Winidis resistendum spondent et Francorum limete de illis partebus custodire promittent." [Rg.F.]

- cap. 75. - "regnum Francorum vastandum Toringia et relequos pagus ingrederint" [Re.F]

- "Deinceps Austrasiae eorum studio limetem et regnum Francorum contra Winedus utiliter definsasse nuscuntur" [Re.F]

- cap.78 - "Anno quarto decimo regni Dagoberti, cum Wascones forteter revellarent et multas predas in regno Francorum" [Re.F] 
- Quod cum decem docis cum exercetebus, id est Arinbertus, Amalgarius, Leudebertus, Wandalmarus, Waldericus, Ermeno, Barontus, Chairaardus ex genere Francorum, Chramnelenus ex genere Romano, Willibadus patricius genere Burgundionum, Aigyna genere Saxsonum, exceptis comitebus pluerimis, qui docem super se non habebant, in Wasconia cum exercito perrixsissent. [OF]

- "Exercitus vero Francorum, qui de Burgundia in Wasconia accesserat. [Exerc.F]

- "leudebus Francorum. [NF]

- Francorum regibus. [RF]

- "regnumque Francorum esse fedilis" [Re.F]

- cap.89 - "Ibique cumtus Nantildis sigallatem adtragens, Flaogatum genere Franco maiorem domus in regnum Burgundiae aelectionem pontevecum." [OF]

- cap.90 - "Eo certamine citiris primus Bertharius comis palatiis, Francus de pago Ultraiorano, contra Willebado confligit' [OF]

\section{Entradas livro IV: 52}

Tabela 6: Os Francos no IV livro de Fredegário

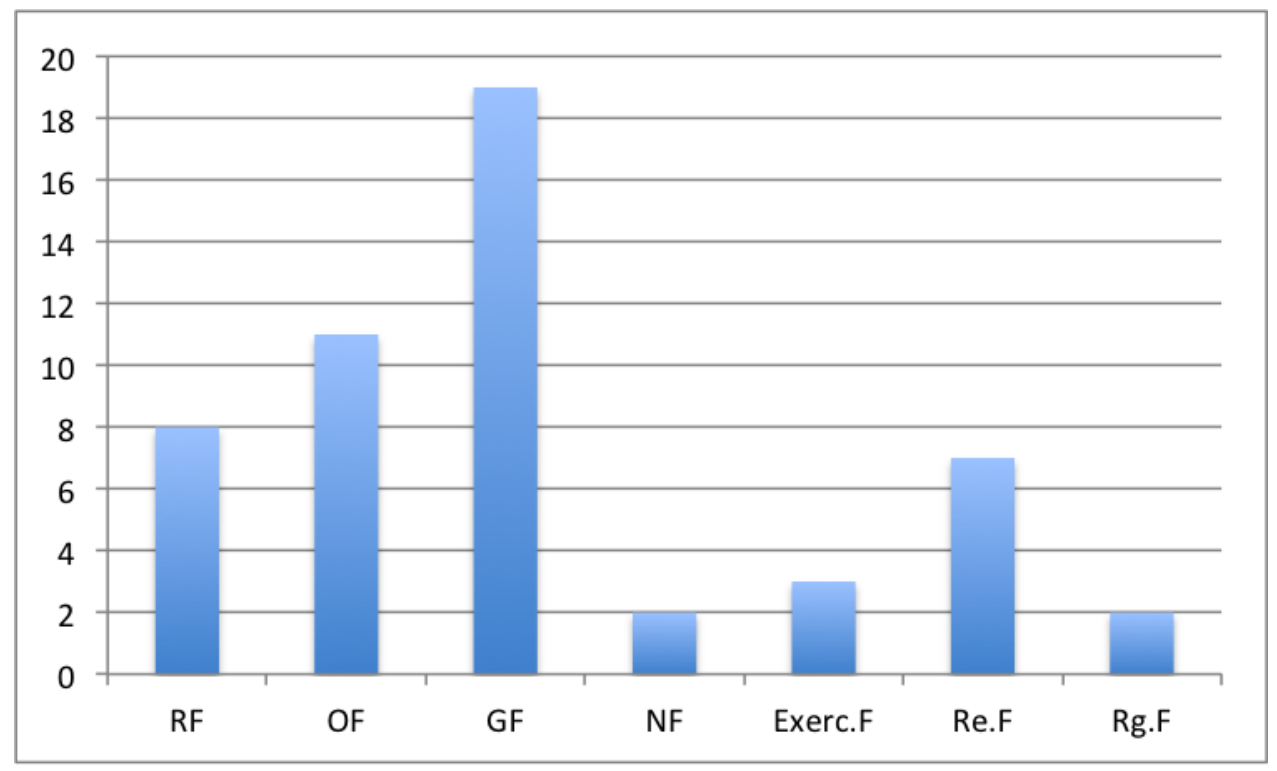

Gráfico 6 Aplicação do termo "francus" no livro quarto de Fredegário

Essas tabelas e gráficos nos trazem alguns dados interessantes. Primeiro notamos que o termo "francus" aparece cento e quarenta e sete vezes em toda a crônica. A maior recorrência do termo está no livro III com sessenta e seis entradas; depois vem o livro IV com cinquenta e duas entradas seguido pelo livro II com vinte e duas entradas e o livro I com sete entradas. Não obstante, observamos que o termo "francus" surge como qualificativo de diversas coisas: o reino dos francos, a gens francorum, pessoas de origem franca, nobres de origem franca, região dos francos, 
etc. Entretanto, é difícil estabelecer com precisão quando "francus" significa gens francorum uma vez que nem sempre o termo vem relacionado com o substantivo "gens", assim inserimos na entrada gens francorum $[\mathbf{G F}]$ todas as recorrências do termo que não vinham como qualificativos para reino, origem, região, etc. A partir disso observamos que francus no sentido de gens francorum é a forma mais recorrente do aparecimento do termo, seguido da aplicação do termo para qualificar os reis, como é possível confirmar com o gráfico 5:

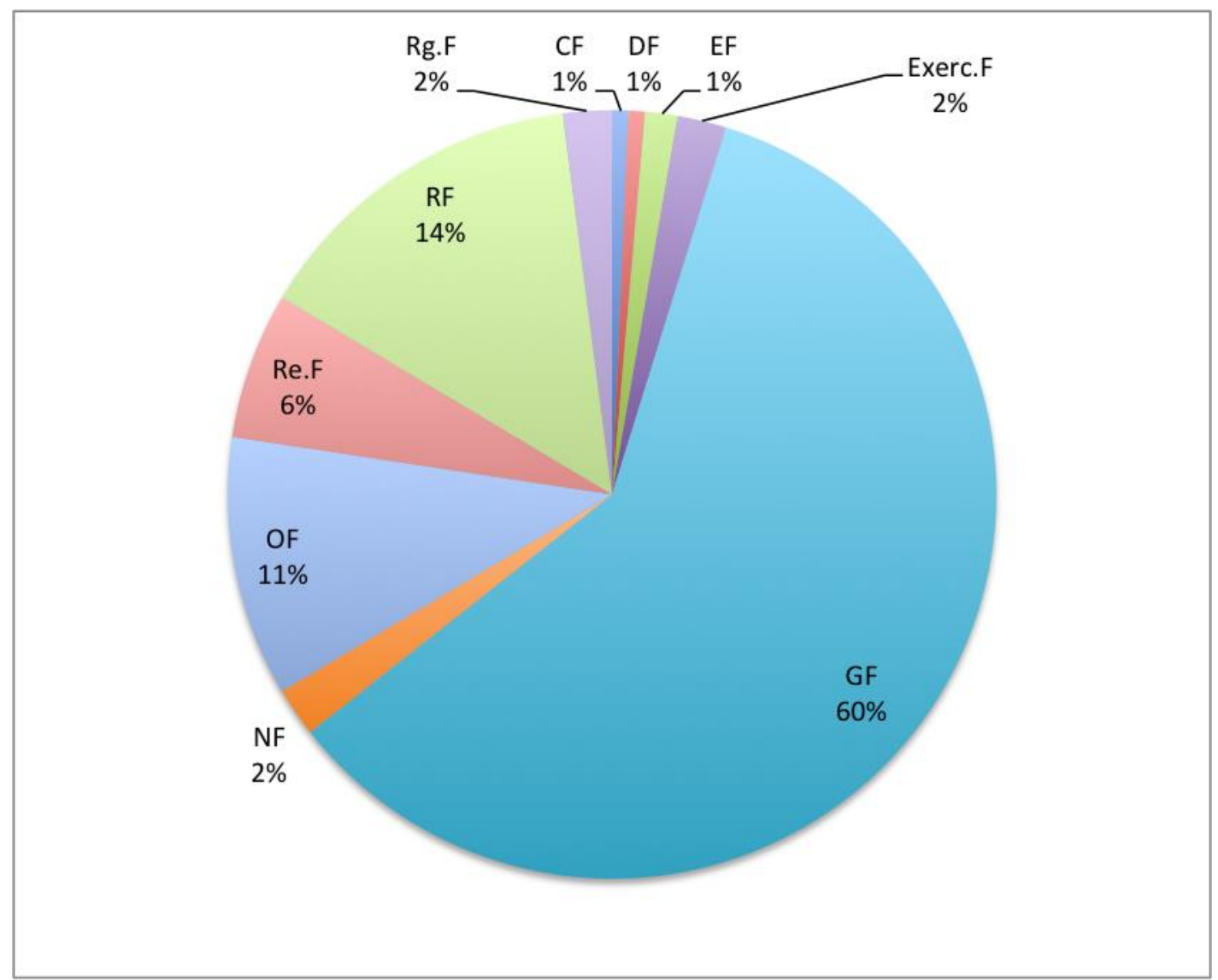

Gráfico 7 especificações do termo "francus" na crônica de Fredegário

A prevalência da aplicação do termo com o sentido de "gens francorum" nos leva a dedicar mais atenção a esse sentido. Inicialmente é pertinente nos concentrarmos na distribuição desse sentido em toda a crônica, como se pode observar pelo gráfico 6 é no livro III, qualificado como uma versão dos Decem Libri Historiarum, que esse sentido aparece mais vezes: 


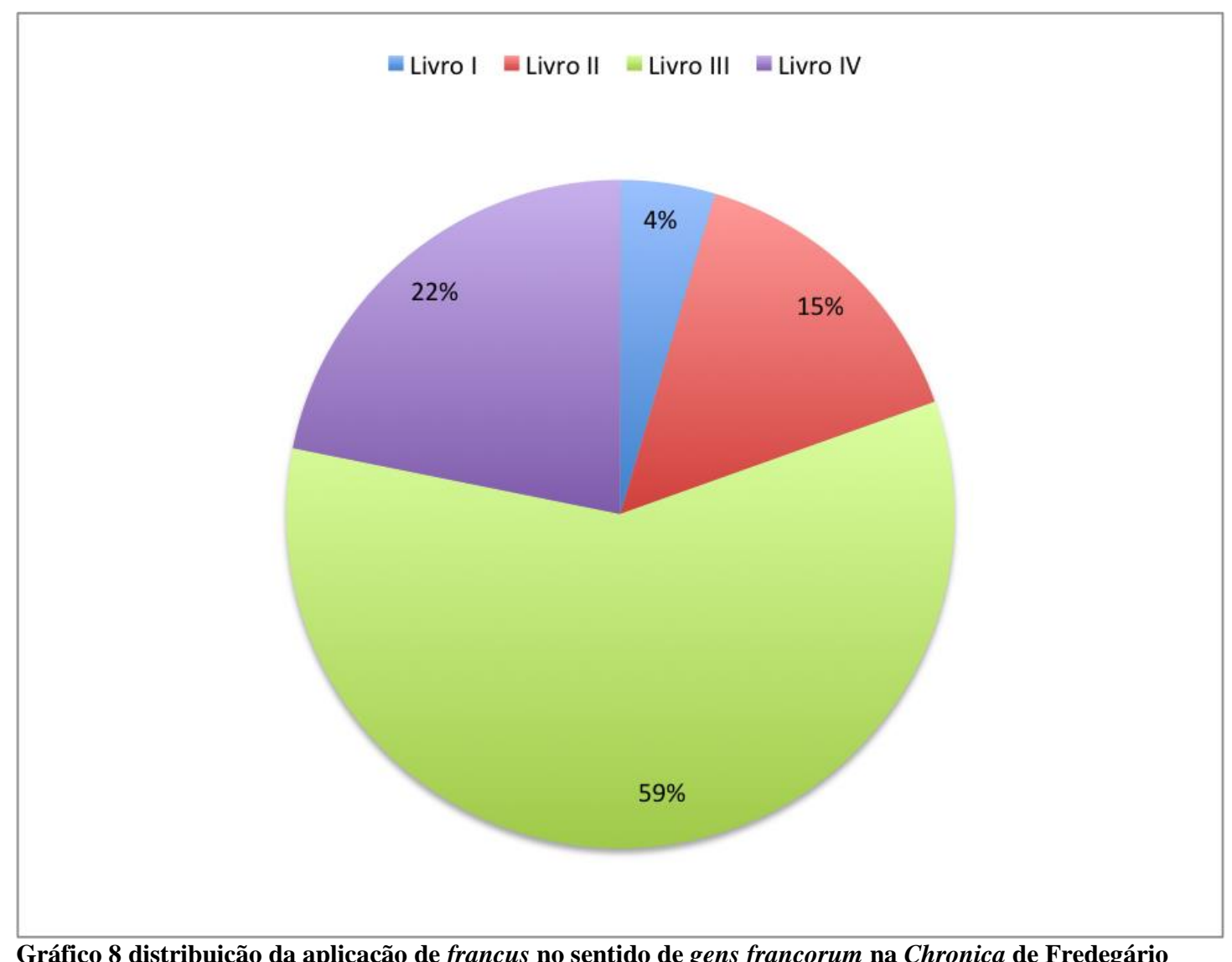

Gráfico 8 distribuição da aplicação de francus no sentido de gens francorum na Chronica de Fredegário

Levando em consideração, como já afirmamos, que o texto de Gregório de Tours tem em todos os dez livros menos menções aos franci que apenas o livro III da Chronica de Fredegário parece cada vez mais equivocado dizer que esse trecho da obra é um mero resumo dos Decem Libri Historiarum. Não só não é como amplifica o papel da gens francorum na narrativa dando a ela mais peso. Outro ponto interessante que podemos observar é que o livro IV, considerado como a Chronica original, tem uma quantidade drásticamente menor de menções aos franci no sentido de gens. $\mathrm{O}$ que surge, entretanto - e que já era assinalado pelo livro III - é a recorrência cada vez mais significativa de termos "regionais": burgúndios, neustrinos e austrasianos. Como indicamos no capítulo dedicado à realeza, essa identidades eram evocadas como bases de reinvidicações políticas. A construção de uma memória referente a gens francorum realizada pelo cronista a partir da apropriação de tradições narrativas aparentemente dava uma resposta a essas novas identidades políticas emergentes. 
Estamos diante de um cenário de crescente polarização que demandava respostas efetivas por parte dos reis. Essas respostas se davam no plano legislativo do reino e na ação dos agentes que atuavam na corte real, como nos indica o Edito de Paris de Clotário II. ${ }^{525}$ Mas também no plano narrativo da construção da memória inserida na prática da escrita da história. E mesmo que Fredegário tenha indicado a fraqueza crescente dos reis francos ao mostrar em seu livro IV o crescimento da força dos nobres e especialmente dos maiores domorum o tom de valorização da gens francorum dos três primeiros livros da Chronica apontam para um esforço pela valorização da gens francorum, representada por seus reis, ${ }^{526}$ em contraste com as forças políticas que se organizavam em torno de outras identidades políticas: como os burgúndios, os neustrinos e os austrasianos.

Desta maneira, a apropriação por parte do autor da Chronica de Fredegário das narrativas acerca da gens francorum se orienta pela valorização da unidade da gens representada pelos seus reis em detrimento às identidades que eram apropriadas pelas nobrezas. Mesmo que os nobres efetivamente estivessem contemplados na narrativa como decisivos na condução da política do reino e não necessariamente num sentido negativo, como quando o autor valoriza a memória de Pepino e enfatiza o

\footnotetext{
${ }^{525}$ Uma importante análise desse documento à luz da política dos reis merovíngios pode ser consultada em: MURRAY, A.C. Immunity, Nobility, and the Edict of Paris. Speculum, v.69, n.1, p.18-39, Jan. de 1994. Vale ainda consultar a breve, mas interessante análise de E. James que tal como Murray, em detrimento à interpretação de H. Mitteis, enfatiza o papel do Edito de Paris mais como um esforço conduzido por Clotário II para afirmar sua autoridade em relação às nobrezas do que como uma concessão à essas nobrezas pelo apoio que ele obteve para se tornar o único rei dos francos depois da guerra entre Teodoberto e Teodorico e a queda de Brunilda: JAMES, E. The Origins of France. From Clovis to the Capetians, 500-1000. Londres e Basingstoke: The Macmillan Press, 1982. p.140-143.

${ }^{526}$ Uma interpretação diversa pode ser encontrada no trabalho de A.C. Murray que ao analisar o mito das origens da dinastia merovíngia - descrita na crônica de Fredegário - sugere que o nascimento de Meroveu poderia ter uma conotação negativa, poderia assim ter servido para maldizer os reis merovíngios. O autor deixa em aberta a hipótese, mas os argumentos dele são interessantes e devem ser considerados. Cf: MURRAY, A.C. Post vocantur Merohingii. Fredegar, Merovech, and 'Sacral Kingship'. In: MURRAY, A.C. (ed.). After Rome's Fall: Narrators and Sources of Early Medieval History. Toronto: Toronto University Press, 1998. p.121-152. Ainda: WOOD, I. Defining the Franks. Frankish origins in early medieval historiography. In: NOBLE, T.F.X. From Roman provinces to Medieval Kingdoms. London \& New York: Routledge, 2006. p.110-119.
} 
pesar que sua morte despertou na Austrásia, ${ }^{527}$ o autor da Chronica ainda via os reis como o centro político do reino.

Isso se evidencia se confrontarmos a narrativa do autor acerca da origem dos duces e depois observarmos como o autor narra a retomada do poder pelos reis. Os duces, conforme nos descreve a Chronica, surgiram de uma contigência. Com a morte de Francione e a grande quantidade de batalhas que os francos deveriam enfrentar os duces foram eleitos para liderar os francos: "Ibique mortuo Francione, cum iam per proelia tanta que gesserat parva ex ipsis manus remanserat, duces ex se constituerunt. ${ }^{\text {} 528}$. Depois da derrota dos duces Marcomer e Sunno, descrita no livro III, os francos voltaram a ser liderados por reis, como outrora foram: "Dehinc, extinctis ducibus, in Franci dinuo regis creantur ex eadem stirpe, qua prius fuerant. ${ }^{, 529}$ Interessante perceber que a escolha de um rei vem em contraste com a derrota dos duces. Mesmo que eles pudessem ser úteis na condução das batalhas, tal como outrora foram, a gens francorum deveria ser liderada pelos reis. O autor reconhece o papel dos duces, mas é nos reis - representantes da vitoriosa gens - que o controle deveria estar. E o novo rei eleito advinha de uma nobre linhagem, aquela que conduziu a gens a grandes vitórias: "Franci electum a se regi, sicut prius fuerat, crinitum, inquirentes diligenter ex genere Priami, Frigi et Francionis super se creant nomen Theudemarem...,.530

\footnotetext{
${ }^{527}$ Post, fertur, anni circolo Pippinus moretur, nec parva dolore eiusdem transitus cumtis generavit in Auster, eo quod ab ipsis pro iusticiae cultum et bonetatem eiusdem delictus fuissit. Grimoaldus, filius eius, cum essit strinuos, ad instar patris diligeretur. Chronica de Fredegário, 1.IV, 85.

${ }^{528}$ Chronica de Fredegário, 1.II, 6.

${ }^{529}$ Chronica de Fredegário, 1.III, 5.

${ }^{530}$ Chronica de Fredegário, 1.III, 9.
} 
Uma apropriação semelhante aparece no Liber Historiae Francorum, texto finalizado aproximadamente em $725^{531}$ que consiste no último relato histórico escrito enquanto os merovíngios ainda era a dinastia reinante da Gália. ${ }^{532}$

\section{O liber Historiae Francorum}

\section{Manuscritos}

Ao contrário da Chronica de Fredegário o Liber Historiae Francorum tem uma tradição manuscrita muito mais significativa, tendo sido reproduzido praticamente ao longo de todo o período dito medieval. Podemos constatar isso contemplando a distribuição dos manuscritos ao longo dos séculos.

\footnotetext{
${ }^{531}$ GERBERDING, R.A. The rise of the Carolingians and the Liber Historiae Francorum. Oxford: Clarendon Press, 1987. p.1.

${ }^{532}$ FOURACRE, P. \& GERBERDING, R.A. Late Merovingian France. History and Hagiography. 640-720. Manchester \& NY: Manchester University Press, 1996. p.79-80.
} 
Tabela 7: Manuscritos do Liber Historiae Francorum

\begin{tabular}{|c|c|c|c|c|c|c|c|c|c|c|c|c|c|}
\hline Séc.VIII & Séc. VIII/IX & Séc. IX & Séc. X & Séc. XI & $\begin{array}{c}\text { Séc. } \\
\text { XI/XII }\end{array}$ & Séc. XII & $\begin{array}{c}\text { Séc. } \\
\text { XII/XIII }\end{array}$ & Séc. XIII & Séc. XIV & Séc. XV & $\begin{array}{l}\text { Séc. } \\
\text { XVI }\end{array}$ & $\begin{array}{l}\text { Séc. } \\
\text { XVII }\end{array}$ & Séc. XVIII \\
\hline $\begin{array}{c}\text { A 1a. } \\
\text { Codex } \\
\text { Bernensis } \\
n r .599 \\
\text { outrora } \\
\text { ecclesiae } \\
\text { cathedralis } \\
\text { Argentorat } \\
\text { ensis }\end{array}$ & $\begin{array}{c}\text { A3b Codex } \\
\text { Vaticanus } \\
\text { bibliothecae } \\
\text { Christinae } \\
\text { reginae } \\
\text { nr.713 }\end{array}$ & $\begin{array}{c}\text { A } 1 b . \\
\text { Codex } \\
\text { Parisiensis } \\
\text { nr. } 5596 \\
\text { (Colbertin } \\
\text { us nr. } \\
5432)\end{array}$ & $\begin{array}{c}\text { B2c1 Codex } \\
\text { bibliothecae } \\
\text { regiae } \\
\text { Hagae } \\
\text { comitum } \\
\text { nr.921 }\end{array}$ & $\begin{array}{c}\text { B2b2 } \\
\text { Codex } \\
\text { Florenti } \\
\text { nus } \\
\text { biblioth } \\
\text { ecae } \\
\text { Laurent } \\
\text { ianae } \\
\text { LXV, } \\
35\end{array}$ & $\begin{array}{c}\text { B 2c4 } \\
\text { Codex } \\
\text { Parisiensis } \\
\text { nr.5923 }\end{array}$ & $\begin{array}{l}\text { A 1c. } \\
\text { Codex } \\
\text { Vindobone } \\
\text { nsis hist. } \\
\text { prof. nr. } \\
991\end{array}$ & $\begin{array}{c}\text { A3a3 } \\
\text { Codex } \\
\text { Sancti } \\
\text { Galli } \\
\text { nr.547 }\end{array}$ & $\begin{array}{c}\text { A } 3 * \mathrm{~B} 2 \\
\text { Codex } \\
\text { Vindobonens } \\
\text { is nr.428 } \\
\text { (Antes nr.57. } \\
\text { et hist. prof. } \\
\text { nr.230) }\end{array}$ & $\begin{array}{c}\text { A3a4 } \\
\text { Codex } \\
\text { Parisiensis } \\
\text { nr.4998 } \\
\text { outrora } \\
\text { Colberti } \\
\text { nr.433 }\end{array}$ & $\begin{array}{c}\text { A3a5 } \\
\text { Codex } \\
\text { Parisiensis } \\
\text { nr.9767 }\end{array}$ & $\begin{array}{c}\text { B 2c3* } \\
\text { Codex } \\
\text { Matriten } \\
\text { sis } \\
\text { bibliothe } \\
\text { cae } \\
\text { regiae } 2 \\
\text { g4 }\end{array}$ & $\begin{array}{c}\text { B 2c3 } \\
\text { Codex } \\
\text { Matrite } \\
\text { nsis } \\
\text { biblioth } \\
\text { ecae } \\
\text { quae } \\
\text { nationa } \\
\text { lis } \\
\text { dicitur } \\
\text { F.58 }\end{array}$ & $\begin{array}{c}\text { A 3a2* } \\
\text { Codex } \\
\text { Giessensis } \\
\text { bibliotheca } \\
e \\
\text { universitati } \\
s \text { nr. 254a }\end{array}$ \\
\hline $\begin{array}{c}\text { B 2a1 } \\
\text { Codex } \\
\text { Vaticanus } \\
\text { bibliotheca } \\
e \\
\text { Ottobonia } \\
\text { nae } \text { nr.663 }\end{array}$ & & $\begin{array}{c}\text { Codex } S . \\
\text { Mariae } \\
\text { Camarace } \\
\text { nsis } n r . \\
711\end{array}$ & & $\begin{array}{c}\text { B 2d1 } \\
\text { Codex } \\
\text { Bamber } \\
\text { gensis } \\
\text { E III, } \\
14\end{array}$ & $\begin{array}{c}\text { 2d3 Codex } \\
\text { Vaticanus } \\
\text { nr.1985 }\end{array}$ & $\begin{array}{c}\text { A 3B1 } \\
\text { Codex } \\
\text { Vaticanus } \\
\text { bibliotheca } \\
e \\
\text { Christinae } \\
\text { Reginae } \\
\text { nr.549 }\end{array}$ & & $\begin{array}{c}\text { B 2c5a* } \\
\text { Codex } \\
\text { Parisiensis } \\
\text { nr.11793 }\end{array}$ & $\begin{array}{c}\text { B 2d } \\
\text { Codex } \\
\text { Oxoniensis } \\
\text { ms. } \\
\text { Magdal. } \\
\text { Lat. } 14 \\
\text { (antea } \\
\text { nr.2155) }\end{array}$ & $\begin{array}{c}\text { A3B3 } \\
\text { Codex } \\
\text { Vindobone } \\
\text { nsis } \\
\text { bibliotheca } \\
e \\
\text { universitati } \\
s \text { nr.3334 } \\
\text { (antes } 838 \\
\text { Repert. } \\
\text { Schwandne } \\
\text { ri I, 611) }\end{array}$ & & & $\begin{array}{c}\text { Codex } \\
\text { Mutinensis }\end{array}$ \\
\hline $\begin{array}{c}\text { B2a2 } \\
\text { Codex } \\
\text { Vaticanus } \\
\text { bibliotheca } \\
e \\
\text { Palatinae } \\
\text { nr.966, } \\
\text { outrora }\end{array}$ & & $\begin{array}{c}\text { A3a1 } \\
\text { Codex } \\
\text { Petropolita } \\
\text { nus F. Otd. } \\
\text { IV. } 4\end{array}$ & & & & $\begin{array}{c}\text { Codex } \\
\text { Carlsruha } \\
\text { nus } \\
\text { bibliotheca } \\
\text { e aulicae } \\
\text { A 5 }\end{array}$ & & $\begin{array}{c}\text { B 2c5b } \\
\text { Codex } \\
\text { Parisiensis } \\
\text { nr.5512 }\end{array}$ & & $\begin{array}{c}\text { A } 3 * \mathrm{~B} 1 * \\
\text { Codex } \\
\text { Graiacensi } \\
s \\
\text { bibliotheca } \\
e \\
\text { universitati } \\
s \text { oct. } 33 / 52\end{array}$ & & & \\
\hline
\end{tabular}




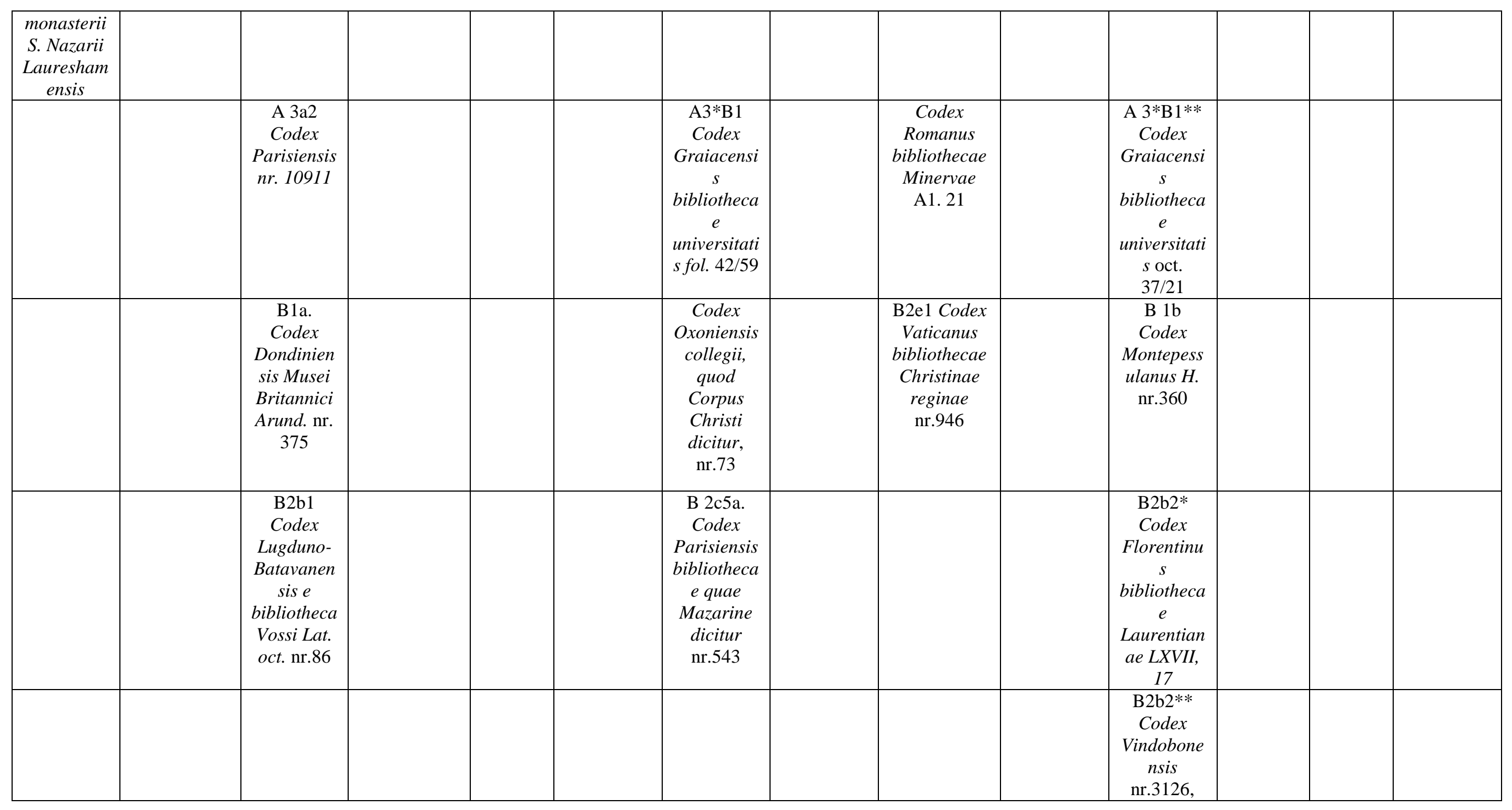




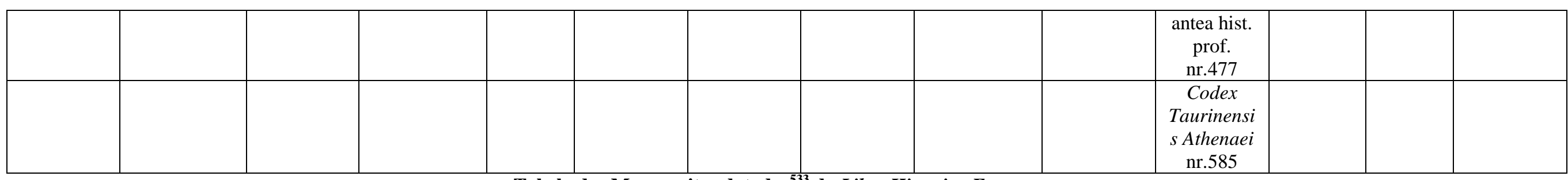

Tabela dos Manuscritos datados ${ }^{533}$ do Liber Historiae Francorum

${ }^{533}$ Dentre os manuscritos não datados pelo editor monumentista estão: A $1 *$ b Codex Remensis S. Remedii; A 1c* Codes Vindobonensis hist. prof. nr.91; A 2* Codex Parisiensis; B2c2 Codex Guelferbytanus e bibliothecae Gudii, olim Lutetiam asportatus nr.131; B 2c5c Codex Thuanus a Chesnio; Codex Pistoriensis bibliothecae quae 'Sapienza' dicitur; Codex Petavianus a Chesnio; B2e2 Codex Cantabrigiensis collegii quod Caius dicitur nr.117. Há ainda o manuscrito Codex Vindobonensis nr. 473 do século IX que traz apenas uma parte do texto. 
Temporalmente os manuscritos se distribuem da seguinte maneira:

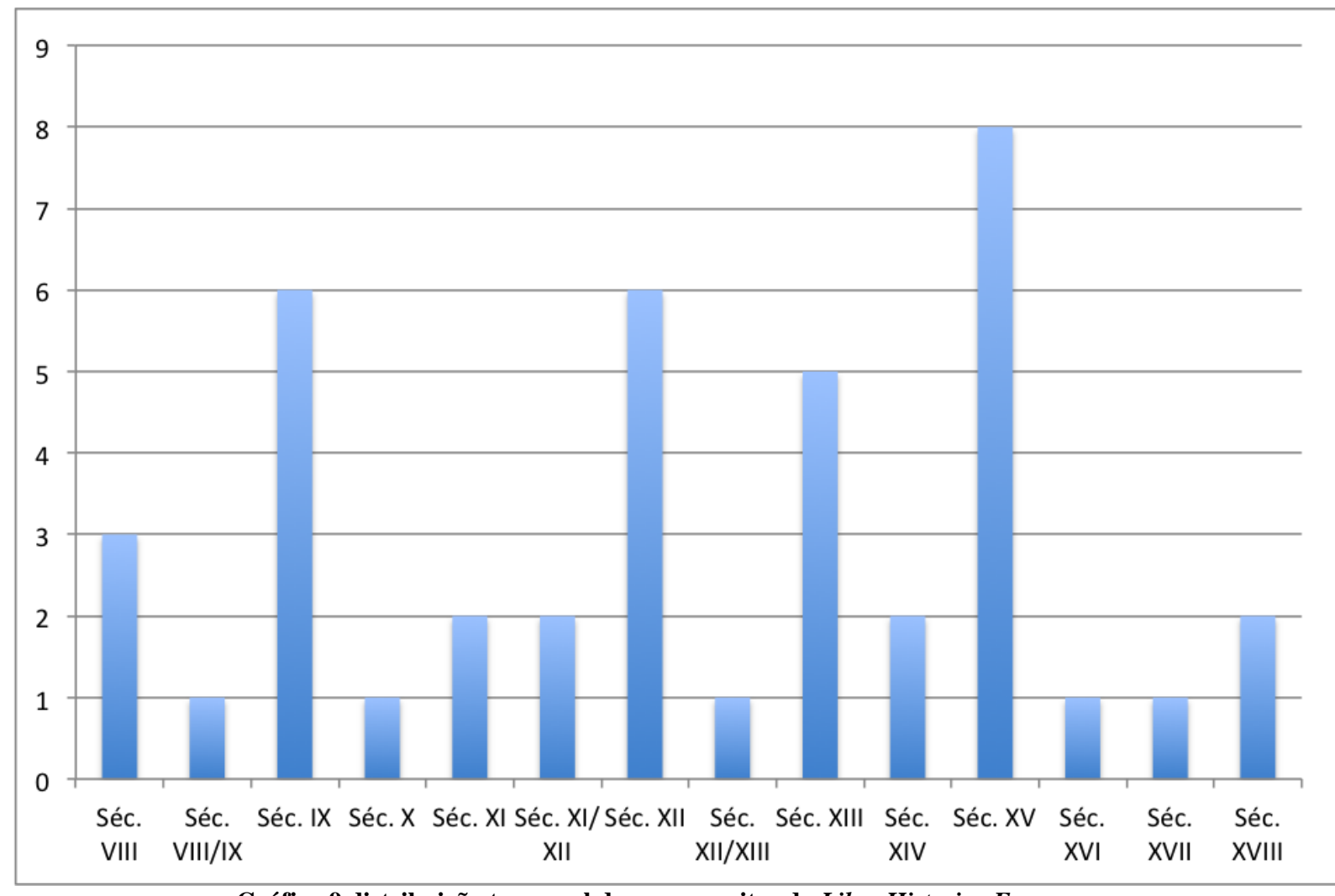

Gráfico 9 distribuição temporal dos manuscritos do Liber Historiae Francorum 
A maior quantidade de manuscritos, como é possível observar pelo gráfico, se concentra nos séculos IX, XII e XV. Há três manuscritos do século VIII o que é bastante entusiasmante uma vez que não é comum que existam testemunhos manuscritos datados de períodos próximos a estimativa de produção das fontes. De todo modo o gráfico indica que durante praticamente todo o período medieval foram produzidos manuscritos que continham o Liber Historiae Francorum, o que pode ser considerado um elemento importante para dizer que o texto circulou bastante, inclusive no período carolíngio que nos legou pelo menos seis manuscritos.

A importância dessa distribuição reside no fato de que uma vez que o texto chegou aos nossos dias em manuscritos datados do século VIII podemos tê-lo como um ponto de referência para confrontarmos fontes que circularam em manuscritos produzidos muito posteriormente em relação a data de produção estimada. $\mathrm{O}$ que queremos dizer é que textos que chegaram aos nossos dias também em manuscritos datados do período estimado da produção do texto podem servir para confrontarmos informações de textos com uma tradição manuscrita mais tardia. Dessa maneira podemos tomar textos com uma tradição manuscrita semelhante a do Liber Historiae Francorum como uma base de informações que pode servir para a construção de um critério de verossimilhança no confronto de outras narrativas. 


\section{O Liber Historiae Francorum - a força de elites locais e o predomínio das identidades regionais}

Como já apontamos, a força das nobrezas em confronto ou apoio à autoridade dos reis fica ainda mais evidente no Liber Historiae Francorum no qual o poder dos maiores domorum se mostra mais acentuado em relação a reis cada vez mais dependentes dos arranjos políticos. Nesse sentido, é interessante analisar como a gens francorum aparece num texto escrito em tal contexto de polarização.

Como muito bem apontou I. Wood, o autor do Liber Historiae Francorum, a partir dos relatos que versam sobre os eventos que ocorreram após a metade do século VI, passou a se referir aos franci como primordialmente representantes da nobreza da Nêustria, ${ }^{534}$ até esse marco o autor não fazia a distinção uma vez que o emprego do termo franci parecia ser uma generalização para dar a idéia de uma gens francorum. E a gens francorum do autor do Liber Historiae Francorum também era relacionada com uma origem troiana:

1. Principium regum Francorum eorumque origine vel gentium illarum ac gesta proferamus. Est autem in Asia opidum Troianorum, ubi est civitates quae Illium dicitur, ubi regnavit Aeneas. Gens illa fortis et valida, viri bellatores atque rebelles nimis, inquieta certamina obiurgantes, per gyrum finitima debellantes. Surrexerunt autem reges Grecorum adversus Aeneam cum multo exercitu pugnaveruntque contra eum cede magna, corruitque illic multum populus Troianorum. Fugiit itaque Aeneas et reclusit se in civitate Illium, pugnaveruntque adversus hanc civitatem annis decim. Ipsa enim civitate subacta, fugiit Aeneas tyrannus in Italia locare gentes ad pugnandum. Alii quoque ex principibus. Priamus videlicet et Antenos, cum reliquo exercitu Troianorum duodecim milia intrantes in navibus, abscesserunt et venerunt usque ripas Tanais fluminis. Ingressi Meotidas paludes navigantes, pervenerunt intra terminos Panoniarum iuxta Meotidas paludes et coeperunt aedificare civitatem ob memoriale eorum appellaveruntque eam Sicambriam; habitaveruntque illic annis multis creveruntque in gentem magnam.

\footnotetext{
${ }^{534}$ WOOD, I. Defining the Franks...op.cit. p.111. Um exemplo dessa mudança de uso pode ser observado no trecho que fala da elevação de Clotário II como único rei dos três reinos: His regibus mortuis, Burgundiones et Austrasii, cum reliquis Francis pace facta, Chlotharium regem in totós tribos regnis in monarchiam elevaverunt. Liber Historiae Francorum, 40.
} 
A valorização da gens mediante a referência a uma origem antiga e prestigiosa e as consequentes vitórias em batalhas é uma tópica que se repete no Liber Historiae Francorum, ${ }^{535}$ entretanto, uma sensível diferença é observada. No texto do século VIII a origem da dinastia merovíngia é ainda mais celebrada especialmente na construção narrativa em torno da ascensão de Clóvis. O nascimento de Clóvis é já adiantando na narrativa de seus antecessores e no valor deles: "Ipse itaque Merovechus genuit filium nomine Childerico, qui fuit pater Chlodovecho rege inclyto atque fortissimo. ",536

Da união entre Childerico e Basina nasceu Clóvis, descrito como o autor do Liber Historiae Francorum como o grande rei dos francos, aquele que garantiria o poder da dinastia e seus liderados, os franci, na Gália: "Illa vero concipiens ex eo, peperit filium vocavitque nomen eius Chlodovechum. Hic fuit rex magnus super omnes reges Francorum et pugnator fortissimus. ${ }^{, 537}$ Na narrativa sobre a ascensão de Clóvis vemos a construção de uma memória que valoriza uma gens e o rei que a consolidou como uma força política na Gália. A relação entre a gens e o rei é sobressaltada no texto do século VIII, Clóvis não é apenas o rex francorum, o texto o retrata como um líder da gens francorum, ${ }^{538}$ o responsável pela glória e as vitórias da gens.

A valorização da figura de Clóvis, o seu protagonismo como o guia da também valorizada gens lança luz ao papel de seus descendentes, os continuadores de sua dinastia, que reinavam no final do século VII e primeiras décadas do VIII. E isso não se deu por acaso. Mesmo que ainda a nobreza apoiasse os descendentes de Clóvis

\footnotetext{
${ }^{535}$ A questão das origens dos francos narrada no Liber Historiae Francorum e a valorização da gens francorum foi muito bem apontada por P. Dörler: DÖRLER, P. The Liber Historiae Francorum - a Model for a New Frankish self-confidence. Networks and Neighbours, v.1, n.1, p.23-43, 2013.

${ }_{536}^{53}$ Liber Historiae Francorum, 6.

${ }^{537}$ Liber Historiae Francorum, 7.

${ }^{538}$ Liber Historiae Francorum, 13.
} 
no poder, o questionamento à autoridade deles era algo que ocorria. Não podemos saber com que frequiência, mas ao menos um relato sobre a tentativa de usurpação chegou aos nossos dias e seu autor foi justamente o autor do Liber Historiae Francorum.

No texto o narrador fala de Grimoaldo, maior domus da corte de Sigiberto da Austrásia. Com a morte de Sigiberto, entre 650 e $651^{539}$ Grimoaldo tonsurou seu filho e herdeiro, Dagoberto, e colocou no lugar do príncipe o seu próprio filho. Foram os nobres de Nêustria que enfrentaram Grimoaldo e o derrotaram:

Franci itaque hoc valde indignantes, Grimoaldo insidias preparant, eumque exementes, ad condempnandum rege Francorum Chlodoveo deferunt. In Parisius civitate in carcere mancipatis, vinculorum cruciatu constrictus, ut erat morte dignus, quod in domino suo exerceuit, ipsius mors valido cruciatu finivit. ${ }^{540}$

Ora, o que esse trecho indica é que Grimoaldo conseguiu poder suficiente na Austrásia a ponto de ter sido capaz de depor - pela primeira vez na história da dinastia merovíngia conforme sabemos pelas fontes - um príncipe merovíngio. Em seu lugar colocou seu próprio filho e foi tão-somente pela intercessão dos nobres da Nêustria, identificados como Franci, que a conspiração de Grimoaldo foi derrotada. A derrota de Grimoaldo e sua morte depois de terríveis torturas foi justificada pelo autor do Liber Historiae Francorum: Grimoaldo mereceu o destino que teve por ter traído seu senhor. Além do poder de Grimoaldo o autor acaba nos trazendo outra informação importante. Foram os nobres de Nêustria que o derrotaram e foram eles que o levaram para a corte de Clóvis II que o condenou à morte. O rei da Nêustria tem um papel coadjuvante no desenrolar dos eventos, talvez por não ter tido força suficiente para derrotar o poderoso maior domus da Austrásia. De todo modo o trecho é precioso e nos ajuda a compreender o lugar da gens francorum e de seus reis no texto.

\footnotetext{
539 Seguimos a cronologia proposta por Gerberding: GERBERDING, R.A. The rise of the Carolingians and the Liber Historiae Francorum ...op.cit. p.48.

${ }^{540}$ Liber Historiae Francorum, 43.
} 
Ao valorizar a gens francorum lideradas pelos reis merovíngios o autor do Liber Historiae Francorum realizou um movimento importante. Apropriou-se de uma tradição narrativa inaugurada por Gregório de Tours que colocou os franci na história, modificada pelo autor da Chronica de Fredegário que destacou o papel da gens francorum e seus reis na história. Ao realizar essa apropriação o autor do Liber Historiae Francorum reforçou a valorização da gens francorum e, mais importante, da importância de seus reis na liderança da gens, algo evidenciado pela celebração da memória de Clóvis.

Esse movimento, no nosso entendimento, tinha uma finalidade: enfatizar a importância da manutenção do controle dos reinos nas mãos do reis merovíngios diante de forças nobres que cada vez mais se fortaleciam. O ápice desse contexto aparece no texto quando o autor narra a revolta de Grimoaldo. Mesmo que não ocorra uma condenação da atuação da nobreza na organização do reino, o autor parecia estar muito ciente que esses nobres conquistavam cada vez mais força, mas a despeito disso, deveriam manter o apoio aos descendentes de Clóvis. A narrativa que reconstroi a memória dos franci no Liber Historiae Francorum deve assim ser compreendida a partir de um objetivo muito pragmático: enfatizar a liderança que deveria permanecer nas mãos dos descendentes de Clóvis num contexto em que os nobres se fortaleciam a ponto de ameaçar a continuidade da dinastia merovíngia. Trata-se da afirmação de uma identidade - a identidade da gens francorum reforçada no início do texto - que deveria ser o norte da política do reino diante de outras identidades que surgiam em torno de grupos nobiliárquicos da Austrásia, Nêustria e Burgúndia.

O crescimento desses grupos políticos fica bastante evidente na narrativa do autor do Liber Historiae Francorum se confrontarmos a recorrência de termos 
fonte. 
Tabela 8: Termos identitários no Liber Historiae Francorum

\begin{tabular}{|c|c|c|c|c|c|c|c|c|c|}
\hline $\begin{array}{ll}\text { Reino } & \text { dos } \\
\text { francos } & \end{array}$ & $\begin{array}{l}\text { Gens } \\
\text { Francorum }\end{array}$ & $\begin{array}{l}\text { Populus } \\
\text { Francorum }\end{array}$ & $\begin{array}{ll}\text { Reis } & \text { dos } \\
\text { Francos } & \end{array}$ & Exército Franco & $\begin{array}{l}\text { Indivíduo } \\
\text { franco }\end{array}$ & Francisca & $\begin{array}{l}\text { Gens } \\
\text { Francorum II } \\
\text { (no sentido de } \\
\text { séquito dos reis } \\
\text { e/ou nobres) }\end{array}$ & Francia & Godos \\
\hline $\begin{array}{l}\text { 1. Principium } \\
\text { regum } \\
\text { Francorum } \\
\text { eorumque } \\
\text { origine vel } \\
\text { gentium } \\
\text { illarum ac } \\
\text { gesta } \\
\text { proferamus. }\end{array}$ & $\begin{array}{l}2 . \quad \text { Tunc } \\
\text { congregati } \\
\text { Troiani, } \\
\text { fecerunt } \\
\text { insidias, sicut } \\
\text { erant edocti ac } \\
\text { cogniti, }[. . .]\end{array}$ & $\begin{array}{l}3 . \quad[\ldots] \quad u t \\
\text { darent } \\
\text { consueta } \\
\text { tributa de } \\
\text { populo } \\
\text { Francorum. }\end{array}$ & $\begin{array}{l}5 . \quad \text { Ab ipso } \\
\text { Merovecho } \\
\text { rege utile reges } \\
\text { Francorum } \\
\text { Merovingi sunt } \\
\text { appellati. }\end{array}$ & $\begin{array}{l}\text { 8. Tunc } \\
\text { Childericus rex } \\
\text { commovit } \\
\text { maximo exercitu } \\
\text { hostium } \\
\text { Francorum, } \\
\text { usque Aurilianis } \\
\text { civitate pervenit, } \\
\text { terras quoque } \\
\text { illas vastavit. }\end{array}$ & $\begin{array}{l}\text { 10. [...] }{ }^{\text {Franus }} \\
\text { levis cum } \\
\text { vociferatione, } \\
\text { elevata } \\
\text { bipenne, quo } \\
\text { est francisca, } \\
\text { percussit } \\
\text { urceo [...] }\end{array}$ & $\begin{array}{l}\text { lo. [...] }{ }^{\text {Fnus }} \\
\text { Francus } \\
\text { levis cum } \\
\text { vociferatione, } \\
\text { elevata } \\
\text { bipenne, quo } \\
\text { est francisca, } \\
\text { percussit } \\
\text { urceo illo } \\
\text { dicens: }\end{array}$ & $\begin{array}{lr}\text { 10. Haec rege } \\
\text { dicente, } & \text { illi } \\
\text { Franci, } & \text { qui } \\
\text { bono } & \text { animo } \\
\text { fuerunt, aiunt. } & \end{array}$ & $\begin{array}{l}\text { 12. [...] cum } \\
\text { magno gaudio } \\
\text { ad } \\
\text { Chlodovechum } \\
\text { regem } \\
\text { adduxerunt } \\
\text { eam } \\
\text { Suessionis } \\
\text { civitate in } \\
\text { Francia. }\end{array}$ & $\begin{array}{l}\text { 5. In illo } \\
\text { tempore in his } \\
\text { partibus citra } \\
\text { Renum usque } \\
\text { Ligere fluvio } \\
\text { habitabant } \\
\text { Romani, ultra } \\
\text { Ligere quoque } \\
\text { Gothi } \\
\text { dominabantur. }\end{array}$ \\
\hline $\begin{array}{l}\text { 7. 'Revertere } \\
\text { ad regnum } \\
\text { Francorum, } \\
\text { quia } \\
\text { pacificata sunt } \\
\text { omnia' }\end{array}$ & $\begin{array}{l}2 . \quad \text { Tunc } \\
\text { appellavit eos } \\
\text { Valentinianus } \\
\text { imperator } \\
\text { Franco Attica } \\
\text { lingua, hoc est } \\
\text { feros, a duritia } \\
\text { vel audacia } \\
\text { cordis eorum. }\end{array}$ & $\begin{array}{l}\text { 10. Grandis } \\
\text { pavor ac } \\
\text { tremor pro } \\
\text { hac causa in } \\
\text { Francorum } \\
\text { populo } \\
\text { deinceps } \\
\text { consurrexit. }\end{array}$ & $\begin{array}{l}\text { 7. Hic fuit rex } \\
\text { magnus } \\
\text { [Chlodoveus - } \\
\text { filho de } \\
\text { Childerico e } \\
\text { Basina, } \\
\text { princesa } \\
\text { turíngia] super } \\
\text { omnes reges } \\
\text { Francorum et } \\
\text { pugnator } \\
\text { fortissimus. }\end{array}$ & $\begin{array}{l}10 . \\
\text { Chlodovechusque } \\
\text { exinde decimo } \\
\text { anno regni sui, } \\
\text { commoto } \\
\text { Francorum } \\
\text { grande hoste, in } \\
\text { Toringam abiit } \\
\text { Toringosque } \\
\text { plaga magna } \\
\text { prostravit }[. . .]\end{array}$ & $\begin{array}{l}\text { 45. Ex quibus } \\
\text { uno Franco } \\
\text { nomine } \\
\text { Bodilone ad } \\
\text { stipitem } \\
\text { tensum } \\
\text { cedere valde } \\
\text { sine lege } \\
\text { precepit. }\end{array}$ & $\begin{array}{l}\text { 10. Accepit } \\
\text { autem rex } \\
\text { franciscam } \\
\text { eius, quod est } \\
\text { bipennis, et } \\
\text { proiecit in } \\
\text { terram. }\end{array}$ & $\begin{array}{l}\text { 12. [...] valde } \\
\text { iram } \\
\text { Francorum et } \\
\text { Chlodovechi[...] }\end{array}$ & $\begin{array}{l}13 . \\
\text { Reversusque } \\
\text { est Aurilianus } \\
\text { cum thesauris } \\
\text { multis ad } \\
\text { dominum } \\
\text { suum in } \\
\text { Francia. }\end{array}$ & $\begin{array}{l}\text { 5. Veniente ad } \\
\text { eum Egecio } \\
\text { patricio } \\
\text { Romanorum et } \\
\text { Tursomodo rege } \\
\text { Gothorum [...] }\end{array}$ \\
\hline $\begin{array}{l}7 . \quad \text { A regno } \\
\text { Francorum } \\
\text { receptus, }\end{array}$ & $\begin{array}{l}\text { 4. Audiens hec } \\
\text { imperator } \\
\text { [Valentianus], }\end{array}$ & $\begin{array}{ll}15 . & {[\ldots]} \\
\text { omnia } \\
\text { populus }\end{array}$ & $\begin{array}{l}8 . \\
{[\ldots] \text { Childericus }} \\
\text { rex }\end{array}$ & $\begin{array}{l}12 . \quad[\ldots] \quad \text { sin } \\
\text { autem non vis, } \\
\text { ille cum exercitu }\end{array}$ & & $\begin{array}{l}\text { 17. Tunc rex } \\
\text { proiecit in } \\
\text { directum a se }\end{array}$ & $\begin{array}{lr}13 . & \text { 'Vicit } \\
\text { dominas } & \text { meus } \\
\text { Chlodoveus } & \text { rex }\end{array}$ & $\begin{array}{l}15 . \quad \text { Factaque } \\
\text { victoria, } \\
\text { reversus est in }\end{array}$ & $\begin{array}{l}\text { 9. [...] Siagrius } \\
\text { lesum cernens } \\
\text { exercitum suum, }\end{array}$ \\
\hline
\end{tabular}

${ }^{541}$ A partir desse ponto é importante destacar que a gens francorum para se referir menos à totalidade da gens e mais à um grupo específico que fazia parte do séquito do rei. Poderíamos separar essa parte, mas como a fonte continua a se referir à esse séquito como franci optamos por manter esse novo sentido na categoria gens francorum a fim de enfatizar que se trata de uma transição de significado. 


\begin{tabular}{|c|c|c|c|c|c|c|c|c|}
\hline $\begin{array}{l}\text { Egidium } \\
\text { Romanum } \\
\text { principem } \\
\text { desuper } \\
\text { expulerunt } \quad \text { se } \\
\text { regno. }\end{array}$ & $\begin{array}{l}\text { in furore et ira } \\
\text { nimis } \\
\text { succensus, } \\
\text { praecepit } \\
\text { hostem } \\
\text { commovere } \\
\text { Romanorum et } \\
\text { aliarum } \\
\text { gentium cum } \\
\text { Arestarco } \\
\text { principem } \\
\text { militiae, } \\
\text { direxeruntque } \\
\text { aciem contra } \\
\text { Francos. }\end{array}$ & $\begin{array}{l}\text { Francorum, } \\
\text { una voce } \\
\text { dicentes }[\ldots]\end{array}$ & Francorum [...] & $\begin{array}{l}\text { Francorum in } \\
\text { occursum tuum } \\
\text { venire disponit. }\end{array}$ & $\begin{array}{l}\text { bipennem } \\
\text { suam, quod } \\
\text { est francisca, } \\
\text { et dixit [...] }\end{array}$ & $\begin{array}{l}\text { et Franci qui } \\
\text { sum eo sunt }[\ldots] \\
\text { 17. Placuitque } \\
\text { hoc consilium } \\
\text { proceribus } \\
\text { Francorum. }\end{array}$ & $\begin{array}{l}\text { Francia ad } \\
\text { reginam suam } \\
\text { narravitque ei, } \\
\text { qualiter per } \\
\text { invocationem } \\
\text { nominis Iesu } \\
\text { Christi } \\
\text { victoriam } \\
\text { meruit } \\
\text { obtenere. }\end{array}$ & $\begin{array}{lr}\text { per fugam } \\
\text { lapsus, ad } \\
\text { Alaricum regem } \\
\text { Gothorum } \\
\text { aufugit ad ar } \\
\text { urbem Tolosam. }\end{array}$ \\
\hline $\begin{array}{l}\text { 9. Post hec } \\
\text { mortuus est } \\
\text { Childericus } \\
\text { rex, } \\
\text { regnavitque } \\
\text { annis 24. } \\
\text { Chlodovechus, } \\
\text { filius eius, } \\
\text { regnum } \\
\text { Francorum } \\
\text { viriliter } \\
\text { recepit. }\end{array}$ & $\begin{array}{l}\text { 4. Videntes } \\
\text { enim Franci, } \\
\text { quod tantum } \\
\text { exercitum } \\
\text { sustinere non } \\
\text { possint, } \\
\text { interfecti ac } \\
\text { cesi, fugierunt; } \\
\text { ceciditque ibi } \\
\text { Priamus eorum } \\
\text { fortissimus. }\end{array}$ & $\begin{array}{l}\text { 15. Albofledis } \\
\text { et } \\
\text { Landechildis, } \\
\text { ipsa die, } \\
\text { baptizaturque } \\
\text { postea } \\
\text { cunctus } \\
\text { populus } \\
\text { Francorum. }\end{array}$ & $\begin{array}{l}11 . \quad \text { Dominus } \\
\text { meus } \\
\text { Chlodoveus rex } \\
\text { Francorum } \\
\text { misit me ad te; } \\
\text { vult te habere } \\
\text { reginam.[...]' }\end{array}$ & $\begin{array}{l}\text { 15. Factum est } \\
\text { autem, } \\
\text { pugnantibus inter } \\
\text { se Francorum et } \\
\text { Alamannorum } \\
\text { exercitu, ut } \\
\text { populus } \\
\text { Chlodoveu nimis } \\
\text { caderet. }\end{array}$ & & $\begin{array}{l}\text { 18. Pro qua } \\
\text { causa indignati } \\
\text { Franci, qui } \\
\text { erant cum eo, } \\
\text { consetiebant } \\
\text { Chlodoveo, } \\
\text { commoventes } \\
\text { eum adversus } \\
\text { Ragnachario. }\end{array}$ & $\begin{array}{l}45 . \quad \text { Ebroinus } \\
\text { capillis } \\
\text { crescere } \\
\text { sinens, } \\
\text { congregatis in } \\
\text { auxilium } \\
\text { sociis, } \\
\text { hostiliter a } \\
\text { Luxovio } \\
\text { caenubio } \\
\text { egressus, in } \\
\text { Francia } \\
\text { revertitur cum } \\
\text { armorum } \\
\text { apparatu. } \\
\text { ("Francia" } \\
\text { nesse contexto } \\
\text { se refere à } \\
\text { Nêustria) }\end{array}$ & $\begin{array}{l}\text { 17. Tunc } \\
\text { Chlodoveus rex } \\
\text { cum venisset } \\
\text { Parisius } \\
\text { civitate, ait ad } \\
\text { reginam suam et } \\
\text { ad populum } \\
\text { suum: 'Satis } \\
\text { mihi molestum } \\
\text { est, quod Gothi } \\
\text { Arriani partem } \\
\text { optimam } \\
\text { Gallearum } \\
\text { teneant. }\end{array}$ \\
\hline
\end{tabular}




\begin{tabular}{|c|c|c|c|c|}
\hline $\begin{array}{l}\text { 41. Dixitque } \\
\text { Bertoaldus: } \\
\text { 'Recede a me, } \\
o \text { rex, ne } \\
\text { interficiam te; } \\
\text { quia si } \\
\text { prevalueris } \\
\text { adversus me, } \\
\text { sic omnes } \\
\text { homines } \\
\text { dicent, quod } \\
\text { servum tuum } \\
\text { Bertoaldum } \\
\text { gentiles } \\
\text { peremisti; si } \\
\text { autem ego } \\
\text { interficero te, } \\
\text { tunc rumor } \\
\text { magnus in } \\
\text { cunctis } \\
\text { gentibus } \\
\text { audietur, quod } \\
\text { fortissimus rex } \\
\text { Francorum a } \\
\text { servo sit } \\
\text { interfectus' }\end{array}$ & $\begin{array}{l}\text { 6. Erant enim } \\
\text { tunc Franci } \\
\text { pagani atque } \\
\text { fanatici, } \\
\text { adorantes } \\
\text { idola et } \\
\text { simulacra et } \\
\text { non Deum } \\
\text { caeli ac terrae, } \\
\text { qui creavit eos. }\end{array}$ & $\begin{array}{l}\text { 16. Post haec } \\
\text { Chlodoveus } \\
\text { contra } \\
\text { Gundobadum et } \\
\text { Godeghiselum, } \\
\text { fratrem eius, } \\
\text { perrexit cum } \\
\text { multo exercitu } \\
\text { Francorum. }\end{array}$ & $\begin{array}{lr}32 . \quad \text { Tunc } \\
\text { Franci, qui } \\
\text { quondam ad } \\
\text { Childebertum } \\
\text { seniorem } \\
\text { aspexerant, ad } \\
\text { Sighibertum } \\
\text { legationem } \\
\text { mittentes, ut ad } \\
\text { eos veneret, et } \\
\text { illi, Chilperico } \\
\text { derelicto, ipsum } \\
\text { super se regem } \\
\text { stabilirent. }\end{array}$ & $\begin{array}{l}\text { 17. [...] ibi enim } \\
\text { tunc Alaricus } \\
\text { rex Gothorum } \\
\text { commorabatur. }\end{array}$ \\
\hline $\begin{array}{l}42 . \quad \text { Ipse } \\
\text { pacificus, } \\
\text { velut Salomon, } \\
\text { quietus } \\
\text { regnum } \\
\text { obtenuit } \\
\text { Francorum. }\end{array}$ & $\begin{array}{l}\text { 6. Childericus } \\
\text { itaque rex, } \\
\text { filius } \\
\text { Merovechi, } \\
\text { cum esset } \\
\text { nimis } \\
\text { luxoriosus et }\end{array}$ & 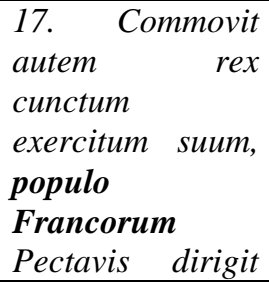 & $\begin{array}{l}35 . \quad \text { Franci } \\
\text { quoque predicto } \\
\text { Chlothario rege } \\
\text { parvolo super se } \\
\text { in regnum } \\
\text { statuerunt. }\end{array}$ & $\begin{array}{l}\text { 17. Chlodoveus } \\
\text { autem rex cum } \\
\text { Alarico rege } \\
\text { Gothorum in } \\
\text { campo } \\
\text { Vogladinse } \\
\text { super fluviam }\end{array}$ \\
\hline
\end{tabular}




\begin{tabular}{|c|c|c|c|c|}
\hline (Dagoberto I) & $\begin{array}{l}\text { regnaret super } \\
\text { Francos }[\ldots]\end{array}$ & {$[\ldots]^{542}$} & & 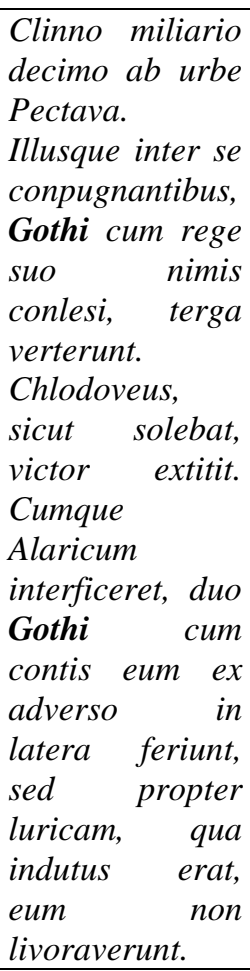 \\
\hline $\begin{array}{l}44 . \quad \text { Eo } \\
\text { tempore } \\
\text { Chlodoveus } \\
\text { brachium } \\
\text { beati Dionisii } \\
\text { martyris } \\
\text { abscidit, } \\
\text { instigante } \\
\text { diabulo. Per }\end{array}$ & $\begin{array}{l}6 . \quad \text { Ille } \\
\text { [Childericus] } \\
\text { haec audiens, } \\
\text { vocavit } \\
\text { amicum suum, } \\
\text { prudentem } \\
\text { consiliarium } \\
\text { nomine } \\
\text { Viomadum, }\end{array}$ & $\begin{array}{l}\begin{array}{l}17 . \\
\text { in }\end{array} \quad \begin{array}{r}\text { corruit } \\
\text { gladio }\end{array} \\
\text { Francorum cum } \\
\text { multis } \\
\text { senatoribus. }\end{array}$ & $\begin{array}{l}36 . \quad \text { Haec } \\
\text { audiens } \\
\text { Fredegundis, } \\
\text { cum Landerico } \\
\text { et reliquos } \\
\text { Fracorum } \\
\text { duces hostem } \\
\text { congregat. }\end{array}$ & $\begin{array}{l}\text { 17. Qui pergens } \\
\text { omnesque urbes } \\
\text { illas a finibus } \\
\text { Gothorum } \\
\text { usque } \\
\text { Burgundiam } \\
\text { subiugavit et in } \\
\text { postestate patris } \\
\text { sui restituit. }\end{array}$ \\
\hline
\end{tabular}

\footnotetext{
${ }^{542}$ E notável como em certas ocasiões exército e povo se confundem. As missões do exército franco eram não raro representadas como missões do próprio povo dos francos.
} 


\begin{tabular}{|c|c|c|c|c|}
\hline \multirow[t]{3}{*}{$\begin{array}{l}\text { id tempus } \\
\text { concidit } \\
\text { regnum } \\
\text { Francorum } \\
\text { casibus } \\
\text { pestiferis. }\end{array}$} & $\begin{array}{l}\text { petiit cum eo } \\
\text { consilium, } \\
\text { qualiter } \\
\text { animos } \\
\text { furentium } \\
\text { Francorum } \\
\text { possit mitigare. }\end{array}$ & & & \\
\hline & $\begin{array}{l}\text { 6. Quando } \\
\text { istam aliam } \\
\text { partem tibi } \\
\text { transmisero, } \\
\text { scias, me } \\
\text { Francos tecum } \\
\text { habere } \\
\text { pacatos, et } \\
\text { securus reverte } \\
\text { in pace. Abiit } \\
\text { ergo } \\
\text { Childericus rex } \\
\text { in Toringam; } \\
\text { apud regem } \\
\text { Bisinum } \\
\text { nomine } \\
\text { uxoremque } \\
\text { eius latuit. }\end{array}$ & $\begin{array}{l}\text { 17. In Sanctonico } \\
\text { vel Burdigalinse } \\
\text { Francos precepit } \\
\text { manere ad } \\
\text { Gothorum } \\
\text { gentem } \\
\text { delendam. }\end{array}$ & $\begin{array}{l}36 . \\
\text { dedicisset, } \\
\text { nimis } \text { quod } \\
\text { exercitus } \\
\text { Austrasiorum, } \\
\text { coniunctis } \\
\text { simul, consilium } \\
\text { dedit Francos, } \\
\text { qui cum ea } \\
\text { erant, dicens } \\
{[. . .]}\end{array}$ & $\begin{array}{l}\text { l7. Interfectis } \\
\text { Gothis, qui } \\
\text { ibidem erant, } \\
\text { ipsam urbem } \\
\text { adprehendit, } \\
\text { omnem terram } \\
\text { illam subiugavit. }\end{array}$ \\
\hline & $\begin{array}{l}\text { 7. Franci vero, } \\
\text { relitto } \\
\text { Childerico, } \\
\text { Egidium } \\
\text { principem } \\
\text { Romanorum in } \\
\text { regnum super } \\
\text { se statuerunt, } \\
\text { malum } \\
\text { consilium }\end{array}$ & $\begin{array}{l}21 . \quad \text { Quod } \\
\text { videntes Franci, } \\
\text { nímio colore et } \\
\text { ira commoti [...] } \\
\text { (no caso o trecho } \\
\text { serefere } \\
\text { aparentemente } \\
\text { ao exército que } \\
\text { acompanhou } \\
\text { Clodomiro na }\end{array}$ & $\begin{array}{l}\text { 38. Cum ei ipsi } \\
\text { Franci seniores } \\
\text { sacramenta } \\
\text { iurarent in } \\
\text { basilica sancti } \\
\text { Gereonis } \\
\text { martyris, visum } \\
\text { ei fuit, ut } \\
\text { percussus } \\
\text { fuisset in } \\
\text { latere }\end{array}$ & $\begin{array}{l}17 . \quad \text { In } \\
\text { Sanctonico vel } \\
\text { Burdigalinse } \\
\text { Francos } \\
\text { precepit manere } \\
\text { ad Gothorum } \\
\text { gentem } \\
\text { delendam. }\end{array}$ \\
\hline
\end{tabular}




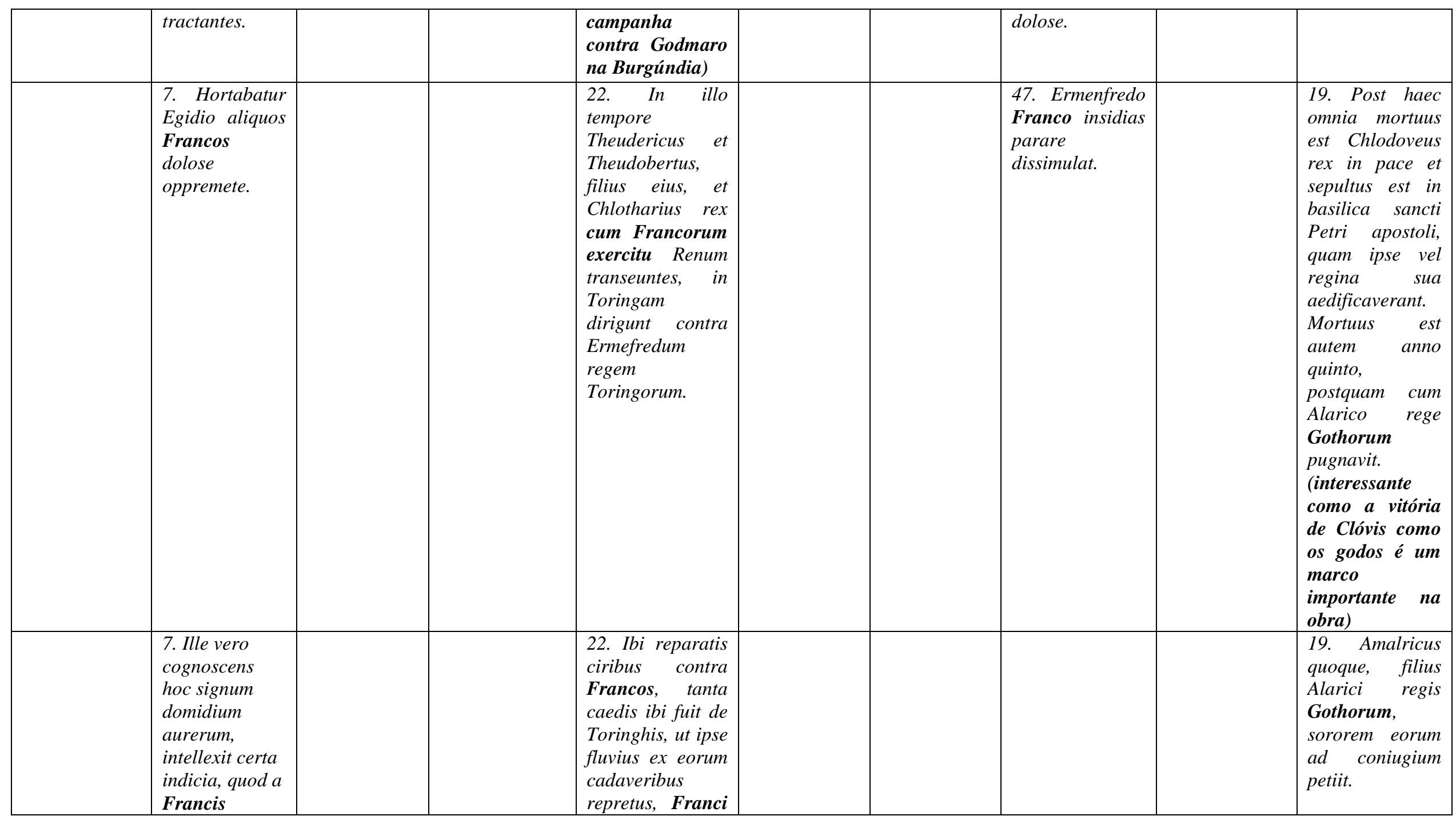




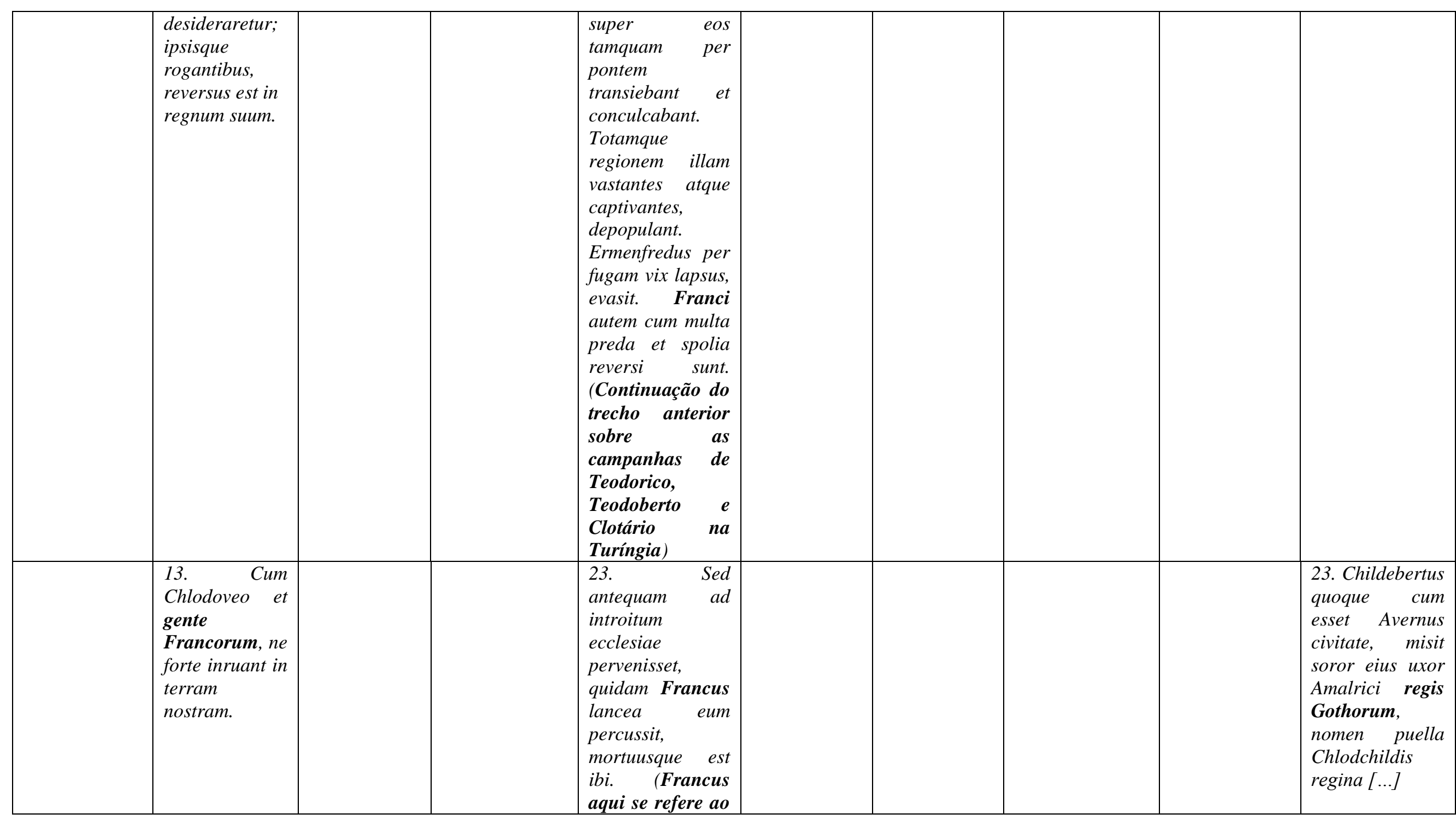




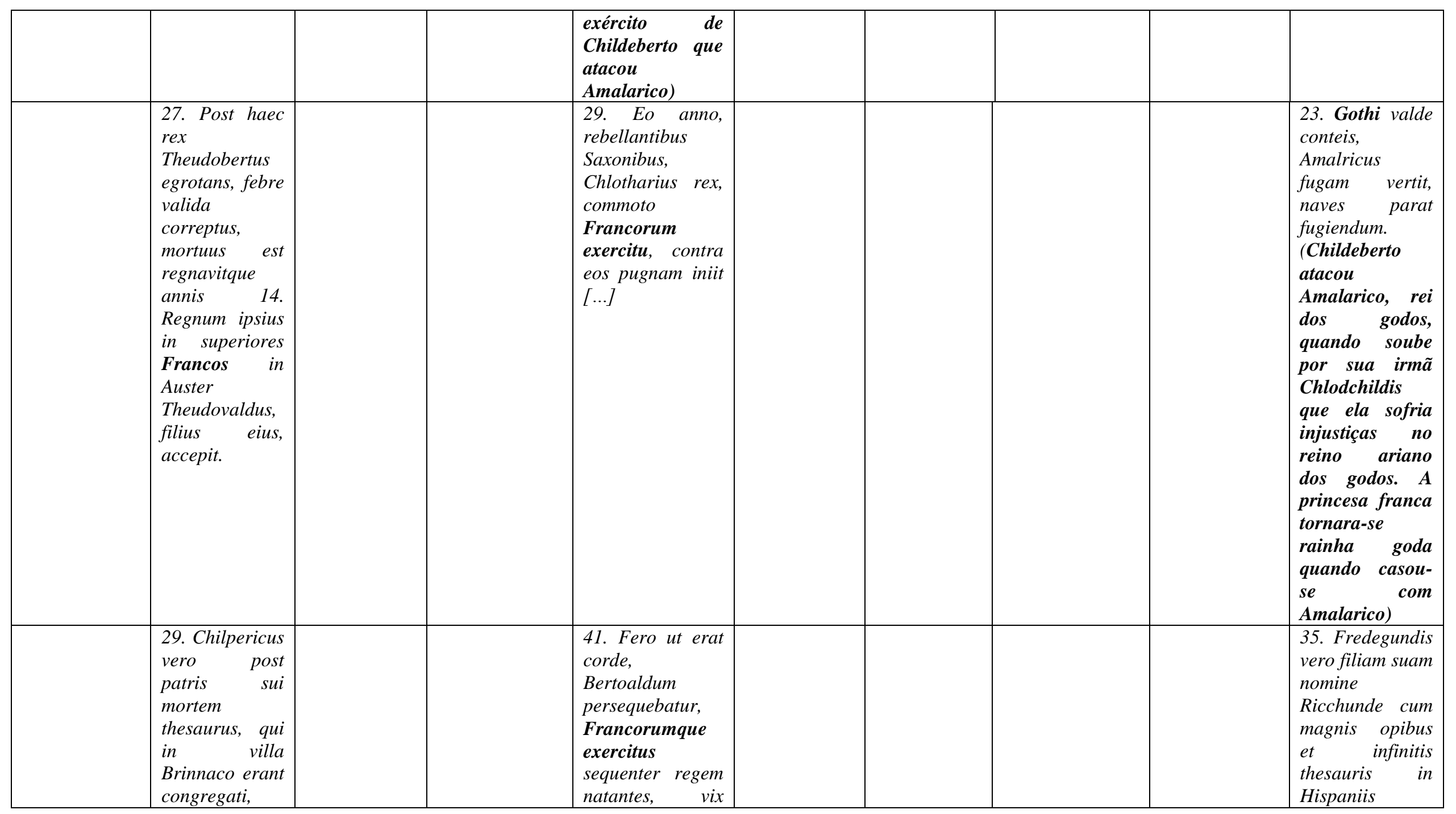




\begin{tabular}{|c|c|c|}
\hline 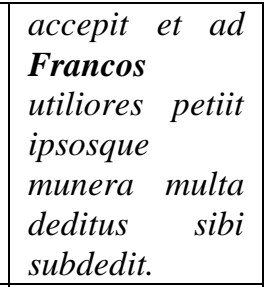 & $\begin{array}{ll}\text { fluvium } & \text { cum } \\
\text { Dagoberto } & \\
\text { transiebant } & \text { per } \\
\text { gurgites } & \\
\text { inmensos. } & \end{array}$ & $\begin{array}{l}\text { Leubighildum } \\
\text { regem uxorem } \\
\text { filii sui cum } \\
\text { magna legatione } \\
\text { Gothorum } \\
\text { direxit. }\end{array}$ \\
\hline 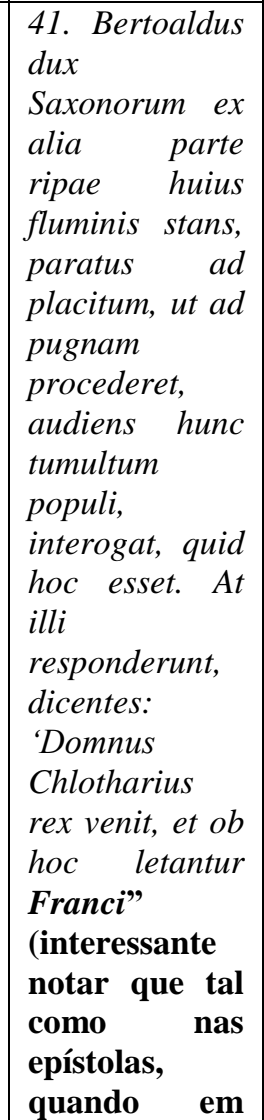 & & \\
\hline
\end{tabular}




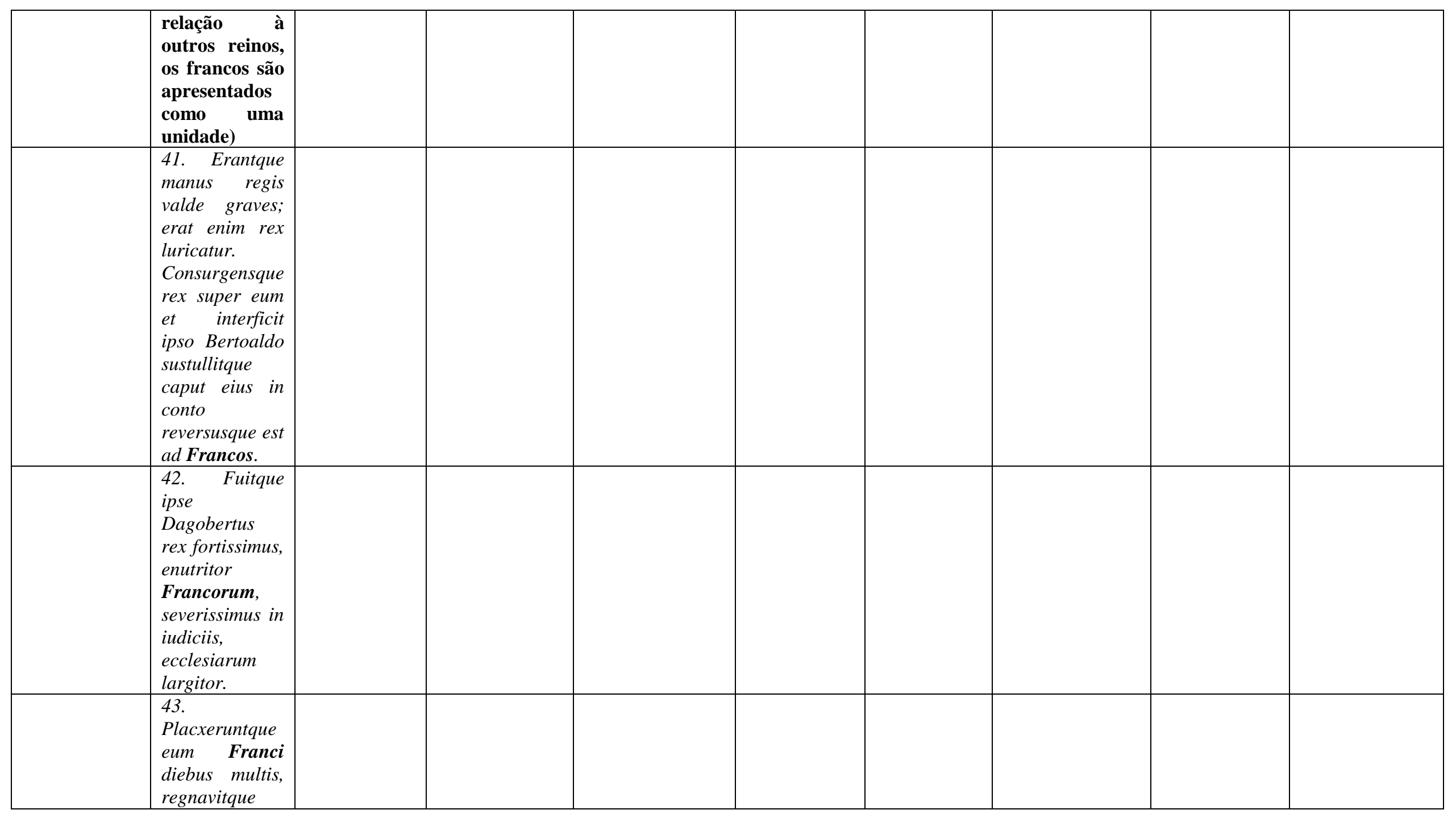




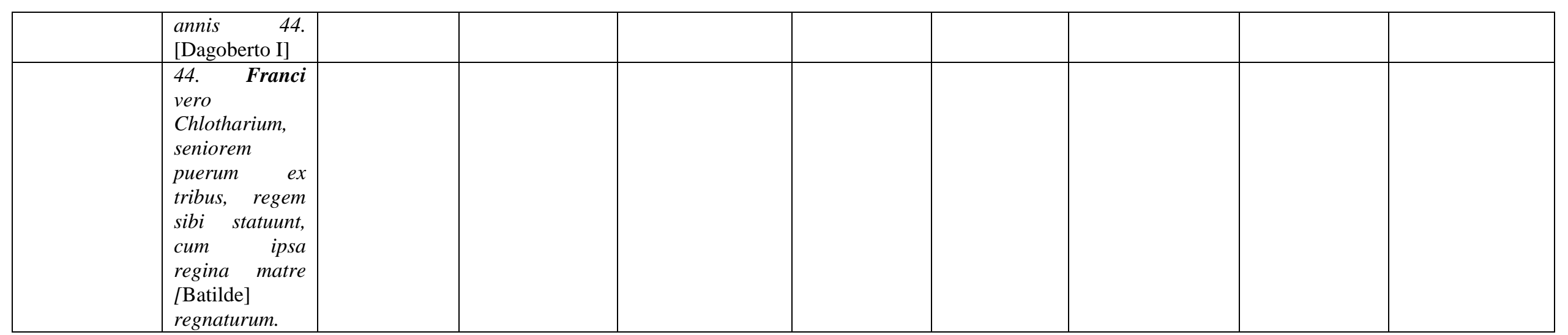

Tabela 9: Austrásia, Burgúndia e Nêstria no Liber Historiae Francorum

\begin{tabular}{|c|c|c|}
\hline Austrásia/Austrasianos & Burgúndia/Burgúndios & Nêustria/Franci ${ }^{543}$ \\
\hline $\begin{array}{l}\text { 27. Post haec rex Theudobertus } \\
\text { egrotans, febre valida correptus, } \\
\text { mortuus est regnavitque annis } 14 . \\
\text { Regnum ipsius in superiores } \\
\text { Francos in Auster Theudovaldus, } \\
\text { filius eius, accepit. }\end{array}$ & $\begin{array}{l}\text { 36. Burgundiones et Austrasii } \\
\text { superiores Franci simul } \\
\text { commoti grande exercitu valde } \\
\text { Campanias digressi, paygo } \\
\text { Suessionico cum Gundoaldo et } \\
\text { Wintrione patriciis vastantes } \\
\text { ingrediuntur. }\end{array}$ & $\begin{array}{l}\text { 36. Burgundiones et Austrasii } \\
\text { superiores Franci simul commoti } \\
\text { grande exercitu valde Campanias } \\
\text { digressi, paygo Suessionico cum } \\
\text { Gundoaldo et Wintrione patriciis } \\
\text { vastantes ingrediuntur. }\end{array}$ \\
\hline $\begin{array}{l}\text { 32. Gundoaldus dux adprehensum } \\
\text { Childebertum, filium parvolum, } \\
\text { furtim per noctem abstullit et cum } \\
\text { eo in Auster fugit [...] }\end{array}$ & $\begin{array}{l}\text { 36. Cum haec agerentur, et } \\
\text { autora diei inicium daret, } \\
\text { inrueruntque Franci cum } \\
\text { strepitu tubarum super } \\
\text { Austrasiis et Burgundiones } \\
\text { dormientibus cum Fredegunde } \\
\text { vel Chlothario parvolo } \\
\text { interfeceruntque maxima parte } \\
\text { de hoste illo, innumerabilis } \\
\text { multitudo, maximus valde }\end{array}$ & $\begin{array}{l}\text { 36. Haec audiens Fredegundis, cum } \\
\text { Landerico et reliquos Francorum } \\
\text { duces hostem congregar. (Nesse } \\
\text { trecho a referência è aos duces da } \\
\text { Nêustria) }\end{array}$ \\
\hline
\end{tabular}

${ }^{543}$ Franci a partir do crescimento da importância da Austrásia e Burgúndia no texto (cap.36), começa a se referir aos neustrinos. 


\begin{tabular}{|c|c|c|}
\hline & $\begin{array}{l}\text { exercitus, a maiore usque ad } \\
\text { minorem. }\end{array}$ & \\
\hline $\begin{array}{l}\text { 35. Childeberto itaque rex Auster } \\
\text { cum hoste in Italia abiit, ipsam } \\
\text { devastavit et tributariam fecit. }\end{array}$ & $\begin{array}{l}\text { 37. [...] ipsumque cum ava sua } \\
\text { Brunchilde in Burgundiam in } \\
\text { regno Gumtramni regis magni } \\
\text { direxit. }\end{array}$ & $\begin{array}{l}\text { 36. Brinnacum villa veniens, multa } \\
\text { dona et munera Francis ditavit, } \\
\text { eosque ad pugnandum contra } \\
\text { inimicos eorum corrtans. }\end{array}$ \\
\hline $\begin{array}{l}35,[\ldots] \text { quod Childebertus rex } \\
\text { Auster insidiatus ei fuisset. }\end{array}$ & $\begin{array}{l}\text { 37. Theudericus itaque rex } \\
\text { Burgundiae erat pulcher et } \\
\text { strenuus ac calidus nimis. Per } \\
\text { consilium avae suae Brunchilde } \\
\text { hoste maximo ex Burgundia } \\
\text { congregans, } \\
\text { Chlotharium, patruelem suum, } \\
\text { dirigens [...] }\end{array}$ & $\begin{array}{l}\text { 36. Brinnacum villa veniens, multa } \\
\text { dona et munera Francis ditavit, } \\
\text { eosque ad pugnandum contra } \\
\text { inimicos eorum coortans. }\end{array}$ \\
\hline $\begin{array}{l}\text { 35. [...] Childeberto rege Austri } \\
{[\ldots]}\end{array}$ & $\begin{array}{l}40 . \text { His regibus mortuis } \\
\text { [Teodorico II e Teodoberto II], } \\
\text { Burgundiones et Austrasii, cum } \\
\text { reliquis Francis pace facta, } \\
\text { Chlotharium regem in totis } \\
\text { tribus regnis in monarchiam } \\
\text { elevaverunt. }\end{array}$ & $\begin{array}{l}\text { 36. Cum autem custodes hostium } \\
\text { Austrasiorum ramis silvarum quasi } \\
\text { in montibus in agmine Francorum } \\
\text { cernerent [...] }\end{array}$ \\
\hline $\begin{array}{l}\text { 36. Audiens autem Childebertus } \\
\text { rex Auster, filius Sighiberti, nepus } \\
\text { Chilperici, avuncolo suo mortuo et } \\
\text { maleficia Fredegundis reginae, } \\
\text { hostem collegit. }\end{array}$ & $\begin{array}{l}\text { 40. Rex namque Chlotharius, } \\
\text { commoto exercitu, in } \\
\text { Burgundiam dirigit, } \\
\text { Brunchilde, quasi ad coniugium } \\
\text { accipere fingeret }[. . .]\end{array}$ & $\begin{array}{l}\text { 36. Cum haec agerentur, et autora } \\
\text { diei inicium daret, inrueruntque } \\
\text { Franci cum strepitu tubarum super } \\
\text { Austrasiis et Burgundiones } \\
\text { dormientibus cum Fredegunde vel } \\
\text { Chlotharioryarvolo } \\
\text { interfeceruntque maxima parte de } \\
\text { hoste illo, innumerabilis multitudo, } \\
\text { maximus valde exercitus, a maiore } \\
\text { usque ad minorem. }\end{array}$ \\
\hline $\begin{array}{l}\text { 36. Burgundiones et Austrasii } \\
\text { superiores Franci simul commoti } \\
\text { grande exercitu valde Campanias } \\
\text { digressi, paygo Suessionico cum }\end{array}$ & $\begin{array}{l}\text { 40. Tunc coadunato exercitu } \\
\text { Francorum et Burgundionum } \\
\text { in unum, cunctis vociferantibus, } \\
\text { Brunchilde morte turpissima }\end{array}$ & $\begin{array}{l}\text { 37. Chlotharius haec audiens } \\
\text { audiens, commoto Francorum } \\
\text { exercitu, contra eum festinus } \\
\text { perrexit. }\end{array}$ \\
\hline
\end{tabular}




\begin{tabular}{|c|c|c|}
\hline $\begin{array}{l}\text { Gundoaldo et Wintrione patriciis } \\
\text { vastantes ingrediuntur. }\end{array}$ & $\begin{array}{l}\text { esse dignissima, tunc, iubente } \\
\text { Chlothario rege, in camelo } \\
\text { levata, toto hoste gyrata, deinde } \\
\text { equorum indomitum pedibus } \\
\text { legata, dissipatis membris, obiit. }\end{array}$ & \\
\hline $\begin{array}{l}\text { 36. Cum dedicisset, quod nimis } \\
\text { esset exercitus Austrasiorum, } \\
\text { coniunctis simul, consilium dedit } \\
\text { Francos, qui cum ea erant, dicens } \\
\text { [...] }\end{array}$ & $\begin{array}{l}\text { 45. Ebroinum totundunt eumque } \\
\text { Luxovio monasterio in } \\
\text { Burgundia dirigunt. In Auster } \\
\text { propter Childericum mittentes, } \\
\text { accomodant. Et una cum } \\
\text { Vulfoaldo duce veniens, in } \\
\text { regno Francorum elevatus est. } \\
\text { Erat enim ipse Childericus levis } \\
\text { nimis, omnia nimis incaute } \\
\text { peragebat, donec inter eos } \\
\text { odium maximum et scandalum } \\
\text { crevit, Francos valde } \\
\text { oppremens. }\end{array}$ & $\begin{array}{l}\text { 40. His regibus mortuis [Teodorico } \\
\text { II e Teodoberto II], Burgundiones } \\
\text { et Austrasii, cum reliquis Francis } \\
\text { pace facta, Chlotharium regem in } \\
\text { totis tribus regnis in monarchiam } \\
\text { elevaverunt. }\end{array}$ \\
\hline $\begin{array}{l}\text { 36. Cum autem custodes hostium } \\
\text { Austrasiorum ramis silvarum } \\
\text { quasi in montibus in agmine } \\
\text { Francorum cernerent [...] }\end{array}$ & $\begin{array}{l}\text { 45. Eratque ex Burgundia in } \\
\text { hoc consilio beatus Leudegarius } \\
\text { Augustudunensus episcopus et } \\
\text { Gaerinus, frater eius, } \\
\text { consentientes. }\end{array}$ & $\begin{array}{l}\text { 40. Tunc coadunato exercitu } \\
\text { Francorum et Burgundionum in } \\
\text { unum, cunctis vociferantibus, } \\
\text { Brunchilde morte turpissima esse } \\
\text { dignissima, tunc, iubente } \\
\text { Chlothario rege, in camelo levata, } \\
\text { toto hoste gyrata, deinde equorum } \\
\text { indomitum pedibus legata, } \\
\text { dissipatis membris, obiit. }\end{array}$ \\
\hline $\begin{array}{l}\text { 36. Cum haec agerentur, et autora } \\
\text { diei inicium daret, inrueruntque } \\
\text { Franci cum strepitu tubarum super } \\
\text { Austrasiis et Burgundiones } \\
\text { dormientibus cum Fredegunde vel } \\
\text { Chlothariorervolo } \\
\text { interfeceruntque maxima parte de } \\
\text { hoste illo, innumerabilis multitudo, }\end{array}$ & & $\begin{array}{l}\text { 41. Eratque Chlothario rege tunc } \\
\text { filius nomine Dagobertus, puer } \\
\text { efficax atque strenuus, ad omnia } \\
\text { solers, versutissimus. Quem rex } \\
\text { adultum una cum Pippino duce in } \\
\text { Auster regnaturum direxit. } \\
\text { Austrasii vero Franci superiores } \\
\text { congregati in unum, Dagobertum }\end{array}$ \\
\hline
\end{tabular}




\begin{tabular}{|c|c|}
\hline $\begin{array}{l}\text { maximus valde exercitus, a maiore } \\
\text { usque ad minorem. }\end{array}$ & super se regem statuunt. \\
\hline $\begin{array}{l}\text { 37. Eo tempore Childebertus rex } \\
\text { Auster habeat filios duos [...] }\end{array}$ & $\begin{array}{l}\text { 43. Chlodovechum, filium eius [de } \\
\text { Dagoberto I] Franci super se } \\
\text { regem statuunt; accepitque uxorem } \\
\text { de genere Saxonorum nomine } \\
\text { Balthilde, pulchra omnique ingenio } \\
\text { strenua. }\end{array}$ \\
\hline $\begin{array}{l}\text { 40. His regibus mortuis [Teodorico } \\
\text { II e Teodoberto II], Burgundiones } \\
\text { et Austrasii, cum reliquis Francis } \\
\text { pace facta, Chlotharium regem in } \\
\text { totis tribus regnis in monarchiam } \\
\text { elevaverunt. }\end{array}$ & $\begin{array}{l}\text { 43. [...] defuncto Sighiberto rege, } \\
\text { Grimoaldus filium eius parvolum } \\
\text { nomine Daygobertum totundit } \\
\text { Didonemque Pectavensem urbis } \\
\text { episcopum in Scocia } \\
\text { peregrinandum eum direxit, filium } \\
\text { suum in regno constituens. Franci } \\
\text { itaque hoc valde indignantes, } \\
\text { Grimoaldo insidias preparant, } \\
\text { eumque exementes, ad } \\
\text { condempnandum rege Francorum } \\
\text { Chlodoveo deferunt. }\end{array}$ \\
\hline $\begin{array}{l}\text { 41. Eratque Chlothario rege tunc } \\
\text { filius nomine Dagobertus, puer } \\
\text { efficax atque strenuus, ad omnia } \\
\text { solers, versutissimus. Quem rex } \\
\text { adultum una cum Pippino duce in } \\
\text { Auster regnaturum direxit. } \\
\text { Austrasii vero Franci superiores } \\
\text { congregati in unum, Dagobertum } \\
\text { super se regem statuunt. }\end{array}$ & $\begin{array}{l}\text { 45. In his diebus Chlotharius rex } \\
\text { puer obiit regnavitque annis } 4 . \\
\text { Theudericus, frater eius, elevatus } \\
\text { est rex Francorum. Childericum } \\
\text { itaque, alium fratrem eius, in } \\
\text { Auster una cum Vulfoaldo duce } \\
\text { regnum suscipere dirigunt. Eo } \\
\text { tempore Franci adversus Ebroinum } \\
\text { insidias preparant [...] }\end{array}$ \\
\hline $\begin{array}{l}\text { 42. Sighibertum vero, maiorem } \\
\text { filium suum, in Auster una cum } \\
\text { Pippino duce direxit in regno } \\
\text { statuto }[. . .]\end{array}$ & $\begin{array}{l}\text { 45. Ebroinum totundunt eumque } \\
\text { Luxovio monasterio in Burgundia } \\
\text { dirigunt. In Auster propter } \\
\text { Childericum mittentes, accomodant. } \\
\text { Et una cum Vulfoaldo duce veniens, } \\
\text { in regno Francorum elevatus est. }\end{array}$ \\
\hline
\end{tabular}




\begin{tabular}{|c|c|}
\hline & $\begin{array}{l}\text { Erat enim ipse Childericus levis } \\
\text { nimis, omnia nimis incaute } \\
\text { peragebat, donec inter eos odium } \\
\text { maximum et scandalum crevit, } \\
\text { Francos valde oppremens. }\end{array}$ \\
\hline $\begin{array}{l}\text { 43. Post haec autem Sighibertus } \\
\text { rex Auster, Pippino defuncto, } \\
\text { Grimoaldo, filio eius, in maiorum } \\
\text { domato instituit. }\end{array}$ & $\begin{array}{l}\text { 45. Haec videntes Franci, in ira } \\
\text { magna commoti, Ingobertis } \\
\text { videlicet et Amalbertus et reliqui } \\
\text { maiores natu Francorum, } \\
\text { sedicionem contra ipsum } \\
\text { Childericum concitantes. }\end{array}$ \\
\hline $\begin{array}{l}\text { 45. In his diebus Chlotharius rex } \\
\text { puer obiit regnavitque annis } 4 . \\
\text { Theudericus, frater eius, elevatus } \\
\text { est rex Francorum. Childericum } \\
\text { itaque, alium fratrem eius, in } \\
\text { Auster una cum Vulfoaldo duce } \\
\text { regnum suscipere dirigunt. Eo } \\
\text { tempore Franci adversus Ebroinum } \\
\text { insidias preparant [...] }\end{array}$ & $\begin{array}{l}\text { 45. Vulfoaldus quoque per fugam } \\
\text { vix evasit, in Auster reversus. } \\
\text { Franci autem Leudesio, Filio } \\
\text { Erchonoldo, in maiorum domato } \\
\text { palacii elegunt. }\end{array}$ \\
\hline $\begin{array}{l}\text { 45. Ebroinum totundunt eumque } \\
\text { Luxovio monasterio in Burgundia } \\
\text { dirigunt. In Auster propter } \\
\text { Childericum mittentes, } \\
\text { accomodant. Et una cum Vulfoaldo } \\
\text { duce veniens, in regno Francorum } \\
\text { elevatus est. Erat enim ipse } \\
\text { Childericus levis nimis, omnia } \\
\text { nimis incaute peragebat, donec } \\
\text { inter eos odium maximum et } \\
\text { scandalum crevit, Francos valde } \\
\text { oppremens. }\end{array}$ & $\begin{array}{l}\text { 47. Ebroinus itaque magis ac magis } \\
\text { Francos crudeliter oppremebat } \\
\text { [...] }\end{array}$ \\
\hline $\begin{array}{l}\text { 45. Vulfoaldus quoque per fugam } \\
\text { vix evasit, in Auster reversus. } \\
\text { Franci autem Leudesio, Filio }\end{array}$ & $\begin{array}{l}\text { 47. Franci vero consilio } \\
\text { pertractantes, Warattonem virum } \\
\text { inlustrem in loco eius cum iussione }\end{array}$ \\
\hline
\end{tabular}




\begin{tabular}{|c|c|}
\hline $\begin{array}{l}\text { Erchonoldo, in maiorum domato } \\
\text { palacii elegunt. }\end{array}$ & $\begin{array}{l}\text { regis maiorum domo palacii } \\
\text { constituunt. }\end{array}$ \\
\hline $\begin{array}{l}\text { 46. Eo quoque tempore, decedente } \\
\text { Vulfoaldo de Auster, Martinus et } \\
\text { Pippinus iunior, filius Anseghiselo } \\
\text { quodam decedentibus regibus, } \\
\text { dominabantur in Austria, donec } \\
\text { tandem aliquando hii duces in } \\
\text { odium versi contra Ebroinum, } \\
\text { exercitum plurimam Austrasiorum } \\
\text { commotum, contra Theudericum } \\
\text { regem et Ebroinum aciem dirigunt. }\end{array}$ & $\begin{array}{l}\text { 48. Franci nempe in diversa } \\
\text { tendentes, vacellabant. }\end{array}$ \\
\hline $\begin{array}{l}\text { 46. Austrasii devicti, in fugam } \\
\text { lapsi terga verterunt. }\end{array}$ & $\begin{array}{l}\text { 48. Interdum Bercharium quondam } \\
\text { statura pusillum, sapientia } \\
\text { ignobilem, consilia inutile, in } \\
\text { maiorum domato oberrantes } \\
\text { statuunt Franci in invicem divisi. }\end{array}$ \\
\hline $\begin{array}{l}\text { 47. Ille quoque per noctem } \\
\text { prefatum Ebroinum interficit, atque } \\
\text { ad Pippinum in Auster fugiens, } \\
\text { evasit. }\end{array}$ & $\begin{array}{l}\text { 51. In illis diebus, instigante } \\
\text { diabulo, Franci denuo Cocia silva } \\
\text { in Francos invicem inruunt ac sese } \\
\text { mutuo dirissima cede prosternunt. }\end{array}$ \\
\hline $\begin{array}{l}\text { 48. Pippinus ab Austrasiis } \\
\text { consurgens, commoto hoste quam } \\
\text { plurimo, contra Theudericum } \\
\text { regem et Bercharium aciem dirigit. }\end{array}$ & $\begin{array}{l}\text { 52. Franci nimirum Danielem } \\
\text { [Chilperico II } 715 / 6-721 \text { ] quondam } \\
\text { clericum, cesarie capitis crescente, } \\
\text { eum in regnum stabiliunt atque } \\
\text { Chilpericum nuncupant. }\end{array}$ \\
\hline $\begin{array}{l}48 . \quad \text { Thesauris acceptis, } \\
\text { Nordebertum quondam de suis cum } \\
\text { rege relictum, ipse in Austria } \\
\text { remeavit. }\end{array}$ & $\begin{array}{l}\text { 53. Franci vere Theudericum, Cala } \\
\text { monasterio enutritum, filium } \\
\text { Dagoberto iunioris, regem super se } \\
\text { statuunt, qui nunc anno sexto in } \\
\text { regno subsisti. }\end{array}$ \\
\hline $\begin{array}{l}\text { 53. Regiones illas vastatas atque } \\
\text { captivatas, itemque cum multa } \\
\text { preda in Auster reversus, Colonia } \\
\text { civitate veniens, ibique seditione }\end{array}$ & \\
\hline
\end{tabular}




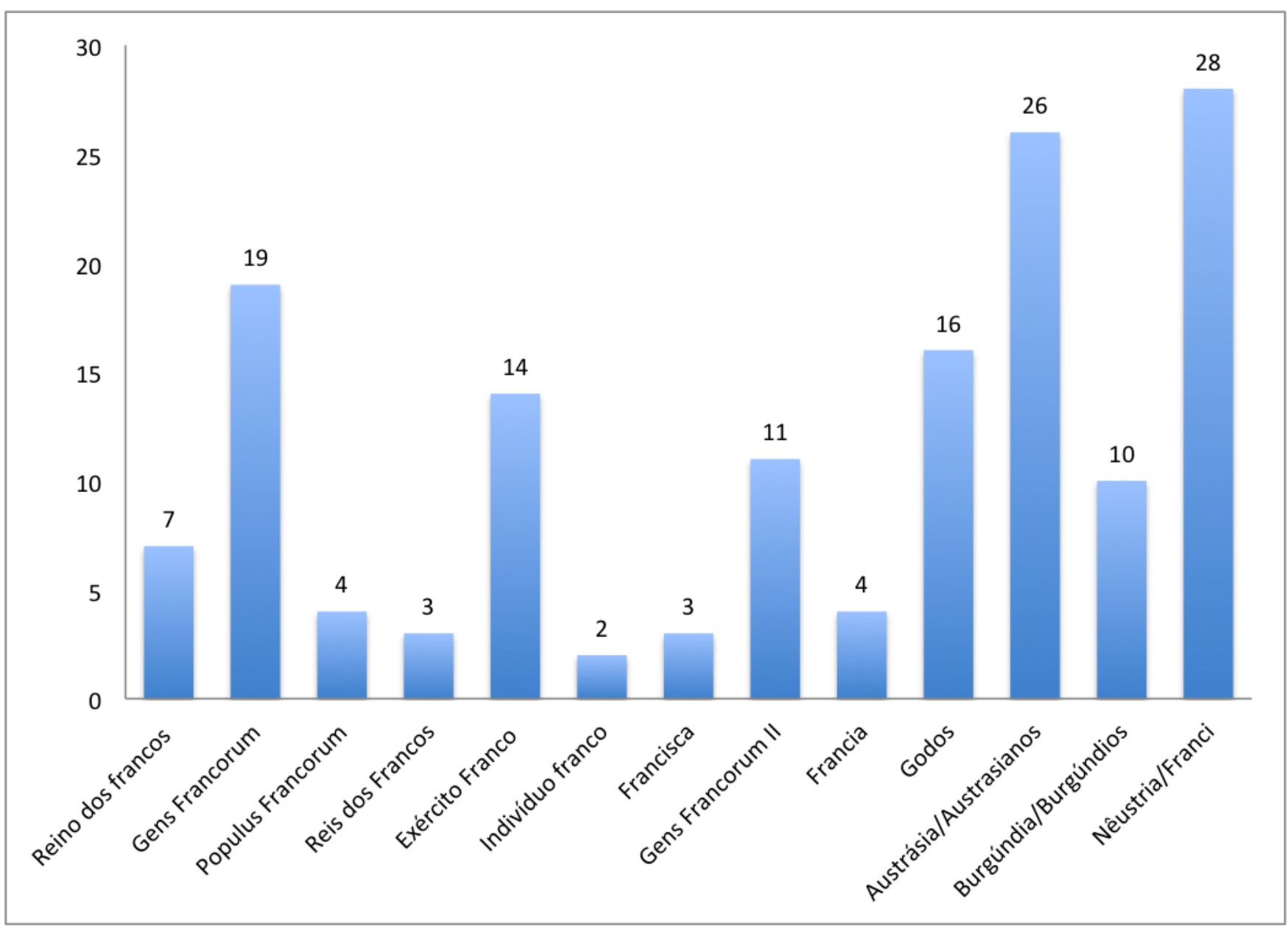

Gráfico 10 Termos identitários no Liber historiae Francorum 


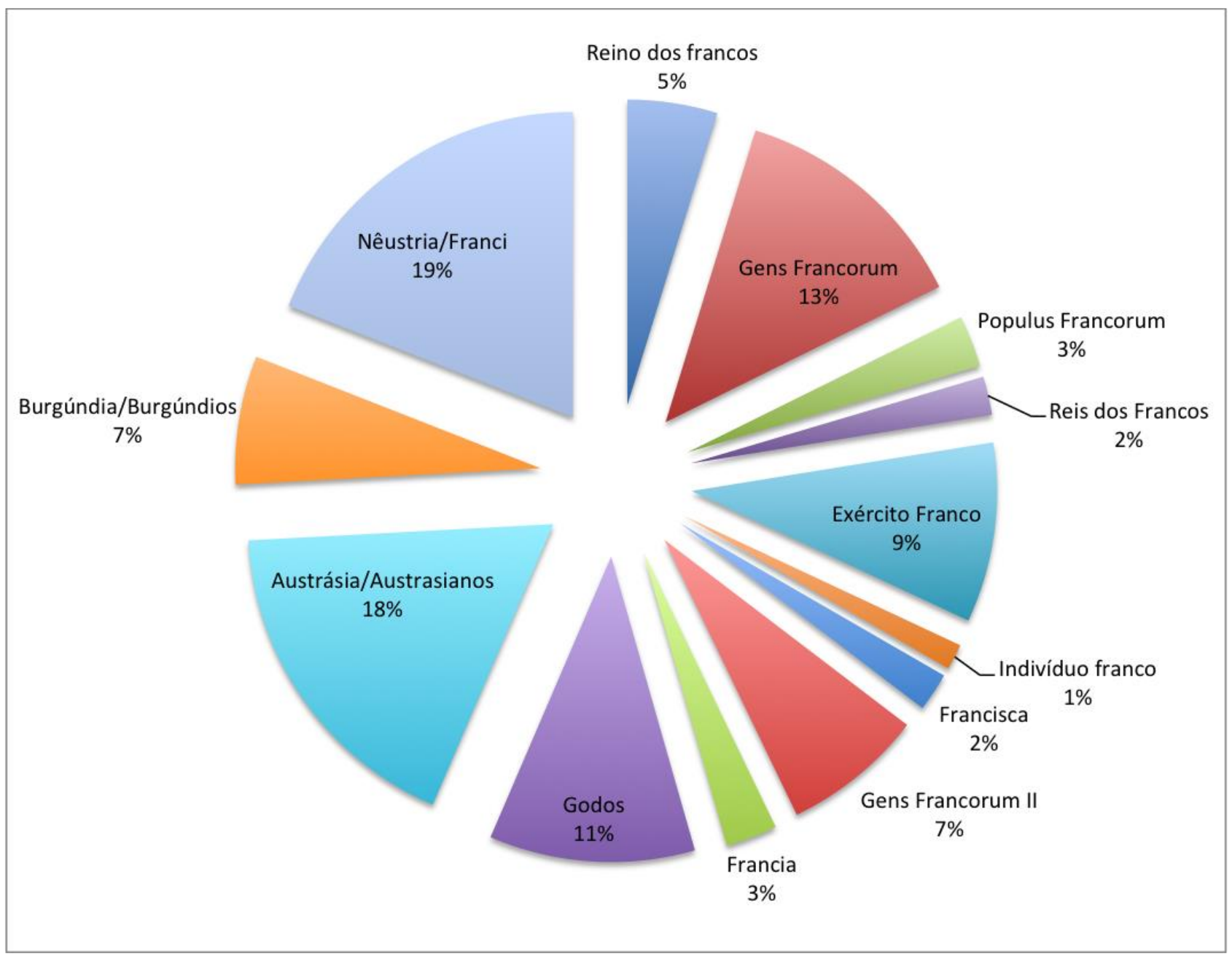

Gráfico 11 Termos identitários no Liber Historiae Francorum (em \%) 
O que temos é que a partir do capítulo 27 a Austrásia começa a ser uma entidade política de peso. A partir do capítulo 36 a Nêustria, e em menor medida a Burgúndia, crescem em importância. O crescimento da importância dessas unidades é refletido na aplicação dos termos "étnicos". A gens francorum, a entidade predominante até o capítulo 27 , aos poucos é preterida em relação ao uso de outras entidades políticas: a Austrásia, a Nêustria, a Burgúndia. Os grupos políticos dessas regiões passam a ser definidos pelos termos regionais: austrasianos, burgúndios, neustrinos (franci) e são eles que começam a ser os personagens principais da narrativa.

A narrativa do Liber Historiae Francorum testemunha algo que já era apontado pela Chronica de Fredegário: o surgimento de novos protagonistas políticos veio acompanhado do surgimento de novos grupos identitários no contexto de disputa políticas. Os "franci" como qualificativo que dava conta de todos esses personagens aparece apenas em poucas ocasiões depois da virada do rumo narrativo da fonte a partir do capítulo 27:

1. No capítulo 41 quando o autor descreve as batalhas dos francos contra os Saxões. Essa aplicação da idéia de uma unidade dos francos em confronto com outros reinos não é uma exclusividade do Liber Historiae Francorum. Vemos esse tipo de emprego nas epístolas trocadas pelos reis francos com outros reinos e o Império. Isso significa que gradativamente o emprego do termo "francus" como uma unidade que englobava todas as unidades políticas da Gália aos poucos se torna muito mais recorrente tãosomente quando o contexto do uso do termo narra as relações dos francus com outros reinos.

2. Nos capítulos 42 quando há referência à Dagoberto I que unificou o comando dos reinos e, de acordo com o autor do texto, pacificou os "francus". Nesse sentido, nas ocasiões em que um único rei governou a Austrásia, a Nêustria e a Burgúndia há o uso do termo francus para dar conta da unificação. Assim, a segunda situação em que o termo é aplicado no sentido de unidade é quando um rei unifica o governo dos três reinos. Nesse sentido, o rei, como no início da narrativa, continua a ser o fator 
principal da unidade da gens.

O crescimento da importância dos austrasianos e da Austrásia, dos neustrinos e da Nêustria e dos burgúndios e Burgúndia no nosso entender não significa que o autor começou a valorizar mais esses grupos do que a gens francorum. Isso se observa pela a análise de toda a fonte e do tom triunfal pelo qual o texto narra o sucesso dos francos até o reinado de Clotário I. As referências a outras unidades identitárias aparentemente são mais a constatação de algo que o autor observava do que uma celebração dessas novas identidades. De fato, elas não são celebradas, a emergência delas não é comemorada, é mais refletida como a crescente polarização política do reino que redundou no crescimento de tensões e batalhas. Quando o autor fala de Dagoberto I, o rei que governou todos os reinos, o autor dá sinais de aprovação ao dizer que ele pacificou os francos.

Outro elemento que consideramos relevante de ser mencionado para sustentar nossa hipótese que o surgimento de outras unidades identitárias na narrativa não diminui a importância da gens francorum como uma unidade é a referência que o autor faz à francisca, o machado com duas lâminas. Essa referência aparece três vezes e nas três vezes o autor descreve como é a arma. Isso nos leva a pensar se a insistência em descrever as características da arma não se deveu ao fato de que ela era relativamente desconhecida. Ainda, observamos que a francisca aparece em três momentos-chave de afirmação da autoridade do rei Clóvis constituindo-se no texto como um símbolo do poder real além dos longos cabelos dos reis merovíngios. Surge no texto um novo símbolo identitário que afirma a unidade da gens francorum concretizada pela autoridade dos reis francos: uma arma que era erguida ou lançada por terra em momentos de grandes decisões. Esse novo elemento, aliado com a comemoração à gens francorum presente nos primeiros capítulos do texto indicam que a celebração da gens francorum no contexto da narrativa do Liber Historiae 
Francorum pode ser lida como uma respostas ao crescimento de outros grupos políticos reunidos em torno de outras identidades políticas. No Liber Historiae Francorum essas novas identidades políticas não se sobressaem sobre a gens francorum: seu passado glorioso, seus reis com origens nobres e míticas. A identidade franca presente nesse texto era uma resposta política incisiva no contexto de uma nova realidade política em que os reis - que outrora eram os bastiões da unidade da gens - se viam fragilizados com o incremento da autoridade das nobrezas locais e as novas identidades que elas evocavam.

Observamos assim em três autores que escreveram em três períodos diversos as apropriações do termo franci num contexto de disputas e alianças políticas. Em Gregório de Tours a gens francorum não é o centro das atenções, não parece ser por acaso, fazer uma história da gens propriamente dita não era a intenção do autor, seu objetivo se centrava mais na narrativa das disputas que opunham os reis e causavam desordens na Gália, eventos estes encaixados numa narrativa histórica providencialista. Mesmo assim, o autor inseriu a gens francorum na gesta temporum de uma maneira até então inédita principalmente ao ressaltar a importância das ações de seus reis. De todo modo, legitimar a dinastia merovíngia não era o que parecia ser urgente para o bispo de Tours. Como argumentamos no capítulo dedicado à realeza, eram outras questões em torno da realeza franca que preocupavam Gregório de Tours, mesmo que os nobres na narrativa do bispo sejam descritos já como importantes no teatro político da Gália eles não pareciam fortes o suficiente para ameaçar a dinastia. Eram as disputas entre os reis que parecia ser a grande ameaça para a manutenção dos reis no poder mais do que movimentos de oposição surgidos nas fileiras nobiliárquicas.

Como observamos, a situação da Hispânia Visigoda era de todo diversa, desde 
sempre as fileiras nobiliárquicas representavam uma ameaça para o poder dos reis.

De qualquer forma, a inserção dos francos iniciada pelo bispo de Tours na gesta temporum tomou novos rumos nas mãos do autor da Chronica de Fredegário e do Liber Historiae Francorum. Entre a segunda metade do século VII e primeiras décadas do século VIII a situação política da Gália era de todo diversa, os dois documentos mostram que a atuação dos nobres se tornava cada vez mais importante a ponto de garantir que um rei se mantivesse no poder e, em certas situações, poderiam mesmo ameaçar a dinastia como observamos no caso de Grimoaldo. A Chronica de Fredegário aponta que identidades emergentes articuladas em torno dos reinos da Austrásia, Neustria e Burgúndia e manipuladas por nobres identificados com as localidades se tornavam cada vez mais impactantes no desenrolar dos eventos políticos do reino, o ápice do processo foi narrado pelo Liber Historiae Francorum. Os dois texto parecem tratar de uma realeza em crise diante de nobrezas cada vez mais fortes, e nesse cenários os dois textos ofereceram uma resposta que se articulou em torno da construção e re-construção da memória da valorização da gens liderada por reis advindos de um passado ilustres.

A construção da memória da gens francorum nesses dois textos, assim defendemos, era um reforço de uma identidade política "franca" diante de outras identidades políticas. Identidade política esta que se baseava num discurso celebrativo de um passado glorioso da gens e seus reges. A própria construção dessa identidade política pode ser assim entendida como uma política identitária. A gens francorum forte e valoroza nasceu então quando seus reis se fragilizaram. Uma narrativa completamente diversa veremos no próximo tópico, este dedicado às hagiografias, que acima de tudo tinham por objetivo propagar o culto de santos, santos estes que advinham majoritariamente justamente das fileiras nobiliárquicas que ganhavam um 
crescente peso político na Gália. A gens francorum tinha outro sentido e valor nos textos hagiográficos, tal como a gens gothorum tinha um outro sentido e valor nas hagiografias visigodas. 


\section{Capítulo VI - Hagiografias}

\section{A vida dos santos, a vida política dos santos}

A mais evidente distinção entre as hagiografias ${ }^{544}$ e as Historiae se refere ao tema das narrativas. Ao contrário das Historiae que versavam sobre uma série de acontecimentos que envolviam diversos personagens as Hagiografias eram textos centrados na figura de um único personagem. Entretanto, essa é apenas a superfície da especificidade desses textos.

Eles estavam intimamente relacionados com o culto aos santos, algo que marcou profundamente o período aqui contemplado. ${ }^{545}$ A compreensão desses cultos e sua concretização nos textos das Hagiografias demanda a consciência de uma característica singular que diferenciava a nossa sociedade contemporânea da sociedade do Alto Medievo, a saber, a relação com a morte. Os mortos daqueles séculos não deixavam de ser parte da sociedade, antes de qualquer coisa a morte significava uma transição de status. Como sumarizou Geary:

The living continued to owe them certain obligations, the most important that of memoria, remembrance. This meant not only liturgical remembrance in the prayers and masses offered for the dead for weeks, months, and years but also the preservation of the name, the family, and the deeds of the departed. For one category of the dead, those venerated as saints, prayers for changed to prayers to. These "very special dead" in the phrase of Peter Brown, could act as intercessors on behalf of the living before God. But this difference was one of degree, not of kind. All the dead interacted with the living. Continuing to aid them, to warn or admonish them,

\footnotetext{
${ }^{544} \mathrm{O}$ termo "hagiografia" é relativamente moderno e designa uma grande quantidade de textos designados como vita, passio, etc. que versavam especificamente sobre as vidas dos homens e mulheres santos. Para uma discussão sobre o termo: PHILIPPART, G. Hagiographes et hagiographie, hagiologes et hagiologie: des mots et des concepts. Hagiographica. Rivista di agiografia e biografia dela Società Internazionale per lo studio del Medio Evo latino. n.1, p.1-16, 1994. Uma interessante discussão pode ser também encontrada em: PEREIRA, Ana Paula L. O relato hagiográfico como fonte histórica. Revista do Mestrado de História, v.9, n.10, p.161-170.

${ }^{545}$ BROWN, P. The rise and function of the Holy Man in Late Antiquity. The Journal of Roman Studies. v.6, p.80-101, 1971.
} 
even to chastise them if the obligations of memoria were not fulfilled. ${ }^{546}$

Nesse sentido, as Hagiografias cumpriam uma importante função na sobrevida dos defuntos e nos tons que suas memórias assumiriam no trato social. A análise da função social dessas pessoas distintas foi o tema de uma quantidade enorme de estudos cujo marco fundador foi o trabalho dos Bollandistas.

Os Bollandistas eram sacerdotes ligados à Companhia de Jesus e muito embora o título que receberam deve ao trabalho de uma de suas figuras mais eminentes, Jean Bolland, o início dos trabalho do grupo se deu com o padre Héribert Rosweyde que no ano de 1607 publicou um tratado intitulado Fasti sanctorum quorum hagiografias in Belgicis bibliotecas manuscriptae, ${ }^{547}$ o primeiro de outros estudos que viriam dedicados a produção de edições dos manuscritos que traziam as narrativas sobre as vidas dos santos. ${ }^{548}$

O exaustivo esforço iniciado por Rosweyde tinha acima de tudo uma motivação religiosa: a tentativa de reconstruir os textos originais que narravam as vidas dos santos era uma empreitada que visava prestar um serviço à Igreja ao reconstruir as histórias de seus santos. ${ }^{549}$ A santidade não era colocada em dúvida, a crítica aos manuscritos objetivava acima de tudo separar a veracidade da irrealidade para dignificar a memória dos santos e edificar os fiéis. Tal empreitada movida pela fé, entretanto, desde o início levantou dúvidas e críticas. O Cardeal Bellarmin

\footnotetext{
${ }^{546}$ GEARY, P. Living with the dead in the Early Middle Ages. Ithaca and London: Cornell University Press, 1994. p.2

${ }^{547}$ Os detalhes sobre o trabalho de Rosweyde que culminaram na publicação da obra podem ser encontrados em: DELEHAYE, H. L'ouvre dês Bollandistes. 1615-1915. Bruxelles: Bureaux de la Société dês Bollandistes, 1920. p.9-13.

${ }^{548}$ Os estudos sobre a história dos Bollandistas que serviram como referência para o nosso trabalho são: GORDINI, G.D. L'Opera dei bollandisti e la loro metodologia. In: Santità e agiografia. Atti dell'VIII Congresso di Terni. (A cura di Gian Domenico Gordini). Genova: Marietti, 1991. p.49-73. Ainda: ${ }^{548}$ DUBOIS, J. \& LEMAITRE, J.-P. Sources \& Méthodes de l'hagiographie médiévale. Paris: Les Éditions du CERF, 1993. p.46-49. E ainda o livro de autoria do mais eminente Bollandista do século XX: DELEHAYE, H. L'ouvre dês Bollandistes. 1615-1915. Bruxelles: Bureaux de la Société dês Bollandistes, 1920.

${ }_{549}$ BOESCH GAJANO, Sofia. Introdução. In: BOESCH GAJANO, S. (ed.). Agiografia altomedioevale. Bologna: Società editrice il Mulino, 1976. p.9-10.
} 
respondeu ao trabalho de Rosweyde com certo ceticismo ao salientar que o tom fantástico dos textos reunidos no volume poderiam suscitar mais risos que edificação: Ne forte in originalibus historiis multa sint inepta, levia, improbabilia, quad risum potius quam aedificationem pariant. ${ }^{550}$ Mesmo com as dúvidas o trabalho de Rosweyde continuou. Em 1616 ele publicou as Hagiografias Patrum que contemplavam o surgimento do monasticismo na Síria e no Egito e que seriam, conforme Delehaye, a pedra fundamental das Acta sanctorum. ${ }^{551}$

Com a morte de Rosweyde no dia 5 de outubro de 1629 o superior da Companhia de Jesus convidou Jean Bolland, coordenador de estudo no colégio dos Malines, a examinar os escritos de Rosweyde. Bolland mudou a direção do projeto inserindo nos compêndios santos que não constavam nas atas, mas cuja a existência era atestada nas fontes, além disso inseriu índices em todos os volumes. Diante da enormidade do trabalho Godefroid Henskens foi apontado para ajudar Bolland em 1635 e depois, em 1659, Daniel Papebroch passou a ajuda-lo. Esses três nomes são considerados os fundadores do grupo que se sagrou sob a alcunha de Bollandistas. ${ }^{552}$ O imenso trabalho redundou na publicação da primeira Acta Sanctorum cujo primeira volume tratava dos santos cujas festas eram celebradas no mês de janeiro.

Mesmo que Bolland tenha aprimorado os parâmetros críticos de análise e ampliado o trabalho de Rosweyde a motivação principal dos esforços de Bolland e seus ajudantes continuava a ser aquela que impulsionou o trabalho de Rosweyde, a saber, prestar um serviço para a Igreja mediante a reconstrução dos textos - e portanto das histórias - de seus santos. No primeiro tomo da Acta Sanctorum de janeiro essa motivação fica evidente nas palavras do próprio Bolland em sua dedicatória a Deus e

\footnotetext{
${ }^{550}$ Carta do Cardeal Bellarmin: APUD: DELEHAYE, H. L'ouvre dês Bollandistes. 1615-1915. Bruxelles: Bureaux de la Société dês Bollandistes, 1920. p.13.

${ }^{551}$ Ibidem, p.16-17.

${ }^{552}$ GORDINI, G.D. L'Opera dei bollandisti e la loro metodologia. In: Santità e agiografia. Atti dell’VIII Congresso di Terni. (A cura di Gian Domenico Gordini). Genova: Marietti, 1991. p.49-73.
} 
ao Papa:

Ipsos vicissim precor Sanctos, ut Te, et quam regis, Ecclesiam universam, favore atque ope caelesti fulcinant ae sustentent: utque gloria sanctitatis, serenato rursum caelo irradiet, Tuique temporis jucundissimam recordationem memoriae posterorum consecret sempiternae. Id supplex iterum et saepius voveo, aeternum. ${ }^{53}$

A dignificação da memória dos santos continuou a ser o motor dos

Bollandistas mesmo na fase contemporânea do grupo. H. Delehaye, o nome mais eminente entre os Bollandistas no século XX, autor de estudos críticos de suma relevância sobre as Hagiografias, mesmo que realizasse um estudo que confrontava o papel da santidade na sociedade, não questinava a própria santidade:

Allo stesso modo, quando moriva un santo vescovo o un illustre solitario, non si trovava lì per lì un letterato capace di traccia per le generazioni future la carriera del defunto. Non è forse una felice combinazione che si siano incontrati san Martino e Sulpicio Severo? Senza quest'ultimo, che cosa sapremmo di preciso sull'apostolo delle Gallie? È da presumere che, tra i santi confessori di cui la posterità ricorda poco più del nome, si trovassero dei capi spirituali e degli eroi della penitenza, ai quali è mancato solo un biografo per entrare nella categoria dei santi popolari, Il silenzio della storia non impediva ai contemporanei di conservare il ricordo delle virtù di quegli uomini di Dio, di serbare piamente la loro memoria e di ravvivarla con la celebrazione dell'anniversario, per mezzo di visite alla tomba, dove il santo prodigava le prove sensibili del suo potere d'intercessione. ${ }^{554}$

É evidente que ele não tinha essa obrigação, como um sacerdote se compreende sua própria fé nos santos. Não se trata aqui de criticar a fé de Delehaye ou de seus predecessores, trata-se antes de revelar a motivação principal dos Bollandistas que permaneceu ao longo dos séculos e permeou a edição das Atas dos Santos. A importância de salientar essa questão deriva do fato de que o serviço que prestavam à Igreja orientou o tratamento outorgado pelos Bollandistas às fontes. Se

\footnotetext{
${ }^{553}$ BOLLAND, J. Acta Sanctorum. Januarii Tomus Primus. p.VI.

${ }^{554}$ DELEHAYE, H. Problemi di metodo agiografico: le coordinate agiografiche e le narrazioni. In: BOESCH GAJANO, Sofia (ed.). Agiografia altomedioevale. Bologna: Società editrice il Mulino, 1976. p.49-71. [Originalmente publicado em: La méthode historique et l'hagiographie. Publicado em: Bulletin de la Classe des Lettres et des Sciences morales et politiques, 5e serie, VI (1930), p.218231] p.51.
} 
inegavelmente eles foram os principais responsáveis por habilitar as Hagiografias como documentos históricos legítimos, a motivação do trabalho deles trazia sempre o pressuposto de evidenciar a verdade sobre os santos nas fontes hagiográficas, mesmo que o significado do que era "verdade", sob a pena de Delehaye, tenha assumido novas tonalidades: é que para o erudito os critérios de verdade dos nossos tempos não servem para a produção textual dedicada à vida dos santos no medievo. Os critérios de verossimilhança daqueles autores fiavam-se sobretudo na tradição narrativa na qual se baseavam. Esse critério diverso de verossimilhança foi retomado anos depois da produção de Delehaye por autores como P. Geary ${ }^{555}$ e M. Heinzelmann ${ }^{556}$ sob outras perspectivas críticas, mas em Delehaye não sublimam o objetivo maior de identificar ao menos traços das vidas dos santos e, no que concerne à principal contribuição de sua obra, no estudo dos desdobramentos de seus cultos. ${ }^{557}$

Abordagens que salientam a função social dos santos sob um ponto de vista político aparecem em trabalhos posteriores como os de A.M. Orselli que salientou as mudanças nas funções desempenhadas pelos bispos nos séculos VI e VII, bispos estes que não raro eram elevados ao status de santos. A autora relaciona a mudança da “cultura dos santos" no período com a gradativa ênfase do papel dos bispos como patronos das suas cidades. O trabalho de Orselli exemplifica a sensível mudança que os estudos da santidade e das Hagiografias apresentam a partir da década de 1960 com novos enfoques na participação política desses personagens santos. As Hagiografias passam a ser analisadas sobretudo em seu papel na propagação de cultos

\footnotetext{
${ }^{555}$ GEARY, P. Living with the dead in the Early Middle Ages. Ithaca and London: Cornell University Press, 1994.

${ }^{556}$ HEINZELMANN, M. Manuscrits hagiographiques et travail des hagiographes: l'exemple de la tradition manuscrite des viés anciennes de sainte Geneviève de Paris. IN: HEINZELMANN, M. (ed). Manuscrits hagiographiques et travail des hagiographes. Sigmaringen: Thorbecke, 1992. p.9-16.

${ }^{557}$ Ibidem.
} 
locais relacionados com o crescente papel político que esses cultos assumem. ${ }^{558}$ Essa perspectiva foi notavelmente desenvolvida por P. Brown no seu artigo fundamental sobre a ascensão do Homem Santo que no trabalho do historiador é analisado acima de tudo como uma figura de poder num mundo em que as antigas instituições de autoridade foram substituídas por um novo senso de autoridade encerrada na figura do santo e na sua relação com a comunidade em que vivia e, após a sua morte, foi cultuado. $^{559}$

Essa mudança de perspectiva foi fundamental ao abrir novos caminhos de análise que interessam particularmente a esse trabalho, ou seja, o papel político das narrativas dedicadas à vida dos santos. Evidentemente que a abordagem política não é a única possível, ${ }^{560}$ a riqueza dessa natureza de textos permite uma série de desdobramentos interpretativos que, entretanto fogem ao nosso objetivo.

\footnotetext{
${ }^{558}$ ORSELLI, Alba Maria. Il Santo patrono cittadino: genesi e sviluppo del patrocinio del vescovo nei secoli VI e VII. In: BOESCH GAJANO, Sofia (ed.). Agiografia altomedioevale. Bologna: Società editrice il Mulino, 1976. p.85-104. [Originalmente publicado em: ORSELLI, A.M. L'idea e il culto del santo patron cittadino nella letteratura latina Cristiana. Bologna: Zanichelli, 1965. p.97-119.]

${ }^{559}$ BROWN, P. The rise and Function of the Holy Man in Late Antiquity. Journal of Roman Studies. v.6, p.80-101, 1971. Desde a publicação do texto de Brown uma quantidade imensa de trabalhos que enfatizam o papel político das hagiografias foram publicados. Destacamos aqui alguns: GRAUS, F. Le funzioni del culto dei santi e della leggenda. In: BOESCH GAJANO, Sofia (ed.). Agiografia altomedioevale. Bologna: Società editrice il Mulino, 1976. p.145-160. [Publicação original: "Die Funktionen des Heiligenkults und der Legenden. In: Volk, Herrscher und Heiliger im Reich der Merowinger. Praha: Nakladatelstvi Ceskoslovenske Akademier Ved, 1965. P.438-450. Tradução de Elisa Ranucci]. Os notáveis estudo de Rapp: RAPP, Claudia. 'For next to God, you are my salvation': reflections on the rise of the holy man in late antiquity. In: : HOWARD-JOHNSTON, J. \& HAYWARD, P.A. The cult of the Saints in Late Antiquity and the Early Middle Ages. Oxford: Oxford University Press, 1999. p.63-81. Ainda: RAPP, Claudia. Holy Bishops in Late Antiquity. The nature of Christian Leadership in an age of transition. Berkeley, LA, London: University of California Press, 2005.

${ }^{560} \mathrm{Um}$ exemplo entusiasmante de análise que contempla principalmente elementos retóricos desses textos pode ser encontrado no trabalho de A. Miatello: MIATELLO, A.L.P. Retórica religiosa e cívica na Itália do século XIII: a composição e os usos das hagiografias mendicantes nas políticas de paz. Tese apresentada ao Programa de Pós-Graduação em História Social da Faculdade de Filosofia, Letras e Ciências Humanas da Universidade de São Paulo para a obtenção do título de doutor em História Social. USP, São Paulo, 2010. p.29-30. Cabe ainda mencionar o trabalho de A. Cameron que enfoca principalmente na construção narrativa que esses textos representavam e no papel que eles desempenhavam na construção de modelos de virtude: CAMERON, Avril. On defining the Holy man. In: HOWARD-JOHNSTON, J. \& HAYWARD, P.A. The cult of the Saints in Late Antiquity and the Early Middle Ages. Oxford: Oxford University Press, 1999. p.27-43.
} 


\section{A especificidade das Hagiografias}

Como já apontava Delehaye ${ }^{561}$ as hagiografias são textos singulares por versarem sobre pessoas singulares, pessoas que se destacavam como membros especiais da sociedade por suas relações com Deus. ${ }^{562}$ A particularidade dos protagonistas das hagiografias nos trazem algumas questões de ordem metodológica que devem ser mencionadas.

Em primeiro lugar, como já apontamos, os critérios de veracidade desses textos são distintos das histórias. A verdade que era visada pelos narradores era sobretudo relacionada com a evidenciação da santidade de seus protagonistas, nesse sentido as referências dos hagiógrafos eram primordialmente outras hagiografias, era a especificidade da narrativa hagiográfica que ressaltava a santidade que servia como critério de veracidade mais do que, como apontou Geary, alguma realidade putativa. ${ }^{563}$ A partir dessa perspectiva a análise da tradição literária hagiográfica seria o caminho possível para a percepção da "realidade hagiográfica". Tal abordagem é interessante sobretudo por revelar os topoi dos textos hagiográficos, entretanto, se adotada exclusivamente acaba por negligenciar um outro elemento comum a esses textos muito bem sublinhado por P. Fouracre: as hagiografias não só transmitiam tradições, mas também criavam novas tradições a partir do estabelecimento do culto de novos santos. ${ }^{564}$ Dessa forma apenas a análise dos topoi não basta para a compreensão desses textos muito devido a uma outra característica das hagiografias: sua função propagandística.

\footnotetext{
${ }^{561}$ DELEHAYE, H. Problemi di metodo agiografico: le coordinate agiografiche e le narrazioni..op.cit.

${ }^{562}$ Sobre a distinção dos santos em relação aos outros membros da sociedade: LEONARDI, Claudio. Agiografie Medievali. DEGL'INNOCENTI, A. \& SANTI, F. (Eds.). Firenze: SISMEL . Edizioni del Galluzo, 2011.

${ }^{563}$ GEARY, P. Living with the dead in the Early Middle Ages. Op.cit. p. 17.

${ }^{564}$ FOURACRE, P. Merovingian History and Merovingian Hagiography. Past and Present. n. 17, p.338, maio de 1990. p.8.
} 
A questão é que muito embora algumas informações passíveis de conformação com outras fontes fora do gênero hagiográfico possam ser encontradas nas hagiografias, em termos gerais esses textos dizem mais sobre a imagem do santo que se queria construir e as orientações de seu culto do que sobre, por exemplo, detalhes acerca de batalhas, ou, como se convencionou dizer "uma realidade empírica". A "realidade" da narrativa hagiográfica era outra e estava relacionada com a função desses textos que eram fundamentalmente peças propagandísticas. ${ }^{565} \mathrm{O}$ fato é que as hagiografias visavam preservar uma determinada memória dos santos para contribuir com a propagação de seu culto. Esse aspecto é chave para a compreensão das especificidades desses textos e deve sempre ser uma referência em suas interpretações. A especificidade da narrativa hagiográfica e a realidade que esses textos podem revelar estão intimamente relacionadas com o objetivo central desses textos que era promover o culto de um santo ou de uma santa comumente identificados com uma comunidade.

Há um outro ponto importante a se destacar acerca das hagiografias. Se trata da singularidade da tradição manuscrita desses textos. Um texto hagiográfico era sobretudo dinâmico, ou seja, era escrito e reescrito, sofria interpolações e mudava de significados. ${ }^{566}$ Um exemplo famoso dessa característica é a vida de Balthilda cuja primeira versão é do período merovíngio e a segunda é do período carolíngio, já as Vidas dos Padres de Mérida parece ter sofrido uma segunda revisão que interpolou a

\footnotetext{
${ }^{565}$ Como bem salientaram: GRAUS, F. Le funzioni del culto dei santi e della leggenda. In: BOESCH GAJANO, Sofia (ed.). Agiografia altomedioevale. Bologna: Società editrice il Mulino, 1976. p.145160. [Publicação original: "Die Funktionen des Heiligenkults und der Legenden. In: Volk, Herrscher und Heiliger im Reich der Merowinger. Praha: Nakladatelstvi Ceskoslovenske Akademier Ved, 1965. P.438-450. Tradução de Elisa Ranucci]. Ainda: GEARY, P. Living with the dead in the Early Middle Ages. Op.cit.. p.12-13. GRÉGOIRE, R. Agiografia: tra storia, filosofia, teologia. In: Santità e agiografia. Atti dell'VIII Congresso di Terni. (A cura di Gian Domenico Gordini). Genova: Marietti, 1991. p.15-24.

${ }^{566}$ HEINZELMANN, M. Manuscrits hagiographiques et travail des hagiographes: l'exemple de la tradition manuscrite des viés anciennes de sainte Geneviève de Paris. IN: HEINZELMANN, M. (ed). Manuscrits hagiographiques et travail des hagiographes. Sigmaringen: Thorbecke, 1992. p.9-16.
} 
vida de São Frutuoso de Braga ${ }^{567}$ Diante dessa característica autores como Geary e Heinzelmann sugerem que o estudo das hagiografias deve sempre levar em conta a tradição manuscrita desses textos e, principalmente, a especificidade desses manuscritos. De fato, para Geary o pouco desenvolvimento dos estudos das hagiografias se deve justamente à falha dos historiadores em levar isso em consideração. ${ }^{568}$

Embora as colocações dos pesquisadores sejam de enorme relevância o risco de adotar esse tipo de aproximação é o de cairmos mais numa história de manuscritos particulares do que numa história que forneça uma visão ampla do papel desses santos nas sociedades em que viveram. Não obstante, interpolações e novas redações de textos, embora mais recorrentes no caso das hagiografias, não são exclusividades de textos hagiográficos. Os Decem Libri Historiarum de Gregório de Tours, por exemplo, tem uma tradição manuscrita marcada por novas redações como se pode constatar pelo trecho da obra reescrito na crônica de Fredegário. Assim, nesse trabalho consideraremos a tradição manuscrita das hagiografias e adotaremos uma postura crítica diante das edições, tratamento que damos a todas as outras fontes, mas sem com isso perder de vista que nosso objetivo ao analisar essas tradições não é apontar para especificidades de manuscritos, mas para a circulação das idéias que esses textos tiveram na época em que foram produzidos.

Assim, o tratamento metodológico que outorgaremos a esses textos consistirá em:

1. Considerar a tradição manuscrita como um todo para avaliarmos a circulação desses textos;

2. Ter em vista a natureza propagandista dessas fontes.

\footnotetext{
567 MAYA SÁNCHEZ, A. Introdução. In: Vitas Sanctorum Patrum Emeritensium. Corpus Christianorum. Series Latina. CXVI. Turnholt: Brepols, 1992. p.XXXVII-XXXVIII

${ }^{568}$ GEARY, P. Living with the dead in the Early Middle Ages. Op.cit.. p.20.
} 


\section{Hagiografias visigodas}

Comparada com a produção hagiográfica da Gália Merovíngia a Hispânia Visigoda produziu poucas hagiografias: As Vidas dos Padres de Mérida, A vida de Desidério, a Vida de Frutuoso, os "O homens Ilustres" de Isidoro de Sevilha, "Os homens Ilustres" de Ildelfonso de Toledo e a Vida de Emiliano de Bráulio de Saragoça. Isso não significa que essa produção foi desimportante. Como bem salientou M. Valverde Castro, o estudo das hagiografias visigodas, por muito tempo negligenciadas em detrimento de fontes legais ou dos textos isidorianos, tem trazido nova luz ao problema da abrangência do poder real visigodo nas regiões periféricas do reino. ${ }^{569}$ Não por acaso, essas hagiografias, tal como as Vitas Sanctorum Patrum Emeretensium, trazem nuanças das especificidades regionais da Hispânia visigoda que nos ajudam a problematizar uma série de questões relacionadas com o poder real e suas relações com os homens santos que atuavam nas regiões mais distantes do centro real de Toledo. Analisemos então alguns desses textos que foram selecionados a partir de suas informações acerca das identidades políticas.

\section{Problemas gerais da tradição manuscrita das hagiografias visigodas}

Como de praxe nos textos produzidos no período do nosso interesse os manuscritos que sobreviveram com as hagiografias visigodas são tardios. ${ }^{570} \mathrm{~A}$ Vita Desiderii de Sisebuto, por exemplo, conta com uma tradição manuscrita muito tardia cujo o manuscrito mais antigo, o Madrid BN 1346, data do século XVI. Já as Vita Sanctorum Patrum Emeretensium tem por manuscrito considerado o mais antigo o

\footnotetext{
569 VALVERDE CASTRO, M.R. La monarquía visigoda en Valerio del Bierzo. Edad Media. Rev.Hist. n.12, p.281-300, 2011.

570 Todos os dados são baseados no banco de dados Mirabile: http://www.mirabileweb.it/author/braulio-caesaraugustanus-episcopus-sedit-631-651-author/19651 e http://www.mirabileweb.it/title/de-viris-illustribus-title/2399 Para o caso das Vitas Sanctorum Patrum Emeritensium nos fiamos principalmente na edição da obra feita por A. Maya Sánchez: Corpus Christianorum, Series Latina, CXVI. Edição: A. Maya Sánchez. Turnholt: Brepols, 1992. p.X-XXVIII
} 
Madrid - Archivo Hist. Nac., carpeta 1452 B, fragm. $n .5$, muito fragmentado e composto por volta de $900 .{ }^{571}$ Por sua vez, a Vita Aemiliani de Bráulio de Zaragoza possui como manuscritos mais antigos dois manuscritos do século X, o El Escorial, Real Biblioteca de San Lorenzao de El Escorial, a.II.9 III e o Madrid, Biblioteca de la Real Academia de la Historia, Códices 13 (F. 177; 6) - s.X. Como veremos, esse padrão se repete no caso das hagiografias merovíngias cuja época de produção dos manuscritos se concentra no século XII. Entretanto, no caso das hagiografias visigodas, o De Viris Illustribus de Isidoro de Sevilha foge sensivelmente do padrão. Primeiro por ter manuscritos bem antigos para a média, por exemplo, o Bern, Universitätsbibliothek. Burgerbibliothek (Bibliotheca Bongarsiana) 289 datado entre os século VIII e IX; segundo por ter uma grande quantidade de manuscritos com o texto - por volta de cinqüenta e sete - o que implica numa tradição manuscrita sólida com uma grande circulação do texto. Mesmo assim, há uma desproporcionalidade dos manucritos com o De Viris Illustribus do hispalense no que concerne a distribuição temporal desses textos como podemos observar a seguir.

Tabela 10: Manuscritos De Viris Illustribus de Isidoro de Sevilha

\begin{tabular}{|c|c|c|c|c|c|}
\hline Sec. VIII/IX & Sec. IX & Sec.X & $\begin{array}{c}\text { Sec.X } \\
\text { I }\end{array}$ & Sec.XII & Sec. XIII \\
\hline $\begin{array}{c}\text { 1. Bern, } \\
\text { Universitätsbiblioth } \\
\text { ek. } \\
\text { Burgerbibliothek } \\
\text { (Bibliotheca } \\
\text { Bongarsiana) } 289 \text { - }\end{array}$ & $\begin{array}{l}\text { 1. León, } \\
\text { Archivo- } \\
\text { Biblioteca de la } \\
\text { Santa Iglesia } \\
\text { Catedral } 22 \\
\text { 2. Madrid, } \\
\text { Biblioteca de la } \\
\text { Real Academia } \\
\text { de la Historia, } \\
\text { Códices } 80 \text { (3; } \\
\text { 12-11-1/3) } \\
\text { 3. Montpellier, } \\
\text { Bibliothèque } \\
\text { Interuniversitai } \\
\text { re, Section de }\end{array}$ & $\begin{array}{l}\text { 1. El Escorial, Real } \\
\text { Biblioteca de San } \\
\text { Lorenzo de El } \\
\text { Escorial d.I.1 } \\
\text { «Codex } \\
\text { Aemilianensis» } \\
\text { 2. Bern, } \\
\text { Universitätsbiblioth } \\
\text { ek. } \\
\text { Burgerbibliothek } \\
\text { (Bibliotheca } \\
\text { Bongarsiana) } 676 \\
\text { 3. El Escorial, Real } \\
\text { Biblioteca de San } \\
\text { Lorenzo de El }\end{array}$ & & $\begin{array}{l}\text { 1. } \\
\text { Cambridge } \\
\text { University } \\
\text { Library } \\
\text { Kk.IV.6 } \\
\text { (2021) - } \\
\text { s.XII } \\
\text { 2. Città del } \\
\text { Vaticano, } \\
\text { Biblioteca } \\
\text { Apostolica } \\
\text { Vaticana, } \\
\text { Barb. lat. } \\
\text { 550 (olim } \\
\text { XI 193) - }\end{array}$ & $\begin{array}{l}\text { 1. Città del } \\
\text { Vaticano, } \\
\text { Biblioteca } \\
\text { Apostolica } \\
\text { Vaticana, Reg. } \\
\text { lat. 551 - } \\
\text { s.XIII } \\
\text { 2. Firenze, } \\
\text { Biblioteca } \\
\text { Medicea } \\
\text { Laurenziana, } \\
\text { Pl. 22 dext. 12 } \\
\text { - s. XIII } \\
\text { 3. Leiden, } \\
\text { Bibliotheek }\end{array}$ \\
\hline
\end{tabular}

${ }^{571}$ Corpus Christianorum, Series Latina, CXVI. Edição: A. Maya Sánchez. Turnholt: Brepols, 1992. p.X-XXVIII. 


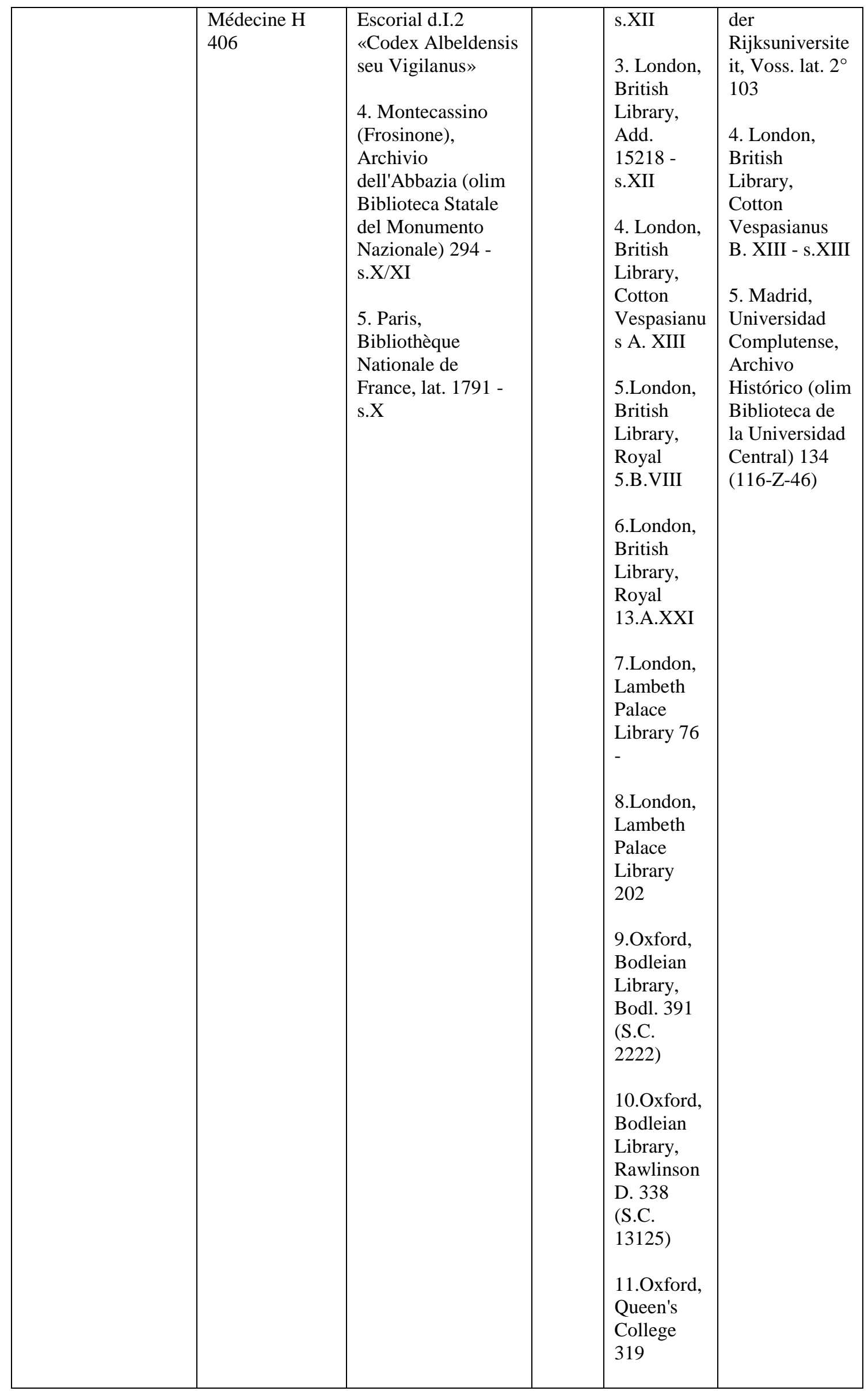




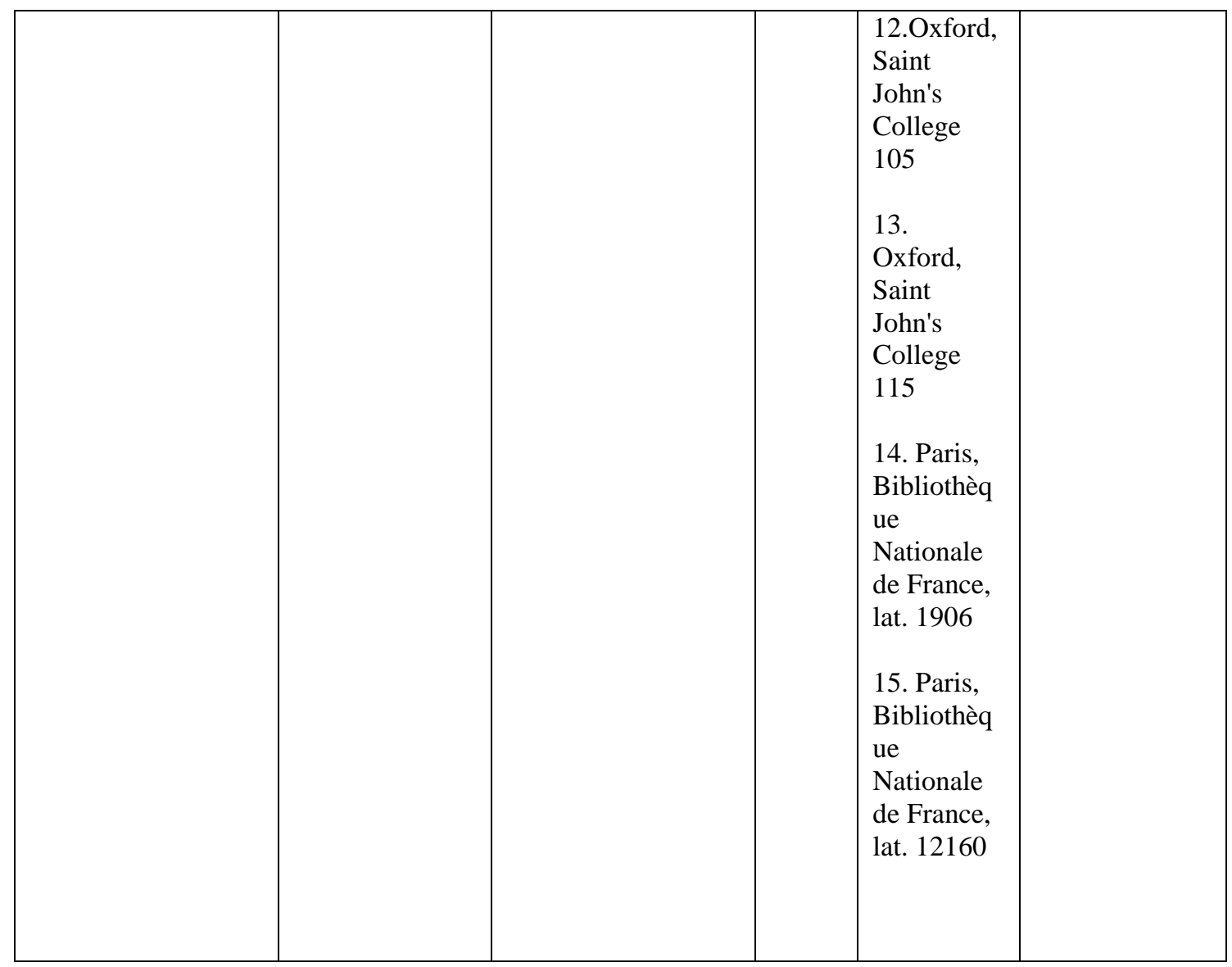

\begin{tabular}{|c|c|c|}
\hline \multirow{6}{*}{\begin{tabular}{l}
\multicolumn{1}{c}{ Sec. XIV } \\
1.Cambridge, King's \\
College 9 - s.XIV-XV \\
\\
2. Firenze, Biblioteca \\
Medicea Laurenziana, \\
Conv. soppr. 447
\end{tabular}} & Sec. XV & Sec. XVI \\
\hline & 1.Bruxelles, Bibliothèque & 1. Città del Vaticano, \\
\hline & Royale «Albert Ier» 144 & Biblioteca Apostolica \\
\hline & $(1264)$ & Vaticana, Ottob. lat. 1720 \\
\hline & 2. Cambridge, Corpus & 2. El Escorial, Real \\
\hline & Christi College 331 (V. 2) & Biblioteca de San Lorenzo \\
\hline & 3. Città del Vaticano, & \\
\hline & Biblioteca Apostolica & 3. London, British \\
\hline & Vaticana, Chig. A.V.131 & Library, Egerton 1873 \\
\hline & 4. Città del Vaticano, & 4. Madrid, Biblioteca \\
\hline & 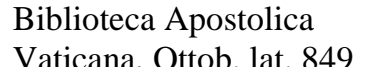 & Nacional 1376 \\
\hline & & 5. Roma, Biblioteca \\
\hline & $\begin{array}{l}\text { 5. Città del Vaticano, } \\
\text { Biblioteca Apostolica }\end{array}$ & Vallicelliana C. 19 \\
\hline & $\begin{array}{l}\text { Vaticana, Urb. lat. } 382 \\
\text { (606) }\end{array}$ & $\begin{array}{l}\text { 6. Roma, Biblioteca } \\
\text { Vallicelliana C. } 23\end{array}$ \\
\hline & $\begin{array}{l}\text { 6. Firenze, Biblioteca } \\
\text { Medicea Laurenziana, Pl. } \\
23.20\end{array}$ & $\begin{array}{l}\text { 7. Segorbe, Museo } \\
\text { Catedralicio Diocesano G } \\
1(+)\end{array}$ \\
\hline
\end{tabular}


7. Firenze, Biblioteca Nazionale Centrale, Conv. soppr. I.7.46

8. Firenze, Biblioteca Riccardiana 410

9. London, British Library, Harley 6503

10. Madrid, Biblioteca Nacional 10224

11. Milano, Biblioteca Ambrosiana I 51 sup.

12. München, Bayerische Staatsbibliothek, Clm 748 (Vict. 35)

13. Salamanca, Universidad de Salamanca. Biblioteca General Histórica, Ms. 2313

14. Siena, Biblioteca Comunale degli Intronati K.VII.3

15. Uppsala, Universitetsbibliotek (Carolina), C 918

16. Wien, Österreichische Nationalbibliothek 138

17. Wolfenbüttel, Herzog August Bibliothek, Aug. $2^{\circ} 83.8$
8. Toledo, Archivo y Biblioteca Capitulares (olim Biblioteca del Cabildo) 27-26 - s.XVI 


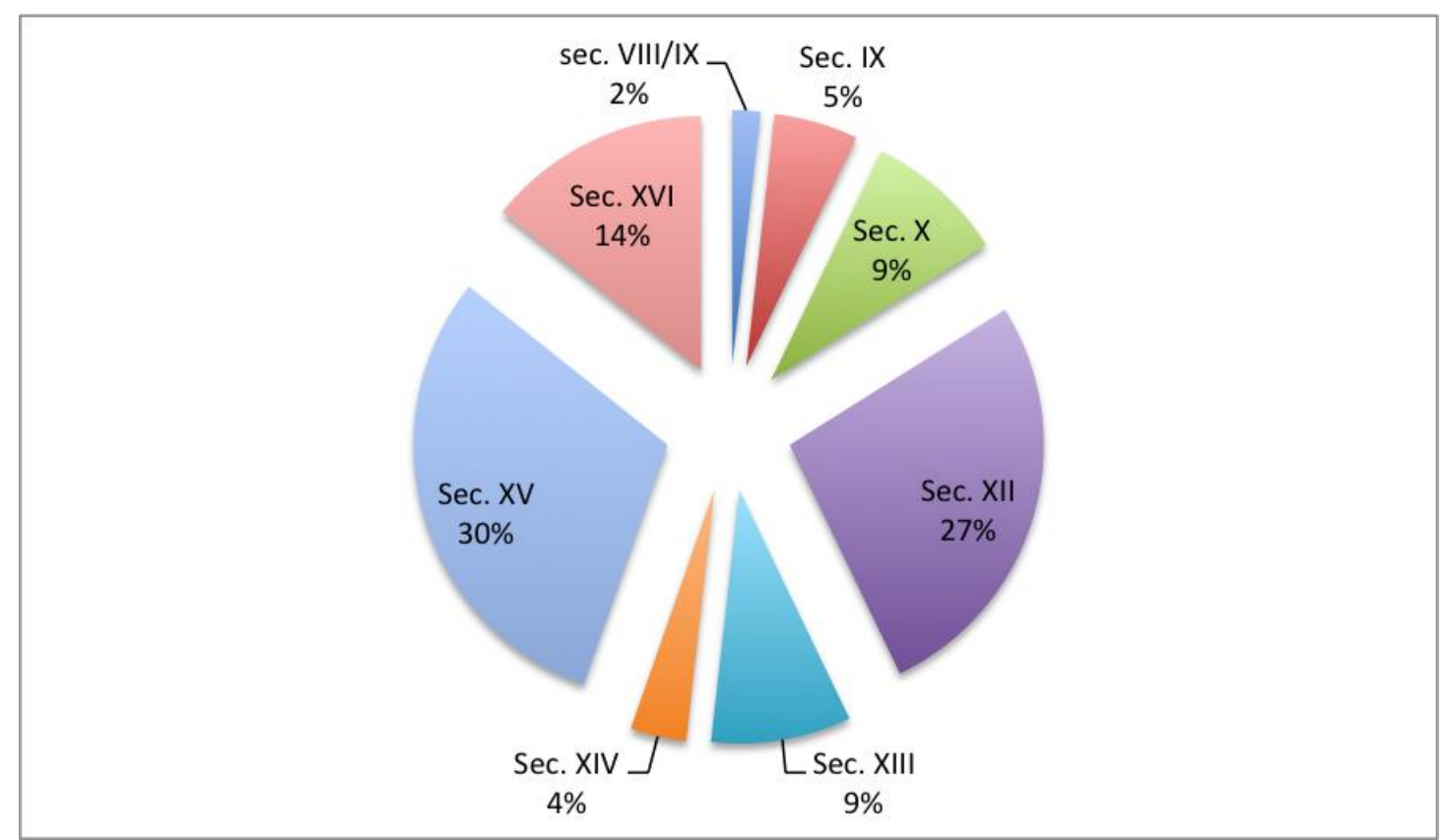

Gráfico 12 - Distribuição temporal dos mss. com o De Viris Illustribus de Isidoro de Sevilha

A tradição não foge do padrão no que se refere à concentração de manuscritos no século XII no que concerne ao período dito medieval. Entretanto, observa-se que a maior quantidade de manuscritos com o texto é do século XV. No caso da Vita Aemiliani de Braulio de Zaragoza a concentração de manuscritos se localiza no século XI, que produziu seis dos dezessete manuscritos com a Vita formando o seguinte quadro: $: 572$

\footnotetext{
${ }^{572}$ Excluímos os manuscritos do século XVII - Madrid, Biblioteca Nacional 13060 e Roma, Biblioteca
} Alessandrina (Universitaria) 99. 


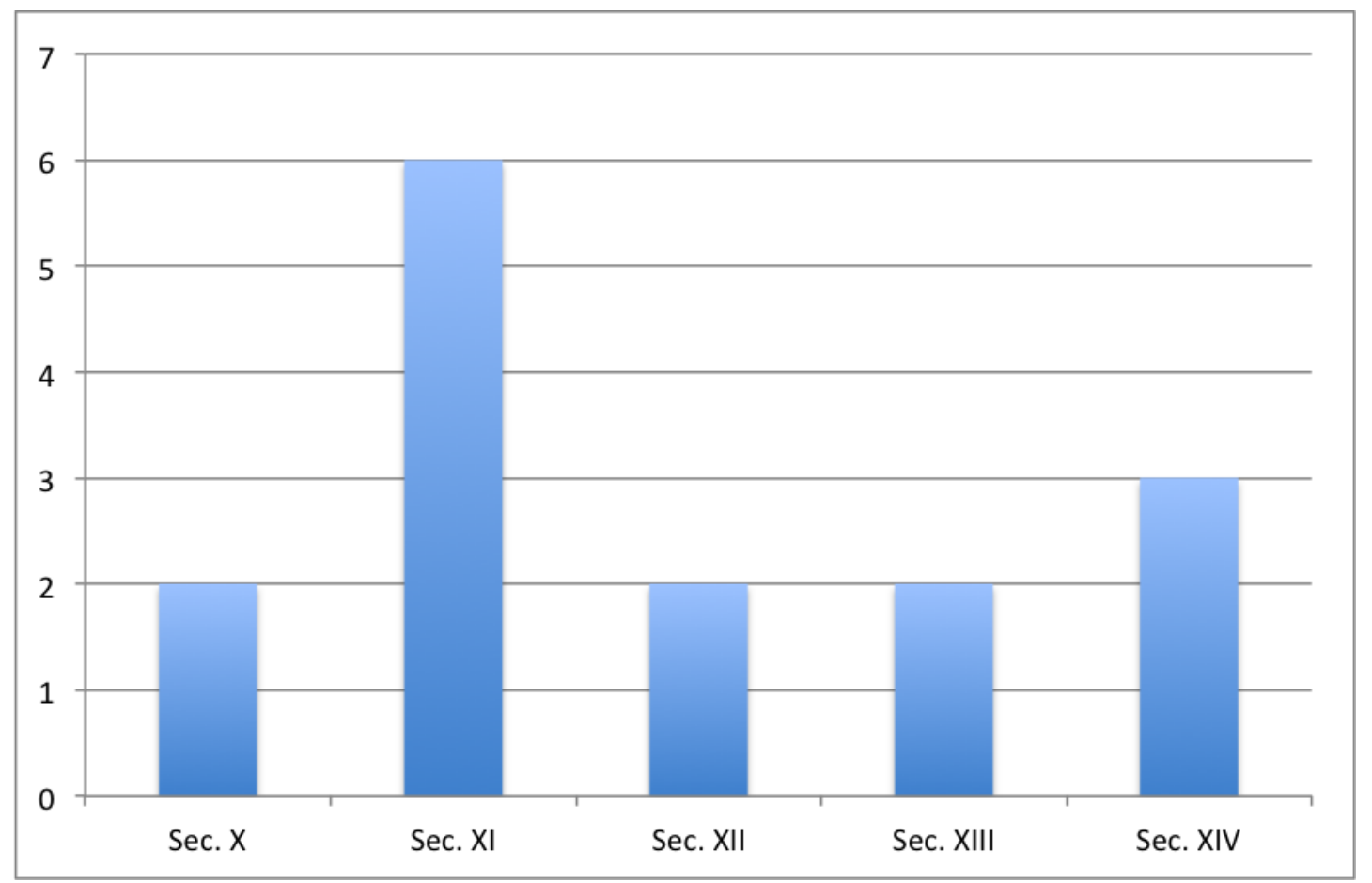

Gráfico 13 - Distribuição temporal dos mss. Com a Vita Aemiliani de Bráulio de Zaragoza

Temos então que exceto por dois manuscritos do De Viris Illustribus de Isidoro de Sevilha lidamos com o problema de uma tradição manuscrita muito tardia. As implicações disso tocam em problemas muito semelhantes aqueles concernentes à tradição manuscrita das hagiografias merovíngias de modo que o tema será desdobrado no tópico 1 da parte III. Mesmo assim, cabe adiantar nosso posicionamento diante da questão: a tradição manuscrita com tal característica implica na necessidade de termos um posicionamento crítico diante dessas fontes no que tange aos seus limites e as possibilidades desses textos terem sofrido grande modificações a posteriori. Isso não significa que devemos ignorar o valor histórico deles para o período que nos interessa aqui, indica antes a importância de confrontarmos esses textos com outras fontes da Hispânia Visigoda para observarmos a verossimilhança entre eles e identificar com mais parcimônia as interpolações ocorridas ao longo dos séculos. A. Maya Sanchéz, em sua excelente edição das Vitas Sanctorum Patrum Emeritensium seguiu esse pressuposto crítico e o resultado foi uma crítica da tradição manuscrita que redundou numa nova interpretação sobre a 
abrangência e, mais importante, significado do texto. Evidentemente o nosso trabalho não consiste numa edição de modo que desdobrar o problema das tradições manuscritas não soa pertinente. Entretanto, consideramos de crucial importância trabalhar de maneira consciente com esses textos no que se refere aos problemas que a transmissão deles aos nossos dias envolve. Dificilmente podemos afirma que temos um texto exatamente tal como foi escrito por, por exemplo, Bráulio de Zaragoza, entretanto, pelo confronto com outras fontes podemos identificar o que no discurso das fontes atribuídas a ele se encaixava no cenário geral do contexto textual da Hispânia Visigoda. É esse norte que seguimos no análise dessas fontes.

\section{Os santos visigodos - contrastes e alianças entre poderes locais e poderes centrais nas Vitas Sanctorum Patrum Emeretensium}

Como bem enfatizou Valverde Castro $^{573}$ as hagiografias visigodas consistem num importante conjunto de fontes que nos trazem informações sobre as regiões mais periféricas do reino visidodo contempladas marginalmente pelas fontes produzidas nos círculos mais próximos à realeza visigoda - como as obras de Isidoro de Sevilha, as leis e mesmo as atas conciliares. O tema tem sido tratado com maestria nos últimos anos por historiadores que voltaram suas atenções a essas fontes por muito tempo negligenciadas e que centram seus estudos nas relações entre os reis e os nobres nas regiões periféricas da península. Além dos trabalhos da já mencionada Valverde Castro, destacam-se os estudos de S. Castellanos e R. Frighetto nessa linha de pesquisa. ${ }^{574}$ À luz dos trabalhos desses historiadores objetivamos assim contribuir

\footnotetext{
${ }^{573}$ VALVERDE CASTRO, M.R. La monarquía visigoda en Valerio del Bierzo...op.cit.

574 Dentre os trabalhos de Castellanos podemos citar: CASTELLANOS, S. Poder Social, Aristocracias y hombre santo en la Hispania Visigoda: La Vita Aemiliani de Braulio de Zaragoza. La Rioja: Universidad de la Rioja, 1998. Ainda: CASTELLANOS, S. Conflictos entre la autoridade y el hombre santo. Hacia el control oficial del Patronatus Caelestis en la Hispania Visigoda. Brocar, n.20, p.77-89, 1996. Mais recentemente: CASTELLANOS, S. \& MARTÍN VISO, I. The local articulation of central power in the north of the Iberian Peninsula (500-1000). Early Medieval Europe,
} 
com os debates a partir de um outro ponto de vista, a saber, a questão das identidades políticas, outrora identificadas como "étnicas", mobilizadas como aparato para lidar com questões políticas nas fontes hagiográficas.

No que concerne à política no seu nível mais óbvio, a saber, as ações dos reis, essas hagiografias por vezes trazem uma imagem sensivelmente distinta da realeza e da nobreza godas em relação as histórias. Isso fica muito evidente nos trechos referentes a Leovigildo presentes nas Vitas Sanctorum Patrum Emeretensium. O rei, considerado legítimo por João de Biclaro e Isidoro de Sevilha especialmente em confronto com o príncipe rebelde Hermenegildo, qualificado como "tirano" "575 pelos dois cronistas, nas Vitas Sanctorum Patrum Emeretensium é por outro lado qualificado como o tirano uma vez, que pela recusa de Masona de Mérida em aderir ao arianismo, Leovigildo nomeou um novo bispo para Mérida, um aliado seu, conhecido por Sunna:

Conperto dehinc crudelissimus tyrannus quod nec minis neque muneribus uiri Dei animum a recta fide ad sue perfidiam apostatare posset, ut erat totus uas ire fomesque uitiorum ac frutex damnationis, cuius obsedebat pectus truculentior hostis et captiuum in sua dicione tenebat callidissimus serpens, amara pro dulcia, pro lenibus aspera obtulit ciuibus, pro salute medicamenta mortifera. Quendam scilicet uirum pestiferum Arriane hereseos prauitatem per omnia uindicantem, cui nomen erat Sunna, pro seditiosis simultatibus excitandis et pro conturbationem sanctissimi uiri uel totius populi in eadem ciuitatem episcopum Arriane partis instituit... $^{576}$

v.13, n.1, p.1-42, 2005. R. Frighetto se confirma hoje entre um dos mais profícuos estudiosos da Hispania Visigoda com um enorme volume de publicações. No que concerne ao problema dos homens santos podemos destacar: FRIGHETTO, R. Sociedade e Cultura no NO. Peninsular Ibérico em finais do século VII, segundo o De Genere Monachorum de Valério do Bierzo.Gallaecia, v.8, p.363-373, 1999. Mais recentemente: FRIGHETTO, R. Infidelidade e barbárie na Hispania visigoda. Gerión, v.20, n.1, p.491-509, 2002.

${ }^{575}$ Em João de Biclaro: 3. Leovegildo ergo quieta pace regnante adversariorum securitatem domestica rixa conturbat. nam eodem anno filius eius Hermenegildus factione Gosuinthae reginae tyrannidem assumens in Hispali civitate rebellione... João de Biclaro, Chronica - an.III de Tibério e XI de Leovigildo. Já em Isidoro de Sevilha: Hermenegildum deinde filium imperiis suis tyrannizantem obsessum exsuperauit. Isidoro de Sevilha, Historia Gothorum, 40.

${ }^{576}$ Vitas Sanctorum Patrum Emeretensium, V, V. 
O sentido de "tirano", ${ }^{577}$ que nas fontes visigodas comumente se referia a quem ilegitimamente tentava usurpar a autoridade real, no caso da Vitas Sactorum Patrum Emeretensium assume um outro significado, dessa vez duplo, deslegitimiza Leovigildo por sua crueldade e se aplica ao iniciar os relatos que desembocariam na elevação de Sunna à sede de Mérida usurpando assim a autoridade legítima de Masona na cidade.

O que percebemos é uma fonte que descreve muito bem uma série de questões importantes: a autoridade dos bispos nas cidades, de tal forma reconhecida que um termo, "tirano", comumente utilizado em referência à autoridade real, é aplicado para denunciar a elevação de Sunna em detrimento a Masona; as origens nobiliárquicas desses bispos, as oposições regionais à autoridade central de Toledo e o interesse dos reis em cooptar esses bispos em regiões mais periféricas.

Como percebemos, a primeira estratégia de Leovigildo foi tentar trazer Masona para o seu lado, não foi um movimento equivocado. Como a própria fonte nos revela o bispo era um homem de origem nobre identificado como um godo "Denique sanctus Masona antestis nobilis hortus in hoc seculo origine, sed uite meritis extitit multo nobilior; genere quidem Gotus..." 578 , ter um nobre que controlava uma sede episcopal como inimigo era politicamente perigoso para o rei. Mesmo que o primeiro movimento tenha sido de reconciliação, a recusa de Masona em aceitar as propostas de aliança com Leovigildo redundaram na escolha de Sunna como o novo bispo de Mérida. Evidentemente que devemos colocar em dúvida o relato da fonte, talvez algo que ia muito além de religiosidade - o problema do

\footnotetext{
${ }^{577}$ O sentido da "tirania" nas fontes visigodas tem como estudo principal o trabalho de J. Orlandis: ORLANDIS, J. Estudios visigoticos III: El poder real y La sucesion al trono en la monarquia visigoda. Cuadernos del instituto juridico español n.16. Madrid-Roma: Consejo superior de investigaciones cientificas. Delegacion de Roma, 1962. Uma definição mais recente, mas ainda na linha dos estudos de Orlandis, pode ser encontrada em: GARCÍA MORENO, L.A. Alaric II et l'Espagne. In: ROUCHE, M. \& DUMÉZIL, B. Le Bréviaire d'Alaric. Aux origines du Code Civil. Paris: PUPS, 2008. p. 112.

${ }^{578}$ Vitas Sanctorum Patrum Emeretensium, V, II.
} 
arianismo - tenha motivado Masona a se opor a Leovigildo. É difícil precisar qual foi a real motivação de Masona, de fato o que temos são informações circunstanciais que dizem muito sobre as relações entre o poder real e as autoridades regionais na Hispania visigoda. E o exemplo de Masona, desde o início da narrativa sobre a sua vita, mostra que havia uma intensa relação entre poderes regionais e reais. O exemplo das tensões entre Masona e Leovigildo é apenas uma face da situação.

Tão logo Recaredo é mencionado pela vida há uma evidente inversão de posições. Masona, outrora um opositor do poder real se torna um aliado enquanto Sunna outrora um aliado se torna um opositor. Na linha dessa virada política o tom sobre o poder real também muda, se no início era negativo, com a ascensão de Recaredo começa a ser celebrado a partir da celebração da conversão do rei que conduziu toda a gens gothorum à verdadeira fé:

Post cuius crudelissimam mortem [de Leovigildo] uenerabilis uir Recaredus princeps, filius eius, iure administratione regni adeptus est meritoque ad culmen sibi deuite principatus euectus est [...] sed Xpum sequens Dominum ab Arriana hereseos prauitate conuersus est totumque Wisegotorum gentem mira predicatione ad ueram fidem perduxit. ${ }^{579}$

Sunna, fragilizado, por sua vez iniciou a sua oposição que mirou inicialmente

Masona. Para tanto ele cooptou bispos e nobres godos para que se opusessem a Masona:

Sunna namque Gotus episcopus, cuius supra memoriam fecimus, irritatus a diabolo quosdam Gotorum nobiles genere opibusque perquam ditissimos e, quibus etiam nonnulli in quibusdam ciuitatibus comites a rege fuerant constituti, consilio diabolico persuasit eosque de catholicorum hagmine ac gremio catholice eclesie cum innumerabile multitudine populi separauit et contra famulum Dei Masonam episcopum fraudulenta consilia, qualiter eum interficeret, commentabit ${ }^{580}$

\footnotetext{
${ }^{579}$ Vitas Sanctorum Patrum Emeretensium, V, IX.

${ }^{580}$ Vitas Sanctorum Patrum Emeretensium, V, X.
} 
Essa oposição, todavia, transcendeu uma disputa entre dois bispos de Mérida. O que se observa é uma mobilização advinda desde Toledo para resolver o problema em curso na cidade, de fato, Cláudio, dux de origem romana que já mencionamos como um aliado importante de Recaredo que liderou tropas vitoriosas contra os francos, interveio no levante de Sunna. Um dos aliados de Sunna, Viterico, que um dia se tornaria rei dos godos, arrependeu-se e abandonou o antigo aliado para se submeter à autoridade de Masona, Cláudio e, em última instância, ao próprio rei Recaredo. A participação de Viterico na rebelião, homem que depois seria o responsável pela morte de Liuva II, filho de Recaredo, indica que a revolta transcendeu a região de Mérida. Não é absurdo supor que essa revolta tinha o objetivo maior de derrubar o próprio rei.

Nessas disputas que envolveram autoridades regionais e a autoridade do rei dos godos uma série de discursos identitários foram levantados e a particularidade da narrativa da fonte nos revela a complexidade dessas filiações identitárias e o quanto elas eram articuladas num cenário de alianças e disputas. Logo de início chama a atenção o emprego do termo Wisegothus para se referir a Leovigildo ${ }^{581}$ e depois para se referir a gens que estava sob a influência do arianismo até a ascensão de Recaredo como rei dos godos. De fato, até o surgimento das Vitas Sanctorum Patrum Emeretensium o termo não aparece. Em textos posteriores, como a Historia Wambae também não. $\mathrm{O}$ fato é que estamos lidando com um emprego particular do termo que nessa fonte em específico tem um significado que nos parece muito evidente, o termo é sempre empregado num sentido de totalidade, a saber, da totalidade da gens gothorum. Por outro lado, o emprego do termo gothus tem um outro sentido, a saber, refere-se a grupos nobiliárquicos específicos. Isso se evidencia no emprego do termo

581 ...crudelissimi Wisigotorum Leouigildi regis... Vitas Sanctorum Patrum Emeretensium. V, IV. 
em duas ocasiões, para falar da origem de Masona e depois para se referir aos nobres que se aliaram a Sunna contra Masona. Isso pode significar que grupos relacionados com o grupo de Masona se opôs à ele, e, para enfrentar essa oposição, ele contou com Cláudio, este, por sua vez, um dux de origem romana:

Idem uero Claudius nobili genere hortus Romanis fuit parentibus progenitus; existebat prossus fide catholicus et religionis uinculis fortiter adstrictus, in prellis strenuus, in timore Dei ualde promtissimus, in bellica studia eruditus, in causis bellicis nicilominus exercitatus. ${ }^{582}$

São então três discursos identitários que se revelam nesse contexto de disputa, o unitário inserido no termo wisegothus e os nobiliárquicos inseridos nos termos gothus e romanus. Ora, pelo o que foi discutido até aqui, à luz da variabilidade e gradativa transformação dos sentidos dos termos (francus $=>$ gens francorum $=>$ genus francorum e gothus $=>$ gens gothorum $=>$ genus gothorum) parece no mínimo imprudente identificar o emprego do termo no contexto das Vitas Sanctorum Patrum Emeretensium como étnico, o contexto textual que estamos nos esforçando por delinear coloca na berlinda tal interpretação. Nessa linha, o que podemos dizer é que wisegothus se referia a todos aqueles sob a autoridade do rei, enquanto isso, gothus e romanus designava grupos nobiliárquicos envolvidos na política do reino e nas articulações entre poder real e poderes nobiliárquicos regionais.

Como observamos no caso de Masona, o fato dele ter uma origem goda, ou seja, estar filiado a um determinado grupo, não impediu que o grupo se voltasse contra ele e que ele se filiasse a uma outra facção, a dos romani liderados por Claudio. Esses grupos nobiliárquicos exerciam sua influência em diversos níveis, no nível episcopal e no nível da autoridade laica, entretanto, como observamos, tecendo entre si alianças.

\footnotetext{
${ }^{582}$ Vitas Sanctorum Patrum Emeretensium, V, X.
} 


\section{Isidoro de Sevilha e memória familiar no De Viris Illustribus}

Interessante contrastar os sentidos presentes nas Vitas Sanctorum Patrum Emeretensium com os usos do termo "godos" no De Viris Illustribus de Isidoro de Sevilha e como a idéia de "gens Gothorum" poderia ser usada para valorizar um determinado grupo. Na obra como um todo a recorrência do termo "gothus" é rara, aparecendo apenas em quatro ocasiões, entretanto, o uso do termo em um determinado momento é especialmente ilustrativo.

Nos quatro momentos em que o termo "gothus" aparece observamos que as circunstâncias narrativas são diversas. $\mathrm{O}$ termo é empregado nas duas primeiras menções como um qualificativo para os reis que estavam no poder no momento em que os religiosos descritos atuavam servindo assim como um indicativo cronológico, esse sentido aparece quando Isidoro de Sevilha fala dos bispos Apringio e Justiniano. ${ }^{583}$

O outro sentido em que o termo aparece se refere à origem, isso ocorre na narrativa de Isidoro de Sevilha sobre João de Biclaro na qual o bispo identifica o Abade do Mosteiro de Biclaro como um godo: "Iohannes, Gerundensis ecclesiae episcopus, natione Gothus, prouinciae Lusitaniae natus", ${ }^{584}$ Nesse trecho Isidoro de Sevilha reconhece a existência de uma gens gothorum, algo que se evidencia quando no seu livro das diferenças gens e natio são colocadas como sinônimos ${ }^{585}$ e identifica João como pertencente à essa gens. Talvez a referência à origem de João de Biclaro tenha objetivado dar relevo ao fato de que ele, mesmo godo, não só não seguiu a arianismo como resistiu à Leovigildo tendo sido inclusive exilado pelo rei. A identidade goda nesses termos valoriza ainda mais a imagem de João de Biclaro que a

\footnotetext{
${ }^{583}$ Em referência à Apringio: XVII. Claruit temporibus Theudi principis Gothorum. E em referência à Justiniano: XX. Floruit in Hispaniis temporibus Theudi principis Gothorum. De Viris Illustribus, XVII e XX.

${ }_{584}^{58}$ De Viris Illustribus, XXXI.

585 “Gens nationis est...” De Differentiis I, 332 (210)
} 
despeito de sua origem não se deixou seduzir pelas investidas do rei. Nesse caso, como observaremos ser comum no caso das hagiografias merovíngias, a gens serve mais para valorizar a figura do religioso do que por seu valor intrínseco.

É entretanto o quarto e último emprego do termo gens Gothorum que apresenta um interesse particular. Trata-se na descrição feita por Isidoro de Sevilha sobre Leandro de Sevilha, seu irmão e antecessor no bispado da cidade:

Leander, genitus patre Seueriano, Carthaginiensis prouinciae Hispaniae, professione monachus et ex monacho Hispaliensis ecclesiae prouinciae Baeticae constitutus episcopus, uir suauis eloquio, ingenio praestantissimus, uita quoque tantum atque doctrina clarissimus, ut etiam fide eius atque industria populi gentis Gothorum ab arriana insania ad fidem catholicam reuerterentur. ${ }^{586}$

O primeiro ponto de interesse é a referência ao pai de Leandro, e também de Isidoro, Severiano. Esse tipo de citação de laços de parentesco na obra isidoriana é rara exceto quanto se trata dos reis. No contexto narrativo do hispalense é de se destacar dessa maneira a preocupação dele em dizer que Leandro era filho de Severiano. Se por um lado isso pode ser entendido como uma valorização da família, podemos ainda levantar uma hipótese mais simples: Isidoro só mencionou o fato porque sabia dele. Embora essa não deixe de ser uma possibilidade, cabe continuar na leitura do trecho. Como se pode perceber, Leandro de Sevilha foi retratado como o grande responsável pela conversão dos godos. Evidentemente o bispo teve um papel importante, ele presidiu o III Concílio de Toledo. Contudo, nas atas do III Concílio de Toledo e nas outras referências à conversão dos godos foi o rei Recaredo o grande protagonista da conversão, não o então bispo de Sevilha, e isso é verdade até mesmo para outros escritos de Isidoro de Sevilha, como a Historia Gothorum que centraliza o protagonismo na figura de Recaredo. É realmente muito interessante perceber o

\footnotetext{
${ }^{586}$ De Viris Illustribus, XXVIII.
} 
quanto a versão do evento ganha uma tonalidade de todo diversa no De Viris Illustribus.

A explicação que parece mais plausível para essa mudança de narrativa parece ser o esforço de Isidoro de Sevilha para valorizar o seu próprio círculo familiar. Assim, nesse trecho da obra, seu irmão se torna o personagem principal do grande evento do reino dos godos: a conversão. Esse objetivo principal do trecho parece ainda mais consistente se retomarmos o fato de que Isidoro citou o pai, Severino, e depois citou um outro personagem de seu círculo familiar, a irmã deles, Florentina: "Praeterea edidit unum ad Florentinam sororem de institutione uirginum et contemptu mundi libellum, titulorum distinctionibus praenotatum." ${ }^{587} \mathrm{Um}$ outro pensonagem ilustre que foi mencionado por Isidoro de Sevilha como próximo de Leandro de Sevilha, o Papa Gregório Magno. A troca epistolar entre ambos é citada tanto na descrição do $\mathrm{Papa}^{588}$ que vem antes da de Leandro quanto no trecho dedicado ao bispo de Sevilha, ${ }^{589}$ Isidoro localiza assim o irmão numa posição privilegiada na ecclesia e, ao referenciar seu pai e sua irmã no trecho dedicado à Leandro vai além ao colocar o próprio círculo familiar nessa posição de prestígio.

É ainda notório o fato de que Isidoro de Sevilha não mencionar a participação do irmão na rebelião de Hermenegildo, o príncipe católico que se opôs ao pai ariano, Leovigildo. Esse fato é ignorado e o episcopado de Leandro é localizado como se ele tivesse sido bispo apenas durante o reinado de Recaredo: . Floruit sub Recharedo, uiro religioso ac principe glorioso, cuius etiam temporibus mirabili obitu mortalis uitae terminum clausit. ${ }^{590}$ Essa omissão, e a valorização da família, talvez tenha sido

\footnotetext{
${ }^{587}$ De Viris Illustribus, XXVIII.

588 "Scripsit etiam et quasdam epistolas ad praedictum Leandrum, e quibus una in eisdem libris Iob titulo praefationis adnectitur...”. De Viris Illustribus, XXVII.

589 "Scripsit et epistolas multas: ad Papam Gregorium de baptismo unam, alteram ad fratem, in qua praemonet, cuiquam mortem non esse timendam." De Viris Illustribus, XXVIII.

${ }^{590}$ De Viris Illustribus, XXVIII.
} 
uma estratégia para obliterar o apoio de Leandro à rebelião que foi censurada por Isidoro de Sevilha em sua Historia Gothorum. Sabemos por outras fontes, como a de João de Biclaro, que a rebelião foi censurada mesmo pelo abade de origem goda e católico que, mesmo tendo sido exilado por Leovigildo, não demonstrou apoio ao levante de Hermenegildo. Notamos desta maneira que o levante de Hermenegildo não desfrutava de um bom prestígio na Hispânia visigoda e a participação de Leandro poderia representar uma mancha na biografia da família de Isidoro de Sevilha. Colocar Leandro como o protagonista da conversão dos godos, não mencionar sua participação na rebelião de Hermenegildo, enfatizar as relações dele com Gregório Magno e mencionar outros membros do círculo familiar no trecho do De Viris Illustribus dedicado ao bispo de Sevilha pode ter servido assim como um mecanismo para ao mesmo tempo valorizar o próprio círculo familiar de Isidoro e diminuir a participação de Leandro de Sevilha na rebelião de Hermenegildo.

Evidentemente que não podemos dizer que todo o De Viris Illustribus de Isidoro de Sevilha tenha servido para valorizar sua própria família, mas essa hipótese parece ser bastante razoável para o trecho dedicado à Leandro de Sevilha. Nesse sentido, a gens gothorum aparece apenas como um elemento que valoriza ainda mais a imagem do próprio Leandro.

Não há uma celebração da gens gothorum por si só nesse escrito do Hispalense, ao contrário do que observamos no caso da Historia Gothorum. A gens gothorum no De Viris Illustribus aparece na metade das vezes como um elemento marginal, em referência a Theudis para localizar cronologicamente dois bispos; como um elemento para celebrar João de Bíclaro, um godo católico que não se dobrou ao assédio ariano; e, finalmente, para celebrar a memória de Leandro de Sevilha e por conseguinte do círculo familiar de Isidoro de Sevilha. Nos dois últimos casos a 
menção ao godos tem um sentido político, com ênfase no segundo caso onde o sentido político volta-se para um grupo em específico, os parentes de Isidoro de Sevilha.

A análise dos documentos mostra assim uma variedade dos usos do discurso identitário em torno da gens gothorum de grande interesse. Observamos que a compreensão desses usos na nossa concepção requer uma abordagem que leve em conta os objetivos políticos por trás dessas obras. Como percebemos, os discursos em torno da gens gothorum variam para enfatizar elementos específicos envolvidos nas disputas políticas daqueles tempos. No caso das Vidas dos Padres de Mérida percebemos que o emprego do termo "Wisegothus" é bastante singular, primeiro pelo próprio uso de "visigodos" para se referir aos godos, algo absolutamente raro nas fontes da Hispânia visigoda que comumente se referem aos visigodos tão somente como "godos". Um emprego também particular aparece em Isidoro de Sevilha que se refere aos godos na Itália como ostrogodos, ${ }^{591}$ mas aos visigodos sempre como “godos". De todo caso, o emprego particular nas Vidas dos Padres de Mérida parece fazer sentido à luz das outras recorrências do termo "gothus" e também à luz do significado que "romanus" assume.

O termo no documento se refere à unidade das gentes sob a autoridade do rei dos godos, primeiro Leovigildo, depois Recaredo, enquanto gothus parece significar algo mais específico, facções nobiliárquicas envolvidas na política na região da Mérida que em determinado momento se opõem tanto à Masona quanto ao próprio rei Recaredo, nesse contexto de oposição é um outro grupo, os romani que se destacam como apoiadores do bispo e do rei a partir da figura do $d u x$ Claudio. Surge assim uma distinção entre os godos e os visigodos que em nada tem a ver com a distinção entre

\footnotetext{
${ }^{591}$ Em referência à Arnulfo, na versão breve, e Odoacro, na versão longa, ambos qualificados como reis dos Ostrogodos: “... fugato Arnulfo rege Ostrogothorum...” [Versão Breve]. “... Odoacar rege Ostrogothorum..." [Versão Longa, 39.]. Historia Gothorum, 39.
} 
ostrogodos e visigodos que aparece em Jordanes e sim com um contexto específico da Hispânia em que visigodos são retratados como uma unidade centralizada em torno da figura do rei enquanto godos como grupos nobiliárquicos locais. Estamos lidando com a mobilização discursiva de identidades políticas que se confrontam: a identidade de sentido unitário dos "visigodos" em detrimento a polaridade das facções nobiliárquicas "godas" de Mérida.

Já nos três usos do termo em Isidoro de Sevilha são outras questões que estão em jogo. Uma que parece mais marginal relacionada com o estabelecimento de marcos cronológicos e duas que se referem à valorização da imagem primeiro de um homem religioso, João de Biclaro, e segundo de um homem religioso e seu entorno familiar, Leandro de Sevilha. O documento se mostra assim com um enorme potencial ao nos indicar como os discursos identitários em torno da gens gothorum poderiam ser mobilizados para outros fins. Evidentemente que a validade dessa mobilização discursiva só faz sentido à luz das fontes históricas. É que esses discursos eram reconhecidos. A gens gothorum fora valorizada, como notamos, nos textos qualificados como "Histórias", a Historia Gothorum e posteriormente a Historia Wambae. É esse contexto textual que deve nos servir de baliza, de norte interpretativo, não a pretensão de que a referência aos godos se relacionava com a existência de uma unidade populacional com um forte sentido identitário étnico. Os godos existiam enquanto uma unidade no plano discursivo, mas não só enquanto uma unidade, as Vidas dos Padres de Mérida indicam isso.

O discurso em torno da gens gothorum era politicamente válido por ser recorrente em outras fontes e, mais importante, celebrado. Isso não significa tampouco que esse discurso tinha um tom monocromático, a comparação entre as fontes indica a pluralidade de tons que esse discurso assumia e como em determinadas 
situações tinha um sentido negativo, como na crítica à Leovigildo presente nas Vidas dos Padres de Mérida na qual o termo "visigodos" é associado à algo negativo: um rei que perseguia cristãos, mas depois ganha uma cor mais positiva com a conversão conduzida por Recaredo. É que o trecho das Vidas dos Padres de Mérida dedicado à Masona não visava valorizar a gens gothorum, visava antes de tudo celebrar a memória do bispo de Mérida, para essa finalidade maior os "visigodos" eram retratados em duas faces, os godos em outras tal como os romanos.

Perceberemos no tópico seguinte que esses usos diversos também aparecem nas hagiografias merovíngias e acreditamos que tal como no caso das hagiografias visigodas é a validade da existência de uma gens francorum célebre em outras fontes que dá sentido à especificidade dos usos do discurso em torno da gens francorum nas hagiografias.

\section{Hagiografias Merovíngias}

\section{Problemas gerais da tradição manuscrita das hagiografias Merovíngias}

Como já mencionamos os textos hagiográficos dispõem de uma tradição manuscrita particular que não pode ser ignorada ao tratarmos dessas fontes. Como muito bem salientou M. Heinzelmann as tradição manuscrita das hagiografias comumente se caracterizam por pouca homogeneidade e por uma profusão de interpolações ${ }^{592}$ que outorgam novos significados aos textos a fim de terem uma função prática no período das novas redações. Isso torna o trabalho de reconstrução dos textos originais - objetivo primeiro dos Bollandistas - um empenho de enorme dificuldade, mas por outro lado nos revela uma outra característica desses textos

\footnotetext{
${ }^{592}$ HEINZELMANN, M. Manuscrits hagiographiques et travail des hagiographes: l'exemple de la tradition manuscrite des viés anciennes de sainte Geneviève de Paris. IN: HEINZELMANN, M. (ed). Manuscrits hagiographiques et travail des hagiographes. Sigmaringen: Thorbecke, 1992. p.9-16.
} 
concernente a suas finalidades pragmáticas. Em seu estudo sobre a vida de Geneviève

M. Heinzelmann explicitou perfeitamente essa qualidade das hagiografias:

D'abord, elle [a questão da tradição dos mss. Da vida de Geneviève] permet de relever deux éléments caractéristiques - et apparemment contradictoires - susceptibles de concerner l'ensemble de la littérature hagiographique, à savoir son traditionalisme et sa recherche d'actualisation. S'agissant du manuscrit Remensis $\mathrm{n}^{0}$ 1402, que nous venons de citer, il est apparu parfaitement convenable de recopier ai XIe siècle un texte, sans doute destiné à un usage pratique immédiat, vieux d'un demi-millénaire, même s'il appartenait à une société d'un autre âge. Mais en même temps, on était aussi capable de confectionner coup sur coup trois versions nouvelles de la même biographie (B, D, E) dans un laps de temps d'une quarantaine d'années seulement ( $c a$. 835/875) ; parallèlement à ces créations, on continuait de copier en nombre croissant des exemplaires des versions anciennes (A et $\mathrm{C}$ ) toujours en faveur. A l'exemple des Vitae sancti Maioli, D. Iogna-Prat présentera plus loin un autre cas frappant de coexistence de conceptions hagiographiques opposées, appartenant à des époques différentes, dans un même milieu hagiographique. ${ }^{593}$

Heinzelmann identifica duas razões para a circulação de versões diferentes da vida de Geneviève: primeiro, o lugar eclesiástico nos quais essas versões foram produzidas, cada um deles estabeleceu uma versão melhor adaptada para suas realidades; segundo, o contexto político, social, literário e espiritual condicionou a criação de novas versões da vida da santa. É preciso considerar isso quando lidamos com as hagiografias, não só a de Geneviève, mas a de outros santos. Lamentavelmente os estudos hagiográficos desde o seu início com os Bollandistas no século XVII, mas especialmente no século XIX, visaram estabelecer a versão original dessas vidas. Esse não parece ser o ponto principal, cada versão possui uma história própria, as reapropriações das vidas dos santos é um objeto de estudo por si.

O fato é que essa singularidade parece ser crucial para caracterizar as hagiografias e distingui-las das Historiae: é que esses textos, quando escritos, não pareciam ter a pretensão de circular tal como a primeira versão, eles parecem ter sido

\footnotetext{
${ }^{593}$ Ibidem, p.15.
} 
concebidos para serem dinâmicos mesmo, reescritos, reinterpretados. Isso ao contrários, por exemplo, das histórias. Ora, Gregório de Tours pediu que os bispos que viessem depois dele não alterassem sua obra. Isso ocorreu a despeito da vontade do bispo, mas o desejo dele era que a história circulasse exatamente tal como ele concebeu. Por outro lado, esse tipo de clamor não aparece nas hagiografias. Como mostrou Heinzelmann, em um curto espaço de tempo a vida de Geneviève ganhou novas versões.

Estamos assim trabalhando com textos inseridos num gênero concebido para ser dinâmico. Uma possível explicação para tal singularidade pode se dever ao objetivo primeiro de um texto hagiográfico, a saber, contribuir para a popularização e manutenção do culto de um santo, nesse sentido, era perfeitamente aceitável que o texto primeiro fosse reescrito a despeito das possíveis "incorreções históricas" que poderiam surgir dessas reinterpretações, é que contar a história de um santo tinha um outro significado que não ser fiel à vida concreta daquele santo: contar essa história significava fortalecer o culto ao santo. Desta maneira, a própria característica do gênero hagiográfico nos ajuda a compreender a complexidade da tradição manuscrita desses textos, do mesmo modo a complexidade da tradição manuscrita nos aponta para os desdobramentos do culto desses santos, para a sua popularidade e quais finalidades assumiu ao longo do tempo.

Tendo isso em vista, o que podemos dizer sobre a tradição manuscrita das Vitae merovíngias? O que elas dizem sobre o culto dos homens e mulheres santos na Gália sob a autoridade da dinastia Merovíngia?

Primeiro cabe refletirmos sobre aspectos gerais da circulação das hagiografias na Gália Merovíngia e aqui, mais uma vez, os estudos de M. Heinzelmann se destacam como um importante ponto de referência. Como observou o estudioso a 
transmissão das hagiografias na Gália até o século VIII era marcada pela prevalência das Vitae Patrum cuja organização aponta para a tendência de leitura sobretudo em contextos monásticos, uma exceção à isso, como observaremos, é a Vita Columbani que provavelmente circulou consideravelmente entre círculos além dos monásticos. De todo modo, ao contrário do que nos levam a entender as edições do $\mathrm{MGH}$, com exceção da vida de São Martinho de Tours, em geral os manuscritos da Gália que mais circulavam traziam recorrentemente vidas de ascetas e mártires orientais como Santo Antão, Hilarion e Malchus, as vidas de bispos e confessores merovíngios circulavam muito menos. Heinzelmann interpreta essa peculiaridade como uma circulação textual fundamentada sobretudo numa ideologia eclesiástica que ressaltava a "Histoire du Salut" e marcava a continuidade da história influenciada pelos santos desde os textos bíblicos até os relatos hagiográficos presentes nos manuscritos merovíngios. Em poucas palavras, as coleções hagiográficas da Gália afirmavam assim a ideologia eclesiástica e é sob essa perspectiva que Heinzelmann analisa as hagiografias do período concatenando-as com as Historiae em sua perspectiva providencialista, com destaque aos escritos de Gregório de Tours. ${ }^{594}$

Mesmo interessantes principalmente por se centrarem no problema das tradições manuscritas, o texto de Heinzelmann acaba por negligenciar certos pontos importantes. Primeiro, como veremos no caso da Vita Columbani, mesmo que não tenham restado testemunhos nos manuscritos da circulação de certos textos na Gália até o século IX, as influências de textos hagiográficos em outros documentos, como a reprodução de trechos da Vita Columbani na Chronica de Fredegário, indicam que havia sim uma significativa circulação de hagiografias de santos e santas da Gália que

\footnotetext{
${ }^{594}$ HEINZELMANN, Martin. Pouvoir et idéologie dans l'hagiographie mérovingienne. In: BOZÓKY, Edina. Hagiographie, idéologie et politique au Moyen Âge en Occident. Acter du colloque international du Centre d'Études supérieures de Civilisation médiévale de Poitiers. 11-14 septembre 2008. Turnhout: Brepols, 2012. p.37-58.
} 
inclusive transcendia os círculos monásticos. Segundo, o autor acaba por não contemplar a modificação na escrita hagiográfica que ocorre na Gália a partir do século VII especialmente durante os reinados de Clotário II e Dagoberto I quando a narrativa hagiográfica começa a contemplar uma audiência aristocrática laica. A já mencionada Vita Columbani aponta para essa mudança narrativa que depois, conforme apontou A.-M. Helvétius, influenciou outras hagiografias como a de Elói de Noyon escrita entre 673 e 675 e a vida de Wandrille escrita por volta de $700 .{ }^{595}$ Disso se infere que tão-somente a existência de uma grande ou pequena quantidade de manuscritos com uma Vita não é o único indicativo da importância dessa Vita e tampouco de sua circulação. A Vita Columbani é a primeira evidência para isso, como indicaremos no próximo tópico, mas cabe também exemplificarmos nossa afirmação com a já mencionada vida de Wandrille que sobreviveu em apenas um manuscrito, o Codex Parisiensis, BNF lat. n.18315 (olim Notre-Dame 101 bis).

A sobrevivência do texto em apenas um manuscrito não pode ser tomada isoladamente para dizermos que o texto não foi importante na Gália Merovíngia. Primeiro porque devemos considerar que o mosteiro de Saint-Wandrille (Fontenelle) onde a vida de Wandrille foi escrita sofreu ataques dos Vikings e foi incendiado em duas ocasiões, primeiro em 851 e depois em 858 , o que pode ter redundado na perda de manuscritos, ${ }^{596}$ isso sem mencionar que tão-logo os Carolíngios assumiram o reino o mosteiro perdeu prestígio, recuperando-o gradativamente. ${ }^{597}$ Além disso, esse

\footnotetext{
${ }^{595}$ HELVÉTIUS, Anne-Marie. Hagiographie et formation politique des aristocrates dans le monde franc (VII ${ }^{\mathrm{e}}$-VIII ${ }^{\mathrm{e}}$ siècles). BOZÓKY, Edina. Hagiographie, idéologie et politique au Moyen Âge en Occident. Acter du colloque international du Centre d'Études supérieures de Civilisation médiévale de Poitiers. 11-14 septembre 2008. Turnhout: Brepols, 2012. p.59-79.

${ }^{596}$ LOWE, J. The Hagiography of Saint-Wandrille (Fontenelle) (Province of Haute-Normandie). In: HEINZELMANN, M. (dir.) L'Hagiographie du Haut Moyen Âge en Gaule du Nord. Beihefte der Francia. Herausgegeben von Deutschen Historischen Institut Paris. Band 52. Stuttgart: Thorbecke, 2001. p.127-192. p. 128

${ }^{597}$ Ibidem. Ainda: WOOD, I. Saint- Wandrille and its Hagiography. In: WOOD, I. \& LOUD, G.A. (ed.) Church and chronicle in the Middle Ages. Essays presented to John Taylor. London and Rio Grande: The Hambledon Press, 1991. p.1-14.
} 
manuscrito mais antigo com a vida de Wandrille não foi o único a versar sobre o fundador do mosteiro de Fontenelle, há versões da vida presente também na Gesta abbatum Fontanellensium datada do século IX e que aparentemente usou a vita prima que sobreviveu no manuscrito de Paris 18315 , mesmo que essa não tenha sido a principal fonte do autor da Gesta. ${ }^{598} \mathrm{O}$ que podemos concluir a partir disso é que mesmo um texto escrito por volta de 700 que sobreviveu em apenas um manuscrito influenciou um outro texto do século IX.

Podemos, assim, retomar Heinzelmann sob um outro ponto de vista:

1. A circulação de manuscritos na Gália que versavam mais sobre vidas orientais não é evidência suficiente para dizermos que as vidas de santos e santas da Gália circulavam pouco uma vez que a tradição manuscrita não é a única evidência para tratarmos da abrangência da circulação de vidas tendo em vista que se nota a influência de hagiografias em outros textos. Não obstante um conjunto de fatores podem ter eliminado manuscritos, como aqueles com a vida de Wandrille que talvez tenham se perdido com a perda de prestígio do mosteiro de Fontenelle com a ascensão dos Carolíngios e com os ataques Vikings da segunda metade do século IX;

2. Os mesmos fatores podem ser usados para criticarmos a idéia de que essas vidas transmitiam apenas uma ideologia eclesiástica. Se as vidas impactavam em textos que não eram escritos apenas para uma audiência eclesiástica não é absurdo supor que eles circulavam em círculos laicos. Além disso a mudança da narrativa hagiográfica na Gália do século VII, bem ressaltada por Helvétius, também aponta para a importância desses textos entre nobres laicos.

3. Por fim, a análise de Heinzelmann acaba por redundar numa divisão entre a autoridade religiosa e a autoridade laica que, como defendem muitos estudos, ${ }^{599}$ não parece ser válida para a Alta Idade Média. A autoridade dos

\footnotetext{
${ }^{598}$ LOWE, J. The Hagiography of Saint-Wandrille...op.cit. p.169-170.

${ }^{599}$ Há de fato uma quantidade enorme de estudos sobre o papel dos bispos na Alta Idade Média. Citemos alguns mais recentes como o interessante trabalho de C. Rapp que analisa o papel desses homens a partir de um ponto de vista que foge do lugar-comum da análise restrita apenas à documentos hagiográficos: RAPP, Claudia. 'For next to God, you are my salvation': reflections on the rise of the holy man in late antiquity. In: : HOWARD-JOHNSTON, J. \& HAYWARD, P.A. The cult of the
} 
bispos, que não raro se tornavam santos e tinham seus cultos propagandeados pelas hagiografias, não se restringia à uma autoridade exclusivamente religiosa.

De qualquer maneira Heinzelmann apontou corretamente que no que concerne à tradição manuscrita - mesmo que essa não seja a única evidência para falarmos da circulação dos textos - há uma concentração de manuscritos com as vidas dos santos e santas da época merovíngia após o século IX. Uma observação dos manuscritos das vidas de Balthilda, Leudegário, Prajecto, Columbano e Gertrudes ${ }^{600}$ indicam bem esse fato como podemos observar pelos gráficos a seguir:

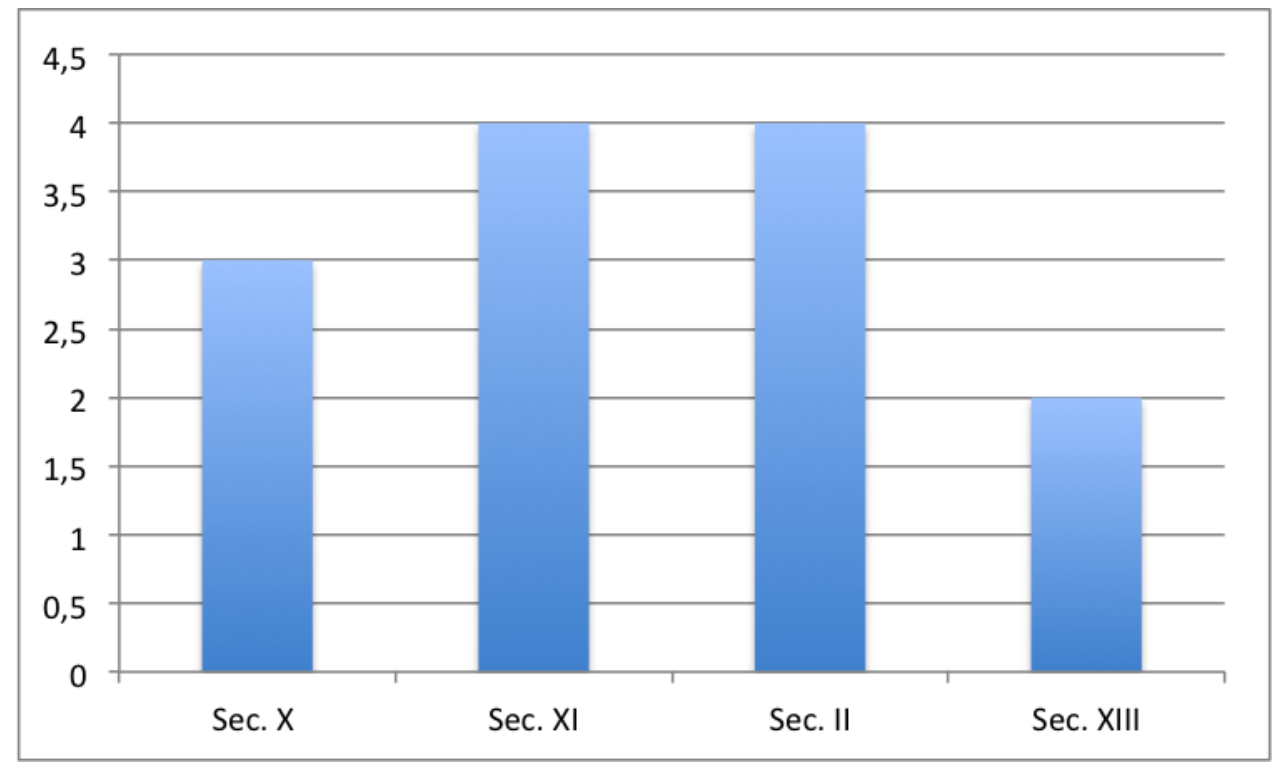

Gráfico 14 - Distribuição temporal dos manuscritos com a Vita Domnae Balthildis

Saints in Late Antiquity and the Early Middle Ages. Oxford: Oxford University Press, 1999. p.6381. Destaque ainda para seu livro mais recente: RAPP, Claudia. Holy Bishops in Late Antiquity. The nature of Christian Leadership in an age of transition. Berkeley, LA, London: University of California Press, 2005. Outros trabalhos importantes: BEAUJARD, Brigitte. Cités, Évêques et Martyrs en Gaule à la fin de l'époque romaine. In: Les fonctions des saints dans le monde occidental. (IIIe-XIIIe siècle). Actes du Colloque organisé par l'École Française de Rome "La Sapienza". Rome, 27-29 octobre 1988. Rome: École Française de Rome, 1991. p.175-191. O já mencionado clássico artigo de Brown: BROWN, P. The rise and Function of the Holy Man in Late Antiquity. Journal of Roman Studies. v.6, p.80-101, 1971.

${ }^{600}$ A produção dos gráficos é baseada sobretudo na análise das edições dos MGH e no banco de dados Mirabile. 


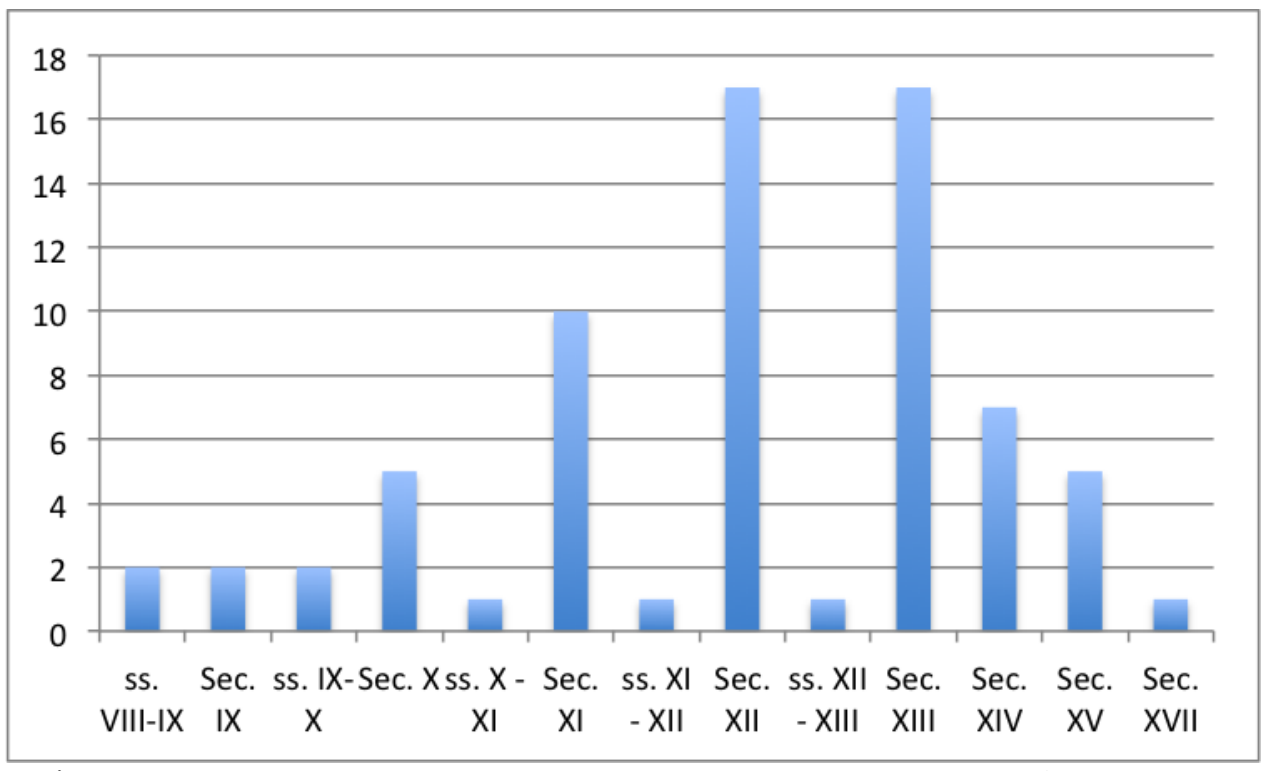

Gráfico 15 - Distribuição temporal dos manuscritos com o Passio Leudegarii

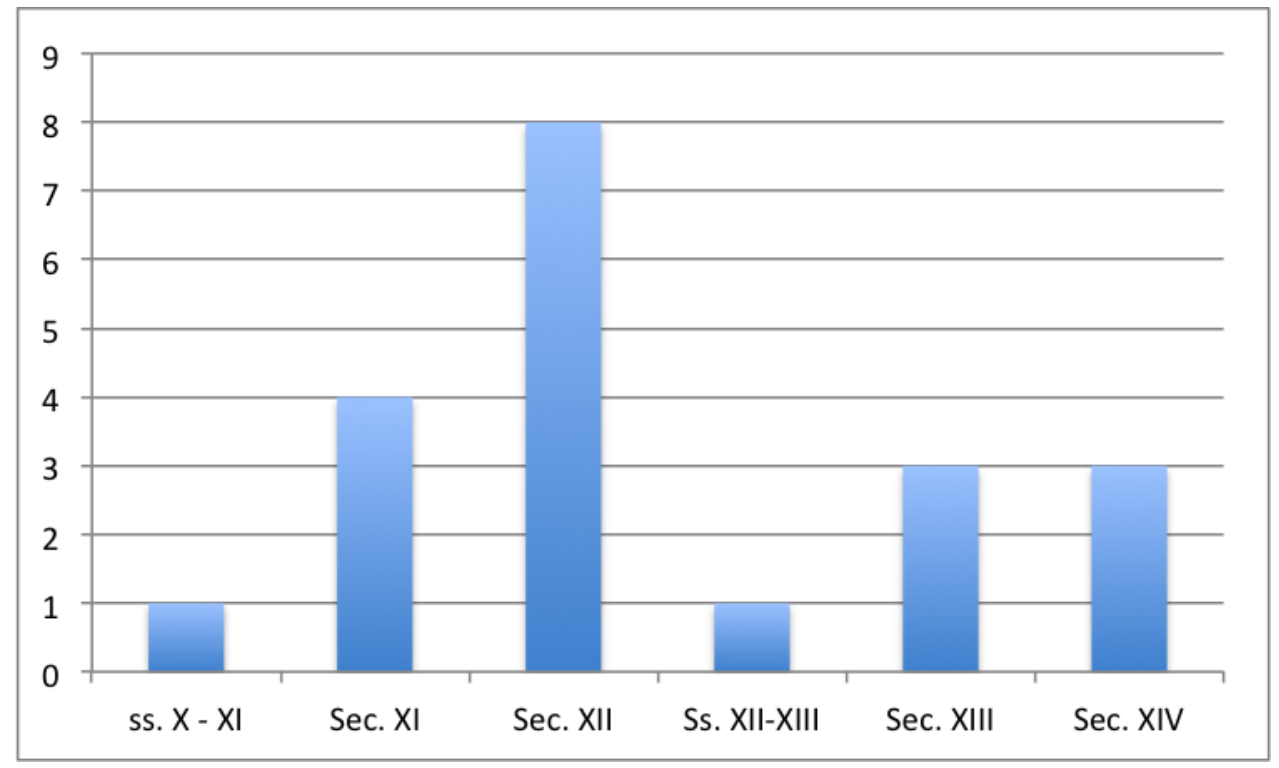

Gráfico 16 Passio Praejecti 


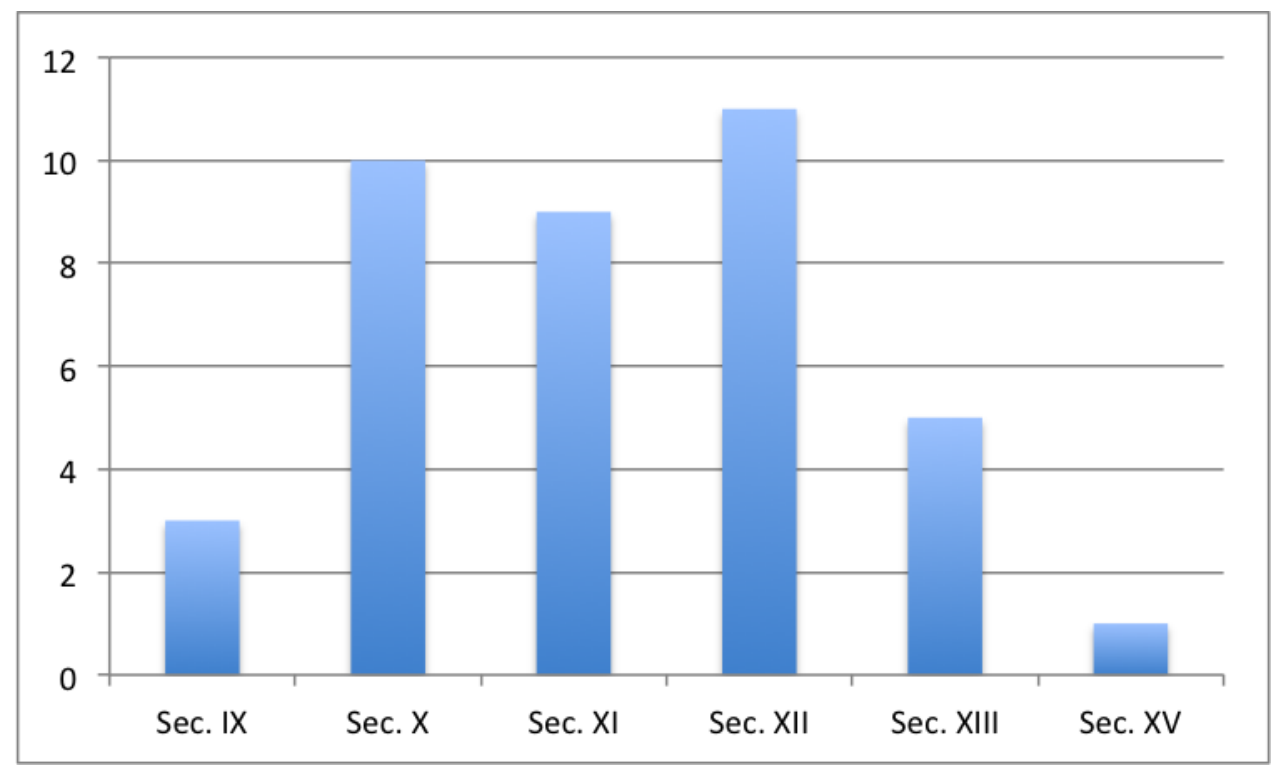

Gráfico 17 - Vita Columbani

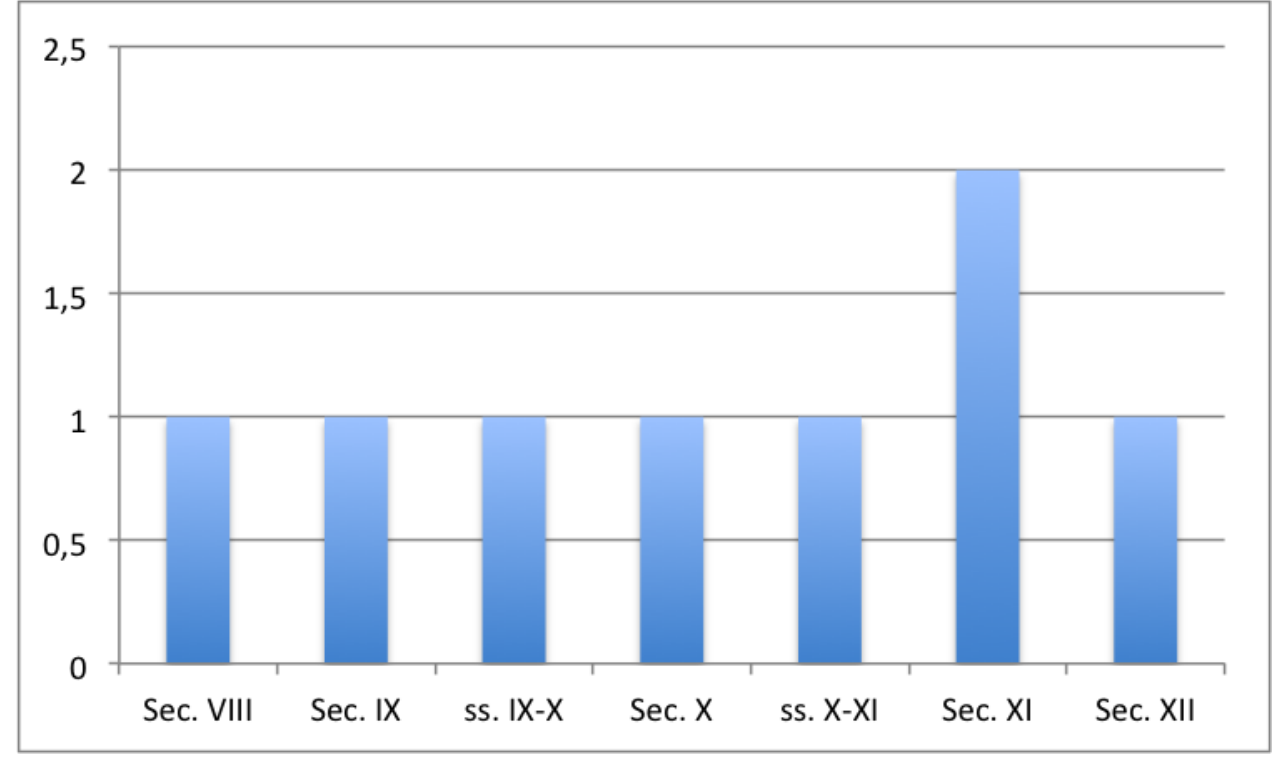

Gráfico 18 Vita Sanctae Geretrudis

Já um gráfico que indica a distribuição temporal geral dos manuscritos com todas as Vitae tem a seguinte configuração: 


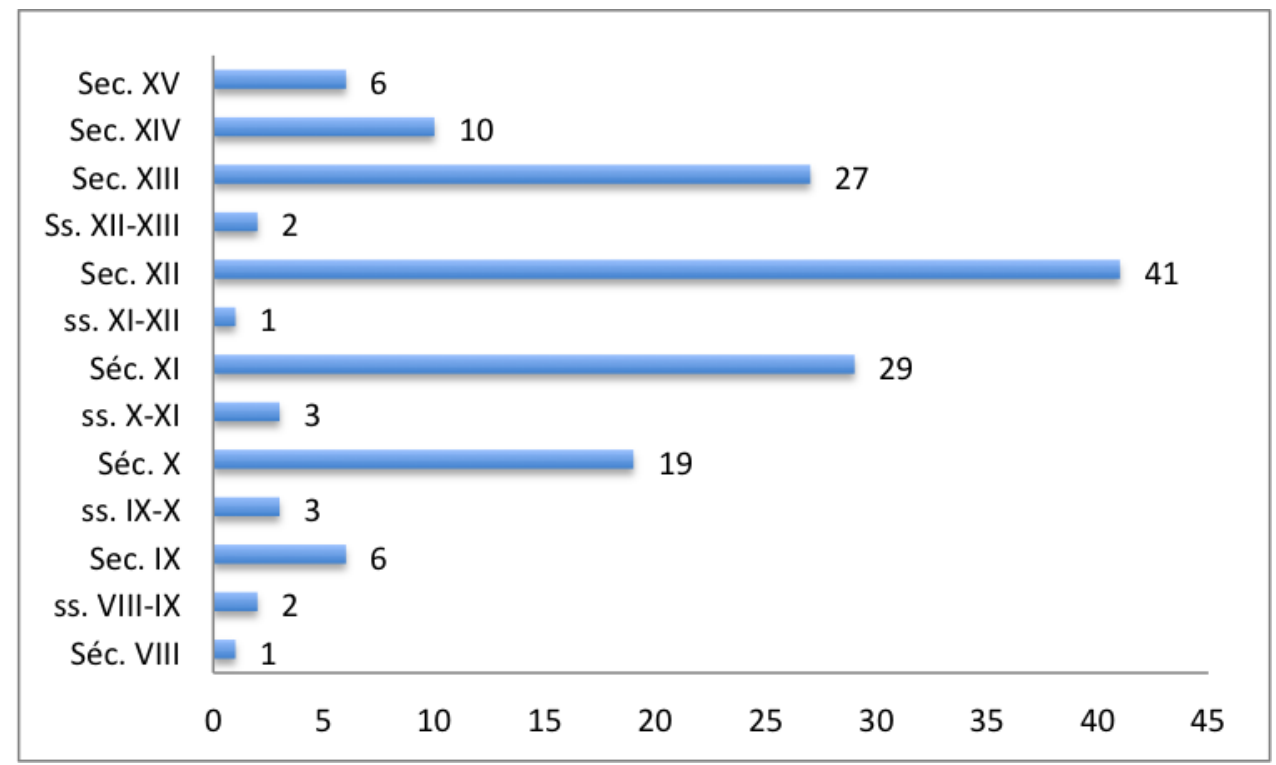

Gráfico 19 - Distribuição temporal geral dos mss. com as Vitae

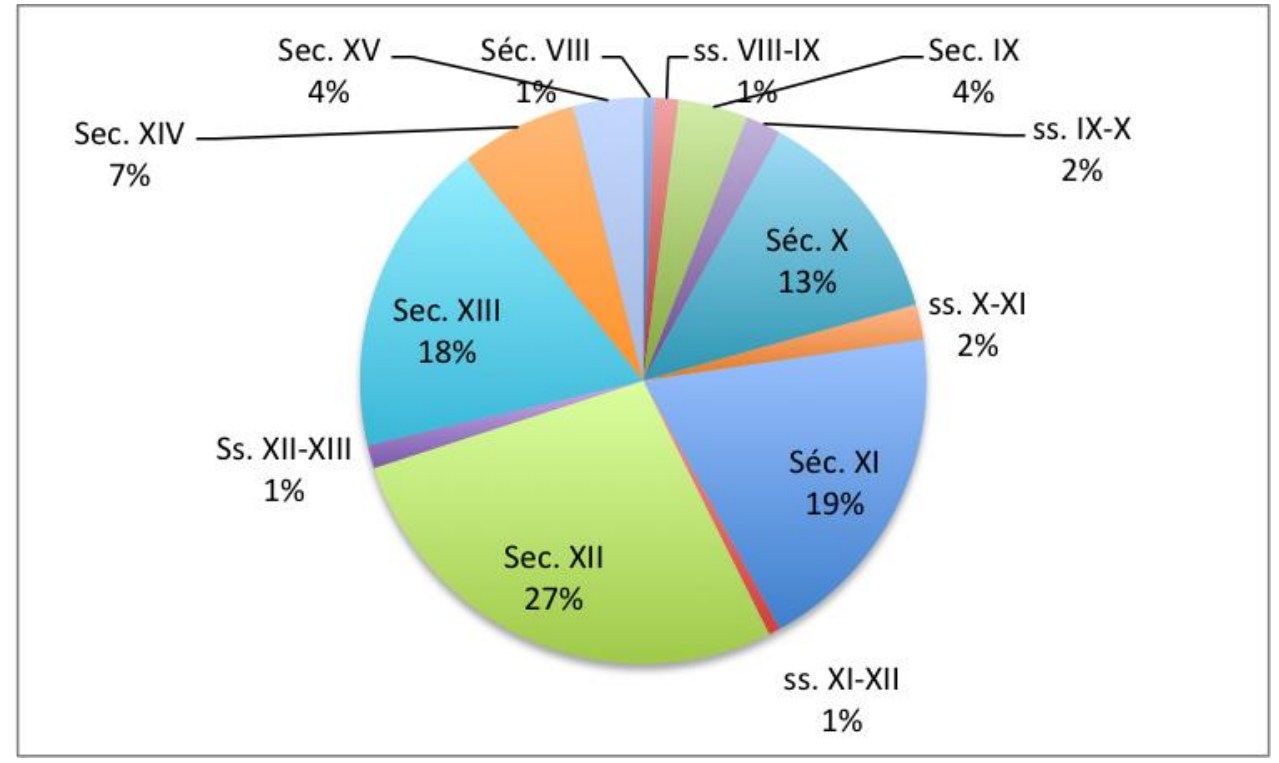

Gráfico 20 Percentual da distribuição geral dos mss. com as Vitae

É notável o pico de manuscritos com as Vitae ocorrido entre os séculos X e XIII que concentram juntos aproximadamente $77 \%$ dos manuscritos, com destaque ao século XII que concentra o maior número de manuscritos com as Vitae dos santos e santas atuantes na Gália Merovíngia. Esses dados nos levam à algumas questões:

$\Rightarrow$ É importante enfatizar que essa distribuição de manuscritos com os textos merovíngios não é uma particularidade das hagiografias, comumente os manuscritos com os textos do período são datados como provenientes de períodos muito posteriores às estimativas da produção dos textos iniciais. Disso surgem dois problemas: 
- As fontes não podem ser analisadas isoladamente, são as referências cruzadas entre elas que nos permitem avaliar a abrangência da circulação das fontes uma vez que da tradição manuscrita podemos concluir quase que exclusivamente que esses textos ganharam relevância após o século IX, especialmente entre os séculos X e XIII;

- Do ponto anterior redunda uma outra questão: por que esses textos se tornaram importantes num período tão posterior? Essa pergunta foge de nosso escopo, mas merece ser pontuada para nos questionarmos até que ponto a idéia de um reino dos francos foi uma construção a posteriori, até que ponto o período Carolíngio e os séculos seguintes foram decisivos para a construção da imagem que temos atualmente sobre o que foi o reino dos merovíngios? A pergunta está longe de ser desimportante e mesmo que não nos caberá respondê-la agora é algo que é considerado seriamente por nós no nosso trato com as fontes, em poucas palavras, essa questão é nosso principal norte crítico especialmente quando lidamos com fontes que foram editadas e interpretadas como documentos que chegaram aos nossos dias como se essa transição nos séculos tivesse se dado sem qualquer alteração, como se hoje tivéssemos acesso às Vitae, mas também as Historiae, atas conciliares, epístolas e leis tal como foram elaboradas nos séculos VI, VII e mesmo VIII. Não parece ser o caso, tampouco isso tudo significa que devemos no ater à um relativismo simplório e dizer que tudo o que sabemos sobre os merovíngios é puramente uma invenção dos séculos seguintes à queda da dinastia, absolutamente não é o caso. Como já afirmamos, o caminho para tratarmos esse problema sob uma perspectiva crítica passa por analisar as fontes a partir da idéia de um contexto textual que só pode ser acessível se compararmos esses textos, identificarmos suas confluências e divergências e tentar entendê-las. Esse é inegavelmente nosso principal referencial teórico-metodológico no trato com nossas fontes.

Uma possível explicação para a distribuição temporal desses manuscritos é mudança com a relação com os textos escritos que surge a partir do período Carolíngio estudada com excelência por R. McKiterrick. Como apontou a pesquisadora, no período Carolíngio houve um grande incremento na produção de livros e bibliotecas além da fundação de muitos mosteiros, centros de enorme 
importância para a produção de livros ${ }^{601}$. Isso ajuda a entender a concentração de textos em períodos posteriores às estimativas das datas originais de produção embora ainda não seja suficiente para nos ajudar a compreender os motivos pelos quais esses textos eram interessantes em outras épocas a ponto de serem copiados. Faz sentido se pensarmos na produção de texto com as vidas de santos fundadores de mosteiros, como o caso de Fontenelle e a vida de Wandrille, ou o caso de Luxeuil e a vida de Columbano, mas não foram apenas as hagiografias, como já dissemos, que foram mais copiadas e preservadas a partir do século IX. A questão, assim, ainda permanece em aberto, mesmo assim, contemplar o cenário geral da tradição manuscrita das hagiografias de santos e santas merovíngias nos ajuda, mais uma vez, a marcarmos um posicionamento teórico e crítico diante das fontes. Feito isso, podemos avançar e pensarmos sobre quais são nossos pontos de referência no trato com as hagiografias merovíngias a partir de uma Vita que consideramos a mais importante como um norte de produção hagiográfica da Gália, a saber, a Vita Columbani de Jonas de Bobbio.

\section{A Vita Columbani - política e santidade na Gália Merovíngia}

Por volta de 591 um grupo de monges vindos da Britania desembarcaram na Gália, entre eles estava Columbano(Leinster meados do século VI- Bobbio 615). ${ }^{602}$ Por volta de 641/2 Jonas de Bobbio escreveu a Vita de Columbano cujo primeiro livro centrava-se na ação do monge na Gália sob o domínio dos reis merovíngios. Jonas de Bobbio talvez não tenha escrito seu texto a partir da Gália, ${ }^{603}$ entretanto estava bem informado. Ele havia mantido contato com alguns discípulos de Columbano, era

\footnotetext{
${ }^{601}$ McKITTERICK, R. The Carolingians and the written word. Cambridge: Cambridge University Press, 1989. p.167.

${ }^{602}$ FOX, Y. Power and Religion in Merovingian Gaul. Columbanian Monasticism and the Frankish Elites. Cambridge: Cambridge University Press, 2014. p.I. Ainda: WOOD, I. The Missionary Life. Saints and the Evangelisation of Europe. 400-1050. Harlow: Longman, 2001. p.31

${ }^{603}$ WOOD, I. The missionary life...op.cit.p.36.
} 
arquivista de Bertulfo, conhecia documentos legais relacionados com o monasticismo de Columbano e registrou aspectos dos reinos merovíngios da Gália que levaram I. Wood a sugerir que o livro primeiro e partes do livro segundo da sua Vita Columbani poderiam ser também classificados como uma história. ${ }^{604}$ Essa última proposição é problemática, mesmo assim, o valor da narrativa de Jonas para o estudo do papel dos homens e mulheres santos na Gália Merovíngia não é desprezível.

O primeiro ponto a ser destacado no que concerne à importância da Vita Columbani se refere a sua tradição manuscrita. Como poderemos observar o texto teve uma considerável circulação tendo sido transmitido por mais de cinquenta manuscritos:

${ }^{604}$ Ibidem, p.35. 
Tabela 11: os manuscritos com a Vita Columbani

MGH

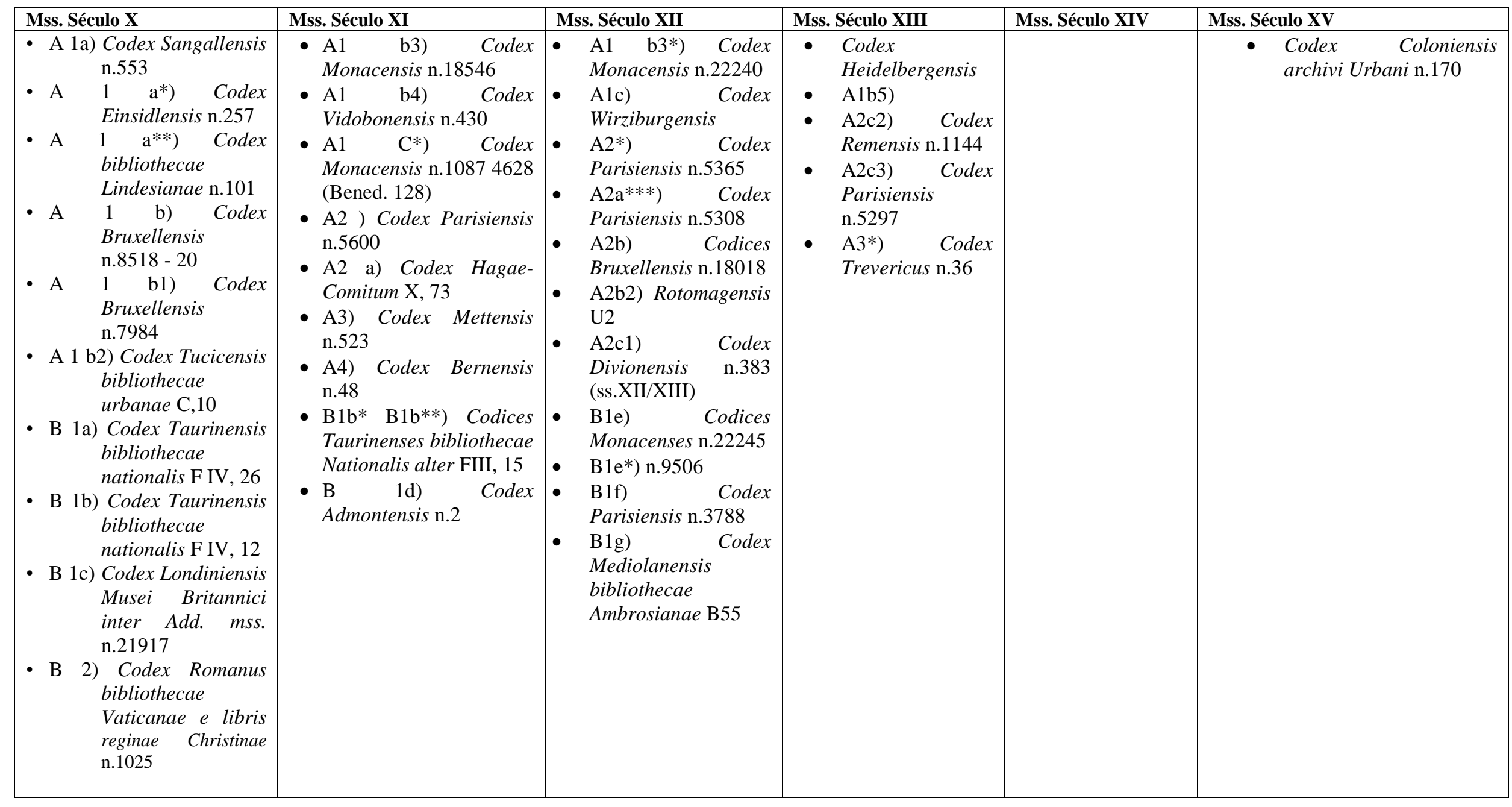


Database: Mirabile (http://www.mirabileweb.it/title/vita-sancti-columbani-title/352)

\section{Cidade: Admont}

Biblioteca e catálogo: Bibliothek des Benediktinerstifts 2

2. Cidade: Augsburg

Biblioteca e catálogo: Staats- und Stadtbibliothek, 295

Datação - 1513-1516

Local de produção: Reichenau - Abadia de St. Maria

3. Cidade: Augsburg

Biblioteca e catálogo: Universitätsbibliothek I.2.4o 6

Datação. ff 1-166 séc.XI / ff.167-171 sec.XV

Local de produção: Tegernsee - Abadia de St. Quirin

4. Cidade: Avignon

Biblioteca e catálogo: Bibliothèque Municipale (olim Musée Calvet) 276 (120)

Datação: séc.X

\section{Cidade: Berlin}

Biblioteca e catálogo: Staatsbibliothek zu Berlin - Preussischer Kulturbesitz, theol. lat. 8o 162

Datação: séc.XII

Local de produção: Huysburg - Abadia de SS. Maria e Gregorio

\section{Cidade: Bern}

Biblioteca e catálogo: Universitästsbibliothek. Burgerbibliothek (Bibliotheca Bongorsiana) 48

Datação: séc. XI 
7. Cidade: Bruxelles

Biblioteca e catálogo: Bibliothèque Royale “Albert Ier” 7460-61 (3176)

Datação: séc. XII

\section{Cidade: Bruxelles}

Biblioteca e catálogo: Bibliothèque Royale "Albert Ier" 7984 (3191)

Datação: séc. X

\section{Cidade: Bruxelles}

Biblioteca e catálogo: Bibliothèque Royale “Albert Ier" 8518-20 (3202)

Datação sec.X

10. Cidade: Cidade do Vaticano

Biblioteca e catálogo: Biblioteca Apostolica Vaticana, Barb.lat. 2720

Datação: séc. XVI-XVII

11. Cidade: Cidade do Vaticano

Biblioteca e catálogo: Biblioteca Apostolica Vaticana, Reg.lat. 1025

Datação: séc. X

12. Cidade: Darmstadt

Biblioteca e catálogo: Universitäts - und Landesbibliothek (Olim Hessische Landes - und Hochschulbibliothek) 205

Datação: 1487

Local de Produção: Niederwerth - Mosteiro de St. Maria Madalena

13. Cidade: Darmstadt

Biblioteca e catálogo: Universitäts - und Landesbibliothek (Olim Hessische Landes - und Hochschulbibliothek) 752

Datação: ss. XI e XII

Local de Produção: Lorsch - Abadia de Lorsch 
14. Cidade: Darmstadt

Biblioteca e catálogo: Universitäts - und Landesbibliothek (Olim Hessische Landes - und Hochschulbibliothek)

Datação: séc.XV

Local de produção: Bad Wimpfen - Convento de Bad Wimpfen

15 Cidade: Douai

Biblioteca e catálogo: Bibliothèque Desbordes-Valmore (olim Bibliothèque Municipale) 855

Datação: séc. XV

16. Cidade: Einsiedeln

Biblioteca e catálogo: Stiftsbibliothek 257 (Msc. 449)

Datação: séc. X

\section{Cidade: Firenze}

Biblioteca e catálogo: Biblioteca Medicea Laurenziana, Aed.134

Datação: séc.XI-XII

Local de produção: Firenze

18. Cidade: Firenze

Biblioteca e catálogo: Biblioteca Medicea Laurenziana, Aed.137

Local de produção: Toscana

\section{Cidade: Firenze}

Biblioteca e catálogo: Biblioteca Medicea Laurenziana, Conv. soppr.302

Datação: ss. XII-XIV

Local de produção: Firenze, Abadia de S. Salvi

\section{Cidade: Firenze}

Biblioteca e catálogo: Biblioteca Medicea Laurenziana, Conv. soppr.474

Datação: séc.XI 
21. Cidade: Firenze

Biblioteca e catálogo: Biblioteca Medicea Laurenziana, Pl.20.2

Datação: ss.XII-XIII

Local de produção: Firenze

\section{Cidade: Firenze}

Biblioteca e catálogo: Biblioteca Nazionale Centrale, Conv. soppr. A1.1213

Datação: séc.XI

Local de produção: Vallombrosa (Firenze)

23. Cidade: Gravenhage's

Biblioteca e catálogo: Koninklijke Bibliotheek 70.E.21 (730; L.29)

Datação: 1461

Local de produção: Weesp, Convento de St. Jan Evangelist

24. Cidade: Gravenhage's

Biblioteca e catálogo: Koninklijke Bibliotheek 70.H.50 (X 73)

Datação: ss. X ou XI

Local de produção: Saint-Bertin (Pas-de-Calais). Abadia de St.-Bertin.

25. Cidade: Heidelberg

Biblioteca e catálogo: Universitätsbibliothek, Salem, IX 21

Datação: séc.XIII

Local de produção Salem. Abadia de St. Maria

26. Cidade: Hereford

Biblioteca e catálogo: Cathedral Library P.VII.6

Datação: ss. XII ou XIII

Local de produção: Hereford 
27. Cidade Köln

Biblioteca e catálogo: Historisches Archiv der Stadt Köln (Stadtarchiv), Best. 7010 (Handschriften - Wallraf) 164b

Datação: c. 1463

Local de produção: Köln - Mosteiro Herrenleichnam (Corpus Christi)

28. Cidade Londres

Biblioteca e catálogo: British Library, Add.21917

Datação: ss.X-XI

29. Cidade: Manchester

Biblioteca e catálogo: John Rylands University Library, lat.91 (Crawford 101)

Datação: séc. XI

30. Cidade: Metz

Biblioteca e catálogo: Bibliothèque du Grand Séminaire 1

Datação: Século IX

Local de produção: Saint-Mihiel (Meuse), Abadia de St. Mihiel

31. Cidade: Metz

Biblioteca e catálogo: Médiathèque "Le Pontiffroy" (olim Bibliothèque Municipale) 523

Datação: séc. XI

Local de produção: Metz (Moselle). Abadia de St.-Arnoul

32. Cidade: München

Biblioteca e Catálogo: Bayerische Staatsbibliothek, Clm 4628

33. Cidade: München

Biblioteca e catálogo: Bayerische Staatsbibliothek, Clm 18546 
34. Cidade: Oxford

Biblioteca e catálogo: Bodlein Library, Digby 112 (S.C.1713)

Datação; Séc. XII

Local de produção: Winchester ou Glastonbury

35. Cidade: Paris

Biblioteca e catálogo: Bibliothèque Mazarine 1712

Datação: séc. XII

Local de produção: Crépy-en-Valois. Igreja de St.-Arnould

36. Cidade: Paris

Biblioteca e catálogo: Bibliothèque Nationale de France lat.5330

37. Cidade: Paris

Biblioteca e catálogo: Bibliothèque Nationale de France lat. 5600

Datação: séc. X

\section{Cidade: Rein}

Biblioteca e catálogo: Zisterzienserstift, Stiftsbibliothek 51

Datação: Séc. XII

Local de produção: Rein. Abadia de Rein.

\section{Cidade: Roma}

Biblioteca e catálogo: Basilica di San Giovanni in Laterano A.81

Datação: Séc. XII

Local de produção: Badia Pozzeri (Lucca). Abadia di S. Pietro

40. Cidade: Roma

Biblioteca e catálogo: Biblioteca Casanatense 719 (B.I.4)

Datação: Séc. XII 
Local de produção: Pistoia

41. Cidade: Rouen

Biblioteca e catálogo: Bibliothèque Municipale U.2 (1399)

Datação: séc. XII

\section{Cidade: Rouen}

Biblioteca e catálogo: Bibliothèque Municipale U. 20 (1404)

Datação: séc. XII

43. Cidade: Rouen

Biblioteca e catálogo: Bibliothèque Municipale U.22 (1410)

Datação: séc. XIII

\section{Cidade: Rouen}

Biblioteca e catálogo: Bibliothèque Municipale U.46 (1333)

Datação: Séc. XI

\section{Cidade: Sankt Gallen}

Biblioteca e catálogo: Stiftscicliothek 553

Datação: séc.IX

Local de Produção: Sankt Gallen. Abadia de St. Gallen

46. Cidade: Torino

Biblioteca e catálogo: Biblioteca Nazionale Universitaria F.II.22

Datação: séc. XV

\section{Cidade: Torino}

Biblioteca e catálogo: Biblioteca Nazionale Universitaria F.III.15

Datação: séc. X-XI 
Local de produção: Bobbio. Abadia de S. Colombano

48. Cidade: Torino

Biblioteca e catálogo: Biblioteca Nazionale Universitaria F.IV.12 (Ottino 33)

Datação: Sec. X

Local de Produção: Bobbio. Abadia de S. Colombano

49. Cidade: Torino

Biblioteca e catálogo: Biblioteca Nazionale Universitaria F.IV.26

Datação: séc.X

50.Cidade: Trier

Biblioteca e catálogo: Bischöfliches Archiv. olim Dombibliothek) 5

Datação: séc. XII

51. Cidade: Utrecht

Biblioteca e catálogo: Bibliotheek der Rijksuniversiteit 390

52. Cidade: Utrecht

Biblioteca e catálogo: Bibliotheek der Rijksuniversiteit 394

53. Cidade: Wien

Biblioteca e catálogo: Österreichische Nationalbibliothek 430

Datação: séc. XI

54. Cidade: Würzburg

Biblioteca e catálogo: Universitätsbibliothek, M.p.th.f. 139

Datação: séc. XI-XII

Local de produção: Würzburg. Abadia de St. Stephan 
55. Cidade: Zürich

Biblioteca e catálogo: Zentralbibliothek, C 10 i (olim 217; cat. 47)

Datação: séc. IX

Local de produção: Sankt Gallen. Abadia de St. Gallen 
Nota-se contudo que os manuscritos mais antigos - o de Metz (Biblioteca du Grand Séminaire 1 - manuscrito produzido na Abadia de St. Mihiel) de Sankt Gallen (Sitiftscicliothek 553 - compilado na Abadia de St. Gallen) e de Zurique (Zentralbibliothek, C 10 i (olim 217; cat 47), manuscrito também produzido na Abadia de St. Gallen) - são do século IX, o que poderia nos levar a perguntar sobre a difusão desse texto na Gália merovíngia. A resposta para esse problema deve ser buscada em outros textos produzidos na Gália no período que nos interessa, percurso esse seguido por A. O’Hara. O autor, respondendo à I. Wood que inferiu que o texto circulou pouco na Gália ${ }^{605}$ - apontou que é observável a influência da Vita Columbani em outros documentos da região e período que nos interessam. O primeiro desses documentos é a Chronica de Fredegário onde o autor usou consideravelmente as informações presentes na Vita no que concerne às relações entre Columbano e os reis, especialmente Teodorico e sua avó Brunilda. A partir dessa observação O’Hara faz apontamentos importantes, conforme ele:

The substantial use of the Vita in the Chronicle should therefore alert us to the danger os perceiving the Vita as a work that was only confined to a monastic audience. Indeed, the use of the work in what has been referred to as 'the supreme' polical tract of the 660' can be taken as an illustration of the strong political connections that were initiated by Columbanus and continued by his disciples. Kings, queens, bishops, and nobles are all prominent in the Vita Columbani and we should consider the possibility that they too might have been part of the early audience of the work. ${ }^{606}$

Além da Chronica de Fredegário, O’Hara identificou a influência da Vita Columbani em outras hagiografias merovíngias, como a Vita Germani, a Passio Praeiecti, a Vita Sadalbergae e a Vita Wandregiseli o que nos aponta para o fato de

\footnotetext{
${ }^{605}$ WOOD, I. The Vita Columbani and Merovingian hagiography. Peritia. v.1, n.1, p.63-80, 1982.

${ }^{606}$ O'HARA, A. The Vita Columbani in Merovingian Gaul. Early Medieval Europe. v.17, n.2, p.126153, 2009. p.128.
} 
que o texto não só circulou na Gália mais do que a tradição manuscrita pode nos levar a crer como também influenciou a escrita de outras vidas de santos na região. ${ }^{607} \mathrm{~A}$ Vita Columbani, assim, constitui-se como um documento de grande importância tanto enquanto um modelo de escrita hagiográfica quanto enquanto um texto que trazia narrativas políticas de tal mote que foram usadas como fonte para o autor da Chronica de Fredegário. Desta maneira restam poucas dúvidas sobre a necessidade de contemplarmos o modelo de santidade presente na Vita Columbani a fim de buscarmos o sentido do papel social desempenhados pelos santos e santas no Gália. Cabe então contemplarmos a seguinte pergunta: O que descreve a Vita Columbani e o que ela pode nos dizer sobre os santos e santas da Gália Merovíngia?

O que podemos apontar desde o início é a atenção dos reis que Columbano despertou tão-logo estabeleceu-se na Burgúndia. Conforme a narrativa de Jonas de Bobbio a fama de Columbano se espalhou de tal maneira que chegou à ciência do rei Sigiberto:

Pervenit ergo fama Columbani Sigiberti regis ad aulam, qui eo tempore duobos regnis Austrasiorum Burgundionorumque inclitus regnabat Francis; quorum eximium nomen prae ceterir gentibus quae Gallias incolunt habetur. ${ }^{608}$

Mas não apenas Sigiberto se admirou com Columbano. Seu neto, Teodorico, filho de Childeberto que conforme Jonas morrera jovem, também inicialmente saudou o monge:

Creverat iam passim fama sancti viri in universas Galliae vel Germaniae provincias, eratque omnium rumore laudabilis, omnium cultu venerabilis, in tantum ut Theudericus rex, qui eo regnabat in tempore, ad eum saepe veniret et orationum suarum suffragio omni cum humilitate deposcerit. ${ }^{609}$

\footnotetext{
${ }^{607}$ O'HARA, A. The Vita Columbani in Merovingian Gaul...op.cit.p.128-132.

${ }^{608}$ Vita Columbani, 6.

${ }^{609}$ Vita Columbani, 18
} 
As boas relações entre Columbano e Teodorico, como veremos, logo terminariam graças a ação da rainha Brunilda. Deixemos isso para adiante, por enquanto o que se deve destacar é o bom trânsito de Columbano entre os reis, algo que se repete na Vita que informa ainda sobre a recepção de Columbano por parte de Clotário $^{610}$ e Teodoberto. ${ }^{611}$

Mais por quais razões os reis estavam tão interessados por Columbano? A primeira possibilidade de resposta que emerge a partir da leitura da Vita é religiosa: a fé de Columbano era tamanha que despertara a atenção dos reis que se postavam diante da dignidade do monge. Por mais que não se possa ignorar essa resposta, uma leitura mais atenta do texto nos revela uma outra dimensão para confrontarmos esse problema, a saber: além do bom trânsito que Columbano tinha entre os reis, ele também circulava com desenvoltura entre os nobres. Como narra a Vita, os mosteiros fundados por Columbano atraíram muitos filhos de nobres: Ibi nobilium liberi undique consurrere nitebantur, ut, exspreta faleramenta saeculi et praesentium pompan facultatum temnentes, aeterna praemia caperent. ${ }^{612}$ Além dessa atração exercida por Columbano sobre os jovens nobres, outros contatos com homens e mulheres importantes se destacam na Vita.

Caso por exemplo dos contatos travados entre Columbano e o dux Waldeleno que nas palavras de Jonas "reinava" sob as gentes que habitavam entre Jura e os Alpes: Eratque enim tunc temporis dux quidam nomine Waldelenus, qui gentes qui intra Alpium septa et Iurani saltus arva incolent regebat. “613

Waldeleno era casado com Flávia, nobre de família e temperamento: Hic cum coligue Flaviam nomine et venere et prudentia mobilem [...] Aqui, a origem nobre de

\footnotetext{
${ }^{610}$ Vita Columbani, 24

${ }^{611}$ Vita Columbani, 27

${ }^{612}$ Vita Columbani 10.

${ }^{613}$ Vita Columbani, 14
} 
Flávia é ressaltada, mostrando que para Jonas uma origem nobre não era desimportante, algo que ganha relevo se compararmos com a menção do hagiógrafo ao fato de que muitos dos filhos dos nobres aderiram à vida religiosa guiada por Columbano. Muito embora Jonas tenha escrito que os filhos desses nobres abdicavam das riquezas que usufruíam, esse trecho da fonte indica que eles não abdicavam da autoridade.

O fato é que com a interseção de Columbano Flávia concebeu um filho que foi nomeado pelo próprio Columbano como Donato e foi educado no mosteiro e se tornou bispo de Besançon, exatamente a cidade de onde viera Flávia e Waldeleno para pedir a ajuda de Columbano. O casal teve ainda um outro filho que foi chamado Rameleno, também nobre e sábio que após a morte do pai o sucedeu em seu posto e em honra a Columbano fundou um mosteiro que colocou sob os cuidados do abade Siagrius: Nam et pise in amoré beati viro in saltam Iorensem super Novisona fluviolum monasterium ex eius regula construxit, in quo Siagrium abatem praefecit. ${ }^{614}$ A própria Flávia, após a morte do marido, fundou um mosteiro feminino em Besançon. O que observamos é a adesão de uma família importante à fé propagada por Columbano, família esta que exercia forte influência na área de Besançon - o filho mais jovem de Waldeleno sucedeu o pai, o filho mais velhos do dux tornou-se bispo da cidade - e que manifestavam a fé pela construção de mosteiros. Dois mencionados por Jonas, aquele fundado por Rameleno e aquele fundado por sua mãe Flávia. A prática de fundação de mosteiros por nobres na Gália é assim documentada por um hagiógrafo que escrevera pouco depois da morte de Columbano, essa prática, como demonstram muitos estudos, ${ }^{615}$ ganharia força ao longo das décadas na Gália

\footnotetext{
${ }^{614}$ Vita Columbani, 14

${ }^{615}$ Há de fato uma considerável bibliografia sobre os mosteiros fundados por Columbano ou sob a influência dele, citemos alguns trabalhos: DIERKENS, A. Prolégomènes à une histoire des relations culturelles entre les Îles Britanniques et le continent pendant le Haut Moyen Âge. La diffusion du
} 
Merovíngia. Mesmo que, como já enfatizamos no início desse tópico, não se possa confiar nas informações das hagiografias enquanto textos empíricos, é preciso tomar o objetivo da narrativa: a adesão de nobres e governantes à religiosidade propagada pelo monge peregrino Columbano, adesão essa que tomava sob a pena de Jonas a concretude da fundação de mosteiros e a ênfase na importância das famílias que patrocinavam o monasticismo columbano.

Se retomarmos nosso argumento na primeira parte desse texto acerca da importância que a aliança com os nobres desempenhava na manutenção da autoridade dos reis a atração que Columbano exerceu sobre reis merovíngios ganha uma outra tonalidade que não apenas religiosa, a saber, pela proximidade que Columbano mantinha com os nobres da Gália tê-lo próximo poderia representar uma fonte de mediação entre os reis e os nobres locais. Esse ponto de vista nos ajuda a interpretar as tensões que surgiram entre Columbano e Brunilda e seu neto Teodorico. Conforme o texto de Jonas, os problemas entre o rei e sua avó e Columbano vieram da censura que Columbano manifestou ao comportamento de Teodorico que mantinha muitas concubinas. Quando Columbano foi visitar a aula de Teodorico Brunilda apresentou os filhos do rei à Columbano que não os reconheceu como legítimos herdeiros do trono do pai por serem filhos das concubinas:

Evenit ergo, ut quadam die beatus Columbanus ad Brunichildem veniret. Erat enim tunc Brocariacum villam. Cumque illa eum in aulam venisse cerniret, filios Theuderici, quos de adulterinis permixtionibus habebat, ad virum Dei adducit; quos cum vidisset, sciscitatur, quid sibi vellint. Cui Brunichildis ait: 'Regis sunt filii; tu eos tua benedictione robora'. At ille: 'Nequaquam', inquid, 'istos regalia sceptra suscepturus scias, quia de lupanaribus emerserunt'

monachisme dit colombanien ou iro-franc das quelques monastères de la région parisienne au VIIe siècle et la politique religieuse de la reine Bathilde. In: ATSMA, H. La Neustrie. Les pays au nord de la Loire de 650 à 850 . Paris: Sigmaringen, 1989. v.II. p.371-394. LESO, T. Columbanus in Europe: the evidence from the Epistulae. Early Medieval Europe. v.21, n.4, p.358-389, 2013. E mais recentemente: FOX, Y. Power and Religion in Merovingian Gaul. Columbanian Monasticism and the Frankish Elites. Cambridge: Cambridge University Press, 2014.

${ }^{616}$ Vita Columbani, 19 
Interessante notar que o tema da legitimidade dos príncipes filhos de concubinas não é inédito, como apontamos no capítulo dedicado à realeza os filhos de Gontrão também não foram reconhecidos pelo bispo Sagitário, algo que foi rebatido por Gregório de Tours em seus Decem Libri Historiarum que afirmou que os filhos dos reis seriam reis independente das mães. A questão é que a hagiografia de Columbano, escrita por um monge de Bobbio, trouxe à tona de fato uma discussão que ocorria na Gália Franca. Evidentemente que o discurso de Jonas estava permeado pela censura à "promiscuidade" do rei, mas notar que da Itália havia ciência sobre a questão da legitimidade dos príncipes francos não parece ser um acaso. De qualquer maneira a recusa de Columbano em aceitar os filhos de Teodorico como herdeiros legítimos do trono geraram problemas ao monge especialmente fomentados pela rainha Brunilda.

As tensões entre Columbano e Brunilda e seu neto Teodorico cresceram. O rei e sua avó prometeram corrigir seus hábitos, mas não cumpriram a promessa. Columbano os censurou e em resposta a rainha colocou o rei e os nobres e bispos contra Columbano que proibiram a circulação dos monges de Columbano e proibiram também que a regra de Columbano fosse adotada. O rei ainda foi até Luxeuil e acusou Columbano de não respeitar os costumes das províncias e impedir que todos os cristãos tivessem acesso aos mosteiros. A falta de respeito aos costumes e a limitação de acesso aos mosteiros foram usados por Teodorico para ameaçar Columbano e o enviar novamente para a terra de onde viera. Nesse sentido, costumes locais, uma identidade local, aparece na Vita como uma justificativa para expulsar o monge. Não obstante, vemos Brunilda mobilizando nobres e bispos contra Columbano:

Ad haec rursum permota Brunichildis, regis animum adversum Columbanum excitat omnique canatu perturbare intendit oraturque 
proceris, auligas, obtimatis omnis, ut regis animum contra verum Dei perturbarent, episcopusque sollicitare adgressa, et de eius religione detrahendo et statum regulae, quam suis custodiendam monachis indederat, macularet. Obtemperantis igitur auligae persuasionibus miserae reginae, regis animum contra verum Dei perturbant, cogentes, ut accederet hac relegionem probaret. Abactus itaque rex ad virum Dei Luxovium venit; conquestusque cum eo, cur ab coprovincialibus moribus discisceret, et itra septa secretiora omnibus christianis aditus non pateret. ${ }^{617}$

Há dois ponto a serem destacados:

1. Columbano não reconheceu a legitimidade dos filhos de Teodorico, pela importância do monge entre os nobres esse fato não era desimportante e pode ter sido a razão principal do início das perseguições à Columbano fomentadas por Brunilda e Teodorico;

2. A Vita narra ainda o início das tensões entre Teodorico e seu irmão Teodoberto, Columbano sugeriu ao rei Clotário que ele não deveria tomar partido na querela entre os irmãos vaticinando que um dia Clotário seria o rei de toda a Gália. ${ }^{618} \mathrm{O}$ não reconhecimento da legitimidade dos filhos de Teodorico à luz das relações que Columbano mantinha tanto com Teodoberto quanto com Clotário ganha ainda tons mais dramáticos. Columbano questionou a legitimidade dos filhos de Teodorico ao mesmo tempo que se relacionava intimamente com nobres da Gália e com outros reis francos. Nobres estes que eram um importante sustentáculo para a autoridade dos reis, mas poderiam também ser decisivos para a queda de um rei. Reis que desde a narrativa de Gregório de Tours mantinha relações tensas entre si e ameaçavam o reinado dos demais reis merovíngios. Columbano assim representou para Teodorico e Brunilda uma séria ameaça.

Assim, o que a Vita Columbani - um texto com considerável circulação após o século IX como indica a tradição manuscrita, mas também que provavelmente circulou significativamente na Gália Merovíngia do século VII - nos mostra são as

\footnotetext{
${ }^{617}$ Vita Columbani, 19.

${ }^{618}$ Morante ergo rum poenes Chlotharium, lis oritur inter Theudebertum et Theudericum. Disceptantibus utrisque de regni termino, uterque ad Chlotharium legatos dirigunt, uterque adversum parem auxilium postulat. Quod Chlotharius beato Columbano insinuare procurat, consulens, ut si videretur eius consilii, se unum consentiendo contra alium dimicare. Ad quem ille prophetico repletus spiritu ait, neutris te fore pariturum consiliis, tua intra triennii tempus in ditione utrorum regna venire. Videns Chlotharius a viro Dei talia sibi prophetico ore dici, neutri parere voluit; sed promissum sibi tempus difeliter expectans, post potitus est triumphus victoriae. Vita Columbani, 24
} 
ações de um "homem santo" que transcendiam em muito apenas atos miraculosos. Antes de qualquer coisas temos um homem que circulava com desenvoltura tanto entre os círculos nobiliárquicos quanto entre os círculos reais, trânsito este que em certo ponto chegou a ameaçar a autoridade do rei Teodorico e fomentou a perseguição contra o santo, perseguição esta que teve uma resposta tanto entre nobres quanto entre outros reis: Clotário e Teodoberto receberam Columbano, Hagnerico, que era um conviva do próprio rei Teodorico também o recebeu. A atuação de Columbano tal como narrada na Vita Columbani nos traz dessa maneira uma dimensão muito importante do papel social dos santos, a saber, a dimensão política da atuação destes homens e mulheres. Os tópicos principais da Vita Columbani no que se refere à atuação política do monge irlandês se repetem nas hagiografias merovíngias que analisaremos de modo que a leitura política da Vita Columbani se constitui como um norte central na análise das vidas que vem a seguir. Cabe ainda ressaltar que tal atuação não se restringia à Gália, como nos indica o exemplo das Vidas dos Padres de Mérida e da ação de Masona na região.

No que concerne as hagiografias merovíngias a Vita Columbani nos traz referências pontuais sobre a vida política dos santos e santas que são recorrentes nesses textos como veremos a seguir. A organização da análise desses textos redundou em duas partes, a primeira referente a santidade oriunda da realeza franca, a segunda concernente aos santos advindos da nobreza, há algumas diferenças importantes entre esses textos especialmente no que se refere à imagem dos francos neles apresentada.

\section{A realeza e a santidade na Gália Merovíngia}


Já argumentado no capítulo dedicado à realeza que a idéia de um modelo sagrado da realeza tanto merovíngia quanto visigoda deve ser problematizado. Isso não significa dizer, entretanto, que das fileiras de ambas as realezas não tenham surgido pessoas que ganharam o status de santos e santas. No lado visigodo temos Hermenegildo, o filho rebelde de Leovigildo, que embora não tenha sido reconhecido como santo pelas fontes da Hispania visigoda foi celebrado por Gregório Magno como um herói da fé em seus Diálogos. ${ }^{619}$ Por outro lado a dinastia Merovíngia foi mais profícua na produção de santos, com destaque para as santas rainhas, como Balthilda e Radegunda, que tiveram suas vidas escritas ainda no período Merovíngio, e Clotilde, esposa de Clóvis, cuja vida foi escrita no século X. ${ }^{620}$ Além das rainhas, recebeu o status de santo Dagoberto II cuja Vita foi escrita entre o fim do século IX e o século XI. ${ }^{621}$ Contemporâneo ao período de nosso interesse, contudo, duas vidas de santas advindas da realeza nos interessam: a de Balthilda e a de Radegunda.

Há pontos em comum entre as vidas de ambas as rainhas. Primeiro, tanto Balthilda quanto Radegunda não eram nascidas na Gália. Conforme a vida de Radegunda escrita por Venâncio Fortunato, ela era uma princesa da Turíngia enquanto a vida de Balthilda a descreve como de origem saxã. A diferença entre elas nesse ponto, entretanto, se deve ao fato de que a vida da primeira a coloca como filha de reis enquanto a segunda é descrita como de origem servil:

\begin{tabular}{|cc|c|}
\hline \multicolumn{2}{|c|}{ Vita Radegunda I } & Vita Balthildis \\
Beatissima $\quad$ igitur Radegundis $\quad$ natione & Et ideo merito ipsius laus canenda est prius \\
\hline
\end{tabular}

${ }^{619}$ MARCOTEGUI BARBER, B. El tratamiento historiográfico de San Hermenegildo. AHIg, n.12, p.289-302. 2003. p.297-299

${ }^{620}$ KRUSCH, B. Vita S. Chrothildis. In: Idem. Fredegarii et Aliorum Chronica. Vitae Sanctorum. MGH, Scriptores Rerum Merovingicarum. v. II. 1888. p. 341-348.

${ }^{621}$ A data da redação da Vita é muito debatida. W. Levison defendeu que o texto foi escrito no fim do século IX, já F. Graus defendeu que foi escrito no fim do século X enquanto C. Carozzi estabeleceu uma data mais tardia, a saber, início do século XI. A. Dierkens defende que o texto é do fim do século IX. Cf: DIERKENS, A. Note sur un passage de la Vita Dagobert II et le domaine de Biesme. Revue belga de philologie et d'histoire. v.62, n.62-2, p.259-270, 1984. p.260. 


\begin{tabular}{|c|c|}
\hline $\begin{array}{l}\text { barbara de regione Thoringa, avo rege } \\
\text { Bessino, patruo Hermenfredo, patre rege } \\
\text { Bertechario, in quantum altitudo saeculi } \\
\text { tangit, regio de germine orta, celsa licet } \\
\text { origine, multo celsior actione. }{ }^{622}\end{array}$ & $\begin{array}{l}\text { in sanctorum meritis sive virtutibus, qui de } \\
\text { parvis efficit magnos, immo qui de stercore } \\
\text { elevat pauperem et eum consedere facit cum } \\
\text { principibus populi sui, sicut et presentem } \\
\text { venerabilem magnamque feminam, domnam } \\
\text { Balthildaem reginam. Quam de partibus } \\
\text { transmarinis divina providentia advocans, et } \\
\text { vili pretio venundata, huc advenit ipsa } \\
\text { pretiosa et optima Dei margarita. [...]. Et } \\
\text { cum esset ex genere Saxonum, forma } \\
\text { corporis grata ac subtilissima et aspectu } \\
\text { decora, vultu hilaris et incessu gravis. }{ }^{63}\end{array}$ \\
\hline
\end{tabular}

A origem nobre de Radegunda foi celebrada por Fortunato, entretanto, sua nobreza se destacava muito mais por suas ações. No caso de Balthilda, sua origem servil era compensada por sua piedade.

O segundo ponto em comum entre as duas rainhas se deve à fundação de mosteiros patrocinados por elas e o fato de que ambas terminaram suas vidas em mosteiros. Radegunda no mosteiro da Santa Cruz em Poitiers, Balthilda no mosteiro de Chelles. Temos assim duas rainhas advindas de terras externas à Gália e que se tornaram patrocinadoras e abadessas de mosteiros e, mais importante, santas. É difícil precisar as razões que tornavam uma pessoa digna da santidade na Gália Merovíngia, entretanto, há algo em comum nas Vitae de todos os santos e santas que nasceram naquele período: todos, sem exceção, desempenharam papéis políticos em vida e depois seus espólios continuaram a ter usos políticos. Desde Columbano, o monge do além mar que, como já indicamos, transitava com desenvoltura entre os círculos reais e nobres, até as duas rainhas que analisamos agora.

Vamos começar por Radegunda. Advinda da realeza Turíngia Radegunda foi a mulher do rei franco Clotário I, por razões que as vitae atribuem à piedade da rainha ela afastou-se do rei e insistiu para que pudesse seguir uma vida religiosa, algo que foi permitido por Clotário I por temor ao castigo que poderia receber caso impedisse o

\footnotetext{
${ }^{622}$ Vita Radegunda I, 2.

${ }^{623}$ Vita Balthildis, 2
} 
desejo de Radegunda. ${ }^{624}$ Após sua morte o culto à Radegunda não parece ter demorado a se propagar, Gregório de Tours em seus Decem Libri Historiarum já relatava a santidade da rainha e ele próprio foi a Poitiers para presenciar seu funeral, conforme B. Brennan a importância do culto à Radegunda pouco depois de sua morte pode nos levar a conjecturar que já no século VII ela se configurava como a padroeira de Poitiers. ${ }^{625}$

A princesa turíngia teve a Vita descrita em dois textos produzidos pouco depois de sua morte em 587: um por Venâncio Fortunato que foi provavelmente escrito muito pouco depois da morte de Radegunda (Vita Radegunda I) e outro por Baudonivia (Vita Radegunda II), monja do mosteiro fundado por Radegunda e que deve ter produzido o texto entre 609 e $614 .{ }^{626}$ Em ambos os textos lemos o relato das ações de uma rainha que não se privava de participar ativamente da política do reino. No texto de Venâncio Fortunato a ação política de Radegunda aparece com mais clareza quando a rainha intercede pelas pessoas que eram condenadas pelo rei:

Qualiter vero, si quis pro culpa criminali, ut assolet, a rede deputabatur interfici, sanctissima regina moriebatur cruciatu, ne designatur reus moreretur in gladio? Qualiter concursabat per domesticos fideles, servientes et proceres, quorum blandimentis mulcebat animum principis, donec in ipsa ira regis, unde processerat sors mortis inde currete vox salutis? $?^{627}$

Mas é interessante perceber que é na segunda versão da vita, escrita pela monja Baudonivina, que a atuação política de Radegunda se sobressai o que indica que conforme a narrativa de Baudonivina o retiro espiritual de Radegunda não implicou num afastamento da vida política da rainha. Radegunda, conforme

\footnotetext{
${ }^{624}$ Vita Radegunda II, 7.

${ }^{625}$ BRENNAN, B. St. Radegund and the Early Development of Her Cult at Poitiers. Journal of Religious History. n.13, p.340-353, 1985.

${ }^{626}$ PEJENAUTE RUBIO, F. La Vida de Santa Radegunda escrita por Baudonivia. Archivum. t.56, p.313-360, 2006. p.314.

627 ? Vita Radegunda I, 10.
} 
Baudonivia, continuou atuante, se correspondendo com reis e nobres e intervindo quando as tensões do reino se intensificavam:

Sempre de pace sollicita, de salute patriae curiosa, quandoquidem inter se regna movebantur, quia totos diligebat reges, pro omnium vita orabat et nos sine intermissione pro eorum stabilitate orare docebat. Ubi eos inter se amaritudinem moveri audisset, tota tremebat, et quales litteras uni, tales alteri dirigebat, ut inter se non bella nec arma tractarent, sed pacem firmarent, et patria ne periret. Similiter et ad eorum proceres dirigebat, ut praecelsis regibus consilia salutifera ministrarent, ut, eis regnantibus, populi et patria salubrior redderetur. ${ }^{628}$

Radegunda foi assim apresentada como uma santa oriunda da corte de Clotário I, uma rainha, que mesmo no mosteiro se mantinha informada e atuante no desenrolar dos eventos políticos da Gália. Essa imagem da santidade política, como já apontamos, também se manteve na Vita Columbani constituindo-se assim como uma tópica discursiva comum nas hagiografias dos santos e santas merovíngios.

Interessante entretanto analisar como os francos aparecem na vita na versão de Baudonivia. Logo na primeira referência aos francos há uma imagem negativa que contrasta com a glorificação da gens presente nas histórias. Nesse trecho Baudovinia retratou os francos como seguidores de, como nos leva a entender o texto, um culto que não era cristão:

Invitata ad prandium Asifridae matronae, dum iter ageret, saeculi pompa se comitante, interiecta longinquitate terrae ac spatio, fanus qui a Franci colebatur, in itinere beatae reginae quantum miliario uno proximus erat. Hoc illa audiens, ibi a Francis fanum coli, iussit famulis fanum igni conburi, iniquum iudicans, Deum caeli contempni et diabolica machinamenta venerari. Hoc audientes Franci universaque multitudo cum gladiis et fustibus vel omni fremitu diabolico conabantur defendere; sancta vero regina inmobilis perseverans, Christum in pectore gestans, equum quem sedebat in antea non movit, antequam et fanus perureretur, et, ipsa orante, inter se populi pacem firmarent. Quo facto, virtutem et constantiam reginae omnes admirantes, Domino benedixereunt. ${ }^{629}$

\footnotetext{
${ }^{628}$ Vita Radegunda II, 10.

${ }^{629}$. Vita Radegunda II, 2.
} 
Temos assim Radegunda como uma intercessora pela concórdia entre os francos a partir do combate à um culto não cristão. É pela intervenção da rainha que os francos abandonam o culto e é pelo incêndio do templo conduzido por ela que a paz entre os povos foi firmada. Não há assim uma qualidade imanente aos francos a não ser aquela que advém da atuação de Radegunda. Evidentemente que tal narrativa deve ser, mais uma vez, compreendida à luz do sentido de um texto hagiográfico. Não se tratava de construir e celebrar a memória do reino inserido na idéia de uma gens mas antes de celebrar a memória da santa que conduz tanto a gens quanto as regna à concórdia: primeiro combatendo os cultos infiéis, segundo aconselhando os reis e os nobres para que abandonassem as intrigas e mantivessem a paz. Nem os reis, nem as regna nem a gens tinha um valor por si. A valorização dessas três entidades se dá pela relação que mantinham com a santa. Isso se evidencia com vigor na narrativa sobre Clotário I e Radegunda, o rei só passa a receber um retrato mais positivo no texto quando se posta aos pés do bispo diante da tumba de Martinho de Tours e pede perdão por ter impedido que Radegunda seguisse a vida religiosa:

Sic rex amaritudine plenus intellegens, hoc petitionem esse beatae reginae, parnitentia ductus, malis consiliariis reputans seque indignum iudicans, quod talem habere reginam diutius non meruisset, prosternit se et ille ante limina sancti Martini pedibus apostolici viri Germani, rogat, ut sic pro ipso veniam peteret beatae Radegundi, ut ei indulgeret, quod in eam per malos consiliarios peccaverat. ${ }^{630}$

Nesse sentido, a imagem dos francos e dos reis serve mais para glorificar a memória da santa do que para indicar um valor instríseco ao rei e à gens. A santidade de Radegunda não estava atrelada ao fato de ter sido uma rainha - não só pelo casamento com Clotário, mas também por ter vindo da realeza Turíngia - e sim pela sua piedade e santidade comprovada pelo papel de pacificadora do reino e dos populi

${ }^{630}$ Vita Radegunda II, 7. 
do reino, incluindo os francos. Essa mesma tópico se observa na Vita Balthildis. Balthilda, ${ }^{631}$ que viera do além mar e era uma saxã tornou-se rainha por ter se casado com o rei Clóvis II. O casamento de Balthilda com Clóvis, segundo foi relatado pelo autor ou autora da sua hagiografia, era já um sinal da intercessão divina uma vez que Balthilda conseguiu escapar do casamento com Equinoaldo ${ }^{632}$ e cumprir sua função providencialista maior que era casar-se com Clóvis e assim dignificar a dinastia merovíngia e garantir a paz entre a Nêustria, Austrásia e Burgúndia:

Quid plura? Deo iubente, rex Chlodoveus, vir eius, migravit de corpore; relictaque sobole filiorum cum matre suscepit ilico post eum filius Chlotharius quondam Francorum regnum, tunc etenim precellentibus principibus Chrodoberhto episcopo Parisiaco et domno Audoeno seu et Ebroino maiore domus cum reliquis senioribus vel ceteris quam pluribus, et regno quidem Francorum in pace consistenti. Tunc etenim nuper et Austrasii pacifico ordine, ordinante domna Balthilde, per consilium quidem seniorum receperunt Childericum, filium eius, in regem Austri; Burgundiones vero et Franci facti sunt uniti. Et credimus, Deo gubernante, iuxta domnae Balthildis magnam fidem ipsa tria regna tunc inter se tenebant pacis concordiam. ${ }^{633}$

Foi assim graças a intervenção de Balthilda e sua descendência que a paz se estabeleceu entre os francos, sendo a ação de Balthilda enquanto uma santa central.

Não havia um valor dos francos, do reino ou dos reis nesse texto apartado da ação de Balthilda, algo que se fortalece no final da vita que descreve a ação de outras rainhas valorosas pela fé que dignificaram o reino:

Recolimus quidem, in Francorum regno nobilis et Dei cultricis fuisse aliquas reginas, Chrodehilde, Chlodoveo quondam antiquo rege regina, nepte Gundebade rege, que virum suum fortissimum et paganum, et tam ipsum per sanctam exortacionem quam et plures

\footnotetext{
${ }^{631}$ E tal como Radegunda a ação política de Balthilda era de grande relevância. O tema foi estudado muito bem por J. Nelson em seu clássico artigo: NELSON, J.L. Queens as Jezebels: Brunhild and Balthilde. In: NELSON, J.L. Politics and ritual in Early Medieval Europe. Londres \& Roceverte: Hambledon Press, 1986. p.1-48. Um outro interessante estudo sobre a ação de Balthilda dessa vez centrado em sua hagiografia é: TATUM, S. Auctoritas as sanctitas: Balthild's depiction as 'queensaint' in the Vita Balthildis. European Review of History - Revue européene d'histoire. V.16, n.6, p.809-834, december 2009.

${ }^{632}$ Vita Balthildis, 3.

${ }^{633}$ Vita Balthildis, 5.
} 
ex Francis seniores, traxit ad christianitatem et ad fidem catholicam eos perduxit et aecclesias in honore sancti Petri Parisus et sancti Georgii in coenobiolo virginum in Kala prima construxit et alia quam plura pro mercede conpendii in honore sanctorum condidit et muneribus pluris ditavit. Et pariter de Ultrogoda fertur, regina Childeberto christianissimi regis, eo quod consolatrix fuisset pauperum et servorum Dei vel monachorum adiutrix. Nec non et de Deu valde fidelissima famula Radegunde regina, Chlotharii quondam anterioris regis regina, quam tanta sancti Spiritus succenderat gratia, ita ut vivum relinqueret coniugem et se Christo domino sub sacro velamine consecraret et multa bona ut Christo sponso peregeret, quae in actibus eius leguntur. ${ }^{634}$

Nota-se portanto, que as hagiografias das rainhas francas trazem uma imagem dos francos de todo diversa daquela observada nas Historiae. Nas hagiografias são as rainhas, independente da própria realeza, que pela santidade garantem a paz do reino intercedendo para arrefecer os ânimos da gens e dos próprios reis, dignificando a dinastia com seus filhos e mesmo combatendo a infidelidade religiosa dos francos, como testemunhamos na Vita Radegunda II. O discurso em torno da identidade da gens nesse sentido é diluído para trazer ênfase à imagem das santas, elas sim responsáveis pelos sucessos dos reis e do reino e pela imagem da gens. É à luz dessa leitura que o lugar dos francos faz sentido nas hagiografias de Radegunda e Balthilda: os francos são antes uma das plataformas que indicam a santidade dessas mulheres do que algo a ser celebrado por si. Interessante notar que tal imagem advém justamente de textos que narram as vidas das rainhas francas, o que se torna ainda mais notável se considerarmos a negatividade com a qual os francos e Clotário I são retratados em alguns trechos da vida de Radegunda escrita por Baudonivia. Torna-se desta maneira interessante conferirmos se esse mesmo tipo de discurso aparece em outras hagiografias, estas que não versavam sobre rainhas, mas sobre santos advindos das fileiras nobiliárquicas.

\section{Nobres santos, santos nobres - nobreza e santidade na Gália Merovíngia}

${ }^{634}$ Vita Balthildis, 18. Ver tradução 45, anexo 1. 
Não só das fileiras da realeza merovíngia vieram santos. De fato, a maioria dos santos da Gália Merovíngia advinham da nobreza. Isso é verdade para Wandrille, fundador do mosteiro de Fontenelle que se tornou um dos mais importantes centros de produção de textos da Gália. É também verdade para Audoíno, um destacado nobre de Rouen, Leudegário bispo de Autun e Praejecto bispo de Clermont. Todos esses quatro nomes não representavam apenas uma fonte de inspiração religiosa, suas Vitae narram também a intensidade com a qual estavam envolvidos na política e como em certos caso, como o de Praejecto, seus envolvimentos políticos redundaram em suas mortes que ganharam tonalidades profundamente religiosas quando descritas como paixões. O retrato da realeza e suas alianças e contrastes com poderes locais emergentes se sobressai nas vidas desses santos, todos homens filiados à famílias de destacada autoridade regional. De fato, na vida dos quatro, as origens nobres são mencionadas. No caso de Audoíno a menção à sua nobreza não aparece apenas em sua Vita, mas também na Vita Columbani indicando que o reconhecimento da importância da sua família parecia ser amplo:

\section{Vita Columbani}

Progressusque inde venit ad villam quendam Vulciacum, quae supra amnem Matronam sita est. Ibi receptus a quodam viro Autharium nomen, cuius coniunx Aiga dicebatur; erantque his filii infra infantiae annis detenti, quos mater ad benedicendum viro Dei obtulit. Videns ille matris fidem infantulos sua benedictione sacravit, qui post, mox ut pubescere coeperunt, Chlotharii regis primum ac deinceps Dagoberti gratissimi habiti; qui postquam saeculi gloria fuerunt inlustrati, anhelare coeperunt, ut per gloriam saeculi non carerent aeternam. Quorum maior natu Ado nomen semet suis voluntatibus abdicavit, postque intra Iorani saltus monasterium ex beati regula Columbani construxit; iuniorque nomine Dado intra Briegensem saltum supra fluviolum Resbacem ex supradicti viri regula
Temporibus Chlotharii gloriosi principis, filium itemque regis Chilperici, provintia Galliarum Suessionico opido orti sunt tres venerabiles viri, ex uno semine nobiles generati, gratia Dei caelitus inluminati, Ado, Dado et Rado. Pater eorum Audecharius, mater vero nomine Aiga, uterque christiano apice decorati. Qui a rudimentis infantiae litterarum sunt acumine informati, ab ipso principe dilecti, prudentissime eruditi $a b$ ilustris viris optime. Primogenitus vero Ado floruit ordine monastico, religiosamque adpetens vitam, mundi huius calcavit malitiam. Rado autem palatii thesauros custos effectus, una cum seculi dignitate adeptus, timorem Domini praecinctus, in elemosynis largus, fideliter custodivit atque fascibus ministravit. Venerabilis ergo Audoinus cognomento Dado pontifex 
monasterium construxit. ${ }^{635}$ (Autharius na Vita Columbani e Audecharius na Vita Audoini) e de Aiga. Autário era um nobre que conforme a Vita Columbani recebeu Columbano em Ussy, a Vita Audoini destaca o local de nascimento de Dado, futuro bispo de Rouen conhecido como Audoíno, a saber, Soissons. O filho mais velho do casal, Ado, fundou um mosteiro sob a forma de vida religiosa inspirada em Columbano em Jura. Conforme especificado na Vita Columbani, Rado serviu ao tesouro do Palácio e já Dado, conforme a Vita Columbani, fundou um mosteiro sob a regula de Columbano.

$\mathrm{Na}$ vita dedicada a ele a narrativa se concentra em seu período como bispo. Temos então a descrição de uma família importante no Nordeste da França que teve um dos seus membros nomeado como bispo numa região mais distante do que aquela em que atuava seu pai e irmãos: Rouen. Essa distante alocação de Audoíno como bispo de Rouen pode ser estranha a priori, mas ganha mais sentido quando observarmos a época em que atuou o bispo, a saber, ele nasceu quando reinava Clotário II e atuou com mais intensidade durante o reinado de Dagoberto. Ambos os reis, como já apontado por Hélvetius, ${ }^{637}$ intensificaram a prática de trazer os filhos da nobreza para o corte de depois enviá-los para cargos episcopais de modo que atuassem como fiéis representantes dos reis. Audoíno se encaixa bem nesse perfil, como $\log 0$ narrou sua vita, ${ }^{638}$ ele desfrutou da confiança de Dagoberto e de fato foi até a corte do rei acompanhado por Elígio, bispo de Noyon: Ex hoc beatum Eligium

\footnotetext{
${ }^{635}$ Vita Columbani, 26.

${ }^{636}$ Vita Audoini, 1.

${ }^{637}$ HELVÉTIUS, Anne-Marie. Hagiographie et formation politique des aristocrates dans le monde franc $\left(\mathrm{VII}^{\mathrm{e}}-\mathrm{VIII}^{\mathrm{e}}\right.$ siècles). BOZÓKY, Edina. Hagiographie, idéologie et politique au Moyen Âge en Occident. Acter du colloque international du Centre d'Études supérieures de Civilisation médiévale de Poitiers. 11-14 septembre 2008. Turnhout: Brepols, 2012. p.59-79.

${ }^{638}$ Vita Audoini, 2.
} 
Noviomensem antestitem, virtutibus conprobatum, fidei caritate coniunxit, et quasi duae oLiuvae pinguissimae vel duo candelabra aurea splendentes, solem iustitiae inluminati, ambo pariter fulgebant aula palatii. ${ }^{639}$

Tal como nas vidas outrora vistas das rainhas merovíngias, a imagem da gens Francorum na vita de Audoíno também é glorificada tão-somente pela ação do santo. Assim, a gens serve mais como mais uma comprovação da santidade de Audoíno do que é comemorada por haver um valor intrínseco. Audoíno, como lemos, por sua fé, obliterou a ferocidade dos francos:

[...] ita protegente Domino in religione fidei roboratus, Francorum saevissima feritate in mansuetudine vertit et ex sacro fonte mellis dulcidinem temperavit parrochiasque suas divino cultui consecravit, ut, relicto rito gentilium, sponte se ad Christi iugum vel servitium colla sua subponerent. ${ }^{640}$

Essa ação do santo em favor das gentes ganha relevo quando vemos que a interceção de Audoíno transcendeu mesmo as fronteiras do reino dos francos e contribuiu para o benefício dos godos que viviam um período de carestia:

Tandem misericors Deus videns adflictionem populi sui, misertus humanis laboribus, in introitu famuli sui Audoini pluviam statim concessit et terram sitientem imbrem mirificum temperavit. Unde felix opinio Gothorum terras penetravit. ${ }^{641}$

A atuação de Audoíno não tinha apenas um impacto positivo de celebração da gens Francorum. A memória construída acerca do bispo glorificava sua autoridade pelas benesses por ele proporcionada tanto aos francos quanto aos godos. Não se tratava sob nenhum ponto de vista de uma construção narrativa que valorizava as regna Francorum, como observamos nas narrativas históricas que valorizavam a gens Francorum e as regna Francorum pelo valor intrínseco as gentes concretizadas pela

\footnotetext{
${ }^{639}$ Vita Audoini, 4.

${ }^{640}$ Vita Audoini, 4.

${ }^{641}$ Vita Audoini, 7.
} 
grandeza de seus reis ou, em caso de fraqueza real evidente, pela valorização da ancestralidade dos merovíngios. Estamos diante de um outro significado para as gentes na construção da memória, nesse caso dos santos: o valor delas é sempre outorgado pela atuação do intermediário de Deus. O abandono da ferocidade, dos cultos não-cristãos e a caminhada em direção à glória da salvação eterna é sempre resultado da interceção de santos em favor das gentes.

Evidentemente que tal construção narrativa salienta em primeira instância a memória do santo e, em última instância, o papel que essas pessoas representavam na construção de identidades locais enquanto patronos de suas regiões e representantes de uma família. Um outro exemplo que destaca essa dimensão identitária é observável no caso da Vita Sadalbergae e a tentativa de salvaguardar o prestígio de sua família. ${ }^{642} \mathrm{O}$ culto aos santos se constituía assim como uma elaboração que celebrava a memória de santos que eram não raro locais e filiados a grupos nobiliárquicos, e eram essas identidades locais baseadas em torno do culto à seus santos que se sobressaíam em detrimento à uma identidade franca propagandeada pelas histórias e baseadas na figura dos reis. Na especificidade dos relatos hagiográficos, a importância da gens se dilui para trazer à tona a importância dos santos locais. Há assim uma certa tensão entre os discursos identitários francos - que nas narrativas hagiográficas por vezes ganhava tonalidades negativas - e os discursos identitários regionais construídos em torno dos santos. Na Vita Audoini isso não fica tão evidente uma vez que o santo era glorificado não só em sua região, mas também na vita foi descrito como um intercessor, tal como Balthilda e Radegunda, que atuava na corte para dirimir as querelas entre os nobres atuando assim em favor também do reino:

Exinde beatus Audoinus cum in pace reversus fuisset ad propria,

\footnotetext{
${ }^{642}$ FOX, Y. Power and Religion in Merovingian Gaul. Columbanian Monasticism and the Frankish Elites. Cambridge: Cambridge University Press, 2014. p.146.
} 
invenit vir pacificus in regno Francorum inter principes palatii orta scandala, instigante diabulo, seminatorem discordiae. Tum vir Domini adsumens arma iustitiae, pernoctans cum vigiliis et ieiuniis nimiis et orationibus assidsuis, pro concordia eorum fortiter desudabat. ${ }^{643}$

Audoíno, formado na corte de Clotário II e depois Dagoberto, promotor da concórdia na corte real e que antes de ser escolhido como bispo de Rouen pelo rei havia atuado como um servidor laico da corte era mais um aristocrata que tornou-se bispo e santo aliado aos reis do que um opositor, como foi Columbano opositor à Brunilda e Teodorico. ${ }^{644}$ Essa filiação política dos homens considerados santos, contudo, nem sempre tinha desfechos favoráveis ao santo, como nos mostra os casos de Leodegário e Praejecto.

Leudegário, bispo de Autun entre 662 e 676, sobrinho do bispo Dido de Poitiers, conforme nos descreve sua vita, foi escolhido por Balthilda para assumir o bispado de Autun depois que uma disputa pelo posto começou na cidade:

\section{[...] tunc Balthildis regina, qui cum Chlothario filio Francorum regebant palatium, divinum, ut credimus, inspirata consilium, ad memoratam urbem hunc strinuum direxit virum ibidem esse episcopum, quatenus et ecclesia, quae pene biennium iam quasi viduata in saeculi fluctiatione remanserat, huius gubernationem vel fortitudinem tueretur et ab his quibus inpugnabatur defensaretur. ${ }^{645}$}

Os acontecimentos descritos na Passio que mobilizaram aliados do maior domus Ebroin e do bispo Leudegário e que culminaram com a morte de Leudegário são importantes apontamentos para as profundas tensões políticas que avançavam na Gália que mobilizavam nobres cada vez mais fortes e identificados com termos regionais como nêustrios, austrasianos e burgúndios, ${ }^{646}$ como apontamos já na leitura

\footnotetext{
${ }^{643}$ Vita Audoini, 12.

${ }^{644}$ Uma interessante discussão sobre a questão pode ser encontrada em: FOURACHE, P. \& GERBERDING, R.A. Late Merovingian France. History and Hagiography. 640-720. Manchester \& NY: Manchester University Press, 1996. p.133-152.

${ }^{645}$ Passio Leudegarii, 2.

${ }^{646}$ Embora I. Wood tenha argumentado de maneira convincente que essas facções nobres não estavam ligadas necessariamente em termos regionais, é notável como referências regionais aparecem nas
} 
da Chronica de Fredegário. O fato é que a Passio de Leudegário nos leva a crer que as disputas entre Ebroin - que alcançou enorme poder especialmente depois do retiro de Balthilda em Chelles - e Leudegário se intensificaram quando Ebroin impediu que os burgúndios tivessem acesso à corte. A partir dessa acontecimento a Passio de Leudegário intensifica a narrativa negativa acerca de Ebroin.

Ebroin, após a morte de Clotário III (651-673), elevou ao trono Teodorico III, mais uma vez impedindo que os nobres tivessem acesso ao rei e portanto à corte:

Cumque multitudo nobilium, qui ad regis novis properabant occursum, mandante Ebroino, iteneris accepissent repudium, inito in cummune consilium, relicto eo, omnes expetiunt Childericum, iuniorem eius fratrem, qui in Auster sortierat regnum. ${ }^{647}$

A resistência de Ebroin ao contato de Teodorico III com os nobres, como podemos constatar, levou os nobres a se reunirem e a reconhecerem Childerico II como rei. A origem desses nobres impedidos por Ebroin de ter com Teodorico III não é discriminada na fonte, mas no capítulo 7 emerge a impressão de que eles advinham de todas as áreas do reino já que a primeira decisão de Childerico II descrita na Passio consiste no reconhecimento do rei de que os três reinos deveriam manter as leis e os costumes locais e que todos deveriam ter acesso à corte:

Interea Childerico rege expetiunt universi, ut talia daret decreta per tria quam obtinuerat regna, ut uniuscuiusque patriae legem vel consuetudinem deberent, sicut antiquitus, iudices conservare, et ne de una provintia rectores in aliis introirent, neque unus ad instar Ebroini tyrrannidem adsumeret, ut postmodum sicut ille contubernales suos despiceret; sed dum mutua sibi successione culminis habere cognoscerent, nullus se alio anteferre auderet. ${ }^{648}$

Não há dúvidas de que a Passio traz um relato centrado na política do reino que cada vez mais se evidenciava como uma disputa de facções nobiliárquicas que lançavam

fontes. $C f$ : WOOD, I. The Merovingian Kingdoms. 450-751. Londres \& NY: Longman, 1994. p. 236237

${ }^{647}$ Passio Leudegarii, 5.

${ }^{648}$ Passio Leudegarii, 7. 
mão de identidades regionais para conduzir suas reivindicações políticas. A oposição a Ebroin, nesse sentido, pode ser lida como um indicativo de que o maior domus tentou suprimir esses grupos nobres que se revoltaram contra ele, derrubaram Teodorico III e elevaram Childerico II ao trono que imediatamente contemplou as reivindicações da nobreza. Não se trata aqui de compreendermos literalmente a fonte e dizermos que a nobreza era de fato enraizada regionalmente, mas de enfatizar que o discurso regional foi usado e que teve um resultado político: uma política que contemplava identidades que se apresentavam como regionais por parte de Childerico, identidades políticas que eram evocadas para reivindicações de nobres. O que é interessante notar é que na Passio de Leudegário os francos enquanto uma construção identitária coerente são personagens secundários, são os três reinos que passam a se tornar a fonte de identidades nas disputas políticas em curso.

Quase que contemporaneamente aos eventos que redundaram na morte de Leodegário, Praejecto, bispo de Clermont, também enfrentou dificuldades que culminaram em sua morte narrada também numa Passio. O autor da Passio Praejecti, como de praxe nas hagiografias merovíngias, celebra a linhagem de Prajecto, enfatizando entretanto que ele era de uma longa linhagem de cristão, o que Fouracre e Gerberding interpretaram como sinal de que ele não advinha de uma família nobre tradicional. ${ }^{649}$ Praejecto foi confiado pelos pais à Genésio que tornou-se bispo de Clermont, educou Praejecto e depois delegou à ele a responsabilidade sob a igreja de Issoire ${ }^{650}$ A contemporaneidade dos eventos que redundaram nas mortes de Praejecto e Leudegário não significa entretanto que os bispos tinham qualquer aliança, pelo contrário, a Passio Praejecti traz uma imagem bastante negativa de Leudegário que conforme a Passio Praejecti esteve envolvido nos acontecimentos que redundaram na

\footnotetext{
${ }^{649}$ FOURACRE, P. \& GERBERDING, R.A. Late Merovingian France. History and Hagiography. 640-720. Manchester \& NY: Manchester University Press, 1996. p.272, nota 52.

${ }^{650}$ Passio Prajecti, 4 e 5.
} 
morte do bispo de Clermont. Hector, um patricius de Marselha, recorreu a corte de Childerico por uma causa e contou com a ajuda de Leudegário para ter seu pedido atendido, conforme a Passio de Leudegário nos relata. Já a Passio de Praejecto especifica a causa: tratava-se de uma requisição feita acerca das terras da filha de uma certa Cláudia que Hector reduziu ao concubinato e ainda acusou Praejecto de tentar roubar as terras que a jovem herdara da mãe. Interessante confrontar a versão dos fatos conforme descritas nas duas paixões:

\section{Passio Leudegarii}

Adfuit enim tunc in illis diebus vir quidam nobilis Hector vocatus nomine, qui tunc regebat in fascibus patriciatum Masiliae, quique generis nobilitate et prudentia saeculi, ut claro stigmate ortus, ita erat prae ceteris praeditus. Hic enim ad Childericum regem pro quadam causa advenerat et per viri Dei intercessionem optinere petita sperabat, eumque gratia hospitalitatis in urbe sua Dei sanctus reciperat, donec, sicut petierat, suis intercessionibus eum regem comendare deberet. Nam sepedicto Childerico in ecclesia urbis sua in paschale solemnitate rogaverat advenire. Hanc invidi repperierunt occasionem, per quam nequitiam, quam nuper in cor regis effuderant, adimpletent. Maiorum domus tunc Vulfoaldum in sua occasione coniungunt, mendacem fabulam de Leodegario et Hectore confingunt, quasi ideo insimul fuisset coniuncti, ut regiam dominationem averterent et potestatis iura sibimet usurparent. ${ }^{651}$

\section{Passio Praejecti}

Erat illo in tempore in supradicto territorio Arverno quedam femina Deo dicata nomine Claudia, ad quem sedule propter causam predicationis veniebat, resque suas ex parte in predicto pontifice vel pauperes, quos ipse regebat, contulit. At non post multum spatium temporis debitum inplevit nature. Que a beato Preiecto summo honore est tumulata. His ita transactis, erat quidam infamis vir Hector nomine, qui aput Massiliam patriciatus honore adeptus fuerat. Qui filiam suprascripte Claudie raptam ex scelere sibi sociaverant, et deinceps concubinarum miseria adorsus, ad Hildericum principem, qui eo tempore uterque regna suscepta gubernabat, alium sibi in scelere sociatum nomine Leodegarium, pervenit ad regem. Quod postea in eiusdem martyrium perficiende fomis scandali fuit. Incusatur pontifice, quod predia predicte femine Claudie sibi vindicaret, causasque regi depromit, obtinuitque cum principe, ut missos ex latere dirigeret, qui eum per fideiussores mitterent $\underset{652}{e t}$ in aula regis facerent presentari. ${ }^{652}$

As duas vidas confluem no início das tensões: tudo começou com o pedido de Hector à Childerico que contrastava com a doação feita por Cláudia à Praejecto. Hector contou com o apoio de Leudegário, de todo modo, em ambos os casos, o desenrolar dos acontecimentos foi negativo tanto para Leudegário quanto para

\footnotetext{
${ }^{651}$ Passio Leudegarii, 9.

${ }^{652}$ Passio Praejectii, 23.
} 
Praejecto. Mesmo assim, além das confluências, as divergências também nos interessam. Primeiro porque a vida de Praejecto especifica o problema que adveio da doação feita por Cláudia e contestado por Hector, sendo esse um dos focos da tensão que acabou com a morte de Praejecto, por outro lado a Passio de Leudegário indica um problema muito mais complexo relacionado com a acusação feita por Vulfoaldo, maior domus, de que tanto Leudegário quanto Hector estavam conspirando contra o rei para tomar o poder real. A ameaça ao poder real não parecia ser algo distante na Gália de meados do século VII, como lemos ainda na Passio de Leudegário, mesmo que a autoridade régia se mantivesse entre os filhos da dinastia merovíngia, a crescente influência do maior domus era forte o suficiente para que um dos príncipes, por exemplo Teodorico elevado ao trono por Ebroin, fosse rei e tivesse o acesso à corte restrito. Por outro lado, os nobres eram forte o suficiente para elevar um outro rei ao trono, Childerico, e pressionar pela queda de Teodorico além de fazer com que Childerico atendesse às suas reivindicações. O cenário que se revela é de extrema complexidade. E nesse cenário de complexidade e disputas emergiram duas paixões que narravam justamente uma mesma história sob os pontos de vista divergentes de duas facções inimigas, paixões que celebravam a memória de um santo em detrimento ao rival, enquanto o rival também teve sua vida celebrada.

Uma disputas por memórias, um cenário de narrativas contrastantes que trazem nuanças de disputas entre facções enquanto celebram as histórias de seus heróis da fé, é isso que vemos quando confrontamos as duas paixões. E nesse cenário de disputas pela memória uma série de elementos eram elencados para defender cada uma das partes: a recusa de Ebroin de reconhecer as especificidades das leis e costumes regionais no caso da Passio de Leudegário, o problema de doações de terras no caso da Passio de Praejecto, as conspirações que ameaçavam os reis e eram 
usadas como justificativa para derrotar bispos como Leudegário de Autun e também patrícios como Hector de Marselha, as disputas entre facções intermediadas pelo rei, como Childerico e seu tribunal para julgar a causa entre Leudegário e Hector contra Praejecto.

Pouco depois Childerico foi assassinado junto a sua rainha que estava grávida, Praejecto, que ao longo de sua Passio é retratado como mantendo boas relações com o rei, como indica o próprio julgamento que ele realizou e deu ganho da causa à Praejecto: o bispo perdera um importante apoio. Por outro lado Leudegário via ressurgir um antigo inimigo que estava exilado no mosteiro, Ebroin. Pela atuação de Ebroin que vira Leudegário aliado aos nobres que o derrubaram pereceu Leudegário, enquanto Praejecto sucumbiu pelas mãos dos nobres de Auvergne, talvez por ter perdido o apoio real, ou talvez por ter desagradado a nobreza local. A despeito das circunstâncias profundamente políticas envolvidas nas disputas que acabaram nas mortes dos bispos, ou mais possivelmente justamente por isso, suas memórias foram celebradas em hagiografias que objetivavam propagar o culto às imagens deles.

O que percebemos é a intensa participação desses santos que por vezes cumpriam um verdadeiro serviço aos reis, como Audoíno filho de uma reconhecida família trazido à corte de Dagoberto e depois nomeado bispo de Rouen, não sem antes servir como um funcionário laico ao rei, e Praejecto, nomeado pela própria rainha Balthilda como bispo de Clermont. Há outros casos em que os santos entram em contraste com os reis, como Leudegário que se opôs a Childerico, mas sofreu especial oposição do maior domus Ebroin e ainda Columbano que se opôs e foi perseguido por Brunilda e Teodorico. A atenção dos reis à esses santos, assim, transcedia a piedade religiosa dos reis, relacionava-se antes, primeiro, ao fato de estarem lidando com facções da nobreza e segundo, e por conta do primeiro fator, por estarem se 
relacionando com homens que exerciam autoridade nas áreas em que atuavam. A importância desses religiosos não se restringia apenas àqueles que exerciam cargos episcopais, os reis também estavam atentos aos religiosos que atuavam no âmbito monacal, como Wandrille que abandonara a vida religiosa para fundar o importante mosteiro de Fontenelle financiado mesmo pelos recursos do fisco, depois de ter obtido o reconhecimento por parte de Dagoberto que ele deveria servir como um homem de Deus ao invés de um funcionário de corte: ${ }^{653}$

Sed quia semper ad illam fontem humilitatis repetebat, nolebat enim in terrenis actibus occupare, queren locum, ubi ei Dominus demonstrarit, qualiter sub sancta regula degerit vita. Qui Dominus talem locum dedit, ubi plurimum gregem Christi bonus pastor curam gessit. Adsedit iuxta fontem uberimam, qui vocatur Fontanella, in heremo qui dicitur Gemeticus, ex fisco quem adsumpsit regale munere. ${ }^{654}$

Esse mosteiro, financiado pelos recursos do fisco, tornou-se um dos mais destacados centros de produção de hagiografias entre o final do período merovíngio e a época carolíngia ${ }^{655}$ indicando que a atenção real aos mosteiros não só foi perene como tinha uma finalidade importante: cooptar o apoio dos religiosos e por conseguinte da nobreza da qual faziam parte. Não por acaso, como já indicamos a partir da leitura da Vita Columbani, desde a passagem do monge irlandês na Gália houve um significativo incremento no número de jovens nobres que adotavam a vida religiosa inspirada no exemplo de Columbano. O mosteiro de Saint-Wandrille, vale a pena destacar, era justamente inspirado no exemplo de Columbano. O financiamento do fisco outorgado por Dagoberto à fundação do mosteiro de Saint-Wandrille dessa

\footnotetext{
${ }^{653}$ Vita Wandregiseli, 7.

${ }^{654}$ Vita Wandregiseli, 14

${ }^{655}$ Sobre a importância do mosteiro de Saint-Wandrille e de suas hagiografias: WOOD, I. SaintWandrille and its Hagiography. In: WOOD, I. \& LOUD, G.A. (ed.) Church and chronicle in the Middle Ages. Essays presented to John Taylor. London and Rio Grande: The Hambledon Press, 1991. p.1-14.
} 
maneira tinha muito possivelmente uma finalidade estratégica ${ }^{656}$ melhor compreendida à luz das tensões e disputas entre facções nobiliárquicas que estamos discutindo até aqui. É à luz dessas tensões que compreendemos a preocupaçãos dos reis com a fundação de mosteiros e escolha de bispos, mas cabe enfatizar, que havia uma contrapartida à atuação régia.

Os nobres não se furtavam de desfrutar do potencial político das fundações religiosas. Disputavam as sedes episcopais, como a de Clermont que teve a intervenção de Balthilda que apontou Praejecto como bispo a despeito dos nobres que buscavam controlar a sede, e também fundavam eles mesmos mosteiros, como a família de Audoíno e também a de Sadalberga, cuja a atividade monacal é destacada em sua vita quando ela começou a vestir o véu religioso e com o apoio do marido iniciou a fundação de mosteiros:

Auctore Deo omnem spem suam post Deum beato viro committens, viro converso prolibusque Deo sacratis, religionis veste accepta, inito cum beato Waldeberto consilio, conniventia existente mariti, coenobium puellarum in suburbio Lingonicae urbis, in hereditate vel successione paterna conatur extruere [...] Vita Sadalbergae, 12.

Filha de Gundoíno, nobre originário da Alsácia, Sadalberga - com o apoio do pai e do marido - iniciou sua atividade de fundação de mosteiros. Além dela, outros membros de seu grupo familiar ${ }^{657}$ também foram profícuos na fundação de mosteiros. Seu pai, além de apoiar a empreitada da filha, foi o patrocinador da fundação do mosteiro de Grandval. O irmão de Sadalberga, Leuduino-Bodo ${ }^{658}$ também seguiu a

\footnotetext{
${ }^{656}$ Essa dimensão da patronagem régia, especialmente de Dagoberto, às fundações monacais foi muito bem estudada por Fox: FOX, Y. Power and Religion in Merovingian Gaul. Columbanian Monasticism and the Frankish Elites. Cambridge: Cambridge University Press, 2014. p.34-39.

${ }^{657}$ FOX, Y. Power and Religion in Merovingian Gaul... op.cit. p.82.

${ }^{658}$ A Vita Sadalbergae menciona dois irmãos de Sadalberga, o já mencionado Leudoíno-Bodo e Fulculfo-Bodo: Tunc vir industrius Gundoinus cum coligue sua Saretrude elegante forma et nobili femina duos bonae indolis adolescentulos ob benedictionis percepturam gratiam praesentavit, quorum senior Leuduinus cognomento Bodo, iunior vero Fulculfus, qui et ipse alio vocabulo Bodo dicebatur. Vita Sadalbergae, 4.
} 
via religiosa e além de ter sido bispo de Toul fundou o mosteiro de Bonmoutier. ${ }^{659}$ Notamos assim que a fundação de mosteiros foi uma atividade capitaneada por reis e nobres e isso não era um acaso, financiar essas fundações era um mecanismo para reforçar a autoridade dos protagonistas do poder, tanto reis quanto nobres como testemunha o exemplo de Sadalberga.

Os exemplos aqui elencados revelam uma série de questões que merecem nossa atenção.

- A primeira é aquela que foi elencada logo no início da discussão referente ao papel social dos homens e mulheres santos. As hagiografias aqui trabalhadas revelam com intensidade um desses papéis, a saber, o político.

- No cenário da participação política dos santos, conforme indicado nos textos que relatam as suas hagiografias, emerge uma enorme complexidade relacionada com disputas políticas como podemos perceber pelo confronto entre as paixões de Praejecto e Leudegário, no contexto dessas disputas a celebração da memória desses santos tinha um papel importante relacionado com a propagação do culto deles, mas também com a defesa narrativa de uma das partes em disputa. Como notamos, nessas construções narrativas um mesmo evento é descrito de formas diferentes ressaltando a tese de uma das partes. O julgamento de Childerico que beneficiou Praejecto é questionado na Passio de Leudegário enquanto tem tonalidades positivas na Passio de Praejecto. Trata-se assim, antes de qualquer coisa, da apresentação de argumentos que defendem uma ou outra facção nobiliárquica em torno de uma disputa relacionada com o controle de terras, como observamos no texto da Passio de Praejecto. Mas além disso, disputas mais complexas se revelam. A Passio de Leudegário traz a descrição do confronto do bispo com Ebroin construíndo um relato extremamente negativo do maior domus, por outro lado, a Passio de Praejecto não é tão crítica ao maior domus. A Passio de Leudegário se constitui assim também como uma resposta do grupo ao qual o bispo estava filiado contra o grupo em torno de Ebroin. Escrever um texto

\footnotetext{
${ }^{659}$ FOX, Y. Power and Religion in Merovingian Gaul... op.cit. p.84. Na fonte: Vita Sadalbergae, 18.
} 
celebrativo à um santo não era assim apenas uma valorização da memória do santo individualmente, mas também um mecanismo político capitaneado pelo grupo ao qual o santo estava filiado politicamente. Nesse sentido, esses textos poderiam servir como um mecanismo de celebração da identidade desse grupo, como percebemos pela Vita Sadalbergae e a valorização da memória do grupo de Gundoíno. As vitae devem, portanto, também ser comtempladas à luz do seu potencial identitário político ao reforçar o valor de um determinado grupo.

- Não só grupos nobiliárquicos poderiam se beneficiar com a atuação dos santos, não por acaso Wandrille e Audoíno contaram com o apoio dos reis. Nesse sentido, a propagação da memória dos santos poderia ter um enorme valor político para os reis, não só quando esses santos estavam vivos e representavam os reis nas sedes episcopais e abadias, mas também quando esses santos faleciam e suas vitae pintavam um relato positivo da relação entre os reis e os santos.

- Nesse contexto de narrativas que cumpriam um papel político as identidades mobilizadas, tal como no caso das vidas das rainhas analisadas no tópico anterior, não tinham relação com as gentes, e tampouco tinha relação com a gens francorum em específico. Tinha relação com identidades de grupos nobiliárquicos e também da realeza no que concerne à glorificação dos reis não só como representantes da gens, algo sobressaltado nas histórias, mas também pelas boas relações que eles mantinham com os santos. A contrapartida também era real, um rei poderia ser duramente criticado por uma hagiografia que narrava a vida de um santo que fazia parte de um grupo que se opunha à um determinado rex, como no caso da Passio Leudegari. No que concerne a valorização das identidades dos grupos nobiliárquicos ela se dava principalmente pela glorificação das origens dos santos. Na Vita Sadalbergae isso fica muito evidente, a Vita foi comissionada por Anstrude, filha de Sadalberga, nela a nobreza da família de Sadalberga é reiteradamente mencionada.

- A leitura das hagiografias revela desta maneira um outro nível identitário político relacionado com, primeiro, o culto aos santos, num outro nível, a valorização das famílias e/ou reis. Não obstante, esses textos revelam o 
complexo edifício político sobre o qual estavam inseridos nobres e reis, por vezes numa relação de aliança, por vezes numa relação de contraste. Revela ainda outros níveis das políticas identitárias empreendidas pela realeza como o reconhecimento das leis e costumes locais descrito na Passio de Leudegário por parte de Childerico II.

\section{Histórias e Hagiografias ou o confronto das memórias}

O que é interessante perceber no confronto entre as hagiografias e as histórias é que as divergências dos textos são notórias. Os reis nas histórias poderiam ser fortes ou fracos, mas nas hagiografias estão sempre sob a proteção ou maldição dos santos e é isso que orienta o valor que eles possuem nos textos, o mesmo vale para os nobres. Evidentemente que essa diferença se deve antes de tudo aos objetivos diversos dessas narrativas e é por isso que consideramos relevante explicitar alguns nortes que apontam para as singularidades dessas narrativas, exercício feito nos tópicos que abriram os capítulos.

As histórias construíam e celebravam a memória do reino, as hagiografias construíam e celebravam a memória dos santos e por essa diferença fundamental as gentes possuíam também um valor diferente nesses textos. Nas histórias não raro eram glorificadas, nas hagiografias eram retratadas não raro como concupiscentes que dependiam da intervenção dos santos para serem dignificadas. As hagiografias, em suas especificidades, revelavam a complexidade das identidades políticas que se confrontavam, não mais intrisecamente relacionadas com as gentes, mas sim com santos aliados a determinados grupos políticos. Já nas histórias, mesmo no caso de 
Fredegário que revela o crescimento de grupos nobres locais identificados como neustrinos, austrasianos ou burgúndios, a gens francorum permanece como um norte, uma referência diante da crescente polarização das forças políticas que representavam cada vez mais os interesses de suas facções em detrimento ao poder régio que, a despeito de suas limitações, ainda se apresentava como uma força central.

A construção da memória - em última instância a função principal tanto de Historiae quanto de Vitae - revelava assim um cenário de contrastes em que reis de um lado, nobres de outro, reis e nobres em alianças, nobres em alianças contra os reis, lançavam mão de narrativas que construíam e propagavam memórias identitárias em diversos níveis, com diversos desdobramentos. Nessa diversidade, uma profusão de sentidos emergiam em torno da idéia de gens gothorum e gens francorum indicando que qualquer tentativa de criar uma definição restritiva aos termos é um enorme equívoco principalmente por esses termos terem tido justamente sentidos diversos nos séculos que nos interessam aqui. Esses sentidos diversos não são fruto de uma falta de coerência, mas sim dos usos estratégicos das identidades mobilizadas como instrumentos de atuação política. As identidades eram assim construções com uma finalidade política muito acentuada que assumiam diversas facetas para chegar à um fim: afirmar a autoridade política dos reis, ou a autoridade política dos nobres. É tãosomente à luz das finalidades políticas num contexto de disputas que defendemos que o significado da gens francorum e da gens gothorum faz sentido em todos os níveis narrativos, inclusive esse que nos atemos nesse capítulo, a saber: a construção da memória. 


\section{Parte IV}

\section{A CONSTRUÇÃO DAS NORMAS}




\section{Capítulo VII -A construção das normas}

Observamos até aqui como as identidades políticas fundamentadas em torno dos discursos acerca da gens gothorum e da gens francorum eram construídas e apropriadas pelas Historiae e hagiografias num contexto de disputas políticas em que tais identidades eram evocadas no plano narrativo para dar conta de contingências muito práticas. Cabe agora nos questionarmos em que medida as normas participaram do processo de construção de identidades e das políticas identitárias.

Como veremos a seguir, as leis são fontes muito complexas e em torno das quais uma série de perguntas e debates historiográficos se articularam principalmente no que concerne às seguintes questões:

1. Há uma evidente tradição germânica em oposição a uma tradição romana nesses textos?

2. Em que medida a elaboração e efetividade dessas leis nos ajudam a compreender os rumos da história do Ocidente europeu depois da "Queda", ou continuidade, do Império romano?

3. Como essas leis nos ajudam a compreender as relações estabelecidas entre bárbaros e romanos nos reinos romano-germânicos?

Esses três problemas serão contemplados ao longo desse capítulo.

\section{Leis - entre as leis "germânicas" e as leis "romanas"}

$\mathrm{O}$ que têm as leis a nos dizer sobre as sociedades onde foram forjadas? No século XIX elas foram um objeto privilegiado contemplado pela análise dos historiadores por seu potencial de influir nos mais diversos aspectos da vida cotidiana. As leis teriam, por característica essencial, a presunção de intervir e influenciar na organização social desde o plano político até o religioso. G.A. Davoud-Oghlou em seu estudo sobre a legislação antiga e dos antigos germanos apontou para o fato de 
que o conhecimento histórico, mais do que um compêndio cronológico, deveria se destacar por sua capacidade analítica, ${ }^{660}$ as leis seriam uma parte essencial do conhecimento histórico pois encerravam justamente os elementos fundamentais para a análise histórica ao guiar as ações dos homens em todos os seus espectros. Por guiar as ações humanas, as leis foram percebidas por Davoud-Oghlou como o fato gerador dos eventos históricos. ${ }^{661}$

A partir desse pressuposto, o estudo das leis teria o potencial de explicar as instituições pretéritas dos germanos tendo em conta a considerada mais germânica das leis: o Pactus Legis Salicae. ${ }^{662}$ As leis visigodas, tidas como as mais romanizadas entre as leis bárbaras, seriam a base para a compreensão da fusão entre romanos e bárbaros e a afirmação da autoridade visigoda na Península Hispânica. ${ }^{663}$ Mas o peso das antigas leis bárbaras não se restringia ao período onde elas foram elaboradas e, supostamente, aplicadas. Essas leis foram também vistas como os fundamentos nas regras da sucessão da monarquia da França no decorrer da época qualificada como Idade Média, ${ }^{664}$ enquanto que na Hispania as leis visigodas teriam se mantido em vigor em determinadas regiões mesmo depois das invasões islâmicas, como

\footnotetext{
${ }^{660}$ Nas palavras do próprio autor: "Pour nous la plus grande importance de l'histoire est dans don analyse: l'humanité à qui appartient l'avenir, a besoin de la philosophie des faits antérieurs pour pouvoir, d'après les règles de l'analogie, apprécier avec justesse le present, e asseoir sur l'avenir un jugement emprunté à l'expérience du passé. L'examen des causes constitue donc la principale utilité de l'étude de l'histoire; or les causes des évènements que celle-ci nous rapporte avec indifférence se trouvent plus ou mins consignées dans les insittutions législatives, là même oú souvent on en soupçonnerait les moins l'existence." DAVOUD-OGHLOU, G.A. Histoire de la Législation Ancient e des Anciens Germaines. Berlim: Reimer, 1845. p. VII-VIII.

${ }_{661}$ "En somme, étudier les lois, c'est étudier l'origine et les causes des faits historiques; les approfondir, c'est s'exercer à raisonner avec justesse sur les évènements qui d'une façon hostile ou favorable influent sur la civilisation: d'où sort la conclusion définitive que 1 'étude des législations est indispensable à celle de l'histoire." Ibdem, p. IX.

${ }^{662}$ SOHM, R. La procédure de la Lex Salica. Paris: Librairie A. Franck, 1873.

${ }^{663}$ DAVOUD-OGHLOU, G.A. Histoire de la Législation Ancient e des Anciens Germaines...op.cit. p.3.

${ }^{664}$ POTTER, J.M. The Development and significance of the Salic Law of the French. The English
} Historical Review, v.42, n.206, p.235-253, 1937. 
evidenciaria a tradução das Leges Visigothorum feita no século XIII e conhecida como Fuero Juzgo. ${ }^{665}$

Com as aproximações antropológica às leis houve uma significativa mudança de foco. As leis deixaram de ser vistas como os fundamentos do edifício social para serem integradas à dinâmica social. ${ }^{666}$ Não era a partir delas que fluíam as condições para a organização das sociedades, mas essas organizações - sempre sujeitas à novas conjunturas - é que influíam nas leis, e por sofrerem as vicissitudes conjunturais, as leis passaram a ser entendidas elas próprias como dinâmicas. Imaginar que as ditas leges barbarorum foram transpostas para o Ocidente europeu e lá se mantiveram tal como se manifestavam na Germania tornou-se um exercício cada vez mais difícil, a própria designação leges barbarorum foi questionada: como chamar aqueles códigos de leis bárbaras se eles encerravam outras tradições como a romana e cristã $?^{667}$ Mais do que isso, circulavam juntos nos manuscritos. Até mesmo nas situações exemplares

\footnotetext{
${ }^{665}$ OSABA, E. Reflexiones en torno a las Leyes Visigodas. Monteadvdo, n.3, p.57-72, 2003.

${ }^{666}$ DEPREAUX, P. La loi et le droit. La part des échanges culturels dans la référence à la norme et les pratiques juridiques durant le haut Moyen Âge. Actes des congrès de la Société des historiens médiévistes de l'enseignement supérieur public. 32e congrés. Dunkerque, 2001. p. 41-70. Ainda: FREEMAN, M. \& NAPIER, D. Introduction. Law and Anthropoloy. In: FREEMAN, M. \& NAPIER, D. (eds.). Law and Antropology. Current Legal Issues, vol.12. Oxford: Oxford University Press, 2008. p.1-12. No mesmo volume: GREENHOUSE, C.J. Law and Anthropology: Old Relations, new relativities. p. 47-66.

${ }^{667}$ Lear, por exemplo, propôs a designação dessas leis mediante a alcunha "Romance": "However, to avoid attributing undue emphasis to the Germanic element, the Leges Visigothorum, and indeed much other barbarian legislation, may best be described as 'Romance law' and not merely as 'barbarian law'. It is true that they are Germanic 'folklaws', but much else is commonly added. These laws do not consist of pure Germanic custum, but contain many Roman elements which at times are transmitted with little change, as in the Visigothic antiquae. In general they reflect the legal ideas and intellectual climate of the age for which they were devised." É interessante fazer um contraponto entre a última frase de Lear, onde ele afirma que as leis refletiam o clima intelectual de sua época, e uma sentença de Davoud-Oghlou onde a lógica é inversa e as leis são descritas como espelho fiel da vida dos povos uma vez que são elas que influenciam a ação dos homens: "La législation, ce fidèle miroir de la vie des peuples et de la tendence de leurs idées religieuses et politiques, est une puissance qui agit incessamment sur le principe d'action de l'homme; les passions s'émeuvent, les âmes les plus apathiques mêmes s'agitent, s'animent ou s'engourdissent au mouvement de ce ressort; en un mot, elle agit sur les hommes comme ceux-ci sur les évènements." ( LEAR, Floyd S. The Public Law of the Visigothic Code. Speculum, v.26, n.1, p.1-23. Jan, 1951. p.1. DAVOUD-OGHLOU, G.A. Histoire de la Législation Ancient e des Anciens Germaines...op.cit. p.VIII). Essas diferenças notáveis exemplificam muito bem a mudança de foco dos historiadores frente às leis.
} 
onde as leis deveriam atuar, como na resolução dos conflitos, notou-se que elas eram apenas uma dentre outras fontes que eram levadas em conta. ${ }^{668}$

\section{As leis - o nascimento de uma nova ordem ou a continuidade de um velho sistema}

A historiografia dedicada à Europa depois da chegada dos grupamentos bárbaros toma o Império Romano como um ponto de referência para interpretar o período que sucedeu "A queda do Império". Como A. Gillet sumarizou muito bem:

Unlike historical periods such as classical Athens, early Islam or Renaissance Italy, models of the Early Middle Ages (at least prior to the Carolingian period) rarely depict the period as self-defining, one which itself generated its characteristic features. It is fundamentally a period of continuities and terminations of the past; its traits are permutations of features from earlier cultural and political forces. ${ }^{669}$

O pesquisador não poderia ter sido mais preciso. Os destinos do Império Romano tem sido tema dos mais importantes debates desde a querela entre Germanistas e Romanistas ${ }^{670}$ até os nossos dias, nos quais o termo que melhor define aqueles séculos é ainda objeto de disputas. Deveríamos falar de uma Antiguidade Tardia, designação que infere uma continuidade dos aspectos romanos depois da consolidação dos "Reinos Bárbaros?"? ${ }^{671}$ Ou deveríamos concentrar nossos esforços

\footnotetext{
${ }^{668}$ HARRIES, J. Resolving Disputes: The frontiers of Law in Late Antiquity. In: MATHISEN,R.W. Law, society and authority in Late Antiquity. p.68-82

${ }^{669}$ GILLET, Andrew. Ethnogenesis: A contested model of Early Medieval Europe. History Compass n.4, v.2, p.241-269, 2006. p.242.

${ }^{670}$ GUZMÁN ARMARIO, Francisco Javier. ¿Germanismo o Romanismo? Una espinosa cuestión del mundo antiguo a la Edad Media: el caso de los visigodos. Anuario de estudios medievales. n.35, v.1, p.3-23, 2005.

${ }^{671}$ CAMERON, Averil. History and individuality of the historian: the interpretation of late antiquity. In: LIM, Richard \& STRAW, Carole. The past before us. The challenge of historiographies of Late Antiquity. Turnhout: Brepols, 2004. p. 70-71. FRIGHETTO, R. Transformação e tradição: a influência do pensamento político e ideológico do mundo romano clássico na Antiguidade Tardia. Diálogos. v.12, n.2/n.3, p.19-42, 2008.
} 
nas transformações, ou até aniquilação, da herança romana, donde o termo Alta Idade Média soa mais correto ${ }^{672}$

Os estudos sobre as leis não escapam dessas disputas e isso não é um acaso. O pressuposto de que as leis exercem uma significante influência nas sociedades as torna um objeto privilegiado a fim de provar ambas as teses referentes ao fim ou continuidade do Império Romano. Por um lado, as leis nos reinos bárbaros são interpretadas como um exemplo da crise que afetou as antigas províncias romanas. C. Wickham alega que a justiça e a leis constituíram uma forma pela qual os governantes mantiveram sua relevância num sistema político potencialmente descentralizado ${ }^{673}$ num contexto de crise. As leis, nesses casos, eram mais uma evidência dessa crise do que da continuidade. Argumentando sobre a situação da Hispania Visigoda, escreveu Wickham:

\begin{abstract}
An alternative view, which seems much more convincing, is to point out that the major evidence for breakdown comes from the law-code, whose late laws are full of highly coloured characterizations of illegalities, expressed in shrill rhetoric, and countered, furthermore, by violent measures. As usual with legislation, one can read lists of illegalities either as evidence for crisis, or as evidence for royal commitment to impose control on civil society. There is, in fact, reasonable evidence for increases both in royal ambition and royal control. But this strengthening state was nonetheless set against an increasingly fragmented set of local societies. ${ }^{674}$
\end{abstract}

Por outro lado, as leis podem ser vistas como evidência da continuidade dos principais elementos do Império Romano em lugar de sinais de sua decadência. P.S. Barnwell chega a uma conclusão oposta à de Wickham mediante a análise de um problema semelhante, a saber, as atividades legislativas dos reis bárbaros. De acordo

\footnotetext{
${ }^{672}$ CÂNDIDO, M. Entre "Antiguidade Tardia" e "Alta Idade Média". Diálogos. v.12, n.2/n.3, p. 53-64, 2008.WARD-PERKINS, B. The fall of Rome and the end of civilization. Oxford e New York: Oxford University Press, 2005. WICKHAM, Chris. Framing the Early Middle Ages. Europe and the Mediterranean. 400-800. Nova York: Oxford University Press, 2005.

${ }^{673}$ WICKHAM, Chris. Framing the Early Middle Ages...op.cit. p.149.

${ }^{674}$ Ibidem, p. 93.
} 
com Barnwell essas atividades legislativas marcam uma evolução, não uma ruptura com as tradições romanas. Conforme ele:

[...]in almost every other aspect of their administration, the 'barbarian' kings, having originally been fitted into an evolving provincial situation, continued to respect and develop the traditions they inherited, adapting them according to circumstance in the same way as had the Roman emperors, prefects, jurists and judges before them. ${ }^{675}$

Tais apontamentos contraditórios exemplificam a complexidade do tema e nos conduz à necessidade de tomar parte num importante debate que, a despeito das colocações de A. Gillet, tem a crise ou permanência, ruptura ou continuidade, como uma referência para quase todas as interpretações sobre a Alta Idade Média. Se devemos superar Roma como a base de nossas leituras, primeiro precisamos investigar se o "mundo Medieval" tinha essa mesma preocupação. O Breviário de Alarico - um sumário de Leis romanas que circulou significativamente na Europa Ocidental - pode ser um caminho para confrontar essa questão.

Podemos retomar a questão da germanidade, assim como do problema da continuidade e ruptura, sob uma outra perspectiva que problematiza a elaboração dessas leis. O Breviário de Alarico, nesse caso, representa uma boa possibilidade de reflexão. Tratemos então dele, começando com a tentativa de tentar compreender os motivos que levaram Alarico II, que ascendeu ao trono em 484 sucedendo Eurico que em 475 promulgou o primeiro código de leis "godas", a promulgar um Breviário.

\section{O Breviário de Alarico}

\footnotetext{
${ }^{675}$ BARNWELL, P.S. Emperors, jurists and kings: law and custom in the Late Roman and Early Medieval West. Past \& Present. n.168, p.6-29, 2000. p.29.
} 
Isidoro de Sevilha foi lacônico nas informações sobre Alarico II. A derrota do rei ocioso e a destruição do reino de Tolosa em 507 diante do avanço dos francos liderados por Clóvis é a informação em destaque sobre Alarico II nos escritos do bispo de Sevilha:

Aera DXXI, anno X imperii Zenonis Eurico mortuo Alaricus filius eius apud Tolosensem urbem princeps Gothorum constituitur regnans ann. XXIII. qui cum a pueritia vitam in otio et concicio peregisset, tandem provocatus a Francis in regione Pictavensis urbis proelio inito extinguitur eoque interfecto regnum Tolosanum occupantibus Francis destruitur. ${ }^{676}$

Infelizmente não há muito mais informações sobre Alarico II além dessa pequena referência presente na Historia Gothorum de Isidoro de Sevilha. Encontramos algo também na Chronica cesaraugustanae, que embora nos ofereça poucas informações sobre Alarico II, versa acerca de alguns eventos que não aparecem em fontes como a Historia Gothorum de Isidoro, como por exemplo, a usurpação tirânica conduzida por um homem chamado Burdunelus na Hispania entre 496 e 497:

ad a. 496. His coss. Brudunelus in Hispania tyrannidem assumit. ad a. 497. His coss. Gotthi intra Hispanias sedes acceperunt et Burdunelus a suis traditus et Tolosam directus in tauro aeneo impositus igne crematus est. ${ }^{677}$

Poucos anos depois a Crônica relata outra rebelião na Hispania:

ad a. 506. His cons. Dertosa a Gotthis ingressa est. Petrus tyrannus interfectus est et caput eius Caesaraugustam deportatum est. ${ }^{678}$

Entre os anos de 496 e 506 Alarico II precisou enfrentar duas querela na Hispania ${ }^{679}$ Além das tiranias de Brudunelus e Pedro, Alarico também estava diante

\footnotetext{
${ }^{676}$ Isidoro de Sevilha,Historia Gothorum, versão breve.

677 Chronicae cesaraugustanae, aa 496 e 497.

${ }^{678}$ Chronicae cesaraugustanae, a.506.
} 
da crescente oposição de bispos Católicos - já que os Visigodos professavam o arianismo - e o crescimento da ameaça franca registrada não só por Isidoro de Sevilha, mas também por Gregório de Tours nos Decem Libri Historiarum. Ele não estava numa situação confortável e parece ter reconhecido esse fato. ${ }^{680}$ Assim, a cooptação de aliados era provavelmente urgente para Alarico II e uma das maneiras de atingir esse objetivo pode ter sido a promulgação de um código legal. Disso se infere que a promulgação de leis que contemplavam todos aqueles que estavam sob a autoridade do rex era antes de tudo um esforço para afirmar a própria autoridade do rei.

O Breviário de Alarico foi composto entre 506 e $507^{681}$ possivelmente em Aire Sur-l’Adour. Ele contém uma coleção de vários textos legais romanos como os códigos gregoriano e hermogeniano de 290, Novellae de Teodósio II e Valentiniano III (425-55) além de citações de juristas como Papiniano, as Sentenças de Paulo e os Institutes de Gaius. A principal fonte do Breviário de Alarico foi o Código Teodosiano promulgado no Império entre 437 e $438 .{ }^{682}$ Nota-se portanto que as fontes do documento advinham principalmente do direito romano. Nesse sentido podemos nos perguntar se o Breviário de Alarico era um código legal destinado a um grupo específico que estava sob a autoridade do rei, a saber, uma população que tinha como base de coesão uma identidade romana em detrimento de uma identidade visigoda que teria sido contemplada pelo código de Eurico. Antes de avançarmos na análise do

\footnotetext{
${ }^{679}$ Uma instigante análise sobre a questão pode ser encontrada em: GARCÍA MORENO, L.A. Alaric II et l'Espagne... op.cit. p.105-127.

${ }^{680}$ O. Guillot percebeu isso. Ao investigar os elementos da interpretatio dados pelo Breviário de Alarico ele concluiu que o Breviário era um conjunto de leis que foram impostar por Alarico II cuja autoridade estava enfraquecida. GUILLOT, $O$. Brèves remarques sur l'esprit de quelques interpretations fondamentales du Bréviaire d'Alaric et sur sa reception par les rois Mérovingiens. In: ROUCHE, M. \& DUMÉZIL, B (eds). Le Bréviaire d'Alaric... op.cit. p.180-191.

${ }^{681}$ GUILLOT, O. Brèves remarques sur l'esprit de quelques interpretations fondamentales du Bréviaire d’Alaric et sur sa reception par les rois Mérovingiens...op.cit.

${ }^{682}$ MATTHEWS, J.F. Interpreting the Interpretationes of the Breviarium. In: MATHISEN, R.W. Law, Society and authority in Late Antiquity. N.Y.: Oxford University Press, 2001.
} 
Breviário, cabe nos debruçar sobre o único fragmento do código de Eurico que chegou aos nossos dias e que faz uma distinção entre os godos e os romanos:

CCLXXVI. Si quodcumque ante adventum Gothorum de alicuius fundi iure remotum est et aliqua possessione aut vinditione aut donatione aut divisione aut aliqua transactione tranlatum est, id in eius fundis, adque a Romanis antiquitus probatur adiunctum, iure consistat. Cum autem proprietas fundi nullis certissimis signis aut limitibus probatur, quid debeat observari, eligat inspectio iudicantium, quos partium consensus elegerit.

Si vero fundorum termini in tertiis, quas habent Romani, fuerint, tunc Gothi [in]grediantur in loco hospitum et ducan[t, ubi] terminum fuerat ostensus. Tunc iud[ex], quos certiones agnoverit, faciat eos s[a]cramenta praebere, quod terminum s[ine] ulla fraude monstraverint. Nullus n[o]vum terminum sine consorte part[is al]terius aut sine <in>spectore constituat.

Este fragmento que lida com a questão das "fronteiras" das terras é cheio de sentido em um contexto de assentamento de uma nova população. Mas é importante notar que ele reconhece uma distinção entre godos e romanos para resolver qualquer eventual disputa que poderia emergir por conta do processo de assentamento e não para fomentar a distinção propriamente dita. O fragmento não parece atentar para um reforço das diferenças, na verdade, o dispositivo oferece um mecanismo para a população romana se proteger de ocupações injustas conduzidas pelos godos.

Já o commonitorium do Breviário de Alarico é um bom exemplo para ilustrar as intenções do texto, mas, mais do que isso, esse documento mostra uma imagem de um rei bárbaro que se esforçou por legislar não só pelos godos, mas também pela população de origem romana:

Utilitates populi nostri propritia divinitate tractantes hoc quoque, quod in legibus videbatur iniquum, meliori deliberatione corrigimus, ut omnis legum Romanarum et antiqui iuris obscuritas, adhibitis sacerdotibus ac nobilibus viris, in lucem intellidentiae melioris deducta resplendeat, et nihil habeatur ambiguum, unde se diuturna aut diversa iurgantium impugnet obiectio. Quibus omnibus enucleatis atque in unum librum prudentium electione collectis, haec, quae excerpta sunt vel clariori interpretatione composita, venerabilium episcoporum vel electorum provincialium nostrorum roboravit assensus. 
O texto não menciona Godos e Romanos. A promulgação do Breviário parece ter objetivado o bem de toda a população sob a autoridade de Alarico, o que incluía tanto godos quanto romanos. Para superar qualquer ambigüidade ou obscuridade nas leis romanas e eliminar as leis iníquas uma comissão de bispos e grandes trabalhou na elaboração do Breviário. A origem desses bispos e nobres não foi mencionada, talvez pela desimportância dessa questão, ou talvez porque a audiência já sabia quem eram esses homens.

Isso, entretanto, não é suficiente para dizer que questões identitárias eram desimportantes; a legislação sobre o casamento é um bom contraponto para a questão. O título IV do Liber Gall no Breviário de Alarico apenas reconhece como legítimos as uniões entre romanos e romanas. ${ }^{683}$ Se o intento explicitado no commonitorium foi respeitado, em outras palavras, se o Breviário de Alarico eliminou as leis iníquas, é possível dizer que a proibição dessas uniões mistas não era considerada uma lei injusta naquele momento. A proibição de casamentos mistos foi anulada tão-somente com uma lei possivelmente promulgada pelo rei Leovigildo, ${ }^{684}$ o mesmo que tentou converter os hispano-romanos para o arianismo num sínodo cujas atas, lamentavelmente, não chegaram aos nossos dias. Talvez Leovigildo tenha tentado eliminar as últimas fronteiras entre romanos e godos, ou talvez ele tenha apenas feito

\footnotetext{
${ }^{683}$ Legitimae sunt nuptiae, si Romanus Romanam nuptiis intervenientibus vel consensu ducat uxorem. Liber Gall, t.IV. Também: Nulli provincialium, cuiuscunque ordinis aut loci fuerit, cum barbara sit uxore coniugium, nec ulli gentilium provincialis femina copuletur. Quod si quae inter provinciales atque gentiles affinitates ex huiusmodi nuptiis exstiterint, quod in iis suspectum vel noxium delegitur, capitaliter expietur. A sentença condena com a pena capital os casamentos mistos. A interpretativo repete a condenação: Nullus Romanorum barbaram cuiuslibet gentis uxorem habere praesumat, neque barbarorum coniugiis mulierer Romanae in matrimonio coniungantur. Quod si fecerint, covereint se capitali sententiae subiacere. Breviary of Alaric (1.III, t. XIV - Codicis Theodosiani)

${ }^{684}$ Sollicita cura in principem esse dinoscitur, cum pro futuris utilitatibus beneficia populo providentur; nec parum exultare debet libertas ingenita, cum fractas vires habuerit prisce legisabolita sententia, que incongrue dividere maluit personas in coniuges, quas dignitas conpares exequabit in genere. $\mathrm{Ob}$ hoc meliori proposito salubriter censentes, prisce legis remota sententia, hac in perpetuum valitura lege sanccimus : ut tam Gotus Romanam, quam etiam Gotam Romanus si coniugem habere voluerit, premissa petitione dignissimam, facultas eis nubendi subiaceat liberumque sit libero liberam, quam voluerit, honesta coniunctione, consultum perquirendo, prosapie sollemniter consensu comite, percipere coniugem. (Leges Visigothorum, L.III,1,1.)
} 
uma lei para reconhecer um comportamento comum, mas a análise das fontes nos levam a concordar com a hipótese de G. Rippol López: Leovigildo não inaugurou o processo que sublimou gradualmente a separação entre os visigodos e os romanos na Gália e depois na Hispania. E essa espécie de fusão não implicou na anulação de nenhum dos grupos até porque a questão que surge é outra: tensões entre as identidades visigodas e romanas foram o combustível para a produção e revisão dessas leis? Ou as ameaças que a autoridade do rei enfrentava vindas de diferentes frentes é que estavam em jogo? ${ }^{685}$ Mesmo se as práticas legais romanas pareçam mais evidentes na Lex Visigothorum do que alguma tradição legal genuinamente visigoda, se existisse algo nesse sentido, o que fica evidente é que essa tradição visigoda foi emulada em parâmetros romanos e respondia a querelas insinuadas em outros textos, como a Chronica Cesaraugustana.

A segunda possibilidade que aparece é pensarmos o papel dessas leis entre os séculos VI e VII, e esse papel não parece ter sido desimportante. A maioria dos documentos medievais que chegaram aos nossos dias são textos legais. ${ }^{686}$ Esse fator nos indica a importância dessa natureza de documentação para tentar compreender o período não só pelas informações que esse tipo de fonte traz, mas também pela própria grande circulação delas e, sobretudo, pelo o que outras fontes dizem sobre elas.

Nas Leges Visigothorum encontramos a definição sobre o que eram as leis. Elas são divinamente formatadas, o testemunho da religião, fonte de disciplina, artífice da justiça, mestre da vida, dentre outras qualidades:

Lex est emula divinitatis, antestis religionis, fons disciplinarum, artifex iuris, boni mores inveniens adque conponens, gubernaculum

\footnotetext{
${ }^{685}$ RIPOLL LÓPEZ, G. The arrival of the Visigoths in Hipania: population problems and the processo f acculturation. In: POHL, W. \& REIMITZ, H. Strategies of Distinction. The Construction of ethnic Communities, 300-800.Leiden, Boston, Köln: Brill, 1998. p.153-187.

${ }^{686}$ BRUNDAGE, James A. Medieval Canon Law. Londres e NY: Longman, 1995. p.1.
} 
civitatis, iustitie nuntia, magistra vite, anima totius corporis popularis. ${ }^{687}$

Já Isidoro de Sevilha, inspirador da substancial revisão legal empreendida por Recesvinto, dedicou grande parte do livro $\mathrm{V}$ de suas Etimologias às leis, partindo de uma breve descrição da promulgação das leis desde Moisés até Teodosio ${ }^{688} \mathrm{e}$ desenvolvendo uma explicação sobre a natureza das leis - divinas e humanas ${ }^{689}$ - e as categorias das mesmas no que concerne às leis humanas. Segundo Isidoro de Sevilha, a distinção se realizava entre "leis" (lex), "direito" (ius) e "costumes" (mos):

1. Ius generale nomen est, lex autem iuris est species. Ius autem dictum, quia iustum [est]. Omne autem ius legibus et moribus constat. 2. Lex est constitutio scripta. Mos est vetustate probata consuetudo, sive lex non scripta. Nam lex a legendo vocata, quia scripta est. 3. Mos autem longa consuetudo est de moribus tracta tantundem. Consuetudo autem est ius quoddam moribus institutum, quod pro lege suscipitur, cum deficit lex: nec differt scriptura an ratione consistat, quando et legem ratio commendet. 4. Porro si ratione lex constat, lex erit omne iam quod ratione constiterit, dumtaxat quod religioni congruat, quod disciplinae conveniat, quod saluti proficiat. Vocata autem consuetudo, quia in communi est usu. $^{690}$

A lei humana, em Isidoro de Sevilha, é assim a concretização escrita dos costumes, ${ }^{691}$ é a formalização do direito que regula as ações e a comunidade. Ela tem sua origem na razão é portanto ganha seu status de "justa", fora da razão não há lei e a razão maior no pensamento isidoriano é aquela que vai de acordo com a religião e leva aqueles submetidos a sua jurisdição ao sentido máximo da existência: a salvação. Desta maneira percebemos que o papel das leis se assemelha ao papel dos reis no pensamento isidoriano, mas sob uma perspectiva em que as leis se sobrepõem à autoridade dos reis uma vez que eles só cumprem o seu papel caso sejam zelosos no

\footnotetext{
${ }^{687}$ Leges Visigothorum (LV), II, 2.

${ }^{688}$ Etimologias, V,1.

${ }^{689}$ Etimologias, V, 2.

${ }^{690}$ Etimologias, V,3.

${ }^{691}$ Etimologias, V, 2
} 
respeito às leis. Com isso notamos que na prática legislativa do reino visigodo as leis cumpriam um papel crucial no governo, serviam de norte para a ação dos reis e regulavam as atividades de todos aqueles que estavam sob a sua autoridade, além de servirem também de justificativa para a deposição dos reis caso esses descumprissem o que regia a letra da lei.

A despeito da importância que as leges parecem ter tido, historiadores como $\mathrm{P}$. Wormald e A. Harding argumentam que essas leges não eram usadas na prática, a função que as leges deveriam cumprir na teoria, eram, na verdade, cumpridas por outros documentos como os capitulários régios. As leges teriam uma outra função que fugia ao ordenamento jurídico do reino, elas existiam como histórias nacionais. ${ }^{692} \mathrm{E}$ segundo essa interpretação as leis poderiam, portanto, também serem analisadas à luz de seu papel na formação de identidades, a saber, elas poderiam nos informar sobre a construção das identidades étnicas das gentes barbarorum. ${ }^{693}$ Voltamos à questão das identidades, mas agora numa perspectiva que coloca essas leis como parte de um processo de construção identitária, não como possível fonte para um direito genuinamente germânico ou como parte dos mecanismos para controlar as relações entre duas unidades identitárias distintas: godos $\mathrm{x}$ hispanorromanos ou francos $\mathrm{x}$ galorromanos.

\footnotetext{
${ }^{692}$ Como define Harding: "In law-codes was a nation history: the structure of a 'State' to be found in the institutions and procedures which the king did justice to his people, and the first expression of ideas about the state of the kingdom are in royal charters and the administrative orders such as are gathered in Frankish capitularies". HARDING, A. Medieval law and the foundations of the State. New York: Oxford University Press, 2005. p.38. WORMALD, P. The Leges Barbarorum. Law and Ethnicity in the Post-Roman West. GOETZ, H-W, JARNUT, J., POHL, W. Regna and Gentes. The relationship between Late Antique and Early Medieval peoples and kingdoms in the Transformation of the Roman World. Boston, Leiden: Brill, 2003. p.33. E ainda A.C. Murray que não analisa as leis à luz da emergência de identidades étnicas, mas ressalta seu caráter muitas vezes mais ideológico do que prático: MURRAY, A.C. Germanic Kinship Structure. Studies in Law and Society in Antiquity and the Early Middle Ages. Toronto: Pontifical Institute of Mediaeval Studies, 1983.

${ }^{693}$ Como defendem: AMORY, P. The meaning and purpose of ethnic terminology in the Burgundian laws. Early Medieval Europe, v.2, n.1, p.1-28, 1993. POHL, W. Introduction. POHL, W. \& REIMITZ, H. Strategies of Distinction. The Construction of ethnic Communities, 300-800.Leiden, Boston, Köln: Brill, 1998. p.1-17. No mesmo volume e do mesmo autor: Telling the difference: signs of ethnic identity. p. 17-70.
} 
O fato é que mais uma vez a Escola de Toronto aparece para questionar as hipóteses que levam em contra um processo de construção de identidades étnicas. A. Gillet questiona fortemente essa hipótese. Ao analisar os termos étnicos usados para identificar os reis, ele afirma que a associação entre codificação das leis e termos étnicos aparece quase que exclusivamente na Itália Lombarda. Gillet afirma ainda que as referências que insinuam identidades étnicas e até orgulho étnico aparecem em várias fontes, mas a pluralidade dessas referências e até os diversos significados que elas apresentam não sustentam a hipótese de que existia um grande projeto a favor da construção de identidades étnicas, e tampouco essas referências esparsas e, por vezes, incoerentes sustentam a tese de que as identidades étnicas eram politizadas. O tom das críticas de Gillet as vezes assumem notas tão altas que ele chega a insinuar uma incompetência de Pohl no trato com as fontes:

Pohl, 'Memory, Identity, and Power', asserts that Lombard Laws and the Origo gentis Langobardorum formed a 'complex' which was 'clearly intended to help give coherence and identity to a political and ethnic community'. This claim rests on the collocation of the laws and the Origo in some manuscripts, since at least the time of Paul the Deacon, and their association with royal courts (unprovable in the case of the Origo); codicology conventionally requires a higher standard of proof of the aims of manuscript collections than simple juxtaposition. ${ }^{694}$

O embate atual pode ser grosso modo resumido pelo peso que os termos ditos étnicos representam nas fontes e em como essas leis testemunhariam a queda ou a continuidade de Roma. Talvez um caminho promissor para tomarmos posição nesse debate seja nos dedicar um pouco às maneiras pelas quais essas leis circulavam. Ora, observaremos que a circulação das leis muito provavelmente indica que não houve a substituição de um determinado código legal por outro, essa evidência nos ajuda a questionar se:

${ }^{694}$ GILLET, A. Was ethnicity politicized in Earliest Medieval Kingdoms? In: GILLET, A. On Barbarian Identity. Critical approaches to Ethnicity in Early Middle Ages. Turnhout: Brepols, 2002. Nota 7, p.87 
1. A existência de dois códigos indica a aplicação das leis conforme a origem dos indivíduos?

2. É possível dizer que houve uma ruptura com Roma uma vez que as leis - de grande importância como indicamos a partir da análise de Isidoro de Sevilha foram preservadas?

\section{As leis bárbaras e a ruptura com Roma}

A circulação do Breviário de Alarico na Gália Franca é uma importante evidência para sustentar a hipótese da perenidade das leis romanas mesmo com o surgimento de outras leis. ${ }^{695} \mathrm{Na}$ verdade, se olharmos para a tradição manuscrita do Pactus Legis Salicae notaremos que uma quantidade considerável de manuscritos também contém trechos do Breviário de Alarico: ${ }^{696}$

Tabela 12: Manuscritos do Pactus Legis Salicae com trechos do Breviário de Alarico

\begin{tabular}{|l|l|l|}
\hline MS & Data & Origem \\
\hline $\begin{array}{l}\text { Wolfenbüttel Weissenburg } \\
97\end{array}$ & c. 770 & $\begin{array}{l}\text { Norte ou Nordeste da } \\
\text { Gália }\end{array}$ \\
\hline BN lat. 9653 & s.IX & Catedral de Lyon \\
\hline BN lat. 4403A & VIII & Luxeuil \\
\hline Montpellier 136 & s.IX (after 819) & Gália \\
\hline St Gall 731 & 793 & Oeste de Suécia \\
\hline Vat. reg. lat. 846 & s.IX & Leges scriptorium \\
\hline Warsaw Quart. 480 & s.IX & Leges scriptorum \\
\hline St Gall 729 & s.IX & Leges Scriptorum \\
\hline Leiden Voss lat. Q. 119 & s.IX & Usado em Chartes \\
\hline
\end{tabular}

\begin{tabular}{|l|l|l|}
\hline BN lat. 10753 & s.IX & Gália \\
\hline BN lat. 4626 & s.IX & Gália \\
\hline Vat. reg. lat. 857 & s.IX & Leges scriptorium \\
\hline Vat. reg. lat. 1128 & s.IX & Oeste de Gália \\
\hline
\end{tabular}

\footnotetext{
${ }^{695}$ Como defende K.F. Drew. DREW, Katherine Fischer. The Laws of The Salian Franks. Translated and with introduction by Katherine Fischer Drew. Philadelphia: University of Pennsylvania Press, 1991. p.8.

${ }^{696}$ As tabelas são baseadas fundamentalmente no trabalho de R. McKitterick. McKITTERICK, R. The Carolingians and the written word. Nova Iorque: Cambridge University Press, 1989.
} 
Forçosamente poderíamos acreditar que um código que intentou substituir as leis romanas circularia significativamente nos mesmos manuscritos onde estava registrado um breviário de leis romanas; e também que esses documentos que circulavam juntos serviam tão somente para a construção de uma identidade! Todavia devemos ter em conta que a tradição manuscrita traz problemas, especialmente porque quase todos esses manuscritos são do século IX. Isso pode indicar que o Breviário foi importante para os Carolíngios. Podemos lembrar ainda um capitulário de Carlos Magno que faz referência à lei romana e a admite como uma fonte do direito tal como as leis sálicas. ${ }^{697}$

É verdade que não podemos dizer com absoluta certeza que essa referência em particular entendia como lei romana alguma lei presente necessariamente no Breviário de Alarico. Mas a tradição manuscrita do Breviário oferece subsídios para conjecturar que não é absurdo imaginar que o breviário poderia ser essa fonte. ${ }^{698}$ Contudo, o que podemos dizer sobre a Gália merovíngia? Era o Breviário importante durante o governo dos Merovíngios?

Podemos encontrar referências às leis romanas em fontes merovíngias. As atas do I Concílio de Orleans de 511, por exemplo, contemplam a questão do uso das igrejas como refúgio para criminosos. O primeiro cânone prevê: "De homocidis, adulteris et furibus, si ad ecclesiam confugerint, id constituimus obseruandum, quod ecclesiasticis canones decreuerunt et lex Romana constituit [...]." Se observarmos o

\footnotetext{
${ }^{697}$ Capitulário 58.

${ }^{698}$ J. Gaudemet afirmou que o Breviário era, sem dúvidas, a fonte para as Leis Romanas durante o reinado de Carlos Magno. GAUDEMET, J. Survivances romaines dans le droit de la monarchie franque du $\mathrm{V}^{\text {ème }}$ au $\mathrm{X}^{\text {ème }}$ Siecle. Tijdschrift voor Rechtsgeschiedenis. n. 23, p.149-206, 1955. p.175. Ainda sobre a influência do Breviário de Alarico na Gália: GUILLOT, O. Brèves remarques sua l'esprit de quelques interprétations fondamentales du Bréviare d'Alaric et sur sa réception par les rois Mérovingiens. In : ROUCHE, M. \& DUMÉZIL, B. Le Bréviaire d'Alaric. Aux origines du Code Civil. Paris : PUPS, 2006. p. 179-198. E ainda: CÂNDIDO, M.S. Le Prince, la Lex et la Iustitia : Le Bréviaire D'Alaric et l'édit attribué à Clotaire II. In : ROUCHE, M. \& DUMÉZIL, B. Le Breviáire d'Alaric. Aux origines du Code civil. Paris : PUPS, 2008. p. 199-212.
} 
Código Teodosiano, título XXXIV, livro IX no Breviário de Alarico notaremos que esse título contempla exatamente a questão de criminosos que procuravam refúgio em igrejas. Não é possível dizer com certeza que os bispos no I Concílio de Orleans usaram o texto do Breviário de Alarico como fonte, apenas quatro anos separam a promulgação do breviário desse concílio, contudo, essa possibilidade não parece tão distante. Precisamos lembrar que graças à vitória de Clóvis contra Alarico em 507 o rei franco pode ter tido acesso aos documentos produzidos no reino visigodo.

Podemos também encontrar referência à lei romana nas Formulae Andecavenses, o mais antigo registro de fórmulas merovíngias. É difícil estabelecer uma data exata para a produção dessas formulae mais elas possivelmente foram compostas durante o século VI ou início do século VII. ${ }^{699}$ As fórmulas 46, 54 e 58 mencionam leis romanas. É interessante observar que essas três formulae lidam com o tema da donatio. A primeira descreve uma doação feita para uma igreja, a segunda uma doação feita por um homem à sua mulher e a última uma doação feita de um pai para o filho. Nenhum dos procedimentos descritos pelas formulae é contraditórios com as leis acerca das doações no Código Teodosiano presente no Breviário de Alarico. Como exemplo podemos comparar a formula 58 com o título V, livro VIII no código teodosiano reproduzido pelo Breviário de Alarico:

Formulae Andecavenses, 58

Lex Romana etdocet, consuetudo pacem consentit, et regalis potestis non proibit, ut unusquis de rem suam, quem in presente diae possedit, faciat quod voluerit. Icirco ego quidem in Dei nomen illi, qui conmaneo illa villa, quia pertractavi circa animus meus, ut omnis res meas, quem in presente seculo habire videor, ad filio meo duas partes per hanc epistola cessione ad die presente trado ad possedendo, tam casas, domibus, edificiis, mancipiis, campis, viniis, silvis, pratis,
Breviário de Alarico - Theod. Cod. l. VIII, t.V

§ 1. Donatio, sive directa sit, sive mortis causa instituta, sive conditionibus faciendi ac non faciendi suspensa, sive ex aliquo notato tempore primissa, sive animo dantium accipientiumve sententiis, quantum ius sinit, cognominata, sub hac fieri debet observatione, ut, quas leges indulgent, actiones, conditiones pactionesque contineat, hisque penitus cognitis vel recipiantur, si complacitae sunt, vel reiiciantur, si sunt

${ }^{699}$ RIO, A. Legal practice and the written word in the Early Middle Ages. Frankish Formulae, c.500-1000. Cambridge, New York: Cambridge University Press, 2009. p.67-80. 
pascuis, aquis aquarumvae decursibus, iunctis et subiunctis, movelibus et inmovelibus, omni rem meam, pro adsidua servicia sua vem 461 uiús461 lência ei, sicut dixi, partir duas diligo adquae transfundo ad diae presente, tercia vere parte ad heredis propinquis reservans, ea tamen condicione, ut, dum advixero, mihi in omnibus, tam de victo quam et de vestito, soniare mihi debiat, et ipsa terra prosovere faciat, et quicquid de ipsis duas partes facere voluerit, abendi, tenendi, donandi, vindendi seu conmutandi, absquae preiudicio sancti illius, cuius terre esse videtur, liberam in omnibus abeas potestatem faciendi. [...] molestae; ita ut minorum defensores, si per eos donationum conditio neglecta est, rei amissae periculum praestent.

É possível perceber que a formula 58 aparentemente respeita o procedimento do Código Teodosiano no Breviário de Alarico. Novamente, isso não significa necessariamente que o Breviário era a fonte para a elaboração da formula, mas outra vez essa possibilidade é razoável, podemos conjecturar que o Código Teodosiano, sem o intermédio do Breviário, foi a fonte para essa fórmula e também para as fórmulas 46 e 54. Essa hipótese parece mais consistente do que usar uma misteriosa ou pouco conhecida lei romana vulgar para pensar na sobrevivência das leis romanas depois do assentamento dos francos na Gália, como defende Polly.

Entretanto, o que a circulação do Breviário pode dizer sobre a aplicação das leis na Gália franca? Parece muito claro que o Pactus Legis Salicae não substituiu a lei romana na Gália, mas como esses diferentes códigos podem ter sido aplicados? Conforme argumentaremos no próximo tópico não acreditamos que o princípio da personalidade das leis é uma boa explicação para o problema. Se retomarmos a citação do capitulário de Carlos Magno perceberemos que o rei reconheceu tanto a leis romana quanto a lei sálica como fontes possíveis para responde à pergunta feita à ele. Também as referência às leis romanas nas formulae citadas indicam que essas leis eram recorrentemente mencionada em questões relacionadas à donatio. Talvez, o 
lapso de títulos dedicados à donatio no Pactus Legis Salicae explique a recorrência das leis romanas em formulae relacionada com esse tópico. O que queremos propor é que a aplicação de ambos os códigos dependia mais do tema submetidos à apreciação dos julgadores do que à pessoa e sua origem étnica submetida ao julgamento. Melhor dizendo, as leis eram aplicadas de acordo com a demanda. Além disso, elas não necessariamente respeitavam as fronteiras dos reinos! Podemos então dizer que essas leis tinham pretensões de construir uma identidade "étnica" quando circulavam e eram usadas em outros reinos? Podemos dizer que houve uma ruptura com Roma quando Códigos legais romanos eram reelaborados para enfrentar questões políticas urgentes, como aquelas com as quais lidava Alarico II?

Podemos reelaborar a reflexão retomando uma pergunta já posta. Talvez um caminho mais razoável para enfrentar a complexidade da aplicação das leis durante a Idade Média seja, mais do que superar o Império como uma chave de leitura, superar as idéias opostas sumarizadas numa crise genuína ou continuidade genuína. Talvez se lermos as diferentes leis operantes, ao menos na Gália franca, como leis que coexistiam e não competiam, que se completavam e não tentavam se suplantar, novas possibilidades de leituras possam emergir inclusive no que concerne ao lugar do gothi e franci nessas fontes e na documentação do nosso período como um todo. 


\section{Pactus Legis Salicae}

O Pactus Legis Salicae ${ }^{700}$ é um dos códigos legais mais mencionados quando se trata de buscar as reminiscências "bárbaras" nas leis do ocidente europeu. Se verídica essa tese seria possível considerar esse documento como de enorme relevância para buscarmos traços de uma identidade "bárbara". Já apontamos para as dificuldades inseridas nessa perspectiva a partir da análise do Breviário de Alarico, mas como será apontado a seguir, essa proposição enfrenta ainda maiores dificuldades quando o Pactus Legis Salicae é confrontado com outras fontes e analisado à luz do contexto de produção de códigos legais na Gália do século VI.

\section{Estrutura do Pactus Legis Salicae}

O epílogo do Pactus Legis Salicae menciona o primeiro rei dos francos como o responsável pelos primeiros sessenta e cinco títulos do compêndio. ${ }^{701}$ Esse epílogo, que circulou em poucos manuscritos, ${ }^{702}$ serviu de base argumentativa para sustentar que Clóvis teria sido o rei responsável pela primeira redação do Pactus Legis Salicae, redigido entre 507 e $511 .^{703}$ Uma segunda redação teria sido feita entre 511 e 533

\footnotetext{
${ }^{700}$ Este tópico foi originalmente publicado na revista Signum. A versão aqui presente traz algumas alterações importantes. $C f$ : SILVEIRA, V.C. Os Romanos nos sessenta e cinco primeiros títulos das leis sálicas e a especificidade do manuscrito A2. Signum. v.13, p.22-45, 2012.

${ }^{701} \mathrm{O}$ primeiro rei dos francos determinou e fez provisões para todas as questões a serem adjudicadas nos títulos I à LXV[...].<Primus rex Francorum statuit a primo titul(o) usque LX(V) disposuit iudicare $[\ldots]$ PLS, epílogo.

${ }^{702}$ WOOD, Ian. The Merovingian Kingdoms. 450-751. Londres e Nova Iorque: Longman, 1994. p.111.

${ }^{703}$ DREW, Katherine Fischer. Introduction. The Laws of The Salian Franks. Translated and with introduction by Katherine Fischer Drew. Philadelphia: University of Pennsylvania Press, 1991. p.2425. Drew adota essa cronologia, mencionada também por: SIEMS, Harald. La vie économique des Francs d'après la lex salica. In: ROUCHE, Michel (ed.). Clovis: histoire et mémoire. Actes du Colloque International d'Histoire de Reims, du 19 au 25 septembre 1996. Paris e Sorbonne : Presses de l'Université de Paris-Sorbonne, 1997. Vol. 1. p.607. e fortemente criticada por J.-P. Poly: POLY, JeanPierre. La corde au cou. Les Francs, la France et la Loi salique. In: Genèse de l'État moderne em Méditerranée. Approches historique et anthropologique des pratiques et des représentations. Actes des tables rondes internationales tenues à Paris (24-26 septembre 1987 et 18-19 mars 1988). Rome: École Française de Rome, 1993. p. 287-320. Do mesmo autor: POLY, Jean-Pierre. Le premier roi des francs. La loi salique et le pouvir royal à la fin de l'Empire. In : CONSTABLE, G. \& ROUCHE, M. Auctoritas. Mélanges offerts à Olivier Guillot. Paris : PUPS, 2006. p.97- 128.
} 
durante o reinado de Teodorico, ${ }^{704}$ e uma terceira redação entre 567 e 593/596 durante os reinados de Gontrão e Childeberto II. K.A. Eckhardt, o editor monumentista do Pactus Legis Salicae, classificou essas três redações em três famílias, A, B e C e as chamou de Pactus Legis Salicae. Uma outra versão, com 100 títulos, classificada como das famílias D e E, é atribuída por Eckhardt como do período carolíngio. A D teria sido feita durante o reinado de Pepino entre 763 e 764 e a E seria uma emendata provavelmente de 798, produzida durante o reinado de Carlos Magno. A essa redação Carolíngia, Eckhardt deu o nome de Lex Salica. Em resumo, o Pactus Legis Salicae, mais curto, foi atribuído ao período merovíngio enquanto a Lex Salica, mais longa, ao período carolíngio. ${ }^{705}$ Há ainda a Lex Salica Karolina, transmitida pelas famílias K, S e $\mathrm{V}$ que conta com setenta títulos e é também atribuída ao reinado de Carlos Magno. ${ }^{706}$ Discutiremos com mais vagar a tradição manuscrita do Pactus Legis Salicae no próximo tópico.

Aos sessenta e cinco títulos considerados como o trecho mais antigo do Pactus Legis Salicae o editor Eckhardt acrescentou os capitulários como adições posteriores feitas ao texto original. Embora esses capitulários estejam presentes em manuscritos que trazem o Pactus Legis Salicae não há como afirmar que eles são parte integrante do texto. Parte integrante ao não da lei, os capitulários não deixam de ser fontes importantes e os estudaremos comparando-os aos sessenta e cinco títulos.

\footnotetext{
${ }^{704}$ Que supostamente foi a tradição transmitida pela família de manuscritos B. Todavia, nenhum manuscrito da família B chegou aos nossos dias. Eckhardt argumentou que traços da família B sobreviveram na família $\mathrm{C}$ e na organização dos manuscritos do século XVI de Herald.

${ }^{705}$ ECKHARDT, K.A. Einleitung. In:____ Pactus Legis Salicae. Leges Nationum Germanicarum. Tomo IV, Parte I. 1962. p.LX. Para uma boa discussão em língua portuguesa: MAZETTO, Milton Jr. A paz e o recurso à violência no Reino dos Francos: os mecanismos de resolução de conflito no período merovíngio (Séculos VI-VII). Dissertação de Mestrado. Programa de Pós-Graduação em História Social. Faculdade de Filosofia, Letras e Ciências Humanas. Universidade de São Paulo. São Paulo: 2009. p.32-46.

${ }^{706}$ Nas palavras de Eckhardt: "Die Textklassen A, B und C bilden den merowingischen Pactus legis Salicae (65 Titel-Text).D und E repräsentieren die frürkarolingische Lex Salica (100 Titel-Text). K, S und V sind Formen der nach der Kaiserkrönung Karls des Grossen entstandenen Lex Salica Karolina (70 Titel-Text)." Ibidem, p. X.
} 


\subsection{Tradição manuscrita}

As primeiras tentativas de edição do Pactus Legis Salicae remontam ao início da sessão Leges do Instituto MGH na metade do século XIX. A primeira edição, contudo, saiu apenas na década de 60 do século XX, nesse meio tempo L.W.A Pernice, G.H. Pertz, M. Krammer e B. Krusch tentaram levar a cabo a empreitada sem sucesso. Krammer conseguiu concluir uma edição que foi duramente criticada e não chegou a ser publicada pelos $\mathrm{MGH}^{707}$

Como muito bem aponta A.C. Murray, as dificuldades encontradas pelos monumentistas não são difíceis de serem notadas. ${ }^{708}$ Além dos trechos considerados como parte do Pactus Legis Salicae terem sido transmitidos de forma fragmentada pelos manuscritos, é notável que o manuscrito mais antigo, o A2, data do século VIII, pelo menos dois séculos após a primeira redação que teria ocorrido no século VI. Não obstante é difícil definir o que são as leis sálicas com precisão: seriam de fato leis aplicadas na prática? ${ }^{709}$ Seria um termo genérico para designar leis reais $?^{710}$ Seriam leis de caráter literário e ideológico? ${ }^{711} \mathrm{Ou}$ leis inspiradas nas leis romanas vulgares $?^{712} \mathrm{Ou}$ ainda, um texto ao mesmo tempo legal e literário conservado nos

\footnotetext{
${ }^{707}$ Sobre os detalhes e debates em torno da tentativas de edição do Pactus Legis Salicae pelos monumentistas: STEIN, Simon. Lex Salica I. Speculum. v.22, n.2, p.113-134, abril de 1947.

${ }^{708}$ MURRAY, A.C. Germanic Kinship Structure. Studies in Law and Society in Antiquity and the Early Middle Ages. Toronto: Pontifical Institute of Mediaeval Studies, 1983. p. 119.

${ }^{709}$ Ibidem, p. 128.

${ }^{710}$ STEIN, Simon. Lex Salica II. Speculum. vol.22, n.3, p.395-418. Julho de 1947. p.395-403.

${ }^{711}$ MURRAY, A.C. Op.cit. Ainda: WORMALD, P. The Leges Barbarorum. Law and Ethnicity in the Post-Roman West. GOETZ, H-W, JARNUT, J., POHL, W. Regna and Gentes. The relationship between Late Antique and Early Medieval peoples and kingdoms in the Transformation of the Roman World. Boston, Leiden: Brill, 2003. p.33.

${ }^{712}$ POLY, J.-P. La corde au cou. Les Francs, la France et la Loi salique...op.cit. POLY, J.-P. Le premier roi des francs. La loi salique et le pouvir royal à la fin de l'Empire...op.cit.
} 
círculos eclesiásticos $?^{713}$ Todas essas barreiras indicam o quão difícil é trabalhar com essas leis e tornam compreensíveis a demora na publicação da edição dos MGH. ${ }^{714}$

Diante das discrepâncias nos manuscritos é muito importante adotarmos um posicionamento sobre como trabalharemos com esse documento. Murray salienta ainda que a despeito do importantíssimo trabalho do Eckhardt, não é seguro usarmos como referência apenas o texto reconstruído pelo monumentista. ${ }^{715}$ Para exemplificarmos o problema observemos o prólogo curto cuja versão supostamente mais antiga foi transmitida pelo manuscrito C6. Conforme o texto reconstruído de Eckhardt, o primeiro parágrafo do prólogo seria da seguinte maneira:

$\S 1$. Placuit auxiliante Domino atque conuenit inter Francos atque eorum proceribus, ut pro seruandum inter se pacis studium omnia incrementa <uirtutum> rixarum resecare deberent, et quia ceteris gentibus iuxta se positis fortitudinis brachio prominebant, ita etiam eos legali auctoritate praecellerent, ut iuxta qualitate causarum sumerent criminalis actio terminum.

O manuscrito mais antigo que traz esse prólogo é o C6, que segundo Eckhardt data do século IX. O texto do C6 difere em aspectos importantes da reconstrução proposta por Eckhardt:

$\S 1$. Placuit atque conuenit inter francos atque eorum proceribus, ut pro seruandum inter se pacis studium omnia incrementa rixarum resecare debent, ita etiam eos legale auctoritate praecellerent, ut iuxta qualitate causarum sumerent criminales actiones terminum.

Notamos logo de início que o texto no manuscrito C6 não menciona a ajuda de Deus (auxiliante Domino) tampouco o destaque dos francos por conta de sua força bélica (et quia ceteris gentibus iuxta se positis fortitudinis brachio prominebant). Tais

\footnotetext{
${ }^{713}$ WALLACE-HADRILL, J.M. Archbishop Hincmar and the authorship of Lex Salica. In: ___. The Long-Haired Kings and Other Studies of Frankish History. New York: Barnes and Noble, 1962. 116-117

${ }^{714}$ Como bem colocou Wallace-Hadrill: "Inability to decide what precisely the barbarian laws were, and thus what principles should underlie the establishing of critical texts, lay at the root of the notorious difficulties with which the Monumenta editors of the Leges section found themselves faced; and their greatest difficult was with Lex Salica." WALLACE-HADRILL, J.M. Archbishop Hincmar and the authorship of Lex Salica... op.cit. p. 106.

${ }^{715}$ MURRAY, A.C. Op.cit
} 
omissões não parecem desimportantes e indicam uma relevante discrepância nos manuscritos. Ora, a menção à ajuda de Deus aparece apenas no manuscrito K31 do século XI, enquanto a referência à força bélica dos francos aparece em todos os manuscritos ${ }^{716}$ que trazem o primeiro parágrafo do prólogo citado, exceto no C6. Aparentemente a menção a Deus foi uma adição do copista do K31 que embora não siga a tendência dos demais manuscritos acabou adicionado ao texto reconstruído de Eckhardt. Por outro lado, a informação sobre a força armada dos francos, um detalhe possivelmente importante para destacar essa gens no documento, ${ }^{717}$ não aparece no manuscrito que traz a redação mais antiga do prólogo.

É, destarte, necessário confrontar as informações nos diferentes manuscritos. Comumente os manuscritos das famílias A e C são privilegiados pelos pesquisadores dedicados ao período merovíngio por supostamente trazerem a redação mais antiga. $\mathrm{O}$ problema de considerarmos apenas as famílias $\mathrm{A}$ e $\mathrm{C}$ é o fato de que esses manuscritos foram produzidos, tal como a maioria das demais famílias, durante o século IX. Diante disso, é pertinente isolar esses manuscritos dos demais? R. McKitterick acredita que não ${ }^{718}$ e vai além ao chamar a atenção para a importância de considerar algumas informações sobre esses manuscritos que foram ignoradas pela edição de Eckhardt, a saber, o conteúdo de cada um desses manuscritos. A pesquisadora empreendeu esse estudo e propôs uma interessante classificação desses textos em: a. textos legais; b. textos de estudo legais e c. textos que circulavam nos círculos religiosos. A seguir apresentaremos uma tabela que mescla as informações presentes na edição de Eckhardt com informações acrescentadas por McKitterick. Essa opção foi adotada porque a edição de Eckhardt apresentou os trechos das Leis

\footnotetext{
${ }^{716}$ Manuscritos: C6a, K31, K32, K33, K65.

${ }^{717}$ Se a hipótese de P. Wormald estiver correta. WORMALD, P. The Leges Barbarorum....op.cit.

${ }^{718}$ McKITTERICK, Rosamond. The Carolingians and the written word. Nova Iorque: Cambridge University Press, 1989. p.40-61.
} 
Sálicas presente nos manuscritos, enquanto o trabalho de McKitterick ofereceu uma leitura sinóptica desses textos.

Seguiremos a sugestão de McKitterick e não ignoraremos as informações presentes nos manuscritos das outras famílias, mas conforme observações que explicitaremos mais à frente, são nos manuscritos que trazem as redações originais atribuídas aos merovíngios onde encontramos diferenças mais significativas de conteúdo acerca dos francos e romanos. Portanto as tabelas que se seguem tratam das famílias A e C.

Tabela 13 Manuscritos da Família A do Pactus Legis Salicae

\begin{tabular}{|c|c|c|c|c|c|c|}
\hline $\begin{array}{l}\text { Class. } \\
\text { conform } \\
\text { e a a } \\
\text { família }\end{array}$ & Mss. & $\begin{array}{l}\text { Data de } \\
\text { produçã } \\
\text { o }\end{array}$ & Origem & $\begin{array}{l}\text { Trechos } \\
\text { das Leis } \\
\text { Sálicas }^{719}\end{array}$ & $\begin{array}{l}\text { Demais } \\
\text { conteúdos }^{720}\end{array}$ & $\begin{array}{l}\text { Classificação } \\
\text { conforme } \\
\text { McKitterick }\end{array}$ \\
\hline A1 & BN lat. 4404 & $\begin{array}{lr}\text { Sec. IX } \\
(800-814)\end{array}$ & Tours & $\begin{array}{l}\text { Lista de } \\
\text { títulos; } \\
\text { texto; } \\
\text { capitulários } \\
\text {; prólogo } \\
\text { longo, } \\
\text { Pactus pro } \\
\text { tenore } \\
\text { pacis e o } \\
\text { Decretio } \\
\text { Childeberti }\end{array}$ & $\begin{array}{l}\text { Lex } \\
\text { Alamannorum, } \\
\text { Lex } \\
\text { Baiuuariorum, } \\
\text { Lex Ribuaria, } \\
\text { Lex Salica }\end{array}$ & Livro de leis \\
\hline A2 & $\begin{array}{l}\text { Wolfenbütte } \\
1 \\
\text { Weissenburg } \\
97\end{array}$ & c. 770 & $\begin{array}{l}\text { Norte ou } \\
\text { Nordeste } \\
\text { da França. } \\
\text { Copista: } \\
\text { Agambert }\end{array}$ & $\begin{array}{l}\text { Títulos e } \\
\text { texto das } \\
\text { leis sálicas, } \\
\text { Capitulários } \\
\text { LXVIII- } \\
\text { LXXVI, } \\
\text { Pactus pro } \\
\text { tenore } \\
\text { pacis, } \\
\text { epílogo } \\
\text { com a lista } \\
\text { de reis de } \\
\text { Teodorico } \\
\text { III a } \\
\text { Childeberto } \\
\text { III. }\end{array}$ & $\begin{array}{l}\text { Lex Salica e o } \\
\text { Breviário de } \\
\text { Alarico }\end{array}$ & Livro de leis \\
\hline
\end{tabular}

${ }^{719}$ Conforme Eckhardt: ECKHARDT, K.A. Einleitung. In: Pactus Legis Salicae. Leges Nationum Germanicarum. Tomo IV, Parte I. 1962. p. XIII - XXVII.

${ }_{720}$ De acordo com McKITTERICK, Rosamond. The Carolingians and the written word. Nova Iorque: Cambridge University Press, 1989. p. 48-55.

${ }^{721}$ Idem. 


\begin{tabular}{|c|c|c|c|c|c|c|}
\hline A3 & Clm 4115 & $\begin{array}{l}\text { Entre os } \\
\text { sécs. VIII } \\
\text { e IX. }\end{array}$ & $\begin{array}{l}\text { Sul da } \\
\text { Alemanha }\end{array}$ & $\begin{array}{l}\text { Lista de } \\
\text { títulos, } \\
\text { texto e o } \\
\text { Pactus pro } \\
\text { tenore } \\
\text { pacis }\end{array}$ & $\begin{array}{l}\text { Lex Salica, Lex } \\
\text { Ribuaria, Lex } \\
\text { Alamannorum. }\end{array}$ & Livro de leis \\
\hline A4 & BN lat. 9653 & $\begin{array}{l}\text { Primeira } \\
\text { metade } \\
\text { do séc.IX }\end{array}$ & $\begin{array}{l}\text { Burgúndia } \\
: \quad \text { catedral } \\
\text { de Lyon }\end{array}$ & $\begin{array}{l}\text { Lista de } \\
\text { títulos } \quad \text { e } \\
\text { texto da } \\
\text { Lex Salica }\end{array}$ & $\begin{array}{l}\text { Lex } \\
\text { Burgundionum } \\
\text {, Lex Salica e } \\
\text { capitulários } \\
\text { adicionais da } \\
\text { Lex Salica e } \\
\text { Lex Ribuaria e } \\
\text { o Breviário de } \\
\text { Alarico. }\end{array}$ & Livro de leis \\
\hline
\end{tabular}

A primeira característica notável na Família A é que todos os manuscritos são, conforme a classificação de McKitterick, livros de leis. A Família A também traz o manuscrito mais antigo que transmitiu a Lex Salica, o A2, o único onde o copista foi identificado. Exceto pelo A4, que provavelmente não por acaso é o que foi produzido mais ao Sul, todos os manuscritos contêm o Pactus pro tenore pacis. O A4 também é o único manuscrito dessa família que contém a Lex Burgundionum, sua origem mais ao Sul no que outrora fora território burgúndio, pode ser uma chave para explicar essa característica única do A4. Todavia, tanto o A4 quanto o A2 são os únicos manuscritos que trazem o Breviário de Alarico e, ainda, o A2 é o único que traz o epílogo com a lista dos reis. Veremos mais a frente que o A2 difere sensivelmente dos demais manuscritos no que concerne às menções aos romanos.

$\underline{\text { Tabela 14: manuscritos da Família } \mathrm{C} \text { do Pactus Legis Salicae }}$

\begin{tabular}{|c|c|c|c|c|c|c|}
\hline $\begin{array}{l}\text { Class. } \\
\text { Conforme } \\
\text { a família } \\
\end{array}$ & Mss & $\begin{array}{l}\text { Data de } \\
\text { produção }\end{array}$ & Origem & \begin{tabular}{l}
\multicolumn{2}{l}{ Trechos } \\
das Leis \\
Sálicas
\end{tabular} & $\begin{array}{l}\text { Demais } \\
\text { conteúdos }\end{array}$ & $\begin{array}{l}\text { Classificação } \\
\text { conforme } \\
\text { McKitterick }\end{array}$ \\
\hline C5 & $\begin{array}{ll}\text { BN lat. } \\
4403 \mathrm{~A}\end{array}$ & Séc. VIII & Luxeuil & $\begin{array}{lr}\text { Títulos } & \text { e } \\
\text { texto da } & \text { Lex } \\
\text { Salica } & \text { e } \\
\text { ainda } & \text { um } \\
\text { trecho do } & \text { prólogo. }\end{array}$ & $\begin{array}{l}\text { De legibus } \\
\text { das } \\
\text { Etimologias } \\
\text { de Isidoro de } \\
\text { Sevilha, Lex } \\
\text { Salica e } \\
\text { Breviário de } \\
\text { Alarico } \\
\text { anotado. }\end{array}$ & $\begin{array}{ll}\text { Livro } & \text { de } \\
\text { estudos } & \end{array}$ \\
\hline
\end{tabular}




\begin{tabular}{|c|c|c|c|c|c|c|}
\hline C6 & $\begin{array}{lr}\text { BN } & \text { lat. } \\
18237 & \end{array}$ & $\begin{array}{l}\text { Segunda } \\
\text { metade do } \\
\text { século IX }\end{array}$ & $\begin{array}{ll}\text { Oeste } & \text { da } \\
\text { França } & \end{array}$ & 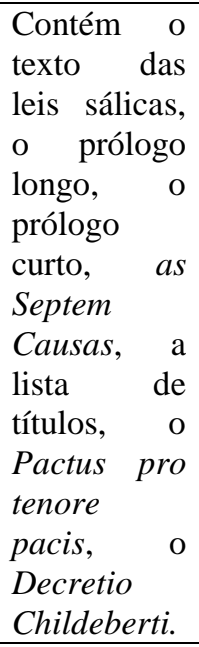 & $\begin{array}{l}\text { De legibus } \\
\text { de Isidoro de } \\
\text { Sevilha, } \\
\text { florilegium } \\
\text { sobre os reis, } \\
\text { De } \\
\text { iudicibus, } \\
\text { capitulários } \\
\text { eclesiásticos. }\end{array}$ & $\begin{array}{ll}\text { Livro de } & \text { de } \\
\text { estudos } & \text { ou } \\
\text { uma } & \\
\text { compilação } \\
\text { eclesiástica. }\end{array}$ \\
\hline C6a & $\begin{array}{l}\text { Leiden } \\
\text { BPL 2005 }\end{array}$ & Séc. XVI & $\begin{array}{l}\text { Países } \\
\text { Baixos }\end{array}$ & $\begin{array}{l}\text { o prólogo } \\
\text { longo, o } \\
\text { prólogo } \\
\text { curto, a lista } \\
\text { de títulos e } \\
\text { trecho do } \\
\text { Pactus pro } \\
\text { tenore } \\
\text { pacis. }\end{array}$ & $\begin{array}{l}\text { Lex Salica } \\
\text { (baseada em } \\
\text { uma cópia } \\
\text { perdida do } \\
\text { século IX) }\end{array}$ & $\begin{array}{l}\text { Não } \\
\text { classificado } \\
\text { por } \\
\text { McKetterick. }\end{array}$ \\
\hline
\end{tabular}

Todos os manuscritos até aqui listados trazem os sessenta e cinco títulos atribuídos ao período merovíngio. Contudo, nem todos estão na íntegra e há diferenças nos conteúdos.

Os dois manuscritos mais antigos da Família C, C5 e C6, foram voltados para os estudos das leis, o que justifica a presença do De legibus extraído das Etimologias de Isidoro de Sevilha, e, além disso, aponta para a importância que o texto Isidoriano teve não só para as revisões das leis visigóticas, mas também para a exegese legal na Gália. O C6a é o único do século XVI e também o único que está fora do eixo Alemanha-França. Supostamente foi baseado num manuscrito perdido do século IX e é interessante justamente por ser oriundo dos Países Baixos e produzido tão posteriormente. Isso indica um interesse tardio nas leges barbarorum.

Além do C6a, outros manuscritos oriundos dos séculos XV e XVI são: o B10 e C10, ambos perdidos e produzidos em Fulda; o K36, produzido na França no século XV; o K37, também oriundo da França e escrito entre os séculos XV e XVI; o K54 do 
século XV; os K66 e K67, feitos na França e ambos do século XVI; o K68a da segunda metade do século XVI e possivelmente originário da França; K74 do século XV e sem local de produção certo, mas produzido na Europa Continental; o K75 do século XVI e também sem local de produção certo; K79, também do século XV.

Há alguns poucos manuscritos dos séculos X e XI, como: o E16 da segunda metade do século X e originário da França; o K22 do século X também originário da França; o K31 do século XI oriundo da França; o K32 do século X originário de Metz; o K34 do século X, produzido em Lyon; o K35 feito entre os séculos X e XI e oriundo da França; o K40, manuscrito britânico do século X; o K44, feito entre os século X e XI provavelmente no Norte da Itália; o K51, do primeiro quarto do século X e feito em Rheims; o K52 do primeiro quarto do século X oriundo do Nordeste da França; o K63, da primeira metade do século X e possivelmente produzido na Alemanha; o K65, datado como de entre os séculos XI e XII e compilado provavelmente na Alemanha; o S83 provavelmente de Mainz e feito entre os séculos X e XI. Mais raros são os manuscritos dos séculos XII e XIII, como: o K76, inicialmente escrito entre os séculos XII e XIII e com adições do século XIV.

Exceto por esses manuscritos listados, todos os outros são originários do período entre a segunda metade do século VIII e decorrer do IX. Se levarmos em conta que ao menos oitenta e sete manuscritos trazem a Lex Salica ou trechos dela, esses vinte e cinco manuscritos posteriores ao período correspondem a exceções na tradição manuscrita.

O que podemos concluir desses dados é que as Leis Sálicas foram de grande interesse a partir do final do século VIII e decorrer do IX. Durante os séculos X e XI há uma diminuição significativa na produção de manuscritos com a Lex Salica; os séculos XII, XIII e XIV são praticamente irrelevantes no que concerne à produção de 
cópias da lei e, a partir do século $\mathrm{XV}$, há uma retomada de interesse por esse texto legal. Todavia, quase todos os manuscritos mais antigos trazem outras leges além da Lex Salica, o que fortalece a hipótese de que a Lex Salica não era a única em vigor no Norte da Gália; ${ }^{722}$ cabe salientar que o manuscrito mais antigo que transmitiu a Lex Salica, o A2, também traz o Breviário de Alarico. Essa questão coloca em xeque a tese de K.F. Drew ${ }^{723}$ que defendeu a substituição das leis romanas pelas leis sálicas no Norte da Gália. Embora Drew não negue que algumas leis romanas vulgares podem ter continuado em vigor, ela enuncia uma predominância das leis sálicas na região. Se levarmos em conta a tradição manuscrita é possível dizer que as leis romanas estavam também em vigor. Proposição que se fortalece se observarmos os formulários, especialmente os de Angers, ${ }^{724}$ onde há menção às leis romanas. ${ }^{725}$ Essa questão será melhor desenvolvida a seguir, já que até aqui nos debruçamos sobre o que a tradição manuscrita tem a nos dizer sobre a Lex Salica.

\footnotetext{
${ }^{722}$ I. Wood defende que pelo menos três leis estavam em vigor na Gália: a Lex Salica na Nêustria, a Lex Ribvaria na Austrásia e o Liber Constitutionum na burgúndia. WOOD, Ian. The Merovingian Kingdoms. 450-751...op.cit. p. 115.

${ }^{723}$ DREW, Katherine Fischer Drew. Introduction. The Laws of The Salian Franks...op.cit. p.8.

${ }^{724} \mathrm{E}$ falamos sobre os formulários de Angers em particular porque eles são, de acordo com A. Rio, possivelmente os mais antigos e que versam sobretudo sobre questões locais. No caso Angers, região que pertencia à Nêustria e onde justamente I. Wood defende que as leis sálicas estavam em vigor. Cf: RIO, Alice. The formularies of Angers and Marculf: Two Merovingian Legal Handbooks. Translated with introduction and notes by Alice Rio. Liverpool: Liverpool University Press, 2008. p.38-46. Esses dados parecem indicar que a limitação da aplicação das leges em termos geográficos é problemática.

${ }^{725}$ Cf: Formulae Andecavenses, 46, 54 e 58.
} 


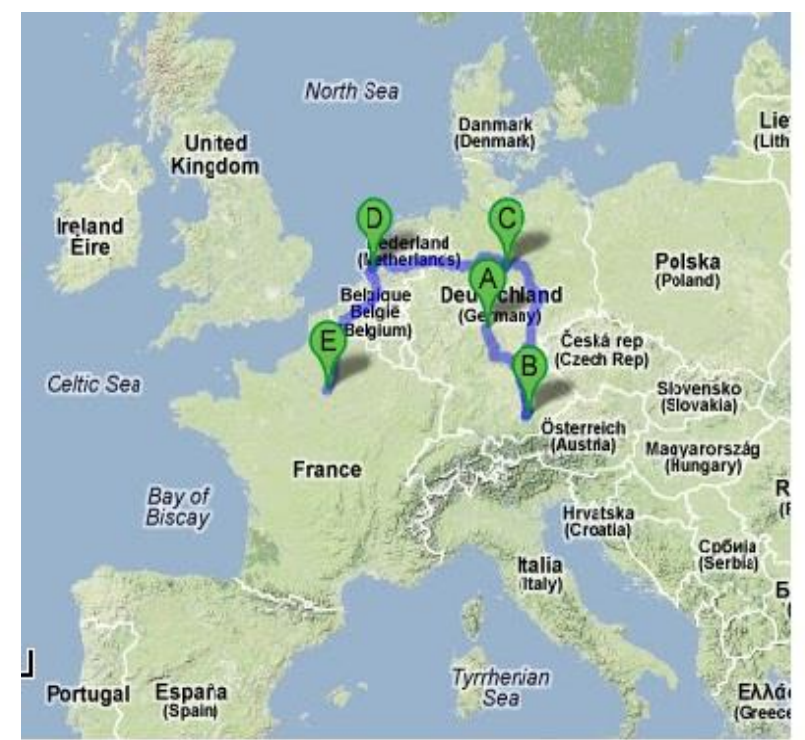

Localização dos Manuscritos do Pactus Legis Salicae

A. Fulda - Abteibibliothek > Provavelmente Manuscritos B10 e C10, ambos perdidos.

B. Munique - Staatsbibliothek > Manuscrito A3

C. Wolfenbüttel - Landesbibliothek > Manuscrito A2

D. Leiden - Bibliotheek der Rijksuniversiteit > Manuscrito C6a

E. Paris - Bibliothèque Nationale $>$ Manuscritos $\mathrm{C} 5, \mathrm{~A} 1 \mathrm{e}$ A4.

Gráfico 21 Localização dos Manuscritos do Pactus Legis Salicae

\subsection{Datação}

Para A.C. Murray, a difusão dos manuscritos a partir do século VIII e principalmente no século IX sugere que a Lex Salica era uma novidade no período carolíngio, muito embora ele não questione que os sessenta e cinco primeiros títulos datem do século VI. ${ }^{726}$ Essa preocupação em atrelar a datação dos sessenta e cinco primeiros títulos ao século VI não deve apenas ao fato dos manuscritos serem posteriores a essa data, mas também ao polêmico artigo de S. Stein onde o autor afirma que o Pactus Legis Salicae era uma fraude e insinua ter sido fabricado por Hincmar de Rheims. ${ }^{727}$ A primeira vista a hipótese de Stein é sedutora, mas é preciso tomar em conta que:

\footnotetext{
${ }^{726}$ MURRAY, A.C. Germanic Kinship Structure...op.cit. p. 131.

${ }^{727}$ Isso é de fato apenas insinuado no artigo de Stein e essa insinuação serviu de base para a crítica feita por Wallace-Hadrill ao trabalho de Stein. O que Stein afirma veementemente é que a Lex Salica é uma falsificação do século IX. Nas palavras dele: "Here is my summary. Since the middle of ninth century, there appear numerous manuscripts transmitting a code which, according to their affirmations, was promulgated by Clovis and his sons. The title of this code - Lex Salica - is not fantastic; it is an ancient term signifying the Royal Law. The Chancellery of Charles the Bald does not possess this code and, while referring to Lex Salica, quotes the Collection of Ansegisus. Moreover, there is no proof that this code had been valid at any time. One part of the norms of this code was not valid either under Charlemagne (Theodulf of Orleans) or under Charles the Bald (Cap. 20). The most characteristic norm of this code is qualified, in a very important legal collection, as being 'diuturna sed impia
} 
1. A tradição manuscrita transmitiu os sessenta e cinco títulos e o epílogo as menciona como leis antigas, anteriores ao século IX e atribuídas pelo texto ao "primeiro rei dos francos". ${ }^{728} \mathrm{O}$ que podemos questionar é se essas leis antigas de fato estavam organizadas em um código chamado Lex Salica. A.C. Murray levanta essa dúvida, enquanto I. Wood acredita na existência de um código justamente por causa da tradição manuscrita que o transmitiu. ${ }^{729}$

2. A tese de Stein é prejudicada pela existência de manuscritos anteriores ao século VIII, como o já citado A2. Seria impossível que a Lex Salica fosse uma invenção do século IX diante desse dado. ${ }^{730}$

Poderíamos mencionar ainda algumas referências externas, o empecilho é a raridade de menções às Leis Sálicas em textos da época merovíngia. As Formulae Andecavenses, por exemplo, citam as leis romanas, notadamente em formulas de transmissão de propriedade, mas as outras referências às leis não especificam a qual lei se referem, exceto a formula 37 que menciona a Lex Aquilia. Interessante notar que a formula 37 também trata da transferência de propriedade dos pais para um filho. Todavia não há nenhuma menção direta às Leis Sálicas, muito embora encontremos nas mesmas Formulae Andecavenses causas que não são estranhas ao texto sálico.

As Leis Sálicas costumam legislar sobre causas bastante específicas, como por exemplo, o ato de esfolar cavalos sem a permissão do dono:

LXV, § 1. Si quis caballum alienum extra consilium domini sui decorticauerit et interrogatus confessus fuerit, caballum ips(um) in capite reddat.

consuetudo'.It seems to me that my final judgment on Lex Salica cannot be considered too daring: LEX SALICA IS A FORGERY.” STEIN, Simon. Lex Salica II. Speculum. vol.22, n.3, p.395-418. Julho de 1947. p. 406.

${ }_{728}$ Conforme o texto reconstruído de Eckhardt: "Primus rex Francorum statuit a primo titul(o) usque LX(V) disposuit iudicare [...]" Epilog. O Manuscrito A2 fala de 62 títulos: "Primus rex francorum statuit a primo titulum usque LXII disposuit iudicare [...]".

${ }_{729}$ Escreveu: "Despite such contradictions the unanimity of the manuscripts in the preservation of the first sixty-five titles makes it clear that these did constitute a code, and it seems probable that other surviving legislation postdates this compilation, and was, at times, intended to complement it. On balance, therefore, it is likely that the sixty-five title of the Pactus Legis Salicae was compiled before 511.” WOOD, Ian. The Merovingian Kingdoms...op.cit. p. 112.

${ }^{730}$ Esse fato também é citado por Wallace-Hadrill. WALLACE-HADRILL, J.M. Archbishop Hincmar and the authorship of Lex Salica...op.cit. 
$\S$ Si uero negauerit et ei fuerit adprobatum, mallobergo secthis hoc est, MCCCC denarios qui faciunt solidos XXXV culpabilis iudicetur excepto capitale et dilatura. ${ }^{731}$

Esse título tão específico trata de uma causa que está também descrita nas Formulae

Andecavenses:

24. Eveniens illi Andecavis civitate ante illo preposito vel reliquis hominibus, qui cum eo adherunt, interprellabat aliquo homine nomen illo, quasi animalia per sua menata heos dicere habuissit, et ipsa animalia per sua menata aliquas mortas fuerant, et ipsa pecora illi excorticassit, posteaque mortas fuerunt. Interrogatum fuit ipsi illi, qui de hac causa respunso darit. Et ipsi illi taliter locutus fuit, quod nec sua animalia numquam menassit, nec per sua menata ipsa animalia digere numquam habuissit, nec de manus suas excorticatas numquam fuissent. Propterea visum fuit ad ipso proposito vel qui cum eo aderant, ut in noctes tantas aput homines tantus ipsi illi in basileca domni illius excusare deberit. Se hoc facere potebat, de hac causa ipsi illi conpascere debirit; sin autem non poterit, quicquid lex de tale causa etdocet, emendare stodiat.

Há muitos problemas na datação das formulae e as formulae andecavenses não são uma exceção, mas há um certo consenso sobre a produção desses textos, ao menos até a formula 57, durante o século VI. ${ }^{732}$ A descrição dessa causa da formula 24 se encaixa na causa prevista na Lex Salica, o que pode nos conduzir para a possibilidade desse crime não ter sido raro no Norte da Gália do século VI, dessa maneira, há traços da Lex Salica que se encaixam em aspectos da região e período onde supostamente ela foi produzida. A formula 24 não nomeia a lei que deveria ser consultada, mas não parece absurdo supor que pode ter sido a lei sálica. Esses dados indicam mais uma vez a importância de não pensarmos esses textos apenas a partir da tradição manuscrita. Ela deve ser considerada, mas sempre confrontada com o contexto textual que discutirmos no primeiro capítulo da tese.

\footnotetext{
${ }^{731}$ Usamos o texto reconstruído de Eckhardt nessa passagem, pois os manuscritos desacordam basicamente no valor da pena.

${ }^{732}$ RIO, Alice. The formularies of Angers and Marculf...op.cit. Especialmente o Appendix I: The original date of the Angers collection: the state of question. p.248-258. Sobre o problema da datação das formulae: RIO, A. Legal practice and the written word in the Early Middle Ages. Frankish formulae, c. 500-1000. Cambridge, Nova Iorque: Cambridge University Press, 2009. p.167-182.
} 
Tratamos de uma prova circunstancial, não definitiva, para afirmarmos que a Lex Salica é sem dúvida do século VI. Há algumas outras evidências, como a levantada por Eckhardt que encontrou no título XIII, §11 da Lex Salica aspectos em comum com o cânone 20 do II Concílio de Tours de $567 .{ }^{733}$ Uma evidência circunstancial já que esse título não é unânime na tradição manuscrita, aparecendo apenas na família C. ${ }^{734}$ G. Monod, por sua vez, cita a querela entre Sicário e Cramesindo descrita por Gregório de Tours nos seus Decem Libri Historiarum, ${ }^{735}$ que segundo ele ocorreu entre 585 e 588, para tentar mostrar que a despeito das dificuldades havia um ímpeto, principalmente por parte dos membros da Igreja, para que as leis - segundo Monod, as sálicas - fossem respeitadas. ${ }^{736}$ De todo modo, tanto as formulae andecavenses, quanto o cânone 20 do II concílio de Tours e os Decem Libri Historiarum não trazem informações que nos sirvam para afirmações categóricas sobre o período de produção dos primeiros sessenta e cinco títulos das Leis Sálicas. Como corretamente apontou T. Anderson a tese da redação do século VI é aceita mais por falta de fundamentação dos argumentos contrários a ela do que por conta de evidências. ${ }^{737}$ A hipótese de Stein traz lacunas graves e não parece segura. Portanto, seguiremos nesse texto o século VI como o período de produção dos sessenta e cinco títulos, os Pactus Legis Salicae conforme a qualificação de Eckhardt. Mas outro problema surge. Ora, se de fato a primeira redação da Lex Salica é do século VI, a que podemos atribuir a falta de referências diretas a essa lei em textos do século VI? Será que isso significa que a Lex Salica era mais um texto literário, ou

\footnotetext{
${ }^{733}$ MAZETTO, Milton Jr. A paz e o recurso à violência no Reino dos Francos...op.cit. p.35.

734 Idem.

735 Decem Libri Historiarum, VII, 47.

${ }^{736}$ MONOD, G. Les aventures de Sichaire. Commentaire. Des chapitres XLVII du livre VII et XIX du livre IX de l'Histoire des Francs de Grégoire de Tours. Revue historique. Paraissant tous les deux mois. Paris : Félix Alcan, Tomo 32, ano 11, p. 259-290, Setembro-dezembro de 1886.

${ }^{737}$ ANDERSON, Thomas Jr. Roman military colonies in Gaul, Salian Ethnogenesis and the forgotten meaning of Pactus Legis Salicae 59.5.Early Medieval Europe. n.4, v.2, p.129-144, 1995. nota 3, p. 129.
} 
com fins ideológicos, sem aplicação prática na resolução das querelas na Gália Merovíngia?

\subsection{Lex Salica - aplicação}

Como já enunciado as Formulae Andecavenses mencionam as leis romanas notadamente em questões que envolvem transferência de propriedade de pais para filhos. A. Rio ${ }^{738}$ sublinhou que essa menção se tratava de um mecanismo para outorgar autoridade à doação. Contudo, se observarmos o Breviário de Alarico, que certamente circulou no norte da Gália merovíngia, como já argumentamos, encontramos cláusulas que tratam especificamente da doação de propriedade de pais para filhos onde há discriminado como esse tipo de doação deveria ser feito. Comparemos. Conforme o Código Teodosiano presente no Breviário de Alarico:

L. VIII, T.V, 1. Donatio, sive directa sit, sive mortis causa instituta, sive conditionibus faciendi ac non faciendi suspensa, sive ex aliquo notato tempora promissa, sive animo dantium accipientiumve sententiis, quantum ius sinit, cognominata sub hac fieri debet observatione, ut, quas leges indulgent, actiones, conditiones pactionesque contineat, hisque penitus cognitis vel recipiantur, si complacitae sunt, vel reiiciantur, si sunt molestae; ita ut minorum defensores, se per eos donationum conditio neglecta est, rei amissae periculum praestent. \$1. In conscribendis autem donationibus nomen donatoris, ius ac rem notari oportet, neque id oculte aut per imperitos aut privatim, sed aut tabula, aut quodcunque aliud materiae tempus dabit, vel ipso vel ab eo, quem sors minitraverit, scientibus plurimis perscribatur.

O título seguinte, o VI, trata da revogação da doação. Ele nos ajuda a compreender quem seriam os principais beneficiados pelo título $\mathrm{V}$ uma vez que prevê basicamente a retomada de propriedade doadas por pais à seus filhos. ${ }^{739}$ Isso não quer dizer que as doações só poderiam ser feitas para os filhos; o título V não especifica isso e tampouco a documentação do período ou posterior, que registra doações para

\footnotetext{
${ }^{738}$ RIO, Alice. The formularies of Angers and Marculf...op.cit.

${ }^{739}$ Para uma discussão introdutória acerca dessas doações: ARJAVA, Antti. The survival of Roman Family law after the Barbarian settlements...op.cit.
} 
igrejas e até servos. Mas o título $\mathrm{V}$ e a formulae que traremos a seguir indicam que esse tipo de doação feita de pais para filhos não era incomum. Como consta na formula 58 das Formulae Andecavenses:

Lex Romana etdocet, consuetudo pacem consentit, et regalis potestis nin proibit, ut unusquis de ream suam, quem in presente diae possedit, faciat quod voluerit. Icirco ego quidem in Dei nomen illi, qui conmaneo illa villa, quia pertractavi circa animus meus, ut omnis res meas, quem in presente seculo habire videor, ad filio meo duas partes per hanc espistola cessione ad die presente trado ad possedendo, tam casas, domibus, edificiis, mancipiis, campis, viniis, silvis, pratis, pascuis, aquis aquarumvae decursibus, iunctis et subiunctis, movelibus et inmovelibus, omni rem meam, pro adsidua servicia sua vel benevolencia ei, sicut dixi, partis duas diligo adquae transfundo ad diae presente, tercia vere parte ad heredis propinquis reservans, ea tamen condicione, ut, dum advixero, mihi in omnibus, tam de victo quam et de vestito, soniare mihi debiat [...]

Parecem estar presentes na formula 58 os elementos essenciais previstos pelo trecho do Breviário de Alarico. Há o documento de cessão, a manifestação do desejo pela doação e os termos da doação: o filho receberia os bens se cuidasse do pai. Se a legislação romana fosse de fato a inspiração dessa formula, o não cumprimento dessa condição poderia redundar na perda da doação por parte do filho, como encontramos no título VI do Código Teodosiano conforme transmitido pelo Breviário de Alarico. A própria existência da formula já é um dado importante, o documento deveria ser registrado para o conhecimento de todos e os nomes das partes deveriam constar, como prevê o título VI. A citação à lei romana na formula, destarte, não parece se tratar de um recurso para dar autoridade ao desejo do pai, a formula não só cita como segue a lei em questão.

Qual é a relevância disso para o intento de compreender razoavelmente a Lex Salica? Ora, a relação entre a formula e a lei romana transmitida pelo Breviário de Alarico é um indício para a tese de que a Lex Salica não substituiu as Leges Romanorum. No mesmo conjunto de formulae, especialmente a 24 , encontramos uma causa que também está prevista na Lex Salica. Levando em conta também a tradição 
manuscrita, parece bastante provável que tanto as leis romanas quanto as leis bárbaras estavam em vigor na Gália. E não estavam em vigor apenas como um "monumento" da história dos francos como supôs A.C. Murray, mas eram aplicadas. De que maneira?

As duas formulae citadas tratam de duas causas distintas: uma versa sobre a esfoliação de um cavalo, crime previsto na Lex Salica e a outra sobre a doação de uma propriedade do pai para o filho, causa prevista no Breviário de Alarico. Será que as leis eram usadas alternadamente de acordo com as causas? Ou seja, causas previstas pelas leis sálicas eram tratadas conforme esse código e causas previstas pelas leis romanas eram tratadas conforme essas leis?

Uma possível barreira para respondermos afirmativamente as perguntas é o princípio da personalidade das leis que supostamente orientou a aplicação das normas conforme a origem étnica do julgado. ${ }^{740} \mathrm{Se}$ o princípio da personalidade das leis for verossímil a sobrevivência de códigos distintos, como os romanos e os bárbaros, se explicaria porque romanos estavam sob a autoridade da lei romana e os bárbaros sob a autoridade das leis bárbaras. Nesse cenário as causas não seriam determinantes para a aplicação das leis, e sim a origem étnica dos réus.

O título XXXV da Lei Ripuária foi utilizado como uma evidência da personalidade das leis bárbaras e generalizada para as demais leges barbarorum em vigor na Gália, diz o texto:

\footnotetext{
${ }^{740}$ Dentre os autores que reconhecem a personalidade da lei como fator essencial para aplicação dos códigos legais: HALPHEN, Louis. Les barbares. Des Grandes invasions aux conquêtes turques du $\mathrm{XI}^{\mathrm{e}}$ siècle. Paris : Libraire Félix Alcan, 1936. p.57-60. Ainda: DEPREUX, P. La loi et le droit. La part des échanges culturels dans la référence à la norme et les pratiques juridiques durant le haut Moyen Âge.In: Actes des congrès de la Société des historiens médiévistes de l'enseignement supérieur public. 32e congrès, Dunkerque, 2001. pp. 41-70. GUTERMAN, Simeon L. The first age of European law: the origin and character of the conflict of laws in the Early Middle Ages. New York Law Forum. v.VII, n.2, p.131-166. Maio de1961. Discussão sobre a produção da história do direito franco na Alemanha do século XIX e início do XX: CAILLEMER, R. Les travaux recentes sur l'état social des germains et sur les sources du droit de l'époque franque et la nouvelle édition de la Deutsche Rechtsgeschichte de M. Brunner. In: Nouvelle Revue Historique de Droit Français et Étranger. 1907. p.545-567.
} 
$X X X V$, 3. Hoc autem constituimus, ut infra pago Ribvario tam Franci, Burgundiones, Alamanni seu de quacumque natione commoratus fuerit, in iudicio interpellatus sicut lex loci contenet, ubi natus fuerit, sic respondeat.

4. Quod si damnatus fuerit, secundum legem propriam, non secundum Ribvariam damnum sustineat.

Numa primeira leitura aparentemente a cláusula reconhece a personalidade das leis, principalmente porque cita nomes considerados "étnicos": Francos, Burgúndios e Alamanos. Eles responderiam e seriam punidos conforme suas leis, não de acordo com a Lei Ripuária. A questão não parece problemática se realmente partirmos do pressuposto que "Franci, Burgundiones, Alamanni" tinham um significado étnico, nesse caso o princípio da personalidade das leis poderia servir como um instrumento explicativo. Mas tal significado não é consensual.

N.D. Fustel de Coulanges refuta a tese de que a Lei Ripuária distingue os sujeitos a ela subordinados conforme a etnia, para ele estava em questão o status social e, no caso específico do título $\mathrm{XXXV}$, a origem geográfica do réu. ${ }^{741} \mathrm{~A}$ hipótese de Fustel de Coulanges é muito razoável frente a uma leitura atenta do trecho. Logo de início deparamo-nos com uma delimitação geográfica da aplicação da Lei Ripuária “[...] pago Ribvario [...]”. Pagus é um termo com diferentes significados, Niermeyer ${ }^{742}$ enumerou oito dentre os quais: o território de uma cidade; o território periférico das cidades e um território onde habitava determinada etnia. O termo "Ribvarius" junto a "pagus" significaria, então, o território dos ripuários? Possivelmente, mas como aponta Fustel de Coulanges os nomes considerados étnicos tinham diversos significados, dentre os quais aqueles que estavam subordinados à uma determinada lei. Fustel de Coulanges argumenta que, por exemplo, na Lei Sálica

\footnotetext{
${ }^{741}$ FUSTEL DE COULANGES, N.D. Nouvelles recherches sur quelques problèmes d'histoire. Paris: Librairie Hachette, 1923. p. 376-385.

${ }^{742}$ NIERMEYER, J.F. Mediae Latinitatis Lexicon Minus...op.cit. p.753.
} 
o termo "francus" não se referia necessariamente àqueles de origem étnica franca, mas aos bárbaros subordinados à autoridade franca independente da origem étnica.

Ora, se levarmos em conta que nos lugares de origem e moradia onde viviam francos, burgúndios e alamanos também coexistiam outras pessoas de origens étnicas distintas, e tendo em vista que a Lei Ripuária de fato parece mencionar o território de origem mediante o emprego de termos como "locus" e "commoratus" é coerente interpretar que os adjetivos "francos, alamanos e burgúndios" significavam aqueles que eram oriundos das terras onde vigoravam as leis dos francos, alamanos e burgúndios, leis estas, que como mostraremos a seguir para o caso franco, versavam também sobre os romani. Enfim, no caso da Lei Ripuária, não estamos mais diante de um princípio de territorialidade das leis do que de personalidade das leis? Mesmo assim, o lapso de distinções puramente étnicas na Lei Ripuária no que concerne às leges a serem aplicadas aparece na Lei Sálica?

A Lei Sálica especificamente não faz a distinção citada pela Lei Ripuária. Não está previsto nem nos seus sessenta e cinco títulos nem nos acréscimos posteriores uma diferenciação dos réus conforme local de origem, todavia, há diferenças substanciais na aplicação da lei, em certas causas, quando os julgados são romani e franci. Se há traços do princípio da personalidade das leis na Lei Sálica ela se refere à aplicação das penas, não à utilização de códigos distintos. As formulae citadas anteriormente parecem mostrar mais que as leis, ao menos no noroeste da Gália, eram utilizadas de acordo com a causa. A esfoliação de animais, crime previsto pela Lei Sálica, poderia ser julgada conforme essa lei, embora ela não seja mencionada diretamente na formula. Já a transmissão de propriedade, tema comum ao Breviário de Alarico, poderia perfeitamente ser realizada conforme o rito jurídico previsto no Breviário, e isso independente da origem étnica propriamente dita das partes. 
Se entendermos que o período carolíngio não significou uma ruptura com o período merovíngio, podemos ainda trazer outra informação que fortalece a hipótese da aplicação das leis conforme as causas. No capitulário 58 "Responda misso cuidam data" de Carlos Magno datado por Boretius como produzido entre 801 e 814, o rei responde a certas perguntas de um grande. Num trecho encontramos:

Cap.58, 2. De secundo unde me interrogasti, si comes notitia solidum unum accipere deberet et scabinii sive cancellarius. Lege Romanam legem, et sicut ib inveneris exinde facias; si autem ad Salicam pertinet legem et ibi minime repereris quid exinde facere debeas, ad placitum nostrum generale exinde interrogare facias.

O trecho indica que Carlos Magno não tinha certeza onde o interlocutor encontraria normas para o caso descrito, de modo que ele deveria primeiro consultar a lei romana, depois a lei sálica e caso não encontrasse informações nas duas leges deveria perguntar para o general como proceder. As leis aqui se complementam não se excluem. Se uma não contemplava o causa em questão, outra deveria ser consultada. Insistimos que esse era o provável procedimento adotado também pelo menos no noroeste da Gália Merovíngia.

Mas o uso concomitante de leges barbarorum e leges romanorum não explicam a diferença entre romani e franci dentro da Lex Salica. Para observarmos a diferença na aplicação das penas referentes a uma mesma causa é mister um estudo interno do texto onde seja contemplado as diferenças nas penas, as diferenças nas penas à luz do contexto geral das penalidades na Lex Salica e o significado ou significados que romani e franci assumem no texto. Assim podemos refletir se uma identidade romana ou franca era fato gerador de um direito específico.

\subsubsection{Lex Salica - aplicação entre os romani e franci nos sessenta e cinto títulos}


Os significados dos termos romanus e francus na Lex Salica fomentou um intenso debate entre os eruditos do século XIX e início do XX. Enquanto que para H. Brunner $^{743}$ eles tinha um caráter étnico, para N.D. Fustel de Coulanges poderiam assumir ao menos três significados: étnico; de condição social ou para designar habitantes de uma determinada região. ${ }^{744}$ Essas duas leituras marcaram as principais tendências explicativas para as distinções nas penalidades entre romani e franci. ${ }^{745} \mathrm{Na}$ primeira, a filiação étnica é tida como fator explicativo para a distinção de penalidades, enquanto que na segunda a condição social assume as vezes de instrumento explicativo, neste caso, franci comumente se referia a homens livres (ingenuus) e romani a semi-livres, redundando dai a desigualdade do valor do wergeld e das penalidades.

Para avaliarmos a questão é mister analisar a aplicação dos termos no texto da Lex Salica começando pelas sessenta e cinco causas e comparando-as com os acréscimos à elas. Comecemos pelo termo romani.

A primeira distinção entre romanus e francus aparece no título XIV que trata de extorsão e pilhagem. Nesse título estão incluídos penas para roubo de tumbas, de homens que estão dormindo, pilhagem de villae e o impedimento de circulação de homens que viajam com a autorização do rei. No parágrafo 2 está previsto o caso de

\footnotetext{
${ }^{743}$ BRUNNER, H. Deutsche Rechtesgeschichte. Leipzig: Duncker \& Humblot, 1887.

${ }^{744}$ FUSTEL DE COULANGES, N.D. De l'inegalité du wergeld dans les lois franques. In : Nouvelles recherches sur quelques problèmes d'histoire. Paris: Librairie Hachette, 1923. p. 361398.

${ }^{745}$ É interessante observar a intensidade do debate expressa na troca de correspondência entre F. Vercauteren e S. Stein publicada na Revue belge de philologie et d'histoire na década de 1930. Cf: VERCAUTEREN, F. Le "Romanus » des sources franques. Revue belge de philologie et d'histoire...op.cit. STEIN, S. Le "Romanus" dans les sources franques. Revue belge de philologie et d'histoire. Tome 17 fasc. 1-2, p. 684-691. 1938. Ainda sobre interpretações que questionam o significado étnico dos termos : SOHM, R. La procédure de la Lex Salica. Trad. M. Trévenin. Paris: Libraire A. Franck, 1873. p.173-175. Na mesma Revue Belge encontramos mais textos que corroboram com Brunner, como: HARSIN, P. Condition des personnes en Germanie dans le haut Moyen Âge. Revue belge de philologie et d'histoire. Tomo 6, fasc.1-2, p. 147-180. 1927.
} 
um romano que rouba um barbarum Salicum. ${ }^{746} \mathrm{O}$ trecho é complexo para a interpretação uma vez que há diferenças significativas nas informações trazidas pelos manuscritos. Conforme a reconstrução de Eckhardt o parágrafo prevê que se não for provado com certeza que o romano roubou o "bárbaro sálico" ele deveria tentar se inocentar mediante a presença de vinte e cinco testemunhas, metade das quais escolhidas pelo acusado. Caso o réu não obtivesse as testemunhas deveria se submeter ao ordálio da caldeira (inium) e comprovada a culpa a pena prevista no parágrafo 1, ou seja, o pagamento de dois mil e quinhentos denários ou sessenta e dois sólidos e meio, deveria ser cumprida. Entretanto, a comprovação da culpa ou inocência mediante o emprego de testemunhas ou submissão ao ordálio da caldeira só consta no texto do manuscrito A2. Os demais manuscritos ${ }^{747}$ indicam apenas que o Romanus culpado precisaria pagar a composição prevista no parágrafo 1 que trata daqueles que expoliam mediante assalto um homem livre. ${ }^{748}$ Comparemos a informação presente na maioria dos manuscritos e a exceção do manuscrito A2:

Manuscritos

2. Si uero romanus <homo/franco > barbarum Salicum expoliauerit causa ${ }^{749}$ superius conpraehensa conuenit obseruare.
A2

2. Si uero romanum franco saligo expoliauerit et certa non fuerit, per XXV se iuratores exsolbat medius tamen electus, se iuratores non potuerit inuenire, mal. Murdo, aut ad inium ambulit aut IIMD din. fac. sol. LXII cul. iu.

Além da significativa mudança de conteúdo o texto do manuscrito A2 também é de difícil tradução. Conforme a regra romanus está no acusativo, de modo que uma

\footnotetext{
${ }^{746}$ Conforme o texto reconstruído de Eckhardt. Observaremos que a designação se modifica conforme os manuscritos. O termo "barbarus salicus" aparece no parágrafo 2 nos manuscritos A1 e A4. No manuscrito A2 encontramos "franco saligo", no A3 "homo barbarum" e no C5 e C6 "homo franco" enquanto que na família $\mathrm{K}$ aparecem diversos termos. Eckhardt reproduziu "homo Francum".

${ }_{747}^{74}$ A1, A3, A4, C5, C6, H10, e família K.

${ }^{748} \mathrm{XIV}, \S 1$. Si quis hominem ingenuum in superuentum expoliauerit et ei fuerit adprobatum, mallobergo mosido hoc est, MMD denarios qui faciunt solidos LXII semis culpabilis iudicetur. (conforme o texto reconstruído de Eckhardt que não difere significativamente das informações dos manuscritos).

749 "legem" no Mss. A2.
} 
tradução literal deveria ser de um franco sálico que expolia um romano, não o contrário. A priori isso não quer dizer muita coisa já que o latim da Lex Salica pode ser bastante confuso. Mas há outra diferença no manuscrito A2. O parágrafo 3 que nos demais manuscritos trata do caso de um bárbaro sálico que rouba um romano, no A2 não discrimina esse dado, nele lemos:

3. Si uero certa probatio non fuerit, $X X$ se iuratores exsoluat medius tamen elictus. se iuratores non potuerit inuenire, mal. musdo sunt din. IMCC fac. sol. XXX si adprobatus fuerit cul. iud.

É possível que o escriba do manuscrito A2 tenha suprimido a referência ao franco sálico ${ }^{750}$ no terceiro parágrafo, uma vez que a penalidade nesse trecho corresponde a aproximadamente a metade da penalidade prevista no parágrafo 2 , o que segue a tendência dos demais manuscritos que impõem uma penalidade para romanus duas vezes superior à penalidade para os bárbaros sálicos. ${ }^{751}$ Interessante notar, todavia, que o parágrafo 3 também traz uma diferença de grafia frente ao parágrafo dois. Onde no primeiro lemos "murdo" no segundo encontramos "musdo", isso pode ser fruto de um erro do compilador, mas não poderia significar que o parágrafo 3 é uma correção ao parágrafo 2? Ora, na próxima citação aos romani na Lex Salica presente no título XVI que trata de incêndios encontramos no texto reconstruído de Eckhardt um quinto parágrafo que só foi transmitido pelo manuscrito A2, conforme o texto desse manuscrito:

$3^{752}$. Si romanus hoc romanus admiserit et certa probacio non fuerit, per XX se iuratores exsolbat medius tamen electus. se iuratoris inuenire non potuerit, tunc ad inium ambulit. hoc dicunt malb. leode cal sunt din. IMCC fac. sol. XXX culp. iudicetur.

\footnotetext{
${ }^{750}$ Seguindo aqui a designação presente no manuscrito A2.

${ }^{751}$ Conforme a designação no texto reconstruído por Eckhardt.

752 No manuscrito o quinto parágrafo no texto reconstruído de Eckhardt corresponde ao terceiro parágrafo.
} 
Para um romanus que é acusado de infringir os crimes previstos no título XVI - referentes sobretudo a incêndios criminosos - vinte testemunhas deveriam ser arroladas para a defesa do acusado. No caso de não conseguir as testemunhas ele deveria se submeter ao ordálio das águas ferventes e pagar uma pena de mil e duzentos denários, ou trinta sólidos, caso a culpa fosse comprovada. Se compararmos essa passagem com o parágrafo 3 do título XIV notamos que o romanus que cometesse crimes contra outro romanus deveria arrolar o mesmo número de testemunhas e pagar a mesma pena em caso de culpa que um bárbaro sálico, se de fato é aos bárbaros sálicos que o parágrafo 3, XIV se refere. O rito processual é idêntico, exceto pelo ordálio da caldeira que não é mencionado no parágrafo 3 do título XIV.

A hipótese do parágrafo 3, XIV ser uma correção do parágrafo 2 se enfraquece quando constatamos que o parágrafo 5 do título XVI não menciona o ordálio como mecanismo de comprovação de culpa ou inocência. Mas o título XVI, 2 em comparação ao título XIV encerra uma importante notícia sobre a aplicação da norma presente na Lex Salica quando concernente às suas especificidades entre franci e romani. O fato do perpetrador da transgressão ser um romanus ou francus não parece ser o fator fundamental para a definição da pena, e sim a categoria social da vítima. Ora, se um romanus expolia um bárbaro sálico sua pena é duas vezes superior à pena que receberia caso o crime fosse infringido a um romanus. Até mesmo o número de testemunhas arroladas para a defesa do romanus acusado, no texto do manuscrito A2, é menor quando o crime acometeu outro romanus: vinte testemunhas ao invés das vinte e cinco que deveriam ser destacadas no caso de um crime contra um bárbaro sálico.

Mas nenhuma das questões que urgem quando lidamos com a Lex Salica se resolvem com facilidade. Como dissemos, apenas o manuscrito A2 contém o 
parágrafo que Eckhardt enumerou como o quinto do título XVI. O manuscrito A2 parece tratar os romani de uma forma distinta dos demais manuscritos. É preciso avançar na apreciação para termos uma visão sinóptica e melhores subsídios para tratarmos da peculiaridade no manuscrito A2.

A próxima referência aos romanos aparece no título XXXII De ligaminibus ingenuorum que trata do ato de amarrar homens livres ingenuus. Conforme o texto reconstruído de Eckhardt:

§3. Si uero Romanus Francum sine causa ligauerit, MCC denarios qui faciunt solidos XXX culpabilis iudicetur.

O parágrafo três não aparece nos manuscritos da família A, que trazem os dois primeiros parágrafos onde o primeiro contempla o crime de amarrar um homem livre e o segundo o crime de amarrar um homem livre e leva-lo amarrado para outro lugar. ${ }^{753}$ Os parágrafos 3 e 4 , o primeiro já reproduzido que trata do crime de um romano amarrar um franco e o segundo que trata da situação inversa, surgem inicialmente nos manuscritos da família C. A família C, conforme a classificação de McKitterick, tem entre os manuscritos mais antigos o C5 produzido no século VIII na região de Luxeuil no nordeste da atual França e o C6 da segunda metade do século IX proveniente do Oeste da França. Ao contrário da família A onde todos os manuscritos são classificados como livros de leis, o C5 e o C6 são respectivamente qualificados como livro de estudos e/ou compilação eclesiástica. Guardemos esse dado.

O título XXXIX “De plagiatoribus” contém mais uma lei específica para os romani sem qualquer menção aos franci. Esse título trata dos casos onde servos são levados para outras terras e também dos casos onde homens livres são feitos escravos e levados para terras estrangeiras. O parágrafo 5 do texto reconstruído de Eckhardt

\footnotetext{
${ }^{753} \S 1$. Si quis hominem ingenuum sine causa ligauerit, mallobergo [obrepus] andrepus hoc est, MCC denarios qui faciunt solidos XXX culpabilis iudicetur. $\$ 2$. $\mathrm{Si}<$ quis> uero ipsum <ligauerit et> ligatum $<$ in> aliquam partem duxerit, mallobergo andrepus sunt MDCCC denarios qui faciunt solidos XLV culpabilis iudicetur. LS, XXXII, §§1 e 2.
} 
trata do crime de escravizar, ou abduzir, um romano. Tal trecho aparece apenas nos manuscritos A1 e A2, onde o A2 difere significativamente do A1:

Al A2

§3. Si romano plagiauerit, sol. LXIII §6. Si romanus ingenuum plagiauerit, culp. Iudic. IIMD din. qui fac. Sol. LXII cul. iud.

Como já enunciamos, o latim da Lex Salica é confuso e o manuscrito A2 não é uma exceção. Mesmo assim não parece inconsistente traduzir o texto do manuscrito A2 como: "Se um romano escraviza um homem livre...". Nesse caso a diferença do conteúdo é notável já que o A1 parece tratar do caso de um romano que é feito escravo $^{754}$ enquanto o A2 fala de algo aparentemente distinto, a saber, o caso de um romanus fazer um de ingenuus escravo.

Há mais uma menção aos romani no título XLI que versa sobre o homicídio de ingenuus. Os parágrafos 8, 9 e 10 tratam do homicídio de romani onde encontramos um detalhamento maior em relação ao homicídio de franci presente no parágrafo 1 que fala apenas da punição para aqueles que matam um franco ou bárbaro que viva sob a Lei Sálica. ${ }^{755}$ Já sobre esse crime cometido contra um romanus o texto reconstruído de Eckhardt distingue três categorias: 1. Romano conviva do rei; 2. Romano proprietário de terras; 3. Romano tributário. As punições conforme a categoria do romano também são diferentes, no primeiro caso o culpado deveria pagar trezentos sólidos, no segundo cem e no terceiro sessenta e dois e meio:

XLI, §8. Si uero Romanus homo, cuina regis, occisus fuerit <cui fuerit adprobatum>, [mallobergo leudi] sunt XIIM denarios qui faciunt solidos CCC culpabilis iudicetur.

\$9. Si uero Romanus homo possessor 〈et conuiua regis non fuerit> occisus fuerit, qui eum occidisse probatur, mallobergo unalaleodi sunt, IVM denarios qui faciunt solidos $C$ culpabilis iudicetur.

\$10. Si quis <uero> Romanum tributarium occiderit <cui fuerit adprobatum>, mallobergo uualaleodi sunt, $M M(D)$ denarios qui faciunt solidos LXII (semis) culpabilis iudicetur.

\footnotetext{
${ }^{754}$ Forma inclusive que é seguida por Eckhardt em sua reconstrução: "Si romanum plagiauerit, MMD denarios qui faciunt solidos LXII semis culpabilis iudicetur”. LS, XXXIX, §5.

755 "Si quis $<$ uero $>$ Francum aut barbarum, qui lege salica uiuit, occiderit, [...]"
} 
É ainda importante destacar que o assassinato de um romanus conviva do rei gera uma pena maior do que o assassinato de um francus, cuja composição era de duzentos sólidos. Não obstante, mais uma vez o manuscrito A2 difere dos demais uma vez que não contém o parágrafo 8 , justamente o que trata dos romanos convivas do rei e cujo assassinato traz uma pena maior do que o assassinato de um franco ou bárbaro que vive sob a lei sálica.

Destacamos todos os trechos que distinguem os romani presentes nos sessenta e cinco títulos das Leis Sálicas, mas quais apontamentos podemos fazer a partir dessas informações? Ora, em primeiro lugar há algo que já enunciamos logo no início da discussão sobre essa lei. Não é possível trabalhar exclusivamente com o texto reconstruído de Eckhardt. Embora o trabalho do monumentista seja realmente notável e sirva como um ótimo guia para a leitura da fonte, ele não consegue transmitir toda a diversidade dos manuscritos. O texto reconstruído deve ser confrontado com os manuscritos também compilados por Eckhardt. Em segundo lugar, e isso ficará mais evidente com o estudo sobre os franci nos sessenta e cinco títulos, notamos que há mais detalhes onde os romani são discriminados do que em relação aos franci. Em terceiro lugar, os romani são destacados em cinco causas: roubo, incêndio, amarrar um homem livre, aliciar escravos para a fuga ou fazer de alguém escravo e, finalmente, homicídio. Isso não quer dizer, todavia, que em todos os títulos onde os romani são mencionados os francos também o são, caso, por exemplo, do título XVI que trata dos incêndios.

Já sobre os francos a questão é mais complexa. Logo na primeira observação dos diferentes manuscritos notamos que eles são associados a adjetivos diversos. Voltemos ao título XIV. Se olharmos o manuscrito apenas o manuscrito A1 já temos uma introdução à complexidade do problema: 
$X I V$, \$2. Si uero romanus barbaro salico expoliauerit, legem superiorem compraehensa conuerit obseruare.

§3. Si uero francus romano expoliauerit, sol.XXXV culp. Iudic.

Se pensarmos que o segundo parágrafo é o oposto do primeiro: se um romano rouba um franco x se um franco rouba um romano, percebemos logo de início que no paráfrafo 2 os francos são citados como "barbaro salico" enquanto no parágrafo 3 lemos tão somente francus. Seria "barbaro salico" sinônimo de francus? A utilização de francus no terceiro parágrafo visou evitar a redundância do texto? No manuscrito A2 lemos "Si uero franco saligo expoliaurit", que denota uma associação entre franco e sálico nesse manuscrito, associação que não é evidente no manuscrito A1. No C6 o termo "barbaro" não aparece: "Si uero romanus homo francum..." seguido de "Si uero francus romanum expoliaurit". Os francos são então citados como apenas "francus", ou "homo francum" e "barbaro salico". Observermos como isso aparece sistematicamente.

\begin{tabular}{|c|c|c|c|c|c|c|c|c|}
\hline Trecho & $\mathrm{A} 1$ & $\mathrm{~A} 2$ & A3 & $\mathrm{A} 4$ & C5 & $\mathrm{C} 6$ & $\mathrm{H} 10$ & $\mathrm{~K}$ \\
\hline XIV & $\begin{array}{l}\text { \$2 - } \\
\text { barbaru } \\
\text { m salico / } \\
\S 3 . \\
\text { francus }\end{array}$ & $\begin{array}{l}\$ 2 . \\
\text { Franco } \\
\text { saligo }\end{array}$ & $\begin{array}{l}\S \$ 2 . \\
\text { Homo } \\
\text { barbaru } \\
m \quad / \$ 3 . \\
\text { francus }\end{array}$ & $\begin{array}{l}\$ 2 . \\
\text { Barbar } \\
\text { o sálico } \\
/ \quad \$ 3 . \\
\text { francus }\end{array}$ & $\begin{array}{l}\$ 2 . \\
\text { Homo } \\
\text { franco } \\
/ \quad \$ 3 . \\
\text { francu } \\
s\end{array}$ & $\begin{array}{l}\$ 2 . \\
\text { Homo } \\
\text { francu } \\
m / \S 3 . \\
\text { francus }\end{array}$ & $\begin{array}{l}\$ .2 \\
\text { barbarus } \\
, \\
\text { Salecum } \\
\text { francum } \\
\text { /\$3. } \\
\text { francus }\end{array}$ & 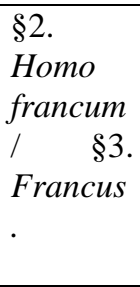 \\
\hline XXXIII & - & - & - & - & $\begin{array}{l}\text { \$3. } \\
\text { Franc } \\
o / \S 4 \\
\text { francu } \\
s\end{array}$ & $\begin{array}{l}\text { Idem ao } \\
\text { C5 }\end{array}$ & $\begin{array}{l}\text { Idem ao } \\
\text { C5 }\end{array}$ & $\begin{array}{l}\text { Idem ao } \\
\text { C5 }\end{array}$ \\
\hline${ }_{756}^{\mathrm{XLI} / \mathrm{XL}}$ & $\begin{array}{l}1 . \\
\text { Franco } \\
\text { aut } \\
\text { barbaro } \\
\text { qui legem } \\
\text { salega } \\
\text { uiuit. }\end{array}$ & $\begin{array}{l}1 . \\
\text { Ingenuus } \\
\text { franco } \\
\text { aut } \\
\text { barbaru } \\
m \quad \text { qui } \\
\text { legem }\end{array}$ & $\begin{array}{l}\text { Idem ao } \\
\text { A2 }\end{array}$ & $\begin{array}{l}\text { Idem ao } \\
\text { A2 }\end{array}$ & $\begin{array}{l}\text { Idem } \\
\text { ao A2 }\end{array}$ & $\begin{array}{l}\text { Idem ao } \\
\text { A2 }\end{array}$ & $\begin{array}{l}\text { Idem ao } \\
\text { A2 }\end{array}$ & $\begin{array}{l}\text { Idem ao } \\
\text { A2 }\end{array}$ \\
\hline
\end{tabular}

\footnotetext{
${ }^{756}$ XL no ms. A2.
} 


\begin{tabular}{|l|l|l|l|l|l|l|l|}
\hline & $\begin{array}{l}\text { salicam } \\
\text { uiuit. }\end{array}$ & & & & & & \\
\hline
\end{tabular}

\section{Tabela 15: Os Francus no Pactus Legis Salicae}

Esses são os trechos onde os franci aparecem nas causas do Pactus Legis Salicae. Pelo quadro comparativo percebemos, que, efetivamente não existe uma única forma pela qual o termo é aplicado. Até mesmo em um mesmo manuscrito há diferenças, se voltarmos a observar o caso do A1, notamos que no título XLI "francus" se segue logo por "aut barbaro", de modo que parece sim existir uma associação entre "francos" e "bárbaros". Essa associação é exclusiva da família dos manuscritos A, onde o A2, A3 e A4 designam "Ingennus franco" indicando que nem todos os francos eram livres, o que contraria uma das hipóteses de Fustel de Coulanges que estabelece que entre os significados de "francus" está "homem livre". ${ }^{757}$ É difícil dizer com certeza se "francus" tem um significado étnico, mas estar nessa categoria implica uma maior pena para quem comete um crime contra esse indivíduo.

Para M. Cândido o termo não tem um significado étnico, ele atribui a diferença no valor da compensação para crimes cometidos contra os francos pelo fato dos francos serem obrigados a renunciar à faida, a contrapartida para a renúncia dessa forma de resolução de conflitos que seria comum aos francos era uma maior compensação financeira. ${ }^{758}$ Ora, a existência de uma forma de compensação específica dos francos não seria indicativo da existência da noção de francus como uma unidade? Uma unidade distinta da dos romani e dos demais bárbaros, que só tinham o valor da compensação aumentado caso vivessem sob as leis sálicas. E aqui tocamos num ponto importante, a associação de um indivíduo aumentava o valor da

\footnotetext{
${ }^{757}$ FUSTEL DE COULANGES, N.D. De l'inegalité du wergeld dans les lois franques. p. 361-398. In :___. Nouvelles recherches sur quelques problèmes d'histoire. Paris: Librairie Hachette, 1923. p.371-372.

${ }^{758}$ CÂNDIDO, Marcelo. Paz e Violência no Pactus Legis Salicae. In: OLIVEIRA, Julio César M. \& SELVATICI, Mônica. (Orgs). Textos e representações da Antigüidade: Transmissão e Interpretações. Maringá: Editora da Universidade Estadual de Maringá, 2012. p.110-111.
} 
compensação por um crime, mas não só isso. Os bárbaros que viviam sob a lei sálica também adquiriam essa vantagem. Não obstante, o fato se ser inserido na categoria romanus, como indicamos no estudo do título LXI concernente ao aparecimento do termo, tampouco indicava que a compensação por um crime cometido contra esse indivíduo necessariamente redundava num valor menor. $\mathrm{O}$ assassinato de um romano conviva do rei penalizava o autor com trezentos sólidos, enquanto o assassinato de um "franco livre ou bárbaro que vive sob as leis sálicas" gerava uma pena de duzentos sólidos para o culpado.

Se por um lado, então, o pertencimento à categoria "francus" pudesse trazer alguma distinção no pagamento de compensações, essa diferença não necessariamente se dava em detrimento aos romanus, que dependendo da posição social, como, por exemplo, ser um conviva do rei, poderia ser compensado por um valor maior do que um francus que não desfrutasse dessa posição. Não parece existir nas penalidades uma distinção que se resume ao fato da vítima ter sido um franco ou romano. Aparentemente estamos lidando com distinções que marcam hierarquias sociais.

Não obstante, se levarmos em conta a quantidade de títulos e parágrafos do Pactus Legis Salicae e destacarmos aqueles que distinguem francos e romanos, notaremos que eles são poucos e, mais ainda, existiam mais títulos que contemplavam os romanos do que os francos. Ora, mesmo que reconheçamos que "francus" possa ter um significado étnico, nas causas das leis sálicas esse significado não parece ser o único fator decisivo para marcar uma distinção nas compensações e tampouco atribui um valor superior aos francis, a proximidade com os reis aparentemente era o fator mais importante para a geração das penalidades. Parece-nos problemático, desta maneira, dizer que as leis sálicas cumpriram um papel na formação da identidade franca tal como diz P. Wormald e isso fica mais evidente não apenas na recorrência 
do termo franci como também na forma como esse documento circulou. Entretanto, se criar uma identidade franca não parece ter sido a função principal da fonte, por que há a distinção dessa categoria e em certas ocasiões essa distinção redundava numa penalidade específica?

Como argumentamos nos capítulos anteriores há uma multiplicidade de sentidos para o termo franci que, especialmente nas histórias, varia entre gens francorum e franci enquanto pessoas próximas ao rei ou a partir da Chronica de Fredegário passa a ser aplicado para identificar uma nobreza da Nêustria. No caso das leis sálicas, como observamos, o termo parece se referir mais a um determinado grupo social do que a uma gens, grupo social este ao qual a lei estabeleceu um regime normativo específico. É difícil, entretanto, definir quem são os franci das Leis Sálicas. Um outro caminho para tentarmos outras hipóteses parece ser observar outros textos normativos da Gália Merovíngia.

Um decreto de Childeberto instituído por volta de 596 estabelece normativas específicas para os franci em dois momentos:

Similiter Kalendas Marcias Colonia convenit, et ita bannivimus, ut unusquisque iudex, criminosum latronem ut audierit, ad casam suam ambulet et ipsum ligare faciat; ita ut si Francus fuerit, ad nostra praesentia dirigatur, et si debilioris personas fuerit, in loco pendatur. ${ }^{759}$

Aqui observamos que caso um criminoso entrasse numa casa e amarasse um Francus deveria ser trazido à presença do rei. Isso revela uma posição especial das pessoas qualificadas na categoria de Francus também presente no Pactus Legis Salicae, contudo, como argumentamos, embora o fato de ser francus nas Leis Sálicas elevava o sujeito à um status especial, a proximidade ao rei era ainda mais importante para determinar a penalidade daqueles que cometessem algum crime contra esses

\footnotetext{
${ }^{759}$ Decreto de Childeberto, 8.
} 
sujeitos. No decreto de Childeberto, entretanto, o fato de ser um franco determinava que o criminoso deveria ser trazido à presença do monarca.

Ora, se levarmos em conta os nossos argumentos anteriores no que se refere à necessidade que os monarcas tinham de ter o suporte de uma nobreza, e se considerarmos que aqueles próximos ao rei era necessariamente membro de uma nobreza, não é de se surpreender que o rei se preocupasse em criar mecanismos legais para proteger seus apoiadores. Nesse caso, francus pode ser compreendido como um apoiador do rei, um aliado de tal forma importante que merecia uma lei que o protegesse. Entretanto percebemos que caso a vítima tivesse alguma debilidade - e inferimos que isso pode significar que tinha menos chances de defesa - o agressor deveria ser enforcado no próprio local do crime. Interessante notar como duas categorias que geravam um lei específica e com sentidos aparentemente tão contrastantes estivessem próximas: uma os francus, que talvez se referisse nesse caso aos aliados do rei, outra pessoas debilitadas, sem chances de se defender. Isso traz um problema. Talvez a legislação especial aos franci não implicava que eles eram poderosos o suficiente para terem leis especiais, mas sim fracos a tal ponto que leis especiais foram estabelecidas para proteger um grupo vulnerável. Isso talvez faça mais sentido se retomarmos o início do texto em que lemos: In sequenti hoc convenit una cum ledos nostros... aqueles que estavam próximos a Childeberto e que junto a ele definiram as normas não eram identificados como franci ou romani e sim por um termo que não possui qualquer conotação que poderia ser identificada como "étnica", a saber, leudes.

Interessante notar que numa outra norma no mesmo documento, Childeberto estabeleceu as penas para aqueles que não observassem o Domingo definindo como penas: ...si Salicus fuerit, solidos quindecim componant; si Romanus, sentem et 
dimidiem solidi. Servus vero aut tres solidos reddat, aut de dorsum suum componat. ${ }^{760}$ Aqui aqueles que deveriam pagar uma penalidade maior são os Sálicos. Nota-se pelo o emprego dos dois termos que o decreto admite como duas categorias diversas os franci e os salici de modo que seria uma interpretação perigosa dizermos que o texto se refere aos "francos sálicos". Mas quem eram os salici?

Ora, há nesse trecho uma categoria social evidente referente à hierarquia social, os servi, a presença dos romani e dos salici junto à uma categoria da hierarquia social pode significar que os romani e os salici eram entendidos, tal como os servi, como uma hierarquia social também distinta, à luz de todo o textos, dos franci. O que notamos é que não há subsídios suficientes que sustentem que essas categorias se refiram a termos étnicos, a análise da normativa estabelecida pelos reis merovíngios parecia contemplar principalmente membros de hierarquias sociais, hierarquias sociais estas que eram identificadas pelos termos "franci", "romani" e, mais raramente, "salici". Nos parece que, mais uma vez, estamos lidando com identidades políticas que marcam posições sociais.

É interessante destacar que as identidades políticas que discutimos nos capítulos anteriores eram reconhecidas não apenas em narrativas que construíam e reconstruíam memórias, mas também tinham impacto na produção legislativa do reino merovíngios. Disso redunda um problema: os textos que construíam memórias davam conta de uma "realidade concreta" na qual indivíduos se identificavam e eram identificados como membros de grupos qualificados como francos ou romanos ou eram elaborações fruto dos trabalhos dos autores, sobretudo de Historiae, que lançavam mão de tradições identitárias com o objetivo de responder a demandas políticas que surgiam no seio de reinos marcados por reis cada vez mais dependentes

\footnotetext{
${ }^{760}$ Decreto de Childeberto, 14
} 
de acordos com aristocracias, como argumentamos no trecho dedicado à Chronica de Fredegário e ao Liber Historiae Francorum?

O cenário se complica se avaliarmos as Formulae de Marculf.

\section{Os formulários de Marculf}

A mais importante estudiosa das Formulae da atualidade, Alice Rio, define esse tipo de documentação como textos descritivos de caráter jurisprudencial que versavam sobre a resolução de casos específicos e, reunidos, deveriam servir como modelos para a resolução de questões semelhantes que surgiam. ${ }^{761}$ Esse tipo de documento, conforme a argumentação de Rio, raramente apresentava uma relação com a corte dos reis, sendo produzidos sobretudo em mosteiros e comumente versavam sobre questões locais. Em poucas palavras, as Formulae, ao contrário das Leges que estabeleciam normas gerais, se voltavam para a resolução de questões específicas que eram trazidas à julgamento. A aparente exceção para essa regra são as Formulae de Marculf que em seu primeiro livro traz formulae de documentos reais. ${ }^{762}$ Muito embora a autora argumente que a relação entre as formulae atribuída nesse formulário pelos pesquisadores como documentos oriundos das cortes régias é sujeita a críticas, é interessante notar que justamente essas formulae aparentemente advindas da corte lançam mão dos termos romani, franci, etc. No conjunto das formulae, por exemplo, nos formulários de Angres, esses termos não aparecem. São tão-somente nas formulae aparentemente reais que esses termos surgem. Por exemplo, numa formula dirigida a condes, patrícios e duques lemos que esses deveriam atuar em favor de todos sob sua égide, fossem romanos, francos ou burgúndios: “...tam Franci,

\footnotetext{
${ }^{761}$ RIO, Alice. Charters, law codes and formulae: the Franks between theory and practice. In: FOURACRE, Paul. \& GANZ, David. Frankland. The franks and the world of the Early Middle Ages. Essays in honour of Dame Jinty Nelson. Manchester and New York: Manchester University Press, 2008. p.7.

${ }^{762}$ RIO, A. Legal practice and the written word in the Early Middle Ages. Frankish Formulae, c.500-1000. Cambridge, N.Y.: Cambridge University Press, 2009. p.82.
} 
Romani, Burgundionis vel reliquas nationis sub tuo regimine et gubernatione degant et moderentur, et eos recto tramite secundum lege et consuetudine eorum regas... ",763 uma fórmula semelhante aparece na formula 40: “...ut omnes paginsis vestros, tam Franco, Romanos vel reliqua natione degentibus...". Observamos que as formulae atribuídas às chancelarias reais não são particulares apenas pela referência aos reis como aqueles que estabeleciam a regra, mas também pelo aparecimento desses termos. Ora, se levarmos em conta que as leis que certamente foram emitidas pelos reis - como os editos e o próprio Pactus Legis Salicae - também recorrem à tal terminologia, no que concerne à legislação parece que a insistência nessas identidades no corpus jurídico era de interesse dos reis e seus aliados. Talvez, tal como parece ser o caso das Historiae, esses grupos, todos tutelados pelo rei, serviam de um argumento que fundamentasse a autoridade do rex no reino como aquele que governava por todos em detrimento a poderes regionais que se fortaleciam ao longo do século VII. Nesse sentido, tal como no caso das Historiae, não parece absurdo supormos que a construção dessas identidades fazia sentido na afirmação da autoridade real, por outro lado, a afirmação de outras identidades, como neustrinos, austrasianos e burgúndios, e mesmo da própria identidade "franca", era também evocada na afirmação das autoridades das nobrezas que se afirmavam como importantes poderes regionais.

Em poucas palavras, assumir que esses termos nas leis tinham um significado étnico parece ser uma interpretação apressada que perde de vista a complexidade pela qual essas identidades eram evocadas num contexto de disputas. Um lei específica para os franci não significa que esses franci eram um grupo específico relacionado etnicamente, parece antes que esse termo se refere à uma identidade política, que redundava numa política identitária concretizada também pela elaboração de leis

\footnotetext{
${ }^{763}$ Marculfi Formularum, 1.I, 8.
} 
emitidas pelos reis e seus aliados como forma de marcar a autoridade desses reis num cenário em que outras autoridades políticas, organizadas em outros grupos identitários, se fortaleciam, como observamos pela Chronica de Fredegário, o Liber Historiae Francorum e as hagiografias que traziam narrativas que entravam em contraste com a celebração à gens presente nas Historiae.

\section{Leges visigothorum}

As relações entre as leis estabelecidas no âmbito do regnum gothorum e as leis romanas é menos obscura do que as relações entre as leis sálicas e as leis romanas. Os godos indubitavelmente conheciam bem as leis romanas e o Breviário de Alarico, no qual, para a utilidade do povo, todas as leis romanas foram reunidas e corrigidas, é a primeira e maior evidência desse fato, com já apontamos. Não é de se estranhar que as Leges Visigothorum sejam cotadas dentre as mais romanizadas no conjunto das leges barbarorum. Se esse for o caso, as Leges Visigothorum constituiriam um importante documento para analisarmos como as leis romanas foram interpretadas e apropriadas pelos godos. Mais importante do que isso, sobretudo tendo em conta o nosso tema, a comparação entre os termos ditos étnicos conforme aparecem no código mais bárbaro, o dos francos sálicos, e no mais romanizado, o dos godos, tem um enorme potencial para nos ajudar a compreender os significados que esses termos poderiam assumir em regiões e fontes diversas. Haveria diferenças significativas entre essas categorias em códigos aparentemente tão distintos entre si?

\section{Leges visigothorum - estrutura}


O que conhecemos como Leges Visigothorum consiste num conjunto de leis produzidas a partir do reinado de Eurico, com acréscimos durante o governo de Alarico, Leovigildo e cuja forma reduzida e final foi fruto dos trabalhos dos reis Chindasvinto e Recesvinto. Estamos então diante de uma lei cuja elaboração e modificação se estendeu de um período que vai pelos menos de 466-484, reinado de Eurico, até 649-672, reinado de Recesvinto. O rei Leovigildo fez uma substancial revisão das leis de Eurico e Alarico. Contudo lamentavelmente, a revisão de Leovigildo não chegou aos nossos dias. As marcações Antiquae em alguns manuscritos são comumente atribuídas como resquícios da revisão de Leovigildo, mas também ao código de Eurico que chegou aos nossos dias fragmentado. Entre 672 e 702 outras revisões foram feitas pelos reis Wamba, Ervígio e Égica. O código de Ervígio e as interpolações de Égica foram transmitidos pela tradição manuscrita numa forma conhecida como "Forma Vulgata". A importância que essas leges assumiram na Península Hispanica parece ter sobrevivido à dominação Islâmica iniciada após a queda do último rei godo, Rodrigo. No século XIII uma tradução delas para o Castelhano, conhecida como Fuero Juzgo, circulou. ${ }^{764}$

Essa grande compilação de leis produzidas num larguíssimo espaço de tempo contêm doze livros onde o primeiro se dedica fundamentalmente à definição das leis, os modos como elas devem ser feitas e sua abrangência. ${ }^{765}$ Esse último aspecto é

\footnotetext{
${ }^{764}$ LEAR, Floyd S. The Public Law of the Visigothic Code. Speculum, v.26, n.1, p.1-23. Jan, 1951. OSABA, E. Reflexiones en torno a las Leyes Visigodas. Monteadvdo, n.3, p.57-72, 2003. Sobre as revisões do código empreendidas por Chindasvinto e Recesvinto: THOMPSON, E.A. The Goths in Spain. Londres: Oxford University Press, 1969. p.190-217. Ainda: KING, P.D. Derecho y sociedad en el reino visigodo. Madrid: Alianza, 1981. As reformas das leges visigothorum, sobretudo aquelas feitas por Recesvinto, são analisadas por R. Frighetto à luz de questões ideológicas envolvidas nos eventos que redundaram na ascensão de Chindasvinto ao poder. Ele, o pai de Recesvinto, chegou ao reinado mediante um golpe que destituíu Tulga em 642. FRIGHETTO, R. O rei e a lei na Hispania visigoda: os limites da autoridade régia segundo a Lex Wisigothorum, II,1-8 de Recesvinto (642-670). In: FRIGHETTO, R. \& GUIMARÃES, M.L. Instituições, poderes e jurisdições. Curitiba: Juruá, 2007.p.117-135.

${ }^{765}$ Cuius artis insigne ex hoc decentius enitere probabitur, si non ex coniectura trahat formam similitudinis, sed ex veritate formet speciem sanctionis, neque sillogismorum acumine figuras inprimat
} 
especialmente importante para termos ciência de que as Leges Visigothorum pretendiam alcançar todos os habitantes do reino:

Lex regit omnem civitatis ordinem, omnem hominis etatem, que sic feminis datur ut maritus, iuventude conplectitus et senectute, tam prudentibus quam indoctis, tam urbanis quam rusticis fertus, que summum salutis principium hac populorum culmen obtinet, et cum manifesto preclaroque preconio in modum lucidissimi solis effulgit. ${ }^{766}$

A abrangência das leges para todos os que viviam no regnum se repete na elaboração do Breviário de Alarico. Ora, os fragmentos do Código de Eurico que chegaram aos nossos dias apontam para o fato de que esse código não deixou de estabelecer leis que também deveriam ser observadas em causas envolvendo romanus, como já citamos.

Esse trecho é especialmente interessante por consistir numa lex dedicada a dar conta dos problemas na definição dos limites e posse das terras advindos com o estabelecimento dos godos em terras que outrora pertenciam aos romanos. Aqui não há prejuízo aos romanos caso os godos tenham ocupado irregularmente suas terras, nesses casos a lei estabelece que os godos (gothi) sejam conduzidos ao lugar onde deveriam se manter conforme o acordo de hospitalidade. A existência de dois códigos, um exclusivo para os romanos e outro para os godos, tal como no caso da Gália Merovíngia, deve ser ponderada com muito cuidado. Parece que esse nunca foi o caso: o título II, 3 do livro I da Leges Visigothorum aparentemente confirmou e fortaleceu o que já existia na prática.

Já o livro II (De negotiis causarum) traz cinco títulos que detalham os procedimentos legais, como eles deveriam ser conduzidos, quais causas deveriam ser 
submetidas à corte, as regras para o testemunho, os documentos válidos como prova para julgamentos. O livro III (De ordine coniugali) contém VI títulos que versam fundamentalmente sobre as relações nupciais, enquanto o livro IV (De origine naturali) com seus cinco títulos trata de laços de parentesco, regulamentação das heranças e tutela. O livro V (De transactionibus) possui sete títulos que tratam de doações para as igrejas, doações em geral, de patronos, comutações e vendas, empréstimos, débitos e a libertação de escravos. O livro VI (De sceleribus et tormentis) tem cinco títulos que versam sobre acusações, assassinatos e amputações. O livro VII (De furtis et Fallaciis) traz seis títulos sobre roubos, usurpações e falsificações. O livro VIII (De inlatis violentiis et damnis) contém seis títulos que contemplam invasões, incêndios, danos a plantações e animais. O livro IX (De fugitivis et refugientibus) possui três títulos que tratam das fugas, fugas das guerras e sobre aqueles que buscam refúgio nas igrejas. O livro X (De divisionibus et annorum temporibus adque limitibus) possui três títulos que regulam as divisões de terras e os limites entre as villae. O livro XI (De egrotis et mortuis adque transmarinis negotiatoribus) possui três títulos sobre doentes, violação de túmulos e negociantes de fora do regnum. E, finalmente, O livro XII (de removendis pressuris et omnium hereticorum sectis extinctis) possui três títulos sobre hereges e judeus.

Os livros e títulos estão, assim, organizados por tema, uma característica que era muito comum nos códigos romanos, por sinal. Essa mesma organização não aparece nos Pactus Legis Salicae e pode ser um indicativo nas diferenças entre os métodos para a elaboração das leis nos dois reinos. Isso não serve de base, todavia, para dizer que a suposta desorganização do Pactus Legis Salicae é sinal do 
barbarismo que norteou sua elaboração. ${ }^{767}$ Ora, se tomarmos em conta que sob os visigodos uma reelaboração das leis romanas foi conduzida e organizada no já apresentado Breviário de Alarico, é de se supor que a elaboração das Leges Visigothorum tenha sido profundamente influenciada pela produção legal romana de modo que o texto visigoda foi formatado tal como comumente eram formatadas e organizadas as leis romanas. Mesmo assim, essa organização é problemática, uma vez que alguns manuscritos, como o Barcelona, Biblioteca Central de Cataluña 944 do século XII, e que não entrou no elenco dos manuscritos da edição de Zeumer, não está dividido tal como vemos na edição tratando-se de uma compilação de 347 leis visigodas sem organização em livros e capítulos. ${ }^{768}$ Não obstante, como já apontamos, o Pactus Legis Salicae era um conjunto de leis que aparentemente objetivavam dar conta de novas demandas que surgiam na Gália e não parece ter substituído as leis romanas que lá circulavam também. Ora, como observamos, mesmo textos visigodos, como o De legibus de Isidoro de Sevilha, circulavam em manuscritos com o Pactus Legis Salicae. Não se tratava assim de uma disputa entre leis bárbaras e leis romanas, e sim de um sistema normativo que abrangeu todos os conjuntos legais disponíveis para a resolução de disputas. Tanto no trato das leis da Gália Merovíngia quanto no trato das leis da Hispânia Visigoda parece ser urgente e necessário superarmos a dicotomia entre leis bárbaras e leis romanas. Assim, não temos leis visigodas "romanizadas" em detrimento a leis francas "bárbaras". Temos esforços empreendidos pela estrutura administrativa de ambos os reinos de elaborar novas leis,

\footnotetext{
${ }^{767}$ Para J.P. Polly as leis sálicas não tinha, a propósito, nada dos bárbaros. Elas eram uma compilação de leis romanas vulgares. POLY, Jean-Pierre. La corde au cou. Les Francs, la France et la Loi salique. In: Genèse de l'État moderne em Méditerranée. Approches historique et anthropologique des pratiques et des représentations. Actes des tables rondes internationales tenues à Paris (24-26 septembre 1987 et 18-19 mars 1988). Rome: École Française de Rome, 1993. p. 287-320. POLY, JeanPierre. Le premier roi des francs. La loi salique et le pouvir royal à la fin de l'Empire. In : CONSTABLE, G. \& ROUCHE, M. Auctoritas. Mélanges offerts à Olivier Guillot. Paris : PUPS, 2006. p.97- 128 .

${ }^{768}$ DÍAZ Y DÍAZ, M.C. La Lex Visigothorum y sus manuscritos. Un ensayo de reinterpretacion.
} Anuario de Historia del Derecho Español, n.6, p.163-224, 1976. p.176. 
mas também de usufruir de outras leis disponíveis a fim de dar conta das demandas jurídicas que surgiam.

\section{Os manuscritos}

A tradição dos manuscritos das Leges Visigothorum aparentemente não é tão complexa e com informações desencontradas como o Pactus Legis Salicae. De todo modo é interessante observamos esses manuscritos para notarmos as formas de circulação das leis. Essas primeiras informações sobre a tradição dos manuscritos das Leges Visigothorum são baseadas na edição de Zeumer para os MHG.

Os manuscritos indicados pela letra $\mathrm{R}$ consistem no corpus com as leis revisadas e promulgadas por Recesvinto. Já os discriminados pela letra E consistem nas revisões de Ervígio e Égica, os indicados pela letra V são os mais problemáticos e foram compilados de diversas formas, Zeumer chegou mesmo a designa-los como "formas inferiores".

R1 (Codex Vaticanus reginae Christinae 1024). Século VIII - Começa com Liber Iudiciorum. Além dele há a Chronica Regum Visigothorum que termina com Tulga. $\mathrm{Na}$ parte inferior do fólio ${ }^{\mathrm{r}}$ a letra cursiva de outro escriba registrou "Incipit Sermo sancti Augustini).

R2 (Codex Parisinus Lat. 4668, outrora 'S. Remigii vol.LIII'. Século IX - Prefácio “Diligenti cura'. Tábula dos livros e títulos das Leges Visigothorum. 'Croneca regum visegothorum'. Texto das leis.

R3 (Codex Holkhamensis 210). Século IX-X. Coleção das leis romano-visigodas, livros com as leis de Recesvinto, exceto os IV, V, VI, VIII, IX, X, XI.

R4 (Codex Musei Britannici addit. 33610, fol.11). séculos VIII ou IX - Fragmento do Código segundo a versão de Recesvinto. ${ }^{769}$

Sobre a classe $\mathrm{R}$ dos manuscritos podemos tecer alguns comentários. O mais antigo deles é o R1 e data do século VIII. A distância entre a revisão de Recesvinto e o

\footnotetext{
${ }^{769}$ É provável que o manuscrito tenha outros textos que não foram citados por Zeumer. Somente a visita ao Museu Britânica e o acesso ao manuscrito poderá elucidar a questão.
} 
manuscrito mais antigo que a contém não chega a ser tão longa como a do Pactus Legis Salicae. As leges são designadas por esse manuscrito como "Liber Iudiciorum". A designação "Lex Visigothorum" parece ser mais fruto da interpretação dos historiadores, notadamente os monumentistas, do que o título mais divulgado nos manuscritos. Percebemos também que na classe $\mathrm{R}$ dois manuscritos trazem a Chronica regum Visigothorum, a crônica foi acrescentada por Zeumer em sua edição. A recorrência da Chronica nos manuscritos é atribuída a uma tentativa de manter uma referência cronológica dos reis que revisaram as leis. ${ }^{770}$

E1 (Codex Parisinus Lat. 4418). Século X - Traz: epitomen Aegidianam Legis Romanae Visigothorum; Juliani epitomen novellarum; Legis Salicam; Legis Ribuariam; Legis Burgundionum; Legem Visigothorum Ervigianam; Chronica regum Visigothorum.

E1 ${ }^{\text {a }}$ (Codex Parisinus Lat. 4669). Século X - Lex visigothorum e Chronica regum Visigothorum.

$\mathbf{E 1}^{\mathbf{b}}$ Fragmento no Archivio Alsatiae Inferiores Argentinensi.

E2 (Codex Parisinus Lat. 4667). Século IX - Livro II das Sentenças de Isidoro de Sevilha; Lex Visigothorum (até o cap. XII, 2, 16)

O manuscrito E1 é interessante por conter diversas leges, ele se insere numa tendência bastante comum dos manuscritos do Pactus Legis Salicae que é trazer mais de um código no manuscrito. Isso pode apontar para algo que já sinalizamos, a saber, a distinção entre "leis romanas" e "leis bárbaras" não parece corresponder aos métodos de aplicação dessas leis na Alta Idade Média e, podemos acrescentar, a tradição manuscrita tampouco sustenta a idéia da existência de "leis nacionais". Esses códigos não raro circulavam juntos e pelo o que podemos observar pelas formulae e editos eram aplicados concomitantemente nos reinos aos quais nos dedicamos. Continuemos.

As classes $\mathbf{R}$ e $\mathbf{E}$ são as que preservaram com maior "pureza" as versões das Leges Visigothorum de Recesvinto e Ervígio e Égica. A classe V, conforme enunciamos, é a mais complicada e traz muitas interpolações, mesmo assim é a classe $\mathrm{V}$ que contém o maior número de manuscritos.

V1 (Codex Skoklosteramus Nr 22) Século XII. Lex Visigothorum.

\footnotetext{
${ }^{770}$ HUETE FUDIO, M. Fuentes menores para el estudio de la historiografia latina de la Alta Edad Media Hispánica (siglos VII-X). Medievalismo, v.4, n.4, p.5-26, 1994.
} 
V2 (Codex Gorlizianus bibliotecae societatis scientiarum Lusitae superiores $8^{0}$ ) Século XII-XIII - Chronicae Regum Visigothorum; comentatione de legibus; interpoloção de informações sobre os reis godos e francos.

V3 (Codex Toletanus, armário 43, nr.5.) Séculos X ou XI.

V4 (Codex Toletanus, armário 43, nr.6) Século XIII.

V5 (Codex Toletanus, armário 43, nr.7) Século XII.

V6 (Codex Parisinus Lat. 4670, $8^{\circ}$ ). Século XII - menção às etimologias de Isidoro de Sevilha.

V7 (Codex reginae academiae historicae Matritensis f.202). Século X.

V8 (Codex S. Laurentii Escurialensis 2112). 1019 - Traz o título "Incipit Liber Iudicum Popularis"; série dos reis godos e francos; Vita de Isidoro de Sevilha; Prólogo da lex Baiuvariorum.

V9 (Codex S. Laurentii Escurialensis K1110) Século XIV - aléms das Leges Visigothorum contêm os Concílios Toledanos.

V10 (Codex S. Laurentii Escurialensis M113) - Leges Visigothorum com a rubrica Forum iudicium.

V11 (Codex S. Laurentii Escurialensis VII 15) Século XIII - Leges Visigothorum I-X, $1,17$.

V12 (Codex S. Laurentii Escurialensis SII 27) Século XIV - Lex Visigothorum I-II, 1,2. II,1,1. Indicada como Emendatis legibus Geticis.

V13 (Codex S. Laurentii Escurialensis dI2) Século X - Produzido no monastério de S. Martinho Albeldensi; Leges Visigothorum ou Liber Iudicium.

V14 (Codex S. Laurentii Escurialensis dI1) Século X - semelhante ao V13

V15 (Codex bibliothecae nationalis Matritensis, Reserv, 4-7, membr. $4^{0}$ ) c.1020. Lex Visigothotum como 'Incipit Liber Goticum'.

V16 (Codex bibliothecae universitatis centralis Matritensis 89) século XIII ou XIV

V17 (Codex bibliothecae nationalis Matritensis D50) Século XIV

V18 (Codex bibliothecae nationalis Matritensis ff 103). Século XVI

V19 (Codex bibliothecae nationalis Matritensis S170). Século XIII ou XIV - Leges Visigothorum interpolada em vários trechos do manuscrito.

V20 (Codex Iohanis Toletani)

A classe $\mathrm{V}$ indica que os manuscritos com a Leges Visigothorum circularam ao longo de todo o período medieval, com destaque para os séculos X, XIII e XIV e 
uma significativa redução no século XV. A classificação de tantos manuscritos numa mesma classe tão-somente porque eles teriam interpolações não parece muito pertinente. O conteúdo sinóptico do manuscrito, data e local de produção pode nos trazem informações muito mais significativas do que encerrar todos esses manuscritos numa mesma classe sem qualquer outro critério. O estudo de McKitterick sobre os manuscritos com o Pactus Legis Salicae que levou em consideração esses critérios indica o quanto esse trabalho é importante e urge a necessidade de que a classificação e edição de Zeumer seja revista. Não se trata aqui de desmerecer o trabalho do editor, mas os critérios do conhecimento histórico de hoje são outros e uma nova edição pode nos revelar um texto bem distinto do apresentado pela reconstrução de Zeumer. A comparação entre as diversas versões do Pactus Legis Salicae com a reconstrução de Eckhardt é um bom exemplo do quanto as reconstruções podem trazer problemas que comprometem a análise dos historiadores. Um esforço por revisar a tradição manuscrita das leges visigothorum foi empreendida por Díaz y Díaz que realizou uma importante crítica à edição de Zeumer. ${ }^{771}$

Mesmo louvando o trabalho de Zeumer o estudioso espanhol aponta que é urgente uma revisão crítica da edição do monumentista. O pesquisador analisou dos manuscritos utilizados pelo monumentista e afirmou que a organização e classificação empreendida pelo erudito alemão parece tão bem estruturada que pode ter sido um fator importante que impediu que uma nova edição crítica das Leges Visigothorum fosse levada a cabo. Díaz y Díaz traz então um ponto de extrema importância que deve ser levado em consideração por todos os pesquisadores que trabalham com as edições dos MGH: essas edições em geral passam uma idéia de que esses textos foram transmitidos de maneira coerente ao longo do tempo. O confronto direto com

${ }^{771}$ DÍAZ Y DÍAZ, M.C. La Lex Visigothorum y sus manuscritos. Un ensayo de reinterpretacion. Anuario de Historia del Derecho Español, n.6, p.163-224, 1976. 
os manuscritos mostra uma realidade muito diversa. O caso do Pactus Legis Salicae, que foi lançado num formato particular em relação aos outros documentos editados pelos eruditos do instituto alemão talvez seja o maior exemplo das dificuldades em torno dessas edições. Díaz y Díaz mostra que os problemas vão muito além. No que concerne às Leges Visigothorum Díaz y Díaz salienta problemas menos graves, como pequenos erros na datação dos manuscritos, mas também erros metodológicos graves. Um desses erros se deve ao tratamento e classificação dos manuscritos. O fato é que testemunhos acerca das Leges Visigothorum foram tratados por Zeumer como se tivessem o mesmo valor que fragmentos e compilações mais íntegras das leges. Díaz y Díaz traz o exemplo do manuscrito de Madrid, Biblioteca Nacional 12909 do século XVI que na edição de Zeumer corresponde ao V8. Conforme o estudioso espanhol, esse manuscrito na verdade é uma espécie de edição comentada das leges feita por D. Diego Covarruvias e seu irmão D. Antonio Covarruvias. Desse texto surgiu um outro manuscrito do século XVI, o Madrid, Bibli. Nac. 772 e um manuscrito do século XVIII, o Madrid 12924. Assim, esses três manuscritos são resultado de trabalhos de eruditos do século XVI que tentaram "editar" e comentar as Leges Visigothororum. De modo que Díaz y Díaz os coloca como testemunhos, não manuscritos que efetivamente transmitiram o código. ${ }^{772}$

A segunda questão importante trazida por Díaz y Díaz se refere ao fato de que a edição dos $\mathrm{MGH}$ não contemplou alguns importantes manuscritos que trazem fragmentos das Leges Visigothorum e que, conforme o estudioso espanhol, trazem importantes contribuições para refletirmos sobre as linhas gerais da transmissão do documentos. Os manuscritos que não foram incluídos na edição de Zeumer são:

- Klagenfurt, Bibliothek der Geschichtsvein fur Kärnten 10/2 editado por H. Menhardt em 1925;

${ }^{772}$ DÍAZ Y DÍAZ, M.C. La Lex Visigothorum y sus manuscritos...op.cit. p.170-172. 
- O manuscrito do século IX alocado no Archivo de la Corona de Aragón, Ripoll 46 estudado em 1958 por Mateu Llopis;

- O manuscrito do século XV de Toledo, Biblioteca Provincial, BórbonLorenzana 175 que Zeumer erroneamente deu por perdido;

- Madrid, Bibl. Nac. 7656 do século XVIII.

- O já citado por nós Barcelona, Biblioteca Central de Cataluña, 944;

- Biblioteca de la Universidad de Zaragoza, 41 que traz 45 leis na forma vulgata;

- Paris, Bibl. Nat. Lat. 4792 dos séculos XII-XIII;

- Kobenhavn, Kunglia Bibliotheket, Thott 373 do século XIII

- Escorial a.IV.8 do século XVI. ${ }^{773}$

Temos assim pelo menos nove manuscritos que não foram consultados pelo editor dos MGH. Isso não necessariamente significa um problema, o fato de um editor não ter consultado todos os manuscritos que trazem um texto não desqualifica uma edição. De fato Díaz y Díaz considera a edição de Zeumer confiável, o que o estudioso espanhol problematiza é o quanto esses manuscritos não trabalhados por Zeumer trazem pontos importantes que podem ajudar a elucidar problemas referentes a transmissão das Leges Visigothorum. E os principais problemas elencados por Díaz y Díaz se referem aos locais de produção desses manuscritos. A partir de uma detalhada análise paleográfica e codicológica o pesquisador estabeleceu a distinção entre “origem" e "proveniência" dos manuscritos, na qual a origem estabelece o local de cópia do texto enquanto a proveniência a tradição na qual o texto se insere, ou seja, um texto copiado em Reims poderia estar relacionado com uma tradição manuscrita de outra região, por exemplo, a Marca Hispânica. O fato é que com esse método o autor estabeleceu ponto absolutamente interessantes sobre a transmissão da fonte.

As conclusões do autor acerca da transmissão dos manuscritos são as seguintes. Entre os séculos VIII e IX muitas cópias foram produzidas na região de Gerona, o que levou

\footnotetext{
${ }^{773}$ Ibidem, p.372-378.
} 
o pesquisador a defender que Gerona era uma área de produção em série desses manuscritos que eram voltados para a Narbonense. Ao longo de toda a história da produção de manuscritos o Nordeste da Hispania continuou a ser uma zona de produção de manuscritos com as Leges Visigothorum sendo encontrados manuscritos oriundos de Vich e Barcelona. Essa regiões irradiaram cópias para a área de Rioja no século X. Para o autor isso indica a emergência de um sentimento pró-visigótico que se afirmava na Galícia e em León e que de lá chegavam à Toledo. Por outro lado, esse tipo de sentimento não parece ter sido significativo em Navarra e Aragão que não estão no mapa da produção de manuscritos com as leges que se torna ainda mais amplo no decorrer do século XIII. O que se percebe pelo mapa estabelecido pelo pesquisador é que os manuscritos são oriundos de zonas periféricas do antigo reino visigodo. 


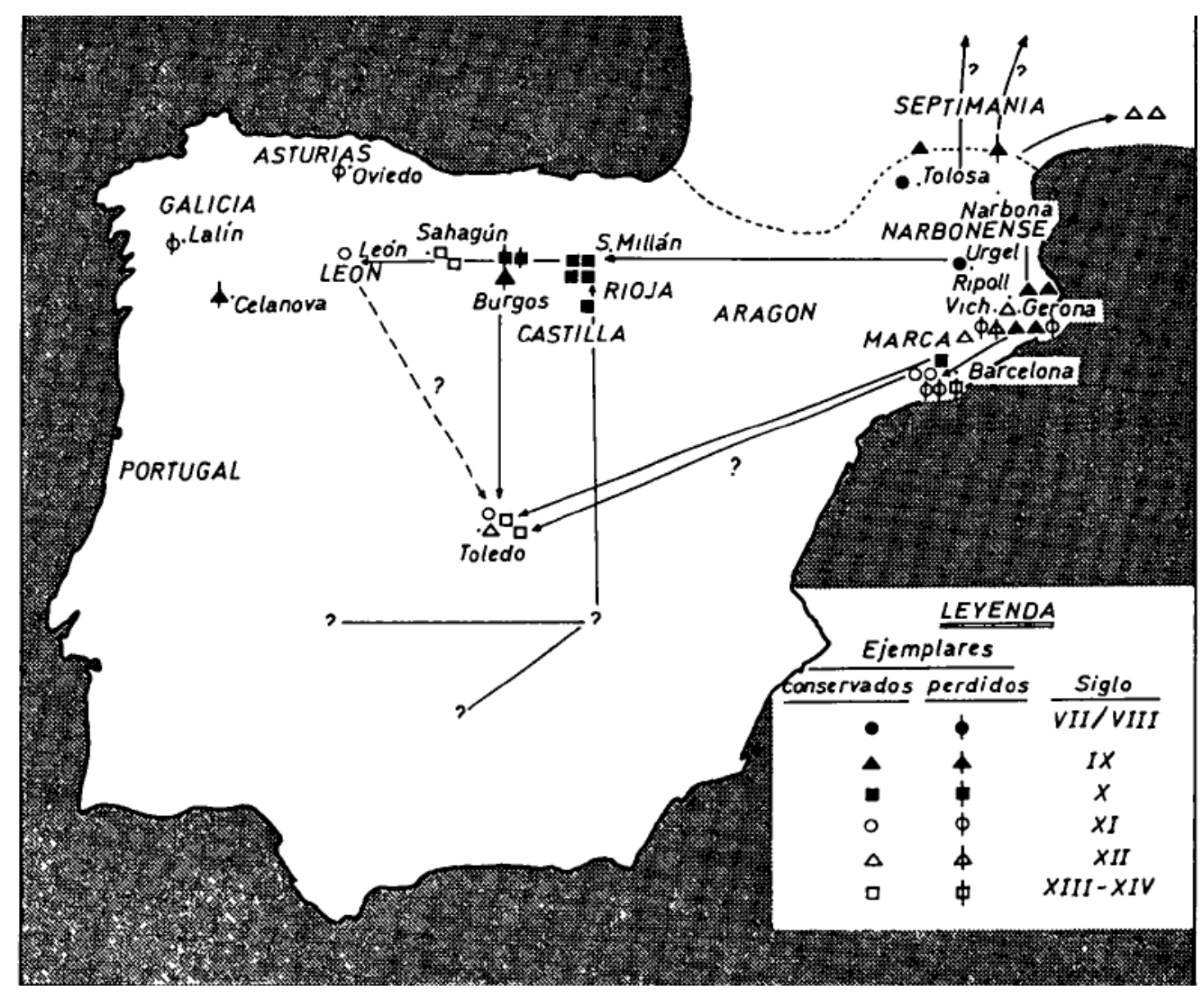

Imagem 1 Mapa da circulação dos mss. das Leges Visigothorum estabelecido por Díaz y Díaz ${ }^{774}$

Mesmo assim a produção de manuscritos não parou. Na fronteira com a Gália desde o século VIII manuscritos continuaram a ser produzidos com intensidade e circulavam pela Península Ibérica e mesmo na própria Gália, como o manuscrito 2 (Paris, Bibl. Nat. lat. 4668) originário de Reims e datado por Díaz y Díaz no século IX. Esse manuscrito traz outro ponto de interesse que influencia diretamente no tratamento da fonte. Como aponta Díaz y Díaz o texto traz uma mescla de grafia carolina e visigótica além de trazer, sem distinção, versões da Revisão de Recesvinto e da vulgata. Disso se infere que provavelmente essa classificação interna da fonte se deve mais a critérios do editor monumentista do que à realidade da circulação do texto. Como um texto dinâmico que se transformava com os acréscimos jurídicos feitos por outros reis, Díaz y Díaz problematiza se as revisões redundaram numa

\footnotetext{
${ }^{774}$ Reproduzido de: DÍAZ Y DÍAZ, M.C. La Lex Visigothorum y sus manuscritos...op.cit.p.224.
} 
anulação dos textos antigos, pela tradição manuscrita. Pelo testemunho do manuscrito 2 o autor defende que não. Assim, isolar as revisões não parece ser um tratamento justo da fonte uma vez que essas revisões não eram distintas na transmissão do texto. Em suma, considerando todas essas informações, notamos que mesmo os manuscritos mais antigos eram provenientes de zonas periféricas e chegavam de lá para a capital de Toledo. Obviamente que isso não significa que Toledo não produziu manuscritos, mas a tradição manuscrita que chegou aos nossos dias mostra que os manuscritos mais antigos vieram da Marca Hispânica, algo interessante que indica que mesmo em áreas mais distantes da capital e próximas à fronteira franca havia uma intensa produção de manuscritos com as Leges Visigothorum. Isso pode indicar que numa área que sofria assédios dos francos e que foi palco de rebeliões como a do duque Paulo contra Wamba era de interesse dos reis de Toledo que suas resoluções legais fossem acatadas. A produção dessas leis naquela localidade pode assim ser vista como um esforço dos reis para afirmar sua autoridade em áreas de conflitos com a Gália franca e oposição oriunda das próprias nobrezas hispânicas.

Além disso esses manuscritos são mais numerosos a partir do século XI o que aponta para o fato de que as leis visigodas permaneceram importantes para uma população moçárabe. Esse interesse se intensificou no século XIII o que mostra a importância que o período visigodo pode ter tido no processo da Reconquista.

É importante adotarmos uma postura crítica em relação à divisão da fonte a partir das revisões: se de fato essas revisões ocorreram, isso não significa que anularam leis antigas, como indica o manuscrito 2 de Paris. É importante confrontar o corpus como um todo sem inserirmos as leis mais antigas numa prisão temporal, é preciso levar em conta que essas leis poderiam estar em vigor mesmo quando Recesvinto e seus sucessores revisaram as Leges. Feitos esses apontamentos sobre o 
tratamento crítico da fonte a partir da tradição manuscrita voltemo-nos para o texto no que concerne ao interesse dele para a pesquisa. A saber, como o texto trata os gothi e os romani? Como isso pode apontar para o impacto que essas identidades políticas tinham na produção legislativa da Hispania Visigoda?

\section{Godos e romanos nas Leges Visigothorum}

$\mathrm{Na}$ edição monumentista para as leis dos visigodos temos a reconstrução baseada em trechos da lex baiauorum e da lex visigothorum - de alguns fragmentos do código euriciano. Do título CCLXXIII ao CCLXXVII encontramos leis que versam sobre os limites de propriedades agrárias, onde os títulos CCLXXVI e CCLXXVII falam explicitamente sobre os godos e os romanos. Dos títulos CCLXXVIII ao CCLXXXV há leis que versam sobre empréstimos, desde animais até dinheiro. Do título CCLXXXVI até CCCIIII lemos sobre as vendas, onde o título CCCIIII citava aparentemente a venda ou transferência de terras entre romanos e godos, todavia, o trecho possui muitas lacunas e é de difícil compreensão. Já a partir do título CCCV até o CCCXVIIII há leis sobre doações, onde o CCCXII fala das doações feitas entre godos e romanos.

A partir dessas informações é possível inferir que nos fragmentos que supostamente preservaram as leis do Código de Eurico onde há distinções entre romanos e godos, as causas envolvidas versavam principalmente sobre questões que

envolviam terras, permutas e outros bens como animais e dinheiro. Mas é extremamente difícil fazer muitas reflexões e estabelecer conclusões, mesmo que parciais, sobre um código que não chegou aos nossos dias e foi reconstruído com severas dificuldades e problemas. Cabe então nos concentramos nos trechos que estão 
presentes nos códigos que efetivamente foram transmitidos pela tradição dos manuscritos.

Nestes, a primeira menção aos godos aparece no Livro II, 1, 8. A lei é atribuída a Chindasvinto e foi revista por Ervígio, ela é iniciada pelo título "De his, qui contra principem vel gentem aut patriam refugi sive insulentes existunt" e contempla casos de traição contra o rei ou a gens ou a pátria. Nela estão previstos os casos onde insolentes não só ameaçavam o reino, como também capitulavam diante de ameaças externas. A lei aparece no código revisto de Recesvinto e sua permanência no de Ervígio é forte indicativo de que esse tipo de traição não foi sanada na ocasião da primeira promulgação da lei.

Para R. Frighetto, ${ }^{775}$ esse trecho deve ser interpretado à luz das ameaças que os reis enfrentavam constantemente por parte dos membros da alta hierarquia romanovisigótica que reiteradamente derrubavam os monarcas. A interpretação de Frighetto é bastante convincente, sobretudo se levarmos em conta as atas do VIII Concílio de Toledo onde o próprio Recesvinto esteve presente e consultou os bispos sobre a revisão das leis que empreendia. Ora, a necessidade de recorrer ao concílio indica que a situação de Recesvinto não era a mais confortável e que ameaças ao seu poder deveriam ser reais e sérias. $\mathrm{O}$ ato de recorrer ao apoio do Concílio não era novidade, o IV Concílio de Toledo de 633, por exemplo, confirmou a ascensão de Sisenando ao poder mesmo depois dele ter deposto o monarca anterior Suintila. Cabe lembrar que Recesvinto era filho de Chindasvinto que havia deposto Tuga.

No que concerne ao termo "gothus" no Livro II, 1,8, ele se relaciona intimamente com a "pátria" e não parece se restringir apenas àqueles de origem goda:

\footnotetext{
${ }^{775}$ FRIGHETTO, R. O rei e a lei na Hispania Visigoda: Os limites da autoridade régia segundo a Lex Wisigothorum, II, 1-8 de Recesvinto (652-670). In: FRIGHETTO, R. \& GUIMARÃES, M.L. (coords). Instituições, poderes e jurisdições. Curitiba: Juruá, 2007. p.117-135.
} 
Quantis actenus Gotorum patria concussa sit cladibus, quantisque iugiter quatiatur istimulis profugorum hac nefanda supervia deditorum, ex eo pene cunctis est cognitum, quod patrie diminuionem agnoscunt, et hac hoccasione potius quam expugnandorum hostium externorum arma sumere sepe conpellimus.

Não estamos diante de uma aplicação étnica do termo, na pátria Gothorum viviam romanos e godos e a dura sentença para a traição deveria recair para qualquer um que assim agisse. De todo modo, como já mencionado, esse trecho relaciona diretamente as gentes com a pátria e o rei. Trair o rei significava trair a pátria e as gentes o que estabelecia uma relação direita entre a fidelidade ao rei e à gens. Nessa narrativa, tal como observamos na Historia Wambae, observa-se a construção de um discurso identitário que concatenava dois elementos (rei e pátria), à luz da Historia Wambae - e de toda a nossa argumentação nos capítulos II e III tal como na discussão acerca da tradição manuscrita - parece fazer sentido que na legislação estabelecida pelos reis visigodos o lugar do discurso identitário em torno do termo gothi se referia a um esforço para fazer frente aos movimentos oposicionistas que se levantavam contra a autoridade dos reis. Mas deixemos isso para adiante.

Outra referência aos godos parece, desta vez, encerrar um sentido étnico. Nela identificamos também os romanos. Trata-se da lei que torna lícito o matrimônio entre godos e romanos.

Sollicita cura in principem esse dinoscitur, cum pro futuris utilitatibus beneficia populo providentur; nec parum exultare debet libertas ingenita, cum fractas vires habuerit prisce legisabolita sententia, que incongrue dividere maluit personas in coniuges, quas dignitas conpares exequabit in genere. Ob hoc meliori proposito salubriter censentes, prisce legis remota sententia, hac in perpetuum valitura lege sanccimus : ut tam Gotus Romanam, quam etiam Gotam Romanus si coniugem habere voluerit, premissa petitione dignissimam, facultas eis nubendi subiaceat liberumque sit libero liberam, quam voluerit, honesta coniunctione, consultum perquirendo, prosapie sollemniter consensu comite, percipere coniugem. ${ }^{776}$

\footnotetext{
${ }^{776}$ Leges Visigothorum, L.III,1,1.
} 
Essa lei é atribuída a Leovigildo - aparece discriminada como Antiqua. Leovigildo foi o rei que tentou converter os hispano-romanos ao arianismo sem sucesso, esse esforço por promover a conversão ao arianismo de todos àqueles que estavam no regnum Gothorum é atribuída à tentativa do rei de eliminar as barreiras que ainda separavam godos e romanos. Se essa lei realmente foi promulgada, evidentemente que os esforços de Leovigildo por solapar as possíveis barreiras baseadas em identificações étnicas não se restringiu à conversão religiosa. Pesquisas mais recentes indicam que essas barreiras ditas étnicas já não eram tão evidentes mesmo na época de Leovigildo. Para G. Ripoll, a L.III,1,1 apenas reconhece uma realidade que já existia na Hispania desde o século V. A autora recorre ao estudo arqueológico centrado no sítio "El Carpio de Tajo" onde as diferenças das sepulturas godas e romanas não são evidentes. ${ }^{777}$ Observação semelhante fez D. Claude que aponta para o desaparecimento de costumes não romanos entre as aristocracias godas entre os anos de $570-580 .{ }^{778}$ Se a citada lei apenas dá conta de uma realidade, então avalia-la à luz da etnicidade aparentemente expressa é um equívoco, já que na própria realidade onde essa lei se inseriu as distinções étnicas entre godos e romanos já não era observável... se é que elas um dia existiram claramente.

No livro VII, 4,2 o termo "godo" aparece mais uma vez. O título versa sobre crimes e define que os juízes deveriam se empenhar para encontrar o acusado, fosse ele godo ou não.

Quotiens Gotus seu quilibet in crimine, aut in furtum aut in aliquo scelere, accusatur, ad corripiendum eum iudex insequatur. Quod si forte ipse iudex solus eum conprehendere vel distringere non potest, a comite civitatis querat auxilium, cum sibi solus sufficere non

\footnotetext{
${ }^{777}$ RIPOLL LÓPEZ, G. The Arrival of the visigoths in Hispania: population problems and processos of acculturation. In: POHL, W. \& REIMITZ, H. Strategies of Distinction. The Construction of ethnic Communities, 300-800.Leiden, Boston, Köln: Brill, 1998. p.153-187.

${ }^{778}$ CLAUDE, D. Remarks about relations between Visigoths and Hispano-Romans in the Seventh century. In: POHL, W. \& REIMITZ, H. Strategies of Distinction ...op.cit. p.117-130.
} 
possit. Ipse tamen comes illi auxilium dare non moretur, ut criminis reus insultare non possit.

Esta é também uma lei identificada como "Antiqua", podendo ser, portanto, de autoria de Leovigildo. Ora, o que percebemos nesse ponto é que a recorrência do termo "godo" nas leis é mais comum nas Antiquae e quando ocorre não destaca os godos, pelo contrário. Neste caso a lei evidentemente pretende fazer com que os acusados por crimes, mesmo se godos, fossem procurados pelos juízes. Não deveria haver privilégios no cumprimento da lei. Se havia algum traço étnico nesse trecho, a lei tenta suprimí-lo. O outro trecho mais uma vez aparece na Antiqua. Nele lemos que se um godo é levado ao serviço do exército e o comandante tomar dele suas coisas, o comandante deve ser punido com cem chibatadas.

Servi dominici, id est conpulsores exercitus, quando Gotos in hostem exire o conpellunt, si eis aliquid tulerint, aut ipsis presentibus vel absentibus sine ipsorum volumtatem de rebus eorum auferre presumserint, et hoc ante iudicem potuerit adprobare, ei, cui abstulerint, in undecuplum restituere non morentur; ita tam en, ut unusquisque eorum in conventu publice L flagella suscipiat. ${ }^{779}$

Poderíamos interpretar o trecho de duas maneiras: a primeira é que os godos que serviam ao exército tinham uma proteção especial aos seus bens caso fossem tomados pelo comandante. A segunda é que o fato da lei mencionar os godos especificamente significa que não só eles serviam ao exército, se assim o fosse não seria necessário especificar os godos nessa passagem.

As outras menções ${ }^{780}$ tratam da divisão das terras entre godos e romanos. Nelas se afirma que as divisões estabelecidas e acordadas entre eles, se comprovada a divisão e se ela tenha ocorrido de acordo com os trâmites, não deve ser objeto de disputa. Há uma reafirmação da lei que supostamente apareceu no Código de Eurico que define que a terra que outrora pertencera a um romano, mas foi tomada por um

\footnotetext{
${ }^{779}$ Leges Visigothorum, IX,2,2

${ }^{780}$ L.X,1,8; L.X1,9; L.X,2,1; L.X,3,5.
} 
godo, se comprovado o fato, deveria ser devolvida ao romano, todavia os processos de devolução não poderiam contemplar terras que tenham sido tomadas e cultivadas por outros donos - tenham sido godos ou romanos - por mais de cinquenta anos. Mais uma vez não detectamos qualquer desvantagem que o status de "godos" ou "romanos" poderia assumir na aplicação das leis e tampouco parece ter havido uma vantagem para os godos, inclusive na resolução de conflitos concernentes às terras é reconhecido que as terras que pertenciam aos romanos e foram tomadas pelos godos deveriam ser devolvidas aos romanos.

Esses trechos já nos parecem suficientes para avaliarmos o significado do termo "godos" (gotos nas redações da Antiqua e na revisão de Recesvinto; gotho na revisão de Ervígio). Interpretamos que as Leges Visigothorum por vezes identificam duas categorias: romanos e godos, sem contudo criar uma distinção que redundasse na supressão de garantias conforme essas categorias, o mesmo não é tão claro para o caso do Pactus Legis Salicae como observamos. Isso não quer dizer que as Leges Visigothorum trazem evidências para questionar completamente a questão da importância etnicidade na Hispania sob a autoridade dos reis godos. A própria existência dos termos, embora não implique numa desigualdade de garantias, apontam para a possível existência dessas desigualdades no cotidiano do reino. As leis, antes de afirmarem e reforçarem essas dicotomias, tentam suprimi-las.

As detalhadas leges Visigothorum, ainda, não definem o que nelas significa "godos" e "romanos". Há algumas pistas, como o primeiro trecho da lei aqui reproduzido que relaciona "gotos" com "patria". Nele a Patria Gothorum é associada com o rei e o território geográfico - que deveria ser defendido caso inimigos de fora tentassem ameaça-la. Entretanto o termo não exclui os outros grupos que viviam sob a égide de rex Gothorum. A fidelidade a ele, e portanto à Patria Gothorum, era algo a 
ser observado por todos que viviam no território. Os outros trechos indicam quem eram aqueles que viviam no território: godos e romanos. Ao contrário do observado no Pactus Legis Salicae, não há diferenças nas leges Visigothorum na aplicação das punições por crimes. A Antiqua VII,4,2 chega a afirmar que os juízes deveriam perseguir criminosos, independente se fossem godos.

O que podemos concluir é que as leges Visigothorum não parecem ter cumprido qualquer papel a favor da construção da identidade dos gothi. Elas reforçam a relação entre o rei e a pátria dos godos possivelmente num esforço por fazer frente à oposição à autoridade do poder real. O caso do Pactus Legis Salicae não é menos complexo já que os diversos manuscritos não formam um todo coerente que nos ajude a identificar com precisão quem eram os franci que aparecem nas causas descritas. Embora no Pactus Legis Salicae por vezes a diferença no wergeld estava associada ao fato da vítima ser identificada como francus, esse não era o único fator decisivo para o valor do wergeld. Se partíssemos do pressuposto que as leges tanto as Salicae quanto Visigothorum expressam um contexto onde o fato de pertencer à gens Francorum e a gens Gothorum tinha alguma importância, haveria muita dificuldade em assumir que essas leis cumpriram algum papel para demarcar essas diferenças, e isso vale sobretudo para a Leges Visigothorum. Talvez a referência aos gothi nessa fonte seja mais uma resposta às identidades regionais que surgiam e se organizavam em torno da tradição inserida no termo gothi do que um reforço dessas identidades. E a concretude dessas organizações que lançavam mão da identidade "goda" foi discutida nas linhas dedicadas às Vidas dos Padres de Mérida.

\section{Os Concílios}

Especialmente após o III Concílio de Toledo observamos que a convocação das reuniões bispais se tornou uma prática comum no reino e era comumente 
convocadas pelos próprios reis, não raro em períodos de crise. Sisenando, após destronar Suintila, convocou o IV Concílio de Toledo que traz um dos mais instigantes exemplos da participação da hierarquia eclesiástica em assuntos políticos do reino. Seu cânone que versa sobre a ilegitimidade dos golpes contra os reis exemplifica os esforços empreendidos pelos reis para garantir a estabilidade de seus governos e impedir os levantes das nobrezas. Interessante notar que os concílios visigóticos, ao contrário dos concílios merovíngios, não raro trazem referências aos gothi.

Para observarmos essa discrepância é mister partirmos dos próprios concílios merovíngios, mas antes, cabem alguns comentários sobre esse tipo de documentação. Entre $^{781} 511$ e 695 tantos concílios foram realizados na Gália que R. Mathinsen chamou o período de "a grande era de Concílios". ${ }^{782}$ Entre 511 e 695 pelo menos 54 concílios ocorreram, e estamos considerando aqueles cujas atas chegaram aos nossos dias, num calculo arbitrário, falamos de uma média de um concílio a cada três anos. Evidentemente que essa periodicidade não é cabível. Seis anos separam o I Concílio de Orleans (511) do I Concílio de Épaone (517). Já no ano de 529 tiveram lugar os Concílios de Orange II e o de Vaison II, ambos reunidos por Cesário de Arles, onde o primeiro dedicou-se a questões doutrinais e condenou os semi-pelagianos e o segundo tratou fundamentalmente sobre temas concernentes à disciplina episcopal. ${ }^{783}$

\footnotetext{
${ }^{781}$ Uma versão dessa reflexão acerca dos Concílios Merovíngios foi apresentada e publicada nas atas do Colóquio de História Medieval LEME/UFMG: SILVEIRA, V.C. Os francos e os romanos nas atas dos concílios merovíngios dos séculos VI e VII. In: Colóquio de História Medieval. Anais do colóquio realizado entre os dias 8 e 11 de outubro de 2012. Laboratório de Estudos Medievais/UFMG. Belo Horizonte: LEME/UFMG, 2013. p.289-332.

${ }^{782}$ MATHISEN, R. Between Arles, Rome, and Toledo: Gallic collections of canon law in Late Antiquity. Cuadernos 'Ilu. n. 2, p.33-46, 1999. p.33.

${ }^{783}$ GAUdEMET, J. \& BASDEVANT, B. Les canons des Conciles Mérovingiens. (VI ${ }^{\mathrm{e}}$-VII ${ }^{\mathrm{e}}$ Siècles). Sources Chrétiennes, n.353. Paris: Les Éditions du CERF, 1989. p.152-153 e 186-187
} 
A profusão de concílios realizados na Gália nesse período é explicada por Mathisen ${ }^{784}$ a partir da pluralidade da região, onde se instalaram godos, burgúndios e francos e depois foi divida em reinos pelos herdeiros de Clóvis. Já Brundage salienta a fragmentação da autoridade com a chegada dos bárbaros e a arbitrariedade de seus reis para explicar esse fato. ${ }^{785}$ Embora a explicação de Mathisen pareça bem mais consistente não podemos nos restringir a ela. Se voltarmos mais uma vez nossos olhos para os Concílios convocados por Cesário de Arles em 529 e levarmos em conta que a região de atuação desse bispo esteve sob domínio dos visigodos, que professavam o arianismo, as questões da disciplina episcopal e de doutrina poderiam ser latentes a ponto do bispo ter tomado a iniciativa de convocar dois concílios no mesmo ano. Forçosamente poderíamos adotar a mesma tentativa de explicação para concílios convocados por reis, como o II de Mâcon de 585 que reuniu bispos tanto do reino de Gontrão quanto de Clotário II e teve as atas confirmadas por um edito de Gontrão que circulou nas coleções canônicas de Saint-Armand e Beauvais(Mss: Cod. Vatic. 3827. Paris 1455. Paris 3846), ${ }^{786}$ onde o rei afirma que a confirmação dessas atas e a garantia de que elas fossem respeitadas era parte do serviço de promoção da justiça que ele devia ao povo. ${ }^{787}$ Essas referência visam, antes de qualquer coisa, apontar para o fato de que explicações gerais não servem para aclarar as peculiaridades dos concílios da Gália. E quais são essas peculiaridades?

A mais notável consiste na própria maneira como esses concílios circularam nos manuscritos, e para falarmos disso precisamos necessariamente mencionar as

\footnotetext{
${ }^{784}$ MATHISEN, R. Between Arles, Rome, and Toledo...op.cit.

${ }^{785}$ BRUNDAGE, James A. Medieval Canon Law. Londres e NY: Longman, 1995. p.18-43

${ }^{786}$ MAASSEN, F. Geschichte der Quellen und der Literatur des canonischen Rechts.1870. p.780784

${ }^{787}$ Per hoc supernae maiestatis auctorem, cuius universa reguntur imperio, placari credimus, si in populo nostro iustitiae iura servamus: et ille pius pater et dominus, qui humanae fragilitatis substantiam suo sempre adiuvare consuevit auxilio, melius dignatibur conctorum necessitatibus quae sunt opportuna concedere, quos cognoscit praeceptorum suorum monita custodire. Guntchramni Regis Edictum. 10 Nov 585.
} 
coleções canônicas, ${ }^{788}$ o meio de transmissão por excelência das atas conciliares. Ora, não se encontram nos manuscritos atas conciliares isoladas. As coleções canônicas trazem diversas delas. Citemos o exemplo da já mencionada Coleção de Saint Armand de aproximadamente o fim do século VII. Além das atas do citado II Concílio de Mâcon, encontramos nela as atas do I Concílio de Mâcon além das do IV de Arles, Carpentras, II de Orange, a série dos cinco concílios de Orléans (511-549), do II de Vaison, Épaone, II de Tours, Auxerre, Chalon. Isso sem nos deter com mais vagar nos concílios Hispanos transmitidos por essa coleção, como o I de Zaragoza, alguns dos concílios Toledanos, com especial destaque para a transmissão do III Concílio de Toledo e assim por diante.

Cabe ainda destacar que não eram apenas atas conciliares que circulavam nessas coleções. G. Fransen ${ }^{789}$ destacou em seu trabalho tipológico acerca desse tipo de documentação que ela trazia, além das atas conciliares, Decretales pontificais ou encíclicas de um concílio; leges (denominadas pelo autor como "textos do direito profano"); textos dos Padres da Igreja; Estatutos, gestae, listas de pontífices de Roma, provincialia (listas de bispos de determinadas regiões) e textos apócrifos, e nesse caso podemos citar o exemplo da coleção Pseudo-Isidoriana, composta provavelmente na metade do século IX que continha, entre cânones e epístolas de bispos de Roma legítimas, textos sem veracidade atestada. De todo modo, até mesmo esses textos "sem veracidade atestada" desfrutaram de prestígio. A Coleção Pseudo-Isidoriana foi uma das que mais foi compilada em manuscritos.

\footnotetext{
${ }^{788}$ Definição de Coleções Canônicas : «[Coleções canônicas] é uma definição comumente admitida para se referir a um compendio de textos que são normativos para a disciplina da Igreja. Nesse sentido, o conjunto de textos conciliares (que podem ser provenientes de concílios gerais ou locais) e epístolas pontificais, ou ainda os estatutos episcopais são coleções canônicas.” Cf: FRANSEN, G. Les Collections Canoniques. Typologie des Souces du Moyen âge Occidental. Fasc.10. Turnhout : Brepols, 1973. p.13

${ }^{789}$ Ibidem, p. 17.
} 
Mencionamos uma característica comum às coleções canônicas que também aparecem nas coleções canônicas da Gália. O que então as coleções da Gália tem de especial? Sua própria diversidade.

Enquanto na Hispânia Visigoda a Coleção Hispana circulou como uma espécie de documento modelo a ser utilizado em várias partes do reino, na Gália, até a ascensão de Carlos Magno, uma grande quantidade de coleções existia. Dentre as consideradas mais importantes ${ }^{790}$ contam-se:

\section{Coleções compostas no Norte}

A coleção do manuscrito de Corbie (B.N., lat. 12097) - séc. VI

Coleção de Lyon (c. secs VI e VII)

Coleção do manuscrito de Lorsch (Vatic. Palat. Lat. 574) - Séc. VI

A Coleção de Albi conhecida por dois manuscritos. O mais antigo é de 600. O manuscrito de Albi (Albigensis 147) é uma cópia do de Toulouse e é datado da segunda metade do século IX.

Coleção do manuscrito de Cologne - composta na região do Ródano aprox. em 600.

\section{Coleções da Gália setentrional}

Coleção de Saint-Maur - de origem incerta, sua composição se iniciou aproximadamente na metade do século VI e continuou até o início do século VII. Coleção do manuscrito de Reims - Conhecida por um único manuscrito (Phillipps 1743) foi compilada na segunda metade do século VI e complementada no século VII. Coleção de Pithou (B.N., lat. 1564) datada aproximadamente do século VI Coleção de Saint-Amand

Temos então uma profusão de coleções, cada qual com sua especificidade, como a de Saint Armand que é a única que traz o Edicto de Guntrão, produzidas em

${ }^{790}$ GAUDEMET, J. \& BASDEVANT, B. Les canons des Conciles Mérovingiens...op.cit. 
diversas localidades. Dentre os problemas de trabalhar com uma documentação que circulou dessa forma está a enorme dificuldade de compreender a singularidade de cada uma. Em geral, como muito bem notou Fransen, os editores e pesquisadores que lidam com essas fontes não atentam com vagar para isso, além de dedicarem-se ao estudo de textos isolados dentro dessas coleções, privilegiando as atas conciliares e negligenciando outros documentos. Se olharmos mesmo para as edições dos Concílios da Gália, como a dos MGH, a tradução de Gaudemet e Basdevant e a edição no Corpus Christianorum, as discussões sobre os manuscritos versam tão somente sobre as atas conciliares. Apenas no trabalho de Maassen "Geschichte der Quellen und der Literatur des canonischen Rechts" encontramos uma descrição mais detida do conteúdo desses manuscritos. Muito embora as edições citadas aqui tenham utilizado o trabalho fundamental de Maassen, comumente ignoram os outros textos citados pelo autor que não se constituem como atas conciliares.

Isso nos remete à hipótese de Wormald que já apresentamos referente ao caráter puramente historiográfico das leges barbarorum. Ora, se observarmos a forma como essas leges circularam, sempre juntas a outros textos e inclusive em manuscritos de coleções canônicas, onde não raro serviram como referência normativa para a prática legislativa eclesiástica, fica difícil sustentar que esses textos eram apenas historiográficos, ou pelo menos, que "historiográfico" era algo sem qualquer função prática. Não obstante, a circulação de atas conciliares em coleções canônicas que traziam diversos textos normativos não restritos às práticas dos membros da hierarquia episcopal mostra que as leis ali expressas visavam ordenar relações de toda a sociedade, não apenas de epíscopos. Justifica-se, por conseguinte, a inserção dos cânones conciliares no amplo leque de textos legais que circulavam no Ocidente Europeu. Apontadas essas especificidades, dediquemo-nos aos concílios merovíngios. 
Qualquer pesquisador que se aventure a buscar termos que podem ser identificados como "étnicos" nos concílios da Gália dos séculos VI e VII ficará frustrado com a pouca quantidade deles. É possível conta-los nos dedos de uma mão: eles aparecem duas vezes com certeza, e uma que não pode ser considerada com certeza como uma qualificação étnica.

Duas dessas vezes aparecem no primeiro concílio de Orleans de 511. Logo no primeiro cânone encontramos a seguinte deliberação que consiste justamente na que não pode ser considerada indubitavelmente uma referência étnica: "De homicidis, adulteris et furibus, si ad ecclesiam configerint, id constituimus obseruandum, quod ecclesiastici canones decreuerunt et lex Romana..."

Lex Romana, a despeito do adjetivo, não se qualifica como uma lei dos romanos - como está evidenciado no texto "lex romana" não "lex romanorum".

Na segunda vez, lemos no cânone 10 do mesmo concílio: “10. De hereticis clericis, qui ad fidem catholicam plena fide ac uoluntate uenerint, uel basilicis, quas in peruersitate sua Gothi hactemus habuerunt [...]."

A terceira e última referência aparece no II Concílio de Tours de 567: "9. Adicimus etiam, ne quis Brittanum aut Romanum in Armonico sine metropolis comprouincialium uoluntate uel literis episcopum ordinare praesummat."

Ora, a raridade dessas referências não as tornam desimportantes. Voltemo-nos para a primeira onde aparece menção à lex romana. Ela pode nos fornecer informações importantes para muitas questões, dentre as quais uma que foi proposta por nós, a saber, a validade de qualificarmos as atas conciliares como textos normativos para além da hierarquia eclesiástica.

Essa referência à lei romana não é mero recurso retórico. Se observarmos o Código Teodosiano, título XXXIV, livro IX no Breviário de Alarico notaremos que 
esse título contempla exatamente a questão de criminosos que procuravam refúgio em igrejas. Não é possível dizer com certeza que os bispos no I Concílio de Orleans usaram o texto do Breviário de Alarico como fonte, apenas quatro anos separam a promulgação do breviário desse concílio, contudo, essa possibilidade não parece tão distante. O que queremos dizer com isso é que esse cânone do primeiro concílio de Orléans versa sobre uma lei concreta e pode indicar como a fronteira entre "lei secular" e "lei canônica" não dá conta da questão. Poderíamos ainda retomar o problema da circulação dessas atas nas coleções canônicas e mencionarmos que algumas dessas coleções traziam leis romanas, como as coleções de Pithou, de Cologne e Corbie. É notável também que nessas três coleções encontramos o I Concílio de Orleáns, em poucas palavras, textos advindos das leis romanas circulavam junto com as atas conciliares nas coleções canônicas. Isso é sintomático e pode nos levar a discutir muitos outros problemas. Citemos a idéia da personalidade das leis. Forçosamente poderíamos acreditar que as leis canônicas voltavam-se apenas para romanus ou francus, elas deveriam contemplar todo o conjunto da Ecclesia, independente da origem étnica. A própria raridade de menções étnicas nessas atas indica que essas distinções não eram objeto desses documentos. Disso se infere que cânones baseados em leis romanas, cânones que citam leis romanas, voltavam-se para qualquer um sob o espectro de autoridade dessa documentação independente da origem "étnica".

Já sobre a segunda citação, concernente aos Gothi, podemos lembrar que poucos anos antes Clóvis os derrotou. Atribuir a eles como característica destacada a heresia ariana reforça o valor da vitória de Clóvis contra godos hereges. Essa tópica aparece também nos Decem Libri Historiarum do já citado Gregório de Tours. 
Recurso semelhante foi usado nas atas do III concílio de Toledo onde lemos sobre a vitória dos godos contra os Suevos:

Nec enim sola Gothorum conversio ad cumulum nostrae mercedis accessit, quinimmo et suevorum gentis infinita mutituto, quam praesidio coelesti nostro regno subiecimus; alieno licet in haeresim deductam vitio, nostro tamem ad veritatis originem studio revocavimus.

Já no que se refere à menção aos Bretões e Romanos no II Concílio de Tours vemo-nos diante de um caso interessante. A restrição à elevação de Bretões ao episcopado de Armórica pode ser explicada por dois fatores que não são necessariamente concorrentes. Ao contrário, podem ser complementares. A primeira se relaciona com as imigrações dos Bretões à Armórica e a segunda com as tentativas de independência que a sede episcopal de Armórica empreendeu diante da sede de Tours.

Certamente que qualquer aproximação a essa passagem peculiar do II Concílio de Tours não pode prescindir de uma breve análise da região da Armórica. Ela já aparecia nos famosos “Commentarii de Bello Gallico” de Júlio César como uma área litorânea onde os Redones, Ambibarii, Caletes, Osismi, Veneti, Lemovices e Venelli se uniram sob a alcunha de armoricanos para enfrentar Roma. ${ }^{791}$ Embora seja prudente desconfiar da precisão etnográfica de Júlio César, ao menos podemos inferir de seu relato que muito possivelmente a região abrigava uma heterogeneidade de gentes. De todo modo, após os relatos de Júlio César as menções à Armórica rarearam até o final do século III quando o Augusto Maximiano organizou uma expedição para enfrentar as desordens na Gália provocadas pelas bagaudas e a ameaça representada por

\footnotetext{
${ }^{791}$ XXX [mil] universis civitatibus, quae Oceanum attingunt quaeque eorum consuetudine Armoricae appellantur, quo sunt in numero Curiosolites, Redones, Ambibarii, Caletes, Osismi, Veneti, Lemovices, Venelli. (Commentarii de Bello Gallico, L. VII)
} 
bárbaros que assediavam o litoral Noroeste da Gália. ${ }^{792}$ Para levar a cabo a empreita, Maximiano delegou tropas ao comando de Carausio que declarou sua independência em relação à Maximiano. Para Pape o "renascimento" da Armórica nas fontes nesse final do século III pode ser fruto da atuação de Maximiano e depois da usurpação de Carausio, todavia, o autor tende a defender a hipótese de que uma espécie de identidade armoricana existia a despeito da inexistência de seu registro nas fontes romanas. ${ }^{793}$ A existência dessa identidade armoricana poderia explicar em certa medida o ímpeto da sede da região em afirmar sua frente à sede de Tours, questão esta, que por sinal, se estendeu até o século XII, ${ }^{794}$ mas por quais motivos o cânone 9 do II concílio de Tours restringe a elevação de bispos Bretões em Armórica?

No mesmo século III, no qual Maximiano tentou enfrentar as bagaudas e ameaças bárbaras na região, ocorreu a primeira onda de imigração de Bretões à Armórica capitaneados pelos próprios romanos a fim de enfrentar ameaças bárbaras. ${ }^{795}$ Esses Bretões, segundo Cassard ${ }^{796}$ se integraram aos romanos até que no início do século $\mathrm{V}$, com a segunda onda imigratória de Bretões insulares empurrados pelos avanços Saxões, os Bretões do continente sofreram uma "barbarização" com a chegada de Bretões menos influenciados por Roma, de todo modo Cassard, tal como Pape, reconheceu a existência de uma identidade específica da região da Armórica

\footnotetext{
${ }^{792}$ FRIGHETTO, R. Antiguidade Tardia. Roma e as monarquias romano-bárbaras numa época de transformações. Séculos II-VIII. Curitiba: Juruá, 2012. p.95-97. Ainda: PAPE, L. L’Armorique dans la Gaule. Éclipse et renaissance. Annales de Bretagne et des pays de l'Ouest. t.105, n.2, p.11-27, 1998. p.11-24

${ }_{793}$ PAPE, L. L'Armorique dans la Gaule...op.cit. p.24.

${ }^{794}$ PONTAL, O. Histoire des conciles mérovingiens. Paris : Éditions du Cerf, 1989. p.156-158.

${ }^{795}$ CASSARD, J.-C. La guerre des Bretons au haut Moyen Age. Revue Historique. t.275, fasc.1, p.327, 1986. p.6.

${ }^{796}$ Idem. Para uma leitura interessante que se opõe significativamente sobre a assertiva de Cassard de que as migrações do século $\mathrm{V}$ não só barbarizaram os Bretões do continente como criaram reinos duplos nos dois lados do Canal da Mancha COUMERT, M. Le peuplement de L'Armorique: Cournouaille et Domnonée de part et d'autre de la Manche aux premiers siècles du Moyen Age. COUMERT, M. \& TÉTREL, H. (eds). Histoires des Bretagnes - 1. Les mythes fondateurs. Brest, CRBC, 2010. p.15-42
} 
que, durante o domínio franco na Gália se opôs aos francos, como os armoricanos da época de Júlio César e depois de Maximiano lutaram contra Roma.

Há aqui uma evidente confusão entre os Armoricanos e os Bretões, teriam eles se unido e formado um único movimento que queria afirmar sua independência? Para E.A. Thompson não. O autor defende que as revoltas que tomaram lugar tanto em Armórica quanto na Britania não representam um único movimento formado por Bretões e Armoricanos. Thompson alegou que a revolta armoricana do século V era um bagauda, enquanto que a revolta dos Bretões motivou-se pelos avanços Saxões e a incapacidade de Roma de auxiliá-los. ${ }^{797}$ Mesmo que Thompson esteja correto, sua análise não explica o cenário que encontramos no II Concílio de Tours. Armórica aparece como uma definição de um espaço geográfico, não há qualquer menção a armoricanos, sim a Bretões e Romanos. Se existisse qualquer identidade armoricana distinta dos Bretões - no início do século V ela não transparece mais no cânone 9 do II Concílio de Tours. Teriam os Bretões suplantado os armoricanos de modo a região ser identificada com eles? É possível, desde o século V com as imigração os Bretões se estabeleceram no Noroeste da Gália e mantiveram sua identidade a ponto da região receber a alcunha de "pequena Britania". ${ }^{798}$ Conforme Ward-Perkinks:

The north-western part of Romano-Gaulish Armorica, during the fifth and sixth centuries, through a process of conquest, immigration and cultural assimilation, became "Brittany", the country of the Britons (later the Bretons), speaking a Brittonic language, and with a powerful sense of its British heritage. ${ }^{799}$

Nesse sentido, as tentativas de independência da sede de Armórica não se referiam a uma identidade armoricana, mas bretã. Essa hipótese, à luz do cânone 9

\footnotetext{
${ }^{797}$ THOMPSON, E.A. Britain. A.D.406-410. Britannia. v.8, p.303-318, 1977.

${ }^{798}$ COUMERT, M. Le peuplement de L'Armorique...op.cit.

799 WARD-PERKINS, B. Why did the Anglo-Saxons not become more British? The English Historical Review. v.115, n.462, p.513-533, 2000.
} 
dos III Concílio de Tours parece mais razoável. Não obstante, ela levanta uma questão importante sobre a identificação de gentes com um determinado território nos séculos entre a fragilização da autoridade imperial no ocidente europeu e o assentamento de bárbaros que formaram os reinos que denominamos romano-bárbaros. Essa identificação territorial estava longe de ser algo rígido, ao contrário, transformava-se conforme as dinâmicas imigratórias e as relações estabelecidas entre as gentes. As gentes que entraram em embates com as tropas de Júlio César e se uniram sob a alcunha de armoricanos evidentemente não eram as mesmas que no século VI tentavam sua autonomia diante dos francos a tal ponto que os bispos reunidos num concílio restringiram a ordenação de Bretões em Armórica possivelmente para evitar que os movimentos de autonomia que marcaram a região redundassem numa ruptura da sede de Armórica com a de Tours. A perenidade das disputas entre as sedes de Armórica e a de Tours até o século XII mostra que as preocupações dos bispos reunidos no século VI não era vã. De todo modo na única referência "étnica" presente nas atas conciliares da Gália Merovíngia observamos uma restrição fundamentada numa idéia de identidade, possivelmente porque as populações vetadas ao acesso à sede episcopal lançavam mão desses discursos identitários a fim de afirmar a legitimidade de seus movimentos autonomistas. Os bispos reunidos no concílio reconheceram isso e a resposta que ofereceram foi vetar o acesso à sede episcopal. Uma identidade política, uma política identitária... observamos que essa dinâmica aparece até mesmo numa ata conciliar merovíngia. Contudo, como já apontamos, esse tipo de discurso é muito mais recorrente nos concílios visigodos.

Isso se evidencia já no III Concílio de Toledo quando Recaredo definiu que a conversão trouxe toda as gentes dos godos à verdadeira fé tal como as outras gentes que estavam sob a autoridade do rei. A relação entre a gens, a patria e o rex, apontada 
nas Leges Visigothorum se mantém nas atas dos concílios toledanos, algo que reforça ainda mais a nossa hipótese de que as identidades políticas elencadas nas leis visigodas afirmavam a autoridade dos reis. Isso fica mais evidente nas atas conciliares uma vez que esse tipo de reunião passou a ser utilizado como um aparato político real. Ora, como já mencionado, Sisenando convocou o IV Concílio de Toledo e obteve o apoio dos bispos não só para o seu reinado, oriundo de um golpe contra Suintila, como a proteção dos bispos que condenaram qualquer um que atentasse contra as vidas dos reis e seus descendentes. Anos mais tarde, Égica, na ocasião do XVI Concílio de Toledo de 693 contaria com apoio semelhante. Tal como nas Leges Visigothorum que relacionavam a traição ao rei à traição à gens e a patria as atas do XVI Concílio de Toledo estabeleceram uma fórmula semelhante, tratando de um caso muito específico, a traição do bispo de Toledo Sisberto que conspirou contra a vida de Égica:

Unde quia Sisbertus Toletanae sedis episcopus talibus machinationibus denotatus repertus est pro eo quod Serenissimum dominum nostrum Egicanem regem non tantum regno privare sed et morte cum Frogello, Theodomiro, Liuvilane, Liuvigotone quoque, Thecla et ceteris interimere de definivit, atque gentis ejus vel patria inferre conturbium et excidium... ${ }^{800}$

Diante de uma ameaça evidente e muito concreta ao seu reinado, Égica contou assim com o apoio dos bispos reunidos no Concílio que lançaram mão de uma fórmula presente nas Leges Visigothorum para condenar a traição ao rei relacionandoa com a traição à pátria e à gens. Evidencia-se assim que a construção de uma unidade entre rei, gentes e patria é enfatizada em momentos de disputas em tensões na construção de uma narrativa normativa que, aparentemente, mais do que insistir num dado, a saber, a existência concreta dessa unidade, lançava mão desse discurso para fazer frente a uma situação exatamente oposta: a fragilidade de um consenso em torno

${ }^{800}$ XVI Concílio de Toledo, IX. 
de uma unidade do reino. Dentre os mecanismos disponíveis aos reis visigodos para afirmar a autoridade deles num cenário de intensas disputas o discurso identitário presente nas Historiae, mas também nas Leges e atas conciliares foi utilizado com intensidade. Não houve entretanto uma ampla utilização dos concílios merovíngios nesse sentido. É muito difícil estabelecer uma hipótese para essa diferença. Talvez ela se deva a falta de uma sede episcopal intimamente relacionada com os reis, como a sede de Toledo e os reis Visigodos. Embora os reis francos contassem com a proximidade com os bispos, a existência de uma sede episcopal central que orientava a organização de toda as igrejas da Gália não existia na Gália Merovíngia enquanto que na Hispânia Visigoda a primazia da sede de Toledo se tornou cada vez mais evidente desde a realização do IV Concílio de Toledo. Essa hipótese é conjectural e de difícil comprovação. De todo modo, os reis merovíngios lançaram mão de outros instrumentos legais para a afirmação da autoridade deles e que recorria ao discurso em torno da gens francorum, tratam-se dos editos e formulae que no caso merovíngio superam em número enormemente o caso visigodo. Isso pode se dever tão-somente a um problema de transmissão de manuscritos, mas essa possibilidade soa estranha se levarmos em conta que as Leges Visigothorum, como indicamos, circularam significativamente mesmo depois da queda da realeza visigoda. Talvez estejamos diante de diferentes estratégias que visavam afirmar a autoridade dos reis em relação à nobrezas que, especialmente no caso visigodo, disputavam o poder diante da falta de uma dinastia tal como a merovíngia.

As leis, assim, nos ajudam a vislumbrar um quadro ainda mais complexo de estratégias construídas em torno de identidades políticas para fazer frente a um cenário de intensas disputas. Isso nos aproxima cada vez mais da idéia de que a recorrência desses discursos identitários não faz sentido pela existência de unidades 
étnicas godas e francas, mas sim pelo uso de uma tradição narrativa para fazer frente a oposições políticas. Em poucas palavras, é tão-somente à luz das disputas políticas que os discursos identitários fazem sentido num quadro de políticas identitárias e $\begin{array}{llll}\text { identidades } & \text { políticas constante } & \text { conflito. }\end{array}$ 
NÓS E OS OUTROS 


\section{Capítulo VIII - Nós e os outros: correspondências entre os reinos}

$\mathrm{O}$ interesse das fontes epistolares reside justamente no fato de apresentarem um outro nível das políticas identitárias e identidades políticas articuladas em torno dos discursos construídos a partir da base "gothi" e "franci". Esse outro nível consiste nas trocas de correspondências entre os reinos e reinos externos, de modo que nos permiter avaliar como os discursos e sentidos que até aqui identificamos funcionavam em narrativas elaboradas para o "outro", outros reinos, ou o próprio Império. Diante desse norte optamos por privilegias epístolas trocadas entre os reis e governantes de outros reinos e Imperadores do Oriente.

\section{A escrita epistolar no Alto Medievo - características narrativas e pressupostos de análise crítica}

A escrita de epístolas ${ }^{801}$ foi muito difundida ao longo do período medieval. ${ }^{802}$ Entretanto, esse tipo de narrativa voltada para a comunicação direta obedecia à certas especificidades, a saber, a escrita epistolar não era espontânea, regras eram usadas para a composição desse texto antes mesmo da formalização das normas narrativas da Ars Dictaminis, ou seja, a composição escrita que teve como principal representante as epístolas, que surgiram a partir do século XI especialmente com os Breviarum de

\footnotetext{
${ }^{801}$ Em geral o termo que aparece nos documentos para definir as epístolas é littera. Poderíamos traduzir a palavra como "carta", mas preferimos o termo "epístola" para marcar a diferença entre a escrita de uma "carta" na atualidade e entre os séculos VI e VII. Cabe ainda salientar que A. Deissmann defendeu uma distinção entre "epístolas" e "cartas" alegando que as primeiras tinham um propósito literário com vistas a serem reunidas futuramente em "epistolários", enquanto as segundas eram pouco literárias e eram produzidas com o único propósito de enviar uma mensagem. A tese de Deissmann foi duramente questionada e devemos concordar com as críticas. É difícil estabelecer os parâmetros de um texto "literário" de um "não-literário". $C f$ : CONSTABLE, G. Letters and LetterCollections. Typologies des Sources du Moyen Âge Occidental, fasc.17. Turnhout: Brepols, 1976. p.24-25.

${ }^{802}$ Como muito bem indica M. Garrison a escrita de cartas não se restringia aos círculos nobiliárquicos, aos círculos régios e aos círculos episcopais. A autora, em seu estudo, indicou que a comunicação por via de cartas era mesmo difundida entre setores mais "baixos" da hierarquia social, como mostram as cartas encontradas em escavações arqueológicas que não entraram nas coleções que chegaram aos nossos dias. $C f$. GARRISON, M. "Send more socks": On mentality and the preservation contexto of Medieval letter. In: MOSTERT, M. (ed.). New Approaches to Medieval Comunication. Turnhout: Brepols, 1999. p.69-99.
} 
dictamine e Dictaminum radii ou Flores rhetorici de Alberico de Monte Cassino. ${ }^{803}$ A partir disso cabe levantarmos algumas questões em torno desse tipo de documento.

O primeiro se refere ao que já apontamos, a saber, as regras que permeavam esse tipo de narrativa e essa primeira questão toca na segunda questão referente a forma pela qual as epístolas que aqui nos interessam foram compiladas e preservadas. Desdobremos.

No que concerne à questão estilística, elas se articulavam sobretudo em torno dos objetivos gerais que deveriam permear a comunicação epistolar. L. Lanham os identificou muito bem:

1. As epístolas deveriam ser escritas como se fossem uma conversa de modo a substituir uma conversação direta impedida por distâncias físicas; ${ }^{804}$

2. Deveriam refletir o caráter do seu autor;

3. Deveriam ser adaptadas de acordo com a relação que mantinham seu autor e o destinatário da carta; ${ }^{805}$

Para que esses objetivos fossem atingidos a escrita epistolar obedecia à uma formatação particular que, em termos gerais, consistia nos seguintes pontos: ${ }^{806}$

- Salutio;

- Exordium (também conhecido como captatio benevolentiae e proverbium);

- Narratio;

- Petitio;

- Conclusio.

\footnotetext{
${ }^{803}$ Para uma boa definição da Ars Dictaminis: CAMARGO, M. Ars Dictaminis. Ars Dictandi. Typologie dês Sources du Moyen Âge Occidental. Fasc.60. Turhnout: Brepols, 1991. p.16-28.

${ }^{804}$ G. Constable tece um comentário muito interessante sobre essa característica das epístolas: "Letters originated as oral messages, when distance made speech impossible, and the earliest letters took the form of instruction to messengers, reminding them of what to say to recipients. [...]. The letters was thus regarded as half of a conversation or dialogue between the sender and the addressee, and it involved a quasi-presence and quasi-speech between the two. CONSTABLE, G. Letters and LetterCollections. Typologies des Sources du Moyen Âge Occidental, fasc.17. Turnhout: Brepols, 1976. p.13

${ }^{805}$ LANHAM, Carol Dana. Freshman composition in the Early Middle Ages: Epistolography and Rhetoric before the ars dictaminis. Viator, p.115-134, 1992.

${ }^{806}$ CAMARGO, M. Ars Dictaminis. Ars Dictandi...op.cit. 20-22.
} 
A existência e aplicação desses parâmetros é detectada antes do surgimento dos manuais do século XI, como já apontamos, e se observa na própria peculiaridade da transmissão dessas fontes. Como bem salientou Garrison, ${ }^{807}$ a maioria das epístolas que chegaram aos nossos dias foram preservadas em coleções epistolares que serviam como modelos para a produção de outras epístolas. ${ }^{808}$ Percebe-se com isso que a maioria das epístolas que possuímos da época merovíngia e visigoda foram deliberadamente reunidas e preservadas para servirem de modelos, o que indica que a existência de parâmetros para a produção desse tipo de texto era presente e importante no período que nos interessa.

De fato podemos observar a aplicação desses modelos nas epístolas conforme testemunham alguns exemplos. Percebemos a idéia das epístolas como uma substitução de uma interlocução entre dois indivíduos nas epístolas trocadas entre Bráulio, bispo de Zaragoza, e seu mentor, Isidoro de Sevilha. Numa das epístolas escritas pelo bispo de Sevilha lemos:

Quia non ualeo te perfruere oculis carnis, perfurar saltim adloquiis ut ipsa mihi sit consolatio incolomem litteris cognoscere quem cupio lidere. Ultrumque bonum esset si liceret; sed uel mente de te reficiar si corporali optutu non ualeo. ${ }^{809}$

Em outra carta de Isidoro de Sevilha fica ainda mais latente o caráter das epístolas enquanto substitutivas de uma conversa direta: Dum amici litteras, carissime fili, suscipis, eas pro amico amplectere non moreris. Ipsa est enim secunda inter

\footnotetext{
${ }^{807}$ GARRISON, M. "Send more socks"... op.cit. p.73-78.

${ }^{808}$ Malaspina também chama a atenção para isso ao indicar como após a morte de Gontrão seu sobrinho Childeberto trouxe o notário da corte de Gontrão para Metz e com ele vieram documentos da chancelaria da Burgúndia. É esse evento que o editor dos MGH das epístolas aponta como o início da produção do Liber epistolarum. Cf. MALASPINA, E. Il Liber epistolarum della cancelleria austrasica. (sec.V-VI). Roma: Herder Editrice e Libreria, 2001.

${ }^{809}$ Bráulio de Zaragoza, Epistolário, I.
} 
absentes consolation ut, si non est praesens qui diligitur, pro eo littere conplexentur. ${ }^{810}$

O segundo ponto elencado por Lanham entendemos como um desdobramento do primeiro, embora seja difícil aceita-lo integralmente uma vez que para além da simples comunicação, as epístolas eram uma forma de afirmação de uma posição, ou seja, quando um bispo, um imperador ou um rei enviava uma epístola sabia que ela provavelmente seria lida em público, é mais provável que esse caráter do autor listado por Lanham tivesse mais relação com a posição social deste do que com seu caráter pessoal. ${ }^{811}$

No que concerne ao terceiro ponto, podemos novamente tomar as epístolas de Bráulio como exemplo. É notável a diferença do tom de Isidoro de Sevilha quando se dirigia à Bráulio de Saragoça em relação ao tom adotado pelo bispo de Saragoça quando remetia uma epístola ao bispo de Sevilha. Logo na "Saudação" ou Salutio 812 parte da epístola que a inicia e onde deve ser observado a posição do remetente e do destinatário vemos essa diferença:

\begin{tabular}{|c|c|}
\hline Carta de Isidoro à Bráulio & Carta de Bráulio à Isidoro \\
\hline $\begin{array}{l}\text { Salutio } \\
\text { IN CRISTO KARISSIMO ET DILECTISSIMO } \\
\text { FRATRI BRAULIONI ARCEDIANO } \\
\text { ISIDORUS. }{ }^{813}\end{array}$ & 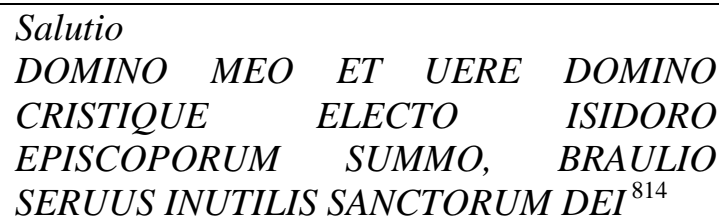 \\
\hline
\end{tabular}

\footnotetext{
${ }^{810}$ Bráulio de Zaragoza, Epistolário, II.

${ }^{811}$ W. Patt raciocina nessa linha, segundo ele: "In short, letters were the primary médium of medieval communication, administration, and propaganda". PATT, William D. The early "ars dictaminis" as response to a changing society. Viator, p.133-155, 1978. p.135.

${ }^{812} \mathrm{Com}$ a sistematização da ars dictaminis - que em geral significava a composição de qualquer texto escrito mas que acabou destacadamente relacionada com a epistolografia - no século XI que ficou evidenciada com os tratados de Alberico de Monte Cassino (Breviarium de dictamine e Dictaminum radii ou Flores rhetorici) as partes das epístolas foram definidas em cinco: Salutio; Exordium (também conhecido como captatio benevolentiae e proverbium); Narratio; Petitio e Conclusio. Antes do século $\mathrm{XI}$, entretanto, essas partes das epístolas figuravam em textos epistolográficos embora sem a recorrência observada a partir do século XI. CAMARGO, Martin. Ars Dictaminis. Ars Dictandi. Typologie des Sources du Moyen Âge Occidental. Fasc.60. Turnhout: Brepols, 1991. p.16-28. Ainda: CONSTABLE, G. Letters and Letter-Collections...op.cit. p.16-20.

${ }^{813}$ Bráulio de Zaragoza, Epistolário, I e II.

${ }^{814}$ Bráulio de Zaragoza, Epistolário, III.
} 
É bastante óbvio que a salutio de Isidoro para Bráulio é bem menos pomposa, nela o bispo de Sevilha trata Bráulio de Saragoça num nível - ao menos discursivo igual. Por outro lado, Bráulio de Saragoça trata Isidoro de Sevilha como o Dominus dele, reforça a sentença reafirmando que Isidoro é seu Dominus merecidamente. Bráulio ainda se referiu à Isidoro de Sevilha com o "Summo Episcoporum”, ou seja, o mais destacado, o primeiro, dos bispos. Já Bráulio, por sua vez, se coloca como um mero e inútil servo (servus) dos santos de Deus. Numa outra carta enviada por Isidoro de Sevilha para Bráulio percebemos a mudança do Salutio:

\begin{tabular}{|l|}
\hline Carta de Isidoro à Bráulio \\
\hline DOMINO MEO ET DEI SERUO BRAULIONI EPISCOPO ISIDORUS. \\
\hline
\end{tabular}

Ora, esta carta foi enviada quando Bráulio já era bispo, ao contrário dos salutiones anteriores, Isidoro aqui chama Bráulio de Dominus tal como Bráulio o chamara na epístola enviada enquanto ainda era arquidiácono. A mudança do salutio da epístola IV evidencia que Isidoro de Sevilha reconheceu a mudança de status de Bráulio, agora bispo de Saragoça. Nestes termos, tendemos a concordar com W. Patt. Embora as epístolas se fundamentassem na idéia de substituírem uma conversa elas não podem ser lidas de maneira ingênua e portanto não devem ser compreendidas como registros de comunicações espontâneas.

Esse elemento é perceptível nas Epístolas Austrasianas também igualmente logo nos salutiones, contudo as salutiones no caso delas marcam a posição do remetente da epístola mais do que do destinatário. A epístola 40, que fora enviada pelo Imperador Maurício para o rei franco Childeberto traz o sumário salutio:

\footnotetext{
${ }^{815}$ Bráulio de Zaragoza, Epistolário, IV.
} 
INCIPIT LITTERAS DE ROMANORUM IMPERATORE DIRECTAS AD DOMNUM REGEM. ${ }^{816}$

Já na epístola 42 o salutio possui um teor completamente diferente:

IN NOMINE DOMINI DEI NOSTRI IESU CHRISTI, IMPERATOR CAESAR FLAVIUS MAURICIUS TIBERIUS, FIFELI IN CHRISTO, MANSUETUS, MAXIMUS, BENEFICUS, PACIFICUS, ALAMANNICUS, GOTHICUS, ANTICUS, ALANICUS, WANDALICUS, ERULLICUS, GYPEDICUS, AFRICUS, PIUS, FELIX, INCLETUS, VICTOR AC TRIUMPHATOR, SEMPER AUGUSTUS, CHILDEBERTHO VIRO GLORIOSO, REGI FRANCORUM. ${ }^{817}$

Para compreendermos a mudança radical entre os salutiones é preciso, evidentemente, atentar para o conteúdo das epístolas. Na epístola 40 Maurício teceu elogios à atuação das tropas de Childeberto contra os lombardos na Itália. O exército dos francos é louvado por sua força pelo imperador, além de ter tido um papel decisivo no enfrentamento aos lombardos. Por fim, Maurício pede à Childeberto que ele liberte os romanos que caíram prisioneiros dos francos. Além da peculiaridade da salutio, breve e direta, encontramos na epístola referências às tropas de Childeberto qualificadas como "francas".

Já na epístola 42 Maurício faz fortes críticas à Childeberto acusando-o de não cumprir com as obrigações implicadas nos laços de amizade que Childeberto alegou querer manter entre as gentes francorum e o governo romano (dicioni romanae). No salutio, Maurício lança mão de vários epítetos, dentre os quais "Gótico", “Ántico", “Alânico", "Vandálico" e assim por diante. Esse tipo de epíteto era comumente recebido por Imperadores romanos quando conquistavam outras gentes, caso por exemplo do Cláudio II que recebeu o epíteto de "Gótico" quando derrotou grupos

\footnotetext{
${ }^{816}$ Epístolas Austrasianas, 40.

${ }^{817}$ Epístolas Austrasianas, 42.
} 
qualificados como godos na região da Mésia. ${ }^{818}$ Se Maurício estivesse seguindo o exemplo que levou Cláudio II à receber o epíteto de "Gótico" ele, ao usar tantos epítetos referentes às gentes, possivelmente marcava para Childeberto sua posição enquanto um grande conquistador que tinha condições de submeter também às gentes francorum caso Childeberto não cumprisse com as exigências dele. O salutio, neste caso, é uma evidente ameaça à Childeberto.

O que notamos é que embora existisse um modelo para a produção desses textos isso não significa que lidamos com narrativas estáticas, as formas pela qual o modelo era apropriado para transmitir um determinado tipo de mensagem - a superioridade do imperador em relação ao rei dos francos; o reconhecimento da mudança da posição de um religioso na hierarquia eclesiástica - traziam em si uma mensagem. É a partir desse norte que lidaremos com as epístolas, não nos interessa notar se os modelos eram aplicados corretamente, mas de que forma as apropriações deles outorgam à mensagem uma dupla validade comunicatica, a primeira fundamentada nos parâmetros estilísticos e a segunda constituída pela mensagem transmitida por si só a partir de um determinado parâmetro. Consideramos esse um elemento importante a ter em vista no trato com essas fontes. Não obstante, outras particularidades que levamos em conta ao trabalharmos com as epístolas são aquelas muito bem elencadas por W. Patt:

- As epístolas não eram privadas, eram escritas tendo em vista que seriam lidas em público;

- As epístolas não podem ser lidas ingenuamente. Uma epístola em nome de um Imperador, bispo ou rei eram mais do que um meio de transmitir notícias ou ordens, era uma afirmação ideológica e muito do que havia de mais importante em seu conteúdo deve ser encontrado nas entrelinhas;

\footnotetext{
${ }^{818}$ FRIGHETTO, R. Antiguidade Tardia. Roma e as monarquias romano-bárbaras numa época de transformações. Séculos II-VIII. Curitiba: Juruá, 2012. p.85.
} 
- As epístolas eram uma forma literária particular. As cartas eram compiladas para servirem de modelo para outras e eram usadas para outros fins além da pura comunicação entre partes, W. Patt traz como exemplo o caso da Querela das Investiduras cuja a documentação que possuímos é fundamentalmente composta por cartas.

- O autor sumariza: In short, letters were the primary médium of medieval communication, administration, and propaganda. ${ }^{819}$

\section{Epistolas Austrasianas e Epistolas Visigodas - "nós e os outros"}

O Liber Epistolarum foi transmitido por apenas um manuscrito, o Vaticano Palatino Latino 869 cuja a primeira parte é datada do século IX e no século XVIII foi unido à um outro manuscrito do século XII, a parte do manuscrito datada como a mais antiga é proveniente do mosteiro de São Nazário de Lorsch $^{820}$ sendo assim mais um exemplo de documento merovíngio que chegou aos nossos dias graças à um manuscrito carolíngio, exatamente a mesma questão que aparece no caso das hagiografias merovíngias por nós estudadas. Embora o problema da "mediação carolíngia" para as fontes do nosso período escapem do escopo desse trabalho, insistimos que um estudo que leve em consideração as implicações desse problema precisa ser conduzido.

Feita essa ressalva, concentremo-nos no texto.

O grande interesse das epístolas austrasianas para o nosso trabalho se refere ao fato de que as epístolas reunidas na coleção indicam uma significativa comunicação não só interna no reino dos francos, mas também entre os reis francos e os imperadores do Oriente. ${ }^{821}$ Além disso, revela um outro nível de tensões e alianças

\footnotetext{
${ }^{819}$ PATT, W.D. The early "are dictaminis" as response to a changing society. Viator, p.133-155, 1978. p.135.

${ }_{820}^{820}$ MALASPINA, E. Il Liber epistolarum della cancelleria austrasica...op.cit. p.27-29.

${ }^{821}$ A. Gillet salienta o papel das epístolas para percebermos a intensidade e importância que as embaixadas desempenharam na política interna e externa do reino dos francos. $C f$ : GILLET, . Envoys
} 
que ocorriam no Ocidente na época que contemplamos. $\mathrm{O}$ fato é que uma boa chave de leitura para as epístolas austrasianas é aquela que considera as relações entre o Império Oriental e o reino dos francos a partir do império de Maurício que tentou cooptar os francos como aliados na luta contra os lombardos no norte da Itália. ${ }^{822}$ Tento esse ponto de referência em vista torna-se interessante perceber como os "francos" são retratados nesses documentos.

Como de praxe, não há apenas um significado para o termo "franci" nas epístolas austrasianas e a mudança desses significados está estreitamente relacionada com os remetentes e destinatários das correspondências. Quando se trata de epístulas enviadas dentro do reino, o termo aparece com um significado que é próximo àquele que observamos em muitas outras fontes, a saber, refere-se aparentemente à um grupo nobiliárquico, como podemos observar pela epístola enviada pelo bispo Mapino de Reims ao bispo Nicetio de Trier. A epístola é muito interessante e trata da convocação dos bispos à Toul feita pelo rei Teodobaldo para tratar de um problema. Conforme o bispo Mapinio, Nicetio estava afastando alguns francos da igreja como castigo por incesto:

Pro qua re, piissime ac multum diligende domne et frater, indicamus nos litteras filii nostri, domni regis Theodebaldi, excipisse, ut in Tullensium urbem die Kalendarum Iuniarum adesse deberem; et, nullam causam evocationis declarantes, reciprocante pagina indicavimus nos illic accedere non debere, quia causam condicionemque nos constabat ignorare; iteratis scriptis edocuit, Beatitudinem Vestram, dum aliquos Francorum pro zelo divini timoris corripit ac pro incestis condicionibus a communitione ecclesiastica removit, scandala seu anxietates multimodas sustinere. ${ }^{823}$

and Political Communication in the Late Antique West, 411-533. Cambridge: Cambridge University Press, 2003. p.267.

${ }^{822}$ Uma interessante análise sobre esse tipo de aliança, mas também de ameaça, pode ser encontrada em: GOFFART, W. Byzantine Policy in the West under Tiberius II and Maurice: Tre pretenders Hermenegild and Gundovald (579-585). Traditio. v.13, p.73-118, 1957.

${ }^{823}$ Epistolae Austrasicae, 11, 2. 
Ora, a preocupação de Teodobaldo com o afastamento dos francos da igreja indica que os francos afetados não eram indivíduos desimportantes, aparentemente tratavam-se de nobres que por algum motivo, talvez tenha sido de fato a questão do incesto, desagradavam o bispo de Trier. Ao punir esses nobres Nicetio chamou a atenção do rei que convocou os bispos para Toul, ao saber do ocorrido, Mapinio censura o bispo de Trier.

Uma outra imagem dos francos aparece na troca epistolar entre Childeberto e o Império Oriental. Childeberto foi apresentado como o rex francorum em todas as epístolas enviadas para o Oriente, contendo nesse título a idéia da unidade representada pelo rei a despeito das já apontadas divisões no seio do reino dos francos. Esse tipo de recorrência aparece nas epístolas 32, 34, 37, 38 e 39 que foram enviadas em 587 em nome do rei para pessoas do entorno de Maurício, respectivamente Onorato um representante do Papa em Constantinopla; Teodoro, um alto funcionário à serviço do imperador; Paulo, pai de imperador; Itálica, uma patrícia esposa do patrício Venâncio e ao próprio Venâncio. Em todas as epístolas o rei requisita que esses personagens intervenham junto ao imperador para que ele considerasse o estabelecimento de alianças com os francos, identificados como as gentes sob a autoridade de Childeberto.

O interesse de Maurício para a aliança com Childeberto foi bem apontado por Goffart, consistia na tentativa de obter o apoio do exército dos francos na luta contra os longobardos na Itália. ${ }^{824}$ De fato, numa epístola escrita em nome do Imperador enviada para Childeberto em 590 isso fica bem explicitado onde o termo francus, quando aparece, faz sempre referência ao exército dos francos:

\footnotetext{
${ }^{824}$ GOFFART, W. Byzantine Policy in the West under Tiberius II and Maurice... op.cit.
} 
$\Rightarrow$ Exposuit ergo nobis quam prumptissimo animo vel devotione integra florentissimum Francorum exercitum ad liberationem Italie Gloria Vestra direxat.

$\Rightarrow \quad$...pugnando et rumpendo muros, ut Francorum videret exercitus...

$\Rightarrow \quad \ldots$ Deo adiutore sumus ingressi festinantes, ne gente nefandissimae Langobardarum se contra Francorum exercitum adunare liceret...

$\Rightarrow$... quam rem et Francorum florentissimus credemus quia facere volebat exercitus...

$\Rightarrow \quad \ldots$ Autharit regis ad Vestram Excellentiam habuerunt deferri vestraque - etsi tardius fuerat - completa esset promissio revera, dum neque intra muros Longobardi totus se esse putabant nec Francis praesumebant obsistere...

$\Rightarrow$ Praeterea quod ex se Gloria Vestra facere consuevit, implenda deposcimus, ut Romanus, quos praedavit Francorum exercitus, pro mercede vestra et filiorum ac nepotum vestrorum relaxare praecipiates... ${ }^{825}$

Essa carta de Maurício comemora as vitórias dos francos contra os longobardos sublinhando o interesse do imperador no apoio armado advindo de Childeberto. $\mathrm{O}$ interesse de Childerto na aliança com o Império já não são tão claros. Podem ser, como aponta Goffart, ${ }^{826}$ fruto de uma tentativa de recuperar o filho de Igunda, princesa franca que casou-se com Hermenegildo, o filho rebelde de Leovigildo. No calor das tensões na Península Hispânica Igunda tentou escapar para Constantinopla morrendo no trajeto. Seu filho, entretanto, conseguiu chegar ao Império Oriental. A própria rainha Brunilda, mãe de Childeberto, escreveu epístolas ao Império requisitando o retorno de seu jovem neto sem sucesso. A possível morte do neto de Brunilda no Oriente é atribuída como a causa na mudança da relação entre Childeberto e Maurício em 590. De fato, uma carta do imperador enviada à Childeberto nesse mesmo ano indica que ambos não mantinham mais relações amistosas. O tom da epístola é agressivo, além do salutio já mencionado no início desse texto em que o imperador enumera suas conquistas militares por meio de epítetos, o corpo do texto diz ainda que:

\footnotetext{
${ }^{825}$ Epistolae Austrasicae, 40.

${ }^{826}$ GOFFART, W. Byzantine Policy in the West under Tiberius II and Maurice... op.cit.
} 
Et mirum nobis videtur, si, rectam habere mentem atque priscam gentis Francorum et dicioni Romanae unitatem esse conprobatam adfirmans, nihil operis usque adhuc amicitiae congruum eminentia tua ostendens visa est: dum in scriptis pollicita atque per sacerdotis firmata et terribilibus iuramentis robata, tanto excesso, nullum effectum perceperunt. ${ }^{827}$

Muito embora a interpretação de Goffart seja interessante, talvez outras coisas estivessem em jogo para determinar a relação de Childeberto com o Império relacionadas mais com o controle sobre áreas da Itália do que por uma vingança contra a morte de Ingunda e seu filho:

\footnotetext{
'Deprecatur etiam pietatem vestram, ut ei solacium contra Langobardus tribuatis, qualiter expulsi de Italia, pars illa, quam genitur suus vindicavit vivens, ad eum revertatur, reliqua vero pars per vestrum suumque solacium imperatoris dicionibus restituatur' Respondit rex: 'Non', inquid, 'possum in Italiam exercitum meum dirigere, ut ultro eos morti tradam. Gravissima enim lues Italiam nunc devastat'. 828
}

O interesse de Childeberto parecia assim transcender uma solidariedade por seu sobrinho. O fato é que mesmo com a recusa de Gontrão Childeberto enviou pelo menos mais duas expedições para a Itália sendo uma delas vítima de uma enorme derrota que, conforme Gregório de Tours: "Tantaque ibi fuit stragis de Francorum exercitu, ut olim simile non recolatur. ${ }^{, 829}$ Talvez tenha sido mais essa derrota e as dificuldades de manter as tropas na Itália que tenha levado Childeberto à abandonar o imperador, mais do que a descoberta de que seu sobrinho estava morto, como hipotetiza Goffart.

A despeito das razões de Childeberto o fato é que Maurício não aceitou bem a perda do apoio e enviou uma epístola com um tom agressivo ao rei. E nessa epístola é uma outra dimensão da gens francorum que aparece, dessa vez vinda do Imperador do Ocidente. Ao contrário da primeira epístola na qual Maurício se refere aos francos

\footnotetext{
${ }^{827}$ Epistolae Austrasicae, 42.

${ }^{828}$ Decem Libri Historiarum, IX, 20.

${ }^{829}$ Decem Libri Historiarum, IX, 25.
} 
apenas no sentido de "exército franco", na segunda epístola o Imperador fala da gens francorum. Aqui o sentido parece ser aquele referente à todos sob a autoridade de Childeberto. Isso nos aponta para dois elementos:

1. Na primeira epístola o Imperador reconheceu uma dimensão do significado de francos, aquele relacionado com o exército, "francos" eram os soldados de Chilperico que obtiveram vitórias contra os longobardos;

2. Na segunda epístola temos um significado mais amplo relacionado com a gens francorum enquanto aqueles submetidos à autoridade de Childeberto.

Essas duas dimensões dos "francos" indica que a pluralidade de significados do termo era também reconhecida pelo Imperador de modo que os diversos níveis de sentidos para os "franci" transcendia as narrativas advindas exclusivamente da Gália. Mais interessante ainda é perceber que a mudança do tom entre as duas epístolas de Maurício indicam que o imperador deu respostas que lançaram mão de dois significados distintos para o termo ao sabor das mudanças das relações entre ele e Childeberto. Primeiro o exército franco - não a gens francorum - era celebrado por suas conquistas militares contra os longobardos; depois a gens francorum foi ameaçada pelo Imperador depois que ele se viu sem o apoio de Childeberto. A variação dos usos do sentido do termo para respostas em contextos políticos - dessa vez entre a Austrásia e o Império - indica que a estratégia dos discursos identitários como mecanismos políticos se dava também para além do contexto textual da Gália Merovíngia. Isso pode nos levar a inferir que esse tipo de prática discursiva era algo aceito e reconhecido em diversas regiões no alto medievo e servia para intermediar querelas políticas, mas também para reforçar alianças.

De fato, ao confrontarmos algumas epístolas produzidas na Hispânia visigoda encontramos um quadro semelhante no que concerne ao uso político dos discursos identitários àquele presente na Gália Merovíngia. No caso das epístolas do conde Bulgarano os godos são sempre apresentados como a gens gothorum que, a partir da 
figura do rei Gundemaro, objetivavam manter a paz, e a gens francorum, identificada com o rei dos francos Teodoberto. São as duas gentes que tem suas imagens projetadas nos reis que estabelecem alianças pelo bem delas. ${ }^{830}$

Já a epístola escrita por Sisebuto ao rei dos Longobardos Adualvado é peculiar e interessante. Nela o rei na salutio se apresente como o "rex wisegotorum”:

$\begin{array}{lcccrr}\text { DOMINIS } & \text { EMINENTISSIMIS } & \text { AC } & \text { VENERANTISSIMIS } & \text { ET } \\ \text { GERMANA } & \text { CARITATE } & \text { MIHI } & \text { CONSOTIS, FRATIR } \\ \text { ADUALUALDO } & \text { REGI } & \text { GENTIS } & \text { LANGOBARDORUM } & \text { ET } \\ \text { THEODOLINDE REGINE } & \text { IN NOMINE } & \text { DOMINI } & \text { SISEBUTUS } \\ \text { REX WISEGOTORUM. } & & & & \end{array}$

A epístola da primeira metade do século VII traz uma referência rara. Como já mencionamos nas fontes da Hispânia visigoda o termo "Wisegoti" em referência aos godos é raro, observamos como ele aparece nas Vitas Sanctorum Patrum Emeretensium com o sentido da unidade das gentes sob a autoridade dos reis, primeiro Leovigildo, depois Recaredo. Esse significado nas Vidas dos Padres de Mérida emerge à luz do confronto das outras recorrências do termo "gothi" na fonte, que, como apontamos, se referia à uma facção da nobreza de Mérida. À luz da outra fonte e da referência de Sisebuto como o Rex Wisegothorum parece pertinente que na epístola do rei o termo foi empregado no mesmo sentido que aquele das vitae. Talvez o fato dos dois documentos serem do século VII não seja um acaso, é possível que naquele período a idéia dos "wisegothi" como distintos dos "ostrogodos" - distinção que aparece na Getica de Jordanes - tenha se popularizado na Península, não, cabe ressaltar, como uma retomada da epopéia narrativa de Jordanes, mas sim por uma razão mais prática: para marcar a diferença entre wisegothi unidos sob a autoridade

\footnotetext{
${ }^{830}$ Como vemos na passagem: "Et quia latere beatitudinem vestram non arbitror, quod filius vester, domnus Theudibertus rex, cum gentem Gotorum a decidentibus velut olim existit conligata principibus, nunc per pactuum allegatione pacem per legatis idem gentis devobit roborare perpetuam ..." Epistolae Wisigoticae, 12.

${ }^{831}$ Epistolae Wisigoticae, 9.
} 
dos reis e grupos nobiliárquicos gothi que surgiam em regiões mais periféricas do reino, como em Mérida. Um novo senso de unidade poderia estar em formação, um novo discurso identitário, que distinguia crescentes poderes regionais da autoridade do rei que se impunha sob todos, sob todas as gentes. Uma política identitária de construção de uma outra identidade política em torno da figura do rei em confronto com identidades políticas regionais que se fortaleciam. Nos parece provável que essa seja a chave que explique o surgimento do termo wisegothi tanto na epístola de Sisebuto quanto nas Vidas dos Padres de Mérida. Entretanto, esse novo discurso identitário transcende as fronteiras do reino e é evocado mesmo quando o rei Sisebuto se dirige ao rei longobardo indicado que, possivelmente, o seu objetivo era que esse novo discurso fosse reconhecido também para além do reino dos godos.

O que o confronto entre as epístolas mostra, à luz da discussão até aqui conduzida, é que os discursos identitários em toda a pluralidade que assumiam no seio dos regna eram também efetivos no trato político com reis de outros reinos e com o próprio imperador. Se a existência das gentes enquanto etnicidades é questionável, a existência discursiva dos gothi e francus mesmo em torno de um discurso unitário era eficiente na lida com outros reis e com os imperadores. Isso indica uma efetividade dos discursos identitários enquanto identidades políticas nas narrativas voltadas para agentes estrangeiros. É tão somente à luz da narrativa política no seio do contexto textual que produzia e legitimava os discursos que podemos entender o valor dos visigodos e dos francos na Gália Merovíngia e na Hispânia visigoda. 


\section{Capítulo IX - Os francos e os godos - alianças e tensões nas Histórias}

Outro ponto crucial para pensarmos sobre as identidades políticas é analisarmos como elas se confrontam diante dos "outros", entendidos aqui como os reinos ou gentes estrangeiras. Vemos pelas epístolas que em confronto com os "outros", os "estrangeiros", a gens francorum e a gens visigothorum, mas principalmente, o regnum francorum e o regnum gothorum são sempre apresentados como uma unidade, como uma entidade política unificada em torno da figura dos reis. Era assim que as embaixadas se apresentavam e, portanto, era assim que os representantes dos reis para além dos regna queriam ser reconhecidos.

A análise das epístolas nos permite vislumbrar esse quadro, mas ainda fica em aberto a questão: como os godos eram percebidos pelos francos e os francos eram percebidos pelos godos? Como esses reinos, ambos marcados por uma forte polaridade interna (como pudemos observar ao longo desse texto), eram percebidos por seus vizinhos? Cabe nos dedicarmos um pouco à essa questão agora.

Algo que é bastante evidente nas fontes - sobretudo históricas - com as quais lidamos é que as relações entre o reino dos francos e o reino dos visigodos eram bastante recorrentes. Por vezes essas relações eram pacíficas, como nos acordos matrimoniais que uniram princesas e príncipes dos dois reinos. ${ }^{832}$ Brunilda, a filha do

\footnotetext{
${ }^{832}$ Há uma considerável historiografia dedicada à questão do matrimônio entre as princesas e príncipes do Alto Medievo a partir do ponto de vista das alianças que essas uniões representavam. A historiadora Régine Le Jan é talvez a mais notória pesquisadora dedicada à questão da família e matrimônio no mundo franco, podemos mencionar dois artigos da autora que exemplificam bem a abordagem dela: LE JAN, R. Douaires et Pouvoirs des Reines en Francie et en Germanie (Vie-Xe siècle). In: LE JAN, R. Femmes, pouvoir et société dans le haut Moyen Age. Paris: Picard, 2001. E no mesmo volume: Aux origines du douaire médiéval (Vie-Xe siècle). Há ainda os estudos de $\mathrm{S}$. Joye com um grande enfoque na questão do matrimônio e da família. Dentre os trabalhos da autora com importantes reflexões teórico-metodológicas: JOYE, S. "Y a-t-il une "évolution"des moeurs?" Historiographie et anthropologie de la familie et du mariare. Labyrinthe, 30, p.115-130, 2008. JOYE, S. \& SANTINELLI-FOLTZ, E. Le couple: une définition difficile, des réalités multiples. Médiévales. Le couple dans le monde franc. n.65, p.5-18, 2013. Ainda sobre a ritualística do matrimônio e a questão dos bens envolvida na aliança matrimonial: RÉAL, I. Entre mari et femme: dons réciproques et gestion dês biens à l'époque mérovingienne d'après les chroniques et les Vies de saints. In: BOUGARD, F.;
} 
rei visigodo Atanagildo, casou-se com Sigiberto, o rei franco da Austrásia num matrimônio mencionado tanto por Gregório de Tours quanto por Venâncio Fortunato que celebravam a origem célebre da princesa visigoda. Nas palavras de Venâncio, Brunilda é louvada sob diversos aspectos.

A primeira coisa que ele enfatiza é a beleza da princesa, um gema nova que a Espanha produziu "nouam genuit Hispania gemmam". ${ }^{833}$ Venâncio ainda faz uma interessante relação entre a Germania e a Hispânia, dizendo que na Hispânia nasceu a soberana que uniu os dois ricos reinos dos francos e godos: Quis crederet autem/ hispanam tibimet dominam, Germania, nasci, / quae duo regna iugo pretiosa conexuit uno $?^{834}$. Fortunato louva ainda a linhagem de Brunilda, filha de Atanagildo, que segundo ele estendeu o reino da Espanha aos confins do mundo e guiou bem o seu povo: Nobilitas excelsa nitet, genus Athanagildi / longius extremo regnum qui porrigit orbi, / diues opum quas mundus habet populumque gubernat hispanum sub iure suo pietate canenda. ${ }^{835}$

Observamos que a ação política de Atanagildo que teria expandido o reino dos visigodos é mencionada para reforçar a imagem positiva da princesa Brunilda, não obstante, a chegada dela é o marco central nas palavras de Venâncio que garantiria a união entre dois grandes reinos. Há evidentemente uma leitura bastante positiva da princesa visigoda e por conseguinte do próprio reino dos visigodos.

Mais interessante é observarmos como Gregório de Tours tratou desse matrimônio nos seus Decem Libri Historiarum.

Porro Sigyberthus rex cum videret, quod fratres eius indignas sibimet uxores acciperent et per vilitatem suam etiam ancillas in

FELLER, L. \& LE JAN, R. Morgengabe, dos, tertia.. et les autres. Les transferts patrimoniaux en Europe occidentale. VIIIe-Xe siècles. Ecole Française de Rome, 295. p.389-406, 2000.

${ }^{833}$ Livro VI, I (De domno Sigiberto rege), verso 111.

${ }^{834}$ Livro VI, I (De domno Sigiberto rege), versos 17-19

${ }^{835}$ Livro VI, I (De domno Sigiberto rege), versos 125-127 
matrimonio sociarent, legationem in Hispaniam mittit et cum multis muneribus Brunichildem, Athanagilde regis filiam, petiit. Erat enim puella elegans opere, venusta aspectu, honesta moribus atque decora, prudens consilio et blanda colloquio. Quam pater eius non denegans, cum magnis thesauris antedicto rege transmisit. Ille vero, congregatus senioribus secum, praeparatis aepulis, cum inminsa laetitia atque iocunditate eam accepit uxorem. Et quia Arrianae legi subiecta erat, per praedicationem sacerdotum atque ipsius regis commonitionem conversa, beatam in unitate confessa Trinitatem credidit atque chrismata est. Quae in nomine Christi catholica perseverat. ${ }^{836}$

O matrimônio de Sigiberto e Brunilda é mencionado após o relato sobre as mulheres de Cariberto e antes do relato sobre os matrimônios de Chilperico. Isso ajuda a compreender a frase "Porro Sigyberthus rex cum videret, quod fratres eius indignas sibimet uxores acciperent [...]" na qual as mulheres escolhidas pelos outros reis são mencionadas como indignas em detrimento à princesa Brunilda: bela, com modos decorosos e fala branda. A imagem de Brunilda contrasta com a de Fredegunda ao longo de todo o texto de Gregório de Tours na qual ela foi descrita como uma conspiradora indigna e cruel. De todo modo, ao mencionar os bons modos e origem real de Brunilda o bispo de Tours criou um imediato contraste com a mulher de seu rival, Fredegunda, esposa de Chilperico.

Embora tanto Venâncio Fortunato quanto Gregório de Tours tracem uma imagem bastante positiva sobre o matrimônio de Brunilda com Sigiberto, é preciso ter em conta que os autores o fazem de maneiras bem diversas. No caso de Venâncio Fortunato há uma verdadeira celebração do matrimônio como um ponto de união entre os reinos dos francos e dos visigodos. Parece que essa leitura deve ser compreendida à luz das relações sociais que Venâncio Fortunato estabeleceu desde quando chegou à Gália e o tênue equilíbrio de poder que ele testemunhou e participou como um narrador que contribuía para marcar a autoridade dos reis e nobres da Gália

\footnotetext{
${ }^{836}$ Decem Libri Historiarum, IV, 27.
} 
Merovíngia, ${ }^{837}$ nesse caso, a imagem do matrimônio de Sigiberto e Brunilda feita pelo autor deve dizer mais sobre as relações que Venâncio manteve com o rei franco do que sobre as vantagens políticas reais do matrimônio. De fato, o matrimônio de Sigiberto e Brunilda - e tampouco os outros matrimônios feitos entre os príncipes dos dois reinos - não determinou o fim das tensões entre os reis francos e visigodos. Ao contrário, por vezes esses matrimônios eram mesmo foco de tensão. Como o destino de Igunda, a princesa franca que casou-se com Hermenegildo e acabou morta enquanto escapava depois que a revolta do príncipe foi debelada pelo rei Leovigildo e que foi uma das justificativas do ataque de Gontrão à Septimania.

Já no caso de Gregório de Tours, o que temos é antes a valorização da escolha de Sigiberto por uma rainha digna em detrimento aos seus irmãos, especialmente Chilperico, que escolheram mulheres indignas. De fato, nas palavras do bispo de Tours, Chilperico, invejoso da escolha de Sigiberto, contraiu matrimônio com Gausvinta, irmã de Brunilda. Todavia, por culpa de Fredegunda a princesa visigoda foi morta a mando de Chilperico. ${ }^{838}$ No caso da descrição de Gregório os matrimônios estão muito focados nas questões internas à própria Gália e, especialmente, à complexa relação que ele manteve com Chilperico. De todo modo, a importância que ele outorgou à escolha de Sigiberto revela a importância que a escolha de uma rainha com origens reais poderia ter para a política traçada entre os reis merovíngios e os seus vizinhos e, em última instância, mesmo na legitimidade da autoridade dos reis, como já mencionamos no caso de Sagitário e a dúvida sobre a legitimidade dos herdeiros de Gontrão.

\footnotetext{
${ }^{837}$ É nesse cenário de competição que C. La Rocca interpreta de maneira muito convincente a obra de Venâncio Fortunato: LA ROCCA, C. Venanzio Fortunato e la società del VI secolo. In: GASPARRI, S.(ed.) Alto Medioevo mediterraneo. Firenze: Firenze University Press, 2005. p.145-164

${ }^{838}$ Decem Libri Historiarum, IV, 28.
} 
O que de fato nos interessa aqui, todavia, é a relevância do dado de que os matrimônios, mesmo que idealmente devessem redundar em alianças, por vezes eram mesmo fruto de discórdia e justificativa para agressões entre os reis francos e visigodos. De todo modo, o que eles indicam em última análise é que a relação entre os reinos era turbulenta, mas significativa. E esse peso fica bastante notável quando analisamos outros relatos referentes às relações entre os francos e os visigodos.

Além dos matrimônios, as Historiae produzidas em ambos os reinos destacavam a relação entre eles principalmente nas guerras que opuseram seus reis. A vitória do recém-convertido Recaredo contra os francos ganhou tons miraculosos sob a pena de João de Biclaro:

Francorum exercitus a Gonteramno rege transmissus Bosone duce in Galliam Narbonensem obveniunt et iuxta Carcassonensem urbem castra metati sunt. cui Claudius Lusitaniae dux a Reccaredo rege directus obviam inibi occurrit. tunc congressione facta Franci in fugam vertuntur et direpta castra Francorum et exercitus a Gothis caeditur. in hoc ergo certamine gratia divina et fides catholica, quam Reccaredus rex cum Gothis fideliter adeptus est, esse cognoscitur operata, quoniam non est difficile deo nostro, sin in paucis, una in multis detur victoria. nam Claudius dux vix cum CCC viris LX ferme milia Francorum noscitur infugasse et maximam eorum partem gladio trucidasse. non inmerito deus laudatur temporibus nostri in hoc proelio esse operatus, qui similiter ante multa temporum spatia per manum ducis Gedeonis in CCC viris multa milia Madianitarum dei populo infestantium noscitur extinxisse. $^{839}$

A vitória do duque da Lusitânia, Cláudio, que liderou as tropas visigodas foi descrita por João de Biclaro como uma prova da ação de Deus à favor do rei convertido Recaredo. A narrativa traça um paralelo entre a vitória de Cláudio com seus trezentos homens contra sessenta mil francos e a vitória de Gedeão e os medianitas, a história dos visigodos a partir da conversão é então colocada em paralelo com a história bíblica e a derrota de um dos seus principais antagonistas, os francos, foi usada como prova da atuação divina à favor dos visigodos. Nesse caso, a

${ }^{839}$ Ano VII de Maurício que é o III ano do rei Recaredo, 2. 
valorização da gens gothorum se dá em contraste com o outro, com o inimigo franco:

Deus atuou a favor dos godos e contra os francos.

Em Isidoro de Sevilha a narrativa é semelhante embora a intervenção divina tenha um peso menor em detrimento à glória da ação militar liderada por Cláudio:

Egit etiam gloriose bellum adversus infestas gentes fidei susceptae auxilio. Francis enim sexaginta fere milibus armatorum Gallias inruentibus misso Claudio duce adversus eos glorioso triumphavit eventu. nulla umquam in Spaniis Gothorum vistoria vel maior vel similis extitit. ${ }^{840}$

A vitória contra os francos, sob a pena de ambos os autores, foi retratada como o ápice do governo de Recaredo, como a recompensa pela conversão dele e dos "gothi" que o seguiram. Percebe-se que os francos eram adversários importantes dos visigodos, mesmo mais do que os Bizantinos que ameaçavam a Hispânia desde o sul da Península. Isso fica mais claro se analisarmos as lutas contra os francos no contexto das outras batalhas enfrentadas pelos reis visigodos narradas pelos autores.

No caso da Chronica de João de Biclaro temos:

\begin{tabular}{|c|c|}
\hline \multicolumn{2}{|c|}{ Chronica Biclarense } \\
\hline Sappos & $\begin{array}{l}\text { 5. Leovegildus rex Sabariam ingressus } \\
\text { Sappos vastat et provinciam ipsam in suam } \\
\text { redigit dicionem duosque filios suos ex } \\
\text { amissa coniuge Hermenegildum et } \\
\text { Reccaredum consortes regni facit. (Ano VII } \\
\text { de Justino e V de Leovigildo) }\end{array}$ \\
\hline Inimigos não identificados & $\begin{array}{l}\text { 6. His die bus Leovegildus rex Cantabriam } \\
\text { ingressus provinciae pervasores interficit, } \\
\text { Amaiam occupat, opes eorum pervadit et } \\
\text { provinciam in suam revocat dicionem. (Ano } \\
\text { VIII de Justino e VI de Leovigildo) }\end{array}$ \\
\hline Aspídio, senhor dos montes Aregenses & $\begin{array}{l}\text { 2. Leovegildus rex Aregenses montes } \\
\text { ingreditur, Aspidium loci seniorem cum } \\
\text { uxore et filiis captivos ducit opesque eius et } \\
\text { loca in suam redigit potestatem. (ano IX de } \\
\text { Justino e VII de Leovigildo) }\end{array}$ \\
\hline Suevos & $\begin{array}{l}\text { 3. Leovegildus rex in Gallaecia Suevorum } \\
\text { fines conturbat et a rege Mirone per legatos } \\
\text { rogatus pacem eis pro parvo tempore tribuit. }\end{array}$ \\
\hline
\end{tabular}

${ }^{840}$ Historia Gothorum, 54. 


\begin{tabular}{|c|c|}
\hline & (Ano X de Justino e VIII de Leovigildo) \\
\hline "Rústicos" & $\begin{array}{l}\text { 2. Leovegildus Rex Orospedam ingreditur et } \\
\text { civitates atque castella eiusdem provinciae } \\
\text { occupat et suam provinciam facit. et non } \\
\text { multo post inibi rustici rebellantes a Gothis } \\
\text { opprimuntur et post haec integra a Gothis } \\
\text { possidetur Orospeda. (I ano de Tibério e IX } \\
\text { de Leovigildo) }\end{array}$ \\
\hline Hermenegildo & $\begin{array}{l}\text { 3. Leovegildo ergo quieta pace regnante } \\
\text { adversariorum securitatem domestica rixa } \\
\text { conturbat. nam eodem anno filius eius } \\
\text { Hermenegildus factione Gosuinthae reginae } \\
\text { tyrannidem assumens in Hispalis civitate } \\
\text { rebellione facta recluditur et alias civitates } \\
\text { atque castella secum contra patrem rebellare } \\
\text { facit. quae procincia Hispaniae tam Gothis } \\
\text { quam Romanis maioris exitii quam } \\
\text { adversariorum infestatio fuit. (III ano de } \\
\text { Tibério e XI de Leovigildo) }\end{array}$ \\
\hline Vascones & $\begin{array}{l}\text { 3. Leovegildus rex partem Vasconiae occupat } \\
\text { et civitatem, quae Victoriacum nuncupatur, } \\
\text { condidit. (V ano de Tibério e XIII de } \\
\text { Leovigildo) }\end{array}$ \\
\hline Hermenegildo & $\begin{array}{l}\text { 3. Leovegildus rex exercitum ad } \\
\text { expugnandum tyrannum filium colligit. (VI } \\
\text { ano de Tibério e XIV de Leovigildo) }\end{array}$ \\
\hline Suevos & $\begin{array}{l}\text { Leovegildus rex civitatem Hispalensem } \\
\text { congregato exercitu et rebellem filium gravi } \\
\text { obsidione concludit, in cuius solacium Miro } \\
\text { Suevorum rex ad expugnandam Hispalim } \\
\text { advenit ibique diem clausit extremum. cui } \\
\text { Eboricus filius in provincia Gallaeciae in } \\
\text { regnum succedit. interea Leovegildus rex } \\
\text { supra dictam civitatem nunc fame, nunc } \\
\text { ferro, nunc Baetis conclusione omnino } \\
\text { conturbat.(I ano de Maurício e XV de } \\
\text { Leovigildo) }\end{array}$ \\
\hline Suevos & $\begin{array}{l}\text { 2. Leovegildus rex Gallaecias vastat, } \\
\text { Audecanem regem comprehensum regno } \\
\text { privat, Suevorum gentem, thesaurum et } \\
\text { patriam in suam redigit potestatem et } \\
\text { Gothorum provinciam facit. (III ano de } \\
\text { Maurício e XVII de Leovigildo) }\end{array}$ \\
\hline Francos & $\begin{array}{l}\text { 4. Franci Galliam Narbonensem occupare } \\
\text { cupientes cum exercitu ingressi. in quorum } \\
\text { congressionem Leovegildus Reccaredum } \\
\text { filium obviam mittens et Francorum est ab } \\
\text { eo repulsus exercitus et provincia Galliae ab } \\
\text { eorum est infestatione liberata. castra vero } \\
\text { duo cum nimia hominum multitudine unum } \\
\text { pace, alium bello occupat. castrum vero qui } \\
\text { Hodierno vocatur tutissimus valde in ripa } \\
\text { Rhodani fluminis ponitur, quod Reccaredus }\end{array}$ \\
\hline
\end{tabular}




\begin{tabular}{|c|c|}
\hline & $\begin{array}{l}\text { rex fortissima pugna agressus obtinuit et } \\
\text { victor ad patrem patriamque redit. (III ano } \\
\text { de Maurício e XVII de Leovigildo) }\end{array}$ \\
\hline Malarico & $\begin{array}{l}\text { 6. Malaricus in Gallaecia tyrannidem } \\
\text { assumens quasi regnare vult, qui statim a } \\
\text { ducibus Leovegildi regis oppressus } \\
\text { comprehenditur et Leovegildo vinctus } \\
\text { praesentatur. (III ano de Maurício e XVII de } \\
\text { Leovigildo) }\end{array}$ \\
\hline Francos & $\begin{array}{l}\text { 6. Desiderius Francorum dux Gothis satis } \\
\text { infestus a ducibus Reccaredi regis superatur } \\
\text { et caesa Francorum multitudine campo } \\
\text { moritur. (Ano V de Maurício e I de } \\
\text { Recaredo) }\end{array}$ \\
\hline Francos & $\begin{array}{l}\text { Francorum exercitus a Gonteramno rege } \\
\text { transmissus Bosone duce in Galliam } \\
\text { Narbonensem obveniunt et iuxta } \\
\text { Carcassonensem urbem castra metati sunt. } \\
\text { cui Claudius Lusitaniae dux a Reccaredo } \\
\text { rege directus obviam inibi occurrit. tunc } \\
\text { congressione facta Franci in fugam vertuntur } \\
\text { et direpta castra Francorum et exercitus a } \\
\text { Gothis caeditur. in hoc ergo certamine gratia } \\
\text { divina et fides catholica, quam Reccaredus } \\
\text { rex cum Gothis fideliter adeptus est, esse } \\
\text { cognoscitur operata, quoniam non est } \\
\text { difficile deo nostro, sin in paucis, una in } \\
\text { multis detur victoria. nam Claudius dux vix } \\
\text { cum CCC viris LX ferme milia Francorum } \\
\text { noscitur infugasse et maximam eorum partem } \\
\text { gladio trucidasse. non inmerito deus laudatur } \\
\text { temporibus nostri in hoc proelio esse } \\
\text { operatus, qui similiter ante multa temporum } \\
\text { spatia per manum ducis Gedeonis in CCC } \\
\text { viris multa milia Madianitarum dei populo } \\
\text { infestantium noscitur extinxisse }\end{array}$ \\
\hline $\begin{array}{l}\text { Argimundo - parte do séquito de } \\
\text { Recaredo }\end{array}$ & $\begin{array}{l}\text { 3. Reccaredo ergo orthodoxo quieta pace } \\
\text { regnante domesticae insidiae praetenduntur. } \\
\text { nam quidam ex cubiculo eius, etiam } \\
\text { provinciae dux nomine Argimundus adversus } \\
\text { Reccaredum regem tyrannidem assumere } \\
\text { cupiens, ita ut, si posset, eum et regno } \\
\text { privaret et vita(VIII ano de Maurício e IV de } \\
\text { Recaredo) }\end{array}$ \\
\hline
\end{tabular}

O quadro geral revela que de acordo com o relato de João de Biclaro, além das rinhas internas, os francos representavam uma grande ameaça. Nota-se que além deles, a única outra gens mencionada são os suevos, que chegaram a apoiar Hermenegildo em sua rebelião contra Leovigildo, talvez porque Leovigildo já havia ameaçado o reinado de Miro. Todavia, além do apoio de Miro à Hermenegildo, os 
suevos não aparentam ser a maior preocupação de Leovigildo. Já os francos foram mencionados em três campanhas cuja a vitória foi dos visigodos. A primeira liderada por Recaredo quando ainda era príncipe e liderava o exército em nome do pai. A segunda quando o dux dos francos, Desidério, foi derrotado pelos duque de Recaredo e, por fim, a grande vitória liderada por Cláudio. É perceptível que as campanhas contra os francos são relatadas com mais detalhes, surpreendentemente mais detalhes em relação aos enfrentamentos ao Sul contra os bizantinos. Além dos francos, as outras ameaças aos reis, como se pode perceber, vinham da própria Hispania. Argimundo, os "rústicos" que não aceitavam o domínio dos godos, Malarico na Galécia, Aspídio e o próprio Hermenegildo. O que temos é um relato que coloca os francos como os grandes opositores dos visigodos fora da Hispânia.

Já no caso de Isidoro de Sevilha vemos os godos enfrentando muitos outros inimigos, não por acaso. O relato de João de Bíclaro cobre um período muito mais curto concentrando-se principalmente no reinado de Leovigildo e nos primeiros anos de Recaredo enquanto Isidoro de Sevilha se propôs a escrever um texto que contemplava a história dos godos desde as duas origens. No texto do Hispalense os primeiros grandes inimigos dos godos são os hunos. ${ }^{841}$ Além dos hunos, como já discurtimos no capítulo dedicado à realeza, as oposições internas advindas da nobreza representavam um dos principais fatores de instabilidade interna na Hispânia. Destacam-se ainda os vascones, cujas as vitórias dos reis godos contra foram sublinhadas pelo hispalense. No que concerne aos francos, o relato de Isidoro de Sevilha se desenvolve da seguinte maneira:

36. Aera DXXI, anno X imperii Zenonis Eurico mortuo Alaricus filius eius apud Tolosensem urbem princeps Gothorum constituitur regnans ann. XXIII. Aduersus quem Fluduicus Francorum princeps

\footnotetext{
${ }^{841}$ Historia Gothorum, 9.
} 
Galliae regnum affectans Burgundionibus sibi auxiliantibus bellum mouit fusisque Gothorum copiis ipsum postremo regem apud Pictauis superatum interfecit. [Versão longa]

40. Eo regnante [Teudis], dum Francorum reges cum infinitis copiis in Spanias convenissent et Tarraconensem provinciam bello depopularent, Gothi duce Theudisclo obicibus Spaniae interelusis Francorum exercitum multa cum admiratione victoriae prostraverunt. dux idem prece atque ingenti pecunia sibi oblata viam fugae hostibus residuis unuius diei noctisque spatio praebuit: cetera infelicium turba, cui transitus conlati temporis non occurrit, Gothorum perempta gladio concidit. [Versão longa]

Por último, Isidoro menciona a vitória de Cláudio contra os francos do exército de Gontrão, conforme já citamos aqui. Temos portanto três relatos de embates entre godos e francos citados por Isidoro de Sevilha, com duas vitórias do exército godo e uma vitória do exército franco sofrida durante o reinado de Alarico II. O que é evidente é o valor positivo dado pelo bispo de Sevilha às duas vitórias, especialmente a última, que salienta o favor divino à Recaredo depois da conversão.

Já na Historia Wambae de Juliano de Toledo há com muito mais clareza uma visão negativa acerca dos francos. Eles são um personagem presente na narrativa logo no início da rebelião na Galia Narbonense quando Ilderico, com o apoio de Gumildo e de Ranimiro entregam aos francos Aregio, o bispo que se opôs à revolta deles na região:

Is igitur criminis caput, dum per diversos ignem suae infidelitatis accenderet, Nemausensis urbis episcopum beatae vitae Aregium ad perfidiae notam trahere nitebatur. Quem casto ore, contantique corde repagnantem suis consiliis cernens, et ordinis et loci dignitate privatum, pondere vinculorum onustum, in Franciae finibus Francorum manibus tradidit inludendum. ${ }^{842}$

A entrega de Aregio aos francos é o início da colaboração deles à rebelião na Narbonense. Quando Paulo, enviado para combater a revolta de Ilderico, se alia aos revoltosos ele se volta aos vascones e aos francos para obter apoio contra Wamba. Ora, a partir da narrativa de Isidoro de Sevillha sabemos que os reis godos tiveram os

\footnotetext{
${ }^{842}$ Historia Wambae, 6
} 
vascones como grandes inimigos, assim como os francos, inimigos óbvios na Chronica de João de Bíclaro. Ao dizer que justamente os francos e os vascones apoiaram Paulo, Juliano de Toledo citou duas gentes já hostis ao reino dos godos. Isso dá a narrativa de Juliano um sentido importante: a rebelião de Paulo não era apenas contra Wamba, mas contra todo o reino uma vez que contou com inimigos estrangeiros. Nas palavras de Juliano esse elemento é sublinhado:

Ubi dum Paulus perfidiae suae socios numerosiores efficere vellet, prolatis primissisque muneribus Francorum Wasconumque multitudines in auxiliam sui pugnaturas adlegit, et intra Gallias cum multitudine hostium persistit, opperiens eventum gratissimi temporis, quo posset in Hispanias pugnaturus accedere, perceptumque regni fastigium vindicare. ${ }^{843}$

É todavia no capítulo 9 que a glorificação da gens gothorum a partir da diminuição da gens francorum aparece mais evidente. Nesse capítulo Juliano de Toledo reproduz a suposta fala de Wamba para o exército godo que se preparava para enfrentar Paulo e seus aliados francos. Nesse trecho o contraste se dá pela oposição entre os efeminados e os viris, onde Wamba clama que os godos mostrem que eles lutam como homens e com seus homens, não com suas mulheres:

Quasi effeminatos et molles nos usquequaque dijudicans, qui urique nullis armis, nullis viribus, nullisque consiliis ejus tyrannidi resistere valeamus. [...]. Neque enim cum feminis, sed cum viris nobis certandum est. ${ }^{844}$

O clamor a favor das armas se dá dessa maneira por uma clara oposição entre os viris godos e os inimigos francos de modo que a virilidade é descrita como imanente à gens gothorum numa afirmação identitária fundada em direta oposição aos outros, aos inimigos francos.

\footnotetext{
${ }^{843}$ Historia Wambae, 8.

${ }^{844}$ Historia Wambae, 9.
} 
Nos três autores, João de Biclaro, Isidoro de Sevilha e Juliano de Toledo, o confronto com os inimigos aparece como um embate entre a gens gothorum - um todo unitário liderado por seus reis - contra o outro inimigo, igualmente retratado como uma unidade. A qualidade da em Juliano de Toledo esse contraste é ainda mais saliente: o combate contra os inimigos passa por algo que transcende a própria disputa territorial, trata-se de um embate entre a virilidade, coragem e bravura representada a partir de uma gens liderada por um rei, cristão e ungido, contra o inimigo covarde. Nesse caso, ao valorizar a gens o autor justifica o poder do próprio rei legítimo contra o tirano Paulo. A tirania de Paulo vai além da traição ao rei, o escândalo reside no fato de que ele se uniu com os inimigos infames e covardes e, ao trair o rei, traiu também a patria e a gens gothorum. Esse tema, como vimos na discussão sobre as leges, não é novidade. A contrução identitária acerca da gens gothorum se dava sobre o tripé da fé - desde a conversão de Recaredo - a patria e o rei que unia todos esses valores. A gens gothorum, no texto de Juliano, é explicitamente uma identidade política que se destaca sobre outras identidades políticas: a dos traidores em torno de Paulo, a dos infames francos. É assim, em torno da identidade goda em confronto com os francos que a autoridade de Wamba se confirma.

Um movimento de construção identitária com certas similaridades ao até agora discutido pode ser encontrado também nos textos produzidos na Gália merovíngia. Cabe começarmos com Gregório de Tours e sua interpretação sobre os godos. Não é novidade a antipatia do bispo de Tours direcionada aos visigodos ${ }^{845}$ e a narrativa do bispo de Tours sobre a gens gothorum explicita o quanto sob sua pena encontramos a valorização dos francos em contraste com os godos. Uma apreciação detida da questão merece destaque.

\footnotetext{
${ }^{845}$ Como já mostrou B. Saitta que num apontamento interessante mostra o quanto a narrativa referente à vitória de Clóvis contra os godos salienta a nobreza imanente dos francos nas suas vitórias contra os godos: SAITTA, B. Gregorio di Tours e i Visigoti. Catania: C.U.E.C.M, 1996. p.29-30.
} 
Tabela 16: Os godos nos Decem Libri Historiarum

\begin{tabular}{|c|c|}
\hline \multicolumn{2}{|c|}{ Os godos nos Decem Libri Historiarum } \\
\hline \multicolumn{2}{|c|}{ Livro II } \\
\hline Trechos & Comentários \\
\hline $\begin{array}{l}\text { Multae enim heresis eo tempore Dei eclesias } \\
\text { inpugnabant, de quibus plerumque ultio } \\
\text { divina data est. Nam et Athanaricus } \\
\text { Gothorum rex magnam excitavit } \\
\text { persecutionem; qui multus christianorum } \\
\text { diversis poenis adfectus gladio detruncabat; } \\
\text { sed et nonnullus exilio datus fame variisque } \\
\text { cruciatibus enecabat. Unde factum est, ut, } \\
\text { inminente iudicio Dei, pro effusione } \\
\text { sanguinis iusti a regno depelleretur et esset } \\
\text { exsul a patria, qui Dei eclesias inpugnabat. } \\
\text { Sed ad superiora redeamus. } 4\end{array}$ & $\begin{array}{l}\text { Os godos são inicialmente mencionados nos } \\
\text { Decem Libri Historiarum já sob uma leitura } \\
\text { negativa que destaca as perseguições } \\
\text { empreendidas por Atanarico contra os } \\
\text { cristãos. }\end{array}$ \\
\hline $\begin{array}{l}\text { Igitur Aetius cum Gothis Francisque } \\
\text { coniunctus adversus Attilanem confligit. } 7\end{array}$ & $\begin{array}{l}\text { Esse consiste num dos raros trechos em que } \\
\text { os godos e os francos lutam lado a lado, } \\
\text { nesse caso, junto à Aécio contra Átila e seus } \\
\text { hunos que representavam uma ameaça para } \\
\text { todo o Ocidente. }\end{array}$ \\
\hline $\begin{array}{l}\text { Renatus Profuturus Frigiretus, cui iam supra } \\
\text { meminimus, cum Romam refert a Gothis } \\
\text { captam atque subversam [...] } 9\end{array}$ & $\begin{array}{l}\text { Referência à Renato Frigireto e o saque de } \\
\text { Roma realizado pelos godos }\end{array}$ \\
\hline Ultra Ligerem vero Gothi dominabantur... 9 & Região dos assentamentos dos godos \\
\hline $\begin{array}{l}\text { Brittani de Bituricas a Gothis expulsi sunt, } \\
\text { multis apud Dolensim vicum peremptis. } \\
\text { Paulos vero comes cum Romanis ac Francis } \\
\text { Gothis bella intulit et praedas egit. } 18\end{array}$ & $\begin{array}{l}\text { Os godos expulsam os Bretões Bourges e o } \\
\text { conde Paulo, junto aos romanos e francos, } \\
\text { declara guerra aos godos }\end{array}$ \\
\hline $\begin{array}{l}\text { Eoricus autem Gothorum rex Victorium } \\
\text { ducem super septem civitatis praeposuit anno } \\
\text { XIIII, regni sui. Qui protinus Arvernus } \\
\text { adveniens, civitatem addere voluit, unde et } \\
\text { criptae illae usque hodie perstant. Ad } \\
\text { basilicam sancti Iuliani colomnas, quae sunt } \\
\text { in aede positae, exhibere iussit. Basilicam } \\
\text { sancti Laurenti et sancti Germani } \\
\text { Licaniacensis vici iussit aedificare. Fuit } \\
\text { autem Arvernus annis novem. Super } \\
\text { Euchirium vero senatorem calumnias } \\
\text { devolvit; quem in carcere positum nocte } \\
\text { extrahi iussit, ligatumque iuxta parietem } \\
\text { antiquum, ipsum parietem super eum elidi } \\
\text { iussit. Ipse vero dum nimium esset in amore } \\
\text { mulierum luxoriosus et ab Arvernus veriritur } \\
\text { interfeci, Romam aufugit, ibique similem } \\
\text { timptans exercere luxoriam, lapidibus est } \\
\text { obrutus. Post cuius excessum regnavit } \\
\text { Euricus annus IIII; obiit autem anno } \\
\text { vicissimo septimo regni sui. Fuit etiam et } \\
\text { tunc terrae motus magnus. }\end{array}$ & $\begin{array}{l}\text { O rei dos godos Eurico (embora Gregório } \\
\text { salienta que ele reformou algumas basílicas, } \\
\text { o relato do bispo acerca do rei termina com } \\
\text { a ênfase em sua luxúria) }\end{array}$ \\
\hline
\end{tabular}




\begin{tabular}{|c|c|}
\hline $\begin{array}{l}\text { Quem Ecdicium mirae velocitatis fuisse, } \\
\text { multi commemorant. Nam quadam vice } \\
\text { multitudinem Gothorum cum decim viris } \\
\text { fugasse perscribitur. } 24\end{array}$ & $\begin{array}{l}\text { Relato sobre o senador Ecdício. Vemos nesse } \\
\text { trecho como Gregório de Tours salienta a } \\
\text { vitória do senador da região da Burgúndia } \\
\text { contra os godos como uma das qualidades } \\
\text { dele. É notável que Gregório afirmou que } \\
\text { Ecdício derrotou com dez homens uma } \\
\text { multidão de godos. Como já vimos no caso } \\
\text { da vitória do dux Paulo contra os francos, o } \\
\text { triunfo de poucos homens contra uma grande } \\
\text { quantidade de inimigos era uma tópica } \\
\text { recorrente comumente presente para destacar } \\
\text { a providência divina em favor dos tementes à } \\
\text { Deus. }\end{array}$ \\
\hline $\begin{array}{l}\text { Huius temporis et Euarix rex Gothorum, } \\
\text { excidens Hispanum limitem, gravem in } \\
\text { Galliis super christianis intulit } \\
\text { persecutionem. Truncabat passim } \\
\text { perversitate suae non consentientis, clericus } \\
\text { carceribus subegebat, sacerdotis vero alius } \\
\text { dabat exilio, alius gladio trucidabat. Nam et } \\
\text { ipsus sacrorum templorum aditus spinis } \\
\text { iusserat obserari, scilicet ut raritas } \\
\text { ingrediendi oblivionem facerit fidei. Maxime } \\
\text { tunc Novimpopulanae geminaeque } \\
\text { Germaniae urbes ab hac tempestate } \\
\text { depopulatae sunt. Extat hodieque et pro ac } \\
\text { causa ad Basilium episcopum nobilis Sidoni } \\
\text { ipsius epistola, quae haec ita loquitur. Sed } \\
\text { persecutor non post multum tempus ultione } \\
\text { divina percussus interiit. } 25\end{array}$ & $\begin{array}{l}\text { Gregório de Tours fala das perseguições } \\
\text { empreendidas por Eurico contra os cristãos } \\
\text { na fronteira da Hispania. }\end{array}$ \\
\hline $\begin{array}{l}\text { Post haec beatus Perpetuus Turonicae } \\
\text { civitatis episcopus, impletis triginta in } \\
\text { episcopatu annis, in pace quievit. In cuius } \\
\text { loco Volusianus, unus ex senatoribus, } \\
\text { subrogatus est. Sed a Gothis suspectus } \\
\text { habitus, episcopatus sui anno septimo in } \\
\text { Hispaniis est quasi captivus adductus, sed } \\
\text { protinus vitam finivit. In cuius loco Virus } \\
\text { succedens, septimus post beatum Martinum } \\
\text { ordinatur episcopus. } 26\end{array}$ & $\begin{array}{l}\text { Os godos continuam com suas suspeitas } \\
\text { contra os cristãos na narrativa de Gregório de } \\
\text { Tours, nesse trecho vemos a ação deles } \\
\text { contra Volusiano, o sucessor de Perpétuo na } \\
\text { diocese de Tours }\end{array}$ \\
\hline $\begin{array}{l}\text { Chlodovechus vero ad Alarico mittit, ut eum } \\
\text { redderit; alioquin noverit, sibi bellum ob eius } \\
\text { retentationem inferri. Ad ille metuens, ne } \\
\text { propter eum iram Francorum incurrerit, ut } \\
\text { Gothorum pavere mos est, vinctum legatis } \\
\text { tradedit. } 27\end{array}$ & $\begin{array}{l}\text { Depois que Siágrio escapa para o reino dos } \\
\text { godos, Clóvis, o rei dos francos, envia } \\
\text { embaixadores para o rei dos godos, Alarico, } \\
\text { requisitando que Siágrio fosse entregue aos } \\
\text { francos. Alarico teme Clóvis e envia Siágrio } \\
\text { acorrentado para os francos. Nesse trecho a } \\
\text { força de Clóvis e seu exército é enfatizada } \\
\text { pelo temor que despertava nos godos, além } \\
\text { disso, Gregório destaca a fraqueza dos godos } \\
\text { que tinham por hábito o medo. O trecho é } \\
\text { emblemático, nele vemos o contraste entre a } \\
\text { bravura imanente aos francos em detrimento } \\
\text { à covardia dos godos. Interessante comparar } \\
\text { o tema da covardia na valorização das gentes }\end{array}$ \\
\hline
\end{tabular}




\begin{tabular}{|c|c|}
\hline & $\begin{array}{l}\text { feita por Juliano de Toledo e Gregório de } \\
\text { Tours. O discurso identitário centrado na } \\
\text { coragem e virilidade é usado por ambos os } \\
\text { autores para finalidades contrárias: um para } \\
\text { valorizar os godos, o outro para valorizar os } \\
\text { francos. }\end{array}$ \\
\hline $\begin{array}{l}\text { Igitur Alaricus rex Gothorum cum viderit, } \\
\text { Chlodovechum regem gentes assiduae } \\
\text { debellare, legatus ad eum dirigit, dicens: 'Si } \\
\text { frater meus vellit, insederat animo, ut nos } \\
\text { Deo propitio pariter videremus'. Quod } \\
\text { Chlodovechus non respuens, ad eum venit. } \\
\text { Coniunctique in insula Ligeris, quae erat } \\
\text { iuxta vicum Ambaciensim terreturium urbis } \\
\text { Toronicae, simul locuti, comedentes pariter } \\
\text { ac bibentes, promissa sibi amicitia, pacifici } \\
\text { discesserunt. Multi iam tunc ex Galleis } \\
\text { habere Francos dominos summo desiderio } \\
\text { cupiebant. } 35\end{array}$ & $\begin{array}{l}\text { O temor que Clóvis despertava em Alarico é } \\
\text { um tema que se repete no capítulo } 35 \text {. Nele, } \\
\text { Alarico, vendo que Clóvis avançava e } \\
\text { derrotava muitas gentes, tenta estabelecer um } \\
\text { pacto de amizade com o rei dos francos. } \\
\text { Como sabemos, o pacto feito entre os reis } \\
\text { descrito nesse trecho não foi respeitado por } \\
\text { Clóvis que em } 507 \text { marchou contra os godos } \\
\text { e destruiu o reino de Toulouse. Gregório } \\
\text { evidentemente sabia disso também e insinua } \\
\text { uma justificativa para a ruptura do pacto por } \\
\text { parte de Clóvis: os habitantes da Gália } \\
\text { ansiavam pela chegada dos francos à região. } \\
\text { O tema do desejo dos habitantes da Gália de } \\
\text { estarem sob o domínio de Clóvis se repete no } \\
\text { capítulo } 36 \text {, até que finalmente no capítulo } 37 \\
\text { o rei dos francos decide tomar o reino } \\
\text { visigodo de Toulouse. }\end{array}$ \\
\hline
\end{tabular}

Percebemos a partir dos relatos sobre os godos no livro II dos Decem Libri Historiarum que as principais características dos godos destacadas por Gregório de Tours são a covardia e a perseguição aos cristãos. Isso contrasta com os relatos acerca dos francos feita pelo bispo de Tours, como já apresentamos no capítulo dedicado às histórias. No livro III há menos menções aos godos, as narrativas basicamente se restringem às tomadas de cidades godas por parte dos filhos de Clóvis ${ }^{846}$ e a tomada de Arles pelos godos. ${ }^{847}$ Há entretanto nessa parte da obra um trecho emblemático que aponta mais uma vez para a antipatia de Gregório de Tours em relação aos godos. Nesse trecho, o bispo menciona o assassinato de três reis godos e salienta que essas mortes foram consequiência de uma hábito ruim dos godos que consistia em assassinar os reis que não os agradava:

Post Amalaricum vero Theuda rex ordinatus est in Hispaniis. Quem

\footnotetext{
${ }^{846}$ Decem Libri Historiarum, III, 21.

${ }^{847}$ Decem Libri Historiarum, III, 23
} 
interfectum, Theudegisilum levaverunt regem. His dum ad caenam cum amicis suis aepularet et esset valde laetus, caereis subito extinctis, in recubitu ab inimicis gladio percussus, interiit. Post quem Agila regnum accepit. Sumpserant enim Gothi hanc detestabilem consuetudinem, ut, si quis eis de regibus non placuisset, gladio eum adpeterent, et qui libuisset animo, hunc sibi statuerent regem. ${ }^{848}$

Efetivamente, como verificamos com a análise da Historia Gothorum de Isidoro de Sevilha, o assassinato de reis não eram incomuns na Hispânia visigótica. No caso dos relatos isidorianos, comumente esses eventos eram interpretados como consequiências dos atos injustos dos reis assassinatos. No caso de Gregório o fenômeno ganha uma outra leitura, o bispo atribui essas mortes à algo imanente aos godos. Esse tema se repete no livro IV quando mais uma vez Gregório de Tours traz notícias sobre a Hispânia. Nesse trecho o bispo fala da ascensão de Liuva I e Leovigildo ao trono, menciona o matrimônio dos filhos de Leovigildo com as princesas francas - uma filha de Sigiberto e outra filha de Chilperico - e fecha o capítulo mencionando o hábito godo que assassinar seus reis:

Ergo, ut ad historiam recurramus, mortuo apud Hispaniam Athanaeldo rege, Leuva cum Leuvieldo fratre regnum accepit. Defuncto igitur Leuvane, Leuvieldus, frater eius, totum regnum occupavit. Qui, uxorem mortuam, Gunsuintham, reginae Brunichildis matrem, accepit, duos filios de prima uxore habens, quorum unus Sigyberthi, alius Chilperici filiam disponsavit. Ille quoque inter eos regnum aequaliter divisit, interficiens omnes illos qui regis interemere consueverant, non relinquens ex eis mingentem ad parietem. ${ }^{849}$

Até esse ponto é possível notar um claro contraste feito por Gregório de Tours entre os francos e os visigodos. Embora as políticas matrimoniais entre os reinos por vezes fossem comemoradas, como o matrimônio de Brunilda com Sigiberto, o relato geral do bispo acerca dos vizinhos da Hispânia é muito negativo.

Não obstante, em uma interessante passagem, o bispo de Tours registra os cuidados com a preparação de Rigunta, filha de Chilperico, que havia sido enviada à

\footnotetext{
${ }^{848}$ Decem Libri Historiarum, III, 30.

${ }^{849}$ Decem Libri Historiarum, IV, 38.
} 
Hispania para casar-se com Recaredo. Próxima à fronteira com a Hispania a caravana que transportava Rigunta e seus muitos tesouros parou para que a princesa fosse vestida de maneira adequada de modo que não despertasse o riso dos godos:

Dum haec agerentur, Rigunthis, Chilperici regis filia, cum thesauris supra scriptis usque Tholosam accessit. Et cernens se iam ad terminum Gothorum esse propinquam, moras innectire coepit, dicentibus sibi tum praeterea suis, oportere eam ibidem commorari, cum ipsi fatigati de itenere vestimenta haberent inculta, calciamenta scissa, ipsosque equorum adque carrucarum apparatos adhuc, sicut plaustris evecti erant, seorsum esse disiunctos. Oportere potius omnia haec prius diligenter stabilire et sic in itenere proficisci ac suscepi cum omni elegantia ab sponso, ne forte, si inculti inter Gothos apparerent, inriderentur ab ipsis. ${ }^{850}$

Transparece nesse trecho uma interessante preocupação com a apresentação da princesa franca. Primeiro, ela trazia uma enorme quantidade de tesouros, o que mostraria para os godos - importantes inimigos dos francos como é já possível constatar pela imagem negativa feita por Gregório de Tours acerca dos vizinhos toda a riqueza que os reis francos possuíam. Segundo, a própria imagem da princesa entrava na visão que a comitiva franca esperava que os godos tivessem dos francos: ela deveria se apresentar bela e esplendorosa como uma legítima filha da realeza franca. Disso se infere que as tensões políticas entre os francos e os visigodos se articulava em diversos níveis. Além das batalhas e das narrativas acerca das vitórias e derrotas, as políticas matrimonias, além das alianças políticas que poderiam garantir, eram envoltas por uma afirmação identitária franca ou visigoda fundamentada nas riquezas que os reis possuíam e que se esforçavam por apresentar aos rivais mediante os tesouros e a beleza que suas princesas portavam. O movimento era de mão dupla. Ao mesmo tempo que Brunilda chegou à corte de Sigiberto carregada de tesouros, Rigunta foi enviada à Hispania com uma quantidade ainda mais deslubrante de riquezas. Desenvolveremos esse tema com mais vagar adiante.

\footnotetext{
${ }^{850}$ Decem Libri Historiarum, VI, 9.
} 
É interessante notar que a imagem acerca dos godos nas outras Historiae escritas na Gália se manteve relativamente semelhante ao texto de Gregório de Tours. A questão do hábito ruim dos godos de assassinarem seus reis aparece também na Chronica de Fredegário com redação ligeramente diferente da de Gregório de Tours:

Decem Libri Historiarum

Post Amalaricum vero Theuda rex ordinatus est in Hispaniis. Quem interfectum, Theudegisilum levaverunt regem. His dum ad caenam cum amicis suis aepularet et esset valde laetus, caereis subito extinctis, in recubitu ab inimicis gladio percussus, interiit. Post quem Agila regnum accepit. Sumpserant enim Gothi hanc detestabilem consuetudinem, ut, si quis eis de regibus non placuisset, gladio eum adpeterent, et qui libuisset animo, hunc sibi statuerent regem.

\section{Chronica de Fredegário}

Post Amalricum Theoda regnat Spaniis; quo interfecto, Teudegyselus regnum adsumit, qui, dum ad caenam letus sederit, extinctis caereis, a suis occidetur. Cui Aggyla succedit in regnum. Gothi vero iam olim habent vicium, cum rex eis non placeat, ab ipsis interficetur.

A repetição na Chronica não pode ser vista como uma mera cópia do texto gregoriano, o que precisa ser sublinhado é antes a repetição de um tema, a saber, a afirmação da superioridade dos francos em contraste com os godos, nesse caso, no que concerne à relação entre os súditos e os reis. Ora, como já argumentamos, as Historiae comumente traçavam um íntimo paralelo entre a gens e os reis no qual especialmente no início da Chronica e do Liber Historiae Francorum - o sucesso da gens se relacionava com os reis uma vez que eles representavam a unidade abstrata da gens francorum. Ao observarmos que Gregório de Tours e o autor da Chronica apontam a fraqueza dessa relação podemos inferir que eles tratavam da própria fragilidade da unidade da gens gothorum em contraste com a força da gens francorum: unida e vitoriosa em batalhas.

Ainda cabe ressaltar que a vitória contra os godos ganha destaque na Chronica também. O final do reinado de Clóvis tem como um dos marcos a vitória do rei contra os godos em 507: “Obiit [Clóvis] post Voglensim bellum anno 5. Regnum tenuit 
ann.30” ${ }^{851}$ Já no Liber Historiae Francorum o destaque se dá com a vitória de Clóvis contra o rei dos godos, Alarico: "Mortuus est autem anno quinto, postquam cum Alarico rege Gothorum pugnavit. ${ }^{852}$ Um interpretação que nos parece cabível para essa mudança narrativa se trata da maior ênfase da vitória dos reis contra outros reis que o autor do Liber Historiae Francorum procurou destacar num cenário de grande polarização, como já discutirmos no capítulo dedicado às histórias. O que queremos dizer é que o contraste entre godos e francos reforça um ideal de força e unidade concretizada na figura dos reis em obras que respondiam à um contexto de polarização política. A narrativa identitária operava em vários níveis, inclusive na construção da imagem do "outro". E isso fica especialmente em evidência quando observarmos a versão "franca" para a derrota de Gontrão diante das tropas de Recaredo.

Como observamos, nos relatos de João de Biclaro e de Isidoro de Sevilha a vitória do exército de Recaredo que liderado pelo dux Cláudio venceu milagrosamente os francos. Já entre os francos o ocorrido ganhou versões bem diversas. Em Gregório de Tours a derrota foi atribuída à falta de respeito com os santos e a perda do costume de construir igrejas para honrar suas memórias. Nos Decem Libri Historiarum, foi o próprio rei Gontrão que fez tal constatação ao se dirigir aos líderes das tropas:

'Qualiter nos hoc tempore victuriam obtenere possumus, quia ea quae patres nostri secuti sunt non costodimus? Illi vero aeclesias aedificantes, in Deum spem omnem ponentes, martyres honorantes, sacerdotes venerantes, victurias obtinuerunt gentesque adversas, divino opitulante adiutorio, in ense et parma saepius subdiderunt.[...] ${ }^{, 853}$

Já na Chronica de Fredegário a derrota tem outra versão. O autor a atribuíu à

\footnotetext{
${ }^{851}$ Chronica, livro III, 28

${ }^{852}$ Liber Historiae Francorum, 19

${ }^{853}$ Decem Libri Historiarum, livro VIII, 30.
} 
incapacidade de Boso, um dos líderes do exército. A questão religiosa perde peso para enfatizar a incompetência de um nobre na liderança do exército:

Anno 29. Gunthramni exercitus in Spaniam eiusdem iusso diregitur, sed negligenciam Bosone, qui capud exercitus fuit, graviter a Gotis exercitus ille trucidatur. ${ }^{854}$

Já o Liber Historiae Francorum não menciona a dita derrota. O que temos nos relatos feitos por autores que escreviam desde o reino dos francos é a atribuição da derrota à duas falhas pontuais sem qualquer relação com uma falha imanente à gens francorum: no primeiro há o relapso com a religião, no segundo um erro de um dux. A grandeza da gens francorum continua intacta.

Percebemos nesses casos algo que tomou um peso importante nos estudos sobre identidades. Elas se constroem e se afirmam também em contraste com os "outros" nas tentativas de alianças e nas tensões com outros reinos. Não obstante, observamos um esforço de criar uma imagem própria: os viris godos de Juliano de Toledo; os godos ajudados por Deus de Isidoro de Sevilha e João de Biclaro. Ainda mais interessante e perceber que a existência de uma entidade "goda" e "franca" era reconhecida mutuamente, mesmo que esse reconhecimento fosse também um movimento de afirmação da própria identidade política contra a identidade do outro: fraco, covarde, infiel com seus reis.

\footnotetext{
${ }^{854}$ Chronica, livro IV, 10.
} 


\section{Capítulo X - Nós e os outros - as rainhas}

Numa interessante conferência apresentada em Leeds no ano de $2014^{855}$ a

Professora Cristina La Rocca mostrou o quanto a imagem das mulheres estrangeiras possui um enorme potencial para a discussão acerca do problema das identidades. De fato, a abordagem da Professora La Rocca dialoga com críticas que já apontavam a relevância de enfrentar o tema das identidades a partir de várias frentes uma vez que não necessariamente as identidades se constroem a partir de um ideal étnico. ${ }^{856}$ Halsall, por exemplo, mostrou o quanto marcadores relacionados ao sexo e à idade dos indivíduos sepultados eram fatores mais relevantes como marcadores identitários do que identidades étnicas. ${ }^{857}$ Essas novas perspectivas são inegavelmente importantes uma vez que ampliam as possibilidades de estudo e apresentam outras possibilidades para pensarmos o problema das identidades. ${ }^{858}$

Nesse último tópico desejamos discutir brevemente esse problema, mas a partir de um enfoque muito específico inspirado no trabalho da Prof ${ }^{\mathrm{a}}$. La Rocca, a

\footnotetext{
${ }^{855}$ LA ROCCA, C. Foreign dangers. Activities, responsibilities and the problem of women abroad. Conferência apresentada no IMC. Leeds, 2014. 19 pp. Disponível em: https://www.academia.edu/7693666/Foreign_dangers._Leeds_IMC_2014

${ }^{856} \mathrm{O}$ volume organizado por J. Smith e L. Brubaker consiste num dos esforços para dar conta das identidades a partir de outras perspectivas, com foco na questão de gênero. Para uma excelente introdução: SMITH, Julia M.H. Introduction: gendering the early medieval world. In: BRUBAKER, L. \& SMITH, Julia M.H. Gender in the Early Medieval World. East and West, 300-900. Cambridge: Cambridge University Press, 2004. p.1-19. Mais recentemente a Prof ${ }^{a}$. La Rocca organizou também um dossiê dedicado ao tema. No mesmo volume, a Prof ${ }^{a}$. apresenta uma interessante discussão historiográfica que indica como o tema ganha gradativamente - embora ainda timidamente importância na historiografia italiana: LA ROCCA, C. Introduzione. Genesis. Rivista dela Società Italiana dele Storiche. (Donne in famiglia nell'alto medioevo. V. IX, n.1, p.5-14, 2010. É de enorme interesse também o conjunto de artigos publicados pela Prof. Le Jan e reunidos no volume: LE JAN, R. Femmes, pouvoir et société dans le Haut Moyen Âge. Paris: Picard, 2001. Uma discussão geral sobre o novo fôlego que a história sobre as mulheres ganhou com a entrada dos estudos de gênero pode ser consultada em: NELSON, J. Family, Gender and Sexuality in the Middle Ages. In: BENTLEY, M. Companion to Historiography. London \& NY: Routledge, 1997. p.153-176.

${ }^{857}$ HALSALL, G. Female status and power in early Merovingian central Austrasia: the burial evidence. Early Medieval Europe. v.5, n.1, p.1-24, 1996.

${ }^{858}$ Mesmo W. Pohl que comumente se dedica mais à questão das identidades étnicas constatou o quanto a questão de gênero pode ser rica para a própria abordagem do problema das etnicidades. POHL, W. Gender and ethnicity in the early Middle Ages. In: BRUBAKER, L. \& SMITH, Julia M.H. Gender in the Early Medieval World. East and West, 300-900. Cambridge: Cambridge University Press, 2004. p.23-43.
} 
saber, como as rainhas estrangeiras foram apresentadas nas fontes com as quais lidamos? De que forma a presença dessas rainhas nas narrativas nos ajudam a compreender como as identidades das gentes se construíam em contraste ou colaboração com o "outro", no caso, mulheres que vinham de reinos distantes para se casarem com os reis godos e merovíngios?

Não poderíamos começar esse trabalho sem mencionarmos Brunilda que esteve presente ao longo de todo esse texto. Não por acaso. A princesa visigoda, filha de Atanagildo, foi um personagem crucial na política da Gália Merovíngia entre a segunda metade do século VI e início do século VII: ela foi peça chave na condução do reino ao lado de seu filho, ela participou ativamente do Tratado de Andelot, ela atuou ao lado de seu neto e, por fim, ela acabou humilhada e morta. Sua intensa vida política redundou numa personagem de difícil interpretação a começar pela pluralidade de imagens que as fontes apresentam sobre a rainha, desde a celebração feita por Venâncio Fortunato e Gregório de Tours até a visão negativa da Chronica de Fredegário e da Vida de Desidério de Sisebuto e o título outorgado por Jonas Bobbio à ela em sua Vita Columbani, a "Segunda Jezebel". ${ }^{859}$ Foi justamente o adjetivo dado por Jonas à rainha que teve repercussão em outras fontes, como a Chronica de Fredegário que chega a reproduzir trechos inteiros do documento e que perdurou mesmo na historiografia até o artigo de G. $\operatorname{Kurth}^{860}$ que buscou resgatar a imagem da rainha retratando-a como uma injustiçada assassinada cruelmente por conta de suas estratégias políticas que visavam defender sua família diante de uma aristocracia violenta que se opunha à ela. Tal como Maria Antonieta, escreve Kurth, Brunilda manteve-se digna mesmo em face à seus momentos derradeiros. A idealização, para o

\footnotetext{
${ }^{859}$ [...] mentem Brunichildis aviae [de Teodorico], secundae ut erat Zezabelis, antiquus anguis adiit eamque contra virum Dei [Columbano] stimulatam superbiae aculeo excitat, quia cerneret viro Dei Theudericum oboedire. Vita Columbani, 18.

${ }^{860}$ KURTH, G. La Reine Brunehaut. Paris: Bureaux de la Revue, 1891.
} 
bem ou para o mal, permeia assim as narrativas sobre Brunilda de modo a tornar a reconstrução da "verdadeira" Brunilda - objetivo de Kurth e em certa medida de B. Dumezil $^{861}$ - uma tarefa inglória, como bem apontou E. Thomas. ${ }^{862}$ Ao lidarmos com Brunilda devemos ter em mente que o esforço por construir uma imagem coerente, realista da rainha, é um erro, tal como é um erro buscar esses mesmo objetivo ao lidarmos com os godos e os francos. De fato, a riqueza de Brunilda está justamente na diversidade de opiniões sobre ela, tese esta defendida com brilhantismo por E. Thomas.

De fato, a bela rainha descrita por Venâncio Fortunato e Gregório de Tours se torna, sob a pena de Sisebuto, uma mulher cruel que alheia à suas nobres origens se tornou capaz das maiores maldades enquanto Teodorico, seu neto, foi descrito como um estúpido:

[...]regnante simul scilicet Theodorico, totius hominem stultitiae dignum, et fautricem pessimarum artium. malis amicissimam Brunigildem. Quandam pariter matronam conveniunt, quae erat prosapiae nobilis, sed mente deformis, Iusta vocabulo, turpis in acto, decus in nomine, sed dedecus magis in opere, bonis indigua, nimium de malis onusta, a veritate externa, a crimine numquam discreta. ${ }^{863}$

Nessa descrição de Sisebuto já podemos tirar alguns comentários interessantes. Ora, cabe lembrar que Sisebuto foi um rei godo e estava ciente da origem goda de Brunilda. A ciência do rei se manifesta pelo contraste que ele traça entre a origem de Brunilda e os atos que ela realizou. Embora nobre de nome e origem, ela era torpe, havia uma mente deformada e atuava de maneira infame de modo que condenou o Santo Desidério em um concílio injusto. Há o reconhecimento da nobreza das origens de Brunilda - uma rainha de origem goda - mas seus atos são

\footnotetext{
${ }^{861}$ DUMÉZIL, B. La reine Brunehaut. Paris: Fayard, 2008.

${ }^{862}$ THOMAS, Emma J. The 'second Jezebel': representations of the sixth-century Queen Brunhild. PhD Thesis. University of Glasgow. School of Humanities. October, 2012. 241pp.

${ }^{863}$ Vita Desiderii, 4.
} 
justificados pela própria transgressão que ela realizou ao perseguir o homem santo. Em poucas palavras, apesar de nobre, Brunilda desonrou suas origem e cometeu atos infames. Observamos uma manobra narrativa realizada por Sisebuto que desvinculou a maldade de Brunilda de sua origem goda.

Surpreendente entretanto notar que no caso de Brunilda sua origem goda não é apontada como fator crucial para a imagem negativa construída sobre a rainha mesmo por fontes francas. No caso de Brunilda, o marcador identitário godo não foi o determinante para a memória negativa construída sobre ela. Mesmo nas epístolas austrasianas atribuídas à própria rainha ${ }^{864}$ ela não tinha a identidade "goda" como referência. Nas três epístolas, Brunilda se autointitulou "rainha", uma rainha preocupada com algo concreto referente à sua progenitura: a permanência de seu neto Atanagildo no Oriente, evento que chegou à esse ponto quando sua filha, Igunda, tentou escapar como o príncipe depois da derrota de Hermenegildo diante do pai, Leovigildo. De fato, foi como rainha, mãe e avó que Brunilda se apresentou sendo esses fatores usados por ela como instrumento político para obter seu desejo, trazer Atanagildo seguro para a Gália.

$\mathrm{Na}$ carta a Atanagildo, seu jovem neto, a rainha expressa seu apego ao neto, a continuação da progenitura de sua filha Igunda que aliviava a dor da rainha pela perda da filha:

Accessit mihi, nepus carissime, votiva magne felicitatis occasio, per quam, cuius aspectum frequenter desidero vel pro parte relevor, cum directis epistulis amabilibus illis oculis repraesentor, in quo mihi, quam peccata subduxerunt, dulcis filia revocatur; nec perdo natam ex integro, si, praestante Domino, mihi proles edita conservatur. ${ }^{865}$

Já na carta anterior, da rainha ao imperador Maurício, o destaque se dá a apresentação de Brunilda como mãe de Childeberto:

\footnotetext{
${ }^{864}$ Epístolas 26, 27 e 44.

${ }^{865}$ Epístola 26.
} 
Serenissimi principatur vestri clementia ad praecellentissimum filium nostrum, Hildebertum regem, directa pervenit epistula: significamus nos pacis dedisse consilium. ${ }^{866}$

Já na epístola à Imperatriz ${ }^{867}$ lemos a rainha apelando para a fé e para a piedade da imperatriz, também ela mãe, a fim de obter o retorno de Atanagildo:

Et quia, augusta tranquilissima, casu faciente, parvuli nepotis mei didicit peregrinare infantia et ipsa innocentia annis teneris coepit esse captiva, rogo per redemptorem omnium gentium, sic vobis non videatis subtrahi piissimum Theodocium, nec ab amplexu matris dulcis filius separetur, sic vestra lumina semper exhilaret sua praesentia, simul et matris viscera augusto delectentur de partu: ut iubeatis agere, favente Christo, qualiter meum recipere merear parvulum, in amplexu refrigerentur viscere, quae de nepotis absentia gravissimo dolore suspirant, ut, que amisi filiam, vel dulce pignum ex ipsa, quod mihi remansit, non perdam, adusque de morte geniti crucior, relever per vos cito nepote redeunte captivo: quatinus, dum me dolentem atque illum innocentem respicitis, et de Deo, qui est universalis redemptio, mercedem gloriae recipiatis, absoluto captivo, et inter utramque gentem per hoc, propitiante Christo, caritas multiplicetur et pacis terminus extendatur. ${ }^{868}$

E. Thomas no seu interessante trabalho indica que o recurso à imagem de mãe e avó nas cartas de Brunilda eram mais um instrumento político que lançava mão do papel das mulheres como mantenedoras da família do que de fato um sentimento maternal nutrido por Brunilda e desinteressado em termos políticos. ${ }^{869}$ Efetivamente seria ingenuidade analisarmos a correspondência de Brunilda com o Bizâncio apenas em termos emotivos. Os argumentos de Thomas são convincentes: ao declarar, no início da epístola 44, que Childeberto havia já alcançado a maioridade Brunilda estava dando um recado para o Bizâncio. Sua correspondência era antes de tudo diplomática e política e relacionado com a questão dos longobardos na Itália e o apoio que os francos dariam às tropas de Maurício. Entretanto podemos ir um pouco além e

\footnotetext{
${ }^{866}$ Epístola 27.

${ }^{867}$ Há um debate sobre quem seria a "Imperatriz" a quem Brunilda se dirigiu, Anastásia, esposa de Tibério, ou Constantina, filha de Anastásia que se casou com Maurício, sucessor de Tibério. Para E. Thomas a carta era endereçada à Constantina. THOMAS, E. J. The 'second Jezebel': representations of the sixth-century Queen Brunhild...op.cit. p.140.

${ }^{868}$ Epístola 44.

${ }^{869}$ THOMAS, E. J. The 'second Jezebel': representations of the sixth-century Queen Brunhild...op.cit. p. 142.
} 
perceber o quanto a identidade assumida por Brunilda como mãe poderia se configurar como uma identidade política, nesse sentido, podemos pensar sobre o quanto o status das mulheres - especificamente das rainhas - pode ser avaliado como um status político que ia muito além da submissão constituíndo-se como uma identidade política com potencial eficiência. Brunilda possivelmente estava ciente disso de modo que se apresentou como mãe para pedir o retorno de Atanagildo, mas também para declarar a maioridade de seu filho e sua disposição em manter boas relações com o Bizâncio mediante o apoio às tropas de Maurício. O status da mulher, nesse caso, como mãe e mantenedora da família, constituía-se como uma identidade também política evocada com finalidades políticas. O que estamos defendendo, em poucas palavras, é que muito embora as rainhas atuassem politicamente muitas vezes com estratégias semelhantes às dos homens, ${ }^{870}$ a estratégia delas se baseava em valores significativamente diferentes relacionado ao papel delas. Um papel politicamente relevante, mas cuja relevância se sustentava na especificidade da atuação feminina no cenário político em que estavam inseridas: a força da identidade política das rainhas.

E naquele cenário, a "origem étnica" dessas rainhas - dessas mulheres estrangeiras - embora por vezes fosse mencionada não necessariamente tinha um valor negativo. Não teve no caso de Brunilda - cuja a origem nobre, filha de um rei estrangeiro, foi celebrada por Venâncio Fortunato e Gregório de Tours - e também não foi no caso de Bathilda, a jovem de origem saxã que, como indicamos na

\footnotetext{
${ }^{870}$ Como argumenta com excelência Pacer: PANCER, Nira. Sans peur et sans vergogne. De l'honneur et des femmes aux premiers temps mérovingiens. Paris: Éditions Albin Michel, 2001. O papel político das mulheres como portadoras da honra da família também foi estudado por S. Joye: JOYE, Sylvie. Grégoire de Tours et les femmes: jugements portés sur les couples laïques et ecclésiastiques. In: LA ROCCA, C. (ed.) Agire da Donna. Modelli e pratiche di rappresentazione (secoli VI-X). Turnhout: Brepols, 2007. p.75-94. Ainda: JOYE, Sylvie. I conflitti familiare per la figlia nubile $^{870}$ (V-IX secolo). Genesis. Rivista dela Società Italiana delle Storiche. (Donne in famiglia nell'alto medioevo. V. IX, n.1, p.29-54, 2010.
} 
discussão sobre as hagiografias, foi salvadora da dinastia merovíngia com a sua prole. Não foi também no caso de Radegunda, a princesa Turíngia, nem na versão de sua vida escrita por Venâncio Fortunado nem na versão de sua vida escrita por Baudonivia. De fato, em ambas as versões, a estirpe nobre de Radegunda foi celebrada:

Vida de Radegunda por Venâncio Fortunato

Beatissima igitur Radegundis natione barbara de regione Thoringa, avo rege Bessino, patruo Hermenfredo, patre rege Bertechario, in quantum altitudo saeculi tangit, regio de germine orta, celsa licet origine, multo celsior actione. ${ }^{871}$

\section{Vida de Radegunda por Baudonivia}

Igitur de beatae Radegundis vita, in primo libro sicut continetur eius regalis origo vel dignitas, nulli habetur incognitum, qualis fuit eius actio, dum cum terreno principe et coniuge rege praecelso Chlotario conversaretur. De regali progeniae nobile germen erupit, et quod sumpsit ex genere suo, plus ornavit ex fide. ${ }^{872}$

O que temos nesse caso é a expressão de outra possibilidade de análise das identidades políticas que revelam a importância de superarmos a relação imediata entre essas identidades e a etnicidade. Nem no caso de Brunilda, nem de Radegunda nem de Bathilda o fato de terem sido originárias da realeza de gentes estrangeiras determinou o comportamento delas e o peso dado às suas ações tanto negativamente como vimos no caso de Brunilda - como positivamente, como vemos no caso de Bathilda e Radegunda. As origens estrangeiras - advindas da realeza - pelo contrário eram mesmo celebradas, exceto no caso de Bathilda que é descrita como de origem servil. O que é celebrado, e mesmo maldito, é como elas desempenharam o papel à elas delegado como mulheres, os ventres da onde advinham os príncipes, que constituía uma identidade política em si.

\footnotetext{
${ }^{871}$ Vita Sanctae Radegundis, I, 2.

${ }^{872}$ Vita Sanctae Radegundis, II, 1.
} 
A Professora Cristina La Rocca, como já apontamos, apresentou o quanto a origem estrangeira poderia ter um peso negativo nos retratos feitos desses mulheres. A outra nuança é a potencialidade positiva de uma origem real e mesmo estrangeira, mas mesmo algo que transcendia a origem em si relacionado ao papel delas como mães que atuavam ativamente em prol da progenitura, mas acima de tudo, que cientes desse papel usavam da identidade "materna" e real como estratégia política no teatro dos acontecimentos.

Lamentavelmente as fontes godas são muito mais pobres no que concerne ao papel político das rainhas. Não são, contudo, totalmente silenciosas. Ora, João de Biclaro revelou a estratégia de Leovigildo que casou-se com a viúva de Atanagildo tão-logo ascendeu ao trono visigodo. O casamento de Leovigildo é de difícil interpretação, mas seria ingênuo restrigirmos à questão algo puramente sentimental. Ao escolher a viúva de Atanagildo talvez Leovigildo buscasse estabelecer uma aliança com os nobres que apoiaram aquele rei usando o potencial político do papel outorgado à Gausvinta. Não obstante Isidoro de Sevilha mencionou Gala Placídia que falhou em dar continuidade ao sangue de seu marido e retornou, enfim, à corte imperial romana.

Embora o "gênero" - com todas as dificuldades inseridas no termo ${ }^{873}$ - não deva ser o único referencial ao lidarmos com a atuação das rainhas nas cortes reais da Gália Merovíngia e Hispânia Visigoda é preciso cuidar para não ignorarmos a especificidade da ação política daquelas mulheres que atuavam a partir de um sentido identitário inserido na função que elas deveriam cumprir como mães e rainhas, sentido esse que Brunilda usou com maestria nas epístolas que escreveu. Esse sentido é de todo específico uma vez que vai além de marcadores identitários mais

\footnotetext{
${ }^{873}$ Uma instigante crítica sobre o conceito deve ser consultada em: COSTA, C.L. O tráfico do gênero. Cadernos pagu. 11, p.127-140, 1998.
} 
tradicionais, especialmente étnicos, e aponta para estratégicas políticas particulares e especialmente interessantes, como indicou J. Smith ${ }^{874}$ ao sugerir o esforço por superar a idéia de que o espaço doméstico habitado pelas mulheres era necessariamente privado, ao contrário, o espaço ocupado por aquelas mulheres era fundamentalmente público. Ao recorrer ao domínio do ambiente "doméstico" as rainhas atuavam efetivamente e profundamente na esfera política do reino usando engenhosamente o papel "doméstico" como um marcador identitário - fundamentados nos pilares "mulher" e "mãe" - para transitarem na esfera política.

${ }^{874}$ SMITH, Julia M.H. Did women have a Transformation of the Roman World? In: STAFFORD, P. \& MULDER-BAKKER, A.B. Gendering the Middle Ages. Oxford: Blackwell Publisher, 2001. p. 2241. 


\section{Conclusão - identidades políticas e políticas identitárias como proposta}

Chegamos finalmente ao final deste trabalho. Ao longo dessa trabalho objetivamos apresentar nossos argumentos favoráveis ao uso de uma proposta terminológica para a análise de um aspecto que consideramos de crucial importância para o estudo do período ao qual nos dedicamos: a construção do senso de um determinado pertecimento à um grupo específico que era usado como argumento para sustentar reivindicações políticas. Essa idéia nós resumimos no termo "Identidades políticas", já as ações propriamente ditas fundamentadas nessas identidades nós chamamos de "políticas identitárias".

A construção de um senso identitário requer o reconhecimento dessa identidade como uma unidade que usufruía de certa tradição para ser identificada pelos membros do grupo, mas também reconhecida pelos outros, por aqueles com os quais os membros desses grupos se confrontavam e aliavam. Verificamos na parte I que é absolutamente difícil percebermos nas fontes mais antigas a existência de uma idéia clara sobre os "godos" e os "francos" e isso é especialmente verdade para os últimos. Ainda mais difícil é notarmos a existência dessas "unidades" que possam ser qualificadas como étnicas, e isso foi, e ainda é, um enorme impasse para a historiografia. Entretanto, ao longo do tempo, essa tradição esparsa e tênue foi sistematizada pelas mãos dos historiógrafos a ponto de ser fundamentada numa tríada entre a gens, a patria e o rex no qual o último constituía a liga que deveria unir e salvaguardar os dois primeiros.

A importância dessas identidades se sobressaem ao verificarmos que o contexto no qual nossos agentes estavam inseridos era profundamente polarizado, esperamos que isso tenha ficado relativamente explícito na nossa parte II. Nesse 
contexto polarizado a elaboração dos historiógrafos faz um enorme sentido em contraste com as identidades regionais que em determinadas situações entravam em tensão com os reis e em outras se aliavam aos reis. Isso fica mais evidente se confrontarmos as Historiae e as hagiografias. As primeiras tinha a pretensão de um discurso generalizante no que concerne à construção da memória enquanto as segundas - a partir do universalismo cristão - enfatizavam a memória de santos, quase sempre homens e mulheres ligados à fortes laços com famílias que constituíam nobrezas regionais que se aliavam, mas também disputavam, a autoridade com os reis. A parte III objetivou apontar para essas narrativas, para as memórias em disputa que estavam longe de serem simples tópicos retóricos, mas dialogavam com o cenário de conflitos explicitados na nossa parte II.

Já na parte IV observamos como muitas das narrativas que expressavam/construíam as identidades repercutiam na produção das normas, não num sentido "étnico", não numa dicotomia entre romanos e germanos. Não estamos lidando com questões isoladas, não estamos lidando com narrativas circunstanciais, estamos lidando com diversas frentes estratégicas em que as identidades operavam. Isso para nós é a evidência mais consistente que sustenta a relevância de termos em conta as identidades políticas. Elas eram efetivas, efetivas a ponto de operarem mesmo fora dos limites das regna. $\mathrm{E}$ isso observamos na parte $\mathrm{V}$ que vai além ao mostrar que as identidades políticas poderiam se construir a partir de outros referenciais que não os das gentes, como observamos no caso das rainhas. A parte $\mathrm{V}$ pode ser considerada um elemento conclusivo dessa tese ao mostrar a transcendência das identidades e indicar que elas poderiam assumir formas que contrariam a idéia de que apenas em torno da gens e da patria a história dos reinos que nos interessam é passível de compreensão. 
A opção por diversas fontes, ou melhor, por diversos gêneros narrativos - que, como já indicamos, não entendemos apenas como elementos retóricos - mostrou-se crucial para elaborarmos a idéia das "identidades políticas". De fato, essa tese começou com objetivos, ou melhor, pressupostos, que iam de encontro aos rumos que tomamos ao decorrer do trabalho. Se inicialmente buscávamos a etnicidade, num determinado momento, diante da pluralidade de narrativas que davam conta da concretude da polarização política, diante das criticas que os partidários da etnogênese brilhantemente elaboraram, notamos que um passo deveria ser dado. Não um "passo além", talvez um "passo atrás" no sentido que, ao fim e ao cabo, acabamos privilegiando um "termo-conceito" mais generalizante do que "identidades étnicas". A generalidade, todavia, pode render bons frutos no sentido de nos permitir uma maior maleabilidade. Ao libertarmos as "identidades" das "etnias" abrimos um leque de oportunidades. A oportunidade que nós desenvolvemos aqui foi a análise das identidades no teatro da política, especificamente das identidades como estratégia políticas que trazem informações profundas sobre o período em que foram forjadas: um período de tensões em que diversos grupos disputavam a autoridade sobre os reinos - sendo o próprio reino uma unidade identitária - ou mesmo sobre regiões. A crescente regionalização é quase tangível nas fontes da Gália, como podemos constatar pela proliferação de termos regionais - estes também identitários - nas fontes daquela região. É por isso que insistimos num ponto ao longo desse texto que talvez não tenha ficado explícito, mas permeou toda a condução da pesquisa: as identidades políticas só fazem sentido no contexto de disputas no qual se inseriam, e poderiam ser usadas mesmo para a pacificação ao serem evocadas para apaziguar, ou ao menos tentar acalmar, os impulsos bélicos. Lembremos do Prefácio V de Gregório de Tours. 
A comparação entre o caso da Gália e da Hispânia se mostrou uma opção tortuosa por ter aumentado muito o volume do trabalho. Todavia parece ter sido uma opção acertada pois, pensamos, conseguimos mostrar que as identidades políticas podem ser usadas como norte para a análise de dois contextos diversos, mesmo quando, ou principalmente, quando usadas de maneiras diversas. Oxalá esse trabalho possa ser útil para pesquisadores que queiram experimentar como nós experimentamos, em outros contextos, em outros espaços temporais... De todo modo, o que cada parte dessa tese tentou indicar é que as identidades políticas e as políticas identitárias atuavam em diversos níveis: na construção da memória, na construção das normas, no confronto com os outros. Não nos parece um tema marginal, nos parece um dos elementos estruturantes dos reinos estudados aqui.

Talvez caiba fazermos uma última observação. Esse trabalho soou ocasionalmente como pretensioso pelo volume de material que nos propusemos a analisar. É possível que no fundo a ambição tenha sido ocultada pela desculpa da curiosidade, mas ela foi exemplarmente esmagada pelo desafio das fontes. A sensação que fica é de um trabalho incompleto, o consolo é que ao menos o exercício foi tentado e, esperamos, continuará a ser realizado. 


\section{Apêndice 1 - Traduções}

Muitas das citações das fontes no texto possuem uma explicação que permite a boa compreensão do trecho. Os trechos mais longos ou aqueles que não possuem uma explicação circunstancial estão traduzidos aqui.

Tradução 1 - Jordanes (tradução a partir da tradução para o inglês de Charles C. Mierow: MIEROW, C.C. The Gothic History of Jordanes. Princeton: Princeton University Press, 1915)

Agora da Ilha de Scandza, como uma oficina de raças ou fábrica de nações, os Godos, dizem, vieram há muito tempo liderados por seu rei, chamado Berig. Tão-logo eles desembarcaram de seus navios e colocaram seus pés na terra, eles imediatamente deram seu nome ao lugar. E ainda hoje [o lugar] dizem ser chamado de Gothiscandza. Logo eles se moveram de lá para as moradas de Ulmerugi, que então habitavam nas margens do Oceano, onde eles [os godos] acamparam. Iniciando batalhas contra eles [os Ulmerugi] e então os expulsando da casa deles. Então eles subjugaram seus vizinhos, os Vândalos, e os adicionaram à suas vitórias. Mas então o número de pessoas cresceu enormemente e Filimer, filho de Gadaric, reinou como rei. Aproximadamente quinze anos desde Berig ele decidiu que o exército dos Godos com suas famílias deveria sair daquela região. Na busca por lares apropriados e lugares agradáveis eles foram para a terra de Escita, chamada Oium naquela língua. Lá eles se deliciaram com a grandeza das riquezas da região, e se diz que quando metade do exército foi trazido, a ponte pela qual eles atravessaram o rio caiu em ruína, de modo que ninguém depois poderia atravessar e é dito que esse lugar era rodeado por grandes pântanos e abismos circulares de modo que por esse duplo obstáculo natural se tornou inacessível. E ainda hoje se pode ouvir naquela redondeza o rumor dos rebanhos e se pode achar o traço de homens, se nós formos acreditar nas histórias dos viajantes, embora nós podemos garantir que eles escutam essas coisas de longe. Essa parte dos godos, sobre a qual se diz que cruzou o rio e entrou com Filimer na terra de Oium, tomou em seu poder a terra desejada, e lá eles logo encontraram a raça dos Spali, lutaram contra eles e venceram. Por isso os vencedores se dirigiram para a parte mais distante da Scythia, que é próxima ao mar de Pontus; assim a história é normalmente contada em suas canções mais antigas, de uma maneira quase adequada ao estilo histórico. Ablabius também, um famoso cronista da raça goda, confirma isso em sua muito confiável explicação. Alguns dos antigos escritores também concordam com o 
conto. Entre eles nós devemos mencionar Josephus, um muito confiável relator de anais, quem sempre segue as regras da verdade e revela as coisas desde o início da origem das causas. Mas porque ele omitiu as origens da raça dos godos, sobre as quais eu falei, eu não sei. Ele muito pouco menciona Magog, e diz que eles eram Escitas por raça e assim eram chamados por nome.

Tradução 2 - Amiano Marcelino Res Gestae. (Tradução baseada na tradução para o inglês de John C. Rolfe: ROLFE, J.C. Ammianus Marcellinus. v.II. Cambridge, Massachusetts, Londres: Harvard University Press, 2000. Primeira edição: 1940)

5. Nesse tempo, como se as trombetas estivessem tocando a nota da guerra através de todo o mundo Romano, as mais selvagens gentes despertaram e avançaram para as proximidades das fronteiras mais vizinhas. Nesse tempo os Alamanni estavam desbastando a Gália e a Raetia, os Sarmatae e os Quasi a Panônia, enquanto os Píctios, Saxões, Scotti e Attacotti estavam ameaçando os Bretões com constante desastres. Os Austoriani e outras tribos mouras excursionavam na África mais ferozmente que nunca e as bandas predatórias dos godos estavam saqueando a Trácia e a Panônia.

Tradução 3 - Paulo Orósio. Os setes livros contra os pagãos (tradução da autora)

O próprio imperador ferido por uma frecha escapou com dificuldade para uma casa numa pequena villa. Enquanto ele estava escondido os inimigos chegaram e o encontraram, eles colocaram fogo na casa e ele foi consumido pelas chamas: e que para a posteridade esse seja o terrível exemplo do maior testemunho da punição e indignação divina. Ele [Valente] ainda foi enterrado numa sepultura comum.

Tradução 4 - Jordanes (tradução a partir da tradução para o inglês de Charles C. Mierow: MIEROW, C.C. The Gothic History of Jordanes. Princeton: Princeton University Press, 1915)

Lá uma terrível batalha ocorreu e os godos prevaleceram. O próprio imperador foi ferido e fugiu para uma "fazenda" próxima à Adrianópolis. Os godos, sem saber que um imperador estava escondido numa cabana tão pobre, atearam fogo, como é de costume ao lidar com um inimigo cruel, e então ele foi cremado com fogo por aqueles aos quais ele perniciosamente guiou à perdição quando eles desejavam a verdadeira fé, levando-os da chama do amor para o fogo do inferno. 
Tradução 5 - Isidoro de Sevilha. Historia Gothorum. (Tradução baseada na tradução para o espanhol: RODRIGUEZ ALONSO, Cristóbal. Las historias de los godos, vandalos y suevos de Isidoro de Sevilla. Estudios, edición crítica y traducción. Leon: centro de estudios e investigación "San Isidoro". Archivo historico diocesano Caja de ahorros y Monte Piedad de Leon, 1975.)

[Os godos] devastam a Tracia a sangue e fogo e, além de aniquilar o exército romano, tocaram fogo no próprio Valente, quando ferido por um dardo, fugia até um casa de campo. Mereceu assim ser queimado em vida por um fogo temporal aquele que havia entregue ao fogo eterno almas tão belas.

Tradução 6 - Idácio de Chaves. Crônica. (Tradução para o português de J. Cardoso: IDÁCIO. Crônica. Versão e anotações de José Cardoso. Braga: Universidade do Minho, 1982)

Enquanto por toda Espanha os bárbaros se entregam a bacanais e, [por todo lado], a epidemia da peste não faz menores devastações, as riquezas e os víveres armazenados nas cidades são esbulhados pelo tirânico coletor de impostos. E as hordas da militância encarregam-se de tudo malbaratar. Grassa uma fome medonha a tal ponto que, sob o acicate da fome, carne humana é devorada por humana gente. E até as mesmas mães tomam por pascigo os corpos daqueles que elas próprias geraram, matando-os e cozendo-os em seguida. Os animais selvagens e ferozes acostumados aos cadáveres dos que morriam pelo ferro, pela fome e pela peste, matam os homens, ainda os mais fortes, e, alimentados pela sua carne, por toda parte se entregam ao extermínio do gênero humano. E destarte, pelas quatro pragas, a saber: ferro, fome e feras, seviciados por toda a parte no mundo inteiro, se cumprem os avisos anunciados pelo Senhor através dos seus profetas.

Tradução 7 - Amiano Marcelino. Res Gestae. (Tradução baseada na tradução para o inglês de John C. Rolfe: ROLFE, J.C. Ammianus Marcellinus. v.II. Cambridge, Massachusetts, Londres: Harvard University Press, 2000. Primeira edição: 1940)

3. Depois dessas preparações ele primeiro apontou para os francos, que eram chamado por costume de Sálicos (Salios) que já haviam estabelecido morada na Toxiandria (Zeelândia, atual holanda). Mas quando ele chegou à Tongros (território da atual Bélgica), um grupo deles o encontrou, esperando encontrar o comandante mesmo no inverno; eles então ofereceram a paz nos seguintes termos: enquanto permanecessem plácidos, como se estivessem no próprio território, ninguém deveria atacá-los ou molestá-los. 
Tradução 8 - Amiano Marcelino. Res Gestae. (Tradução baseada na tradução para o inglês de John C. Rolfe: ROLFE, J.C. Ammianus Marcellinus. v.II. Cambridge, Massachusetts, Londres: Harvard University Press, 2000. Primeira edição: 1940)

Pela voltade dos céus fui unido à vocês desde o início da minha juventude, eu enfrentei as excursões constantes dos alammani e francos e seus desenfreados ímpetos pela pilhagem, e pela combinação de nossa coragem eu tornei possível que o Reno fosse cruzado pelas tropas romanas com a frequência que elas desejassem, e mantendo-me firme contra o clamor dos rumores e as invasões forçadas à poderosas nações que eu conduzi, asseguro-vos honrar vossa confiança.

Tradução 9 - Fredegário. Chronica. (Tradução da autora)

Então a outra banda [dos francos] que partiu da Frígia foi enganada pela fraude por Ulisses, todavia não foram feitos cativos, mas percorreram muitas regiões com suas esposas e crianças. Escolheram como seu rei um homem de nome Francio, e a partir de seu nome se chamam francos. Mais tarde, por serem os francos fortíssimos, depois de se lançaram às guerras e por muito tempo lutarem contra muitas gentes e devastarem parte da Ásia, se dirigiram à Europa através do Reno, Danúbio e o mar.

Tradução 10 - Isidoro de Sevilha. Historia Gothorum. (Tradução baseada na tradução para o espanhol: RODRIGUEZ ALONSO, Cristóbal. Las historias de los godos, vandalos y suevos de Isidoro de Sevilla. Estudios, edición crítica y traducción. Leon: centro de estudios e investigación "San Isidoro". Archivo historico diocesano Caja de ahorros y Monte Piedad de Leon, 1975.)

Na era DCLXI no ano 20 do império de Maurício, assassinado Liva, Viterico reivindicou para si durante sete anos o reino, que havia invadido enquanto aquele ainda vivia. Foi homem valente na arte das armas, mas desconheceu a vitória; pois, ainda que tenha realizado alguns intentos com a guerra contra os soldados imperiais, não conseguiu nenhum resultado bastante glorioso, exceto ter se apoderado de alguns soldados em Sagontia por meio de seus generais. Fez em vida muitas ações ilícitas, e na morte, porque havia matado com a espada, morreu pela espada. Não ficou sem vingança a morte de um inocente, pois foi assassinado em um banquete vítima de uma conjuração de alguns. Seu cadáver foi de maneira vil arrastado e sepultado.

Tradução 11. Sisebuto. Vita Desiderii. (Tradução baseada na tradução para o Espanhol de P.R. Díaz y Díaz: DÍAZ Y DÍAZ, P.R. Tres biografías latino medievales de San Desiderio de Viena (traducción y notas). Fortunatae: Revista canaria de 
filología, cultura y humanidades clásicas. n.5, p.215-252, 1993)

De seu final não será de mais falar a partir da versão mais extensa, a qual tivemos acesso. Há um animal curvado [com corcunda], de complexão gigantesca e com duas corcundas de nascimento (a parte superior do lombo elevada e saliente permite uma conformação mais elevada de suas extremidades, muito apropriada para a carga) e no que concerne ao transporte de mercadorias muito superior aos demais animais. No centro desse trono se senta desprovida de roupas e exibida para a sua vergonha ante à vista de seus inimigos. Durante um momento ofereceu aos espectadores um triste espetáculo; logo depois é atada a uns corcéis selvagens e arrastada por um terreno pedregoso e intransitável. Deste modo seu corpo já decrépito pela idade é destroçado pelos fogosos cavalos e seus restos irreconhecíveis jazem destruídos e lacerados por todas as partes. Assim, sua alma, livre da matéria terrena e relegada, com razão - às penas perpétuas, resta para arder entres as abrasadoras ondas do inferno.

Tradução 12 - Isidoro de Sevilha. Historia Gothorum. (Tradução baseada na tradução para o espanhol: RODRIGUEZ ALONSO, Cristóbal. Las historias de los godos, vandalos y suevos de Isidoro de Sevilla. Estudios, edición crítica y traducción. Leon: centro de estudios e investigación "San Isidoro". Archivo historico diocesano Caja de ahorros y Monte Piedad de Leon, 1975.)

Além desses motivos de celebração à glória militar de Suintila, tinha esse rei muitas virtudes próprias da majestade real: fidelidade, prudência, habilidade, exame extremo nos juízos, atenção primordial ao governo do reino, munificência para com todos, generosidade para com os pobres e necessitados, pronta disposição para o perdão; tanto que mereceu ser chamado não só príncipe dos povos, mas também pai dos pobres.

Tradução 13 - Fredegário (Tradução da autora)

Assim que ele tomou todo o reino da Hispânia sob a sua autoridade, conhecedor do falta dos godos, que depunham os reis, dos quais muitas vezes tinha sido cúmplice, ele fez matar um a um todos daqueles que ele sabia que tiraram vantagem às custas dos reis que foram expulsos do trono. Ele condenou outros ao exílio enquanto que deixou suas esposas e filhas e bens aos seus fiéis. Diz-se que dentre os primeiros dos godos que caíram nessa repressão duzentos foram mortos; dentre aqueles de hierarquia menor quinhentos foram mortos. Enquanto Chindasvinto sabia que esse mal dos godos não seria superado não cessou de trucidar com a espada aqueles dos 
quais ele tinha suspeitas. Quanto aos godos que foram subjugados por Chindasvinto, nada contra ele eles puderam fazer, aqueles que conspiravam contra os reis.

Tradução 14 - V Concílio de Toledo. (Tradução baseada na tradução para o espanhol de Vives: VIVES, J. Concílios visigóticos y hispanorromanos. Barcelona-Madrid: CSCI, 1963.)

Deve-se buscar novos remédios para as enfermidades desconhecidas e novas. E porque inconsideravelmente os ânimos de alguns não cabem em si e aos que não adornam sua linhagem nem acredita na sua virtude, crêem aqui e acolá poder alcançar licitamente o alto do poder real, por isso se promulga, evocando ao céu, nossa comum decisão: que se algum ao que não eleve o voto comum, nem a nobreza da gens goda o conduza a esta suma honra, trame algo parecido, seja privado do trato com os católicos e condenada ao anátema de Deus.

Tradução 15 - Juliano de Toledo. Historia Wambae. (Tradução da autora)

Viveu nos nossos dias o ilustríssimo príncipe Wamba, quem a dignidade do principado quis Deus, quem a unção sacerdotal declarou, quem toda as gentes e a pátria em comunhão elegeu, quem dos povos a amabilidade buscou, que diante do declínio do reino, se prediz frequientemente, reinará. Este ilustríssimo varão que do defunto príncipe Recesvinto a morte na procissão fúnebre segue e lamenta, de súbito todos em concórdia se unem, tanto de um mesmo modo quanto de ânimo, afetados por uma expressão igual, clamam que se deleitariam de tê-lo como príncipe. Entonaram com uma única voz que ele e nenhum outro entre os godos deveria reinar e para que ele não recusasse o pedido se postaram ao redor de seus pés.

Tradução 16. Carta de Remígio à Clóvis. (Tradução baseada na tradução para o inglês de P. Geary: GEARY, P.J. Readings in Medieval History: the Theodosian Code. Toronto: University of Toronto Press, 2010.)

Você deve se associar com conselheiros que são capazes de honrar sua reputação. Seus feitos devem castos e honestos. Você deve defender seus bispos e sempre ter disposição para seus conselhos. Se você está em bons termos com eles sua província mais facilmente ficará firme. Encoraje sua gente, conforte os aflitos, proteja as viúvas, alimente os órfãos, e assim garanta que todos te amarão e temerão. Não peça nada aos pobres ou estranhos, não se permita a receber presentes deles. Deixe que seu tribunal esteja aberto à todos os homens, de modo que nenhum homem o deixe com 
lamentações. Você possui as riquezas que seu pai deixou à você. Use-as para ajudar os cativos e liberta-los da servidão. Se alguém for admitido à sua presença não o deixe sentir-se como um estranho. Divirta-se com os homens jovens, tome decisões com os mais velhos. Se você deseja governar mostre-se digno disso.

Tradução 17 - Gregório de Tours. Decem Libri Historiarum. (Tradução baseada na tradução para o inglês de E. Brehaut: BREHAUT, E. Gregory of Tours. History of the Franks. NY: Columbia University Press, 1916.)

Eu estou muito cansado de relatar os detalhes da guerra civil que poderosamente aflige a nação e reino dos Francos; e o pior disso é que nós vemos nelas o início daquele tempo de sofrimento que o Senhor anuncia: "O pai deve se erguer contra o filho, o filho conta o pai, irmão contra irmão, parente contra parente". Eles deveriam ter se dissuadido pelos exemplos dos antigos reis que eram temidos por seus inimigos uma vez que eles eram divididos. Quão frequentemente tinha a cidade das cidades, a grande capital de todo o mundo, caído pela guerra civil e novamente, quando acabava, se reergueu do chão! Deveriam vocês também, oh reis, estarem engajados em batalhas como aqueles em que seus pais lutaram, que os pagãos terrificados com a vossa união deveriam ser esmagados por sua força! Lembrem-se como Clóvis ganhou grandes vitórias, como ele derrotou reis opositores, esmagou gentes fracas e dominou suas terras, e deixou à vós uma completa e total dominação sobre eles! E quando ele fez isso ela não tinha nem prata nem ouro como vocês têm em seus tesouros. Qual é o objetivo de vocês? O que vocês estão procurando? O que vocês não possuem em abundância? Em vossas casas há luxos em abundância, nas suas despensas vinho, grãos e óleo, ouro e prata estão empilhados em seus tesouros. Falta uma coisa à vós: sem paz vocês não têm a graça de Deus. Por que um toma de outro? Por que um deseja o que o outro tem? Eu imploro à vós, atenção às palavras do apóstolo: "mas se um morde e devora o outro, atenção para não ser consumido pelo outro". Examinem cuidadosamente os livros dos antigos e vocês verão o que as guerras civis geraram. Leia o que Orósio escreveu sobre os Cartaginenses, que disse que depois de setecentos anos a cidade deles e o país eram arruinados e adicionou: "O que preservou essa cidade por tanto tempo? União. O que a destruiu em pouco tempo? desunião". Cuidado com a desunião, cuidado com as guerras civis que destroem vocês e vossa gente. O que mais pode ser esperado além de que seu exército cairá e que você ficará sem força e será esmagado e arruinado por hostis? E, rei, se a guerra civil te dá prazer, 
administre esse impulso que o apóstolo disse que é urgente com o homem, deixe o espírito vencer a carne e os vícios caíres diante das virtudes; e seja livre e sirva seu líder que é Cristo, você que é um escravo acorrentado ao pés do mal.

Tradução 18 - Gregório de Tours. Decem Libri Historiarum. (Tradução baseada na tradução para o inglês de E. Brehaut: BREHAUT, E. Gregory of Tours. History of the Franks. NY: Columbia University Press, 1916.)

Mas Sagitario foi transportado com raiva, fazendo a ação ser mais difícil, e sendo baixo e vão e pronto com a fala irracional, ele começou a fazer muitas acusações em voz alta sobre o rei e a dizer que seus filhos não poderiam herdar o reino porque a mãe deles foi tomada para a cama do rei das escravas de Magnachar, sem ele saber que as famílias das esposas são irrelevantes e que eles chamam os filhos dos reis que foi gerado de rei.

Tradução 19 - Fredegário. Chronica. (Tradução da autora)

Gontrão era rei dos francos por 23 anos. Reinava no reino da Burgúndia com bondade e plenitude. Com os sacerdotes ostentava uma imagem sacerdotal e com os leudes era muito apto, com os pobres distribuía muita caridade, obteve tanta prosperidade no reino que todas as gentes vizinhas celebravam a sua plenitude.

Tradução 20 - Fredegário. Chronica. (Tradução da autora)

Quanto a gens Lombarda relatarei como naquele ano eles pagaram um tributo de doze mil soles de ouro ao francos, da mesmo forma que não ocultarei as circunstâncias que os levaram a renunciar de duas cidade, Aosta e Susa com seus territórios a favor dos francos.

Tradução 21. Vita domnae Bathildis. (Tradução baseada na tradução para o inglês: FOURACRE, P. \& GERBERGING, R.A. Late Merovingian France. History and Hagiography. 640-720. Manchester \& NY: Manchester University Press, 2008.)

O que mais há para dizer? Sob o comando de Deus, seu marido, o rei Clóvis II, partiu de seu corpo deixando uma linhagem de filhos com a mãe. Em seu lugar depois dele, seu filho, o futuro rei Clotário III [rei da Nêustria entre 657-673], tomou o trono dos francos e então também com os excelentes principes, Crodoberto, bispo de Paris, e o senhor Audoino, e Ebroin, mestre do palácio [maiore domus], assim como com outros grandes senhores [senioribus, que significa possivelmente Grandes] e muitos outros. 
E assim o reino dos Francos se manteve em paz. Então um pouco depois os Austrasianos pacificamente [Tunc etenim nuper et Austrasii pacifico ordine...] receberam seu filho [de Bathilda] como rei na Austrasia graças ao arranjo de Bathilda e, de fato, mediante os conselhos dos grandes senhores. Os Burgúndios e os Francos estavam unidos [Burgundiones vero et Franci facti sunt uniti] . E nós acreditamos que, com a ajuda de Deus, e graças à grande fé da senhora Bathilde, esses três reinos mantiveram a harmonia e paz entre eles.

Tradução 22. Vita domnae Bathildis. (Tradução baseada na tradução para o inglês: FOURACRE, P. \& GERBERGING, R.A. Late Merovingian France. History and Hagiography. 640-720. Manchester \& NY: Manchester University Press, 2008.)

[os francos] Temendo que a senhora ficasse contra eles e almejando defender sua causa, eles imediatamente permitiram que ela fosse para o mosteiro [de Chelles]. E não há dúvida razoável que foi sem boa vontade que esses principes permitiram isso.

Tradução 23 - Lex Visigothorum. (Tradução baseada na tradução parcial para o inglês de S.P. Scott: SCOTT, S.P. The visigothic Code. Forum Judicum. Boston: Boston Book Co., 1910.)

Se alguém declarar que suspeita da integridade ou dos condes, ou dos vicários dos condes e demanda acesso ao seu superior, ou mesmo alegar que ele tenha suspeita do próprio superior, ele não pode ser submetido a demora nesse caso, especialmente se ele for pobre. Todos que tomam decisões no caso devem fazê-lo com o bispo da diocese e suas opiniões e julgamentos devem ser registrados por escrito e assinados.

Tradução 24. Lex Visigothorum. (Tradução baseada na tradução parcial para o inglês de S.P. Scott: SCOTT, S.P. The visigothic Code. Forum Judicum. Boston: Boston Book Co., 1910.)

Portanto para que essas condutas desprezíveis sejam abolidas e a manifestas entidades desses transgressores não mais fiquem sem punição, nós decretamos por essa lei, que deve prevalecer para sempre, que qualquer um, desde o tempo do príncipe Chintila de sagrada memória, até o segundo ano do nosso reinado, que tenha desertado, ou que deserte para o inimigo, ou que queira reparar para qualquer reino estrangeiro, o que mesmo tenha desejado, ou deseje, em qualquer momento, agir como intentos criminais contra a gente dos godos ou conspire contra sua pátria ou talvez tentou em qualquer momento conspirar contra ela, e que tenha sido, ou venha a ser capturado e descoberto no ato de qualquer uma dessas ofensas, e se, mesmo que no primeiro ano 
do nosso reinado tentou, ou em seguida, qualquer um nos limites da pátria dos godos tentar fomentar desordem ou causar qualquer escândalo contra o nosso governo, ou contra a gente, ou, o que é indigno de mesmo ser mencionado, tenha planejado a nossa morte ou injúria, ou que venha a conspirar contra os reis seguintes, ou pareceu ou parece manifestar, de qualquer maneira, as intenções de um traidor, qualquer um que seja culpado desses crimes, ou qualquer um desses, dever ser condenado a sentença de morte, nenhuma piedade deve ser mostrada à ele sob nenhum condição.

Tradução 25 - II Concílio de Toledo. (Tradução baseada na tradução para o espanhol de Vives: VIVES, J. Concílios visigóticos y hispanorromanos. Barcelona-Madrid: CSCI, 1963.)

Do mesmo modo tivemos conhecimento que para a consagração das basílicas foram convidados por vós bispos de outros lugares, e ainda que estejam unidos conosco em Cristo pelo laço da mesma fé, sem embargo é coisa clara que isso não é conveniente nem aos privilégios da província, nem aos interesses das coisas do senhor rei, porque chegou até ele a notícia dessas coisas, e portanto ordenamos saudavelmente que se alguma vez ocorrer tal necessidade, deveis nos informar por carta, e com a ajuda de Deus poderá celebrar-se a consagração das igrejas, ou por nós pessoalmente, ou por aquele dos irmãos e co-epíscopos nossos que nós indicaremos.

Tradução 26. VII Concílio de Toledo. (Tradução baseada na tradução para o espanhol de Vives: VIVES, J. Concílios visigóticos y hispanorromanos. Barcelona-Madrid: CSCI, 1963.)

Portanto, tivemos por bem ordenar agora, de comum acordo, que qualquer que pertença ao ordenamento clerical, em qualquer grado do maior ao menor, que em qualquer ocasião passar ao território de outra gens, que desde lá exigir com soberba seu regresso o qualquer outra coisa, ou que tente fazer, ou fizer de algum modo, algo que naquela ocasião possa prejudicar especialmente o povo dos godos, a pátria, ou o rei, assim como qualquer um que seja convicto de estar em cumplicidade com tais, e os haver ajudado com seu conselho ou com sua obra, tanto para que fugissem para os inimigos, ou para que continuassem nos crimes que haviam começado, o para que causassem algum dano ao povo dos godos, ou a pátria ou ao príncipe depois de sua fuga, e a todos aqueles que se sabe que tenha aconselhado a perseverança em tais malhados, todos esses sujeitos serão imediatamente privados do grau de sua honra para que outro possa em seguida ocupar perpetuamente o posto dele. 
Tradução 27 - Gregório de Tours. Decem Libri Historiarum. (Tradução baseada na tradução para o inglês de E. Brehaut: BREHAUT, E. Gregory of Tours. History of the Franks. NY: Columbia University Press, 1916.)

Agora Lupo, dux da Champagne, estava há muito tempo sendo continuamente assediado e roubado por seus inimigos, especialmente por Ursio e Betafredo. Eles ainda fizeram um acordo para o matar e eles marcharam contra ele. Mas quando a reina Brunilda ouviu isso, ela lamentou a injustiça dos ataques à seu leal apoiado e se armou como um homem e correu para o meio das fileiras opositoras e lamentou: "Não, oh guerreiros, não façam esse mal; não ataquem o inocente; não façam que um homem se engaje numa batalha que destruirá o bem da região". Ursio respondeu: "Deixe-nos, mulher; deixe que seja suficiente para você ter governado sob o teu marido; mas agora o governo de seu filho e o reino dele não será mantido pelos seus aliados, mas pelos nossos.

Tradução 28 - Gregório de Tours. Decem Libri Historiarum. (Tradução modificada a partir da tradução para o inglês de L. Thorpe: THORPE, L. Gregory of Tours. The history of the Franks. Londres: Penguin Books, 1974)

O dux Mumolo que, como já dissemos, estava na cidade de Avignon. O dux Gontrão Boso aprisionou o bispo Teodoro acusando-o de trazer homens estrangeiros à Gália com a intenção de submeter o reino dos Francos ao domínio imperial.

Tradução 29. Fredegário. Chronica. (Tradução da autora)

Não posso conseguir a paz na Austrásia, um grande número de todos os primados e livres em toda a Austrásia são meus consangüíneos; não posso sobre eles impor a disciplina nem contra eles intervir. Eles podem insurgir contra mim onde reside a superstição. Os atos deles, não permita Deus, que me levem para o claustro do inferno. Escolha entre vós quem deseja esse empenho.

Tradução 30 - Gregório de Tours. Decem Libri Historiarum. (Tradução baseada na tradução para o inglês de E. Brehaut: BREHAUT, E. Gregory of Tours. History of the Franks. NY: Columbia University Press, 1916.)

Enquanto eu conto esses coisas eu me lembro de Salústio que disse referenciando-se na crítica aos historiógrafos. Ele diz: "É difícil escrever história. Primeiro porque os feitos devem ser representados com exatidão nas palavras e segundo porque muitos homens pensam que a condenação dos atos ruins é fruto da maldade ou inveja. 
Todavia, deixe-nos continuar.

Tradução 31 - João de Biclaro. Chronica. (Tradução da autora)

No III ano do império de Justino, enquanto reinava Liuva seu irmão Leovigildo se estabelece no reino da Hispânia citerior. Leovigildo toma Gosuinta, viúva de Atanagildo, como esposa e as províncias dos godos, que diminuíram por rebeliões diversas, ele restabeleceu admiravelmente aos antigos limites.

Tradução 32 - João de Biclaro. Chronica. (Tradução baseada na tradução para o espanhol de I.A. Arias: ARIAS, I.A. Traducciones. Crónica Biclarense. Cuadernos de Historia de España. n.X, p.130-141, 1948)

O rei Leovigildo reúne na cidade de Toledo um sínodo de bispos da seita ariana e reforma a antiga heresia com um novo erro, dizendo da religião romana que os que fossem [a sua seita] a partir da nossa fé católica não devem ser batizados, mas sim purificados pela imposição das mãos e a prescrição da comunhão e que devem dar glória ao Pai pelo Filho no Espírito Santo. Com esses enganos muitos dos nossos passam ao dogma ariano mais por seu próprio desejo do que por imposição.

Tradução 33. Isidoro de Sevilha. Diferenças. (Tradução da autora)

Entre gentes, gente e gênero. Gens é nação, como Grécia, Ásia, de modo que dizemos gentilitas. Gente se refere à família, como Julia, Cláudia. Gênero se refere à qualidade, como rebanho, pomário.

Tradução 34. Isidoro de Sevilha. Etimologias. (Tradução baseada na tradução para o espanhol: de J.O. Reta e M.A.M, Casqueros. Madrid: BAC, 1975.

IX, 1. A multiplicação das línguas teve origem na construção da Torre [de Babel] depois do dilúvio. Antes que a soberba daquela torre dividir a sociedade humana em múltiplas linguagens diferentes, uma só era a língua de todas as nações, e esta era a hebraica, utilizada pelos patriarcas e profetas, não só em seus sermões, mas também nas sagradas escrituras. No princípio havia tantas línguas quantos povos, mas mais tarde o número de povos superou o de línguas, porque de uma mesma língua se desgarraram diferentes gentes.

Tradução 35 - Isidoro de Sevilha. Etimologias. (Tradução baseada na tradução para o espanhol: de J.O. Reta e M.A.M, Casqueros. Madrid: BAC, 1975.) 
IX, 2. Gens é uma multidão de pessoas que tem uma mesma origem ou de procedência distinta de acordo com sua particular identificação, como Grécia ou Ásia. Disso seu nome de "gentilidade". E se chama gens pelas "gerações" das famílias, enquanto o vocábulo deriva de "gerar", o mesmo que "nação" deriva de nascer.

Tradução 36 - Isidoro de Sevilha. Historia Gothorum. (Tradução baseada na tradução para o espanhol: RODRIGUEZ ALONSO, Cristóbal. Las historias de los godos, vandalos y suevos de Isidoro de Sevilla. Estudios, edición crítica y traducción. Leon: centro de estudios e investigación "San Isidoro". Archivo historico diocesano Caja de ahorros y Monte Piedad de Leon, 1975.)

\section{Breve}

É coisa certa que o reino dos godos é antiquiíssimo, já que surgiu do reino dos escitas.

\author{
Longa \\ O povo [gens] dos godos é antiqüíssimo. \\ Alguns acreditam que eles são \\ descendentes de Magog, filho de Jafet, \\ por causa da semelhança de sua última \\ sílaba e, sobretudo, porque o deduzem do \\ profeta Ezequiel; mas os antigos eruditos \\ acostumaram-se a chamá-los mais \\ "Getas" do que "Gog" e "Magog".
}

Tradução 37 - Isidoro de Sevilha. Historia Gothorum. (Tradução baseada na tradução para o espanhol: RODRIGUEZ ALONSO, Cristóbal. Las historias de los godos, vandalos $y$ suevos de Isidoro de Sevilla. Estudios, edición crítica y traducción. Leon: centro de estudios e investigación "San Isidoro". Archivo historico diocesano Caja de ahorros y Monte Piedad de Leon, 1975.)

\section{Breve}

Tiveram durante muitos séculos um reino e reis, que, como não foram anotados nas crônicas, permanecem ignorados.
Longa

Durante muitos séculos se governaram por chefes, depois por reis, cuja cronologia, nomes e atuação convêm expor por ordem e sucessivamente, servindo-se para isso de dados tirados das histórias.

Tradução 38 - III Concílio de Toledo. (Tradução baseada na tradução para o espanhol de Vives: VIVES, J. Concílios visigóticos y hispanorromanos. Barcelona-Madrid: CSCI, 1963.)

Presente está toda a ilustre gente dos godos, apreciada por quase todas as gentes por sua genuína virilidade, a qual, ainda que separada até agora da fé pela maldade de seus doutores, e da unidade da Igreja católica, sem embargo, neste momento, unida comigo de todo coração, participa na comunhão daquela Igreja que recebe com seio maternal a multidão dos mais diversos povos e os nutre em seus peitos de caridade, e da qual se diz pela boca do profeta: 'minha casa será chamada casa de oração para todos os povos'. 
Tradução 39 - João de Biclaro. Chronica. . (Tradução baseada na tradução para o espanhol de I.A. Arias: ARIAS, I.A. Traducciones. Crónica Biclarense. Cuadernos de Historia de España. n.X, p.130-141, 1948)

Ano sétimo de Maurício e terceiro do rei Recaredo

2.Um exército franco, a mando de Boso, enviado pelo rei Gontrão, chega a Gália narbonense e assentaram-se próximos da cidade de Carcasona. Cláudio, duque de Lusitânia, enviado pelo rei Recaredo, se apresenta ali. Então, travada a luta, os francos são postos em fuga, seu acampamento é destruído e seu exército destroçado pelos godos. Por certo que nessa batalha se pôs em manifesto a ação da graça divina e da fé católica, que o rei Recaredo e os godos receberam fielmente, pois para o senhor não é difícil que se dê vitória a poucos contra muitos. Com efeito, se sabe que o duque Cláudio afugentou, com apenas trezentos homens, quase sessenta mil francos e matou com a espada a maior parte deles. Com toda justiça, em nossa época, se atribui a glória de ter atuado nessa batalha a Deus, quem se sabe que, de modo similar, em tempos passados, deu morte a muitos milhares de medianitas, hostis ao povo de Deus, pelas mãos de Gedeão e com só trezentos homens.

Tradução 40 - III Concílio de Toledo. (Tradução baseada na tradução para o espanhol de Vives: VIVES, J. Concílios visigóticos y hispanorromanos. Barcelona-Madrid: CSCI, 1963.)

Não só a conversão dos godos se conta entre a série dos favores que recebemos, mas também a multidão infinita do povo dos suevos, que com a ajuda do céu submetemos ao nosso reino, ainda que conduzida a heresia [ariana] por culpa alheia, foi trazida por nossa diligência a origem da verdadeira fé.

Tradução 41 - Isidoro de Sevilha. Historia Gothorum. (Tradução baseada na tradução para o espanhol: RODRIGUEZ ALONSO, Cristóbal. Las historias de los godos, vandalos y suevos de Isidoro de Sevilla. Estudios, edición crítica y traducción. Leon: centro de estudios e investigación "San Isidoro". Archivo historico diocesano Caja de ahorros y Monte Piedad de Leon, 1975.)

49. Finalmente [Leovigildo] levou a guerra aos suevos e reduziu seu reino com admirável rapidez ao domínio se sua gens. Apoderou-se de grande parte da Espanha, pois antes a gente dos godos se reduzia a uns limites estreitos. Mas o erro da impiedade ensombreceu nele a glória de tão grandes virtudes.

Tradução 42 - Isidoro de Sevilha. Historia Gothorum. (Tradução baseada na 
tradução para o espanhol: RODRIGUEZ ALONSO, Cristóbal. Las historias de los godos, vandalos y suevos de Isidoro de Sevilla. Estudios, edición crítica y traducción. Leon: centro de estudios e investigación "San Isidoro". Archivo historico diocesano Caja de ahorros y Monte Piedad de Leon, 1975.)

54. Realizou também gloriosamente a guerra contra gentes inimigas, apoiado pelo auxílio da fé. Logrou, com efeito, um glorioso triunfo sobre quase sessenta mil soldados francos, que invadiram as Gálias, enviando contra eles o duque Cláudio. Nunca se deu na Espanha uma vitória dos godos nem maior, nem semelhante.

Tradução 43 - Isidoro de Sevilha. Historia Gothorum. (Tradução baseada na tradução para o espanhol: RODRIGUEZ ALONSO, Cristóbal. Las historias de los godos, vandalos y suevos de Isidoro de Sevilla. Estudios, edición crítica y traducción. Leon: centro de estudios e investigación "San Isidoro". Archivo historico diocesano Caja de ahorros y Monte Piedad de Leon, 1975.)

57. Na era DCXL, no ano doze depois de Recaredo tomou o cetro do reino seu filho Liva durante dois anos, filho de mãe ignóbil, mas certamente notável por suas qualidades e virtudes. A Liva, em plena flor da idade, sendo inocente, o expulsou do trono Witerico, depois de tiranizar o poder, e, tendo cortado sua mão direita, o assassinou aos vinte anos de idade e dois de reinado.

Tradução 44 - Isidoro de Sevilha. Historia Gothorum. (Tradução baseada na tradução para o espanhol: RODRIGUEZ ALONSO, Cristóbal. Las historias de los godos, vandalos $y$ suevos de Isidoro de Sevilla. Estudios, edición crítica y traducción. Leon: centro de estudios e investigación "San Isidoro". Archivo historico diocesano Caja de ahorros y Monte Piedad de Leon, 1975.)

92. Leovigildo, rei dos godos, levando a guerra contra os suevos, imediatamente depois de obter aquele reino, depôs Audeca, e, depois de tonsurado, o privou das honras do reino, e o submeteu aos deveres dos presbíteros. Foi assim, pois, justo que o que ele havia feito a seu rei, o sofresse o mesmo, por sua vez, a merecida pena.

Tradução 45 - Isidoro de Sevilha. Historia Gothorum. (Tradução baseada na tradução para o espanhol: RODRIGUEZ ALONSO, Cristóbal. Las historias de los godos, vandalos y suevos de Isidoro de Sevilla. Estudios, edición crítica y traducción. Leon: centro de estudios e investigación "San Isidoro". Archivo historico diocesano Caja de ahorros y Monte Piedad de Leon, 1975.)

3. Enquanto Leovigildo reina em tranquila paz com seus inimigos, uma rinha doméstica pertuba a segurança, pois naquele ano seu filho Hermenegildo, por conspiração da rainha Gosuinda, assume a tirania na cidade de Sevilha, depois de se 
ter rebelado, e la consigo a rebelião contra o pai a outras cidades e castelos. Esta causa produziu maiores danos no reino da Espanha, tanto para os godos como para os romanos, do que a incursão dos inimigos.

Tradução 45 - Vita domnae Bathildis. (Tradução baseada na tradução para o inglês: FOURACRE, P. \& GERBERGING, R.A. Late Merovingian France. History and Hagiography. 640-720. Manchester \& NY: Manchester University Press, 2008.)

Nós ainda relembramos aquelas outras rainhas que no reino dos Francos foram nobres e trabalhadoras de Deus: Clotilde, a rainha do rei Clóvis e sobrinha do rei Gundobado, que por suas sagradas exortações, guiou seu ao mesmo tempo bravo e pagão marido e muitos dos nobres francos para o cristianismo e os trouxe para a fé católica. Ela foi também a primeira a construir as igrejas em honra a S. Pedro em Paris e S. Jorge no pequeno mosteiro de virgens em Chlles, e ela fundou muitos outros em honra aos santos de maneira a garantir seu recompensa e ela os enriqueceu com muitos presentes. O mesmo é dito sobre Ultrogoda, a rainha do mui Cristão rei Childeberto, porque ela confortou os pobres e ajudou os servos de Deus e os monges. E também a rainha Radegunda, verdadeiramente a mais fiel servente de Deus, rainha do outrora rei Clotário, que a graça do Espírito Santo inflamou de tal modo que ela deixou seu marido enquanto ele ainda era vivo e consagrou-se ao Senhor Cristo sob o sagrado véu, e, com Cristo como o seu marido, realizou muitas coisas belas. Essas coisas $\begin{array}{lllll}\text { podem } & \text { ser } & \text { lidas } & \text { atos. }\end{array}$ 


\section{Apêndice 2 - Os reis godos em Jordanes}

As primeiras referências em Jordanes sobre os reis godos são confusas, o gráfico a seguir mostra uma perspectiva aproximada das primeiras referências aos reis.

Os reis Godos em Jordanes
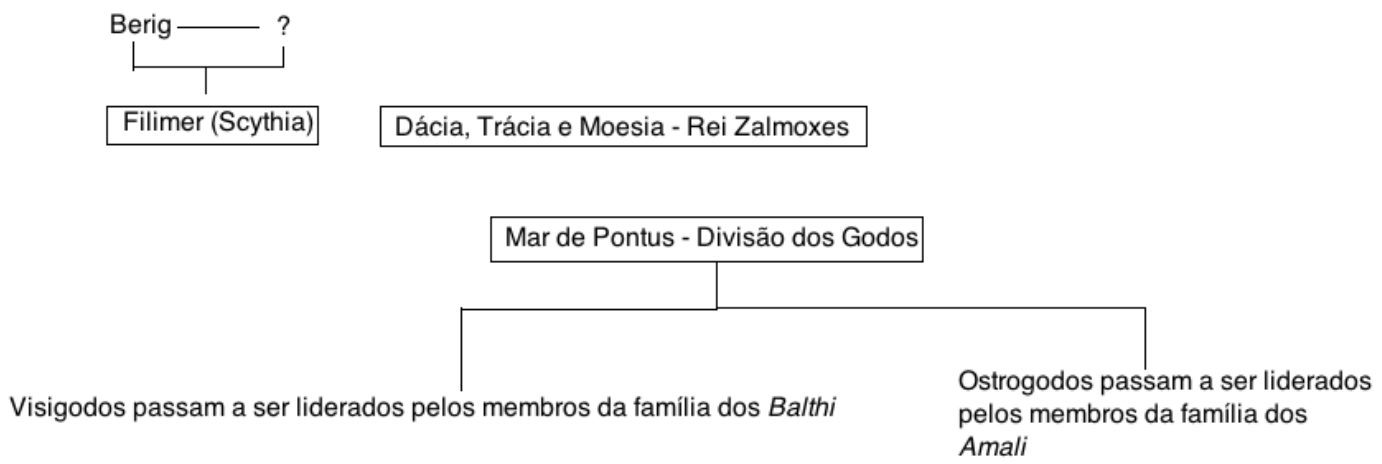

A partir do relato da divisão ocorrida no Mar de Pontus é absolutamente difícil definir se os reis citados por Jordanes eram reis dos visigodos ou reis dos ostrogodos de modo que apresentamos apenas a sucessão de reis presente na Getica: 


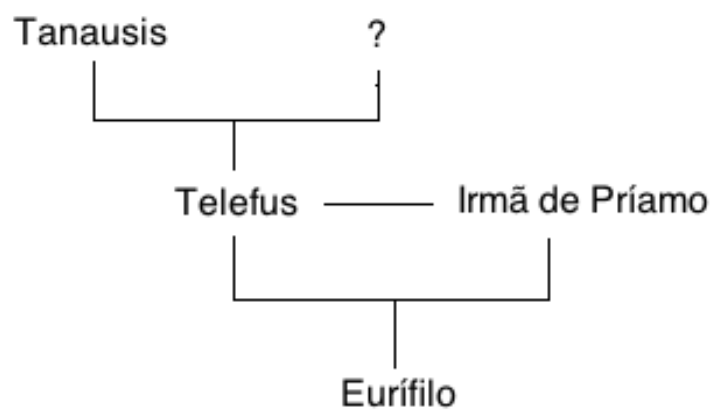

Antiros

Gudila (século IV a.C)

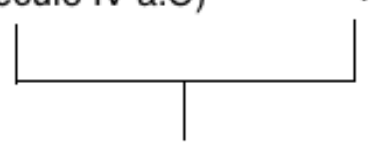

Filha não nomeada Filipe da Macedônia

Buruista (c. I a.C)

Corillus - rei na Dácia c. I d.C

Dorpaneus c. 81-96 d.C

A partir da narrativa da chegada dos godos no banco do Danúbio e da intensificação dos contatos com os Romanos a partir do Império de Domiciano Jordanes nos apresenta a genealogia dos Amali grupo que ele afirmou ser da onde advinham os líderes dos ostrogodos desde a divisão ocorrida no Mar de Pontus. 


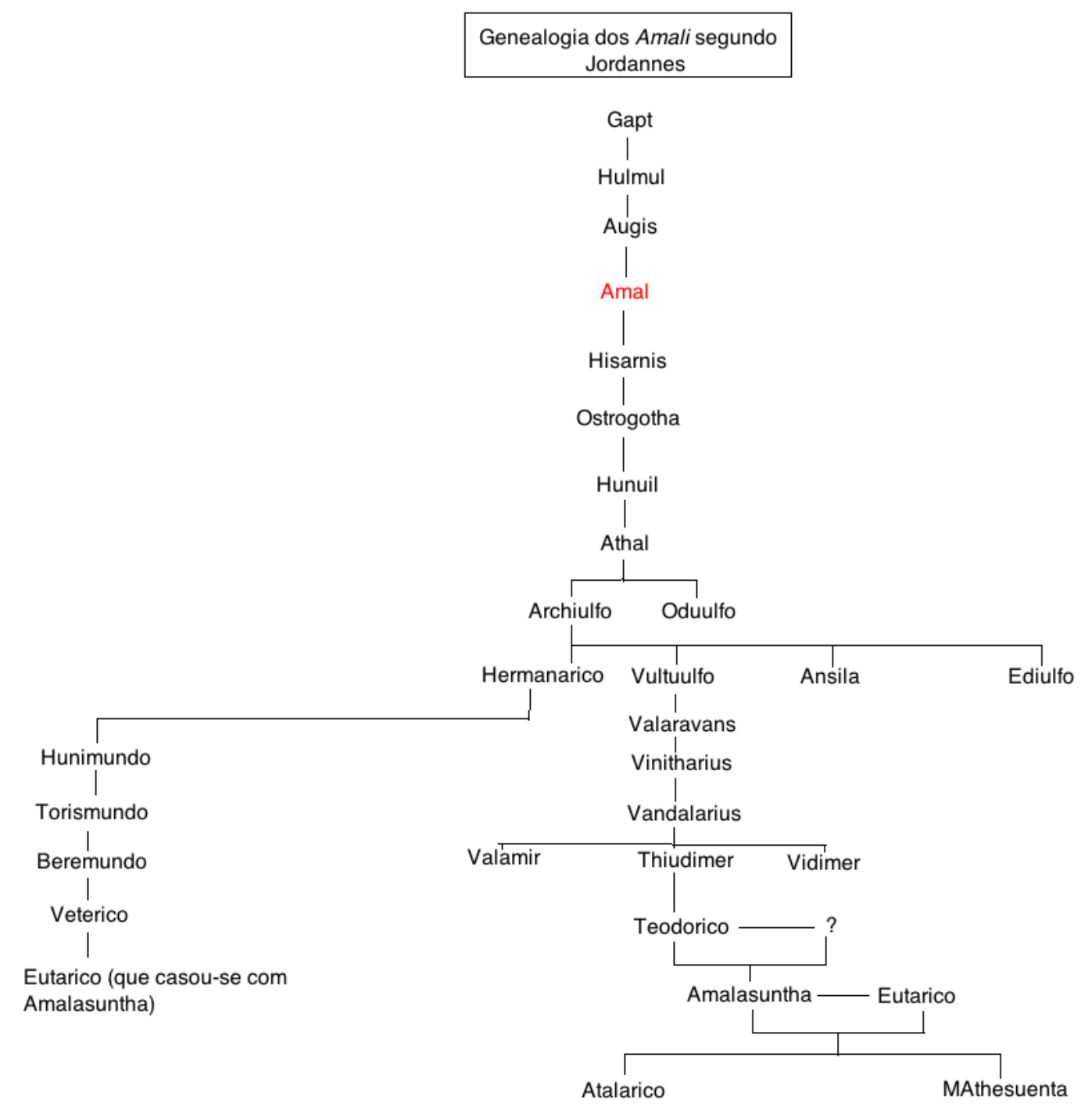

Jordanes descreveu também os reis visigodos desde o chefe Fritigerno até Amalarico. A sucessão estebelecida por Jordanes segue a seguinte ordem: 
Os reis Visigodos conforme Jordanes

Fritigerno (morto em 380)

Atanarico

Alarico I (395-410)

Ataulfo (410-415)

Segerico (415)

Valia (415-418)

Turismundo (451-453) Teodorico I (418-451)—? 


\section{Apêndice 3 - Os reis visigodos na Historia Gothorum de Isidoro de Sevilha}

As imagens a seguir trazem uma tentativa de reconstruir a sucessão régia na Hispânia visigoda conforme a Historia Gothorum de Isidoro de Sevilha. As datas que por vezes não estão de acordo com a historiografia se devem ao fato de que em alguns trechos da obra há uma discrepância entre a cronologia presente na versão breve - comumente aceita pela historiografia) e a versão longa que normalmente está um ano atrás da versão breve. Para dar conta dessa discrepância apresentamos as duas cronologias quando elas estão em desacordo.

Cabe ainda ressaltar que os quadros a seguir são tão-somente baseados no testemunho de Isidoro de Sevilha de modo que algumas informações conhecidas sobre a sucessão régia não estão presentes. Por exemplo, Isidoro de Sevilha não mencionou que Leovigildo casou-se com

Gosvinta, ${ }^{875}$ viuva de Atanagildo de modo que ela poderia ter sido a mãe de Recaredo e Hermenegildo. Além disso Isidoro de Sevilha não descreveu o fim do reinado de Suintila em 631 com o golpe de Sisenando, evento que o bispo não só testemunhou como ratificou nas atas do IV Concílio de Toledo de 633. Como essa informação não está presente na Historia Gothorum optamos por deixá-la em aberto, tal como descrita no texto do hispalense.

\footnotetext{
${ }^{875}$ Essa informação é dada por João de Biclaro (Chronica, III ano de Justino, 4) e Gregório de Tours (Decem Libri Historiarum, IV, 38)
} 
Os reis visigodos na Historia Gothorum de Isidoro de Sevilha (os reis de Tolosa)

Atanarico (369-381) Fridigerno - Assumiu quando os godos se dividiram na

Istria, evento datado por

Isidoro como ocorrido em

377. A data precisa da morte

dele não é clara na Historia

Gothorum

Alarico I (382/historiografia 395 - 410)

Ragadaiso (rei da linhagem escita

registrado por Isidoro no período

entre 399 e 405)

Ataulfo (410 - 416 / 415 na historiografia)

Sigerico (416 / 415 na historiografia)

Valia (416 - 419 / 415-418 na historiografia)

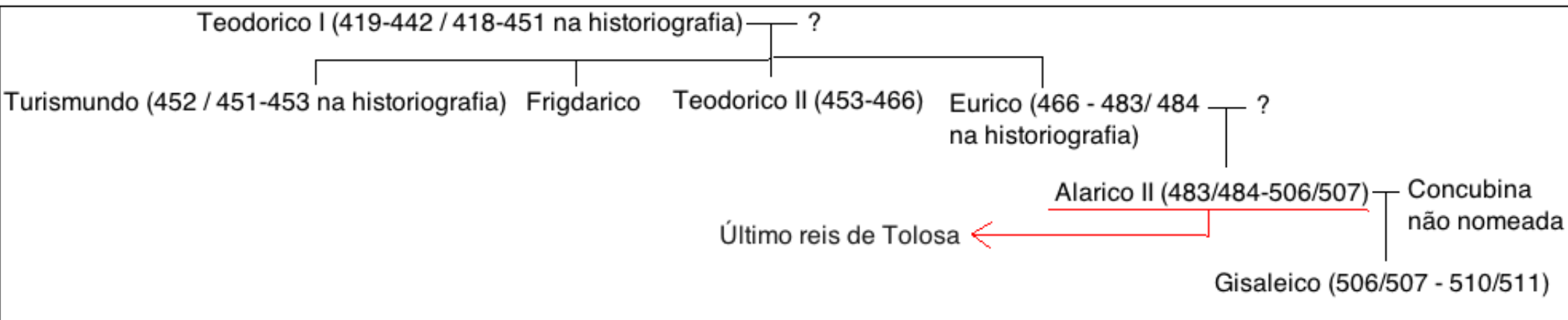


Os reis visigodos em Isidoro de Sevilha

Os reis da Hispânia

Amalarico (510/511-526 sob a regênci

de Teodorico o Grande / 526-531 -

rei independente

Teudis (531-548)

Teudisclo (548-549)

Ágila (549-554/555)

Atanagildo (554/555 - 567-568)

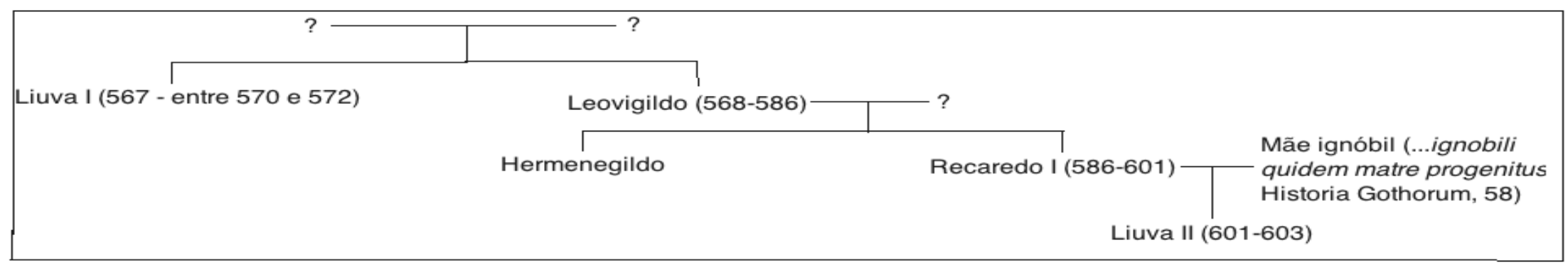

Viterico (603-610)

Gundemaro (610/611 - 612/613)

Sisebuto (612-621)-

Recaredo II (621)

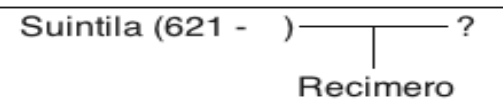


Apêndice 4 - Genealogia dos reis francos

GENEALOGIA DOS REIS FRANCOS CONFORME O LIBER HISTORIAE FRANCORUM

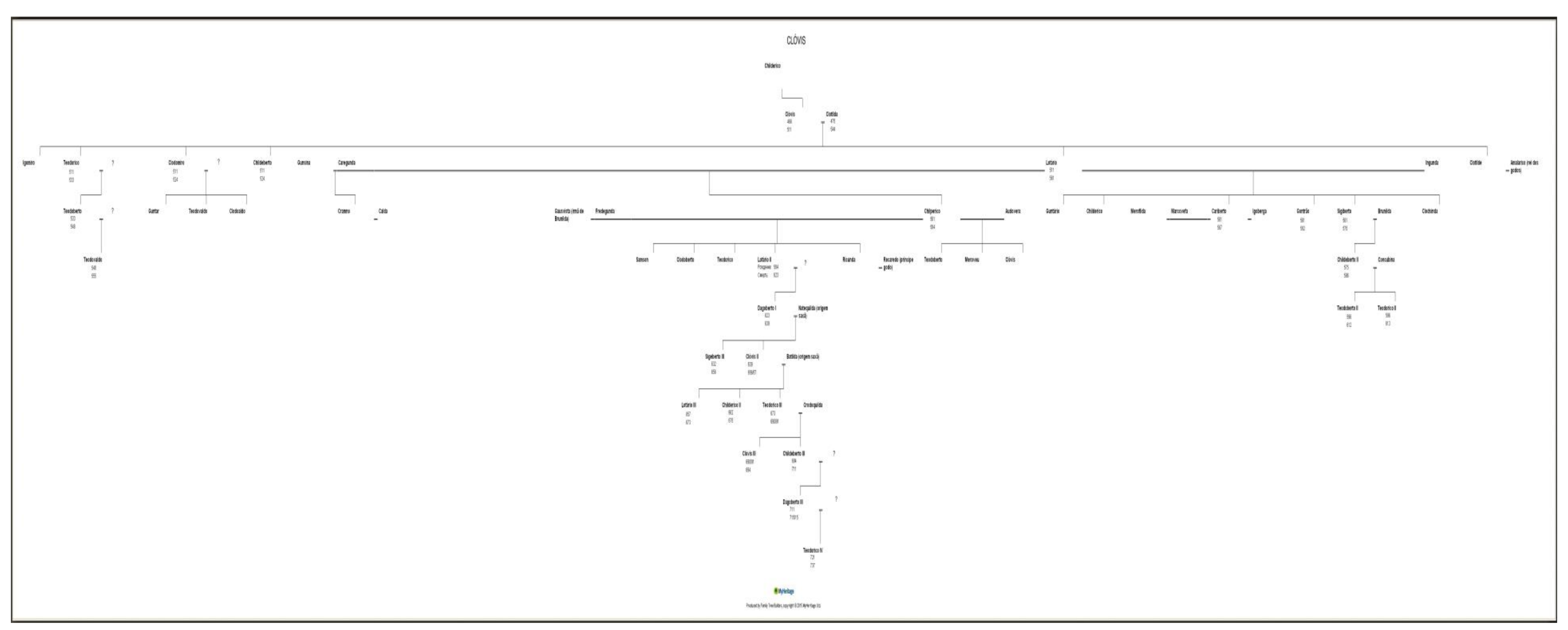




\section{CLÓVIS - DESCENDENTES DA PRIMEIRA GERAÇÃO}

\section{Childerico}

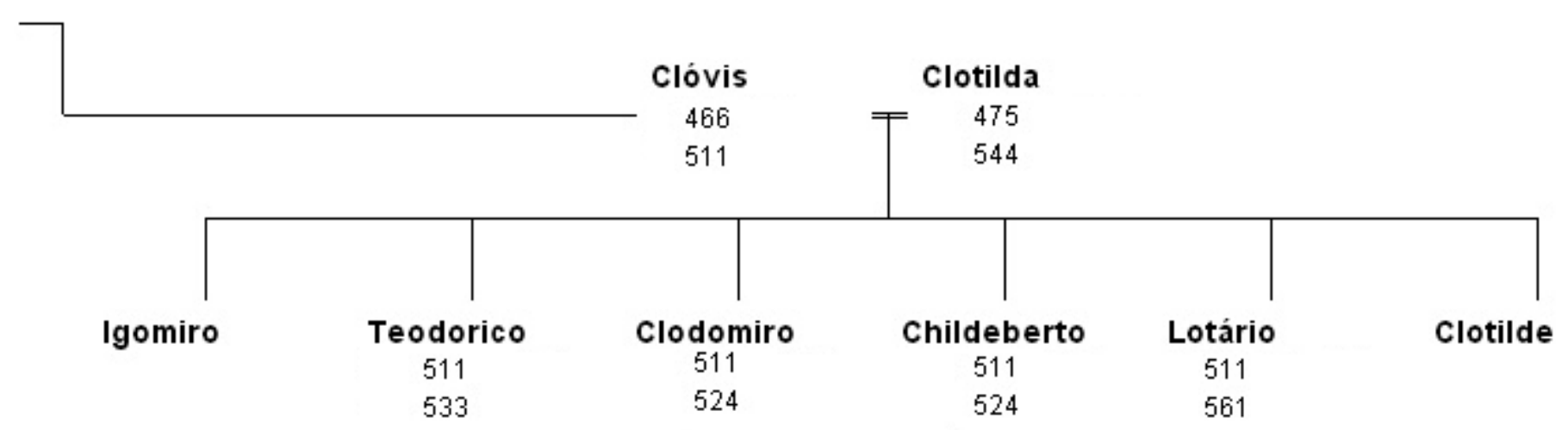

( ) MyHeritage

Produced by Family Tree Builder, copyright (6 2015 MyHeritage Ltd. 
OS FILHOS DE CLÓVIS

\section{TEODORICO I}

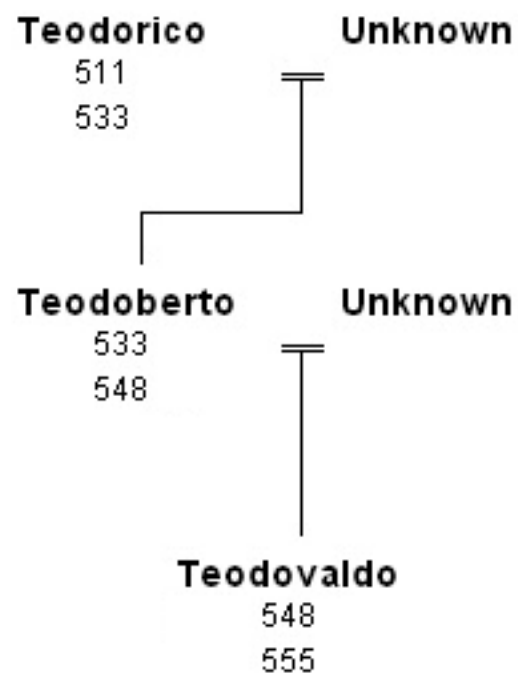

(A) MyHeritage

Produced by Family Tree Builder, copyright (9 2015 MyHeritage Ltd. 


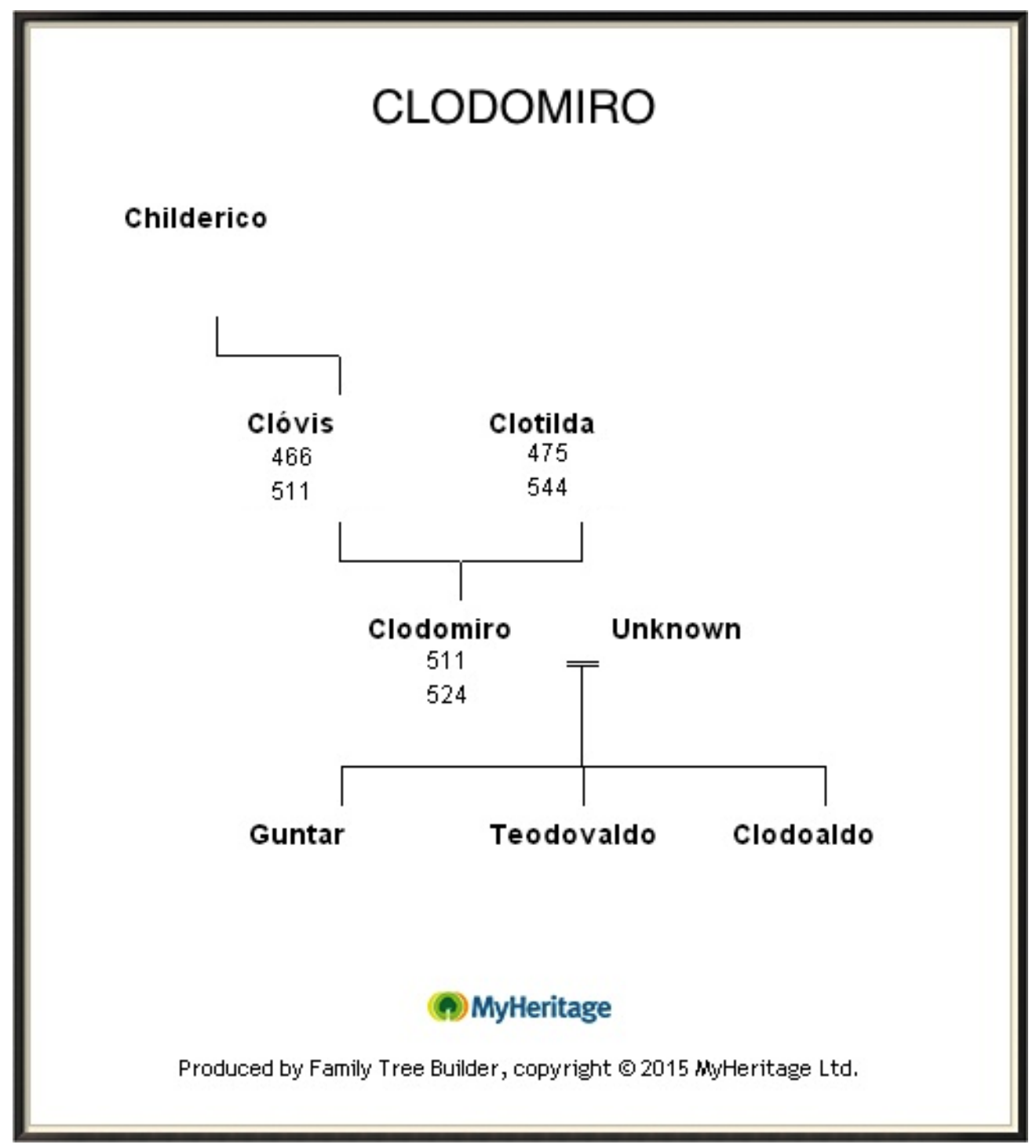


DESCENDÊNCIA DE CLOTÁRIO

\section{LOTÁRIO E INGUNDA}

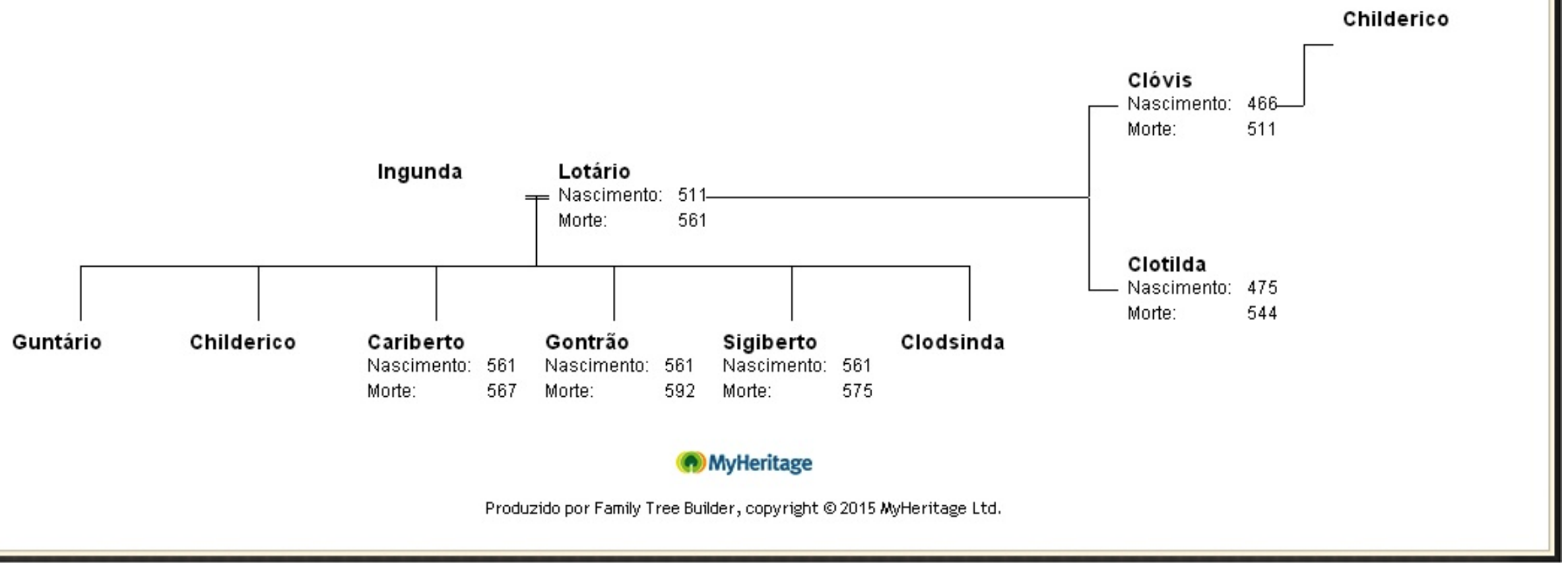




\section{LOTÁRIO E CAREGUNDA}

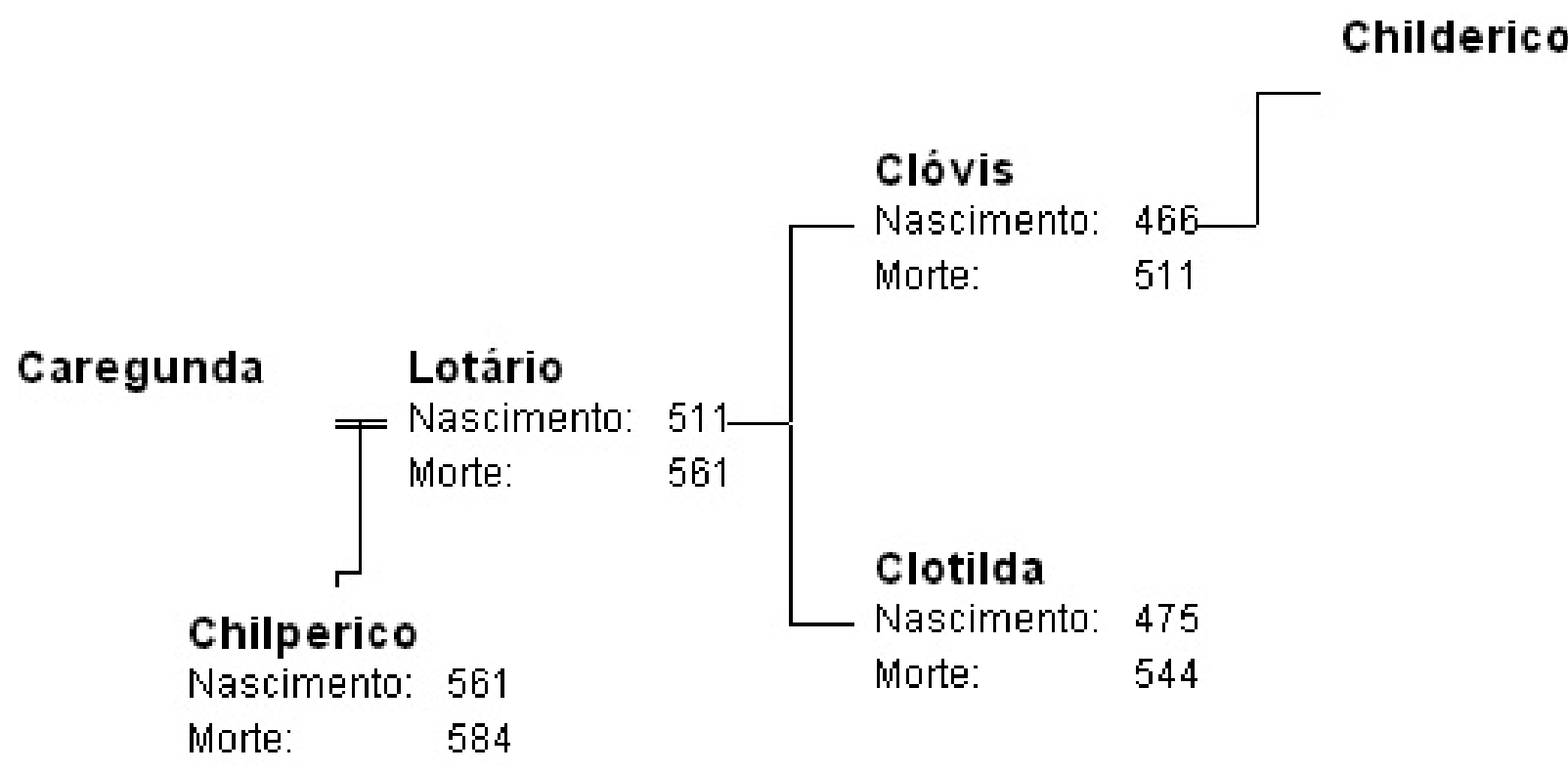

(D) MyHeritage

Produzido por Family Tree Builder, copyright @2015 MyHeritage Ltd. 
OS FILHOS DE CLOTÁRIO

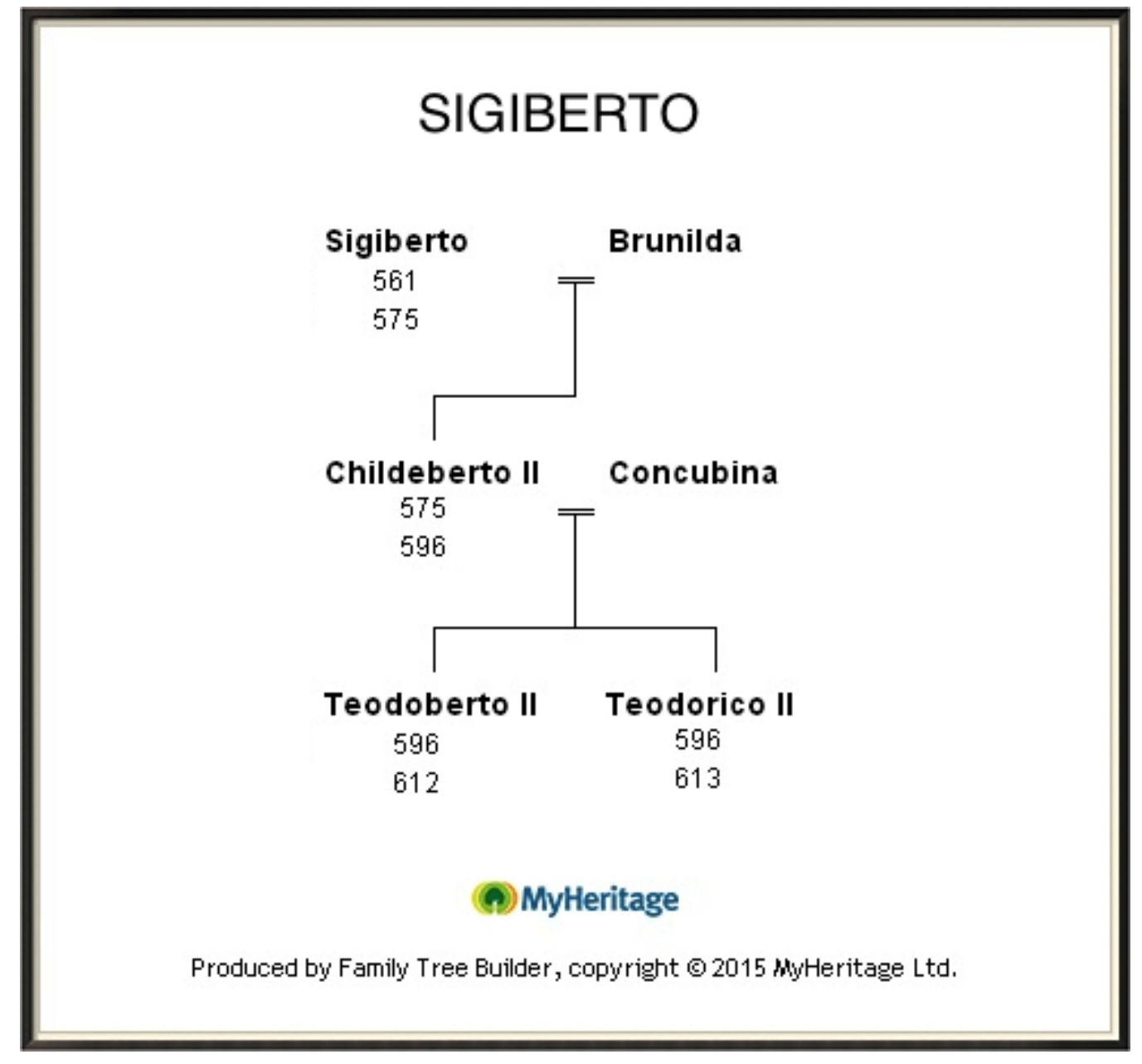




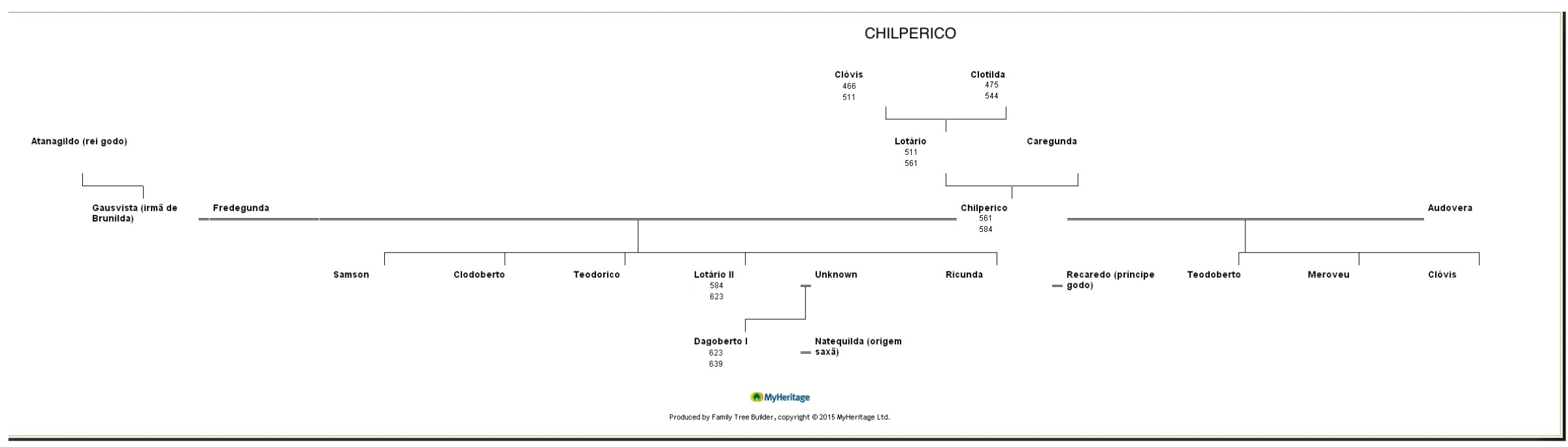




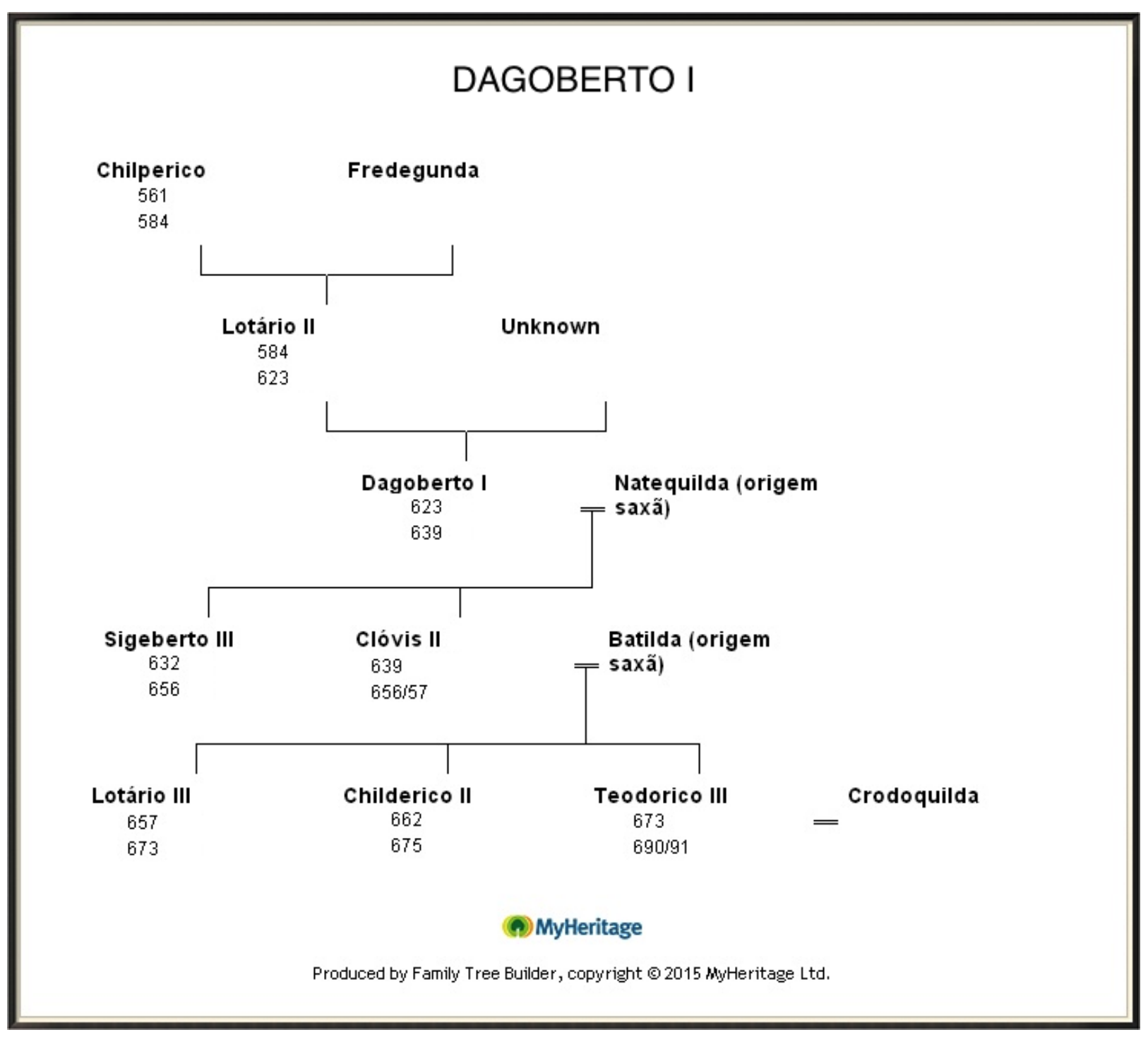




\section{Childeberto III}

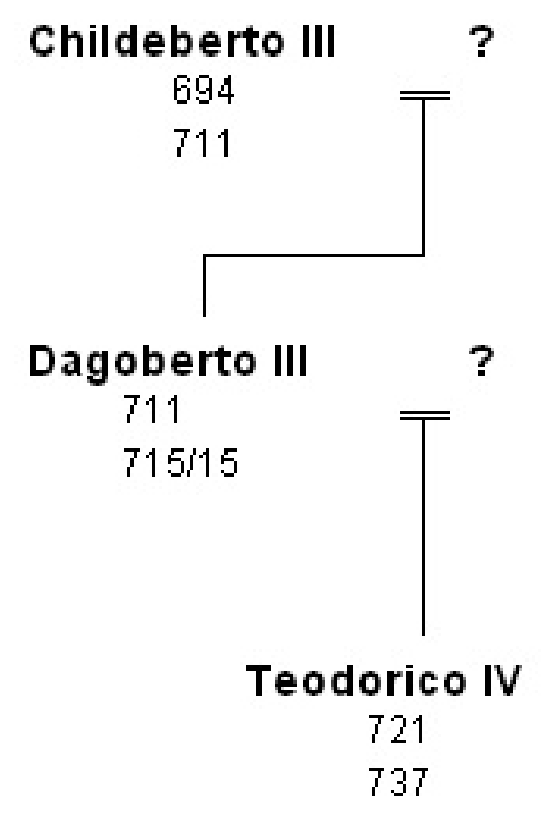

( ) MyHeritage

Produced by Family Tree Builder, copyright $\odot 2015$ MyHeritage Ltd. 


\section{Bibliografia}

\section{FONTES PRIMÁRIAS}

AMIANO MARCELINO

Res Gestae. Edição bilíngue (latim-inglês): ROLFE, J.C. Ammianus Marcellinus. Res Gestae. 3 Vols. Londres \& Cambridge: William Heinemann, Harvard University Press, 1935.

"AURELIO VICTOR"

De Caesaribus. Edição: PILCHLMAYR, F. Sexti Aurelii Victoris de Caesaribus Liber. Programma Gymnasii Ludoviciani Monacensis, 1892.

BRAULIO DE ZARAGOZA

Renotatio librorum Isidori. Edição: MARTÍN, J.C. Scripta de vita Isidori episcopi Hispalensis. CCSL 113B. Brepols, 2006.

BREVIÁRIO DE ALARICO

ed. HAENEL, G. Lex Romana Visigothorum. Leipzig, 1849.

\section{CHRONICA CAESARAUGUSTANA}

Edição MGH: MOMMSEN, T: Chronica Caesaraugustanorum reliquae. A.A. Tomo XI, V.II.1894.

\section{CONCÍLIOS TOLEDANOS}

Edição: Bilíngue (latim-espanhol) Ed. VIVES, J. Concílios visigóticos y hispanorromanos. Barcelona-Madrid: CSCI, 1963.

\section{Diplomata Maiorum Domus e Stirpe Arnulforum}

Edição MGH - PERTZ, K.A.F. Diplomatum. Tomus I. 1872. Nova edição MGH KÖLZER, T. Diplomata Regum Francorum e Stirpe Merovingica. Hannover, 2001.

\section{EPISTOLAS AUSTRASIANAS}

Epistolae Austrasicae. Edição: GUNDLACH, W. Epistolae Austrasicae. In: Epistolae Merowingici et Karolini. Tomo I. 1892.

EPÍSTOLAS VISIGODAS 
Epistolae Wisigoticae. Edição MGH: GUNDLACH, W. Epistolae Wisigoticae In: Epistolae Merowingici et Karolini. Tomo I. 1892.

\section{EUTRÓPIO}

Breviarium. Edição: DROYSEN, H. Eutropi Breuiarium ab urbe condita. Wedmann, 1878

"FREDEGÁRIO”

Chronica. Ed. Krusch, B. MGH (SRM). t.II.1888.

\section{GREGÓRIO DE TOURS}

Decem Libri Historiarum. Gregorii episcopi Turonensis historiarum libri X. Monumenta Germaniae historica (MGH). Scriptores Rerum Merowingicarum (SRM). Ed. KRUSCH, B. Fasc. I e II, 1937-1942; fasc. III, Praefatio et Indices. KRUSCH, B, LEVISON, W e HOLTZMANN, W. Hanover: 1951. Traduções: THORPE, L. The history of the Franks. Harmondsworth/New York: Penguin Books, 1974. LATOUCHE, R. L'Histoire des Francs. Paris: Les Belles Lettres, 1999.

\section{IDÁCIO DE CHAVES}

Chronica. Edição MGH: MOMMSEN, T. Hydatii Lemici Continuatio chronicorum Hieronymianorum. A.A. Tomo XI, V.II.1894. TRANOY, A. edição bilingue latim-francês. Paris: Les éditions du Cerf, 1974. 2.tom.

\section{ILDEFONSO DE TOLEDO}

Liber de Viris Illustribus. Edição: YARZA URQUIOLA, V. \& CORDOÑER MERINA, C. De virginitate Sanctae Mariae. De cognitione baptismi. De itinere deserti. De viris illustribus. CCSL 114 A. Brepols, 2007.

\section{ISIDORO DE SEVILHA}

De Differentiis $I$ - Edição: Bilíngue (latim-espanhol) de CODOÑER, Carmen. Paris: Belles Lettres, 1992.

De Viris Illustribus. Ed. CORDOÑER MERINO, C. El "De viris Illustribus" de Isidoro de Sevilha. Salamanca, 1964.

Etymologiarum. Ed. Bilíngüe (latim-espanhol) de J.O. Reta e M.A.M, Casqueros. Madrid: BAC, 1975.

Historia Gothorum, Sueborum et Wandalorum. Edição MGH: MOMMSEN, T. Chronica Minora. A.A. Tomo XI, V.II.1894. Edição crítica e texto bilíngue (latim-espanhol): RODRIGUEZ ALONSO, Cristóbal. Las historias de los godos, vandalos y suevos de Isidoro de Sevilla. Estudios, edición crítica y traducción. Leon: centro de estudios e investigación "San Isidoro". Archivo historico diocesano Caja de ahorros y Monte Piedad de Leon, 1975.

Sententiae. Edição: CAZIER, P. CCLS III. Brepols, 1998. Tradução para o Espanhol: 
Los três libros de las "Sentencias". Introdução, tradução e notas: Ismael Roca Meliá. Madrid: BAC, 2009.

JOÃO DE BICLARO

Iohannis abbatis Biclarensis chronica. Edição MGH: MOMMSEN, T. Chronica Minora. A.A. Tomo XI, V.II.1894.

JORDANES

Gética - Edição MGH: MOMMSEN, T. Iordanis. Romana et Getica. A.A. Tomo V. 1882.

JULIANO DE TOLEDO

Historia Wambae. Edição: LEVISON, W. Sancti Ivliani Toletanae sedis episcopi Historia Wambae regis. CCSL CXV. Brepols, 1976.

\section{LEGES VISIGOTHORUM}

ed. ZEUMER, K. MGH Leges 1/1, 1902.

\section{LIBER HISTORIAE FRANCORUM}

Liber Historiae Francocum. Edição: Ed. Krusch, B. MGH (SRM). t.II.1888.

\section{PACTUS LEGIS SALICAE}

Ed. ECKHARDT, Karl August. MGH Leges.1962. Tradução para a Língua Inglesa: The Laws of The Salian Franks. Translated and with introduction by Katherine Fischer Drew. Philadelphia: University of Pennsylvania Press, 1991.

PAIXÃO DE LEUDEGÁRIO

Passio Leudegarii. Edição MGH: KRUSH, B. SRM, V. 1910.

PAIXÃO DE PRAEJECTO

Passio Praejecti. Edição MGH: KRUSCH, B. SRM, V.

PAULO OROSIO

Historiarum Libri Septem. Edição: ZANGEMEISTER, C. Paulus Orosius. Historiarum Adversum Paganos Libri VII. Accedit Eiusdem Liber Apologeticus. Recensuit et commentario critico. Georg Olms, 1967.

\section{SISEBUTO}

Vita Desiderii. Edição MGH: KRUSCH, B. SRM. Tomo III. 1896. 
TÁCITO

Germania. Edição bilíngue (latim-francês): PERRET, Jacques. Tacite. La Germanie. Paris: Belles Lettres, 1949. Edição em língua portuguesa: Germânia. Públio Cornélio Tácito. Tradução de João Penteado Erskine Stevenson. São Paulo: Ed. e Publicações Brasil, 1952.

\section{VENÂNCIO FORTUNATO}

Carmina. Edição bilíngue (Latim-Francês) e tradução: Venance Fortunat. Poèmes. Livres V-VIII. Paris: Les Belles Lettres, 1998. Tradução de Marc Reydellet.

\section{VIDA DE AUDOÍNO}

Vita Audoini Episcopi Rotomagensis. Edição MGH: LEVISON, W. SRM, V. 1910. VIDA DE S. BALTILDA

Vita Domnae Balthildis. Edição MGH: KRUSCH, B. SRM, Tomo II. 1888.

VIDA DE S. COLUMBANO

Vita Columbani. Edição MGH: KRUSCH, B. SRG, 37. 1905.

VIDAS DOS PADRES DE MÉRIDA

Vitas sanctorum patrum Emeretensium. Edição: MAYA SÁNCHEZ, A. Vitas sanctorum patrum Emeretensium. CCSL, 116. Brepols, 1992.

VIDA RADEGUNDA I e II

Vita Radegunda. Edição MGH: KRUSCH, B. SRM, II. 1888.

VIDA DE SALDABERGA

Vita Sadalbergae. Edição MGH: KRUSCH, B. \& LEVISON, W. SRM V. 1910.

VIDA DE WANDRILLE

Vita Wandregiseli Abbatis Fontanellensis. Edição MGH: KRUSCH, B. SRM, V. 1910.

ZÓZIMO

Historia Nova. Edição: Zosimus. New History. Tradução e comentários críticos: Ronald T. Ridley. Sydney: Australian Association for Byzantine Studies, 1982. 


\section{Historiografia}

ALMEIDA, Néri de Barros. Raul Glaber: um historiador na Idade Média (980/9851047). Revista Signum. vol.11, n.2. p.76-108. 2010.

ALONSO CAMPOS, J.I. Sunna, Masona y Nepopis. Las luchas religiosas durante la dinastia de Leovigildo. Los visigodos. Historia y civilización. Antigüedad y cristianismo, III, 1986.

AMORY, P. The meaning and purpose of ethnic terminology in the Burgundian laws. Early Medieval Europe, v.2, n.1, p.1-28, 1993.

ANDERSON, Thomas Jr. Roman military colonies in Gaul, Salian Ethnogenesis and the forgotten meaning of Pactus Legis Salicae 59.5.Early Medieval Europe. n.4, v.2, p.129-144, 1995.

ARJAVA, Antti. The survival of Roman Family law after the Barbarian settlements. In: MATHISEN, R. (Ed). Law, society and authority in Late Antiquity. Oxford: Oxford University Press, 2001.

BALDWIN, B. Sources for the Getica of Jordanes. Revue belge de philologie et d'histoire. T.59, fasc.1, p.141-146, 1981.

BARBIERA, I. Memorie sepolte. Tombe e identità nell'alto medioevo (secoli VVIII). Roma: Carocci Editore, 2012.

BARLOW, J. Gregory of Tours and the Myth of the Trojan Origins of the Franks. Frühmittelalterliche Studien. Jahrbuch des Instituts für Frühmittelalterforschung der Universität Münster. n.29. p. 86-95. 1995.

BARNWELL, P.S. Emperors, jurists and kings: law and custom in the Late Roman and Early Medieval West. Past \& Present. n.168, p.6-29, 2000.

BARTH, F. I Gruppi Etnici e I Loro Confini. In: MAHER, Vanessa (ed.). Questioni di Etnicità. Torino: Rosenberg \& Sellier, 1994.

BARTHÉLEMY, D. \& WHITE, S.T. The 'Feudal Revolution'. Past \& Present, n.152, p.196-122, 1996.

BARTOLOMÉ, Miguel A. As etnogênese: velhos atores e novos papéis no cenário cultural e político. Mana, n.12, v.1, p.39-68, 2006.

BÉMONT, Charles. et MONOD, Gabriel. Histoire de l'Europe au Moyen Age (3851270). Paris: Libraire Félix Alcan, 1924.

BICKERMAN, E. Origines Gentium. Classical Philology, v.47, n.2, p.65-81, 1952. 
BIERBRAUER, V. 'Archäologie und Geschichte der Goten vom 1.-7. Jahrhundert'. Frühmittelalterlichen Studien, n. 28, p.51-172, 1994.

Les Wisigoths dans le royaume franc. In: Actes des XVIIIes Journées Internationales d'Arquéologie Mérovingienne. Saint-Germain-en-Laye. Musée des Antiquités Nationales, 23-24 avril 1997.

BLOCH, M. A Sociedade Feudal. Lisboa: Edições 70, 1970.

Apologia da história. Ou o ofício do historiador. Rio de Janeiro: Jorge Zahar, 2001.

Les Rois Thaumaturges. Étude sur le caractère surnaturel attribué a la puissance royale particulièrement en France et en Angleterre. Paris : Armand Colin, 1961.

BOESCH GAJANO, Sofia. Introdução. In: BOESCH GAJANO, S. (ed.). Agiografia altomedioevale. Bologna: Società editrice il Mulino, 1976.

BOLLAND, J. Acta Sanctorum. Januarii Tomus Primus.

BOUGARD, F., FELLER, L. \& LE JAN, R. Les élites au haut Moyen Age. Crises et Renouvellements. Turnhout: Brepols, 2006.

BRENNAN, B. St. Radegund and the Early Development of Her Cult at Poitiers. Journal of Religious History. n.13, p.340-353, 1985.

BRESTIAN, S. de. Vascones and Visigoths: Creation and Transformation of Identity in Northern Spain in Late Antiquity. In: In: MATHISEN, R.W. \& SHANZER, D. (ed.) Romans, Barbarians and the transformation of the Roman World. Cultural Interaction and the Creation of Identity in Late Antiquity. Farnham: Ashgate, 2011.

BRINK, S. People and Land in Early Scandinavia. In: GARIPZANOV, I.H; GEARY, P. \& URBAŃCZYK, P. Franks, Northmen and Slavs: Identities and State Formation in Early Medieval Europe. Turnhout: Brepols, 2008.

BRONISCH, Alexander P. El concepto de España en la historiografía visigoda y asturiana. Norba. v.9, p.9-42, 2006.

BROWN, E. The Tyranny of a Construct: Feudalism and Historians of Medieval Europe. The American Historical Review, v.79, n.4, p.1063-1088, 1974.

BROWN, P. The Making of Late Antiquity. Cambridge: Harvard University Press, 1993.

. The rise and function of the Holy Man in Late Antiquity. The Journal of Roman Studies. v.6, p.80-101, 1971. 
BRUBAKER, L. \& SMITH, Julia M.H. Gender in the Early Medieval World. East and West, 300-900. Cambridge: Cambridge University Press, 2004.

BRUNDAGE, James A. Medieval Canon Law. Londres e NY: Longman, 1995.

BRUNNER, H. Deutsche Rechtesgeschichte. Leipzig: Duncker \& Humblot, 1887.

BRUNNER, Otto. Storia Sociale Dell'Europe nel Medioevo. Bologna: Mulino, 1980.

BUCKLE, H.T. History of Civilization in England. NY: D. Appleton, 1876.

CAILLEMER, R. Les travaux recentes sur l'état social des germains et sur les sources $\mathrm{du}$ droit de l'époque franque et la nouvelle édition de la Deutsche Rechtsgeschichte de M. Brunner. In: Nouvelle Revue Historique de Droit Français et Étranger. 1907.

CAMARgO, M. Ars Dictaminis. Ars Dictandi. Typologie dês Sources du Moyen Âge Occidental. Fasc.60. Turhnout: Brepols, 1991.

CAMERON, A. History and individuality of the historian: the interpretation of late antiquity. In: LIM, Richard \& STRAW, Carole. The past before us. The challenge of historiographies of Late Antiquity. Turnhout: Brepols, 2004.

On defining the Holy man. In: HOWARD-JOHNSTON, J. \& HAYWARD, P.A. The cult of the Saints in Late Antiquity and the Early Middle Ages. Oxford: Oxford University Press, 1999.

CAMPOS, Julio. Juan de Biclaro obispo de Gerona. Su vida y su obra. Madrid: Consejo superior de investigaciones cientificas, 1960.

CÂNDIDO, M. \& MAZETTO, M. A realeza nas fontes do período merovíngio (séculos VI-VIII). História Revista. v.11, n.1, p.89-119, jan./jun. 2006.

CÂNDIDO, M. A realeza cristã na Alta Idade Média. São Paulo: Alameda, 2008.

. Entre "Antiguidade Tardia" e "Alta Idade Média". Diálogos. v.12, n.2/n.3, p. 53-64, 2008.

Paz e Violência no Pactus Legis Salicae. In: OLIVEIRA, J.C.M \& Selvatici, M. Textos e representações da Antiguidade: Transmissão e interpretação. Maringá: UEN, 2012.

. Le Prince, la Lex et la Iustitia : Le Bréviaire D'Alaric et l'édit attribué à Clotaire II. In : ROUCHE, M. \& DUMÉZIL, B. Le Breviáire d'Alaric. Aux origines du Code civil. Paris : PUPS, 2008.

CANNING, J. A History of Medieval Political Thought. 300-1450. Londres e Nova York: Routledge, 1996. 
CARBONELL, C.-O. Les origines de l'Etat moderne: les traditions historiographies françaises (1820-1990). In: Visions sur le développement des États européens. Théories et historiographies de L'État moderne. Actes du colloque de Rome (18-31 mars 1990). Rome: École Française de Rome, 1993.

CASSARD, J.-C. La guerre des Bretons au haut Moyen Age. Revue Historique. t.275, fasc.1, p.3-27, 1986.

CASSIRER, E. Linguagem e mito. São Paulo: Perspectiva, 1972.

CASTELLANOS, S. \& MARTÍN VISO, I. The local articulation of central power in the north of the Iberian Peninsula (500-1000). Early Medieval Europe, v.13, n.1, p.1-42, 2005.

. Conflictos entre la autoridade y el hombre santo. Hacia el control oficial del Patronatus Caelestis en la Hispania Visigoda. Brocar, n.20, p.77-89, 1996.

Poder Social, Aristocracias y hombre santo en la Hispania Visigoda: La Vita Aemiliani de Braulio de Zaragoza. La Rioja: Universidad de la Rioja, 1998.

CERTEAU, M. A escrita da história. Rio de Janeiro: Forense Universitária, 2002.

CHÂTELET, François. La naissance de l'histoire. Tomo I. Paris: Seuil, 1962.

COELHO, Maria Filomena. Justiça e Ordenamento. In: FONSECA, C.; RIBEIRO, M.E. Instituições, cultura e poder na Idade Média Ibérica. Atas da VI Semana de Estudos Medievais - I Encontro Luso-brasileiro de História Medieval. Brasília: PEM-UnB, 2007

COLLINS, R. Fredegar. Aldershot: Variorum, 1996.

. La España Visigoda. 409-711. Barcelona: Crítica, 2005.

. Merida and Toledo. 550-585. In: JAMES, E. (ed.). Visigothic Spain: New Approachs. Oxford: Clarendon Press, 1980. p.189-219.

CONSTABLE, G. Letters and Letter-Collections. Typologies des Sources du Moyen Âge Occidental, fasc.17. Turnhout: Brepols, 1976.

CORDERO RUIZ, T. El territorio emeritense durante la Antigüedad Tardía. (siglos IV-VIII). Génesis y evolución del mundo rural lusitano. Mérida: Anejos de AEspA, LXVI, 2013.

COSTA, C.L. O tráfico do gênero. Cadernos pagu. 11, p.127-140, 1998.

COUMERT, M. Le peuplement de L'Armorique: Cournouaille et Domnonée de part et d'autre de la Manche aux premiers siècles du Moyen Age. COUMERT, M. \& TÉTREL, H. (eds). Histoires des Bretagnes - 1. Les mythes fondateurs. Brest, CRBC, 2010. 
Origines des Peuples. Les récits du haut Moyen Âge Occidental (550-850). Paris: Institut d'Études Augustiniennes, 2007.

CROKE, Brian. Cassiodorus and the Getica of Jordanes. Classical Philology. v. 82, n.2, p. 117-134, abril de 1987.

CURTA, F. Some Remarks on ethnicity in medieval archaeology. Early Medieval Europe. v.15, n.2, p. 159-185. 2007.

DAGRON, G. Une lecture de Cassiodore-Jordanès: les Goths de Scandza à Ravenne. Annales. Histoire, Sciences Sociales, 26, n.2, p.290-305, 1971.

DARWIN, C. A origem do homem. São Paulo: Hemus, 1974.

DAVOUD-OGHLOU, G.A. Histoire de la Législation Ancient e des Anciens Germaines. Berlim: Reimer, 1845.

DE PALOL, P. La arqueologia cristiana en la Hispania romana y visigoda. Descubrimientos recientes y nuevos puntos de vista. In: Actes du XIe congrès international d'archéologie chrétienne. Lyon, Vienne, Grenoble, Genève, Aoeste. 21-28 septembre 1986. École Française de Rome, 1989. p.1975-2022.

DELEHAYE, H. L'ouvre dês Bollandistes. 1615-1915. Bruxelles: Bureaux de la Société dês Bollandistes, 1920.

Problemi di metodo agiografico: le coordinate agiografiche e le narrazioni. In: BOESCH GAJANO, Sofia (ed.). Agiografia altomedioevale. Bologna: Società editrice il Mulino, 1976. p.49-71. [Originalmente publicado em: La méthode historique et l'hagiographie. Publicado em: Bulletin de la Classe des Lettres et des Sciences morales et politiques, 5e serie, VI (1930), p.218-231]

DEMOULE, J.-P. Archäologische Kulturen und modern Nationen. In: BIEHL, P.F., GRAMSCH, A. \& MARCINIAK, A. Archäologien Europas. Gerschichte, Methoden und Theorien. Münster, NY, Munich and Berlin: Waxmann, 2002.

DEPREAUX, P. La loi et le droit. La part des échanges culturels dans la référence à la norme et les pratiques juridiques durant le haut Moyen Âge. Actes des congrès de la Société des historiens médiévistes de l'enseignement supérieur public. 32e congrés. Dunkerque, 2001.

. L'historiographie des élites politiques. In: Textes de travail rédigés dans le cadre de la recherche sur «Les Élites dans le haut Moyen Âge VI ${ }^{\mathrm{e}}-\mathrm{XII}$ ' siècle », (Marne-la-Vallée et Paris 1), 27 et 28 novembre 2003. Disponível em: http://lamop.univ-paris1.fr/spip.php?article438\#.VEELv4uUffI

DERKS, T. \& ROYMANS, N. (Eds). Ethnic Constructs in Antiquity. The role of power and tradition. Amsterdam: Amsterdam University Press, 2009.

DÍAZ Y DÍAZ, M.C. La Lex Visigothorum y sus manuscritos. Un ensayo de reinterpretacion. Anuario de Historia del Derecho Español, n.6, p.163-224, 1976. 
DÍAZ, Pablo C. Visigothic Political Institutions. In: HEATHER, P. The visigoths. From the migration period to the seventh century. An ethnographical perspective. Woodbridge: Boydell Press, 1999.

DIERKENS, A. Note sur un passage de la Vita Dagobert II et le domaine de Biesme. Revue belga de philologie et d'histoire. v.62, n.62-2, p.259-270, 1984.

- Prolégomènes à une histoire des relations culturelles entre les Îles Britanniques et le continent pendant le Haut Moyen Âge. La diffusion du monachisme dit colombanien ou iro-franc das quelques monastères de la région parisienne au VIIe siècle et la politique religieuse de la reine Bathilde. In: ATSMA, H. La Neustrie. Les pays au nord de la Loire de 650 à 850. Paris: Sigmaringen, 1989.

DÖRLER, P. The Liber Historiae Francorum - a Model for a New Frankish selfconfidence. Networks and Neighbours, v.1, n.1, p.23-43, 2013.

DREW, Katherine Fischer. The Laws of The Salian Franks. Translated and with introduction by Katherine Fischer Drew. Philadelphia: University of Pennsylvania Press, 1991.

DUBOIS, J. \& LEMAITRE, J.-P. Sources \& Méthodes de l'hagiographie médiévale. Paris: Les Éditions du CERF, 1993.

DUMÉZIL, B. La reine Brunehaut. Paris: Fayard, 2008.

ECKHARDT, K.A. Einleitung. In: Germanicarum. Tomo IV, Parte I. 1962.

EFFROS, B. Caring for Body \& Soul. Burial and the afterlife in the Merovingian World. Pennsylvania: Pennsylvania University Press, 2002.

- Merovingian Mortuary Archaeology and the Making of the Early Middle Ages. Berkeley, Los Angeles \& Londres: University of California Press, 2003.

ELLIS, L. 'Terra Deserta': Population, Politics, and the [de]Colonization of Dacia. World Archaeology, v.30, n.2, p.220-237, 1998.

FINE, John V.A. Jr. When ethnicity did not matter in the Balkans. A Study of Identity in Pre-Nationalist Croatia, Dalmatia, and Slavonia in the Medieval and Early-Modern Periods. Michigan: University of Michigan Press, 2006.

FONTAINE, J. Isidore de Séville. Genèse et originalité de la culture hispanique au temps des Wisigoths. Turnhout: Brepols, 2000.

King Sisebut's Vita Desiderii and the political function of Visigothic hagiography. In: JAMES, E. (ed.). Visigothic Spain. New approaches. Oxford: Clarendon Press, 1980. 
FOURACRE, P. \& GERBERDING, R.A. Late Merovingian France. History and Hagiography. 640-720. Manchester \& NY: Manchester University Press, 1996.

FOURACRE, P. Merovingian History and Merovingian Hagiography. Past and Present. n.17, p.3-38, maio de 1990.

FOX, Y. Power and Religion in Merovingian Gaul. Columbanian Monasticism and the Frankish Elites. Cambridge: Cambridge University Press, 2014.

FRANSEN, G. Les Collections Canoniques. Typologie des Souces du Moyen âge Occidental. Fasc.10. Turnhout : Brepols, 1973.

FREEMAN, M. \& NAPIER, D. Introduction. Law and Anthropoloy. In: FREEMAN, M. \& NAPIER, D. (eds.). Law and Antropology. Current Legal Issues, vol.12. Oxford: Oxford University Press, 2008.

FRIGHETTO, R. Infidelidade e barbárie na Hispania visigoda. Gerión, v.20, n.1, p.491-509, 2002.

Memória, História e identidades: Considerações a partir da Historia Wambae de Juliano de Toledo (Século VII). Revista de História Comparada. n.5, v.2, p.50-73, 2011.

. O rei e a lei na Hispania visigoda: os limites da autoridade régia segundo a Lex Wisigothorum, II,1-8 de Recesvinto (642-670). In: FRIGHETTO, R. \& GUIMARÃES, M.L. Instituições, poderes e jurisdições. Curitiba: Juruá, 2007.

Sociedade e Cultura no NO. Peninsular Ibérico em finais do século VII, segundo o De Genere Monachorum de Valério do Bierzo.Gallaecia, v.8, p.363373, 1999.

. Transformação e tradição: a influência do pensamento político e ideológico do mundo romano clássico na antiguidade tardia. Diálogos. Maringá: DHI/PPH/UEM, vol., 12, n.,3, p.19-42. 2008.

A Antiguidade Tardia. Roma e as monarquias romano-bárbaras numa época de transformações. Séculos II-VIII. Curitiba: Juruá, 2012.

FUCHS, E. Conceptions of Scientific History in the Nineteenth Century West. In: WANG, Q. \& IGGERS, G.G. Turning points in Historiography. A cross cultural perspective. NY: The University of Rochester Press, 2002.

FUSTEL DE COULANGES, N.D. Histoire des institutions politiques de l'ancienne France. Paris: Libraire Machette, 1890.

L'Alsace est-elle allemande ou française? Réponse a M. Mommsen. Paris: E. Dentu, 1870. 
Nouvelles recherches sur quelques problèmes d'histoire. Paris: Librairie Hachette, 1923.

FUTUYAMA, Douglas J. Biologia evolutiva. Ribeirão Preto: Sociedade Brasileira de Genética/CNPq, 1992.

GABBA, Emilio. True and false history in Classical Antiquity. The Journal of Roman Studies. v.71, p.50-62, 1981.

GADAMER, H.-G. O problema da consciência histórica. Rio de Janeiro: FGV, 2003.

Verdade e método. Traços fundamentais de uma hermenêutica filosófica. Petrópolis: Vozes, 1999.

GANSHOF. F.L. O que é feudalismo. Lisboa: Europa-América, 1968.

GARCÍA MORENO, L.A. Alaric II et 1'Espagne. In: ROUCHE, M. \& DUMÉZIL, B. Le Bréviaire d'Alaric. Aux origines du Code Civil. Paris: PUPS, 2008.

Building an Ethnic Identity for a New Gothic and Roman Nobility: Córdoba, 615 AD. In: MATHISEN, R.W. \& SHANZER, D. (ed.) Romans, Barbarians and the transformation of the Roman World. Cultural Interaction and the Creation of Identity in Late Antiquity. Farnham: Ashgate, 2011.

. Historia de España Visigoda. Madrid: Cátedra, 1989.

. Prosopography, nomenclature and Royal Succession in the Visigothic Kingdom of Toledo. Journal of Late Antiquity, v.1, n.1, p.142-156, 2008.

. Transformaciones de la Bética durante la tardoantigüedade. Mainake, XXIX, p.433-471, 2007.

GARRISON, M. "Send more socks": On mentality and the preservation contexto of Medieval letter. In: MOSTERT, M. (ed.). New Approaches to Medieval Comunication. Turnhout: Brepols, 1999.

GASPARRI, S. Prima delle nazioni. Popoli, etnie e regni fra Antichità e Medioevo. Roma: La Nuova Italia Scientifica, 1997.

GAUDEMET, J. \& BASDEVANT, B. Les canons des Conciles Mérovingiens. (VI ${ }^{\mathrm{e}}$ VII ${ }^{\mathrm{e}}$ Siècles). Sources Chrétiennes, n.353. Paris: Les Éditions du CERF, 1989.

GAUDEMET, J. Survivances romaines dans le droit de la monarchie franque du $V^{\text {ème }}$ au $X^{\text {ème }}$ Siecle. Tijdschrift voor Rechtsgeschiedenis. n. 23, p.149-206, 1955.

GEARY, P. Living with the dead in the Early Middle Ages. Ithaca and London: Cornell University Press, 1994.

O mito das nações: a invenção do nacionalismo. São Paulo: Conrad, 2005. 
GERBERDING, R.A. The rise of the Carolingians and the Liber Historiae Francorum. Oxford: Clarendon Press, 1987.

GIBBON, Edward. Declínio e queda do Império Romano. Vol.2. Lisboa: Difusão Cultural, 1995.

GILLET, A. Was ethnicity politicized in Earliest Medieval Kingdoms? In: GILLET, A. On Barbarian Identity. Critical approaches to Ethnicity in Early Middle Ages. Turnhout: Brepols, 2002.

. Ethnogenesis: A contested model of Early Medieval Europe. History Compass. n.4, v.2, p.241-269, 2006.

GUILLOT, O. Brèves remarques sua l'esprit de quelques interprétations fondamentales du Bréviare d'Alaric et sur sa réception par les rois Mérovingiens. In : ROUCHE, M. \& DUMÉZIL, B. Le Bréviaire d'Alaric. Aux origines du Code Civil. Paris : PUPS, 2006. p. 179-198.

GINGRICH, Andre. Envisioning Medieval Communities in Asia: Remarks in Ethnicity, Tribalism and Faith. POHL, W. GANTNER, C. \& PAYNE, R. (eds.) Visions of Community in the post-roman world. The West, Byzantium and the Islamic World, 300-1100. UK: Ashgate, 2012.

GOFFART, W. Barbarian Tides. The Migration Age and the Later Roman Empire. Philadelphia: University of Pennsylvania Press, 2006.

Byzantine Policy in the West under Tiberius II and Maurice: Tre pretenders Hermenegild and Gundovald (579-585). Traditio. v.13, p.73-118, 1957.

Does the distant past impinge on the invasion age germans? GILLET, A.(ed.). On Barbarian Identity. Critical Approaches to Ethnicity in the Early Middle Ages. Turnhout: Brepols, 2002.

From Historiae to Historia Francorum and back again: aspects of the textual history of Gregory of Tours. In: Rome's fall and after. Londres e Roceverte: Hambledon, 1989.

. The Fredegar Problem Reconsidered. Speculum. v.38, n.2, p. 206-241, 1963.

Zosimus, the first historian of Rome's Fall. The American Historical Review. v. 76, n.2, p.412-441, 1971.

Jordane's "Getica" and the disputed authenticity of Gothic origins from

Scandinavia. Speculum. v. 80, n.2, p.379-398, Abril de 2005.

GONZALÉZ, Teodoro. Historia de la Iglesia en España. Madrid: BAC, 1979. 
GORDINI, G.D. L'Opera dei bollandisti e la loro metodologia. In: Santità e agiografia. Atti dell'VIII Congresso di Terni. (A cura di Gian Domenico Gordini). Genova: Marietti, 1991.

GRAUS, F. Le funzioni del culto dei santi e della leggenda. In: BOESCH GAJANO, Sofia (ed.). Agiografia altomedioevale. Bologna: Società editrice il Mulino, 1976. p.145-160. [Publicação original: "Die Funktionen des Heiligenkults und der Legenden. In: Volk, Herrscher und Heiliger im Reich der Merowinger. Praha: Nakladatelstvi Ceskoslovenske Akademier Ved, 1965. P.438-450. Tradução de Elisa Ranucci].

GRÉGOIRE, R. Agiografia: tra storia, filosofia, teologia. In: Santità e agiografia. Atti dell'VIII Congresso di Terni. (A cura di Gian Domenico Gordini). Genova: Marietti, 1991.

GRININ, L.E. Production Revolutions and periodization of History: a comparative and theoretic-mathematical approach. Social Evolution \& History. Moscou: Uchitel, vol., 6, n., 2, p.75-121. 2007.

GUENÉE, B. Histoire et culture historique dans l’Occident Médiéval. Paris : Aubier Montaigne, 1980.

GUIBERNAU, Montserrat. Nacionalismos. O estado nacional e o nacionalismo no século XX. Rio de Janeiro: Jorge Zahar, 1997.

GUIZOT, F. Histoire de la Civilisation en Europe. Paris: Librairie Académique Didier, 1898.

GUTERMAN, Simeon L. The first age of European law: the origin and character of the conflict of laws in the Early Middle Ages. New York Law Forum. v.VII, n.2, p.131-166. Maio de1961.

GUZMÁN ARMARIO, Francisco Javier. ¿Germanismo o Romanismo? Una espinosa cuestión del mundo antiguo a la Edad Media: el caso de los visigodos. Anuario de estudios medievales. n.35, v.1, p.3-23, 2005.

HAAR, I. \& FAHLBUSCH, M. (eds). German Scholars and Ethnic Cleansing, 1919-1945. NY \& Oxford: Berghahn Books, 2005.

HAKENBECK, S.E. Situational Ethnicity and Nested Identities: New Approaches to an Old Problem. Anglo-Saxon Studies in Archaeology and History, n.4, p.1927, 2007.

HALPHEN, L. L'Essor de L'Europe. (XIe - XIIIe siècles). Paris: Libraire Féliz Alcan, 1932.

Les barbares. Des Grandes invasions aux conquêtes turques du $\mathrm{XI}^{\mathrm{e}}$ siècle. Paris : Libraire Félix Alcan, 1936. 
HALSALL, G. Barbarian Migrations and the Roman West. 376-568. Cambridge: Cambridge University Press, 2007.

. Cemeteries and Society in Merovingian Gaul. Selected Studies in History and Archaeology. 1992-2009. Leiden \& Boston: Brill, 2010.

Ethnicity and early medieval cemeteries. Arqueología y Territorio Medieval. n.18, p.15-27, 2011

Female status and power in early Merovingian central Austrasia: the burial evidence. Early Medieval Europe. v.5, n.1, p.1-24, 1996.

Movers and Shakers. The barbarians and the fall of Rome. In: NOBLE, Thomas F.X.(ed.). From Roman provinces to Medieval Kingdoms. NY \& Abingdon: Routledge, 2005.

Settlement and social organization. The Merovingian region of Metz. Cambridge: Cambridge University Press, 1995. p.262-264

. The Preface to Book V of Gregory of Tourse Histories: Its Form, Context and Significance. English Historical Review. v. CXXII, n.496. p.297-317, 2007.

HARDING, A. Medieval law and the foundations of the State. New York: Oxford University Press, 2005.

HÄRKE, H. Archaeologists and Migration. A problem of attitude? Current Anthropology. v.39, n.1, p. 19-45, 1998.

HARRIES, J. Resolving Disputes: The frontiers of Law in Late Antiquity. In: MATHISEN,R.W. Law, society and authority in Late Antiquity.

HARSIN, P. Condition des personnes en Germanie dans le haut Moyen Âge. Revue belge de philologie et d'histoire. Tomo 6, fasc.1-2, p. 147-180. 1927.

HARTOG, F. O século XIX e a história. O caso de Fustel de Coulanges. Rio de Janeiro: Editora UFRJ, 2003.

HEATHER, P. Disappearing and reappearing tribes. In: POHL, W. \& REIMITZ, H. Strategies of Distinction. The Construction of ethnic Communities, 300800.Leiden, Boston, Köln: Brill, 1998. p. 95-111.

. The Goths. Oxford \& Cambridge: Blackwell, 1996.

. The Barbarian in Late Antiquity. Image, reality, and transformation. In: MILES, Richard (Ed.). Constructing Identities in Late Antiquity. London and New York: Routledge, 1999. p. 234-258.

HEGEL, G.W. Introduction to the Philosophy of History. Indianapolis \& Cambridge: Hackett Publishing Company, 1988. 
HEINZELMANN, M. Gregory od Tours: History and Society in the Sixth Century. Cambridge: Cambridge University Press, 2001.

- Manuscrits hagiographiques et travail des hagiographes: l'exemple de la tradition manuscrite des viés anciennes de sainte Geneviève de Paris. IN: HEINZELMANN, M. (ed). Manuscrits hagiographiques et travail des hagiographes. Sigmaringen: Thorbecke, 1992.

Pouvoir et idéologie dans l'hagiographie mérovingienne. In: BOZÓKY, Edina. Hagiographie, idéologie et politique au Moyen Âge en Occident. Acter du colloque international du Centre d'Études supérieures de Civilisation médiévale de Poitiers. 11-14 septembre 2008. Turnhout: Brepols, 2012.

HELVÉTIUS, Anne-Marie. Hagiographie et formation politique des aristocrates dans le monde franc (VII ${ }^{\mathrm{e}}-\mathrm{VIII}{ }^{\mathrm{e}}$ siècles). BOZÓKY, Edina. Hagiographie, idéologie et politique au Moyen Âge en Occident. Acter du colloque international du Centre d'Études supérieures de Civilisation médiévale de Poitiers. 11-14 septembre 2008. Turnhout: Brepols, 2012.

HEN, Y. A Visigothic king in search of an identity - Sisebutus Gothorum gloriosissimus princeps. In: CORRADINI, R., GILLIS, M., McKITTERICK, R. \& RENSWOUDE, I. van. Ego trouble: authors and their identities in the Early Middle Ages. Forschungen zur Geschichte des Mittelalter, n.15. Wien: Verlag der Österreichischen Akademie der Wissenschaften, 2010.

HERDER, J.G. Outlines of a philosophy of the history of man. Vol.II. Londres: Luke Hansard, 1803.

HEUSCH, Luc De. L'Ethnie: les vicissitudes d'un concept. In: MOFFA, Claudio. L'etnia fra "invenzione" e realtà. Storia e problematiche di un dibattito. Torino: Editrice L'Harmattan Italia, 1999.

HILLGARTH, J.N. Historiography in Visigothic Spain. In: Settimane di studio del centro italiano di studi sull'alto Medioevo, XVII. La storiografia altomedievale. Tomo primo. Spoleto: Centro italiano di Studio sull'alto medioevo, 1970. p.261-311.

HOPPENBROUWERS, Peter. Such stuff as peoples are made on: ethnogenesis and the construction of nationhood in Medieval Europe. The Medieval History Journal, n.9, v. 2, p.195-242. 2006.

HUETE FUDIO, M. Fuentes menores para el estudio de la historiografia latina de la Alta Edad Media Hispánica (siglos VII-X). Medievalismo, v.4, n.4, p.5-26, 1994.

HUMMER, H.J. Franks and Alamanni: a discontinuous ethnogenesis. In: WOOD, I. Franks and Alamanni in the merovingian period. An ethnographic perspective. Woodbridge: Boydell Press, 1998. 
The fluidity of barbarian identity: the ethnogenesis of Alemanni and Suebi, AD 200-500. Early Medieval Europe, v.7, n.1, p.1-27, 1998.

HUPPERT, G. The Trojan Franks and their critics. Studies in the Renaissance, v.12, p.227-241, 1965.

JAMES, E. 'Les problèmes archéologiques du Sud-Ouest wisigothique et franque', in: PÉRIN, P. (ed).Gallo-Romains, Wisigoths et Francs en Aquitaine, Septimanie et Espagne. Actes des VIIe Journées internationales d'Archéologie mérovingienne, Toulouse 1985. Rouen, 1991.

Gregory of Tours and the Franks. In: MURRAY, A.C. Narrators and Sources of Early Medieval History. Toronto: University of Toronto Press, 1998.

Septimania and its Frontiers: An Archaeological Approach. In: JAMES, E. (ed.). Visigothic Spain: New Approachs. Oxford: Clarendon Press, 1980.

. The historical and archaeological context of the south-west gallic sarcophagi. Antiquité Tardive. v.1, p.23-28. 1993.

The origins of France. From Clovis to the Capetians, 500-1000. London \& Basingstoke: The Macmillan Press, 1982.

JONES, S. The archaeology of ethnicity. Construction identities in the past and present. London \& New York: Routledge, 1997.

JOYE, S. "Y a-t-il une "évolution"des moeurs?" Historiographie et anthropologie de la familie et du mariare. Labyrinthe, 30, p.115-130, 2008.

JOYE, S. \& SANTINELLI-FOLTZ, E. Le couple: une définition difficile, des réalités multiples. Médiévales. Le couple dans le monde franc. n.65, p.5-18, 2013.

JOYE, S. Les idées de germanisé et de romanité dans l'historiographie française du XIXe siècle. MEFRM, v.119, n.2, p.279-296, 2007.

. Grégoire de Tours et les femmes: jugements portés sur les couples laïques et ecclésiastiques. In: LA ROCCA, C. (ed.) Agire da Donna. Modelli e pratiche di rappresentazione (secoli VI-X). Turnhout: Brepols, 2007.

I conflitti familiare per la figlia nubile ${ }^{1}$ (V-IX secolo). Genesis. Rivista dela Società Italiana delle Storiche. (Donne in famiglia nell'alto medioevo. V. IX, n.1, p.29-54, 2010.

KANTOROWICZ, E. Os dois corpos do rei. Um estudo sobre teologia política medieval. São Paulo: Companhia das letras, 1998.

KAZANSKI, M. \& PÉRIN, P. Les barbares 'orientaux' dans l'armée romaine en Gaule. In: VALLET, F. KAZANSKI, M., PÉRIN, P. (ed.). Des Royaumes barbares au Regnum Francorum: L'Occident à l'époque de Childéric et de 
Clovis. (vers 450-vers 530). Actes des XVIIIes Journées Internationales d'Arquéologie Mérovingienne. Saint-Germain-en-Laye. Musée des Antiquités Nationales, 23-24 avril 1997.

KAZANSKI, M. Les goths. (Ier-VIIe après J.-C.) Paris: Editions Errance, 1991.

KAZANSKI, M. MASTYKOVA, A. \& PÉRIN, P. Die Archäologie der Westgoten in Nordgallien. Zum Stand der Forschung. In: Zwischen Spätantike und Mittelalter. (Actes du colloque Gräber, Siedlungen und Identitäten des 4. Bis 7 . Jahrhunderts im Western, Freiburg in Br. 2005). RGA-E, 149-192. Boston \& Berlin: Gruyter, 2007.

KELLAS, James G. Nazionalismi ed Etnie. Bologna: Il mulino, 1993.

KERN, F. Kingship and Law in the Middle Ages. Oxford: Basil Blackwell, 1968.

KING, P.D. Derecho y sociedad en el reino visigodo. Madrid: Alianza, 1981.

Law \& Society in the Visigothic Kingdom. Cambridge: Cambridge University Press, 1972.

KLANICZAY, G. Holy rulers and Blessed Princesses. Dynastic Cult in Medieval Europe. Cambridge: Cambridge University Press, 2002.

KOSELLECK, R. historia/Historia. Madrid: Trotta, 2004.

. On the need for theory in the discipline of History. In. Idem. The Practice of Conceptual History. Timing, History, Spacing Concepts. Stanford: Stanford University Press, 2002.

Uma história dos conceitos: problemas teóricos e práticos. Estudos Históricos. v.5, n.10, p.134-146, 1992.

KULIKOWSKI, M. Rome's Gothic Wars. From the third century to Alaric. Cambridge, NY: Cambridge University Press, 2007.

KURTH, G. La Reine Brunehaut. Paris: Bureaux de la Revue, 1891.

LA ROCCA, C. Cassiodoro, Teodato e il restauro degli elefanti di bronzo della Via Sacra. Reti Medievali Rivista. v.11, n.2, p.25-44, junho-dezembro de 2010. Disponível em: www.retimedievali.it

Foreign dangers. Activities, responsibilities and the problem of women abroad. Conferência apresentada no IMC. Leeds, 2014. 19 pp. Disponível em: https://www.academia.edu/7693666/Foreign_dangers._Leeds_IMC_2014

Introduzione. Genesis. Rivista dela Società Italiana dele Storiche. (Donne in famiglia nell'alto medioevo. V. IX, n.1, p.5-14, 2010.

. Venanzio Fortunato e la società del VI secolo. In: GASPARRI, S.(ed.) Alto Medioevo mediterraneo. Firenze: Firenze University Press, 2005. p.145-164 
LANHAM, Carol Dana. Freshman composition in the Early Middle Ages: Epistolography and Rhetoric before the ars dictaminis. Viator, p.115-134, 1992.

\section{LANTIER, R. Comptes-rendus de l'Académie dês Inscription. 1947 e 1948}

LE GOFF, J. Tentative de conclusions. In: Les élites urbaines au Moyen Âge. XXIVe Congrès de la S.H.M.E.S. (Rome, mai 1996). Paris e Roma: École Française de Rome e Publications de la Sorbonne, 1997.

LE JAN, R. Femmes, pouvoir et société dans le Haut Moyen Âge. Paris: Picard, 2001.

Historiographie des élites. Introduction. Textes de travail rédigés dans le cadre de la recherche sur «Les Élites dans le haut Moyen $\hat{A} g e \mathrm{VI}^{\mathrm{e}}-\mathrm{XII}{ }^{\mathrm{e}}$ siècle », (Marne-la-Vallée et Paris 1), 27 et 28 novembre 2003. Disponível em: http://lamop.univ-paris1.fr/spip.php?article438\#.VEELv4uUffI

LEAR, Floyd S. The Public Law of the Visigothic Code. Speculum, v.26, n.1, p.1-23. Jan, 1951.

LEONARDI, Claudio. Agiografie Medievali. DEGL'INNOCENTI, A. \& SANTI, F. (Eds.). Firenze: SISMEL . Edizioni del Galluzo, 2011.

LESO, T. Columbanus in Europe: the evidence from the Epistulae. Early Medieval Europe. v.21, n.4, p.358-389, 2013.

LIM, Richard \& STRAW, Carole. The past before us. The challenge of historiographies of Late Antiquity. Turnhout: Brepols, 2004.

LLINÀS POL, J. et al. Pla de l'Horta (Sarrià de Ter, Girona): una necrópolis con inhumaciones visigodas en la Tarraconense Oriental. Archico Español de Arqueología. n.81, p.289-304, 2008.

LÓPEZ QUIROGA, J. Elementos "foráneos" en las necrópolis tardorromanas de Beiral (Ponte de Lima, Portugal) y Vigo (Pontevedra, España): de nuevo la cuestión del siglo V d.C. en la Península Ibérica. CuPAUAM, 27, p.115-124, 2001.

La presencia "Germánica" en Hipania en el siglo V d.c. Arqueología y procesos de etnogénesis en la Península Ibérica. CuPAUAM, 30, p.213-223, 2004.

LOT, Ferdinand. Encore la chronique du pseudo-Frédegáire. In : Recueil des travaux historiques de Ferdinand Lot. Tome I. Genève, Paris : Droz \& Minard, 1968. Originalmente publicado em : Revue historique, 15, p.305-337, 1914. p.518519. 
LOWE, J. The Hagiography of Saint-Wandrille (Fontenelle) (Province of HauteNormandie). In: HEINZELMANN, M. (dir.) L'Hagiographie du Haut Moyen Âge en Gaule du Nord. Beihefte der Francia. Herausgegeben von Deutschen Historischen Institut Paris. Band 52. Stuttgart: Thorbecke, 2001.

MAASSEN, F. Geschichte der Quellen und der Literatur des canonischen Rechts. 1870.

MAKKREEL, R.A. \& RODI, F. (Eds). Hermeneutics and the study of History. Wilhelm Dilthey. Selected Works. Vol. IV. New Jersey: Princeton University Press, 1996.

MALASPINA, E. Il Liber epistolarum della cancelleria austrasica. (sec.V-VI). Roma: Herder Editrice e Libreria, 2001.

MARCOTEGUI BARBER, B. El tratamiento historiográfico de San Hermenegildo. AHIg, n.12, p.289-302. 2003.

MARTÍN, J.C. Verdad Histórica y verdad hagiográfica en la vita desiderii de Sisebuto. Habis, n.29, p.291-301, 1998.

MARTÍNEZ BERMEJO, S. Translating Tacitus: the reception of Tacitus's works in the vernacular languages of Europe. 16th-17th centuries. Pisa: Plus-Pisa University Press, 2010.

MATHISEN, R. Between Arles, Rome, and Toledo: Gallic collections of canon law in Late Antiquity. Cuadernos 'Ilu. n. 2, p.33-46, 1999.

MATTHEWS, J.F. Interpreting the Interpretationes of the Breviarium. In: MATHISEN, R.W. Law, Society and authority in Late Antiquity. N.Y.: Oxford University Press, 2001.

MAYA SÁNCHEZ, A. Introdução. In: Vitas Sanctorum Patrum Emeritensium. Corpus Christianorum. Series Latina. CXVI. Turnholt: Brepols, 1992.

MAYR, Ernst. Biologia, Ciência Única. São Paulo: Companhia das Letras, 2005.

MAZETTO, Milton Jr. A paz e o recurso à violência no Reino dos Francos: os mecanismos de resolução de conflito no período merovíngio (Séculos VI-VII). Dissertação de Mestrado. Programa de Pós-Graduação em História Social. Faculdade de Filosofia, Letras e Ciências Humanas. Universidade de São Paulo. São Paulo: 2009.

MAZZARINO, Santo. O fim do mundo Antigo. São Paulo: Martins Fontes, 1991.

McKITTERICK, R. The Carolingians and the written word. Cambridge: Cambridge University Press, 1989.

MIATELLO, A.L.P. Retórica religiosa e cívica na Itália do século XIII: a composição e os usos das hagiografias mendicantes nas políticas de paz. Tese apresentada ao Programa de Pós-Graduação em História Social da 
Faculdade de Filosofia, Letras e Ciências Humanas da Universidade de São Paulo para a obtenção do título de doutor em História Social. USP, São Paulo, 2010. p.29-30.

MICHELET, J. Histoire de France au Moyen Age. La Gaule - Les invasions. Charlemagne. Paris: Calmann-Lévy, 1893.

MILLER, David H. Ethnogenesis and Revitalization beyond the Roman Frontier: The Case of Frankish Origins. Journal of World History, v.4, n.2, p.277-285, 1993.

MOMIGLIANO, A. Some observations on the 'Origo Gentis Romanae'. The Journal of Roman Studies, v.48, n.1/2, p.56-73, 1958.

As raízes clássicas da historiografia moderna. Bauru: Edusc, 2004.

MONOD, G. Du lieu d'origine de la chronique dite de Frédégaire. Jahrbuch für schweizerische Geschichte. n.3, 1878.

La compilation dite "Frédégaire". Études Critiques sur les sources de l'histoire mérovingienne. Soixante-troisième fascicule. Paris: F. Vieweg, 1885.

. Les aventures de Sichaire. Commentaire. Des chapitres XLVII du livre VII et XIX du livre IX de l'Histoire des Francs de Grégoire de Tours. Revue historique. Paraissant tous les deux mois. Paris : Félix Alcan, Tomo 32, ano 11, p. 259-290, Setembro-dezembro de 1886.

MURRAY, A.C. Germanic Kinship Structure. Studies in Law and Society in Antiquity and the Early Middle Ages. Toronto: Pontifical Institute of Mediaeval Studies, 1983.

Germanic Kinship Structure. Studies in Law and Society in Antiquity and the Early Middle Ages. Toronto: Pontifical Institute of Mediaeval Studies, 1983.

Immunity, Nobility, and the Edict of Paris. Speculum, v.69, n.1, p.18-39, Jan. de 1994.

Post vocantur Merohingii: Fredegar, Merovech, and 'Sacral Kingship'. In: Idem (ed.). After Rome's Fall. Narrators and Sources of Early Medieval History. Essays presented to Walter Goffart. Toronto, Buffalo, London: University od Toronto Press, 1998.

NELSON, J. Family, Gender and Sexuality in the Middle Ages. In: BENTLEY, M. Companion to Historiography. London \& NY: Routledge, 1997.

Queens as Jezebels: Brunhild and Balthilde. In: NELSON, J.L. Politics and ritual in Early Medieval Europe. Londres \& Roceverte: Hambledon Press, 1986. 
NICOLET, C. 1889, Réflexions sur Fustel de Coulanges. Comptes-rendus des séances de l'Académie des Inscriptions et Belles-Lettres. v.133, n.3, p.721726, 1989.

O'HARA, A. The Vita Columbani in Merovingian Gaul. Early Medieval Europe. v.17, n.2, p.126-153, 2009.

O’DONNELL. The aims of Jordanes. Historia: Zeitschrift für Alte Geschichte, v.31, n.2, p.223-240, 1982.

OLMO ENCISO, L. The royal foundation of Recópolis and the urban renewal in Iberia during the second half of the sixth century. In: Henning, J. (ed.). PostRoman towns, trance and settlement in Europe and Byzantium. Millennium-Studien, 5. v.1-2. Berlim, 2007. p.181-198.

ORLANDIS, J. El poder real y la sucesion al trono en la monarquia visigoda. In: Estudios visigoticos. Consejo superior de investigaciones cientificas delegacion de Roma/ Cuadernos del instituto juridico español. n.16, Roma-Madrid, 1962.

.Estudios visigoticos III: El poder real y La sucesion al trono en la monarquia visigoda. Cuadernos del instituto juridico español n.16. Madrid-Roma: Consejo superior de investigaciones cientificas. Delegacion de Roma, 1962.

ORSELLI, Alba Maria. Il Santo patrono cittadino: genesi e sviluppo del patrocinio del vescovo nei secoli VI e VII. In: BOESCH GAJANO, Sofia (ed.). Agiografia altomedioevale. Bologna: Società editrice il Mulino, 1976. p.85104. [Originalmente publicado em: ORSELLI, A.M. L'idea e il culto del santo patron cittadino nella letteratura latina Cristiana. Bologna: Zanichelli, 1965. p.97-119.]

OSABA, E. Reflexiones en torno a las Leyes Visigodas. Monteadvdo, n.3, p.57-72, 2003.

PANCER, Nira. Sans peur et sans vergogne. De l'honneur et des femmes aux premiers temps mérovingiens. Paris: Éditions Albin Michel, 2001.

PAPE, L. L'Armorique dans la Gaule. Éclipse et renaissance. Annales de Bretagne et des pays de l'Ouest. t.105, n.2, p.11-27, 1998.

PATT, William D. The early "ars dictaminis" as response to a changing society. Viator, p.133-155, 1978.

PEJENAUTE RUBIO, F. La Vida de Santa Radegunda escrita por Baudonivia. Archivum. t.56, p.313-360, 2006.

PEREIRA, Ana Paula L. O relato hagiográfico como fonte histórica. Revista do Mestrado de História, v.9, n.10, p.161-170.

PERRET, Jacques. Tacite. La Germanie. Paris: Belles Lettres, 1949. 
PHILIPPART, G. Hagiographes et hagiographie, hagiologes et hagiologie: des mots et des concepts. Hagiographica. Rivista di agiografia e biografia dela Società Internazionale per lo studio del Medio Evo latino. n.1, p.1-16, 1994.

POHL, W. Aux origines d'une Europe ethnique: Transformations d'identités entre Antiquité et Moyen Âge. Annales. Histoire, Sciences Sociales. 60e Année, n.1, p.183-208, 2005.

El concepto de etnia en los estúdios de la Alta Edad Media. In: LITTLE, Lester K. \& ROSENWEIN, Barbara (eds.) La Edad Media a Debate. Madrid: Akal, 2003.

Ethnicity, theory and tradition: a response. In: GILLET, A.(ed.). On Barbarian Identity. Critical Approaches to Ethnicity in the Early Middle Ages. Turnhout: Brepols, 2002.

Gender and ethnicity in the early Middle Ages. In: BRUBAKER, L. \& SMITH, Julia M.H. Gender in the Early Medieval World. East and West, 300-900. Cambridge: Cambridge University Press, 2004.

Introduction - strategies of identification: a methodological profile. In: POHL, W. \& HEYDEMANN, G. Strategies of identification. Ethnicity and Religion in Early Medieval Europe. Turnhout: Brepols, 2013.

. Telling the difference: signs of ethnic identity. In: POHL, W. \& REIMITZ, H. (eds.) Strategies of Distinction. The Construction of Ethnic Communities, 300-800. Leiden, Bostin, Kölh, 1998.

. The Regia and the Hring - Barbarian places of power. In: DE JONG, M. THEUWS, F. \& VAN RHIJN, C. Topographies of power in the Early Middle Ages. Leiden, Boston, Köln: Brill, 2011.

POLY, Jean-Pierre. La corde au cou. Les Francs, la France et la Loi salique. In: Genèse de l'État moderne em Méditerranée. Approches historique et anthropologique des pratiques et des représentations. Actes des tables rondes internationales tenues à Paris (24-26 septembre 1987 et 18-19 mars 1988). Rome: École Française de Rome, 1993.

Le premier roi des francs. La loi salique et le pouvir royal à la fin de l'Empire. In : CONSTABLE, G. \& ROUCHE, M. Auctoritas. Mélanges offerts à Olivier Guillot. Paris : PUPS, 2006.

PONTAL, O. Histoire des conciles mérovingiens. Paris : Éditions du Cerf, 1989.

POTTER, J.M. The Development and significance of the Salic Law of the French. The English Historical Review, v.42, n.206, p.235-253, 1937.

RANKE, L. von. Preface to the First Edition of Histories of the Latin and Germanic Peoples. (October 1824). In: Idem. The Theory and Practice of History. Leopold von Ranke. Ed. IGGERS, G.G. London \& NY: Routledge, 2011. 
Da unidade essencial dos povos romanos e germânicos e de sua comum evolução. In: História. São Paulo: Ática, 1979.

RAPP, Claudia. 'For next to God, you are my salvation': reflections on the rise of the holy man in late antiquity. In: : HOWARD-JOHNSTON, J. \& HAYWARD, P.A. The cult of the Saints in Late Antiquity and the Early Middle Ages. Oxford: Oxford University Press, 1999. p.63-81.

. Holy Bishops in Late Antiquity. The nature of Christian Leadership in an age of transition. Berkeley, LA, London: University of California Press, 2005.

RÉAL, I. Entre mari et femme: dons réciproques et gestion dês biens à l'époque mérovingienne d'après les chroniques et les Vies de saints. In: BOUGARD, F.; FELLER, L. \& LE JAN, R. Morgengabe, dos, tertia.. et les autres. Les transferts patrimoniaux en Europe occidentale. VIIIe-Xe siècles. Ecole Française de Rome, 295. p.389-406, 2000.

REIMITZ, H. The providential past: visions od Frankish identity in The Early Medieval History of Gregory of Tours' Historiae (sixth-ninth century). In: POHL, W.; GANTNER, C. \& PAYNE, R. Visions of community in the postRoman World. The West, Byzantium and the Islamic World, 300-1100. Farham \& Burlington: Ashgate, 2012.

REIS, José C. A história entre a filosofia e a ciência. São Paulo: Ática, 1996.

REYDELLET, M. La conception du souverain chez Isidore de Séville. Isidoriana. Leon: Centro de Estudios "San Isidoro", 1961. p.457-466.

La royauté dans la littérature latine de Sidonio Apolinaire à Isidore de Séville. Rome: École Française de Rome, 1981.

. La significatión du Livre IX des Etymologies: erudition et actualite. In: GONZÁLEZ BLANCO, A. Antigüedad y Cristianismos. Monografias historicas sobre la Antigüedad Tadia III - Los Visigodos. Historia y Civilizacion. Actas de la Semana Internacional de Estudios Visigóticos (Madrid - Toledo - Alcalá de Henares, 21-25 octubro de 1985) Universidad de Murcia, Fundación Pastor de Estudios Clasicos, Universidad de Alcalá de Henares, 1986.

REYNOLDS, S. Our Forefathers? Tribes, Peoples, and Nations in the Historiography of the Age of Migrations. In: MURRAY, A.C. (ed.) After Rome's Fall. Narrators and Sources of Early Medieval History. Toronto, Buffalo \& London: University of Toronto Press, 1998.

RIO, A. Legal practice and the written word in the Early Middle Ages. Frankish Formulae, c.500-1000. Cambridge, New York: Cambridge University Press, 2009.

Charters, law codes and formulae: the Franks between theory and practice. In: FOURACRE, Paul. \& GANZ, David. Frankland. The franks and the 
world of the Early Middle Ages. Essays in honour of Dame Jinty Nelson. Manchester and New York: Manchester University Press, 2008.

. The formularies of Angers and Marculf: Two Merovingian Legal Handbooks. Translated with introduction and notes by Alice Rio. Liverpool: Liverpool University Press, 2008.

RIPOLL, G. Características generales del poblamiento y la arqueología funeraria visigoda de Hispania. Espacio, Tiempo y Forma, S.I. Prehist. y Arqueol., t.2, p.389-418, 1989.

RIPOLL, G. Changes in the Topography of Power: From Civitates to Vrbes Regiae in Hispania. In: CORRADINI, R.; DIESENBERGER, M. \& REIMITZ, H. The Construction of Communities in the Early Middle Ages. Texts, resources and Artefacts. Leiden, Boston: Brill, 2003.

RIPOLL, G. The arrival of the Visigoths in Hipania: population problems and the processo $\mathrm{f}$ acculturation. In: POHL, W. \& REIMITZ, H. Strategies of Distinction. The Construction of ethnic Communities, 300-800.Leiden, Boston, Köln: Brill, 1998.

RUST, Leandro D. Colunas de São Pedro. A política Papal na Idade Média Central. São Paulo: Annablume, 2011.

SÁCHEZ VELASCO, J. \& GARCÍA FERNÁNDEZ, F.J. Identidades y élites germánicas en la arqueología tardoantigua de la Bética? Estado actual de la investigación y perspectivas de estudio. In: ÁLVAREZ JIMÉNEZ, D., SANZ SERRANO, R. \& HERNÁNDEZ DE LA FUENTE, D.(eds). El espejismo del bárbaro. Ciudadanos y extranjeros al final de la Antigüedad. Anejo 1 de Potestas. Univesitat Jaume I de Castellón, Cartellón, 2012. p.306-328.

SAITTA, B. Gregorio di Tours e i Visigoti. Catania: C.U.E.C.M, 1996.

SCHLEIER, H. German historiography under National Socialism. In: BERGER, S., DONOVAN, M. \& PASSMORE, K. Writing National Histories. Western Europe since 1800. NY \& London: Routledge, 1999.

SCHMAUDER, M. The relationship between Frankish gens and regnum: a proposal based on the archaeological evidence. In: GOETZ, H.-W., JARNUT, J. \& POHL, W. (eds). Regna and Gentes. The Relationship between Late Antique and Early Medieval Peoples and Kingdoms in the Transformation of the Roman World. Leiden \& Boston: Brill, 2003.

SCHNÜRER, Gustav. Die Verfasser der sogenannten Fredegar-Chronik. Collectanea Friburgensia. Fasciculus IX, 1900.

SIEMS, Harald. La vie économique des Francs d'après la lex salica. In: ROUCHE, Michel (ed.). Clovis: histoire et mémoire. Actes du Colloque International d'Histoire de Reims, du 19 au 25 septembre 1996. Paris e Sorbonne : Presses de l'Université de Paris-Sorbonne, 1997 
SILVEIRA, V. História e historiografia na Antigüidade Tardia à luz de Gregório de Tours e Isidoro de Sevilha. 2010. 181 f. Dissertação de Mestrado Faculdade de Filosofia, Letras e Ciências Humanas/USP. São Paulo, julho de 2010.

Reflexões sobre o conceito de Antiguidade Tardia. Anais do XXVI Simpósio Nacional de História - Anpuh. São Paulo. Julho de 2011. Disponível em:

http://www.snh2011.anpuh.org/resources/anais/14/1300808380_ARQUIVO_1 silveira_reflexoes_sobre_o_conceito_de_antiguidade_tardia_anpuh_2011.pdf

SISMONDI, J.C.L. History of the Fall of the Roman Empire. Filadélfia: Carey, Lea \& Blanchard, 1835.

SIVAN, H.S. Funerary monuments and funerary rites in late antique Aquitaine. Oxford Journal of Archaeology. v.5, n.3, p.339-353, 1986.

SKINNER, Q. Some problems in the analysis of Political thought and action. Political Theory. v.2, n.3, p.277-303, 1974.

SMITH, Julia M.H. Did women have a Transformation of the Roman World? In: STAFFORD, P. \& MULDER-BAKKER, A.B. Gendering the Middle Ages. Oxford: Blackwell Publisher, 2001. p. 22-41.

SOHM, R. La procédure de la Lex Salica. Trad. M. Trévenin. Paris: Libraire A. Franck, 1873. p.173-175.

SOUSA, Adriana C. Literatura hagiográfica e cristianização das atribuições régias no reino visigodo de Toledo (séc. VII): uma análise da atuação dos monarcas na Vita Desiderii, do rei Sisebuto. Anais do XXVI Simpósio Nacional de História - ANPUH. São Paulo, julho 2011. (Disponível em: http://www.snh2011.anpuh.org/resources/anais/14/1313028855_ARQUIVO_Ar tigoAnpuh2011_AdrianaSousa.pdf )

STEIN, S. Le "Romanus" dans les sources franques. Revue belge de philologie et d'histoire. Tome 17 fasc. 1-2, p. 684-691. 1938.

. Lex Salica I. Speculum. v.22, n.2, p.113-134, abril de 1947.

. Lex Salica II. Speculum. vol.22, n.3, p.395-418. Julho de 1947.

STRAUSS, A. \& WAIZBORT, R. Sob o signo de Darwin? Sobre o mau uso de uma quimera. RBCS, v.23, n.68, p. 125-134, outubro de 2008.

TATUM, S. Auctoritas as sanctitas: Balthild's depiction as 'queen-saint' in the Vita Balthildis. European Review of History - Revue européene d'histoire. V.16, n.6, p.809-834, december 2009.

TESTA, Rita L. Le transformazioni delle élite in età Tardoantica. Atti del 
convegno internazionale, Perugia, 15-16 marzo 2004. Roma: "L'ERMA" di Bretschneider, 2006.

THEUWS, F. Grave goods, ethnicity, and the rhetoric of burial rites in Late Antique Northern Gaul. In: DERK, T. \& ROYMANS, N. Ethnic Constructs in Antiquity. The role of power and tradition. Amsterdam: Amsterdam University Press, 2009. p.283-285

THOMAS, Emma J. The 'second Jezebel': representations of the sixth-century Queen Brunhild. PhD Thesis. University of Glasgow. School of Humanities. October, 2012. 241pp.

THOMPSON, E.A. Britain. A.D.406-410. Britannia. v.8, p.303-318, 1977.

. Early Germanic Warfare. Past \& Present, n.14, p. 2-29, 1958.

. The Goths in Spain. Oxford: Clarendon Press, 1969.

TODD, Malcolm. The Early Germans. Maryland, Oxford, Victoria: Blackwell Publishing, 2004.

TURTON, D. History, age and the Anthropologists. In: AUSENDA, G (ed.). After Empire. Towards and Ethnology of Europe's Barbarians. San Marino: The Boydell Press, 1995.

ULlMANN, W. Principi di governo e politica nel medioevo.Bologna: Società editrice il Mulino, 1982.

VALVERDE CASTRO, M.R. La monarquía visigoda en Valerio del Bierzo. Edad Media. Rev.Hist. n.12, p.281-300, 2011.

VELÁZQUEZ, I \& RIPOLL, G. Recopolis: Vrbs Relicta? An HistoricoArchaeological debate. In: CHRISTIE, N. \& AUGENTI, A. (eds). Vurbes Extinctae. Archeologies of abandoned Classical Towns. Aldershot-Burlington: Ashgate, 2012.

VERLINDEN, C. Frankish Colonization: a new approach. Transactions of the Royal Historical Society, Fifth Series, v.4, p.1-17, 1954.

VERSLYPE, L. "Limites sans frontières". Réflexions sur la perception archéologique de l'espace en Neustrie septentrionale (Ve-VIIIe siècle). Revue du Nord. v.3, n.351, p.551-572, 2003.

VIGIL-ESCALERA, A. Is it really relevant the ethnicity of our historical subjects? Arqueologia y Territorio Medieval. 18, p.45-53, 2011.

VON RUMMEL, P. Migrazioni archeologiche. Una nota sul problema dell'identificazione archeologica dei barbari. In: EBANISTA, C. \& ROTILI, M. (eds). Archeologia e storia delle migrazioni. Europa, Italia, Mediterraneo fra tarda età romana e alto medioevo. Atti del Convegno internazionale di studi. 
(Cimitile-Santa Maria Capua Vetere, 17-18 giugno, 2010). Tavolario Edizioni, 2011.

WALLACE-HADRILL, J.M. Archbishop Hincmar and the authorship of Lex Salica. In:__. The Long-Haired Kings and Other Studies of Frankish History. New York: Barnes and Noble, 1962.

. The long-haired kings and other studies of Frankish History. NY: Barnes and Noble, 1962.

WARD-PERKINS, B. Why did the Anglo-Saxons not become more British? The English Historical Review. v.115, n.462, p.513-533, 2000.

A carved marble fragment at Riom (Puy-De-Dôme) and the chronology of the Aquitanian sarcophagi. The Antiquaries Journal. v.40, n.1-2, p.25-34, abril de 1960.

WENSKUS, Reinhard. Stammesbildung und verfassung: Das werden der frühmittelalterlichen gentes. Colônia: Böhlau, 1961.

WERNER, K.F. Nascita della nobiltà. Lo sviluppo delle élite politiche in Europa. Torino: Giulio Einaudi editore, 2000.

. Structures du monde franc (VIe - XIIe siècles). London: Variorum, 1979.

WHITE, H.W. Tacitus reconsidered. Greece \& Rome. v.2, n.4, p.38-46, 1932.

. The value of narrativity in the representation of reality. Critical Inquiry, v.7, n.1, p.5-27, Autumn 1980.

WICKHAM, C. The inheritance of Rome. Illuminating the Dark Ages 400-1000. Londres: Viking, 2009.

Framing the Early Middle Ages. Europe and the Mediterranean. 400-800. Nova York: Oxford University Press, 2005.

WIDDOWSON, Marc. Merovingian partitions: a 'genealogical charter'? Early Medieval Europe. v.17, n.1, p.1-22, 2009.

WINTERBOTTOM, M. The manuscript tradition of Tacitu's Germania. Classical Philology. n.1, p.1-7, 1975.

WOLFRAM, H. History of the Goths. Berkeley, Los Angeles, London: University of California Press, 1987.

Le genre de l'Origo gentis. Revue belge de philologie et d'histoire. T. 68, fasc.4, p.789-801. 1990.

. The Goths in Aquitaine. German Studies Review, v.2, n.2, p.153-168. 1979. 
. The shaping of Early Medieval kingdom. Viator. v.I, p.1-20, 1970.

WOOD, I. Barbarian, Historians, and the Construction of National Identities. Journal of Late Antiquity, v.1, n.1, p.61-81, Spring 2008.

. Continuity or calamity?: the constrains of literary models. In: DRINKWATER, J. \& ELTON, H. Fifth-century Gaul: a crisis of identity? Cambridge, New York, Melbourne: Cambridge University Press, 1992.

Defining the Franks. Frankish origins in early medieval historiography. In: NOBLE, T.F.X. From Roman provinces to Medieval Kingdoms. London \& New York: Routledge, 2006.

. Saint- Wandrille and its Hagiography. In: WOOD, I. \& LOUD, G.A. (ed.) Church and chronicle in the Middle Ages. Essays presented to John Taylor. London and Rio Grande: The Hambledon Press, 1991.

. Social relations in the Visigothic Kingdom from the fifth to the seventh century: the example of Mérida. In: HEATHER, P. The visigoths. From the migration period to the seventh century. An ethnographical perspective. Woodbridge: Boydell Press, 1999.

. The Merovingian Kingdoms. 450-751.London \& NY: Longman, 1994.

The Missionary Life. Saints and the Evangelisation of Europe. 400-1050. Harlow: Longman, 2001.

. The Vita Columbani and Merovingian hagiography. Peritia. v.1, n.1, p.6380, 1982.

. Usurpers and Merovingian Kingship. In: BECHER, M. \& JARNUT, J. Der Dynastiewechsel von 751. Vorgeschichte, Legitimationsstrategien und Erinnerung. Münster: Scriptorium, 2004.

(ed.) Franks and Alamanni in the merovingian period. An ethnographic perspective. Woodbridge: Boydell Press, 1998.

WOOD, J. The politics of Identity in Visigothic Spain. Leiden \& Boston: Brill, 2012.

WORMALD, P. The Leges Barbarorum. Law and Ethnicity in the Post-Roman West. GOETZ, H-W, JARNUT, J., POHL, W. Regna and Gentes. The relationship between Late Antique and Early Medieval peoples and kingdoms in the Transformation of the Roman World. Boston, Leiden: Brill, 2003.

YOUNG, B.K. Has anyone seen the Barbarians? Remarks on the missing archeology of the Visigoths in Gaul. In: MATHISEN, R.W. \& SHANZER, D. (ed.). The Battle of Vouillé, 507 CE. Where the France Began. Boston \& Berlin: De Gruyter, 2012. 
ZEISS, H. Die Grabfünde aus dem spanischen Westgotenreich. Berlin, 1934. 